\title{
La femme fatale en la publicidad del siglo XX. La popularización de un arquetipo decimonónico
}

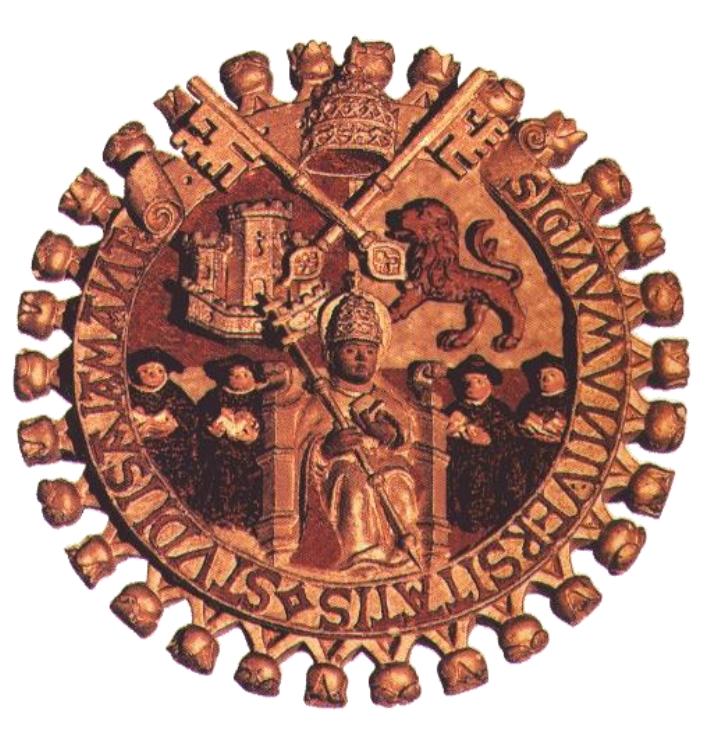

Universidad de Salamanca

Área de Teoría de la Literatura y Literatura Comparada

Departamento de Lengua Española

2013 
Para Pedro, in memoriam 


\section{Agradecimientos}

La presente tesis es el fruto de ocho largos años de estudios. Periodo en el que me he permitido dudar, flaquear, abandonar varias veces el proyecto y volver a retomarlo siempre con la misma ilusión con la que lo empecé. Mentiría si dijera que terminarlo fue fácil, pero ahí radica la grandeza de las personas que me han rodeado.

Estoy muy agradecida a don Manuel González de Ávila por su cálida hospitalidad y sus continuos ánimos. Estoy segura que sin su infinita paciencia y sus consejos nunca hubiera terminado la tesis.

Estoy muy agradecida a mis padres, Salvador Ballester LLorens y Maria Jesús Maroto Trilles, quienes, cargados cariño, siempre me han apoyado en todas mis decisiones. También me gustaría agradecerles la paciencia con la que han vivido mis esfuerzos en los últimos tres años. Pero, no quisiera dejar pasar la oportunidad de destacar que, ha sido la entereza y la fuerza de ambos, lo que me ha servido de ejemplo y guía para superar todas y cada una de las dificultades que he encontrado a lo largo de mis estudios.

Para el valiente Salvador Ballester Maroto nunca tendré suficientes palabras de agradecimiento, pues él fue quien me introdujo en el mundo de la femme fatale y me enseñó que en la actualidad esta figura literaria sigue proliferando en el mundo de la ciencia-ficción. Esta tesis tampoco existiría sin su enriquecedor punto de vista, ya que han sido muchas las sobremesas en las que hemos discutido sobre mujeres y publicidad.

También me gustaría agradecer a mis heroicas amigas el tiempo y el esfuerzo que han dedicado al aconsejarme y al animarme. Sin Alicia Sáez, Amparo Lisart y 
Natividad Cana, nunca hubiera encontrado la energía necesaria para continuar. Todas ellas me dieron aliento y comprensión cuando más lo necesité.

Pero el principal culpable de que haya terminado la tesis en el Área de Teoría de la Literatura y Literatura Comparada es Pedro. Cuando yo apenas contaba con cinco años de edad, Pedro reunió a mis padres y les comentó que, aunque yo apenas sabía escribir y leer, ya apuntaba hacia el mundo literario. Tal vez fue la primera persona en encaminarme, pero sin lugar a dudas siempre ha sido una luz que me ha abierto camino en el mundo del conocimiento. Pese a todas las dificultades que me haya encontrado en mi labor investigadora, le estaré siempre muy agradecida. 


\section{Páginas}

Introducción

1.- La imposibilidad de la identidad individual

1.1.- La simulación o falsificación de la identidad femenina 23

1.2.- Sistemas de parentesco. Las oposiciones dentro del sistema sexual 25

1.2.1.- El orden lógico del poder político y social. El rol social 26

1.2.1.1.- La construcción social de los sexos 27

$\begin{array}{ll}\text { 1.2.1.2.- Sistema patriarcal } & 28\end{array}$

1.2.2.- El sistema sexual en continuo cambio $\quad 30$

1.2.2.1.- Género y desarrollo 31

1.2.3.- Las relaciones regladas del sistema de parentesco 34

1.2.3.1.- La terminología y sus funciones 35

1.2.3.2.- El matrimonio 37

1.2.3.3.- Tipos de matrimonio 39

1.3.- La mujer como sujeto. La mujer como objeto literario 40

1.3.1.- Definición del sujeto desde el punto de vista masculino 41

1.3.1.1.- La figura femenina en el amor mundano 45

1.3.1.2.- La crítica del amor mundano 48

1.3.2.- Definición del sujeto desde el punto de vista femenino $\quad 50$

1.3.2.1.- Teorías feministas moderadas $\quad 52$

1.3.2.1.1.- Hélène Cixous $\quad 54$

1.3.2.1.2.- Monique Wittig 55

1.3.2.1.3.- Esther Tusquets $\quad 56$

$\begin{array}{ll}\text { 1.3.2.1.4.- Rosa Montero } & 57\end{array}$

1.3.2.1.5.- Rosario Ferré $\quad 58$

1.3.3.- La mujer como sujeto ficcional $\quad 60$ 
1.3.3.1.- La mujer como identidad desdibujada 62

1.3.3.2.- La cultura femenina fragmentada 63

1.3.3.3.- La intertextualidad remarca la ficcionalidad del texto $\quad 65$

2.- Organización político-social del cuerpo femenino 68

2.1.- Iniciaciones sexuales y ritos del cortejo. Adolescencia y juventud 69

2.1.1.- Sociabilizar a los jóvenes: cofradías y cencerradas $\quad 70$

2.1.2.- Rituales de seducción y prácticas prenupciales 72

2.1.3.- Iniciaciones y aprendizaje sexual 76

$\begin{array}{ll}\text { 2.2.- El matrimonio y sus aledaños } & 79\end{array}$

2.2.1.- El cuerpo en el discurso religioso 80

2.2.1.1.- El cuerpo de la mujer descrito por el catolicismo $\quad 82$

2.2.1.2.- Virginidad y contingencia 85

2.2.1.3.- El débito conyugal 86

$\begin{array}{ll}\text { 2.2.1.4.- La postura ascética } & 87\end{array}$

2.2.2.- El cuerpo en el discurso médico $\quad 89$

$\begin{array}{ll}\text { 2.2.2.1.- El cuerpo fragmentado } & 89\end{array}$

2.2.2.2.- La exploración del cuerpo 90

2.2.2.3.- El dolor y la relación terapéutica $\quad 92$

2.2.2.3.1.- El cuerpo inválido y la monstruosidad 93

2.2.2.3.2.- El cuerpo y la degeneración 95

2.2.2.4.- La necesidad de un cuerpo limpio 96

2.2.2.4.1.- El cuerpo femenino y su higiene personal 98

2.2.2.4.1.- El aseo parcial $\quad 99$

2.2.2.4.1.2.- El baño 100

2.2.3.- Prohibiciones y límites entre procreaciones y placer 101

$\begin{array}{ll}\text { 2.2.3.1.- Prohibiciones dentro del matrimonio } & 101\end{array}$ 
2.2.3.2.- Prohibiciones en la promiscuidad popular 105

2.2.4.- La prostituta como remedio de algunos males 108

2.2.4.1.- Sodomía 109

$\begin{array}{ll}\text { 2.2.4.2.- El bestialismo } & 110\end{array}$

$\begin{array}{ll}\text { 2.3.- El cuerpo femenino en el discurso artístico } & 111\end{array}$

$\begin{array}{ll}\text { 2.3.1.- El desnudo } & 112\end{array}$

2.3.2.- El cuerpo castigado en la Revolución Francesa 113

$\begin{array}{ll}\text { 2.3.2.1.- El cuerpo masacrado } & 113\end{array}$

$\begin{array}{ll}\text { 2.3.2.2.- El cuerpo atormentado } & 115\end{array}$

$\begin{array}{ll}\text { 2.3.3.- El cuerpo violado } & 116\end{array}$

2.3.4.- El cuerpo deteriorado del trabajador 118

$\begin{array}{ll}\text { 2.4.- Riesgos y prejuicios de la visibilidad del cuerpo } & 119\end{array}$

3.- Definición de la femme fatale 121

3.1.- La descentralización de la belleza 122

3.2.- La identidad de la femme fatale creada a partir de varios métodos discursivos

3.2.1.- Cambio en el discurso literario 126

3.2.2.- Los recursos formales del discurso religioso y el discurso médico 128

3.2.3.- Los pilares creativos de la femme fatale $\quad 130$

3.3.- Sacralización de los rasgos femeninos $\quad 132$

3.3.1.- La corriente francesa. La función estética del desorden 133

3.3.1.1.- Caracterización física de la femme fatale 137

3.3.1.2.- La naturaleza exótica de la femme fatale 141

3.3.1.3.- La naturaleza mística de la femme fatale 144

3.3.2.- La corriente alemana y la inglesa. La función de la maldad femenina

3.3.2.1.- La corriente inglesa y la simbología del castillo 147

3.3.2.1.1.- La amada fantasma 148 
3.3.2.2.- La corriente blanca y el folklore alemán

3.3.2.2.1.- Hadas, brujas y otras representaciones populares 154

4.1.1.- La condena del erotismo

4.1.1.2.- La metamorfosis de Ave

4.1.1.3.- La coronación de la maldad femenina 
4.2.4.2.- La persistencia de la mujer que arrastra 203

4.3.- El orientalismo como caracterización física 203

4.3.1.- La mujer-bestia 205

4.3.1.1.- La esfinge 206

$\begin{array}{ll}\text { 4.3.1.2.- Medusa } & 215\end{array}$

$\begin{array}{ll}\text { 4.3.1.3.- Las sirenas } & 222\end{array}$

4.3.1.4.- Las arpías $\quad 226$

$\begin{array}{ll}\text { 4.3.1.5.- Vampiros } & 228\end{array}$

$\begin{array}{ll}\text { 4.3.1.5.1.- Lamia } & 230\end{array}$

$\begin{array}{ll}\text { 4.3.1.5.2.- Empusa } 231 & 231\end{array}$

4.3.1.5.3.- Las herederas 232

4.3.1.5.3.1.- La proliferación 233

4.3.2.- La mujer monstruosa 234

$\begin{array}{ll}\text { 4.3.2.1.- El vientre maldito } & 237\end{array}$

4.3.3.- Las mujeres animales 238

$\begin{array}{ll}\text { 4.3.3.1.- La serpiente } 240 & 240\end{array}$

4.3.3.1.1.- Salambó 245

$\begin{array}{ll}\text { 4.3.3.2.- La pantera } & 249\end{array}$

$\begin{array}{ll}\text { 4.3.3.2.1.- Cat People } & 251\end{array}$

4.3.3.2.2.- Catwoman 252

4.3.3.3.- Las mujeres insectos $\quad 254$

4.3.3.3.1.- La araña 256

4.4.- Los personajes históricos como iconos de la feminidad 262

4.4.1.-Mujeres seductoras y asesinas $\quad 263$

4.4.1.1.- Cleopatra 264

$\begin{array}{ll}\text { 4.4.1.2.- Mesalina } 268 & 268\end{array}$

4.4.1.3.- Lucrecia de Borgia 273 
4.4.1.5.- Astarte Syriaca 280

4.4.1.6.- Proserpina 282

4.4.2.- Mujeres causantes del infortunio de la humanidad 285

4.4.2.1.- Eva 285

$\begin{array}{ll}\text { 4.4.2.2.- Pandora } & 291\end{array}$

4.4.2.3.- Helena de Troya 294

4.4.3.- Mujeres capaces de llegar a un hombre a su propia perdición 299

4.4.3.1.- Salomé 299

$\begin{array}{ll}\text { 4.4.3.2.- Judith } & 309\end{array}$

$\begin{array}{ll}\text { 4.4.3.3.- Dalila } 314 & 314\end{array}$

$\begin{array}{ll}\text { 4.4.3.4.- } \text { Medea } & 318\end{array}$

$\begin{array}{ll}\text { 4.5.- Las mujeres imaginadas por la burguesía } & 321\end{array}$

4.5.1.- La loca o la histérica 322

4.5.1.1.- Madame D’opporidol 323

4.5.1.2.- María de las Angustias $\quad 324$

4.5.2.- La muñeca o la autómata 325

4.5.2.1.- La muñeca diabólica 327

$\begin{array}{ll}\text { 4.5.3.- La materialidad femenina } & 329\end{array}$

4.5.3.1.- Rosalía, la de Bringas 332

4.6.- El cuerpo femenino como simulacro de enfermedad 335

$\begin{array}{ll}\text { 4.6.1.- La cortesana } & 336\end{array}$

$\begin{array}{ll}\text { 4.6.1.1.- Olimpia } & 338\end{array}$

$\begin{array}{ll}\text { 4.6.1.2.- Nana } & 339\end{array}$

$\begin{array}{ll}\text { 4.6.2.- La mujer venal } & 340\end{array}$

4.6.2.1.- La maldad de la prostituta 342

4.7.- La era del Individualismo 345 
4.7.1.- Normas estéticas ante las que responde 346

$\begin{array}{ll}\text { 4.7.1.1.- El satanismo } & 347\end{array}$

4.7.1.1.1.- Elementos que lo caracterizan 348

4.7.1.1.2.- El pacto 349

4.7.1.1.3.- El pacto femenino. Las brujas $\quad 351$

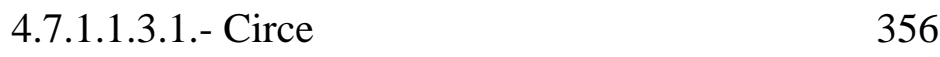

4.7.1.1.3.2.- Sidonia von Bork 358

4.7.1.1.3.3.- La Condesa Sangrienta $\quad 359$

$\begin{array}{ll}\text { 4.7.1.2.- El titanismo } & 361\end{array}$

4.7.1.2.1.- Carmen 362

4.8.- El aprendizaje de la femme fatale 363

4.8.1.- Las niñas 365

5.- La imagen femenina de las marcas publicitarias 369

5.1.- El objeto publicitario como objeto público 370

5.1.1.- El cambio de sociedad 371

5.1.2.- El objeto publicitario pierde su función original 372

5.1.3.- La nueva publicidad 373

5.2.- El objeto publicitario como signo de status social 377

5.2.1.- La Antigüedad Clásica. Las señas como objeto publicitario $\quad 377$

5.2.1.1.- Grecia 378

$\begin{array}{ll}\text { 5.2.1.2.- Roma } & 379\end{array}$

5.2.2.- La Edad Media. La evolución de las señas $\quad 380$

$\begin{array}{ll}\text { 5.2.3.- La popularización de las señas } & 381\end{array}$

5.3.- La felicidad como único objetivo humano 383

5.3.1.- El amor, prisión femenina 386

5.3.2.- Concepción moderna de la belleza femenina 387 
5.3.2.1.- El culto a la belleza femenina 390

5.3.2.2.- AVE. El Ángel del hogar 391

5.3.2.3.- Los elementos físicos de la belleza 392

5.3.3.- La juventud 395

6.- El destino de la seducción masculina 398

6.1.- El boom de la belleza 398

6.1.1.- La fiebre de la belleza y el mercado del cuerpo 400

6.1.2.- El activismo estético y la prensa femenina 401

6.2.- La condición poética del objeto publicitario 403

$\begin{array}{ll}\text { 6.2.1.- El lenguaje publicitario } & 404\end{array}$

6.2.2.- El objeto publicitario 408

6.2.3.- La condición poética de la publicidad 411

6.3.- Las diferentes funciones del objeto publicitario 412

6.3.1.- Función ideológica 412

6.3.2.- Función social $\quad 414$

6.4.- Los poderes mediáticos de la seducción 418

6.4.1.- La cultura demiúrgica $\quad 419$

6.4.1.1.- Los arquetipos $\quad 420$

6.4.1.1.1.- Función pedagógica $\quad 421$

6.4.1.1.2.- Función semántica 423

6.4.2.- El espacio del arquetipo $\quad 424$

6.4.2.1.- El arquetipo frustrado $\quad 425$ 
7.5.2.- Las féminas y los animales

7.5.5.- El orientalismo burgués

7.5.5.1.- La Lolita publicitaria

7.5.6.- El sueño del cliente 


\section{$\underline{\text { Introducción }}$}

Cuando un tema se presta mucho a controversia -y cualquier cuestión relativa a los sexos es de este tipo- uno no puede esperar decir la verdad.

Sólo puede explicar cómo llegó a profesar tal o cuál opinión.

Virginia Wolf Una habitación propia

Lo primero con lo que tropieza el observador superficial es que las mujeres no son como los hombres. Son "el sexo opuesto" (por qué "opuesto" lo desconozco; ¿cuál es el "sexo vecino"?). Pero lo fundamental es que las mujeres se parecen más a los hombres que nada en este mundo.

Dorothy L. Sayers "The human-not-quiet-human"

Creo recordar que fue en el año 2004 cuando por primera vez alguien me propuso el presente estudio. Mi respuesta fue radical: NO. Me gustaría poder decir que no sé por qué lo dije y también me gustaría decir que me arrepentí de mi rotundidad. Pero nunca lo he hecho porque mi negación inicial me ayudó a cuestionarme todo lo que iba aprendiendo a medida que recorría el camino. Siempre me ha dado la sensación de que trataba de entender ideas arduas y muy pesadas. Al principio pensé que la dificultad procedía porque se trataban de imágenes tradicionalmente antiguas. Pero, ya con el paso del tiempo, he comprendido que mis primeras dificultades en este estudio estaban vinculadas a aquel primer NO.

La cuestión es que, desde la adolescencia, he sentido un increíble afán por la filosofía.

Con apenas dieciséis años empecé a devorar libros de Platón, Aristóteles, Nietzsche, 
Kant, Hegel... De todos ellos asimilé ideas que, posiblemente, más que ayudarme, han constituido una losa. El primer problema lo encontré al trabajar la definición de mujer. La pregunta ¿qué es una mujer? me pareció increíble, por no decir una tomadura de pelo. Pero, ya cuando escuché cultura femenina me quedé sin palabras. El origen de mi obstinación partía de que la idea de la feminidad y de la masculinidad son esencias. Es decir, un atributo natural propio de cada cuerpo y, como algunas de las propiedades corpóreas, estas no estaban ligadas a las experiencias. Así, desde mi primer punto de vista, estaba ante características innatas y, en consecuencia, muy difíciles de definir por ser consideradas propiedades universales ${ }^{1}$.

Mi primer acercamiento al tema me llevó a estudios que partían desde un punto de vista antropológico. Así que me encontré con muchas autoridades que explicaban que las experiencias de los individuos nacían de las diferencias biológicas entre el cuerpo masculino y el cuerpo femenino. De esta forma, una mujer es como es porque desde su más tierna infancia se siente limitada por su físico y sus funciones biológicas:

¿La mujer? Es muy sencillo, dicen los amantes de las fórmulas sencillas: es una matriz, un ovario; es una hembra, y basta esta palabra para definirla ${ }^{2}$.

Así pues, la identidad femenina se advertía como una hoja en blanco en la que no sólo el propia mujer se encargaba de escribir a través de su experiencia, sino que también se reflejaban las enseñanzas adquiridas por la sociedad. Biológicamente, la mujer fue definida como el opuesto del hombre. Esto la limitó política, social y económicamente,

\footnotetext{
${ }^{1}$ Existen dos tipos de conocimiento. Uno es el que se sustenta sobre las condiciones empíricas, es decir, el conocimiento que una persona adquiere tras una experiencia. El otro es el conocimiento apoyado sobre las condiciones transcendentales (a priori), es decir que son conocimientos anteriores a las experiencias. Estos últimos son conceptos universales, tales como la noción de "Dios" o de "Infinito". Nociones que todos los sujetos sienten como necesarias y que no pueden ser alteradas. Este último tipo de conocimiento acabó desarrollando el Innatismo, que iniciado por Platón fue continuado por René Descartes, Baruch Spinosa, Kant y Gottfried Leibniz.

${ }^{2}$ Simone de Beauvoir, El segundo sexo, Madrid, Cátedra, 2008, p. 67.
} 
y durante un largo período de tiempo se vio condicionada por las condiciones de producción. Toda la vida de las mujeres estaba organizada con arreglo a una teoría social y económica de los bienes simbólicos donde ellas eran el agente pasivo.

Nunca se ha educado igual a un niño que a una niña. Desde la más tierna infancia, las niñas han estado rodeadas de muñecas y los varones de balones, coches, motos y otros artilugios mecánicos. A ellos se les enseñaba a correr, a empujar y a pegar, y a ellas se les enseña la quietud y la delicadeza. Ellos juegan al fútbol y al baloncesto, ella ballet o gimnasia rítmica. Durante la infancia, las niñas aprenden canciones, juegos y cuentos que inspiran paciencia y esperanza. El cuento de La bella durmiente, Piel de asno, Cenicienta, Blancanieves... se basan en patrones de pasividad que enseña a las jóvenes princesitas a esperar al príncipe azul. Para ser felices hay que ser amadas y, para ser amadas hay que saber esperar el amor.

Pero los patrones de conducta no finalizan aquí, sino que siguen durante la juventud y en la adolescencia. La juventud es comprendida como el periodo en el que se acabe la espera. La muchacha, ya en edad de merecer, busca someterse a la dulce autoridad y protección de un marido. Así que mientras los muchachos comienzan a desarrollar su virulencia física, ellas se manifestaran como el objeto pasivo que han aprendido durante la infancia. Desde la más servil hasta la más altiva aprenden que para gustar al varón deben abdicar y depender. Ellas deben ser bellas para gustarles a ellos.

En un movimiento complejo, busca la glorificación de su cuerpo a través del homenaje de los varones a los que está destinado este cuerpo; sería simplificar las cosas decir que quiere ser belle para gustar, o que trata de gustar para estar segura de que es bella ${ }^{3}$.

\footnotetext{
${ }^{3}$ Simone de Beauvoir, op. cit., p. 443.
} 
Una mujer socialmente plena y realizada es aquella que, casada, tiene hijos. Por lo que la función reproductora se presenta como una carga voluntariamente asumida. Sin embargo, el matrimonio es un estatuto en donde hombres y mujeres desempeñan papeles completamente diferentes. Socialmente, el hombre es un individuo autónomo y completo. Se considera productor y su existencia se justifica por el trabajo que él aporta a la colectividad. Sin embargo, tal vez a causa de una moral muy tradicional y muy antigua, la mujer permanece pasiva y dependiente de la figura varonil. Aunque, una mujer desee independizarse y trabajar por su propia cuenta, desempeña profesiones no tan bien pagadas como a los varones.

Por supuesto, la evolución económica de la condición femenina ha ido cambiando con los años. Pero todo esto ha creado un sustento, una base o un poso, en donde la identidad masculina y femenina ha formado parte de un imaginario colectivo. Ideas que han sido asumidas y representadas por todos. A esto Simone de Beauvoir lo llamó el eterno femenino. Fueron ideas económicas, sociales e históricas que constituyeron a las mujeres como una sociedad gobernada por valores masculinos. Nunca constituyeron una sociedad autónoma ni cerrada, pues eran el reflejo de una sociedad dependiente y secundaria. El universo era en su conjunto completamente masculino. Ellos lo han conformado, regido y dominado, y a la mujer no le queda más que obedecer.

Desde una perspectiva histórica, las enseñanzas anatómicas han sido impartidas a través de las descripciones del discurso religioso y el médico ${ }^{4}$. Originariamente, ambos vincularon y codificaron la anatomía humana a sus correspondientes funciones

\footnotetext{
${ }^{4}$ Thomas Laqueur, La construcción del sexo. Cuerpo y género desde los griegos hasta Freud, Madrid, Cátedra, 1994, pp. 234-246 y pp. 329-413.
} 
biológicas y sociales. De este modo, la mujer quedó limitada a su función reproductiva y, sobre el varón recayó el peso del sustento familiar. Si bien es cierto que él es quien sale, se mueve, trabaja, se relaciona y vuelve a casa con dinero, ella es reclutada y reducida a la intimidad del hogar ${ }^{5}$. Aunque sea cierto que estas teorías están todavía muy presentes en el subconsciente femenino, también es cierto que la realidad práctica lleva años cambiando y evolucionando.

La antropología se hizo eco de este cambio y vio desatinado mantenerlas hoy en día. Como consecuencia, en los años '70 se comenzó a focalizar los estudios en la figura de la mujer. Como ya planteó anteriormente Simone de Beauvoir, es obvio que muchos estudios de investigación se han dejado llevar por el enfoque de la dominación universal masculina. Pero, por el contrario, otros estudios antropológicos destacaron que limitarse a este punto de vista ayudaba a dar por sentado tres puntos que podían llevar a errores graves en sus conclusiones ${ }^{6}$ :

$\left.1^{\circ}\right)$ El investigador limita las relaciones entre hombres y mujeres a los temas del matrimonio y la familia.

$\left.2^{\circ}\right)$ El hecho de que se considere que la mujer siempre esté sometida al varón, ejerce una visión distorsionada de la realidad.

$3^{\circ}$ ) Los investigadores comparan la relación asimétrica entre hombres y mujeres de otras culturas con la desigualdad que existe en la propia cultura occidental.

\footnotetext{
${ }^{5}$ Judith Butler, Cuerpos que importan. Sobre los límites materiales y discursos del "sexo”, Buenos Aires, Paidós, 2002, pp. 58-66.

${ }^{6}$ Isabel de la Cruz, Introducción a la antropología para la intervención social, Valencia, Tirant lo Blanch, 2002, p. 147-148.
} 
Estos tres puntos son los que me han motivado a seguir con la investigación. Obviamente, estamos ante la problemática de la identidad femenina. Ante la necesidad de explicar que la propia naturaleza viene dada porque, originariamente, se crearon unos límites para establecer qué era hombre y qué era mujer. Sin embargo, en pleno siglo XXI parece anacrónico seguir explicando la figura femenina bajo patrones de dominación.

A causa de los pilares inamovibles del sistema paternalista, las estructuras históricas del orden masculino han sido definidas como dominadoras, y en consecuencia, las estructuras históricas del orden femenino como las sometidas. Si explicamos la existencia femenina como fruto de la dominación masculina, corremos el peligro de caer en un círculo vicioso de la objetualización científica del tema. Sí, es cierto que, tanto el discurso como la figura femenina, han sido silenciadas a lo largo de toda la historia. Pero si sólo vemos esto, podríamos perdernos los cambios que se han dado dentro de las relaciones estructurales de poder. Así pues, es interesante para el presente estudio introducirse en las diferentes percepciones que las mujeres tienen de su propio cuerpo, pero no menos importante es la percepción que ellas quieren transmitir al género opuesto ${ }^{7}$.

Desde un punto de vista evolutivo Gilbert Durand mantiene que la historia es una vasta realización simbólica de las aspiraciones frustradas. Para argumentarlo, manifiesta que en cada fase histórica está presente una doble y antagónica motivación:

- La pedagogía de la imitación

- Las fantasías adversas debidas a la represión

\footnotetext{
${ }^{7}$ Isabel de la Cruz, op. cit., pp. 37-38.
} 
Por así decirlo, existe una tensión social creciente que especifica el simbolismo del arquetipo femenino a imitar. Históricamente, los incidentes sociológicos persisten sobre la universalidad de los arquetipos y de los símbolos más generales. Aquí, entramos de nuevo en el trayecto antropológico, pues todos ellos responden a esquemas universales en la expresión social. Como es lógico, nuestra figura femenina responde a presiones pedagógicas muy determinadas. Pero si queremos juzgar las presiones pedagógicas que estos arquetipos han sufrido, tendremos que adoptar un punto de vista estructural y sociológico.

Las imágenes que procedemos a investigar se sostienen sobre fenómenos que nacen de los contenidos de un imaginario colectivo. En consecuencia, apelarán a la totalidad del trayecto antropológico mediante la metodología de los imperativos biopsíquicos. Desde este punto de vista, no se puede separar la conciencia del imaginante de las imágenes concretas y, para conseguir este fin, el presente estudio tiene dos objetivos muy concretos. Primero, hacer un análisis detallado de la femme fatale del siglo XIX y XX y, en segundo lugar, una clasificación estructural de los diversos arquetipos femeninos que perduran en la actualidad. Pero, ambos intentaran sustentar la revisión de la imagen de la femme fatale en el imaginario colectivo.

El análisis de los arquetipos femeninos y la posterior evolución se convierten en los dos pilares que atravesan la tesis. A través de ellos, se intentará perfilar el imaginario colectivo en el que residen. Utilizando las palabras de Gilbert Durand, mantendremos que el imaginario colectivo nace de la semanticidad de las imágenes.

Para poder abarcar con claridad el concepto de semantismo imaginario, se ha llevado a cabo un estudio exhaustivo de la morfología clasificadora de las estructuras imaginarias de la femme fatale. Así pues, los tres primeros capítulos responden a la necesidad de 
analizar los diferentes símbolos que han descrito a la mujer a lo largo de la historia. En el primer capítulo se intenta desmenuzar la figura femenina dentro del sistema patriarcal; en el segundo capítulo se analiza cómo el discurso médico y religioso han colaborado en la construcción político-social del cuerpo femenino; y finalmente, en el capítulo tercero se hacen coincidir las imágenes justas para describir a la mujer fatal.

Sin lugar a dudas, y siguiendo las afirmaciones de Mario Praz, observamos como en el cuarto capítulo se hace un especial hincapié en la proliferación de la mujer fatal en el siglo XIX. Esto se debe a que la figura femenina alcanzó su mayor auge en este período. Este capítulo constituye el centro de la tesis porque se trata de una serie de ejemplos, que agrupados por temas intentan visualizar cómo la imagen femenina ha ido evolucionando y enriqueciéndose. Se destacan como agrupaciones de isótopos y de estructuras reveladoras para la época, pero que con el paso del tiempo se han consolidado. Esto conlleva el estudio de una fisiología de la función imaginativa.

Para ello, y siguiendo a Lacroze en La función de la imaginación, asumiremos tanto la universalización de las imágenes como de las funciones que estas desempeñan. Para Lacroze, la imagen siempre está reducida a un signo dudoso y empobrecido. Sin embargo, en la literatura del siglo XIX y en el discurso publicitario se elaboran por medio de imágenes simbólicas. El capítulo quinto abarca precisamente el simbolismo publicitario de la mujer fatal. La publicidad, heredera de la literatura decimonónica, destaca que la imagen simbólica es semántica. Es decir, que su sintaxis no se separa de su contenido ni de su mensaje. En el capítulo sexto se explica la conexión sintáctica que une a las imágenes caóticas y sin sentido de la publicidad.

La hipótesis del capítulo séptimo apunta hacia la popularización de la femme fatale en pleno siglo XX y XXI. El éxito de esta figura femenina no se da en la literatura, sino en los anuncios publicitarios de marcas de alto standing. Todas ellas contratan a artistas 
gráficos que reciben importantes y reconocidísimas influencias decimonónicas. El resultado fue la reactualización de un arquetipo que siempre se ha mantenido en el subconsciente colectivo. Pero la rehabilitación de esta figura no responde a una represión social. Todas las imágenes que se recopilan son un ejemplo de que no sólo se simboliza lo reprimido ni que únicamente lo reprimido tiene necesidad de ser simbolizado. Pues la función fantástica desborda el mecanismo de la represión. Así que incidir en los elementos represivos significaría limitar nuestra figura femenina. En consecuencia, la hipótesis final del presente estudio sigue las teorías de Alain y Bachelard, en donde afirmaremos que el imaginario colectivo de la femme fatale no alude a ninguna motivación machista o paternalista, sino que sólo remite a sí misma y al erotismo que la sustenta. 


\section{$\underline{\text { 1.- La imposibilidad de una identidad individual }}$}
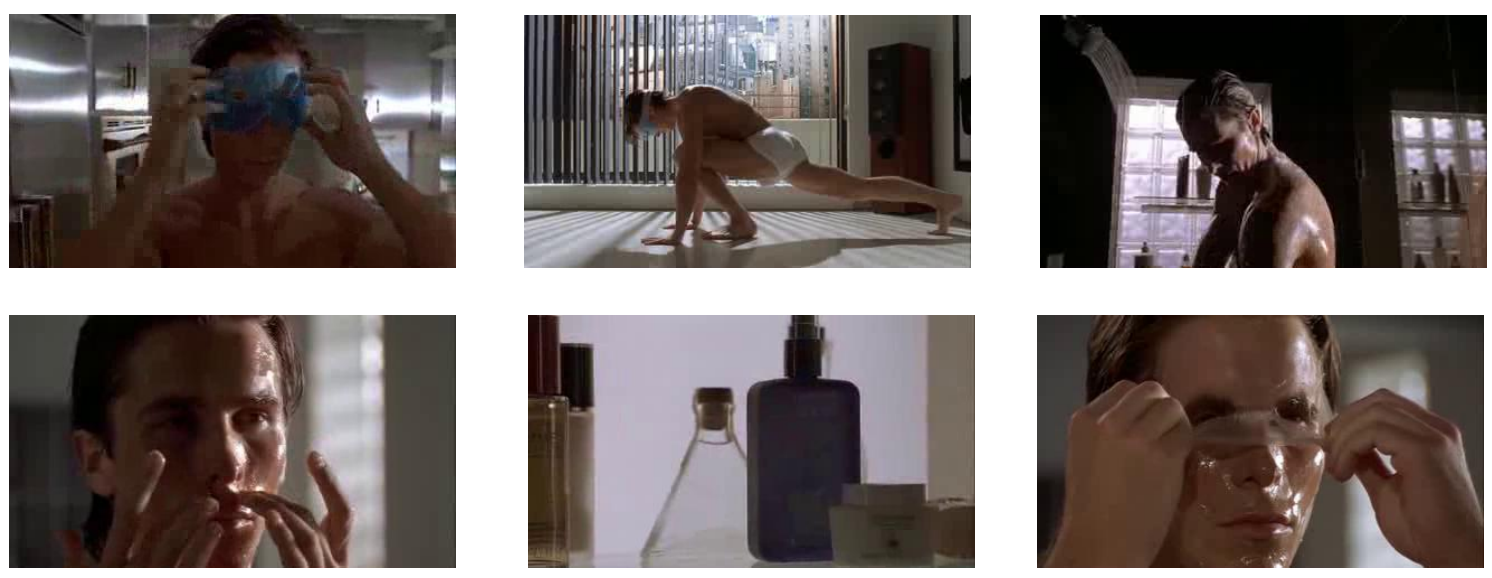

Vivo en el edificio American's Garden en la calle 81 oeste, en el undécimo piso. Me llamo Patrick Bateman. Tengo 27 años. Me gusta cuidarme. Sigo una dieta equilibrada y una rutina rigurosa de ejercicios. Por la mañana, si tengo los ojos hinchados, me pongo una bolsa de hielo mientras hago mis abdominales. Ya consigo hacer 1.000. Después de quitarme el hielo, me aplico una loción limpiadora de poros. En la ducha utilizo un gel con espuma activada por agua. Luego, un jabón corporal limpiador de poros de miel y almendra, y para la cara un gel exfoliante. Luego, me aplico una mascarilla facial de hierbabuena y la dejo 10 minutos mientras sigo con el resto de mi rutina. Siempre utilizo un aftersave sin alcohol, o con poco alcohol, porque el alcohol te seca la cara y te hace parecer mayor. Luego crema hidratante, emulsión antiarrugas para los ojos y, al final, otra crema hidratante dermoprotectora. Existe la idea de que un tal Patrick Bateman es una especie de abstracción, porque yo no existo de verdad, sino sólo como ente, como algo ilusorio. Y aunque pueda ocultarte mi mirada fría, si me das la mano, notarás que mi carne roza la tuya. Incluso, tal vez es probable que intuyas que tenemos estilos de vida parecidos. Pero yo, sencillamente, no estoy ${ }^{8}$.

\footnotetext{
${ }^{8}$ American Psycho, Dir. Mary Harron, Universal Studios, 2000.
} 
En La estrategia de la ilusión (1999) ${ }^{9}$, Umberto Eco afirmó que la cultura del siglo XX se basaba en la imagen. Se trataba de una idea muy particular, que se alza sobre los conceptos de representación e interpretación. Eco mantiene que, por medio de las nuevas tecnologías, como el video, el fax, el ordenador... los individuos crean de sí mismos una idea completamente falsa porque está manipulada. Actualmente, en una fotografía uno puede ser más alto, más joven, más atractivo... Así que todo en ellas es apariencia y alteración. De este modo, el concepto de realidad se ve completamente alterado. La imagen real responde a una estética ilusoria de lo que uno desea representar. Es decir, que la imagen sería el espejo de la realidad deseada. Así, el todo verdadero se identifica con el todo falso, el todo ilusorio ${ }^{10}$. Pero esta idea ya había sido planteada con anterioridad por Jean Baudrillard en La transparencia del mal (1989). Baudrillard afirma que los medios de comunicación, y las incipientes tecnologías, han potenciado las falsas apariencias para acabar escondiendo la raquítica realidad. Esto favoreció el crecimiento de imágenes sin origen, imágenes sin huella, sin sombra, sin consecuencias $^{11}$. Estamos ante imágenes planas, sin ramificaciones hacia el futuro, ni raíces que las anclen a un pasado. Se presiente que detrás de cada una de ellas ha desaparecido algo, porque sólo son una fachada estética sin apenas consecuencias históricas. La imagen no es una representación verdadera de la realidad, sino que es una falsificación hiperreal. No estamos rodeados de realidad, sino de efectos de realidad, lo cual imposibilita llegar a la idea original.

\footnotetext{
${ }^{9}$ Umberto Eco, La estrategia de la ilusión, Barcelona, Lumen, 1986, pp. 17-19.

${ }^{10}$ Umberto Eco, op. cit., pp. 245-261.

11 Jean Baudrillard, La transparencia del mal. Ensayo sobre los fenómenos externos, Barcelona, Anagrama, 1991, pp. 43-66.
} 
El cuerpo, además de una imagen, es algo que nos imaginamos constantemente estableciendo sistemas de representación que lo expliquen. Desde esta perspectiva, la mujer es tanto más femenina, en tanto más lo que se espera de ella, cuanto menos ella es, cuanto más se acerca a una re-presentación, a la re-construcción de un yo real que le han enseñado (...). La feminidad se define a través de una relación especular con una imagen en la que es precisamente la propia mujer quien debe ser dueña de esta imagen, aun cuando tenga que someterse a la rigurosa disciplina de la reconstrucción de su cuerpo ${ }^{12}$.

A modo de crítica, la literatura y el arte del siglo XX intentan reflejar el problema que reside en una sociedad hedonista, consumista, hipermanierista, repetitiva, intransitiva, antiteológica y permisiva. Es una sociedad donde la ética ha sido sustituida por un relativismo absoluto, y sus seres están vacíos de contenido y se encuentran completamente entregados al dinero, al poder, al éxito y al gozo ilimitado sin restricciones. Son personajes que reinventan sus vidas mediante la falsificación descarada y la hiperevaluación del significante ${ }^{13}$.

Esta es la sociedad del espectáculo, también conocida como la feria de las vanidades. En ella el hombre light logra difuminarse y disolverse en una sociedad sin normas y sin límites ${ }^{14}$. Hablamos de una serie de personajes que, viviendo encerrados en su cotidianidad, aceptan los roles sociales de la gente con la que se rodean y viven enmascarados, encubiertos.

\footnotetext{
${ }^{12} \mathrm{M}^{\mathrm{a}}$ Carmen África Vidal Claramonte, op. cit., p. 58.

${ }^{13} \mathrm{M}^{\mathrm{a}}$ Carmen África Vidal Claramonte, op. cit., pp. 19-40.

${ }^{14}$ Enrique Rojas, El hombre light: una vida sin valores, Madrid, Temas de Hoy, 1998, pp. 111-115.
} 


\section{1.- La simulación o falsificación de la identidad femenina}

Para Lipovetsky, el siglo XX es herencia directa del siglo XIX. El cual era conocido como la era del vacío, donde comer no es nunca una necesidad, sino un acto social para dejarse ver. Dime con quién comes y te diré quién eres.

El dinero ya no sirve para comprar cosas, ahora nos permite acceder al right kind of life. Como resultado, podemos encontrar un sinfín de obras literarias en donde los protagonistas no se muestran como héroes ni heroínas, porque son individuos desorientados, sin norte por el cual guiarse. Son personajes perdidos ante la falta de una utopía o un sueño al que seguir ${ }^{15}$. Si focalizamos nuestra atención en las mujeres, veremos cómo los ideales femeninos también caen. Las protagonistas aparecen perdidas ante una sociedad que les pone trabas de todo tipo económico, social, amoroso, matrimonial... François Revel traslada el problema al ámbito social y, en su ensayo $E l$

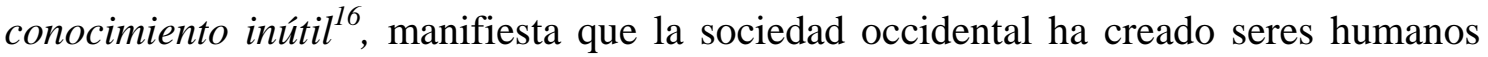
bien formados para desempeñar un papel meramente funcional y puntual en un trabajo cotidiano. Pero fuera del horario laboral, todos ellos parecen perdidos y sin ninguna función lógica que desempeñar.

En esta sociedad encontramos a mujeres inteligentes y eficaces. Pero, en su vida cotidiana, todas ellas viven a la sombra de los modelos paternalistas, y se rigen por la estricta funcionalidad del ideal femenino que se viene heredando desde hace siglos. En el siglo XIX, la mujer desempeña un trabajo mecánico y repetitivo durante toda su vida:

\footnotetext{
${ }^{15} \mathrm{M}^{\mathrm{a}}$ Carmen África Vidal Claramonte, op. cit., pp. 32-34.

${ }^{16}$ Jean-François Revel, El conocimiento inútil, Madrid, Espasa-Calpe. Ministerio de Educación y Ciencia, 1993.
} 
el cuidado de la familia. Ahora bien, toda su vida gira en torno a una función muy puntual: el matrimonio ventajoso ${ }^{17}$.

Todo gira a favor de este momento, y de él se desprende la idea de que el matrimonio es el símbolo de la estabilidad social. Pues a través de él se adquiere un status de por vida y, por lo tanto, el matrimonio en una forma de asumir los modos de autorrepresentación que se interpretarán durante toda la vida. No es lo mismo ser la esposa de un tendero, que la de un banquero, que la de un médico, que la de un comerciante... Todas ellas tienen hábitos de vida muy diferentes ${ }^{18}$. Pero de todas formas, el universo material que rodea a la esposa se caracteriza por la ausencia del origen. Es decir, todas ellas buscan representar el ideal de la perfecta casada. La mujer feliz que se encuentra realizada bajo la protección de su esposo. Realmente, se conciben como un conjunto de reflejos de un modelo imaginario, pero en diferentes estratos sociales.

Como consecuencia, en el campo artístico Deleuze rechaza la idea tradicional de la representación como mímesis, y se reafirma en el derecho al simulacro. ¿Por qué la copia ha de ser una versión degradada del original? ¿Por qué el original y el derivado no pueden ser series interiorizadas sin ningún tipo de jerarquía entre ellas? Ante estas teorías, Gilles Deleuze, en su Lógica del sentido (1989), propone la inversión del platonismo.

La semejanza subsiste, pero es producida como el efecto exterior del simulacro en cuanto que se construye sobre las series divergentes y las hace resonar. La identidad subsiste, pero es

\footnotetext{
${ }^{17} \mathrm{M}^{\mathrm{a}}$ Carmen África Vidal Claramonte, op. cit., p. 31.

${ }^{18}$ Más adelante, en el siglo XX, veremos cómo las marcas no se adquieren para facilitar el camino al éxito, sino que el hecho de vestirse con ellas implica haber obtenido el éxito. Así que los objetos dejan de medirse por su función y, comienzan a evaluarse por su tentador envoltorio. Este materialismo es el que comienza a perfilarse en todo el siglo XIX.
} 
producida como la ley que complica todas las series y las hace volver a todas sobre cada una en el curso del movimiento forzado ${ }^{19}$.

El ideal femenino se convierte en una máscara completamente plana. Tras ella se ocultan las féminas con sus auténticos ideales sociales y económicos. El dogma pierde su idea de centro y se convierte en pura estética representativa que sólo sirve para ocultar o atraer al esposo deseado ${ }^{20}$.

\section{2.- Sistemas de parentescos. Las oposiciones dentro del sistema sexual}

No es nada nuevo para el lector decir que la escritura suele estar vinculada al concepto de poder. Estamos acostumbrados a que todo lo que queda fijado por la escritura, queda legitimizado $^{21}$. Por ejemplo, las leyes no tienen valor alguno si no se escriben o, las enseñanzas médicas se olvidarían si no fuesen escritas en los tratados. La escritura tiene la facultad de dar el nivel de autoridad a quien escribe. Por lo tanto, la autoridad es la persona que tiene poder para escribir, o para dejar algo escrito. De este modo, el cuerpo descrito se convierte en un cuerpo fijado. Es un cuerpo canonizado con elementos reglados que marcarán o, más bien, servirán de medidor. A través de él se dirá si el resto de cuerpos son buenos o son malos. Por lo tanto, estamos presentando la actitud activa de quién lo presenta como un canon, y la pasividad de quién lo representa y lo asume. Ambos son dos discursos muy diferentes cuyos lugares de producción vienen determinados por los sistemas de presentación.

\footnotetext{
${ }^{19}$ Gilles Deleuze, La lógica del sentido, Barcelona, Paidós, 1989, pp. 263-234.

${ }^{20} \mathrm{M}^{\mathrm{a}}$ Carmen África Vidal Claramonte, op. cit., pp. 81-132.

${ }^{21} \mathrm{M}^{\mathrm{a}}$ Carmen África Vidal Claramonte, op. cit., pp. 43-46.
} 
El cuerpo reglado, o legitimizado, enmarca a cada uno de los individuos en funciones sexuales muy concretas. No es que los limite a ellas, pero sí ayuda a describir y diferenciar físicamente el cuerpo de un hombre y el de una mujer. Como consecuencia, la identidad de las personas se encuentra perfectamente ordenada y encajada dentro de un sistema sexual regulado. El resultado es un sinfín de leyes que determinan la correcta intervención de un cuerpo y de sus sistemas de significación. La propia experiencia de cada uno de sus cuerpos no sólo ayudará a remarcar las diferencias biológicas entre ambos, sino que además contribuirá a legitimizar a cada uno de los bandos ${ }^{22}$.

\subsection{1.- El orden lógico del poder político y social. El rol social}

Desde un punto de vista antropológico, el universo está formado por un conjunto de oposiciones. Se trata de un sistema de oposiciones donde el elemento catalizador es el binomio hombre/mujer. A partir de él, todo el cosmos aparece caracterizado como alto/bajo, arriba/bajo, delante/detrás, derecha/izquierda, recto/curvo... Asimismo, no se puede entender ninguna categoría por sí misma, ni tampoco la sexual. Normalmente, se apoyan en juegos prácticos o metafóricos de oposiciones. Todos ellos responden a un esquema del pensamiento universal registrable en los ciclos naturales y biológicos ${ }^{23}$.

Dentro de la categoría sexual de los individuos podemos diferenciar entre el carácter anatómico del cuerpo y el carácter biológico. Cuando nos referimos a este último, hacemos referencia al cuerpo en sí como representante de una realidad biológica. Digamos que, a través de él, diferenciamos entre sexos y funciones sexuales. Lo que vendría a considerarse bajo el sistema de oposiciones como activo/pasivo,

\footnotetext{
${ }^{22} \mathrm{M}^{\mathrm{a}}$ Carmen África Vidal Claramonte, op.cit., pp. 84-85.

${ }^{23}$ Pierre Bourdieu, La dominación masculina, Barcelona, Anagrama, 2007, p. 20.
} 
reposo/trabajo, recolección/gestación... ${ }^{24} \mathrm{Al}$ mismo tiempo, las diferencias anatómicas también marcan unas oposiciones muy interesantes entre ambos sexos: fuerte/débil, superioridad/inferioridad, independencia/dependencia...

Ambos sistemas, tanto el anatómico como el biológico, constituyen la categoría social y, por lo tanto, la interacción entre ambos. La diferencia que los separa nos ayuda a profundizar en la división de tareas: tareas del hogar/tareas de fuera de casa, tejer/traer comida a casa... ${ }^{25} \mathrm{El}$ orden social funciona como una máquina simbólica que ratifica la dominación masculina en la que se apoya la división sexual del trabajo, del espacio, de los momentos, de sus instrumentos y en cada una de las actividades asignadas a los diferentes $\operatorname{sexos}^{26}$.

\subsubsection{1.- La construcción social de los sexos}

Para poder entender la función de la gestación y del embarazo, los estudiosos se han remontado a la época de las poblaciones prehistóricas. Por supuesto, en aquella época no existen ni los matrimonios ni las relaciones de compromiso a largo plazo. Es un momento en que las funciones de los individuos estaban fuertemente marcadas por las diferencias anatómicas de los cuerpos. De esa forma, los hombres eran quiénes salían de caza para mantener a la población. En un período tan duro de la historia, el carácter de la supervivencia era elemental para comprender las relaciones entre hombres y mujeres.

Se cree que cuando los hombres volvían de caza compartían la carne con los más allegados, pero además ofrecían algo a la mujer con quien deseaban mantener relaciones

\footnotetext{
${ }^{24}$ Pierre Bourdieu, op. cit., p. 35.

${ }^{25}$ Isabel de la Cruz, op. cit., p. 149.

${ }^{26}$ Pierre Bourdieu, op. cit., p. 49.
} 
sexuales. Así pues, se ofrecía un intercambio simbólico de bienes. Por supuesto, las mujeres no ofrecían sus servicios al primer individuo que les ofrecía carne, sino que barajaban diferentes posibilidades y solían quedarse con el pretendiente que más carne, o mejor carne, les ofreciera. Pero, también es cierto que este tipo de relación implica que un hombre o una mujer pueden tener relaciones con más de una persona. Las mujeres, con el fin de almacenar el máximo posible de carne o de pieles, podían mantener relaciones con más de un hombre. Por otra parte, los hombres con el fin de repartir su simiente por el mundo, podían visitar a diferentes mujeres.

Pero, ahora bien, siguiendo esta teoría no se explica por qué un hombre una vez ha dejado embarazada a una mujer, sigue visitándola y ofreciéndole carne. Tal vez para asegurarse que el fruto de su simiente crezca sano y fuerte. Pero esto ya no encajaría en una relación de intercambio simbólico de bienes, pues el niño ya no tiene nada que ofrecer. Por lo que puede que entren en juego las relaciones afectivas de los individuos ${ }^{27}$.

\subsubsection{2.- Sistema patriarcal}

En la actualidad se explica que en las relaciones sexuales los agentes nunca se tratan de igual a igual. Estas son relaciones asimétricas en donde entran en juego determinadas funciones que caracterizan a las personas. Las oposiciones arriba/debajo y pasivo/activo son las que marcan las reglas generales del acto reproductivo. En ellas la afirmación viril viene caracterizada por la posición erguida y vertical, mientras que la sumisión femenina se define por la posición tumbada y horizontal. Ambas posiciones, no hacen otra cosa que remarcar la dominación masculina. Desde este punto de vista, para John

\footnotetext{
${ }^{27}$ Isabel de la Cruz, op. cit., pp. 150-154.
} 
Boswell $^{28}$, el acto de penetración está fuertemente relacionado con el acto de posesión, y por lo tanto, con el uso de poder masculino ${ }^{29}$.

Llegados a este punto, diferenciamos dos visiones del mismo problema. De acuerdo con Lyotard, Irigaray, Deleuze, Derrida y Foucault, consideramos el cuerpo como un objeto político donde actúan las relaciones de poder $^{30}$. Este mismo esquema, heredado socialmente, también plantea el abuso de poder. En estas circunstancias es cuando nace la otra parte del binomio: la resistencia, o tal vez debería decir la supervivencia. Ahora bien, estas son relaciones llevadas al extremo, pues dentro de un campo biológicamente sano podríamos decir que es muy importante que la mujer ceda simbólicamente a la penetración. Pues, aunque puede simbolizar que cede ante la autoridad, también simboliza que adquiere la protección que le ofrece el varón. Es entonces cuando la mujer asume voluntariamente la relación de dependencia guiada por un sentimiento afectivo o por intereses económicos.

Utilizando términos culturales podríamos hablar de aculturación y de asimilación. Con ambos vocablos explicamos la relación entre la cultura masculina dominante y la cultura femenina sometida, pero también añadiremos, que ambas parten de la experiencia individual. Es decir, cada persona crece y se forma bajo circunstancias sociales e inscripciones de los significados sociales muy diferentes. Es así como nos damos cuenta de que el cuerpo nos individualiza y nos da una perspectiva muy personal del mundo ${ }^{31}$.

\footnotetext{
${ }^{28}$ John Boswell (1947-1994) fue un importante escritor e historiador estadounidense que investigó acerca de la historia de las relaciones sexuales. Cabe destacar su obra Cristianismo, Tolerancia Social y Homosexualidad en el cual se observa cómo la Iglesia comienza a legitimar los sistemas de reproducción a partir del siglo XII. Hasta esta fecha existía un vacío en el que más o menos había una mayor tolerancia sexual.

${ }^{29}$ Pierre Bourdieu, op. cit., 2007, pp. 22-35.

${ }^{30} \mathrm{M}^{\mathrm{a}}$ Carmen África Vidal Claramonte, op. cit., p. 60.

${ }^{31} \mathrm{M}^{\mathrm{a}}$ Carmen África Vidal Claramonte, op. cit., pp. 46-47.
} 
Pero no sólo desde un punto el punto de vista de la oposición masculino/femenino, pues también la identidad de cada cuerpo femenino es único e intransferible, y cada mujer tiene su memoria y su experiencia particular ${ }^{32}$.

\subsection{2.- El sistema sexual en continuo cambio}

El sistema sexual viene constituido por dos términos que no podemos confundir: el sexo y el género. En primer lugar, diremos que el sexo es la categoría biológica que hace referencia a elementos de carácter orgánico diferenciales. Claro está, estas son características que están presentes en todas las especies animales y, según estas, podemos hablar de machos y de hembras. Ahora bien, cuando hablamos de género, hablamos de la construcción cultural que define el conjunto de rasgos de lo que se considera masculino y femenino en un momento histórico determinado. El sistema sexual engloba ambas expectativas, y una persona será socializada partiendo de las categorías sexuales y de género a las que se hayan adscrito.

El sistema sexo/género será el resultado de las normas que cada sociedad utiliza para transformar la sexualidad biológica en producto cultural. Pero resulta muy interesante que, de la definición que acabamos de dar de género, se derivan ciertas ideas, tales $\operatorname{como}^{33}:$

- Que el género es una construcción social que puede ser transformada. Es decir, que en cada sociedad se comprende el término mujer de diferente forma. Por ejemplo, no es lo mismo ser mujer en España, en los Emiratos Árabes, en China o en Angola. Cada una de ellas desempeñan roles sociales diferentes.

\footnotetext{
${ }^{32}$ George Grosz, Arte y sociedad, Buenos Aires, Calderón, 1990, pp. 120-122.

${ }^{33}$ Isabel de la Cruz, op. cit., pp. 150-153.
} 
- El género es una práctica social que involucra mucho más que la biología. Realmente, debemos de admitir que engloba todo el escenario reproductivo que va más allá de los meros aspectos biológicos o bioquímicos. Por ejemplo, el parto es un hecho biológico, pero la maternidad está relacionada con el embarazo y marca la relación madre-hijos, que es un hecho social, cultural e histórico. De hecho, el término buena madre no es igual ahora que hace cincuenta años.

- La asignación de un género estipula una serie de papeles o roles que ya están presescritos por la cultura del lugar y del tiempo en que se ha nacido. A la mujer y al hombre no les queda más remedio que asumir el conjunto de roles, las actitudes, las expectativas o los comportamientos que configuran la identidad de su propio género.

- Además, la identidad del individuo viene marcada también por la clase social a la que se pertenece o al grupo étnico de referencia. Es decir, dentro de un mismo país o ciudad, podemos diferenciar varias clases sociales y no todas ellas tienen las mismas relaciones culturales.

\subsubsection{1.- Género y desarrollo}

Hemos visto cómo las diferencias de género afectan a todas las mujeres en cualquier lugar y en cualquier tiempo. La ONU lo tuvo muy presente al estudiar el desarrollo femenino, y afirmó que la primera década del avance femenino fue la de los años 60 . Estas fechas tuvieron como base el crecimiento económico de las naciones, en el que los hombres son el principal motor y, las mujeres resultan invisibles bajo el supuesto de que sólo benefician al núcleo familiar. De esta forma no sólo se mantiene que su silencio beneficia al hombre, sino también a la propia mujer. Por supuesto, se trata de un sistema patriarcal, en donde las mujeres eran consideradas inferiores, tanto física como 
intelectualmente. Lo curioso es que la posición subordinada que ocupaban estaba más que justificada por determinados discursos institucionales como la educación.

La segunda década del desarrollo femenino se dio en los años de $70 \mathrm{y}$, en ella la mujer logra hacerse visible mediante un plan para satisfacer las necesidades básicas de la familia y de la comunidad. Por consiguiente, contribuye al crecimiento económico y al mecanismo de redistribución de la renta. Ahora la figura femenina no queda reducida a la intimidad del hogar porque se la considera agente económico activo, y se convierte en una figura públicamente reconocida de la familia. Es entonces cuando aparece el libro de Esther Boserup en donde se describe la marginación y discriminación de la mujer en las políticas de desarrollo debido a los estereotipos ${ }^{34}$. Aunque, también es cierto que no explica las causas de la desigualdad ni los cambios necesarios para superarlos. Pero ya es un avance para que 'el desarrollo femenino' se ponga en el punto de mira de muchos estudiosos $^{35}$

En 1980 la crisis económica mundial pone en marcha programas de ajuste estructural auspiciados por el Fondo Monetario Internacional. Estos programas de políticas ultraliberales conllevan la desaparición de los servicios sociales del estado. Y es así como las mujeres de clases sociales más pobres se ven abocadas a amortizar los efectos de los recortes en los sectores domésticos y económicos, con lo que conlleva la aparición de jornadas laborales dobles y triples. Tras la búsqueda de la feminización nace MED (Mujeres en el Desarrollo) ${ }^{36}$. Esta organización busca destacar cómo las áreas consideradas por tradición femeninas aumentan su productividad y mejoran su

\footnotetext{
${ }^{34}$ Esther Boserup, La mujer y el desarrollo económico, Madrid, Minerva, 1993.

${ }^{35}$ Isabel de la Cruz, ibídem, p. 161.

${ }^{36}$ Isabel de la Cruz, op.cit., pp. 165-168.
} 
economía. Su objetivo es aumentar al máximo la contribución económica de las mujeres, pero no erradican la subordinación ni la explotación ${ }^{37}$.

En 1985, con la celebración de la Tercera Conferencia Mundial de la Mujer en Nairobi (Kenya), tratan de integrar a las mujeres en el desarrollo político y de construir un nuevo modelo que tenga como objetivo el acceso de las mujeres al poder. Para ello, se hace hincapié en la mejora de la situación y en la mejora de la autoestima. Esto es lo que da lugar al nacimiento de la perspectiva GED (Género en el Desarrollo) ${ }^{38}$, cuya finalidad es buscar una perspectiva centrada en el análisis de las diferentes funciones, responsabilidades e intereses de los hombres y de las mujeres. Al mismo tiempo que ahondan en las relaciones de poder y conflictos existentes entre ambos.

En 1995, la Conferencia Mundial sobre las Mujeres celebrada en Beijing (China) concluyó con una declaración que reflejaba un acuerdo internacional sobre una estrategia para la igualdad de género. Además, también promovieron la creación de una plataforma para la acción ${ }^{39}$. Para la acción. Esto significaba que la mujer se ha preparado progresivamente para asumir responsabilidades políticas y sociales. Y lo que es más importante: es reconocida como autoridad con capacidad para ejercer el poder.

Esta evolución ha supuesto ir despojándose de las capas heredadas por el sistema paternalista. Poco a poco, se ha dejado de ver a la sociedad como un mecanismo de producción, y se ha comenzado a centrar la atención en la importancia de los fenómenos culturales que los propios individuos han fomentado. Se comenzó a hablar de la estructura cultural de las sociedades, que es muy diferente a la estructura económica.

\footnotetext{
${ }^{37}$ Isabel de la Cruz, ibídem, p. 161.

${ }^{38}$ Isabel de la Cruz, op.cit., pp. 169-171.

${ }^{39}$ Isabel de la Cruz, op. cit.., p. 163.
} 
Cuando hablamos de la estructura cultural, hacemos referencia a un conjunto de fenómenos observables y a un conjunto de fenómenos latentes pero no visibles. Deberíamos definir las relaciones entre hombres y mujeres como algo que depende de los actos sociales, y que responde a las reglas de creación y de interacción. Sólo al combinarlos entre sí sus elementos adquieren algún significado.

\subsection{3.- Las relaciones regladas del sistema de parentesco}

El sistema de parentesco es un modo de organizar las relaciones (...) es un sistema cultural donde se encuentra todo aquello que se espera de los parientes. Está basado en los hechos biológicos de la fecundación, la gestación y el parto, pero no seguidos de un modo mecánico sino ideológico. Es decir, que cada grupo hará una interpretación determinada de esas funciones biológicas. El sistema de parentesco no consiste en los lazos objetivos de filiación o consanguinidad dados entre los individuos; existe solamente en la conciencia de los hombres; es un sistema arbitrario de representaciones y no el desarrollo espontáneo de una situación de hechos ${ }^{40}$. Pero dentro de este tipo de relaciones podemos diferenciar entre: la relación de afinidad y la relación de filiación. Existen diferencias muy importantes entre ellas. Por un lado, la afinidad es la relación que se obtiene por vía del matrimonio. En cambio, la filiación es la relación de consanguinidad. En esta última es donde se ve con claridad el aspecto social y cultural del parentesco ${ }^{41}$. Pero, de todas formas, ambas, tanto la relación de afinidad como la relación de filiación, conforman el sistema de parentesco.

\footnotetext{
${ }^{40}$ Claude Lévi-Strauss, Las estructuras elementales del parentesco, Barcelona, Paidós, 1991, p. 121.

${ }^{41}$ Si nos damos cuenta se tiende a diferenciar entre pater (el padre biológico) y genitor (el padre social). Al mismo tiempo, también se diferencia entre mater (la madre biológica) y genitrix (la madre social).
} 
Para la antropología el estudio de los sistemas de parentesco es una manera universal de organizar las relaciones sociales. También tenemos que destacar que no se rige por reglas objetivas marcadas por el matrimonio, ni por las relaciones de consanguinidad. Pues, sinceramente, estas últimas tienen un carácter arbitrario muy importante, y sólo existen en la conciencia de los hombres. Si sólo nos centráramos en el aspecto biológico correríamos el riesgo de olvidarnos de estos elementos. Es verdad que el sistema de parentesco está basado en los hechos biológicos de la fecundidad, la gestación y el parto. Pero también entran en juego las relaciones afectivas que establecemos con personas ajenas a nuestra relación de consanguinidad. Pues muchas veces llamamos tía a una amiga de nuestra madre. Por lo tanto, el sistema de parentesco es un conjunto de vocablos que utilizamos para referirnos a nuestros parientes. Pero, al mismo tiempo, de la elección de cada uno de los términos de parentesco se desprende una serie de reglas que rigen la elección del vocablo. Según la mayor o menor cercanía que podamos tener con los miembros de la familia, utilizaremos una palabra u otra ${ }^{42}$.

\subsubsection{1.-Terminología y funciones de los términos}

Como he intentado explicar, si limitamos el sistema de parentesco a la función reproductiva, cometeremos errores de nominalización. Los términos del parentesco sirven para delimitar al amplio grupo social al que consideramos parientes, pero también utilizamos las mismas palabras para clasificar y designar a cada uno de los miembros. Esta clasificación nos ayuda a marcar las pautas de conducta, el comportamiento, actitudes y expectativas hacia los diferentes miembros familiares.Según las palabras que empleamos, existen dos sistemas diferentes. Uno de ellos es el sistema de parentesco descriptivo, donde cada pariente tiene un término

\footnotetext{
${ }^{42}$ Isabel de la Cruz, op. cit., pp. 121-123.
} 
específico que lo denota en función del puesto (o el lugar que ocupa dentro del parentesco). El otro es el sistema de parentesco clasificatorio, donde cada término pude hacer referencia a personas y a relaciones distintas. Teniendo en cuenta que todas las vías afectivas se han desarrollado paralelas a las relaciones de consanguinidad, nuestra sociedad ha fomentado un sistema de parentesco clasificador. El objetivo es que cada palabra pueda hacer referencia a una sola persona, pero, al mismo tiempo, ayudará a determinar qué tipo de relación mantenemos con él o ella. Por ejemplo, la tía es la hermana de mi padre, la hermana de mi madre, la esposa de mi tío, e incluso, la amiga de mi madre ${ }^{43}$.

De ahí que existan diferentes formas de organizar el parentesco ${ }^{44}$ :

A) Cognaticia, en donde es igual de importante la vía masculina que la femenina para establecer derechos y deberes.

B) Unilineal, donde las líneas de afiliación se establecen sólo a partir una línea. La de los varones recibe el nombre de patrilinealidad, y la de las mujeres matrilinealidad.

C) Sistema de doble filiación, en este sistema no todos los parientes cuentan igual. Es decir, no todos los parientes de mi padre o de mi madre son mis parientes, sólo son parientes aquellos que vienen marcados por la línea matrilineal o patrilineal en cada uno de los casos.

D) El linaje, cuando existe un antepasado común. Por ejemplo Abraham.

E) El clan vive en comunidad de la misma forma que el linaje, pero a diferencia de este no se puede demostrar la existencia de un antepasado.

\footnotetext{
${ }^{43}$ Isabel de la Cruz, op.cit., pp. 124-127.

${ }^{44}$ Isabel de la Cruz, op. cit., pp. 128-131.
} 
Como no podía ser de otro modo, el sistema patriarcal se alzó sobre las líneas de afiliación del varón: la patrilinealidad. Como herencia, seguimos conservando la importancia del apellido del padre sobre el de la madre. Sin embargo, hoy en día, asentimos sin reparos a que nuestra sociedad europea se confirme en la cognaticia.

\subsubsection{2.- El matrimonio}

Definir una institución tan antigua como el matrimonio no es fácil. Existen numerosas trabas de las que debemos desprendernos. Unas son las del incesto y de la exogamia ${ }^{45}$. Estas no sólo nos dificultan la tarea, sino que no nos dejan ver más allá del escándalo social. Pero, además, intentaremos dejar de lado todas aquellas críticas sociales y económicas que clasifican algunos matrimonios de meras "conveniencias" con el fin de ridiculizarlos.

Tras quitarnos estos prejuicios, diremos que el matrimonio es una relación socialmente aprobada entre un varón socialmente reconocido y una mujer socialmente reconocida, de tal modo que, los hijos nacidos de la esposa sean aceptados como la descendencia de ambos. Por supuesto, y no negaremos lo contrario, ésta es una definición pura y llanamente elitista. Pues de ella se desprende que existen personas que no están reconocidas socialmente y, en consecuencia, no tienen derecho al matrimonio. Edmund Leach hace una lista de las funciones que deben desempeñarse para que cada uno de los miembros de la pareja sea reconocida como miembro del matrimonio. En muchos lugares el matrimonio implica mucho más que la unión de los cónyugues ${ }^{46}$.

\footnotetext{
${ }^{45}$ La exogamia es el matrimonio fuera del grupo familiar, social o local, y el incesto es la relación sexual entre un hombre y una mujer pertenecientes a un mismo grupo de parientes. Ambos se comprenden como uniones que se dan fuera de las leyes propias de una sociedad, por lo que son tratadas como tabú.

${ }^{46}$ Isabel de la Cruz, op. cit., pp. 131-134.
} 
Para muchas personas el matrimonio es la unión corporativa de dos familias. Esto implica la unión de dos universos diferentes. Debemos entender a cada familia como una organización cerrada en sí misma, con sus propias relaciones sociales internas y externas, con sus correspondientes relaciones de poder, su economía, su cultura... Para todos ellos, el matrimonio implica una obertura, y el intento de acoplarse a los hábitos culturales de unos desconocidos ${ }^{47}$. La unión de ambas familias se solía plasmar con el intercambio de bienes y de servicios. Todo esto dio lugar a la compensación de la novia, el servicio del pretendiente o la dote ${ }^{48}$.

A) La compensación por la novia se produce cuando la familia del marido entrega a la familia de la novia bienes con un valor determinado. Dicho pago se puede hacer de golpe o por plazos. En este último caso, una parte se paga cuando se realiza el acuerdo, otra cuando la mujer va a vivir con el marido, y la última cuando se da el nacimiento del primer hijo de la pareja. Este tipo de relación gira alrededor de la prole; esto supone que si la mujer fuera esteril el acuerdo puede romperse. Estamos hablando de compensación de la novia, que no es lo mismo que el precio de la novia, porque, según las reglas de la economía de mercado no se trata de una compra-venta. El nuevo grupo no tiene la propiedad total de la mujer, por lo que si no es bien tratada puede reclamarla su propio grupo (aunque no sea fácil).

B) El servicio del pretendiente tiene lugar cuando el futuro esposo trabaja durante varios meses o años para el grupo de la mujer antes de llevársela. Es decir, trabaja lo que no puede pagar.

\footnotetext{
${ }^{47}$ Edmund Ronald Leach, Replanteamiento de la Antropología, Barcelona, Seix Barral, 1972, pp. 90-163.

${ }^{48}$ Isabel de la Cruz, op. cit., pp. 134-136.
} 
C) La dote. Al no trabajar, la mujer siempre ha sido considerada una carga, tanto para su familia como para el marido; por ello la familia del novio exige una compensación económica $^{49}$. Normalmente, esto ocurre en las clases sociales más bajas, pero no debemos confundirlo con el ajuar, pues este es solamente la ropa de cama.

\subsubsection{3.- Tipos de matrimonio}

Si realmente el matrimonio se trata de la unión de dos personas, de clanes o de familias completamente diferentes, también estamos hablando de la unión de dos mundos, de dos tradiciones o de dos formas de ser diferentes. Así pues, la unión de dos personas puede vivirse de maneras muy diferentes. No vamos a intentar clasificar todos los tipos de matrimonio que pueden existir, pero sí nombraremos algunos necesarios para clasificar a las mujeres que vamos a estudiar ${ }^{50}$ :

- El matrimonio monógamo es aquel formado por dos personas.

- El matrimonio polígamo es aquel que está formado por más de dos personas. Dentro de la poligamia diferenciamos entre: la poliginia cuando un hombre tiene varias mujeres, y la poliandria cuando una mujer tiene varios hombres.

- El matrimonio de grupo es la unión simultánea de varios hombres y varias mujeres.

- El matrimonio perspectivo es aquel que nos dice con quién debemos de contraer matrimonio. Esto se da normalmente dentro de determinados grupos sociales, como la monarquía.

\footnotetext{
${ }^{49}$ Aunque también es cierto que la dote femenina, a segura a la mujer un mínimo de bienestar económico. Pues muchos jóvenes de familias arruinadas buscaban esposas con una gran dote.

${ }^{50}$ Isabel de la Cruz, ibídem, pp. 137-139.
} 
- El matrimonio preferencial es aquel que nos dicen con quien sería deseable que nos casáramos.

- Después, tenemos el matrimonio levirato ${ }^{51}$. Es aquel que nos dice que si una persona enviuda debe casarse con el hermana/o del cónyuge fallecido.

Estas reglas ayudaron a consolidar el matrimonio como una institución y como la unión públicamente reconocida de dos personas. Pero, también tenemos diferentes reglas para clasificar los diferentes tipos de familia. No entraremos en estos detalles, pues lo que nos concierne es perfilar el ideal femenino que todas las jóvenes en edad de merecer pretendían representar: la perfecta casada o la esposa perfecta.

\section{3.- La mujer como sujeto. La mujer como objeto literario}

Existen temas en el mundo literario que además de ser canónicos en cierta cultura, son de por sí universales. Tal es el caso del amor, el odio, la venganza, la incomprensión, la locura... Todos ellos son universales no porque hablen de valores morales, sino porque se sostienen sobre los sentimientos de los personajes. Puede que una novela nos cuente la ficción más irreal que hayamos leído nunca, pero si reposa sobre los sentimientos, la lectura será tomada como verdadera. No en su historia, pero sí en su fondo. Trabajar sobre estos sentimientos consiguió la inmortalidad de obras como El collar de la paloma, Otelo, El rey Lear, El Quijote, Cárcel de Amor, La Celestina ... ${ }^{52}$ Nosotros nos centraremos en el tema del amor, y más concretamente, en el papel que ha ido ejerciendo la mujer en la pareja. Ya desde la Edad Media, la épica y las fábulas

\footnotetext{
${ }^{51}$ Este es el caso de Herodias, madre de Salomé, que al enviudar se casa con el hermano de su esposo, Herodes.

${ }^{52}$ Miguel Cereceda, El origen de la mujer sujeto, Madrid, Tecnos, pp. 27-28.
} 
moralistas definen el ideal de la esposa perfecta con fuertes rasgos de influencia mariana $^{53}$. Pero será más tarde, en el siglo XV, cuando se la exaltará o denigrará, según si se sigue la tradición femenina o la tradición misógina ${ }^{54}$.

\subsection{1.- Definición del sujeto desde el punto de vista masculino}

(...) cuando se enfrentan dos categorías humanas, cada una quiere imponer su soberanía a la otra: si las dos insisten en sostener esa reivindicación se crea en ellas, en la hostilidad, o en la amistad, pero siempre en la tensión, una relación de reciprocidad; si una de ellas es privilegiada triunfa sobre la otra y se dedica amantenerla en la opresión ${ }^{55}$.

Son muchos los estudios que han demostrado la opresión femenina en el campo sociológico, económico y político. De todos ellos vemos cómo los hombres han impuesto una clasificación de valores masculinos y femeninos. Para Simone de Beauvoir esta división responde a los deseos masculinos de crear un dominio femnino para mantener encerrada en él a la mujer ${ }^{56}$. Sin embargo, es interesante examinar como esa división ha servido para asentar un código amoroso que ha sobrevivido desde la Edad Media hasta nuestros días.

Jamás creación poética logró transformar de manera tan profunda la sensibilidad, los modales, las relaciones entre hombres y mujeres como la invención occidental del amor. Desde el siglo XII, el amor nunca ha dejado de ser celebrado, cantado e idealizado, ha inflamado el deseo y los corazones, ha remodelado las maneras del sery de obrar de los hombres mujeres, alimentando sus más locos sueños. Con la retórica del amor pasión se constituyó o sólo una

\footnotetext{
${ }^{53}$ Elena Gascón Vera, Un mito: la mujer como sujeto/objeto literario, Madrid, Pliegos, 1992, p. 235.

${ }^{54}$ Miguel Cereceda, op. cit., pp. 29-30.

${ }^{55}$ Simone de Beauvoir, op. cit., p. 125.

${ }^{56}$ Simone de Beauvoir, op. cit., p. 129.
} 
forma nueva de relaciones entre los sexos, sino una de las figuras más singulares de la aventura occidental moderna ${ }^{57}$.

Dentro del campo artístico, desde la Edad Media, una de las características más importantes es el reconocimiento de la grandeza del sentimiento del amante enamorado. Para observar el desarrollo de estos temas en la literatura española, se tendrá presente que tanto el amante como la amada se debaten entre varios códigos de conducta: el código del amor cortes y el código de caballerías. El hombre, por su parte, está completamente embelesado y muestra, sin reparo alguno, el amor desmedido que siente $^{58}$. A ella no le queda más remedio que mostrarse cruelmente indiferente. Este es un tipo ideal de mujer cruel e inaccesible que progresivamente se irá desarrollando.

Con toda seguridad, esto ya marca el destino trágico al que está abocada la relación. En cuanto a las formas de actuar, observamos que el amante considera a la dama perfecta, divina y prácticamente inalcanzable. Es un ángel en la tierra, es un suspiro divino hecho carne, y es por ello por lo que no podrá poseerla nunca. Pues si ella se deja arrastrar, este amor la igualaría al resto de las mujeres, por lo que sería imperfecta. Su perfección radica especialmente en la crueldad, la indiferencia y el rechazo. Así que el código del perfecto amante descansa en la esperanza. Esto le lleva a un amor frustrado (por la intensidad y el empeño), a la desesperación (por el dolor), y finalmente a la tragedia, porque es un amor obsesivo y autodestructivo ${ }^{59}$.

Por supuesto, la sátira, al igual que el amor cortés, reconoce la grandeza del sentimiento del amante, quien pese a la indiferencia luchará por acercarse más y más a la amada. Del mismo modo, también se dan varias razones en la sátira para justificar la crueldad y

\footnotetext{
${ }^{57}$ Gilles Lipovetsky, La tercera mujer, Barcelona, Anagrama, 1999, p. 15.

${ }^{58}$ Miguel Cereceda, op. cit., p. 32.

${ }^{59}$ Elena Gascón Vera, op. cit., pp. 241-243.
} 
la indiferencia de la amada ${ }^{60}$. Un ejemplo muy claro lo encontramos en Cárcel de amor de Diego de San Pedro, en donde se observa que la crueldad femenina es una máscara para defenderse del castigo social que caería sobre ella si diese sus favores a su amante. En este caso, el amante puede morir de amor con actitud aristocrática y elevada; pero si la mujer consiente será vituperada y condenada ${ }^{61}$. Por lo que a las féminas no les queda más que recubrirse de una máscara dura, inexpresiva y altiva ${ }^{62}$.

No descubrimos nada nuevo cuando decimos que en la sátira aparecen dos ideas con respecto a la amada: una positiva y otra negativa. En la positiva se hace una alabanza y una exaltación de la mujer como ser que ennoblece al hombre. Ella es su compañera, su otra mitad capaz de complementarlo y hacer de él un ser completo. Por el contrario, en la negativa se rechaza a la mujer porque produce una obsesión amorosa en el hombre. Lo malo es que esta obstinación lleva a la anulación de la voluntad y de la razón y, por consiguiente, a la destrucción del hombre. Este pierde todas las características propias de un noble caballero y se convierte en un mojigato, llorón y fácilmente ridiculizable por el autor.

Mientras tanto, el estereotipo de la perfección femenina ya había sido descrito por Alfonso X en Las Partidas. En ellas se dice que la esposa perfecta debía contar con un buen linaje, una belleza perfecta, una intachable lealtad, buenas maneras y riqueza. Pero todo esto se ya se daba por sentado, así que en la sátira los autores deciden darle otra

\footnotetext{
${ }^{60}$ Miguel Cereceda, op. cit., pp. 39-40.

${ }^{61}$ Elena Gascón Vera, op. cit., p. 246.

${ }^{62}$ Miguel Cereceda, op. cit., pp. 34-35.
} 
vuelta de tuerca a la figura femenina y reducirla a dos cualidades positivas (la belleza y la virtud) y a una cualidad negativa (la crueldad) ${ }^{63}$.

En Grissel y Mirabella de Juan de Flores la sátira tiene varias partes. En primer lugar encontramos la alabanza a la mujer con un elogio central, en donde se justifica la perfección femenina con una alabanza extremadamente hiperbólica. Realmente, se trata de una idea derivada del estoicismo en donde la gloria y la fama se consiguen a través de la virtud. Estos son dos alardes importantes capaces de mezclar dos dimensiones: las medievales y las renacentistas. En segundo lugar, debemos destacar el análisis que se hace de la belleza física femenina. Porque las facciones se describen de forma ordenada, pero van progresivamente clasificadas en la exaltación física. En tercer lugar, y por último, observamos que también existe un tipo de belleza interno. Algo que no tiene nada que ver con la gracia, el porte, la mirada o la charla. Son características morales que la elevan hacia la divinidad. De esta forma, la alabanza de la mujer se apoya en el elogio basado en virtudes morales, como las cristianas. Entre ellas distinguimos la Fortaleza, que siendo la más importante, ayuda a la mujer a defenderse contra los deseos y los peligros del amor. La mujer nunca debe de ser Piadosa, sino Indiferente con el amante. Para ello debe mediar con la Prudencia, la Justicia, la Templanza y la Virtud. Esta última la impedirá tener envidia o celos, y siempre se comportará con bondad $^{64}$.

Es característico en los libros de caballerías y en el código del amor cortés nombrar las siete virtudes cardinales, o también llamadas virtudes morales, y teologales. Con ellas se pretende probar que las mujeres las poseen, y que cumplen con el ideal femenino ${ }^{65}$. Pero

\footnotetext{
${ }^{63}$ Elena Gascón Vera, op. cit., p. 247.

${ }^{64}$ Elena Gascón Vera, op. cit., pp. 249-252.

${ }^{65}$ Miguel Cereceda, op. cit., p. 33.
} 
a pesar de su perfección física debe expresarse con moderación, ser discreta y moderarse en el vestir, en el mirar y en el hablar. Estos son cánones fijados del buen comportamiento. Todos ellos basados en el principio aristotélico de que la perfección está en la moderación y en la armonía de las partes. De este modo, la belleza es una síntesis de gracia y de hermosura basado en el equilibrio físico y moral.

Somos conscientes de que el hecho de ensalzar a la mujer como a una diosa es un acto de creación, de donde surge un individuo socialmente falso ${ }^{66}$. Y en segundo lugar, la defensa de la mujer sólo se plantea desde el punto de vista del enamorado. Es decir, desde el punto de vista masculino, para justificar sus sentimientos. Cuando más sublime sea el objeto amado, más se ensalza la nobleza y el espíritu del hombre enamorado. Por lo tanto, cuando se describe a la mujer en la literatura de caballerías, en el amor cortés o en la sátira, se está ennobleciendo indirectamente al hombre. Es así como se comprende el contraste que se da en las narraciones entre la exagerada hipérbole y la moderación de la dama. Se trata de un amor ideal lleno de ambigüedades y contradicciones. En el fondo tanta adoración hacia la amada sólo sirve para justificar la superioridad de las virtudes masculinas. Aunque se utilice la crueldad femenina, la mujer es comprendida como un espejo que refleja narcisístamente la figura del hombre ${ }^{67}$.

\subsubsection{1.- La figura femenina en el amor mundano}

Anteriormente hemos visto cómo algunos autores glorificaban a la mujer como si se tratara de una deidad. Completamente contrapuesto encontramos el punto de vista antifeminista. Es aquí donde situamos al Corbacho o El Libro del Arcipreste de

\footnotetext{
${ }^{66}$ Miguel Cereceda, op. cit., pp. 34-41.

${ }^{67}$ Elena Gascón Vera, op. cit., pp. 253-255.
} 
Talavera de Martinez de Toledo. En ambos vemos como se denigra el amor mundano, porque se defiende la teoría de que el único amor verdadero es el de Dios y, por lo tanto, la mujer no puede ser adorada como si de una deidad se tratase. Ella forma parte de la humanidad, y su amor es terrenal. Esto nos lleva a afirmar que alzarla a niveles celestiales implica el sacrilegio y un ataque al cristianismo. La crítica feroz que se hace a los hombres que se abandonan a ese amor está basada en dos ideas. Una es la tradición "De contemptu mundi", en donde se estudia la vanidad y brevedad del mundo material, frente a la felicidad que el hombre encuentra después de la muerte. Otra idea es que el mundo y todas las cosas que en él encontramos son vistos como la causa de la caída del hombre. Bajo esta perspectiva, la relación con la mujer es asimilada desde el pecado originario de Eva.

Este amor, que es capaz de arrastrar al hombre a la imperfección terrenal, parte de los principios descriptivos del amor cortés con la única intención de ridiculizar a la amada. ¿Cómo lo consiguen? Mediante una estructura perfectamente organizada y razonada. En el plano moral, vemos cómo toman la técnica de los sermones medievales, y dan un ejemplo de cómo el amor mundano destruye la paz y la felicidad de un hogar. Por ello, condenan a varios tipos de hombres: el sanguíneo, el colérico, el flemático y el melancólico. Sin embargo, la técnica para hablar de las mujeres no es muy diferente. Primero, critican la alabanza hiperbólica fruto de escritores idealistas que distorsionan la realidad y confunden la prudencia con la soberbia, la justicia con la vanidad, la fortaleza con la mentira, y la templanza con la depravación ${ }^{68}$.

En segundo lugar, critican el análisis de la belleza física pues, aunque es una descripción completa y rica en detalles, sólo se consigue un aspecto general y

\footnotetext{
${ }^{68}$ Elena Gascón Vera, op. cit., pp. 255-258.
} 
meramente abstracto. Además, se olvidan de sus defectos. Para subsanar este problema siguen los principios fijados por las retóricas medievales para describir viñetas cotidianas. Es entonces cuando los tópicos de la belleza femenina, tales como el color de la piel, la delgadez, el rostro, el cuello o los pechos son sustituidos por los de la fealdad. Como consecuencia, consiguen un aspecto grotesco. Lo que en la prosa sentimental es bello, ahora es monstruoso. Se trata de la técnica de la deformación que compara los rasgos mundanos con los rasgos de animales como el toro, la cabra y la cigüeña. Estos consiguen mantener la atención paródica y crítica para producir un efecto cómico. Este se basa en la rotura del sistema descriptivo esperado. Muestran el reflejo cóncavo de una dama que, creyéndose bella, es vista por los ojos envidiosos de sus compañeras.

En tercer lugar, y siguiendo la figura de la pecaminosa EVA, podemos llegar a la crítica del amor loco. Esta se basa en el aspecto moral. Desde el momento en que Eva escucha a la serpiente, se convierte en el punto de mira de todos los pecados. Es entonces cuando las mujeres se caracterizan por poseer todos los pecados y vicios existentes: la gula, la avaricia, la inconstancia, la desobediencia, la falsedad, la lujuria... Pero ellas encarnarán sobre todo la codicia, el ansia de poder y la soberbia. Estos últimos tienen que ver con el exceso: el exceso de poder, el exceso de materiales, el exceso de conocimientos... y será por este motivo por los que a Eva, a lo largo de toda la historia del cristianismo, se la relacione con los pecados que impliquen abundancia. Tal es el caso de la lujuria, que no es otra cosa que un amor desenfrenado cuyo único objetivo es el exceso de placer carnal. A consecuencia de ello, su tendencia al amor sensual las lleva a pecar y a empujar al hombre al amor mundano. Los pecados más domésticos 
como la desobediencia, la pereza o ser parlanchina son tratados en el Juez de los divorcios de Cervantes ${ }^{69}$.

\subsubsection{2.- La crítica del amor mundano}

Al poco tiempo comienzan a publicarse ciertas novelas que inician un debate. Tales son Grissel y Mirabella (1480) de Juan de Flores; Cárcel de Amor (1492) de Diego de San Pedro; Sátira de infelice e felice vida (1450) de don Pedro contestable de Portugal... En todas ellas se pone en duda que la dama sea auténticamente merecedora del gran amor que por ella profesan los varones. Para que ellas sean dignas de ese cariño, deben encarnar las siete virtudes. Las siete virtudes femeninas coinciden con las características del código de caballerías:

\section{El código de caballerías}

Fortaleza

Piadosa

Indiferencia

Prudencia

Justicia

Templanza

Virtud

\footnotetext{
${ }^{69}$ Elena Gascón Vera, op. cit., pp. 259-262.
} 
Todas ellas intentan dar fe de la perfección de la amada, aunque realmente estas virtudes no hacen otra cosa que reducir a la mujer a un objeto. Pero no se trata de un objeto cualquiera, es un objeto que si cumple con todas las virtudes alcanzaría el calificativo de divino. Por supuesto, esta técnica de exaltación no es nueva. Ya había sido utilizada anteriormente por Boccaccio en De claris mulieribus y por Christine de Pisan en Cité des dames. En ambos casos se tratan biografías de mujeres famosas basadas en información procedente de la Biblia, de Tito Livio, de Salustio, Valerio Máximo y de Séneca. También don Álvaro de Luna, inspirándose en la obra de Boccaccio, escribe en 1466 el Libro de las virtuosas e claras mujeres. En él, don Álvaro intenta liberar a la mujer actual de la pesada losa del pecado.

Llegados a este punto, tenemos que advertir que las características del código de caballerías se muestran completamente paralelas a las características del amor mundano. De esta forma, es mucho más fácil criticar a las féminas y mofarse de ellas.

\begin{tabular}{ll} 
El código de caballerías & El amor mundano \\
\hline Fortaleza & Debilidad \\
Piadad & Ateismo \\
Indiferencia & Atención/coquetería \\
Prudecia & Imprudencia \\
Justicia & Injusticia \\
Templanza & Inseguridad \\
Virtud & Pecado
\end{tabular}


Sin embargo, don Álvaro de Luna recupera ejemplos de las mujeres de la antigüedad para probar la excelencia y la dignidad de las presentes. Es así como manifiesta que las mujeres participan de las mismas condiciones humanas que el hombre y, por ello, no deben de ser culpadas por el pecado original.

También encontramos el Tratado en defensión de las virtuosas mujeres (1444) de Mosén Diego de Valera. En él se ataca ferozmente a la corte, porque para Diego de Valera, la mujer es pura por naturaleza, nace con la virtud de amar y de perdonar incondicionalmente, y sólo se corrompe debido al ámbito pernicioso en el que viven la nobleza y la aristocracia ${ }^{70}$.

\subsection{2.- Definición del sujeto desde el punto de vista femenino}

Siglos después de la consolidación del discurso paternalista, observamos que si articulamos la historia de la figura femenina bajo el esquema de la intertextualidad, lo que surgen son diferentes modelos pasivos. Pero no podemos olvidar que todos ellos responden al modelo de copia, calco y traslado ${ }^{71}$. En esta apropiación artística existe una traducción directa del modelo de dependencia, en el cual, ya originariamente, el escritor inventa la cultura femenina al mismo tiempo que la silencia. Podríamos decir que se trata de un proceso de aculturación ${ }^{72}$, en donde primitivamente la cultura masculina empezó imponiéndose política y socialmente a la femenina ${ }^{73}$.

\footnotetext{
${ }^{70}$ Elena Gascón Vera, op. cit., pp. 235-240.

${ }^{71}$ Elena Gascón Vera, op. cit., p. 63.

${ }^{72}$ José Lorite Mena, op. cit., p. 50.

${ }^{73}$ Linda McDowell, op. cit., pp. 262-266.
} 
Pero también es cierto que haríamos un flaco favor a las féminas si no reconociéramos que han ejercido una importante influencia en el sistema económico y cultural ${ }^{74}$. Desde este punto de vista, nos encontramos ante el proceso silencioso de transculturación. Este podría definirse a partir del hecho de que dos culturas diferentes entran en contacto y ambas sufren cambios por igual. Este proceso permite reconocer la apropiación creativa, en cuyos procesos se fundan elementos naturales y elementos culturales. Obviamente, el resultado no es una simple fusión, sino que se trata de un goteo cultural que nunca cesó. Ésta va más allá de la dependencia, incluye la mezcla del hombre y de la mujer. Es decir, que se apuesta por mantener vivas ciertas formas identitarias. Normalmente, la transculturación se da en tres niveles. En el de la lengua ${ }^{75}$, la estructura literaria ${ }^{76}$ y la cosmovisión de la recuperación de los mecanismos mentales que dibujan el mito, o también la recuperación de las estructuras cognitivas que forman el mito. Se tratan de movimientos oscilantes desde el interior hasta el exterior.

Ambas nociones se vieron fomentadas apenas iniciados los primeros años del siglo XX. El sociólogo George Simmel estimuló importantes debates dentro del movimiento feminista alemán de su época. En ellos manifestaba el carácter disimétrico y jerárquico de las relaciones sexuales que ocasionalmente se daban en términos de $\operatorname{poder}^{77}$.

El que el sexo masculino no sólo era relativamente superior al sexo femenino, sino que además se convierta en lo humano en general que regula las manifestaciones de lo masculino

\footnotetext{
${ }^{74}$ Linda McDowell, op. cit., p. 266.

${ }^{75}$ Se parte de la idea de que el lenguaje de una escritora aporta nociones importantes de género que un escritor no manifestaría.

${ }^{76}$ En donde las narraciones orales y populares se retoman para mantener resultados modernos.

${ }^{77}$ Georges Duby, Michelle Perrot, Historia de las mujeres en Occidente, Madrid, Taurus, T. 5, 1993, p. 292.
} 
particular y de lo femenino particular, se apoya, con diversas mediaciones, en la posición de fuerza de los hombres ${ }^{78}$.

En los años 20, el filósofo Ortega y Gasset dio a conocer a Simmel en España con su traducción de "Lo masculino y lo femenino" en la Revista de Occidente ${ }^{79}$. Estas teorías dieron pie a una serie de ideas feministas muy polémicas. Todas ellas representadas por Monique Wittig y Hélène Cixous, en las que intentan ofrecer una forma de escribir puramente femenina alejada de la dominación falo-céntrica ${ }^{80}$. En el fondo buscan crear la necesidad de una voz y una escritura distintas. Buscan que la escritora se desquite de todas las reglas que marcan la escritura canónica y varonil, para que representen plenamente a la mujer.

\subsubsection{1.- Teorías feministas moderadas}

Cuando una escritora describe a un personaje femenino se enfrenta ante su propia alteridad personal y cultural. Por el contrario, cuando describe al otro masculino, reafirma su propia identidad femenina. Pero antes de continuar, observamos que ambos puntos de vista parten de la idea del otro. El segundo sería el otro masculino y el primero el otro femenino. La cuestión es que la figura del otro responde ante todo a aquello que nos resulta extraño. Es decir, que es algo que no forma parte de nuestra propia identidad $^{81}$. Así pues, el hecho de que una escritora describa a una figura

\footnotetext{
${ }^{78}$ Régis Debray, Le Pouvoir intellectuel en France, París, Ramsay, 1979, Folio, Gallimard, p. 247.

${ }^{79}$ Georges Duby, Michelle Perrot, op. cit., p. 293.

${ }^{80}$ Elena Gascón Vera, op. cit., p. 61.

${ }^{81}$ Andrés Piqueras, "La identidad” en Isabel de la Cruz (Coord.), Introducción a la antropología para la intervención social, Valencia, Tirant lo Blanch, 2000, pp. 42-45.
} 
femenina implica la creación de una figura exterior que debe encarnar una identidad objetiva $^{82}$.

Para describir a la mujer se inaugura un nuevo lenguaje y, a partir de él, se trabaja la imagen femenina como algo completamente nuevo. Algo que sólo la escritora ha visto y el lector desconoce. No se puede optar por un "no tengo palabras". El lector se enfrenta a algo desconocido hasta ahora, y acude atónito a la reestructuración femenina mediante nuevos procesos de significación. El objetivo de las escritoras es describir una esencia silenciada. La posible solución pasaría por medir a la fémina con lo que el espectador ya conoce. En consecuencia, las características femeninas versarán sobre comparaciones de cosas ya conocidas. Se buscarán términos familiares cuya función es codificar a la mujer. Así trabajaran en varios tópicos literarios:

- La representación paradisíaca viene dada por el mismo término que caracterizó a Eva: el de la abundancia. El paraíso será el exceso de la naturaleza.

- La intertextualidad se da a través de varias fábulas y mitos.

- Los paisajes cultos, bucólicos y bíblicos, eran paisajes edénicos en donde se ve la relación directa entre la pureza y la naturaleza. Esta es la misma que hay entre la relación Adán-Eva, en donde la inocencia y la felicidad vienen ligadas a la imagen del hombre y la mujer desnudos.

- La mezcla de lo fabuloso y lo real. Esta característica es originaria de las novelas de caballerías y de las crónicas de viajes. En ellas se inicita a la

\footnotetext{
${ }^{82}$ Por supuesto, cada cultura diseña sus propios otros, donde suelen confluir estereotipos, terrores e ilusiones.
} 
hazaña y a la aventura. Pero a ello contribuyen los elementos de ficción que se filtran en los textos como "los hombres o mujeres monstruo".

\subsubsection{1.- Hélène Cixous}

A partir de su obra La escritura femenina, Hélène Cixousse se dedica a la búsqueda de una nueva voz que logre definir la figura femenina completamente desvinculada del punto de vista masculino. Pero no será hasta 1976 cuando Hélène publica La risa de la $M e d u s a^{83}$. Es en esta obra donde la autora manifiesta que los hombres y las mujeres son diferentes biológicamente, por lo que sexualmente deben ser descritos de forma distinta. Pero además, el discurso debe expresar esta diferencia. Para Hélène Cixous la escritura debe partir desde los cuerpos de las protagonistas y liberar su inconsciente, para conseguir sacarlas del silencio. Cixous replantea el cuerpo femenino como unidad cohesiva en una metáfora cósmica, pero esta unidad también puede ser concebida por partes. Pues cada uno de estos fragmentos está capacitado para crear una escritura propia. Tal es el caso del pecho, de la vagina (a través de los fluidos), del vientre (como fuente de la maternidad), de la cabeza... todos ellos con pensamientos propios imposibles de controlar.

Hélène Cixous comienza a explorar el determinismo biológico de las féminas y, llega a la conclusión, de que la maternidad se presentaba como algo natural e innato en la mujer, pero realmente se contrapone a su libertad. Asegura que la maternidad ha sido un concepto utilizado por el hombre para ejercer una presión y un dominio hacia la mujer. Por ello, mantienen que se trata de la manipulación de unos términos que encubren la ignorancia de las características propias de la gestación. Partiendo de estas dudas e

\footnotetext{
${ }^{83}$ Otras mujeres importantes en esta cuestión fueron Luce Irigaray y Julia Kristeva.
} 
incógnitas, Cixous busca la definición real de mujer. Así pues, a su entender, la escritura femenina es o debe ser una reproducción metafórica de su cuerpo y de su libido. Con ello se logra una voz femenina mediante juegos de palabras, aliteraciones multilingües y multiculturales con los que plasma la universalidad femenina de su discurso ${ }^{84}$.

\subsubsection{2.- Monique Wittig}

Monique Wittig reúsa crear una escritura femenina porque eso significa mantener la diferencia tradicional entre el hombre y la mujer. Intenta a toda costa eliminar este eterno paralelismo, por lo que trabaja el cuerpo femenino como idea central en su obra sin ningún tipo de referente. Para ello intentará despojarse de todas las metáforas que se han creado alrededor de la mujer. Pues, bajo su punto de vista, todas ellas se han convertido en un supermito creado por el pensamiento falo-céntrico. Para conseguir su objetivo, Monique Wittig elimina todas las imágenes sexuales impuestas sobre el cuerpo femenino, e intenta recuperar la idea del cuerpo intacto porque la mirada masculina lo ha fragmentado y fetichado.

En este desmembramiento se representan todas las partes deseables, no sólo las ensalzadas por el discurso masculino como son: el cuello, los ojos, la boca, las piernas, los pechos... sino también las repugnantes: los mocos, el pus, los excrementos, la bilis... De esta forma, se ve que tanto lo atractivo como lo repugnante es deseable y, se intenta dibujar un cuerpo íntegro, deseable y completamente, alejado de los estereotipos

\footnotetext{
${ }^{84}$ Elena Gascón Vera, op. cit., pp. 64-67.
} 
masculinos. Bajo estas premisas Wittig publica en 1973 El cuerpo lesbiano, donde la autora desmiembra y reconstruye el cuerpo de su amante ${ }^{85}$.

\subsubsection{3.- Esther Tusquets}

Esther Tusquets intenta crear en sus novelas una forma de escribir distinta al discurso tradicional masculino. Sus protagonistas, ya sean esposas o madres, buscan continuamente el amor y la comunicación con el hombre. Pero sólo encuentran la falacia del discurso masculino dominante que las utilizó, las sedujo y excluyó de su propio mundo. Son mujeres que a través del desengaño buscan su propia identidad mediante la comunicación y participación con el amante. Esto le lleva a trabajar desde dos frentes diferentes. Un frente es el masculino y su incapacidad para comprender la sensibilidad femenina. El otro es el frente femenino, en donde vemos cómo sus personajes intentan liberarse de la opresión y de la presión mediante el amor y la sexualidad.

Cuando Esther Tusquets menciona que las protagonistas femeninas buscan en el amor y en el sexo la posibilidad de realizarse personalmente, es porque sus chicas se auto conciben como un ser que engendra. Un ser capaz de crear vida debido a su función específica dada por su situación de mujer. Pero, a causa de su desilusión amorosa, se ven incapaces de continuar su vida en pareja. Por lo que rechazan el mundo erótico masculino y, como consecuencia, se sienten libres del sentimiento de opresión.

Simbólicamente, su gran personaje es Eva en la novela Varada. En esta novela podemos encontrar un marcadísimo erotismo femenino que debe sobreentenderse a través del

\footnotetext{
${ }^{85}$ Elena Gascón Vera, ibíem, pp. 67-69.
} 
silencio forzoso que ha sufrido. Para abolir este silencio Esther cuenta con una escritura sin abstracciones, ni símbolos. Tiene un estilo directo y familiar, lleno de coloquialismos, modismos y culturalismos ${ }^{86}$.

\subsubsection{4.- Rosa Montero}

Crónica del desamor (1979) se ha catalogado como un libro de inflexión en la carrera de Rosa Montero. En él las mujeres logran realizarse profesional y afectivamente sin la presencia de los hombres, porque son más independientes y autónomas. Pero para Montero, el problema de las mujeres es que son incapaces de prescindir de los hombres, a pesar de la desilusión, de la violencia y de la tristeza que les causan. Por lo que, paradójica y compulsivamente sienten una necesidad sensual/sexual de anular su autonomía y doblegarse a la campaña destructiva del hombre. Esta necesidad irracional está fijada en una cultura falocéntrica, en donde la mujer asume el papel tradicional de de servir y cuidar al hombre. Sin embargo, los hombres aparecen como personajes débiles y egoístas incapaces de comprender las circunstancias físicas y económicas de las mujeres. Estamos ante un modelo que las somete y anula, porque les imposibilita la plena realización sexual. La sexualidad femenina se encuentra completamente deslindada de la masculina, pues es mucho más compleja e indeterminada, ya que se encuentra anclada en los deseos de la maternidad.

Sus protagonistas son mujeres que siguen esperando al príncipe azul, pero sólo consiguen la anulación de su propia personalidad. En consecuencia, se observa que la realidad masculina es un modelo completamente opuesto a la mujer. Rosa Montero, a

\footnotetext{
${ }^{86}$ Elena Gascón Vera, op. cit., pp. 70-72.
} 
diferencia de Wittig, mantiene que la presencia masculina no debe ser descrita en las novelas a través de la sensibilidad femenina.

El hombre representa lo contraio a la naturaleza femenina, se percibe como el enemigo al que hay que atacar. La idea de la pareja heterosexual satisfactoria aparece visualmente como imposible para Montero, pues no se realiza de forma completa para ambos. Su actitud negativa hacia la pareja está más cerca de las teorías lesbianas de Wittig, ya que mantiene que las mujeres están atrapadas en su feminidad frustrada y que las lleva al rechazo y a la soledad ${ }^{87}$.

\subsubsection{5.- Rosario Ferré}

En su ensaño Sitio a Eros: Quince ensayos literarios (1987) Rosario Ferré revisa conceptos culturales, antropológicos y psicológicos. Esto les lleva a cuestionar los términos femenino y género y, gracias a ello, busca un lenguaje con el que las mujeres puedan definirse a través de él. Está en línea de Simone de Beauvoir, de Kate Miller, de Adrianne Rich, de Robin Morgan y de Dorothy Dinnerstein, quienes revisaron las teorías patriarcales de Freud y Marcuse. Su lenguaje gira alrededor de dos temas. Uno es el amor natural de toda mujer, el que la caracterizan en su dimensión sensible la ternura, la entrega, la generosidad y la relación afectiva ${ }^{88}$. El segundo tema es la maternidad. Ésta es algo natural y propio del cuerpo femenino, pero además, se añade la idea de que la sociedad patriarcal no duda en frustrar continuamente a la mujer embarazada como mujer creadora de algo extraordinario. Así que, desde el sistema paternalista, el acto de parir se ve con completa naturalidad. En su ensayo

\footnotetext{
${ }^{87}$ Elena Gascón Vera, op. cit., pp. 77-87.

${ }^{88}$ Elena Gascón Vera, op. cit., p. 99-103.
} 
"Frankensttein: una versión política del mito de la maternidad", Ferré se opone a este punto de vista y manifiesta que la maternidad es una fuerza creadora. La sociedad todavía no exalta la felicidad, la satisfacción, la fuerza ni el poder que tiene la creación de otro ser. Para estas feministas es muy importante dar a conocer la unión que existe entre el cuerpo y la mente durante el proceso creativo de un ser vivo. Las mujeres no deben avergonzarse de su función reproductora. Así lo cita Rosario Ferré en Sitio a Eros:

Somos nosotras las que gestamos a los hijos y las que los damos a la luz, las que los alimentamos y nos ocupamos de su supervivencia. Este destino que nos impone la naturaleza nos coarta..., pero también nos pone en contacto con las misteriosas fuerzas generadoras de la vida $^{89}$.

Este último tema es el que caracteriza el lenguaje de Rosario Ferré, es la dialéctica de la libertad de elección, expresión, creatividad, de posibilidad de transformación y de regeneración. Ferré se une a las múltiples escritoras que hablan como esposa, madre, amantes o compañeras de ideologías, pero también como individuos subyugados, ignorados, malentendidos y despreciados por la cultura dominada por los hombres ${ }^{90}$. Partiendo de este sentimiento, Ferré mantiene que las mujeres deben escribir para reinventarse $e^{91}$ :

La mujer debe escribir para reinventarse, para disipar su temor a la pérdida y a la muerte, para enfrentarse cada día al esfuerzo que representa vivir (...). Como todo artista, en fin, la mujer

\footnotetext{
${ }^{89}$ Elena Gascón Vera, op. cit., p. 104.

${ }^{90}$ Tal es el caso de Mary Shelley, Anaïs Nin, George Sand, Sylvia Plath, Julia de Burgos, Lilian Hellman, Virginia Wolf, Jean Rhys, Flora Tristan, Alexandra Kollontai y Tina Modotti.

${ }^{91}$ Esto coincide con las teorías feministas norteamericanas de Adriene Rich, Mary Daly y Robin Morgan, quienes creen que el "eros femenino" se expresa como una fuerza vital basada en los sentimientos privados de la maternidad, de entrega, de análisis y de pasión. Así rompen los dualismos entre la naturaleza y la cultura, entre el yo y el otro. Aceptan las contradicciones del ser como la única forma real y auténtica del ser y del devenir. Para más información ver Adriene Rich, The Dream of a Common Languages: Poems 1974-1977.
} 
escribe como puede, no como quiere, ni debe. Si le es necesario hacerlo rabiando y amando, riendo y llorando, con resentimiento e irracionalidad, al borde mismo de la locura y de la tridentina estética, lo importante es que lo haga, lo importante es que siga escribiendo ${ }^{92}$.

\subsection{3.- La mujer como sujeto ficcional}

Antaño todo acto relacionado con la escritura estaba vinculado al poder. Por supuesto, no todo el mundo sabía leer ni escribir, y todo el mundo que podía hacerlo no sólo tenía el poder de nombrar, sino también de dejarlo por escrito ${ }^{93}$. Este carácter siempre recayó en el papel varonil, pues es bien sabido que se negaba el acceso de la mujer a la educación. Lo que intento decir es que la descripción legal, social y política de la mujer pasaba por la escritura de los hombres ${ }^{94}$. A través de la letra se legitimizó la posición de subordinación de la mujer, y se dio poder al hombre para imaginarla e inventarla ${ }^{95}$. Desde el punto de vista del canon literario el hombre se asentó como figura de poder, ya que en sus manos recaía la responsabilidad de alzar a la mujer o de denigrarla. Ya se trate de una imagen ficcional o real, el lenguaje lograba establecer una relación de subordinación en donde el hombre escribía y la mujer era silenciada.

El hombre reacciona a todas las preguntas con el pensamiento, la mujer reacciona con el sentimiento. Todo lo cual le lleva a la conclusión de que la mujer no sólo está excluida de los

\footnotetext{
${ }^{92}$ Elena Gascón Vera, ibídem, p. 104.

${ }^{93}$ Irene Lozano Domingo, Lenguaje femenino, lenguaje masculino. ¿Condiciona nuestro sexo la forma de hablar?, Madrid, Minerva, 1995, p. 127.

${ }^{94}$ José Lorite Mena, El orden femenino. Origen de un simulacro cultural, Barcelona, Anthropos, 1987, p. 83.

${ }^{95}$ Irene Lozano Domingo, op. cit., p. 20.
} 
atlas lingüísticos, sino prácticamente del lenguaje en general, que Dios ha creado para el varón ${ }^{96}$.

Hoy en día, en pleno siglo XXI, sería un tanto extraño seguir manteniendo estas teorías. No es que el canon se haya llenado de escritoras, pero si es cierto que estas han aumentado en número y, ahora, queda desubicado hablar de mujeres silenciadas tras una pluma varonil. Así que nos encontraremos con autores heterogéneos con poder para inventar a cada uno de sus personajes y al mundo que le rodea. Como consecuencia, el presente estudio se centra sólo en el personaje descrito, independientemente del género y de los ideales de autor.

Desde un punto de vista narrativo nos encontramos a una mujer que no tiene por qué responder al paradigma real, aunque sí es cierto que se hace eco de este. Siguiendo el esquema de Ángel Rama, llamaremos a esta figura la mujer pensada o la mujer ficcional $^{97}$. Es decir una mujer que no existe, que se da sólo en la mente del escritor y del lector. Realmente, es una mujer idealizada e inventada que, a partir de la combinación de diferentes discursos, busca producir un efecto de verosimilitud ${ }^{98}$. Para ello, el lenguaje literario intentará materializar y legitimizar a la mujer en su correspondiente campo social y político. Por lo que estaríamos ante una figura inscrita en una geografía social determinada, una mujer legalmente inscrita en el campo o en la ciudad, y en una clase social concreta. Para conseguirlo, el escritor/a se hará eco de las

\footnotetext{
${ }^{96}$ Irene Lozano Domingo, op. cit., p. 83.

97 Ángel Rama, Ciudad letrada, Montevideo, Arca, 1998, pp. 1-5.

${ }^{98}$ José Lorite Mena, op. cit., p. 95.
} 
formas en que la ley logra materializar y legalizar la figura femenina, y esto se consigue por medio de tres modelos de orden ${ }^{99}$.

Primero, asentar las normas para el acto de nombrar. Aquí se buscan descripciones canónicas con respecto a los lugares donde viven, donde trabajan, la familia que forman... etc. En segundo lugar, se las describe mediante los actos que las definen como mujeres; estos se perfilan como ritos perfectamente codificados que dan una justificación jurídica y social:

La hembra se "mujeriza" con la capacidad para crear y utilizar un espacio objetival articulado significativamente en palabras, al mismo tiempo que queda incluida, adquiere realidad, en ese espacio (...). La mujer es la posicionada, es llamada a existir socialmente, en el ámbito de las palabras-situaciones que la circunscriben como sujeto con relación a determinados objetos en acciones precisas ${ }^{100}$.

Y por último, y en tercer lugar, tenemos el plan simbólico, en donde se desarrollan diferentes tipos de metáforas que ponen en circulación principios ideológicos.

\subsubsection{1.- La mujer como identidad desdibujada}

Todas las imágenes femeninas que se dan en el mundo literario están sostenidas por un doble discurso: por una parte la ficción y, por otra parte, los elementos que la avalen y la hagan creíble. Para conseguir el efecto de verosimilitud los escritores, ya sean hombres o mujeres, trabajan sobre esquemas de estabilidad social. Es decir que, limitados por los recursos literarios, describen la identidad femenina basada en aspectos

\footnotetext{
${ }^{99}$ José Lorite Mena, op. cit., pp. 69-130.

${ }^{100}$ José Lorite Mena, op. cit., pp. 95-96.
} 
sociales y jurídicos. El objetivo es perfilar imágenes reales dentro de la ficción, que al mismo tiempo, son reconocibles y accesibles para el lector.

Por consiguiente, la identidad femenina es algo nacido del discurso, de una imagen discursiva creada e inventada. Estos relatos están articulados discursivamente para definir qué es lo femenino y obtener campos de subordinación. No obstante, no son imágenes aisladas, sino que nacen tras solapar figuras canónicas ya creadas antaño. De hecho, a las mujeres nunca se las describe como algo nuevo, pues en el fondo, lo que se hace es dibujar constantemente sus límites sociales, políticos y económicos. Límites definidos a través del saber y del poder del autor/a. Aún así, son características que se alzan sobre otras ya creadas anteriormente. Ya sea como ruptura o como continuación de lo anterior, asistimos a la creación de una imagen que nace solapada a su predecesora. Los personajes femeninos del siglo $\mathrm{XX}$ no han cambiado, sino que se constituyen a través de una reescritura. De esta forma, resulta imposible llegar al modelo originario, pues estamos ante ideas que se enriquecen unas a otras.

De ahí, que encontremos tantos conceptos relacionados con la identidad femenina. Porque todos ellos parten de una misma piedra angular: la contraposición entre mujer/hombre. Esta es la oposición sobre la que cada una de las generaciones marcará sus límites sin eliminar los que también han heredado. Naturaleza/razón, barbarie/civilización, luz/oscuridad, intimidad/público...

\subsubsection{2.-La cultura femenina fragmentada}

A causa de la variedad de imágenes fijadas por un canon, la identidad femenina no es algo fácil de definir. No es una esencia total y unificadora, sino que, se vislumbra como una especie de cuerpo fragmentado e imaginado a partir de diferentes relatos que ha 
dado la historia. Para superar ideológicamente la fragmentación y llegar a una idea originaria articularé y superpondré los textos canónicos. Sólo así podremos ver algunos puntos comunes que hay entre las imágenes canónicas ${ }^{101}$. Estos puntos nos ayudarán a comprender y a recuperar ideas muy antiguas, que aunque hayan evolucionado mediante la representación de elementos modernos, su sombra sigue presente en la actualidad. Esto nos llevará a afirmar que muchas imágenes modernas siguen basándose en la imitación y en la dependencia de los modelos arcaicos. En conclusión, todos estos modelos sólo nos ofrecen imitaciones y falsas definiciones de mujer ${ }^{102}$.

De todos ellos se desprende una autoridad que se alza sobre los pilares de su sabiduría. Toda una institución constituida por y para sostener al que se autoinstala en la cima. De forma que, desde su superioridad el varón juzga al inferior como su contrario. Es entonces cuando, surgen oposiciones metafóricas que ayudan a justificar su superioridad. Pero no es más que una falsa erudición nacida de la inseguridad y de la subjetividad tanto masculina como femenina. Es una erudición que procede del texto inventado y del almacenamiento en bibliotecas y viejos archivos. Estos darán lugar al poder artificial que ostenta el escrito/a.

Desde este punto de vista no tiene sentido la oposición entre civilización/razón o barbarie/naturaleza, porque estas son falsas metáforas que no ofrecen ningún tipo de información acerca de la identidad femenina, sino que sólo nos informan sobre el aprendizaje de los modelos femeninos anteriores.

\footnotetext{
${ }^{101}$ Linda McDowell, Género, identidad y lugar. Un estudio de las geografías femeninas, Madrid, Cátedra, Universidad de Valencia, Instituto de la Mujer, 2000, pp. 79-88.

${ }^{102}$ Linda McDowell, op. cit., pp. 111-144.
} 


\subsubsection{3.- La intertextualidad remarca la ficcionalidad del texto}

Muchas veces detrás de una descripción hay un trabajo documental. Es decir que toda novela que reescribe una figura femenina se remonta a fuentes clásicas, medievales y mitológicas. Pero estas imágenes quedarían obsoletas para el lector si no se le sumaran rasgos de novelas, temporalmente, más próximas al lector. Estos son elementos culturales propios de la época que se superponen para dar lugar a la construcción del personaje femenino. Así nos encontramos ante fragmentos novelísticos que parecen contestarse o complementarse unos a otros. Un ejemplo muy claro lo encontramos en la evolución textual que se ha hado de la figura de Salomé, pues ya en la Biblia, la joven aparece caracterizada de forma muy sencilla, pero posteriormente, bajo la pluma de Oscar Wilde se enriquecerá cargándola de erotismo:

SALOMÉ.- ¡Jokanaan! Estoy prendada de tu cuerpo, Jokanaan. Tu cuerpo es blanco como las azucenas del campo, nunca tocadas de la hoz. Tu cuerpo es blanco como la nieve de las montañas de Judea. Las rosas del jardín de la reina de Arabia no son tan blancas como tu cuerpo; ni las rosas del jardín de la reina de Arabia, ni los pies de la aurora en la cepeda, ni el seno de la luna sobre el mar, nada en el mundo es tan blanco como tu cuerpo. ¡Déjame que toque ese cuerpo tuyo!

JOKANAAN.- ¡Atrás hija de Babilonia! Por mediación de la mujer vino el mal a este mundo. No me hables. No quiero oírte. Yo sólo escucho la voz del Señor, mi Dios.

SALOMÉ.- Tu cuerpo es horrible. Es como un cuerpo leproso. Es como un muro blanqueado, en el que anida áspides; como un muro enjalbegado, donde los escorpiones hicieron nido. Es como un sepulcro blanqueado lleno de cosas repulsivas. Espantoso es tu cuerpo, hediondo. Yo estoy prendada de tus guedejas, Jokanaan. Tu pelo es como racimos de uvas, como racimos de garnachas en los lagares de Edom. Tu pelo es como los cedros, los corpulentos cedros del Líbano que brindan sombra a los leones y a los bandoleros. Las largas y negras noches, en que se oculta la luna tiemblan las estrellas, no son tan negras como tus cabellos. El silencio de las selvas... Nada en el mundo es tan negro como tu pelo. ¡Déjame que toque ese pelo tuyo! 
JOKANAAN.- Atrás, hija de Sodoma. ¿No me toques!¡No profanes el templo del Señor, mi Dios!

SALOMÉ.- Tu pelo es hediondo. Está áspero del polvo y desaseo. Es como una corona de espinas puesta en tu cabeza. Es como una serpiente enroscada a tu cuello. No me gusta tu pelo. (Con un tono muy apasionado). Lo que me seduce es tu boca. Tu boca es como una banderola escarlata izada en una torre de marfil. Es como una granada, partida con cuchillo de plata. Las flores del granado en los jardines de Tiro, más encendidas que rosas no son tan encarnadas. Las bermejas fanfarrias de los clarines que anuncian la llegada de los reyes y cuyos sones hacen temblar al enemigo, no son tan rojas como tu roja boca. Tu boca es más bermeja que las plantas de los hombres que vendimian el mosto en los lagares. Más encarnada es que las patitas de los palomos, que anidan en el templo al cuidado de los sacerdotes. Más roja que el que torna de la selva, de matar leones y luchar con tigres dorados. Tu boca es como un ramo de coral en la penumbra de los mares que el pescador saca de lo hondo y guarda para el potentado; como la púrpura en las minas de Moab, la púrpura de los reyes. Es como el arco del rey de Persia, pintado de rojo y adornado con cuernos de coral. (Enajenada.) Nada en el mundo es tan rojo como tu boca. Déjame que te la bese.

JOKANAAN.- (Quedo, con un escalofrío.).- Nunca, hija de Babilonia, hija de Sodoma... Nunca $^{103}$.

Desde este punto de vista, escribir es leer y releer. Es robar parte de otras escrituras para combinarlas y encontrarles un nuevo sentido. Pero, la escritura en sí misma, es para reflexionar sobre la historia y cómo se han escrito históricamente algunos de los textos. Esta es una manera de traer el pasado al presente, y de actualizar a los clásicos, porque mediante la lectura del presente se puede mostrar la construcción del pasado. No importa que la intertextualidad se realice a partir de textos ficticios, cosmográficos o históricos. Ya que lo importante no es cuál de todos esos textos mezclados prevalece, sino ver cuál es el eje hegemónico que surge. De ahí, el papel activo del lector, pues es

${ }^{103}$ Oscar Wilde, Salomé, Madrid, Biblioteca Nueva, 2000, pp. 34-35. 
67 | La femme fatale en la publicidad del siglo XX

él quién lo construye mediante su lectura. Pero, aún así, seguimos ante una presencia femenina caracterizada por estar vacía, y que espera ser comprendida según los parámetros culturales con los que el lector se enfrente a la lectura. Por ende la identidad femenina se encuentra a la espera de ser dibujada por la predisposición que aporte el lector. En consecuencia, la identidad femenina es una idea en construcción continua. 


\title{
2.- Organización político-social del cuerpo femenino
}

La realidad está tejida de ficciones. La ficción trabaja con la creencia y en este sentido conduce a la ideología, a los modelos convencionales de realidad y por supuesto también a las convenciones que hacen verdadero (o ficción) a un texto.

Ricardo Piglia Crítica y ficción

\begin{abstract}
This is a work of fiction. All of the characters, incidents, and dialogue, except for incidental references to public figures, products, or services, are imaginary and are not intended to refer to any living persons or to disparage any company's products or services
\end{abstract}

Bret Easton Ellis American Psycho

Las imágenes literarias que se dan de los personajes femeninos se sostienen sobre un doble discurso. Por un lado, tenemos la parte ficcional o ilusoria y, por otra, tenemos los elementos verídicos que la avalan y la hacen creíble. El presente capítulo tiene la intención de analizar los elementos que constituyen la verosimilitud de las féminas. Pues si la ficción recaía sobre el desenfreno sexual de las protagonistas, los elementos reales recaen sobre el género y sus aledaños.

Los estudios de los últimos treinta años demuestran que todo tema vinculado al género está cubierto por la pesadez de la costumbre. Pero, al mismo tiempo, este aparece protegido por la legislación de la época. Al encontrar razones de peso en el discurso religioso y en el médico, el sistema legal decide acotar la libertad de la mujer. Históricamente, la mujer aparece limitada a una función muy concreta: el matrimonio. 
Efectivamente, a nivel político durante el siglo XVIII y XIX, existen importantes preocupaciones demográficas que se alzaban sobre las alarmas que emitían el magistrado, el clero, las parroquias, los municipios y los médicos. Todos ellos defienden el matrimonio como el reflejo de los auténticos valores que debe mostrar una sociedad. Realmente, estas afirmaciones destilan el miedo que las autoridades tenían por la pérdida del control del cuerpo y su sexualidad. Esto condujo al presente estudio a indagar en las prácticas sexuales del siglo XVIII y XIX. Periodo en el que las autoridades oficiales publicaron escritos en donde ponían entredicho el control del individuo sobre su propio cuerpo y su sexualidad. Por este motivo, todos ellos libraron una larga batalla contra la transgresión o desviación de las conductas sexuales. Para ello utilizaron estrategias flexibles, no para castigar, sino para recuperar unas conductas morales que, bajo su punto de vista, eran las adecuadas y se encontraban dentro de la norma $^{104}$.

\section{1.- Iniciaciones sexuales y ritos del cortejo. Adolescencia y juventud}

Desde el último tercio del siglo XIX hasta la primera mitad del siglo $\mathrm{XX}$, se defiende que la sexualidad femenina se basa en la inexistencia del deseo. Durante este periodo: el liberalismo, el capitalismo, la ciencia, la iglesia... consiguieron legitimizar el buen comportamiento de las damas burguesas y aristocráticas. Un ejemplo muy claro lo encontramos a través del médico anglosajón William Acton, quien afirma que la sexualidad femenina se llena con la procreación y la vida doméstica ${ }^{105}$.

\footnotetext{
${ }^{104}$ Alain Corbin, Historia del cuerpo, Madrid, Taurus, 2005, vol. I, pp. 167-170.

${ }^{105}$ Isabel Morant, Historia de las mujeres del siglo XIX a los umbrales del XX, Madrid, Cátedra, 2006, vol. III, pp. 181-183.
} 
Se comprende que el sentimiento primordial que debe ocupar el corazón de una mujer es la ternura, y nunca la pasión. El llamado ángel del hogar será una especie de sacerdotisa dedicada en exclusiva al culto de la familia. Pero, en especial a las figuras varoniles: el padre, el esposo, los hijos... Desde muy niñas, las muchachas asumen el papel de la mujer decente, en donde su función principal es la protección de la moralidad del hogar. De esta manera, el discurso médico también contribuyó en la definición de true womanhood ${ }^{106}$. Dentro del tema de la sexualidad, esta nos ayuda a diferenciar el sexo legítimo y el sexo ilegítimo ${ }^{107}$. La sexualidad legítima no se limitaba sólo al matrimonio, porque, aunque, nos encontramos en una sociedad muy controlada, los y las jóvenes podían acceder a diversas prácticas sexuales ${ }^{108}$. Estas solían cambiar de forma significativa según si el individuo se movía en un ámbito urbano o en un ámbito rural. No obstante, nunca fueron bien vistas por las autoridades ni por la comunidad, pero sí es cierto que fueron toleradas tanto en chicos como en chicas dependiendo de la $\operatorname{edad}^{109}$.

\subsection{1.- Sociabilizar a los jóvenes: cofradías y cencerradas}

Tanto en la ciudad como en el campo, los chicos recibían formación profesional lejos de casa. Muchos predicadores se preocupaban por los jóvenes adolescentes que andaban

\footnotetext{
${ }^{106}$ Georges Duby, Michelle Perrot, op. cit., p. 355.

${ }^{107}$ Alain Corbin, op. cit., vol. I, p. 169.

${ }^{108}$ Michel Perrot, "El elogio del ama de casa en el discurso de los obreros franceses del siglo XIX", (en) James S. Amelang, Mary Nash, Historia y género. Las mujeres en la Europa Moderna y Contemporánea, Valencia, Ed. Alfons el Magnánim. Institució Valenciana d’Estudis i Investigació, 1990, pp. 241-249.

${ }^{109}$ Alain Corbin, op. cit., vol. I, pp. 167-182.
} 
por la ciudad sin control paterno ${ }^{110}$, pues se creía que eran una presa muy fácil para los sodomitas o las prostitutas. Así que para evitar posibles desórdenes sociales y morales, las parroquias constituyen grupos de jóvenes. Estas eran cofradías religiosas y seglares, hermandades, congregaciones o bachillerías, cuyo origen se remonta hasta el siglo XV. Todas ellas evitaban que los jóvenes alterasen en las calles y ayudaban a guiarles hacia actividades organizadas: procesiones religiosas, obras de teatro, juegos, mascaradas (como la de Carnaval) ... Estas asociaciones de jóvenes buscaban canalizar la transformación de los adolescentes montaraces en hombres guardianes de las costumbres públicas y privadas. Estas agrupaciones encarnaban los valores sociales de la madurez ${ }^{111}$.

Ahora bien, el caso de las muchachas adolescentes no era tan diferente. En los albores del siglo XX, nos encontramos con que, por un lado, los médicos afirmaban que la sexualidad femenina sólo se activaba para cumplir la función reproductiva y, por otro lado, vemos cómo las autoridades religiosas encargaban a sus pintores cuadros de la Virgen. Es bien cierto que, los cuadros religiosos a finales del siglo XIX comienzan a escasear, pero aún así la imagen más repetida fue la Inmaculada Concepción. Hinterhäuser mantiene que este culto a la Virgen contribuyó a crear la imagen de mujer ideal, pues, la Virgen María se convirtió en el modelo que todas las mujeres debían seguir. Su referente de pureza y de castidad formaba una educación moral que la enraizaba con el cuidado familiar ${ }^{112} \ldots$ A nivel teórico, esto se convierte en una

\footnotetext{
${ }^{110}$ En 1424, un predicador destinado en la Iglesia de la Santa Croce llamado Bernardino de Siena denunciaba estas situaciones y culpaba a los padres por ser incapaces de controlar a sus hijos. Para más información consultar: Michael Rocke, "Sodomite in fifteenth century Tuscany: the views of Bernardino of Siena", en Kent Gerard y Gert Hekma, The Pursuit of sodomy: Male Homosexuality in Renaissance and Enlightenment Europe, New York - Londres, Harrington Park Press, 1989, pp. 7-31.

${ }^{111}$ Alain Corbin, op. cit., vol. I, pp. 171-172.

${ }^{112}$ Isabel Morant, op. cit., vol. III, pp. 184-192.
} 
complicada etiqueta de conducta que limita severamente su libertad. Pero, a nivel práctico, las jóvenes contaban con bastante libertad, tanto en la ciudad como en el campo. Sobre todo durante los ritos y fiestas paganas, bailes, cuadrillas y contradanzas ${ }^{113}$. Durante estos festejos, a las jóvenes les resultaba bastante fácil escabullirse del control paterno. Sin embargo, la presión psicológica de la etiqueta les hacía temerosas de causar una mancha en el apellido familiar. A diferencia de los varones, lo correcto para una señorita es que no tuviera ningún tipo de experiencia ${ }^{114}$. Ellas debían de llegar completamente ignorantes al matrimonio ${ }^{115}$. Hay que advertir que los hombres tampoco recibían formación sexual, pero adquirían experiencia con criadas, dependientas, modistillas...

\subsection{2.- Rituales de seducción y prácticas prenupciales}

En este apartado definiremos al matrimonio como la forma de consolidar los bienes materiales de la familia y, de hacerlos perdurar lo máximo posible para mantener económicamente a todos los miembros familiares. Bajo esta premisa, la elección de un futuro conyugue es muy seria, y debe tomarse con calma. Muchas familiar hacían uso del mediador para llevar a buen puerto su tarea. El mediador era la persona contratada para evaluar el estatus social y las perspectivas financieras del posible candidato.

\footnotetext{
${ }^{113}$ Georges Duby, op. cit., pp. 358-359.

${ }^{114}$ Madaleine Pelletier cuenta en sus memorias que en la primavera de 1886 sale de la escuela muy angustiada porque la monja le había reñido por llevar la falda manchada de sangre. Al llegar a casa, asustada Madaleine le hace preguntas a su madre, pero ella se niega a responderle. Fue su padre, mediante frases muy brutas, quién se sentó con ella para darle de una sola vez toda la educación sexual. Este es un pequeño ejemplo que nos ayuda a ver cómo entre las mujeres no se transmitía ningún conocimiento sexual, por lo que muchas llegaban ignorantes hasta la víspera de la boda.

${ }^{115}$ Isabel Morant, op. cit., vol. III, p. 196.
} 
Antes del cortejo amoroso existían juegos y contactos supervisados para coquetear. Estos se centraban en fechas tan señaladas como San Valentín, El Carnaval, las Fiestas del mes de Mayo, la celebración de san Juan y las relacionadas con la Cosecha. Estos eran vistos como un pasatiempo para filtrear antes de pasar al cortejo amoroso. Pero la progresión de la intimidad, el afecto y los favores físicos se daban de diferentes formas.

Por ejemplo, si nos centramos en las clases sociales acomodadas podemos observar que existen dos modos de cortejo diferentes. El primero gira alrededor de la legitimación conyugal, en donde la familia del chico o chica elige a un cónyuge con la ayuda de un mediador. Ambas familias se reúnen y dejan fijadas las cuestiones económicas. A partir de ese momento, el futuro matrimonio tiene autorización para verse con la finalidad de aceptarse uno al otro. Si nadie pone objeciones, el matrimonio puede llevarse a cabo. En el segundo caso, la iniciativa la podría tener el joven cuando se sentía interesado por una muchacha vista en algún lugar público como la iglesia, el baile o alguna fiesta. El chico solía pedirle permiso a la familia para cortejarla; como es lógico el beneplácito se le daba después de que la familia hubiera investigado al candidato. Entonces comenzaba el cortejo con todos sus ritos correspondientes: visitas, conversaciones íntimas, cartas de amor, expresiones de cariño y devoción ${ }^{116}$. El alto estatus social en el que vivían estas parejas les permitía verse a solas en la corte, balnearios, cacerías y bailes. En donde, escapando a todo tipo de vigilancia, podían mantener en secreto sus relaciones. En este caso las cuestiones económicas y las propiedades inmobiliarias se trataban en la última fase del cortejo ${ }^{117}$. Uno de los riesgos de este tipo de matrimonio concertado es que podía romperse si la familia de alguno de los pretendientes se arruinaba durante el transcurso del noviazgo.

\footnotetext{
${ }^{116}$ Alain Corbin, ibídem, vol. I, pp. 174-176.

${ }^{117}$ Detalles que se gestionaban con la ayuda de un notario.
} 
Amelia, que estaba en el piso de arriba muy nerviosa, al oír la campanilla que reclamaba el burdeos pensó que aquel sonido presagiaba algo aciago y misterioso. La gente que tiene muchos presentimientos siempre acaba por acertar alguno.

- Lo que deseo saber, George -dijo mister Osborne cuando saborearon el primer vaso-, es cómo anda tus asuntos con... esa chica que se encuentra arriba.

- Me parece, señor que está bien claro -respondió George con una mueca de satisfacción-. Salta a la vista... ¡Excelente vino!

- ¿Qué quiere decir con eso de salta a la vista?

- ¡Pero, por Dios, señor, no me apure demasiado! Soy un hombre algo tímido. No me ha educado para convertirme en verdugo de una mujer; aunque hay que reconocer que ella me ama con locura. Eso lo ve cualquiera con los ojos cerrados.

- ¿Y tú a ella?

- Pero, señor, ¿no me ordenó usted que nos casáramos? Soy un hijo obediente. ¿No está arreglado el matrimonio desde hace un tiempo?

$(\ldots)$

- No lo niego, pero la posición de la gente cambia. No negaré que Sedley labró mi fortuna, mejor dicho, me puso en condiciones de llegar, con mi capacidad y mi trabajo, a la envidiable situación que ocupo en el mercado del sebo y en la city. Ya he dado pruebas suficientes de mi agradecimiento a Sedley, como refleja mi talonario de cheques. Te digo en confianza, Georges, que no me gusta el cariz que están tomando los negocios de mister Sedley. A mi secretario, mister Chopper, tampoco le gusta, y es un gato viejo que conoce la Bolsa como nadie en Londres. Hulker \& Bullock lo miran de reojo. Lo que temo es que se haya metido en negocios por su cuenta. Dicen que el Jeune Amélie, capturado por el corsario yankee Molasses, era suyo. Y, lisa y llanamente, mientras no vea yo las diez mil libras esterlinas de Amelia, no te casarás 
con ella. No quiero en mi casa a la hija de un hombre arruinado. Pásame el vino, o llama para que nos sirvan el café ${ }^{118}$.

Los pasos seguidos por las clases medias eran un poco diferentes. En Inglaterra existía la night courysh o bundling ${ }^{119}$, y en Francia recibía en nombre de maraichinage o albergement. Esta era una antigua costumbre que permitía al novio pernoctar en la residencia de la joven con o sin el consentimiento de los padres. La pareja podía conversar frente a la chimenea, en la habitación de la joven o en la misma cama. Esta práctica se regía por convenciones estrictas por lo que el embarazo era muy raro ${ }^{120}$. A menudo eran denunciados como matrimonios a prueba, en donde las frecuentaciones nocturnas permiten a los jóvenes explorar sus compatibilidades físicas, emocionales, e incluso la fertilidad de la pareja ${ }^{121}$.

Pero, sin lugar a dudas, todo este tipo de coqueteo resultaba ser un problema para salvaguardar la pureza de la joven. Pues ¿dónde estaban los límites exactos? ¿Hasta dónde llegaban las fronteras del arreglo? Traspasar esta línea significaba adentrarse en el país de las coquetas, frívolas y presumidas. Un territorio escabroso y muy complicado para salir. Muchas de ellas no se casaban, porque los jóvenes temían la vanidad que las caracterizaba y que las podía arrastrar a la lujuria propia de las malgastadoras ${ }^{122}$. Por estas razones Copus Barga llega a afirmar que la carrera de una señorita casadera

\footnotetext{
${ }^{118}$ William M. Thackeray, La feria de las vanidades, Barcelona, Debolsillo, 2011, pp. 177-180.

${ }^{119}$ Alain Corbin, op. cit., vol. I, p. 175.

${ }^{120}$ Esto era muy común desde en Italia hasta en Suecia y Rusia.

${ }^{121}$ El magistrado bordelés, Jean d’Arreac describe esta práctica como la más extraña costumbre del mundo.

${ }^{122}$ Además es que una vez satisfecho su gusto por el lujo se temía que acabaran en manos de un amante. Tal es el caso de Madame Bovary de Gustave Faubert.
} 
presentaba más dificultades y sorpresas que la de un ingeniero de Caminos o de $\operatorname{Minas}^{123}$.

\subsection{3.- Iniciaciones y aprendizaje sexual}

El matrimonio era el único locus oficialmente autorizado de la sexualidad y, el único medio para conseguirlo era la iglesia católica o la protestante. Sin embargo, existían otros medios no legítimos para iniciarse en la sexualidad. Pero, ¿qué tipo de experiencias sexuales podían tener los jóvenes antes del matrimonio? Normalmente, las casas contaban con una o dos habitaciones donde convivían familias enteras. De esta forma, los dormitorios y las camas eran compartidos por los padres, los hijos y los criados. Inevitablemente, los niños se veían expuestos a la actividad sexual de los adultos. Por lo que, desde la Edad Media hasta el siglo XIX, la mayoría de la población convivía con un concepto de promiscuidad permanente ${ }^{124}$. La intimidad sexual era imposible. Los hijos crecían viendo y oyendo el acto físico del coito. Los padres y los recién casados vivían juntos, y las miradas indiscretas eran inevitables. Paradójicamente los únicos lugares en donde se podía conseguir un poco de intimidad, eran los espacios públicos: graneros, tabernas, burdeles o habitaciones alquiladas. E incluso también, al aire libre: campos, prados, parques urbanos o callejones oscuros.

Focalizando nuestra atención en los varones, afirmaremos que existen infinidad de memorias aristocráticas llenas de anécdotas acerca de la iniciación sexual de los niños. Los hijos crecían observando la figura del pater familias. Esta era una figura autoritaria que se mostraba como un ejemplo a seguir por los jóvenes varones de la casa. Su

\footnotetext{
${ }^{123}$ Isabel Morant, op. cit., vol. III, p. 198.

${ }^{124}$ En 1681 Monseñor Le Camus, obispo de Grenoble, lo denuncia.
} 
función era cuidar y proteger a todos los que vivían bajo su techo. Pero el señor de la casa también tenía derecho a explotar el cuerpo de las personas que vivían con él, incluso el de sus criados. Por lo que algunos padres exigían a sus empleados el derecho al trabajo físico y a los favores sexuales. Esto marca una relación de superioridad entre los señores varones de la casa y las criadas. Una relación que los niños aprenden como algo natural. Como resultado, muchos de los niños de las clases altas tuvieron sus primeras relaciones sexuales a una edad muy temprana con la criada. Este tema alcanzó tanta fama que se convirtió en un topos literario. Este recurso literario cuenta con dos figuras femeninas muy diferentes. Primero, se nos cuenta la historia de cómo un niño perdía la inocencia aún a riesgo de contraer una enfermedad venérea o desarrollar un gusto precoz por la lujuria, lo cual convertía a la criada en una figura agresiva y peligrosa. En segundo lugar, nos encontraremos con la idea de que muchos niños, al llegar a una edad adulta, toman conciencia del poder legal que asumían en el núcleo familiar y, ahora, la criada deja de ser la agresora para convertirse en la víctima.

Es interesante señalar que los chicos también gozaban del privilegio de El Grand Tour. Este era un viaje que se presentaba como una experiencia necesaria para la formación cultural de los hijos de las élites. Pero también se esperaba que los jóvenes tuvieran ocasión de iniciarse sexualmente. La nobleza inglesa optaba por Paris para introducirse desde en la danza hasta en la esgrima o desde en la arquitectura hasta en las artes plásticas. En este tipo de viajes, se bebía, se jugaba y se frecuentaba a prostitutas. E incluso, estaban permitidas las relaciones de muchachos adolescentes con esposas casadas. En realidad, ésta última era una práctica sexual segura, porque los posibles hijos nacidos de estas relaciones eran fácilmente atribuibles al marido. En cambio, otros chicos con costumbres turbulentas recurrían a las violaciones y, lo que era más común, a 
las violaciones colectivas. Normalmente, se aprovechaban de que la víctima era de un estatus social inferior, la mayoría de las veces era una criada que volvía sola a casa ${ }^{125}$.

Aunque las autoridades no lo viesen bien, los hombres estaban autorizados a experimentar los placeres antes del matrimonio. Así que estas faltas eran subsanadas con el pago de una multa. Sin embargo, a las mujeres se las obligaba a conservar su virginidad hasta el día de la boda. La relación sexual se le presentaba como un peligro que abría dos posibles males: el embarazo ilegítimo y la pobreza. Pero, como podría pasar mucho tiempo hasta que una pareja se casaba, las familias y los párrocos imponían una unión conyugal para evitar la humillación de un embarazo durante el cortejo. Pero lo más curioso es que se esperaba que la esposa siguiera siendo santa después de estar casada. Así que, en ningún caso, la mujer podía verse dominada por el deseo. Lo que significaba que la sexualidad conyugal se limitaba a cumplir los deseos del marido en aras de la maternidad conyugal. El pudor, el recato y la modestia se consideraron cualidades esenciales en una mujer que ni siquiera podía perderlas en la intimidad. Se definía a la mujer como un ser sin apetitos sexuales. Lo cual tranquilizaba al marido, porque su carácter asexuado aseguraba que no producía exigencias en su conducta $^{126}$. Esta negación era tan general que, cuando en las novelas se habla del amante de la esposa, se especifica con claridad que se trata de una relación pueril en donde el amante es tratado como un niño puro. Tal fue el caso de Connie, la protagonista de El amante de Lady Chatterley de D. H. Laurence, El yerno del señor manzano de Carbou y Martín; Consuelo de López de Ayala y Salón de Moda.

\footnotetext{
${ }^{125}$ Alain Corbin, op. cit., vol. I, pp. 178-182.

${ }^{126}$ Isabel Morant, op. cit., vol. III, p. 198.
} 


\section{2.- El matrimonio y sus aledaños}

En el siglo XIX las aventuras extraconyugales, la seducción y las violaciones eran bastante más frecuentes de lo que indican los archivos judiciales. En consecuencia, la sexualidad es un tema que tiene a los médicos y a los religiosos muy preocupados. Ambas instituciones apuestan por el matrimonio como un medio de procreación responsable ${ }^{127}$. La sexualidad conyugal se caracterizará por unos parámetros de normalidad que fijará el clero y los médicos.

El clero defenderá el bienestar del alma y las relaciones honestas alejadas del pecado. En este tipo de relación normalizada, la esposa tiene que mostrarse agradable al marido. Pero, su atractivo también tiene unos límites reglados, porque se entendía que la mujer puede ejercer una imperiosa lujuria sobre el hombre. Como esto no era deseable se le repite una y otra vez que la pasión turba el matrimonio. La responsabilidad del marido era mantener la castidad de su mujer, y no obligarla a actuar contra su naturaleza de madre, porque si no la actitud varonil podría tener siniestras consecuencias. Tal es el caso de Angustias en la novela Miedo al hombre de Frontaura ${ }^{128}$.

En el siglo XIX, el clero manifiesta que el espacio privado $^{129}$ está ordenado por la dicotomía alma/cuerpo. Estas afirmaciones también estaban respaldadas por el discurso médico. En este último campo nos encontramos con el doctor Russell quien, junto con otros colegas, elabora un discurso para fijar el dogma de la supremacía del alma sobre el cuerpo. Esta responsabilidad recaía sobre la figura femenina dentro del matrimonio. Pues, a través de su función maternal, el alma femenina es la que modela al cuerpo y al

\footnotetext{
${ }^{127}$ Alain Corbin, op. cit., vol. I, pp. 182-183.

${ }^{128}$ Isabel Morant, op. cit., vol. III, pp. 200-202.

${ }^{129}$ Philippe Ariès, Georges Duby, Historia de la vida privada. De la Revolución francesa a la Primera Guerra Mundial, Madrid, Taurus, 1990, pp. 452-453.
} 
espíritu, y no el cuerpo ${ }^{130}$. En consecuencia, todo el auge de la moda de la ropa interior fue condenado ${ }^{131}$.

\subsection{1.- El cuerpo en el discurso religioso}

Cuando hablamos del cuerpo dentro del cristianismo, tenemos que andar con pies de plomo. Aunque el cristianismo cuente con 2.000 años de antigüedad, no podemos negar que es una de las religiones más recientes que existen. Sin embargo, durante este periodo ha ejercido una importante influencia sobre los cuerpos ${ }^{132}$. Ya con el Génesis se asienta la idea de que los seres humanos estamos hechos a imagen y semejanza de Dios. Con ello no queremos decir que seamos el vivo retrato de la divinidad, pues el concepto es un poco más complicado. Físicamente hablando, el cuerpo es algo que está condenado a muerte per natura. Pero simbólicamente recoge la idea de tabernáculo.

El cuerpo, obra de Dios, que ha creado al hombre a su imagen, además del receptáculo del alma es un templo dispuesto para recibir el de Cristo en el Sacramento de la Eucaristía, lo que explica la frecuencia del término "tabernáculo" para designarlo. Los ritos del bautismo, de la

\footnotetext{
${ }^{130}$ Philippe Ariès, Georges Duby, op. cit., p. 442.

${ }^{131}$ Uno de los hechos históricos que renueva las conductas privadas es el auge inaudito de las prendas íntimas. La ropa invisible le da un valor muy importante a la desnudez. A finales del siglo XIX aumenta la riqueza de los encajes y de los bordados, y las telas íntimas se llenan de nudos, broches y cordones. Todo esto añade un creciente erotismo que contribuye a renovar la mitología libertina. De esta forma no es sorprendente el auge del fetichismo, pues, realmente es una consecuencia directa como muy bien reflejan Zola, Huysmans y Maupassant. Por lo que, desde el punto de vista literario, se potencian las descripciones míticas del talle y de la curva, la fijación del deseo en las suaves redondeces del pecho, el valor erótico del pie, el cuerpo de los botines, el deseo de cortar la cabellera femenina para olerla a placer... Sin embargo, en el siglo XIX encontramos otro cambio importante en las funciones de la belleza femenina. El corsé se mantiene hasta 1810, porque con él se afina el talle y se consigue resaltar el trasero y los pechos. Pero, al mismo tiempo, es tan ajustado que favorece el dominio permanente de las formas y de las actitudes de las 'damas de bien'. Por el contrario, entre 1854 1868, las ropas aumentan su volumen para intentar disimular sus formas. Antes los vestidos eran estrechos y tubulares y, ahora, se ensanchan las faldas hasta tres metros de diámetro, con lo que se gastaban unos treinta metros de tela.
}

${ }^{132}$ Alain Corbin, op. cit., vol. II, pp. 57-58. 
confirmación, y mucho más la extremaunción, manifiestan esta sacralidad del cuerpo de hombre, que también está destinado a la resurrección ${ }^{133}$.

El cuerpo se debe comprender como un recinto sagrado para depositar nuestra alma ${ }^{134}$. Es un templo que debemos de cuidar, pues este protege al origen de la vida y el auténtico sentido de la cristiandad, el alma. Ahora bien, a diferencia de otras religiones monoteístas, el cristianismo se basa en la encarnación de la divinidad. El auténtico centro del sistema de creencias es el milagro de Dios hecho carne. En consecuencia, los días más importantes son Navidad (en donde se celebra el nacimiento del Niño Dios) y Pascua (en el que se celebra la Pasión, Muerte y Resurrección).

Se han escrito infinidad de páginas acerca de la violencia sobre el cuerpo, por lo que no insistiré mucho en el tema, sino que más bien lo perfilaré ${ }^{135}$. A principios de siglo XIX se resalta la figura de Cristo Redentor, es decir la imagen de Cristo martirizado antes de alcanzar la divinidad. Esto se potencia con mayor realismo en la imagen del Ecce Homo y en el culto a los Instrumentos de la Pasión, el Sagrado Corazón de Jesús, la Santa Faz, la Verónica, la Ascensión del Monte del Calvario... Todos estos elementos darán una mayor amplitud simbólica al concepto de cuerpo. A través del martirio, se reconoce el dolor y el sufrimiento como parte necesaria de este mundo para alcanzar la eternidad. Gracias al desarrollo de esta idea, vemos la descripción de la vida como un valle de lágrimas que se ha dado a lo largo de toda la historia de la literatura y que nos ayudara a

\footnotetext{
${ }^{133}$ Alain Corbin, op. cit., vol. II, pp. 58-59.

${ }^{134}$ Realmente sería muy complicado comprender el cristianismo sin esta noción de cuerpo, pues son innumerables los elementos simbólicos que podemos encontrar tanto en el acto de la eucaristía como dentro de la propia iglesia o catedral. Uno de los más importantes al respecto es cómo el cuerpo, al igual que el Sagrario y la iglesia, está llamado a ser un recinto sagrado. Todos en nuestro interior podemos hacer oración y culto, no necesitamos ningún edificio para recogernos, nuestro propio cuerpo sobra y basta.

${ }^{135}$ Para una información más detallada puede consultarse: Alain Corbin, op. cit., vol. I, pp. 27-166.
} 
perfilar el dolor en el cuerpo femenino. Esto se asume y se recuerda en el rito eucarístico, en donde los fieles reciben a Cristo ${ }^{136}$.

El cristianismo exigirá a sus fieles que cuiden su cuerpo y su alma. Porque, al igual que Cristo, ellos también están llamados a la santidad. Deben recordar que pese al sufrimiento, Jesús de Nazaret se mantuvo firme en su fe y alejado de cualquier tipo de tentación. Por supuesto, este no es un ejemplo fácil de seguir, ya que desde la concupiscencia del pecado original, el cuerpo parece tener voluntad propia. Pero hay que dominar el cuerpo ${ }^{137}$. En cuanto a las posesiones demoníacas, el cristianismo explica que estamos ante un cuerpo elegido para el milagro. Es un cuerpo donde la curación es una manifestación evidente de Dios, porque las curaciones alteran las leyes de la naturaleza ${ }^{138}$.

\subsubsection{1.- El cuerpo de la mujer descrito por el catolicismo}

Desde la figura de Eva, el cuerpo femenino ha sido caracterizado por su naturaleza pecaminosa. Así que, con la intención de reorientarlo, el cristianismo busca un modelo de comportamiento que le sirva de referente y afiance su pureza ${ }^{139}$.

Este modelo lo encarna el dogma de la Inmaculada Concepción reconocido por el Papa Pío IX en 1854. Este es uno de los pilares del catolicismo y defiende que Dios vivo no

\footnotetext{
${ }^{136}$ Alain Corbin, op. cit., vol. II, pp. 58-67.

${ }^{137}$ Alain Corbin, op. cit., vol. II, p. 59.

${ }^{138}$ La oficina de comprobaciones exige a un milagro que sea radical, instantáneo, duradero e independiente de las causas anteriores. En consecuencia, el milagro debe representar un momento de transformación física ajeno a las leyes de la naturaleza, por lo que la curación milagrosa está en relación con la historia del cuerpo.

${ }^{139}$ Isabel Morant, op. cit., vol. III, pp. 185-187.
} 
puede nacer de una mujer marcada por el pecado original. Por lo que es lógico que María deba ser una mujer intacta. Apenas promulgado el Dogma, se observa una gran repercusión en el pueblo y se impone la delicada visión de María como la Mater Dolorosa que ha perdido a su hijo. Se edifican iglesias y catedrales a su consagración ${ }^{140}$ y las Instituciones le dedican fiestas en su honor. Tal es el caso del ocho de diciembre, el quince de agosto y todo el mes de mayo. En todas ellas se alaba a la figura amorosa de la madre que se mantiene alejada del pecado.

A nivel popular, esto se refuerza con las numerosas apariciones que se dan a lo largo del siglo XIX. Primero, y por orden cronológico, nos encontramos con la de La Salette en 1846, en donde dos niños pequeños ven a la Virgen Dolorosa con un cuerpo muy pequeño y de aspecto maternal. Es una Virgen de verbo apocalíptico que vaticina desgracias. Después, en 1870-1871, en Pontmain la Virgen vuelve a aparecer como una silueta recortada sobre la noche estrellada que de algún modo recuerda a los iconos bizantinos. En aquel entonces su aparición coincide con la amenaza de los prusianos de invadir la región. Esto consigue potenciar la imagen de una Virgen llena de dolor y sufrimiento por todos sus hijos. Su aparición tiene que ver con la intención de socorrerlos, de ayudarlos y de trasmitir un mensaje.

Un tanto diferente se comprende la aparición de la Virgen en la primavera de 1858 en una grieta de la gruta Massabielle a orillas del río Gave. La silueta era la de una pequeña dama, de un metro y cuarenta centímetros de altura, y con apenas doce años de edad. Fue descrita por la pastora Beradette Soubirous con una sonrisa a veces velada por la tristeza, de rostro blanco como un cirio, recogida, rezando, inmóvil... Aquí vemos

\footnotetext{
${ }^{140}$ La Puerta de los Hierros de la Catedral de Valencia está dedicada a su ascensión bajo el lema "Pura y Electra como la luna".
} 
que ya no vaticina catástrofes, pero se sigue mostrando triste ante sus fieles ${ }^{141} \mathrm{y}$, al igual que en todas las apariciones de principios de siglo, todavía mantendrá la imagen de una madre joven.

Las apariciones aumentan el número de fieles, pero la iglesia no puede contentarse con la aparición de una virgen de semblante infantil, por lo que se lleva a cabo un trabajo de adaptación para que la imagen se corresponda con los modelos icónicos dominantes ${ }^{142}$. Este cambio fue estudiado en profundidad por Maurice Agulhon. A lo largo de su investigación mantiene que se trabajó muy duro para dibujar un cuerpo que representase un fuerte vínculo entre lo físico y lo moral. Para ello, se cuenta con cinco elementos: 1) los debates relativos a la representación de la virginidad; 2) las directrices de la teología moral destinada a los cónyuges; 3) las prácticas que intentan controlar las pulsiones corporales a través de la mortificación; 4) los efectos del culto católico sobre las posturas y la gestualidad; 5) el recurso del cuerpo enfermo e inválido a la intercesión de la virgen.

Mantener la imagen de una Virgen de carácter infantil podría ofrecer una idea inalcanzable, y lo que se busca es crear un modelo a seguir. Por lo que al mismo tiempo que el dogma de la Inmaculada Concepción defiende la pureza de María, también enriquece la escena de la Anunciación, reforzando la idea del Milagro Divino y el de la Perfecta Sierva del Señor. Está última será la que la iglesia propague como modelo a seguir para las mujeres.

\footnotetext{
${ }^{141}$ Alain Corbin mantiene que su descripción se ajusta a las descripciones de las hadas que vivían en las grutas y manantiales de los Pirineos. De todas formas para más información se puede consultar: René Laurentin, Lourdes. Historique authentique des apparitions, vol. 6, París, P. Léthielleux, 1961-1964. Y Ruth Harris, Lourdes. Boy and Spirit in the Secular Age, Allen Lane, The Penguin Press, 1999.

${ }^{142}$ Isabel Morant, op. cit., vol. III, pp. 192-193.
} 


\subsubsection{2.- Virginidad y contingencia}

A los ojos de la iglesia, la virginidad es una virtud que consiste en la perfecta abstinencia de toda acción voluntaria. Es una virtud que no descansa sobre la disposición del cuerpo, sino en la disposición del alma. Bajo esta afirmación las jóvenes se caracterizan por estar más cerca de la divinidad que del pecado terrenal.

La vida de las vírgenes es bella como la vida de los ángeles; es la inocencia primitiva y la ignorancia del pecado; la vida de las vírgenes es sublime como la vida de Dios, es la carne que se rebaja y el espíritu que se glorifica; la vida de las vírgenes es deseable como puede ser deseable Dios mismo, es el abandono de la tierra y el comienzo del cielo ${ }^{143}$.

Por estas razones la figura de la joven virgen es fuente de gracia y de la perfecta belleza. El agua que no ha sido separada de sus orígenes porque nace pura en el Jardín del Edén. Así lo muestra Chateaubriand en El genio del cristianismo, en donde san Ambrosio concibe a la Virgen libre de toda mancilla. Pero, además, es como si su cuerpo irradiase desde su interior: pureza, encanto, candor, modestia, sencillez, discreción, dulzura, franqueza... Esta es la marca interior del dulce milagro, que se ve completamente contrapuesta a la marca que deja el pecado. A partir de 1850, y mediante numerosos cánticos, se refuerza el modelo virginal sobre las jóvenes piadosas. Chateaubriand subrayaba que se glorificaba a las jóvenes que milagrosamente combinaban virginidad y maternidad. Ambos eran concebidos como los dos estados divinos de la mujer.

El culto a la Virgen demuestra la intención de las novicias de salvaguardar su inocencia. Pero también remarca el papel que ejercían los padres y los educadores como guías. El clero se encubría bajo este rol para manifestar su hostilidad ante el baile. Aunque su intención era protectora, también se manifestaba con una excesiva obstinación por

\footnotetext{
${ }^{143}$ Alain Corbin, ibídem, vol. II, p. 66.
} 
controlar todas las festividades juveniles. Su objetivo era que todas ellas se dieran en el seno de la parroquia ${ }^{144}$. Para ello, muchas parroquias contaban con cofradías juveniles y agrupaciones de Hijos de María. Todas ellas tenían instrucciones específicas para la preservación de las hijas del pueblo ${ }^{145}$.

\subsubsection{3.- El débito conyugal}

En el cristianismo, la relación sexual es el último paso de lo que se considera el amor. Como resultado, la unión carnal está llena de una tremenda intensidad emocional. Bajo estas premisas, el modelo a seguir sería el de María y José que, una vez garantizada la caterva de hijos, exaltan el autodominio y la contingencia ${ }^{146}$. En el mensaje religioso, los esposos se entregaban al acto carnal con fines de procreación, y nunca para buscar la satisfacción sexual. Así, toda práctica que no busque el embarazo será rechazada de pleno. Cualquier acto que haga olvidar que el único fin es la reproducción debe proscribirse. En consecuencia, no se aceptan el refinamiento erótico, el coito anal, bucal o la masturbación recíproca, porque, históricamente, estas se han considerado prácticas para evitar el embarazo ${ }^{147}$. Este es un punto muy discutido por los teólogos ${ }^{148}$, pues algunos teólogos, que no condenan los preliminares, admiten la reiteración del placer, dejan libertad a las posiciones, e incluso, mantienen que la mujer puede buscar su

\footnotetext{
${ }^{144}$ Aquí podemos destacar el papel del párroco de Ars, de Veretz, de Jean-Louis Flandrin y Jean Faury.

${ }^{145}$ Alain Corbin, op. cit., vol. II, pp. 65-69.

${ }^{146}$ En el discurso religioso se elimina todo elemento erótico y se exalta el misterio de la concepción, el cuerpo sagrado de la mujer-madre, la fidelidad, la donación recíproca de los seres, la atmósfera de la habitación conyugal, la cama coronada por un crucifijo...

${ }^{147}$ Para más información consultar Jean-Louis Flandrin, L'Eglise et le Contrôle des naissances, París, Flammarion, 1970.

${ }^{148}$ Aquí señalaremos a Monseñor Bouvier, obispo de Le Mans, y a M. Thomas Gousset.
} 
propio $_{\text {placer }}{ }^{149}$. Tal es el caso de Jean-Pierre Gury, que sigue las huellas de Alfonso de Ligorio.

\subsubsection{4.- La postura ascética}

Para las almas de élite no es suficiente con evitar la concupiscencia, ellas buscan contrariar la naturaleza sexual de su cuerpo. En 1884 Désiré Graglia, autor de varias instrucciones espirituales destinadas a la congregación de las Hermanitas de la Caridad, habla de la mortificación del cuerpo como práctica usual en los conventos femeninos. De ella podemos destacar ${ }^{150}$ :

- La ropa de las religiosas tiene como objetivo negar el cuerpo, porque este sólo está llamado a la putrefacción. En un principio las ropas son comprendidas como un sudario que sepulta la condición carnal. Pero las ropas de las Hermanitas de la Caridad no ocultan sus formas femeninas. Sus trajes tienen pinzas y una cintura entallada; lo único que mantiene es un velo para cubrir su cabello. Este fue un elemento simbólico que se rescató en aras de la modestia y siguiendo las doctrinas de san Agustín del siglo V.

- En los conventos reina el silencio. Chateaubriand, a petición de su guía espiritual, lo analiza, y observa que el silencio es signo de aprendizaje y de autocontrol, aumenta la posibilidad de dominar los impulsos, evita las dispersiones, facilita la introspección y prepara para la oración.

\footnotetext{
${ }^{149}$ Alain Corbin, op. cit., vol. II, pp. 72-74.

${ }^{150}$ Alain Corbin, op. cit., vol. II, pp. 74-82.
} 
- El ayuno favorece el recogimiento en el refectorio y ayuda a controlar las pulsiones.

- El cilicio o flagelación se practicaba el viernes para conmemorar el suplicio y la muerte de Cristo. Y es claramente recomendado en los ejercicios espirituales.

- Se pide control en los gestos para evitar la vitalidad de las novicias. Para ello se exige moderación, control de las formas al estar de pie y al estar sentadas. Por supuesto, las manos, deben estar siempre ocupadas. Eso se extiende hacia las feligresas, las cuales, dentro del templo, deben controlar los gestos. Por supuesto no se puede correr, las manos deben de unirse como signo de recogimiento, deben de moverse a cámara lenta y las actitudes corporales han de cortar todo tipo de agitación para favorecer la concentración interior.

- Se debe controlar los cinco sentidos. Ante todo evitar las miradas impúdicas, para lo que se prohíbe mirar fijamente, y se les retiran todos los espejos para que no puedan observarse desnudas. Tampoco pueden deleitarse con olores agradables; pero, por el contrario pueden buscar olores pestilentes, porque les ayudan a buscar a Dios en los pobres.

- Poco se ha dicho de la genuflexión doble y de la prolongada. Esta se practicaba durante las sesiones de adoración perpetua y durante los oficios, y preparaba para la confesión. Es una práctica que buscaba endurecer las rodillas, e incluso llegaba a encallecerlas. Es una posición que representa la sumisión ante la divinidad y la imploración. Pero también tenemos la genuflexión sencilla, que siendo más leve, obliga al ejercicio muscular. Estas prácticas marcaban la celebración de los oficios. 
La vida en los conventos apuesta por el abandono del cuerpo, por reforzar el espíritu y el alma. Este modelo, que proponen las religiosas, se extiende a los internados y a la sociedad. Para ello fue necesaria la influencia del confesor o del director espiritual.

\subsection{2.- El cuerpo en el discurso médico}

Actualmente, no somos capaces de hablar de nuestro cuerpo sin aludir o recurrir al vocabulario médico. Este préstamo no es casual ni gratuito, se debe a una creciente popularización de las fórmulas médicas heredadas desde el principio de su historia. Esta evolución es la que intentaré abordar en el siguiente apartado.

Sería exagerado afirmar que el vocabulario médico se impone a la sociedad. Pero si es cierto que la sociedad, de forma progresiva, irá adquiriendo algunos términos a través de las consultas médicas. Las reiteradas visitas de los pacientes a los doctores hacen que en ellos crezca la necesidad de explicarles sus males. Los pacients intentarán adoptar el lenguaje médico para ser comprendidos de la forma más clara posible ${ }^{151}$.

\subsubsection{1.- El cuerpo fragmentado}

Los médicos del siglo XIX contaban con una impresionante tendencia para fragmentar el cuerpo. Hasta la fecha los males se trataban de forma separada, y no se contaba con la noción completa del cuerpo como conjunto. Por ejemplo, si a un enfermo le dolía un pie y la espalda, se trataba como dos males diferentes, y no se pensaba que el dolor de espalda podía ser causado por una mala posición al andar. En el periodo de entre siglos, esto comienza a cambiar. Se imponen entonces nuevos principios médicos que ayudarán

${ }^{151}$ Alain Corbin, op. cit., vol. II, pp. 23-25. 
a asentar las bases de la medicina moderna ${ }^{152}$. Entre ellos encontramos la observación. Este fue un cambio sustancial que exige al médico analizar detalladamente el entorno del enfermo; luego se comienza a comprender que de él también se pueden derivar algunas enfermedades. Otro principio importante fue la fisiología: en ella se ve la idea del cuerpo como una unidad total, que al mismo tiempo es divisible en varias partes, como un universo ${ }^{153}$. Estos dos enfoques, el medioambiental y el fisiológico ${ }^{154}$, constituirán los dos pilares de la medicina moderna ${ }^{155}$.

\subsubsection{2.- La exploración del cuerpo}

En los hospitales se tiende a la polarización del cuerpo del enfermo. Es decir que toda la investigación gira en torno a dos polos opuestos: muerto y vivo. Ambos son cuerpos sumisos, pero uno ofrece más información que el otro. El cuerpo muerto se comprende como un libro porque se puede abrir y diseccionar. La finalidad de abrir un cadáver es la de analizar la enfermedad, realizar un diagnóstico y definir un tratamiento. La preocupación de los médicos es intentar adelantar todo este trabajo lo antes posible, para salvar al próximo paciente de la muerte. Así, un cuerpo muerto es un cuerpo susceptible de ser investigado, porque en su interior guarda las respuestas para salvar a otras personas.

\footnotetext{
${ }^{152}$ Alain Corbin, ibídem, vol. II, p. 24.

${ }^{153}$ Por supuesto, esto no es nada nuevo, pues ya existía un tratado griego de Hipócrates que lo comentaba, pero sí se redescubre a finales del siglo XVIII.

${ }^{154}$ Se apunta al Tratado De aires, lugares y aguas.

${ }^{155}$ Sin embargo, hoy en día la medicina especializada es criticada por tratar un órgano, o una disfunción específica, y no a la persona ni al cuerpo del enfermo. Este problema existe como mínimo desde hace dos siglos. En un principio no fue una consecuencia del desinterés humano por parte de los médicos, sino que era el reflejo de la expresión de un nuevo humanismo. Esta fragmentación aumentó los conocimientos sobre el organismo y perfeccionó los tratamientos.
} 
Pero el cuerpo vivo es hermético y, por lo tanto, es un cuerpo cerrado en sí mismo que no puede decir nada. Los médicos intentan romper estas barreras, y buscan signos para hacer visible la enfermedad. Para ello, inventan una serie de instrumentos. Estos objetos les ayudarán a ver el cuerpo por dentro; es entonces cuando nacen las exploraciones anales, vaginales, de vejiga (espéculo uretrocístico) y de oído (otoscopio); crece el uso de la sonda, las velas y los estiletes (que ya existían en la antigüedad); se observará el ojo con el oftalmoscopio (inventado por Hermann von Helmholtz en 1851); en 1761 Auenbrugger crea el estetoscopio (que precederá al rayos $\mathrm{X}^{156}$ ), derivado de la técnica que utilizan los viticultores para valorar el contenido de las barricas al golpearlas ${ }^{157}$.

Mediante todos estos instrumentos, el cuerpo se puede explorar de forma más precisa y más fragmentada. Esta fragmentación supone una especialización seguida del uso de unas técnicas concretas y de unos determinados instrumentos. La especialización moderna del siglo XIX se ocupa ante todo de las enfermedades malditas. Es decir, de los males de difícil curación o poco prestigiosos, como la enajenación mental, las enfermedades venéreas, el parto, las enfermedades de mujeres o de niños. En consecuencia, algo tan natural como dar a luz requiere conocimientos específicos, propios de una rama marginada ${ }^{158}$.

\footnotetext{
${ }^{156}$ A finales de 1885 se descubren los rayos X por parte de Roentgen, y se les adjudica una función muy específica: ayudar a estudiar las enfermedades consideradas como "plagas sociales". Estas eran la tuberculosis y el cáncer.

${ }^{157}$ Alain Corbin, ibídem, vol. II, pp. 29-33.

${ }^{158}$ Isabel Morant, op. cit., vol. III, pp. 188-190.
} 


\subsubsection{3.- El dolor y la relación terapéutica}

A la nueva medicina del siglo XIX se la critica por intentar aunar especialización y observación. Son médicos que trabajan sobre cuerpos vivos y que, mediante la ayuda de instrumentos y de los síntomas del dolor, ayudarán al paciente. Pese a las novedades que ofrecían, esta rama médica se asentaba sobre la tradición clínica. En ella se defendía que el dolor y el relato que el enfermo hacía eran un elemento muy importante para el diagnóstico ${ }^{159}$. En consecuencia, muchos médicos no buscaban aliviar el dolor del paciente, primero, porque les ayudaba a clasificar los síntomas de la enfermedad y, en segundo lugar, porque les servía como punto de partida para observar el proceso de recuperación. Esto se llamaba vitalismo, el cual basándose en la fuerza vital de una persona, observaba el desencadenamiento de la enfermedad y la recuperación de la salud. El dolor, en este caso, se ve como un signo de la fuerza vital que, dependiendo de la función, intensidad y forma, marca una etapa u otra en el camino hacia la curación. Es un elemento destinado a la observación y, en función de la categoría, la intensidad y de las formas, se obra de una forma o de otra ${ }^{160}$. Si la naturaleza es la guía suprema, el dolor es una manifestación saludable que no hay que impedir ${ }^{161}$.

En consecuencia, la charla con el enfermo va perdiendo importancia ${ }^{162}$. En las guías destinadas a los médicos se les aconseja que hagan preguntas de respuesta breve. El diálogo debe ser dominado totalmente por el médico, porque el cuerpo y el dolor dan

\footnotetext{
${ }^{159}$ Este pasaje le debe mucho a la obra de Roselyne Rey, Histoire de la doluleur, París, La Découverte, 1993, y a los trabajos de Peirre Peter, De la douleur: Observations sur les attitudes de la médecine prémoderne envers la douleur, París, Quai Voltaire, 1993.

${ }^{160}$ Alain Corbin, op. cit., vol. II, p. 34.

${ }^{161}$ La moda de la teoría del dolor no excluye el uso de los calmantes como el opio o el láudano. Aunque incluso algunos médicos están en contra del uso de la morfina en enfermos terminales.

${ }^{162}$ Olivier Faure, Histoire sociale de la médecine (XVII-XX siècle), París, Anthropos, 1994.
} 
los suficientes indicios, $\mathrm{y}$ es el médico quien debe asignarles el sentido correspondiente $^{163}$. Así el médico es el encargado de transformar la enfermedad en signo, y el cuerpo se ve como un lenguaje codificado que sólo el médico sabe descifrar $^{164}$.

Esto conlleva una crítica muy fuerte, pues se dice que el médico no tiene en cuenta el dolor que sufre el enfermo ${ }^{165}$. Pero también es cierto que muchos médicos contaban con una pesada herencia cristiana. Muchos de ellos entendían que el dolor y el sufrimiento formaban parte de la gracia y, también, de un castigo divino. A lo cual se añade que los dolores del parto son el castigo del pecado de Eva y Adán.

\subsubsection{1.- El cuerpo inválido como monstruosidad}

Hasta finales del siglo XVIII los monstruos se definían a través de características físicas tremendamente exageradas ${ }^{166}$. Pero hacia finales de siglo XVIII y todo el siglo XIX la monstruosidad se comienza a concebir como una alteración de la naturaleza de las $\operatorname{personas}^{167}$.

\footnotetext{
${ }^{163}$ Alain Corbin, op. cit., vol. II, p. 37.

${ }^{164}$ Por supuesto esto es lo que sabemos mediante las guías médicas, pero desconocemos si estas teorías se conseguían llevar a la práctica o no.

${ }^{165}$ Para atestiguar estas preocupaciones tenemos dos testimonios de dos médicos diferentes que se defienden. Por un lado encontramos a Velpeau (inventor del vendaje) que dice "evitar el dolor por medios artificiales es una quimera" (1840). Por otro lado, tenemos a Magendie (maestro de Claude Bernard) que condena la anestesia en 1847. Como era de esperar, se abre un intenso debate acerca de los métodos utilizados para evitar el dolor al paciente, pero Magendie critica el uso de la anestesia por razones morales y éticas, pues eran innumerables los casos de los pacientes que morían debido al uso de esta.

${ }^{166}$ En la Lettre sur les aveugles à l'usage de ceux qui voient Diderot se hace eco de que los ciegos pertenecen a la categoría de los monstruos.

${ }^{167}$ Estas ideas se desprenden de la biografía de Joseph Boruwlask un enano que nació en 1739 y murió en 1837, aunque fue mucho más conocido como Joujou, el juguete.
} 
Los monstruos eran accidentes de las leyes de la naturaleza. Esta visión apuntaba hacia la necesidad de la observación y el análisis de los hechos. Tras un previo estudio de las leyes de la naturaleza, Diderot plantea la desviación de la regla ${ }^{168}$. Esto representa una doble problemática, que ya se trató en el Traité de tératologie de Isidore Geoffroy Saint-Hilaire al dar la definición de monstruo:

Cualquier desviación de tipo específico, o dicho de otra manera, cualquier particularidad orgánica que presente un individuo en comparación con la gran mayoría de individuos de su especie, edad y sexo constituye lo que puede denominarse una anomalía. La palabra "monstruosidad" se ha utilizado a menudo como sinónimo de anomalía [...] al contrario que otros autores sólo han incluido bajo el nombre de 'monstruosidad' las anomalías más graves y evidentes, por lo que han dado a este término un sentido mucho menos amplio ${ }^{169}$.

Isidore Geoffroy Saint-Hilaire separó monstruosidad e invalidez. Se habla de monstruosidad cuando se produce una dualidad donde debe de haber sólo una unidad, como dos cabezas en lugar de una o dos troncos en lugar de uno. También se llama monstruo al individuo que reduce a la unidad lo que debe de ser doble, como un ojo, una oreja, un brazo, una pierna... El loco, o el inválido, era aquel que debía de estar encerrado en un asilo para enseñarle la razón. Sin embargo, el monstruo debía estar en el frasco del embriólogo para enseñar a sus alumnos cuál era la norma. La historia conjunta de ambos cuerpos toca a su fin con la llegada de los estudios de Isidore Geoffroy $^{170}$. Jules Guérin ${ }^{171}$ también apoya las ideas de Isidore Geoffroy y, además, en

\footnotetext{
${ }^{168}$ Annie Ibrahim, "Le statut des anomalies dans la philosophie de Diderot", Dix-huitième siècle, $\mathrm{n}^{\circ}$ 15, 1983, pp. 318-319.

${ }^{169}$ Isidore Geoffroy Saint-Hilaire, Historie générale et particulière des anomalies de l'organisation chez l'homme et les animaux ou Traité de tératologie, 2 vols., Bruselas, Société belge de librairie, Hauman Cartoir et Cie, 1837, pp. 30-31.

${ }^{170}$ Isidore Geoffroy Saint-Hilaire, Considérations générales sur les monstres, comprenant une théorie des phénomènes de la monstruosité, París, Imprimerie Tastu, 1826.

${ }^{171}$ Jules Guérin, Mémoire sur les difformités, Bureau de la Gazette médicale, 1843, pp. 40-41.
} 
sus memorias técnicas reconoce ser el primer fundador de una clínica de anomalías. A través de él se perfilará la cirugía correctora y reparadora. Esta se inscribe dentro de la misma racionalidad de la medicina normal, y le permite orientar sus estudios hacia las $\operatorname{anomalías~}^{172}$.

\subsubsection{2.- El cuerpo y la degeneración}

A Bénédict-Augustin Morel (1809-1873) se le debe la principal elaboración de la degeneración. A partir de su trabajo, se mantiene que la degeneración no tiene nada que ver con la monstruosidad: mientras, la degeneración procede de la medicina alienista, los monstruos proceden de la biología. La función de la medicina alienista es la de abarcar las enfermedades mentales, como el degenerado, el cretino o el idiota. Pero conviene señalar que estos estudios se vieron influenciados por temas tan novedosos como la evolución de las especies y la herencia genética. La deducción a la que se llegó fue que los degenerados son signos peligrosos, porque representan una degeneración de la especie. En este caso, la herencia desempeñaba un papel esencial, pues la degeneración se tiene que buscar en las raíces. Es decir, la figura de los padres era la que ofrecía la solución del problema. La herencia era un hecho biológico que podía transmitir taras resultantes de ciertos modos de vida. De forma que el medio físico y social donde se mueve la pareja se comprende también como un peligro. El alcoholismo era un prototipo que se mantenía en las sociedades pobres. En el periodo del embarazo, estas prácticas provocaban taras en los hijos que daban lugar a degeneraciones.

\footnotetext{
172 Por otro lado, Camille Dareste (1822-1899) se apoya en la concepción lamarckiana de la transformación de las especies. Dr. Dareste logró diferenciar entre monstruos y degeneración. El monstruo significaba una mutación en la especie. Es decir, una alteración biológica que se daba a través de la influencia del medio en la especie.
} 
Dentro de esta afección degenerativa se incluían: el microcéfalo, el enano, el alcohólico, el idiota, el aquejado de criptorquidia (no tenía testículos), el cretino, el aquejado de bocio, el palúdico, el epiléptico, el escrofuloso, el tuberculoso, el raquitismo... Todas ellas eran fácilmente detectables en las clases obreras. Lo cual llevó a establecer a

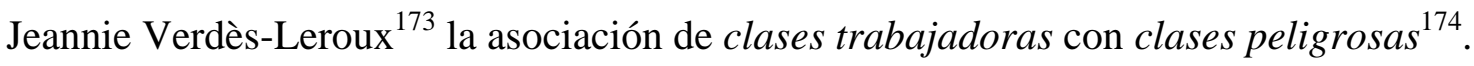

\subsubsection{4.- La necesidad de un cuerpo limpio}

La ambición de comprender la enfermedad y el funcionamiento del cuerpo lleva a la formación médica a abandonar total o parcialmente los hospitales. Ahora los médicos intentarán centrarse en el análisis de las funciones de los órganos y de los tejidos. De forma que, siguiendo los pasos de los físicos y de los químicos, algunos se especializan en el campo de la investigación y de los experimentos ${ }^{175}$. Esta práctica abrirá un foso entre los clínicos y los fisiólogos, de forma que pronto comenzaran caminos separados.

Existen dos descubrimientos que marcan un antes y un después en esta ruptura. Uno es el descubrimiento de los gérmenes de Pasteur. Con la llegada de los gérmenes nace la figura del dispensario, quien se llega a hacer imprescindible. Estas personas eran los encargados de detectar a los individuos que podían ser portadores de gérmenes. Para ello, hacían un análisis bacteriológico de los cuerpos y, después, desarrollaban las topografías médicas. Estas eran simples descripciones de las diferentes formas de vida. En sus explicaciones se abarcan condiciones de trabajo, el hábitat, hábitos humanos,

\footnotetext{
${ }^{173}$ Esta afirmación la lleva a cabo Jeannie Verdès-Leroux en su obra Le Travail social. ${ }^{174}$ Alain Corbin, op. cit., vol. II, pp. 268-277.

${ }^{175}$ Fue muy conocido en la época el experimento en que se mata a un perro al hacerle inspirar prolongadamente gas carbónico.
} 
hábitos sexuales y morales. Los factores mórbidos más investigados corresponden a la esfera personal y apelan a la responsabilidad social. Los higienistas como Villermé hacen responsables a los obreros de su propia miseria material y de su deterioro físico. Durante todo el siglo XIX se les tacha de poco previsores, a veces de depravados, perezosos, aprovechados, tentados por la bebida, sucios, apegados a las costumbres antiguas y peligrosas... Este discurso, que no fue nada novedoso, alcanza su punto más alto durante la epidemia del cólera. Para evitar el contagio, los higienistas les aconsejan mantener la sangre fría, que limpien sus tugurios y que coman bien.

Este higienismo social debe mucho al contexto ideológico, social y político del fin de siglo, donde el temor a la despoblación, la degeneración y el declive tienen un papel importante en la nueva representación unitaria del cuerpo. El cuerpo se convierte en el blanco perfecto para todas las amenazas que acechan a la sociedad, tanto las depravaciones presentes como pasadas. Ahora, los cuerpos estigmatizados, los cuerpos marginales, los cuerpos contagiosos... se definen mediante bacilos y signos de desviación.

Esta práctica rompe con el higienismo moralizante anterior, pero al mismo tiempo se desarrolla un discurso que confunde la protección de la salud con el control moral y social.

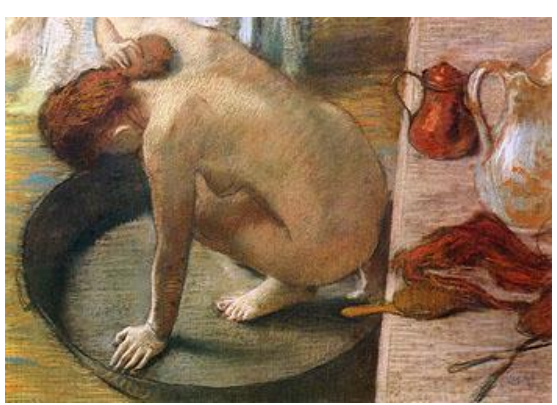

Edgar Degas (1886)

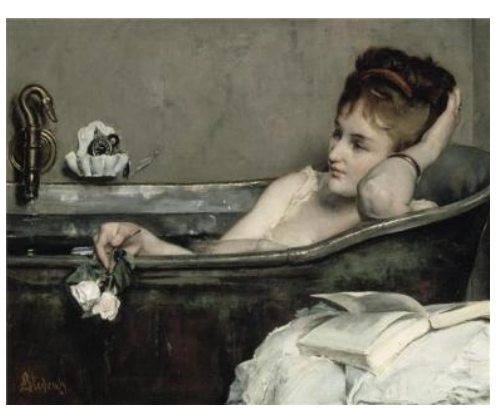

Alfred Stevens (1867) 
La obsesión por la decadencia de la humanidad lleva a propagar ciertas unas teorías un tanto extrañas acerca de la herencia. Al margen del descubrimiento de la teoría hereditaria de Mendel (1866), se llega a la conclusión de que un individuo en la actualidad podía desarrollar ciertas patologías que algún antepasado (muy lejano) había sufrido. Crece una enorme alarma por parte del gran público, y los médicos comienza a preocuparse. Hasta tal punto llega la obsesión que se escriben tesis sobre la sífilis hereditaria, en donde un antepasado remoto puede contagiar a los presentes. Entre estas políticas, el higienismo pretende ser científico y protector. Aunque, en realidad, lo que hace es cargar de prejuicios y fantasías a los sujetos desviados ${ }^{176}$.

\subsubsection{1.- El cuerpo femenino y su higiene personal}

El uso de las bañeras o barreños aparece hacia finales del siglo XIX, por lo que, su empleo no era corriente ni tampoco formaba parte de la vida cotidiana de las féminas. El cambio de la ropa interior, los enjuagues y los frotamientos eran prácticas algo más habituales, pues el uso higiénico del agua supone la convergencia de varias representaciones, y el aprendizaje y difusión de cierta instrumentación.

Los progresos de la toilette íntima revolucionan en efecto la vida privada y las condiciones de la relación. Desde los comienzos del siglo, son múltiples los factores que contribuyen a la acentuación de las antiguas exigencias de limpieza que habían germinado en el interior del espacio conventual. El descubrimiento de los mecanismos de la respiración lo mismo que el gran éxito de la teoría infeccionista llevaron a subrayar los riesgos de la obturación de los poros por la grasa, portadora de miasmas. Algo más tarde, la difusión del concepto de “depuración” impuso una vigilante limpieza de los "secretores” del organismo. La influencia reconocida de lo físico sobre lo moral determina el valor de lo limpio y lo ordenado (...)

\footnotetext{
${ }^{176}$ Alain Corbin, op. cit., vol. II, pp. 40-54.
} 
El agua, cuyos efectos, tanto sobre lo físico como sobre lo moral se sobrestiman, reclama precauciones ${ }^{177}$.

Fue preciso que se descubrieran los gérmenes para que a principios de siglo se diera importancia a la limpieza del cuerpo. La limpieza desvió por completo la mirada hacia lo que no se sentía ni se notaba. No sólo se buscaba eliminar la suciedad, el mal olor de la piel y el malestar físico ${ }^{178}$, sino que también se resaltaba la alerta de que el agua transparente y la piel blanca podían tener bacterias. El principal foco de atención fue la mujer, pues en ella residía la esencia de la procreación. Esto conlleva que durante la segunda mitad del siglo XIX aumentasen sobre ella las exigencias sanitarias. Como consecuencia, se antepone el baño depurativo de uso diario al baño termal.

Como es de esperar, la mujer tiene que entrar sola, nunca acompañada; quedará terminantemente prohibido que alguien la acompañe; incluso el marido tiene prohibida la entrada. Como consecuencia directa, aparece el tiempo para sí misma y, con él, la llegada del individualismo a la higiene. La profusión del agua a finales del siglo XIX se pone al servicio de la intimidad y del retiro ${ }^{179}$.

\subsection{1.- El aseo parcial}

En las viviendas del siglo XIX todavía era raro encontrar espacios dedicados al baño. De forma que en 1827 todavía se sigue diferenciando entre el baño general y el baño

\footnotetext{
177 Alain Corbin, "Entre bastidores", (en) Philippe Ariès, Historia de la vida privada, Madrid, Taurus, 1991, p. 144.

${ }^{178}$ Para más información acerca de la salud de las mujeres en relación con el baño consultar Michelle Perrot, "El elogio del ama de casa en el siglo XIX", en James S. Amelang y Mary Nash, Historia y género. Las mujeres en la Europa Moderna y Contemporánea, Valencia, Alfons el Magnànim, Institució Valenciana d’Estudis i Investigació, 1990, pp. 241-265.

${ }^{179}$ Alain Corbin, op. cit., vol. II, pp. 281-290.
} 
parcial $^{180}$. Tal es el caso de Madame Celnart, que en su obra Art de la toilette, dedica muy pocas líneas al baño general, pero especifica abiertamente que el baño parcial tiene que ver con frotarse detrás de las orejas con un trozo de batista o de lana, con enjuagarse la boca y con el cuidado de los pies. Además, dada la dificultad para acceder a un baño general, los médicos insisten en la importancia de un baño parcial cada día.

Estas abluciones que se aplican cada día en ciertas partes del cuerpo sólo se realizan una vez, por la mañana al levantarse; no obstante, algunas, sobre todo en el caso de las mujeres, se repiten varias veces al día (...). Se consideraba que el cuerpo hecho de zonas oscuras, espacios ocultos, sometidos a transpiración, a olores, lugares más amenazados que otros por la suciedad. Estos eran los lugares que precisaban de manera prioritaria de lavados parciales. Se trataba de los lugares a los cuales estaban reservados los cuartos de aseo de la burguesía de principios del siglo XIX con sus palanganas y bidés: signos de progreso, sin duda alguna, en comparación con otras épocas en las que el cambio de muda se consideraba lo único importante para la higiene corporal ${ }^{181}$.

\subsection{2.- El baño}

El primer diccionario que recogió la entrada baño fue el Diccionario Enciclopédico de Courtin en 1826. Es entonces cuando se muestra la distinta práctica que se hacía del agua a principios del siglo XIX. Por aquel entonces, la práctica del baño era una técnica especializada, cuyos efectos dependían de un principio mecánico. Es decir que, según su temperatura, buscaban provocar una cosa u otra, como la conmoción, la relajación y el fortalecimiento. Por ejemplo, el baño con agua fría ayudaba a fortalecer la constitución

\footnotetext{
${ }^{180}$ Alain Corbin, op. cit., vol. II, p. 284.

${ }^{181}$ Alain Corbin, ibídem, vol. II, p. 285.
} 
y redoblaba la energía de los músculos. Por el contrario, el baño con agua caliente provocaba reacciones irritantes y trataba abscesos cutáneos crónicos y reumáticos.

En realidad estamos hablando de opciones terapéuticas que dependen del termalismo, más que de la higiene. Las consecuencias de esta visión tienden a limitar el baño. En todo caso hay que tomarlos una vez al mes, porque el baño tibio podía debilitar poco a poco a los jóvenes o conseguir hacerles impresionables ${ }^{182}$.

\subsection{3.- Prohibiciones y límites entre procreación y placer}

La sexualidad conyugal se ve limitada por un conjunto de discursos normativos. En ellos encontramos restricciones religiosas a través de los sermones, y recomendaciones médicas a través de divulgaciones orales, libros secretos, literatura médica popular o tratados biológicos; todos ellos daban consejos acerca de la procreación y de la biología femenina $^{183}$.

\subsubsection{1.- Prohibiciones dentro del matrimonio}

La mayoría de las prohibiciones dentro del matrimonio tienen que ver con la doble función que representa la institución. Por un lado, permitía engendrar una prole sana y numerosa. Pero, por otro lado, el lecho se transformaba en un lugar de prevención de la lujuria. En consecuencia, el débito conyugal otorga a cada miembro de la pareja el derecho de exigirle al otro su disposición. Pero, aun así, la sexualidad de la pareja estaba regulada por condiciones materiales y por condiciones teóricas.

\footnotetext{
${ }^{182}$ Alain Corbin, op. cit., vol. II, pp. 281-283.

${ }^{183}$ Alain Corbin, op. cit., vol. I, pp. 167-183.
} 
En cuanto a las condiciones materiales podemos diferenciar ${ }^{184}$ :

- El primero lo llamaremos el tributo físico. Se trataba de períodos de duro trabajo físico. En las zonas agrícolas podríamos concretarlo en la época de la recogida. Este era un trabajo que iba desde el alba hasta el anochecer, y que dejaba poca energía para las relaciones amorosas.

- Las separaciones temporales de la pareja. Normalmente, eran separaciones marcadas por la profesión del varón, el cual debía partir y pasar algún tiempo alejado de su familia. Este era el caso de los peregrinos, de los marineros y de los soldados, pastores...

- La abstinencia exigida por la Iglesia Católica durante la Cuaresma y la Pascua.

- Las supersticiones populares y los tabús tradicionales también se sumaban a estas prácticas. Por ejemplo, se evitaban las bodas durante el mes de mayo, por miedo a que el marido quedase sojuzgado por la mujer. También se evitaba engendrar un hijo en Carnaval, por miedo a que saliera chiflado. En cambio la primavera era un pico muy alto para engendrar, tanto en la ciudad como en el campo.

En cuanto a las condiciones teóricas, observamos cómo las autoridades religiosas, los médicos y los humanistas escribían tratados para propugnar la castidad conyugal. Se predicaba a favor del control estricto de las pasiones sexuales y se pedía el uso moderado de las relaciones porque debían de limitarse sólo a la procreación. Además existían determinados momentos, muy concretos, en los que se prohíbe concebir ${ }^{185}$ :

\footnotetext{
${ }^{184}$ Alain Corbin, ibídem, vol. I, pp. 183-184.

${ }^{185}$ Alain Corbin, op. cit., vol. I, pp. 185-187.
} 
- Se consideraban incompatible la lactancia con el embarazo. Es decir, una mujer lactante no podía volver a quedarse embarazada, porque se imaginaba que los senos y el útero estaban relacionados. Se comprendía que la leche materna era una versión purificada de la sangre menstrual; de ahí, la imposibilidad de repartir el alimento entre dos hijos, lo cual reforzó la idea de que algunos embarazos hacen peligrar a la madre ${ }^{186}$. También, se pensaba que las relaciones sexuales durante el período envenenaban la leche.

- Entre otras cosas, los médicos eruditos empezaban a pensar que la sangre menstrual era una especie de excremento, un residuo que era necesario evacuar porque no había sido digerido. En esta definición perdura todavía un poso de la creencia común en el pecado original: es el recuerdo envenenado de la inferioridad femenina. Realmente, esto no refleja nada más que un vago conocimiento sobre la fertilidad. Se observaba y se estudia cómo las hembras en las especies animales eran fecundadas durante el celo. Pero, por el contrario, las mujeres se ven limitadas por la naturaleza corrompida del período, y se consideraba que era nocivo concebir durante este tiempo. Este tipo de relaciones podían producir monstruos, así que eran terminantemente prohibidas tanto por el clero como por los médicos. Los hijos malformados, monstruosos o enfermos se comprenden como un signo tangible de padres irresponsables que lo único que conseguían era una progenie imperfecta.

- Los médicos aconsejaban sólo una posición para el coito, en la que la mujer debía estar tumbada y el hombre encima. Posición que no sólo simboliza la

\footnotetext{
${ }^{186}$ Aunque, realmente, los embarazos en sí mismos eran un peligro porque la mayoría de la población femenina arrastraba deficiencias de vitaminas y una malnutrición crónica. Problemas que evidentemente se agravaban con el embarazo.
} 
jerarquía de sexos, sino que también refuerza las convicciones culturales en donde el hombre es activo y la mujer es pasiva. Toda posición alternativa a esta se consideraba incorrecta, y se temía que la posición invertida fuera una de las causas del nacimiento de "hermafroditas". Al mismo tiempo, el nacimiento de monstruos estaba vinculado con la relación carnal a la manera de las bestias $\mathrm{o}$, también, a un exceso de libido.

- Todas estas prohibiciones estaban destinadas a procurar que las parejas concibieran al hijo perfecto. Todas las teorías médicas galénicas del siglo XVI y los tratados médicos-legales de finales del siglo XVIII mantenían que el orgasmo femenino era una condición indispensable para el éxito de la procreación. Se pensaba que la mujer liberaba su germen que, mezclado con el del varón, formaba al hijo perfecto. La mayoría de los textos que describen la sexualidad ${ }^{187}$ lo hacen como un proyecto divino para la preservación y la multiplicación de la especie. Pero también cuentan que el placer físico es natural y necesario para el éxito de la procreación.

Si la procreación es un plan divino, evidentemente la anticoncepción es comprendida como lo contrario a los mandamientos divinos y a la finalidad natural del matrimonio. El único método legítimo anticonceptivo es la abstinencia. El resto de prácticas, muy comunes en la época, se comprendían como métodos ilegítimos y, por lo tanto, prohibidos. Estos eran el coito interruptus ${ }^{188}$, el pecado de Onán ${ }^{189}$, el sexo oral, la masturbación mutua, la penetración anal... Como se trataba de procedimientos

\footnotetext{
${ }^{187}$ Textos como The Compleat Midwife's Practice Enlarged (Londres, 1659) y Aristotle's Masterpiece (Londres, 1690).

${ }^{188}$ Era la técnica más empleada por las parejas de novios, las parejas casadas y por aquellos que mantenían relaciones ilícitas.

${ }^{189}$ Fue identificado a principios del siglo XVIII y tratado en la novela Dames galantes de Brantôme.
} 
incorrectos, sólo se podían encontrar descritos en los libros secretos, en libros de recetas y de medicina popular bajo el nombre de "secretos funestos" o de "artes de engañar a la naturaleza". Además, médicos y comadronas daban recomendaciones para librarse del feto mediante baños tibios y ejercicio moderado. Un ejemplo muy claro lo encontramos en 1725 de la mano de Caroline Fox. Además del aborto, se practicaba la obstrucción vaginal con esponjas empapadas de vinagre y de fundas preservativas. La utilización de estas últimas no era tan común porque estaban asociadas al sexo ilícito, a la prostitución, a las enfermedades venéreas... Ya eran utilizadas antes del siglo XVIII y fueron popularmente conocidas en Francia como "vestido" o "capota inglesa" y, en Inglaterra, se llamaron "french letter". Al principio estaban hechas de lino o de tripa de cerdo y se fijaban con cintas verdes y rojas. Posteriormente, en el siglo XIX apareció el caucho, que sustituyó a estos materiales ${ }^{190}$.

\subsubsection{2.- Prohibiciones en la promiscuidad popular}

La regla general mantenía firmemente la idea de que la mujer tenía la obligación moral y religiosa de permitir al marido acceder a su cuerpo. Porque, si se lo negaba, podía conducirlo a las aventuras amorosas con otras mujeres, y se culpaba a la esposa por su mala conducta. De todas formas, el adulterio masculino, aunque fuera denunciado por la iglesia, se consideraba normal. Por el contrario, el adulterio femenino era menos frecuente porque la reputación sexual de las mujeres era más frágil. No obstante los archivos judiciales están llenos de papeles que manifiestan las relaciones ilícitas al margen del matrimonio que existían en la época.

\footnotetext{
${ }^{190}$ Alain Corbin, op. cit., vol. I, pp. 188-192.
} 
En cuanto a los hombres, las formas más comunes de actividad extraconyugal eran la explotación sexual de las sirvientas o las visitas a las prostitutas. En el caso de las sirvientas, avisaremos que no siempre terminaban en embarazo ni en escándalo, pues el temor a las enfermedades venéreas llevaba a los hombres a evitar las relaciones completas, y estas se limitaban a caricias furtivas o a masturbaciones mutuas. Las relaciones sexuales podían ser motivadas por la frustración del trabajo, el tedio, la soledad, e incluso, bajo las amenazas de reducción de salario o del despido. Es cierto que a los criados se les confiaba las tareas de vestir a sus amos, de desnudarlos, meterlos en la cama, levantarles e incluso de despiojarlos en sus partes más íntimas. Aunque en un principio las sirvientas se negasen, es probable que un acoso continuo durante las tareas de cada día las pudiera hacer ceder ante la autoridad. Existen numerosos diarios íntimos y memorias que relatan estos hechos.

En el caso de las mujeres, podemos afirmar que en las clases altas, el adulterio femenino era una estrategia de promoción masculina. Como es natural, la mujer era comprendida como un objeto que pertenecía al hombre, cuanto más la cuidará y mejor la vistiera, más bella aparecería ante los demás. Por lo tanto, la mujer es un objeto bello y predispuesto a ser mostrado. La figura del esposo por sí sola es símbolo de autoridad, pero si va acompañado esta simbología puede verse enriquecida. De este modo, la mujer bella es un objeto que complementa a la autoridad. Pero al mismo tiempo, también es un objeto que se puede ceder. Tal es el caso en el Diario de Samuel Pepys, donde se nos narra detalladamente los innumerables intercambios de favores. Concretamente, se cuenta, más o menos, cincuenta contactos eróticos de mujeres casadas cuyos maridos tenían alguna relación con la oficina de Pepys. La intervención femenina en estos casos estaba destinada a conseguir un puesto de trabajo para el marido o una pensión. 
Ahora bien, en las capas sociales bajas, la promiscuidad solía ir unida a la violencia. Si comprendemos a la mujer como parte de la propiedad masculina, la violación es asumida como un crimen contra la propiedad. El cuerpo femenino pertenece al padre, al marido o a Dios y, como consecuencia directa, es el hombre quien recibe un duro golpe. Las sanciones ante estos crímenes dependían de la edad y del estatus social de la víctima y del agresor. Por ejemplo, si la violación se producía sobre un cuerpo que no había llegado a la pubertad, es decir de entre 12 y 14 años, el castigo era mucho más severo. Incluso el agresor podía ser condenado a muerte. En cuanto al estatus social, podemos diferenciar dos casos. En primer lugar, si la víctima pertenecía a un orden social superior al de su agresor, el castigo también era muy severo, e incluso se le podía condenar a muerte. Pero en la mayoría de los casos era al revés, la mujer presentaba un estatus social inferior al hombre. En este caso la justicia trabajaba para que la víctima recobrase su honor y reputación. De este modo, si el agresor y la víctima tenían la misma condición social, el problema se solucionaba con el matrimonio. Pero si existía una condición social diferente, a la víctima se le pagaba una indemnización. Para que esto tuviera lugar la violación debía ser probada. Durante este proceso el cuerpo, que no la mujer, tenía que demostrar su firmeza y rectitud moral antes de la agresión. El cuerpo era un signo externo de la resistencia que ella había mostrado ante su agresor. Por lo que cualquier cardenal, cicatriz, heridas en la carne, heridas vaginales, gritos, testigos... eran una muestra de que el agresor había recurrido a la fuerza porque la víctima había ofrecido una mayor resistencia. Los registros parroquiales de asistencias a los pobres estaban llenos de historias tristes, de abusos sexuales y emocionales... pero también se daban muchos casos de chicas expulsadas porque tras ser violadas habían aceptado el pago como compensación. Así se las acusaba de avaricia y de lujuria. Normalmente, 
estos casos eran muy frecuentes en jóvenes campesinas que emigraban a la ciudad para trabajar como criadas.

El incesto era otra de las relaciones ilícitas que la iglesia y los médicos prohibían. Pero, sin embargo, estaba favorecida por las condiciones de proximidad, de desigualdad social y de dependencia hacia el bienhechor. Ante los ojos de las autoridades el impacto de la mortalidad favorecía la formación de hogares incestuosos, pero para sus ocupantes se trataba de hogares funcionales. Muchas veces se trataba de casas en donde, ante la muerte de la esposa, la sobrina o la hijastra trabajaban de ama y de gobernanta. $\mathrm{O}$ en donde una viuda con muchos hijos aceptaba vivir con su cuñado ${ }^{191}$.

En conclusión, las mujeres de las capas sociales más bajas eran una presa fácil. Porque, como dice Alain Corbin, la violación es el producto de una cultura que considera a la mujer no sólo inferior al hombre, sino que ésta sólo sirve para satisfacer sus deseos sexuales.

\subsection{4.- La prostituta como remedio de algunos males}

En la Francia y en la Italia del siglo XIV y XV se dieron numerosos desordenes en la población soltera. Los militares, los aprendices, los obreros y los criados llegaron a representar una amenaza durante sus salidas nocturnas. Estos jugaban y bebían en exceso, lo cual les llevaba a realizar prácticas infames contra las hijas e hijos de ciudadanos honrados. El aumento de estos desordenes provocó el temor de la población, y llevó a los gobiernos municipales y a las autoridades a aunar sus fuerzas.

\footnotetext{
${ }^{191}$ Alain Corbin, op. cit., vol. I, pp. 192-197.
} 
Algunas de las soluciones fueron aumentar las guardias nocturnas e institucionalizar el comercio del sexo. En un principio, las prostitutas se vieron como una medida para apaciguar los alborotos ${ }^{192}$. Pero esto con el paso de tiempo se fue consolidando. Hasta que en el siglo XIX vemos como la idea está perfectamente asentada y normalizada. Los prostíbulos fueron relegados a barrios muy concretos y mucho más fáciles de controlar. Además, estos proporcionaban a la prostituta un lugar donde vivir y tenían la función de proteger a la sociedad urbana de su mala influencia ${ }^{193}$.

\subsubsection{1.- Sodomía}

Aunque fuera condenada por el discurso religioso y médico, la sodomía no se veía como una molestia para la sociedad ${ }^{194}$. De alguna forma, se toleró. Durante las reformas religiosas se la catalogó como una subcultura que reside en lo más profundo de la sociedad. Desde el siglo XV hasta el siglo XVII, las actitudes hacia estas relaciones dependían de la edad y del sexo. Por lo que, si no se abusaba de ningún menor, esta práctica no era motivo de escándalo. Pero hacia mediados del siglo XV se manifiesta

\footnotetext{
192 Judith R. Walkowitz, "El vicio masculino y virtud feminista", (en) James S. Amelang y Mary Nash, Historia y género. Las mujeres en la Europa Moderna y Contemporánea, Valencia, Alfons el Magnànim, institució Valenciana d’Estudis i Investigació, 1990, p. 226.

${ }^{193}$ Alain Corbin, ibídem, vol. I, pp. 199-200.

${ }^{194} \mathrm{Al}$ hablar de sodomía sólo hago relación a las relaciones homosexuales entre hombres porque, como citaré a continuación, las relaciones homosexuales entre mujeres no se reconocían como tales:

"Las relaciones sexuales entre las mujeres raras veces, por no decir nunca, se ponían en paralelo con la homosexualidad masculina. La cultura sexual altamente falocéntrica de la Europa del Antiguo Régimen definía la sodomía por el acto de penetración. De ahí la inevitable consecuencia de que las relaciones homosexuales entre mujeres no entrasen dentro de la legislación sobre las malas conductas sexuales a menos que conllevasen al falo artificial. La masturbación mutua entre mujeres no era considerada como una práctica sexual, puesto que sólo un acto que conllevase la penetración y la eyaculación podía definirse como una verdadera relación carnal. Ésta es la razón por la cual las relaciones sexual entre hombres se tomaban en serio, mientras que las relaciones entre mujeres era ridiculizadas, juzgadas necesariamente imperfectas e insatisfactorias". (Alain Corbin, Historia del cuerpo, Madrid, Taurus, 2005, vol. I, pp. 221-222).
} 
como el reflejo del libertinaje, y como una moda que se desarrollaba en las élites urbanas $^{195}$. La subcultura se desarrolló y, partir del siglo XVIII desplegó una identidad propia denominada "El Tercer Sexo".

En el siglo XIX, las autoridades políticas comenzaron a temer que los sodomitas perdieran la voluntad de casarse y de tener hijos ${ }^{196}$. Así que los intereses morales, religiosos y demográficos coincidieron en favorecer la tolerancia hacia la prostitución como única solución al problema de la sodomía. En resumidas cuentas, la sodomía era peligrosa porque se oponía a los principios fundamentales de la estructura de la sociedad, de la familia y, sobre todo, de la reproducción. Por lo que amenazaba la organización sexual y la identidad de los $\operatorname{sexos}^{197}$.

\subsubsection{2.- El bestialismo}

En el siglo XIX el bestialismo fue considerado el crimen más abominable contra las pasiones del alma. Pero no siempre fue así, pues podemos especificar que desde el siglo XV hasta el siglo XVIII este tema era bastante popular en los bestiarios medievales, los tratados médicos de monstruos, los manuales de confesión y en los archivos judiciales. En todos ellos se explicaba que, en el mundo rural, el bestialismo era comprendido como un juego de mozos, y que no tenía mayores consecuencias que la masturbación. Pues al animal se le consideraba un objeto inanimado y, por lo tanto, distinto a los seres

\footnotetext{
${ }^{195}$ Alain Corbin, op. cit., vol. I, pp. 214-215.

${ }^{196}$ Judith R. Walkowitz, "El vicio masculino y virtud feminista", (en) James S. Amelang y Mary Nash, Historia y género. Las mujeres en la Europa Moderna y Contemporánea, Valencia, Alfons el Magnànim, institució Valenciana d’Estudis i Investigació, 1990, p. 228.

${ }^{197}$ En el siglo XV en Génova, en Lucca, en Florencia (1418) y en Venecia (1458) se establece una magistratura especial para extirpar el vicio de Sodoma y Gomorra.
} 
humanos. Esta práctica sólo se presentaba como un problema cuando se prolongaba en la edad adulta.

Sin embargo, la actitud hacia los animales fue cambiando progrsivamente. Al final de la Edad Media el bestialismo se equiparó a la homosexualidad. Los animales se percibían como más próximos a los seres humanos, y esto hace que se desarrolle una legislación contra el bestialismo. Estas leyes ayudan a fijar los límites entre los animales y los hombres y, como consecuencia, hay un cambio hacia la percepción de la naturaleza del pecado.

Hacia finales de la Edad Media y durante el Renacimiento la pena impuesta al hombre y a las bestias se endurece. Se investiga la represión en materia de la moralidad sexual y se condena a la horca y a la hoguera tanto al hombre como al animal ${ }^{198}$.

\section{3.- El cuerpo femenino en el discurso artístico}

Antes del siglo XIX, y por herencia del humanismo, el cuerpo era comprendido como un milagro de la naturaleza. Un poema legible y expresivo en sí mismo que alcanza la armonía y la perfección en todas y cada una de sus partes. En conjunto, el cuerpo desnudo y sano refleja el equilibrio natural. Muestra de ello son los grandes desnudos venecianos desde Giorgione hasta Tintoreto, cuyo punto más álgido lo encontramos: en la Betsabé de Memling, en Adán y Eva de Durero, en las investigaciones anatómicas de Leonardo y en el humanismo imaginado por Miguel Ángel ${ }^{199}$.

\footnotetext{
${ }^{198}$ Alain Corbin, ibídem, vol. I, pp. 212-214.

${ }^{199}$ Alain Corbin, op. cit., vol. II, p. 88.
} 
Ahora bien, en el siglo XIX el cuerpo adquiere una nueva expresividad. Los artistas se estaban haciendo eco de la fragmentación que el discurso religioso y el médico hacen del cuerpo. Bucean en el saber popular y consolidan un imaginario interiorizado a partir del estudio de las partes, por lo que no representan una crónica visual del cuerpo, sino que elaboran un equivalente metafórico de gran complejidad. Esta metáfora intentará representar la experiencia del cuerpo frente a la realidad de las cosas. Ya desde el realismo de Coubert, y de su continuador Degas ${ }^{200}$, nos encontramos con cuadros que plasman la mecánica corporal mediante la tensión del maxilar en un bostezo, o la tensión de los brazos de una planchadora. Estas eran posiciones desde un punto de vista completamente ajeno a las convenciones ordinarias, y mostraban un cuerpo desconcertante, ininteligible... pero, a través de su franqueza, se garantizaba la realidad representada. Con el fin de plasmar este fenómeno, en el mundo literario vemos como muchos escritores estudian anatomía, visitan el anfiteatro de disección, leen tratados, frecuentan médicos... y a través de sus investigaciones consiguen perfilar un nuevo código en donde todos los individuos aparecen enmarcados en diferentes esferas ${ }^{201}$.

\subsection{1.- El desnudo}

La representación del cuerpo remite a una experiencia vivida, una experiencia que por supuesto no es sólo visual. El concepto real que se tiene de un cuerpo pasa por todos los sentidos: la vista (donde residirá la armonía de las partes), el odio (la dulzura de la voz), el olfato (donde se aprecian los perfumes), el gusto (el sabor de la piel) y el tacto (el peso y la consistencia). Tal es ejemplo en Cándido de Voltaire donde leemos:

\footnotetext{
${ }^{200}$ Alain Corbin, op. cit., vol. II, pp. 102-105.

${ }^{201}$ Las investigaciones anatómicas más famosas son las que realizaron Mary Shelley para escribir Frankenstein, o las de Edgar Allan Poe para Un entierro prematuro.
} 
Cunegunda, de diecisiete años, era de color subido, fresca, jugosa, apetitosa ${ }^{202}$.

A esta nueva percepción del cuerpo se le suma la imagen del desnudo. El resultado es que se advierte como una nueva forma de acercarse a la realidad y, en consecuencia, se convierte en una nueva necesidad. Esta nueva percepción abre todo un abanico de posibilidades y, mediante diferentes artificios, se sugiere una experiencia más completa de la carne.

\subsection{2.- El cuerpo castigado en la Revolución Francesa}

La nueva representación corporal busca experiencias interiorizadas; esto da pie a que el dolor se convierta en una fuente de inspiración. Uno de los grandes protagonistas del siglo XIX es la pena; esta subyace en lo profundo del alma o en la conciencia. Pero, pictóricamente esta ha de hacerse visible. Así que el dolor físico también será fuente de inspiración. Uno de los grandes recursos artísticos se deriva de la creciente evolución de la cultura de lo sensible del siglo XIX. Por lo que, mediante el tema recurrente de la revolución francesa, se busca impactar al espectador. De este modo, aumentarán considerablemente las diferentes representaciones de cuerpos dolientes. Nos podremos encontrar un cuerpo atormentado, violado o deteriorado por culpa de las presiones del trabajo.

\subsubsection{1.- El cuerpo masacrado}

El término "masacre" deriva de la palabra árabe "matadero". En Francia, el término es utilizado para hacer referencia a una matanza simultánea de un conjunto de presas por

\footnotetext{
${ }^{202}$ Alain Corbin, ibídem, vol. II, p. 94.
} 
parte de un grupo de cazadores que siguen un ritual dionisíaco. Aunque el término masacre ha evolucionado, todavía subyace en él la idea de carne y muerte. Esta técnica se remonta a mediados del siglo XVIII y determina un interminable debate sobre la crueldad ejercida en la revolución francesa. Durante esta época, la ejecución aparece como un acto de teatralización porque seguía unos pasos muy concretos: primero, el anuncio verbal por parte de los soldados; segundo, el desafío y el escarnio por parte del pueblo; y tercero, el ataque de las tropas sobre el pueblo. Desde el punto de vista corporal, a nosotros sólo nos interesa este último paso, en donde la acción de los soldados consiste en cortar el cuello a la víctima y, si fuese necesario, abrirla en canal y sacarl el corazón. Estos gestos han sido estudiados por varios historiadores de la prehistoria, como es el caso de Claude Masset, John Scheid y Claudy Valin. Todos llegan a la conclusión de que las mutilaciones y el descuartizamiento del cadáver es un acto de vejación. El hecho de llevarse mechones de pelo, cortar orejas, sacar trozos de carne y de cortar órganos como los genitales, implica una posición de superioridad, no sólo física sino autoritaria, pues estos trozos eran exhibidos o enarbolados en el extremo de una pica, un bieldo o una estaca. Pero lo más importante es que se trata de un trofeo sangrante que abría un cortejo, un paseo, una cabalgata y una fiesta salvaje ${ }^{203}$. Evidentemente este mantenía una relación directa con el carnaval. Como ejemplo citaremos el 21 y el 22 de marzo de 1793 en:

En la Rochelle, la gente se pinta, se disfraza para la masacre, se tiran trozos de sangre unos a $\operatorname{otros}^{204}$

El concepto de dolor físico es observado en las masacres desde un punto de vista antropológico. Artísticamente, fue muy estudiado a través de estos actos violentos. Pues

\footnotetext{
${ }^{203}$ Alain Corbin, ibídem, vol. II, pp. 203-207.

${ }^{204}$ Alain Corbin, ibídem, vol. II, p. 206.
} 
la revolución francesa fue una sucesión de guerras civiles y de matanzas muy específicas que sólo se daban en la ciudad. El campo se vio libre y, por lo tanto, el levantamiento del campesinado nunca se dio. Realmente, fueron hecatombes que ensangrentaron barrios muy concretos de la capital. Al mismo tiempo, también hay individuos que se distancian del espectáculo, de los olores y de los gritos. De hecho, la retórica de la sensibilidad derivó de los testimonios de estas personas ${ }^{205}$.

\subsubsection{2.- El cuerpo atormentado}

Durante el último tercio del siglo XVIII se critica el tratamiento penal que se da al cuerpo. En 1788 se muestra una nueva sensibilidad y se deroga la tortura. Pero la pena capital sigue siendo la "piedra angular" del sistema penal en la Europa preindustrial. El cuerpo torturado y estigmatizado sigue siendo símbolo de poder de la autoridad, y el tormento se comprende como la gramática del dolor corporal, la cual se modula según la gravedad del crimen.

Pero el protagonista de la tortura no era ni el estado ni el condenado, sino la chusma carnavalesca. Las autoridades definían a la muchedumbre como ruidosa, borracha y llena de deseo sexual. Así pues algunos médicos recomendaban asistir a las ejecuciones como remedio a la impotencia sexual. De esto se desprende que la ejecución le ofrecía la oportunidad de la algarabía y de celebrar una auténtica fiesta. La ejecución era una comedia donde, al igual que el Carnaval, se permitía la inversión de los roles y la exhibición del cuerpo grotesco del pueblo ${ }^{206}$. Bajo estas premisas se entienden escenas

\footnotetext{
${ }^{205} 28-30$ de julio de $1830 ; 22-25$ de febrero de 1848; junio de 1832 ; abril de 1834 ; junio de 1848; diciembre de 1851; marzo-mayo de 1871.

${ }^{206}$ En Inglaterra las ejecuciones son suprimidas en 1868.
} 
como los crueles pasajes que se describen en El jardín de los suplicios de Octave Mirbeau y el final de la novela El perfume de Patrick Süskind.

El 25 de abril de 1792 se inaugura la guillotina. Este instrumento modifica radicalmente el suplicio, pues se intenta acortar lo máximo posible la sensación de dolor ${ }^{207}$. En 1832 la guillotina se traslada de la plaza de Grève a la puerta de Saint-Jacques, por lo que vemos cómo se intenta alejar las ejecuciones de las aglomeraciones del pueblo, pues antes se realizaban en pleno día y justo en frente del ayuntamiento y ahora, se realizan al alba y en las afueras de la ciudad ${ }^{208}$. En abril de 1848 se derogan las exposiciones públicas porque son consideradas como una práctica degradante para la humanidad ${ }^{209}$. A partir de 1851 la guillotina se traslada cerca de la prisión y, posteriormente, en provincias y a ras de suelo, para que pierda visibilidad. Hasta que el 25 de noviembre de 1870 surge un decreto ley que suprime el cadalso como antigua tribuna del suplicio.

\subsection{3.- El cuerpo violado}

La historia de la violación está estrechamente relacionada con la historia de la representación y prácticas de la unión sexual. Antes de 1791, el discurso teológico y el pecado de lujuria exigían que las mujeres llegaran vírgenes al matrimonio. De forma que si alguna fémina era violada, se comprendía que había realizado una ofensa directa a Dios, porque a la mujer se la dibujaba dentro del círculo de Eva Tentadora. Aquí es donde juegan las ideas populares de que es la mujer la que provoca y el hombre el que

\footnotetext{
${ }^{207}$ Simbólicamente, la tortura se centra sólo en la cabeza. Igual que en el mito de Medusa, es la parte del cuerpo que más ha fascinado en la historia de las torturas. En este sentido la guillotina se comprende como un instrumento infernal y productora de monstruos.

${ }^{208}$ Alain Corbin, ibídem, vol. II, pp. 215-218.

${ }^{209}$ Alain Corbin, ibídem, vol. II, p. 221.
} 
debe resistirse. Además, la sospecha del consentimiento de la víctima siempre estará presente, y por lo tanto el pecado de lujuria. En este contexto, y aunque la mujer era la víctima, ella experimentaba el sentimiento de vergüenza, suciedad y culpa. A causa de esto se la expulsa de la parroquia, de la familia, del convento...

Pero en 1791 el código penal inaugura una transición. La violación ya no es una ofensa a Dios, sino que es la violación de una propiedad. Ahora, el perjudicado es un ser privado: el padre, el marido o el tutor. Las principales fuentes que atestiguan todo esto son los informes redactados por médicos forenses. Estas autoridades hacían un reconocimiento médico a las jóvenes violadas para buscar señales de violencia. Así que la dignidad femenina era probada por la mayor o menor violencia recibida durante la agresión. Moratones, arañazos, ruptura de telas, mechones arrancados... justificaban una mayor resistencia por parte de la víctima y, en consecuencia, se deducía que la agresión no había sido consentida. Las señales hablaban de cómo se había producido y cómo se había desarrollado. A modo de resumen, estamos ante un cuerpo marcado por una brutalidad invisible que sólo el médico puede descifrar. Muchas veces las víctimas eran niñas, sirvientas, criadas, pastoras, espigadoras... agredidas por algún miembro de la familia o por vecinos próximos. Las viudas eran perfectas porque carecían de protección y de autoridad. Los periódicos desarrollaban todo un catálogo de perversiones hacia ellas. Se trataba de discursos sobre el crimen basados en las agresiones sexuales más inauditas que provocaban escalofríos. El ejemplo más famoso acerca de este tipo de crímenes inspiró la figura de Jack el Destripador, cuyo nombre original fue Joseph Vacher.

Esta evolución del concepto de violación marcó una interpretación y un esquema fuertemente interiorizado. Los discursos artísticos se hicieron eco del grado de opresión en el que vivían las mujeres, y de la necesidad de oponerse físicamente. Pero también 
dibujaron la imagen de la presa adormilada. Una figura completamente sumisa que no puede presentar ningún tipo de resistencia. Esto se vio en el cuento de La Duquesa de $O$ de Kleist ${ }^{210}$.

\subsection{4.- El cuerpo deteriorado del trabajador}

El cuerpo de la clase obrera siempre ha representado la potencia física que se atribuye a la plebe. Físicamente es un cuerpo modelado por un trabajo específico en las minas, las fábricas, en las canteras, en las obras... El pueblo es un cuerpo simbólico que representa la figura de Hércules, en donde la potencia muscular está dotada de sentidos rudimentarios. En realidad, es un cuerpo desequilibrado, porque físicamente está más desarrollado que a nivel intelectual ${ }^{211}$. Esta sobrecarga dificulta el progreso de la mente y se destaca la primacía del instinto. Entre el vulgo triunfa como entretenimiento todo acto que sirva para la exhibición de la fuerza de cada individuo, como la ostentación del músculo, el desafío, la lucha, el gusto por la violencia, el boxeo... y el orgullo que suscita poder vencer a un rival. Son cuerpos físicamente poderosos pero minados por el deterioro de la fatiga, la dureza del trabajo ${ }^{212}$, la insalubridad en los puestos que ocupan, la vulnerabilidad biológica ${ }^{213}$, la brutalidad de las máquinas ${ }^{214}$.

\footnotetext{
${ }^{210}$ Alain Corbin, ibídem, vol. II, pp. 230-235.

${ }^{211}$ Alain Corbin, op. cit., vol. II, pp. 237-239.

${ }^{212}$ Como ejemplo podemos citar las Memorias de Léonard de Martin Nadaud.

${ }^{213}$ Como ejemplo podemos citar La Sífilis de los inocentes de Alfred Fournier.

214 Eran innumerables los accidentes que se producían con las máquinas. Desde desgarros hasta aplastamientos, mitilaciones o arrancamientos.
} 


\section{4.- Riesgos y prejuicios de la visibilidad del cuerpo}

Es muy curioso que el siglo que más cultivó el desnudo haya sido el mismo que más prejuicios ha creado hacia la visibilidad del cuerpo. Antaño se pensaba que ver un cuerpo desnudo puede llegar a producir daños irreparables en la psicología femenina. Podemos encontrar un sinfín de ejemplos a finales del siglo XVIII y principios del siglo XIX. Una de las cosas más llamativas se dio en las ferias ambulantes. Estas mostraban figuras de cera anatómicas, que físicamente representaban a mujeres muy bellas, mujeres horrorosas e, incluso, malformaciones humanas. En estos casos las mujeres sólo podían visitar las bellezas, y el resto estaba limitado a los hombres mayores de 20 años. Otro caso muy sorprendente lo narra Baudelaire cuando, acompañado por Louise Villedieu, visita el Louvre. Allí se sorprende al ver cómo la joven se ruboriza y, tras taparse los ojos, decide salir del lugar porque hay muchas indecencias expuestas en el museo. Al mismo tiempo, en 1847, la justicia persigue a Anthony Méray por publicar La part des femmes. Otro caso simbólicamente poderoso es que la sala erótica del museo Borbónico de Nápoles permaneció cerrada a todo el público hasta 1860. A partir de esta fecha, se abre al público y se muestran todas las figuras eróticas que se han conservado de Pompeya.

Son demasiados ejemplos para que no existiera una razón de peso detrás. Tamar Carb mantiene la tesis de que durante el siglo XIX se debió de prohibir a la mujer la visión del propio cuerpo y del cuerpo ajeno. De esta forma, el poder de la visibilidad quedaba reservado al círculo masculino. Jann Matlock complementa esta tesis destacando el aprendizaje progresivo de las mujeres en relación con la apropiación lenta del poder de mirar. 
Cuando hablamos de la visibilidad del cuerpo en el siglo XIX se hace referencia a la exhibición del cuerpo y a la ostentación de los detalles anatómicos ${ }^{215}$. Por lo que todo lo que implica remarcar las formas, o llevar alguna parte destapada, suscita un temor particular. Un cuerpo femenino que ostenta formas es un cuerpo deseado, un cuerpo que incita al deseo de quien mira. Las autoridades recomiendan el recogimiento, el control y la moderación en los gestos y la forma de vestir. Pero el florecimiento del individualismo, el efecto de desenfado de la teología moral, las prácticas de la higiene y la extensión del comportamiento erótico llevan a la mujer a tener una nueva conciencia de su propio cuerpo. Las mujeres modernas de finales del siglo XIX establecen un vínculo entre la honra y las formas de vestir discretas. Con ellas se establecerá cierto nivel de clase asociado a ciertos valores morales. Así que la tragedia de finales de siglo vino simbolizada por mujeres que trabajaban en las fábricas y en los talleres. Todas ellas establecieron su propia moda que las diferenciaba del resto. Pero también fueron tachadas por las autoridades de estar afectadas de males venéreos, alcoholismo y tuberculosis. Este tipo de mujer fue clasificada por los médicos como la histérica y la degenerada.

\footnotetext{
${ }^{215}$ Alain Corbin, op. cit., vol. II, pp. 195-197.
} 


\section{3.- Definición de la femme fatale}

Je est un autre

Rimbaud

No existe una verdadera obra de arte en la que no entre la colaboración del Demonio

André Gide

- ¿Cree usted en los fantasmas? - No, pero me dan miedo.

Madame Du Deffand

Seymour Chatman, en su obra Historia y discurso ${ }^{216}$, comenta lo complicado que resulta el estudio de un personaje literario a causa de la falta de material crítico que existe sobre el tema. Pero cuando yo intenté abordar el análisis de la femme fatal, mi mayor problema resultó ser todo lo contrario. No sólo me encontré con una cantidad excesiva de información, sino que toda ella estaba orientada hacia aspectos sociales, económicos y políticos. Toda esta información me ayudó para acercarme por primera vez a un sistema patriarcal que, obviamente, ha condicionado la historia de la mujer. Pues, socialmente, para que las féminas no presentasen ningún tipo de impedimentos se las anuló y se las redujo a un mero objeto que no tiene ni voz ni voto. A partir de aquí, la mujer sólo tiene una función material: tener hijos. Desde este punto de vista, toda mujer que no puede tener hijos es una mujer que funcionalmente no sirve. Ahora bien,

\footnotetext{
${ }^{216}$ Seymour Chatman, Historia y discurso: la estructura narrativa en la novela y el cine, Madrid, Taurus, 1990.
} 
una mujer que sí puede, pero no quiere, es una mujer que se atreve a cuestionar la jerarquía y el sistema paternalista ${ }^{217}$.

Se trata de un discurso de base que existió y que limitó históricamente la libertad de millones de mujeres durante siglos. Probablemente, muchos escritores se vieron motivados por él, pero como filólogos no podemos dejarnos llevar tan sólo por un discurso social, y mucho menos por una realidad económica. Por supuesto, debemos de tenerlo en cuenta porque, de alguna forma, marca la esencia individual de los signos y de las convenciones culturales de los personajes. Pero esto no lo es todo. Si sólo nos centramos en los aspectos sociales que crearon al personaje de la femme fatale limitaremos nuestro estudio a las cuestiones propias de la realidad, pero nunca llegaremos a profundizar en los elementos ficcionales que conforman las novelas. ${ }^{218}$

\section{1.- La descentralización de la belleza}

Toda creación artística es el culmen de un trayecto personal que el artista vive y experimenta según sus influencias. Así la obra final es definida como el fruto de una experiencia marcada en un espacio y en un tiempo real determinados. En el siglo XIX, el sistema económico cae. Los nobles y los aristócratas ${ }^{219}$ pierden su gran poder adquisitivo y, en consecuencia, su posición social se tambalea. Ahora son los burgueses quienes hacen los negocios y quienes sustentan la economía de las ciudades con fábricas,

\footnotetext{
${ }^{217}$ A nivel popular esta figura recibe en nuestros días el nombre de "mujer desnaturalizada".

${ }^{218}$ Gonzalo Navajas, Mímesis y Cultura en la ficción. Teoría de la novela, London, Tamesis Books Limited, 1985, pp. 86-89.

${ }^{219}$ Los aristócratas acostumbrados a vivir de las rentas y sin necesidad de trabajar se ven acosados por la cultura de consumo y de la producción. Este fue el reflejo de un nuevo sistema económico que capitaneaban los burgueses e importantes comerciantes.
} 
minas, mataderos... A causa de esto crece la demanda de mano de obra, y se produce una emigración masiva del campo a la ciudad. Acaba de nacer la clase social obrera: el proletariado. Este ambiente de cambio exige una nueva redefinición del sujeto en la sociedad, pues se comienza a perfilar una sociedad productiva y, en consecuencia, todo sujeto debe desempeñar una función económica y material.

Los escritores se dejaron llevar por esta realidad social y perfilaron a individuos cuyo destino estaba marcado por la producción en un determinado ambiente. Si en el siglo XVIII asistíamos a la sacralización de la belleza de la mujer, ahora se nos presenta la sacralización del dolor interno. Este dolor se sitúa en el seno de una sociedad, que sumida en el veloz enriquecimiento de un país, se alza sobre las clases más pobres y desheredadas $^{220}$. Porque son personajes, explotados y deteriorados, que se sacrifican por la progresiva evolución de la sociedad. Díaz Rodríguez muestra este desplazamiento de lo sagrado, y logra aunar en el mismo arco a Ruskin, Pater, Nietzche, Baudelaire, Maeterlink, Ibsen, Tolstoy, Wilde y los modernísimos Darío y Valle Inclán.

Esto nos lleva a una serie de personajes que necesitan nuevos elementos descriptivos, porque son individuos marcados por la confusión y la novedad, por la velocidad y la angustia. Estos sentimientos son los que intentará buscar continuamente la prosa novelesca del siglo XIX mediante el discurso religioso y médico. Son novelas que contarán las historias de personajes angustiados, dubitativos, que han perdido la certeza de lo absoluto, y sobre todo, de la razón y de la lógica. Se muestran dañados por la nueva moral que presenta el vértigo de la modernidad, completamente dedicada al "oro".

\footnotetext{
${ }^{220}$ Peter Burke, La cultura popular en la Europa moderna, Madrid, Alianza, 1991, pp. 343-396.
} 
Esto marcará una diferencia discursiva que ayudará a distanciar a los escritores modernos de los del período anterior ${ }^{221}$. Esa distancia obliga a delinear un nuevo programa de actuación especializada en lo estético. Por supuesto, no sólo estamos ante una evolución social, sino también ante un nuevo argumento en el mundo literario. Según Raymond Trousson, la investigación de nuevos argumentos debe ir acompañada de apariciones paralelas en todos los campos de la historia del arte, porque debe ir seguido de un análisis de los conocimientos de la historia, de la forma y del estilo. De entre todos estos campos nace el arquetipo. Este último se comprende como un personaje insustituible, y fruto irremplazable de un argumento que ha ido experimentado diferentes cambios hasta convertirse en lo que el lector conoce. De esta forma no prestaremos excesiva atención a los elementos extraliterarios ${ }^{222}$. En cambio, sí nos detendremos mucho en los componentes intraliterarios, porque pueden resultar importante para la historia.

\section{2.- La identidad de la femme fatale creada a partir de varios métodos discursivos}

¿Qué es la mujer? Antes de responder, diré que no debemos olvidar que estamos analizando textos literarios, y por lo tanto son textos artísticos cuyo cuerpo central descansa en el uso de la retórica y de sus elementos. Esta representa un vasto conjunto de reglas o instrucciones, concebidas y destinadas a guiar la elaboración lingüísticodiscursiva de los materiales temáticos. Como es lógico, estos fueron hallados y seleccionados en las operaciones de la invención y, posteriormente, organizados en las

\footnotetext{
${ }^{221}$ Estamos ante tiempos mudables, donde la velocidad es un signo.

${ }^{222}$ Entendemos por elementos extraliterarios las características históricas, económicas, sociales y políticas que influyeron en la creación de una obra de arte.
} 
operaciones de la disposición ${ }^{223}$. Por lo que estamos ante un cuerpo artístico que, por muy real que pretenda ser, se ve condenado a entremezclar realidad y ficción.

Pero volviendo a la pregunta sobre qué es una mujer, diremos que es una pregunta destinada únicamente a cuestionar la identidad real de un ser humano, y toda pregunta que cuestiona la identidad, está relacionada con el origen. En consecuencia, toda respuesta -individual o colectiva- implica la fabulación de un comienzo, de un principio fundacional que se mitifica y transforma en relato. Cada época, cada cultura, cada sujeto, reconstruyen, matizan o recrean, ese relato, otorgándole un valor que dirige un sentido hacia el futuro y colorea sus propios objetivos y realizaciones. Pero si narrar el origen es el punto de partida de un relato de identidad, encontrar el origen es poner un límite a la genealogía, esto es establecer una frontera primera que se constituye en el comienzo.

Sin embargo, Mario Praz ${ }^{224}$ e Isabel-Argentina Fuentes ${ }^{225}$ manifestaron que el origen no era importante. Es más, para ellos el hecho de indagar en el pasado se veía como un acto completamente innecesario, porque lo que se debía estudiar era la época en la que las femmes fatales proliferan. Por supuesto, esta época es la correspondiente al siglo XIX y a su ambiente preindustrial, cuyo núcleo más importante es la ciudad ${ }^{226}$. Evidentemente, este es el lugar perfecto para que nuestra figura literaria evolucione, pues la ciudad encarna un signo ambiguo y contradictorio $^{227}$. Bajo esta bipolaridad aumentan las

\footnotetext{
${ }^{223}$ Jose Antonio Mayoral, op. cit., pp. 16-28.

${ }^{224}$ Mario Praz, La carne, la muerte y el diablo en la literatura romántica, Caracas, Monte Ávila, 1969.

${ }^{225}$ Isabel-Argentina Fuentes, Del naturalismo al decadentismo, pasando por la mujer fatal. Imagen femenina y literatura española en los inicios de la modernidad, Valencia, Universidad de Valencia, 2001.

${ }^{226}$ Esto conlleva algunos riesgos, pues es cierto que el ámbito campestre, donde crecen infinidad de leyendas pobladas de demonios femeninos, se ha olvidado a favor del hábitat industrial, y esto implica el riesgo de llegar a creer que la figura de la femme fatale puede tener sus raíces en la ciudad.
}

${ }^{227}$ Giuseppe Zarone, Metafísica de la ciudad: encanto utópico y desencanto metropolitano, Valencia, Pre-textos, 1993, p. 11. 
mujeres falsas y mujeres enmascaradas porque todas ellas, tras una imagen dulce e inocente, esconden una maldad pre-fabricada en el ámbito corrupto que representa la ciudad. Desde el punto de vista artístico se buscarán diferentes discursos para ayudar a perfilar a un personaje moderno y dinámico que nace de la incipiente corrupción urbana $^{228}$.

Sin lugar a dudas, el ámbito urbano tuvo una gran importancia para la evolución del personaje, pero lo que interesa al presente estudio es analizar las características que se potenciaron en la ciudad. Estas fueron las mismas que previamente se habían desarrollado en otros ámbitos sociales, y que en el futuro seguirán evolucionando. Así que no nos centraremos tanto en las causas de su evolución como en la propia evolución de las características.

\subsection{1.- Cambios en el discurso literario}

Para comprender la evolución de nuestro personaje femenino, será necesario apuntar que el escritor del siglo XIX es heredero de las revoluciones culturales que se manifestaron en el romanticismo ${ }^{229}$.

Es bien sabido que, durante este periodo, se experimenta con nuevas formas y complicados recursos literarios. Pero es el Romanticismo cuando se dieron cuenta que

\footnotetext{
${ }^{228}$ Peter Burke, op. cit., 1993, pp. 77-85.

${ }^{229}$ En España, se siguieron los modelos italianos que situaban en el centro del universo al individuo. De este antropocentrismo brotará la concepción de la dignidad humana y el importante valor que se le dará a la razón y al pensamiento. En cuanto al estilo literario, podemos afirmar que esta imagen del hombre como centro ayuda a perfilar cánones ideales y universales que se mantendrán en las descripciones. Se toma como herencia directa a los clásicos, el concepto de decoro, los géneros cultivados y los elementos temáticos y formales. Pero con ellos se trabajará duro para conseguir la perfección técnica y la belleza. El método a seguir es completamente racionalista, por lo que primará ante todo el orden, la claridad, la simetría, el equilibrio armónico, la proporción, la serenidad y la mesura.
} 
los recursos literarios empleados en épocas pasadas simbolizaban una extensión recargada de las técnicas clásicas ${ }^{230}$, por lo que se revisaron muchas de las obras canónicas de origen griego. Fruto de ello es la correspondencia entre Goethe y Schiller. Concretamente, las cartas del 19, 21 y 22 de abril de 1797 en donde se cuestiona la tensión como un elemento de débil presencia en los poemas de Homero. Para ellos, la cuestión era que Homero solía presentar de forma completa la escena y, sin dejar nada oculto, mostraba la conciencia de los personajes. Pero, por el contrario, encuentran que en sus poemas existe el efecto de retardado, que consistía en el avance y en el retroceso de la acción por medio de intercesiones. Claro, la causa de este estilo es que Homero no dejaba nada en la penumbra. Los personajes de Homero nos dan a conocer su interioridad sin omitir nada. Incluso sus momentos más pasionales son destapados porque ellos mismo los expresan a otros o para sí mismos. Homero no tenía la necesidad de copiar la verdad histórica, porque lo que más le importaba era mostrar la existencia de lo sensible. Por lo que tratará de hacerlo presente mediante un refinamiento de lo verbal, de lo sintáctico y de lo sensorial.

Una vez entrado en el siglo XIX, la tensión viene creada de la mano del discurso religioso y médico. Ambos son completamente diferentes, y ninguno de ellos busca conseguir un encanto sensorial, pero son capaces de producir vigorosos efectos plásticos, porque los sucesos religiosos y médicos representan una realidad íntima y ética que se

\footnotetext{
${ }^{230}$ Ya los primeros románticos proclamaban la imitación literaria de la vida que mezclaba lo sublime y lo grotesco. Además, a esto se le añade la aniquilación de la idea clásica de diferentes niveles literarios donde lo real cotidiano y lo práctico se entremezclaban para dar lugar al nivel bajo o medio (que era el género cómico-grotesco) y el del entretenimiento agradable, ligero, pintoresco y elegante. Desde la creación de la novela de costumbres, la comédie larmoyante (siglo XVIII) o sturn und drang (prerromanticismo), los límites con el realismo de los siglos XVI y XVII son eliminados. Por lo que se demuestra que a la regla clásica de los niveles no tenía validez universal, y se derriba la barrera estilística entre la realidad y la tragedia. Para más información consultar: Erich Auerbach, Mímesis. La representación de la realidad en la literatura occidental, Fondo de Cultura Económica, México, 1950, p. 522.
} 
concretiza en la materialidad de la vida sensible de las personas ${ }^{231}$. El empleo de esta nueva técnica supone una ruptura con los argumentos (que no la tematología) que antaño se había establecido y, de alguna forma, favorece la proliferación de personajes marginales como la femme fatale. En consecuencia se vuelve a las fórmulas sencillas.

\subsection{2.- Los recursos formales del discurso religioso y el discurso médico}

Para entender cómo el discurso científico y el religioso influyeron en la retórica literaria, primero debemos saber que el siglo XIX es conocido como el siglo de la revolución científica e industrial. Pero lo que hizo que estos avances tuvieran lugar fue el asentamiento del método científico. Con él se pudo llevar a cabo un nuevo procedimiento para investigar y demostrar la verdad ${ }^{232}$. Esto supuso que muchas teorías médicas fueran puestas en duda y se revisarán constantemente. Asimismo, era imposible que se representaran leyes fijas, porque iban cambiando a medida que evolucionaban los descubrimientos. Al mismo tiempo, los textos bíblicos no se presentan como realidades mudables, sino que son textos no atestiguados, y que el lector tiene que creer como única verdad (objetiva) que se le ofrece. En ambos discursos entra en juego la fe. La fe en una ciencia médica y en un discurso religioso que propagan la salvación de la humanidad siempre y cuando se sigan sus consejos ${ }^{233}$.

Pero a diferencia de los textos literarios, aquí la verdad no tiene nada que ver con la mímesis o la verosimilitud. Ninguno de ellos pone el acento en la narración ni buscan

\footnotetext{
${ }^{231}$ Eric Auerbach, op. cit., pp. 19-30.

${ }^{232}$ Uno de los elementos nuevos era la "prueba"; sin ella una teoría no era aceptada como válida, y no podía ser considerada como ley científica.

${ }^{233}$ Rafael Llopis, Esbozo de una historia natural de los cuentos de miedo, Madrid, Júcar, 1974, pp. 16-19.
} 
ser una realidad contada. No intentan distraernos ni embelesarnos durante unas horas. Lo que realmente buscan estos textos es dominar al lector, y si no lo consiguen, simplemente, se declara a este rebelde. Para ello, ambos crearán una doctrina autoritaria que busca definir una vida saludable. Ambos perfilaban el mundo bajo unas premisas, unos consejos que la gente debería seguir para sentirse mejor. Ahora bien, antes de aconsejar la doctrina subrayan la realidad en la que viven los cuerpos, y destacan los malos hábitos adquiridos de forma cotidiana. Así que concebiremos los consejos bíblicos y médicos como acaeceres cotidianos de la época ${ }^{234}$.

En ellos, la verdad histórica es impuesta e incuestionable. Este método de escritura es el que se reflejará en la literatura del siglo XIX. Ya no se buscará la verosimilitud, sino todo lo contrario, se intenta que no se cuestione lo narrado, porque el propio texto aparece como Verdad.

Dado el éxito que tuvo el método científico en el siglo XIX, E. Zola lo utilizó como método de escritura. Para ello escogía a un personaje y lo situaba en un ámbito concreto (la mina, la taberna, la fábrica...) y lo condicionaba por medio de determinaciones biológicas, sociales, económicas, morales... Todo ello era lo que Zola utilizaba para representar la verdadera naturaleza de los hombres. Así lo explica Emilia Pardo Bazán al afirmar:

Después de Madama Bovary, Salambona es lo mejor de Flaubert. (...) y la heroína de la novela fue la virgen Salambona sacerdotisa de la Luna. Parece a primera vista que tales elementos compondrán un libro enfadoso, erudito quizá, pero no atractivo; algo semejante a las novelas arqueológicas que escribe el alemán Ebers. Pues nada de eso. Aunque el autor de Salambona nos conduzca a Cartago y a las cordilleras líbicas, al templo de Tanit y al pie monstruoso ídolo Moloch, Salambona es en su género un estudio tan realista como Madama Bovary.

\footnotetext{
${ }^{234}$ Erich Auerbach, op. cit., p. 146-149.
} 
Prescindamos de la infatigable erudición que desplegó Flaubert para pintar la ciudad africana, de su viaje a las costas cartaginesas, de su esmero en revolver autores griegos y latinos; también lo hace Ebers, y mejor y más sólidamente; pero no por eso son menos soporíferas sus novelas. Lo que importa en sus obras, como Salambona, no es que los pormenores científicos sean incuestionablemente exactos, sino que la reconstrucción de la época, costumbres, personajes, sociedad y naturaleza no parezca artificiosa, y que el autor, permaneciendo sabio, se muestre artista; que en todo haya vida y unidad, y que ese mundo exhumado de entre el polvo de los siglos se nos figure real, aunque extraño y distinto del nuestro; que nos produzca la misma impresión de verdad que causa el escrito jeroglífico al descifrarlo un egiptólogo, o el fósil al completarlo un eminente naturalista, y que si no podemos decir con certeza absoluta “así era Cartago”, pensemos al menos que Cartago pudo ser así ${ }^{235}$.

\subsection{3.- Los pilares creativos de la femme fatale}

Mario Praz abre su obra La carne, la muerte y el diablo ${ }^{236}$ mencionando que para estudiar a la femme fatale del siglo XIX no es necesario recurrir a sus orígenes mitológicos ${ }^{237}$. Primera y principalmente, porque estamos ante un lector que mayoritariamente se encuentra desconectado de esos argumentos. Lo cierto es que tiene razón. Normalmente, a casi todos los lectores los mitos les quedan demasiado lejos y, en consecuencia, los desconocen. En segundo lugar, también es cierto que adoptar esta perspectiva significaría subestimar la etnología religiosa, y por lo tanto, dejar de lado el discurso cristiano que tanto nos importa ${ }^{238}$.

\footnotetext{
${ }^{235}$ Emilia Pardo Bazán, La cuestión palpitante, Barcelona, Anthropos, 1989, pp. 225-226.

${ }^{236}$ Mario Praz, La carne, la muerte y el diablo, Caracas, Monte Ávila, 1969.

${ }^{237}$ Mario Praz, op. cit., p. 207.

${ }^{238}$ Claude Lévi-Strauss, Antropología estructural, Barcelona, Paidós, 1995, pp. 229-252.
} 
Para salvarnos de estos pormenores, observaremos que el mito es conocido por cumplir dos requisitos: el rítmico y el narrativo. En cuanto a la característica rítmica, aludiremos a que ha sido potencialmente estudiada bajo las oposiciones hombre/mujer, sol/luna, equilibrio/caos, línea recta/curva, día/noche... Incurrir en ellos, nos llevaría a una mitología que se ha considerado fuente primera del sistema patriarcal. Pero, que sin embargo, no nos ayuda a explicar el discurso literario ${ }^{239}$.

El mito es una narración en prosa o en poesía y, como tal, su instrumento de trabajo es el lenguaje. Para los lingüistas del siglo XIX esto simbolizó una fuente muy importante de estudios que les llevó a afirmar que:

Si queremos dar cuenta de los caracteres específicos del pensamiento mítico, tendremos que establecer entonces que el mito está en el lenguaje y al mismo tiempo más allá del lenguaje. Esta nueva dificultad tampoco es ajena al lingüista: ¿acaso el lenguaje mismo no engloba diferentes niveles? Al distinguir entre la lengua y el habla, Saussure ha mostrado que el lenguaje ofrecía dos aspectos complementarios: uno estructural, el otro estadístico; la lengua pertenece al dominio de un tiempo reversible y el habla al de un tiempo irreversible. Si es ya posible aislar estos dos niveles en el lenguaje, nada excluye la posibilidad de definir un tercero $^{240}$.

Así que el mito es un sistema temporal formado por varios constituyentes. Uno es el pasado, porque el mito se refiere siempre a acontecimientos ya finalizados: antes de la creación del mundo o durante las primeras edades de la humanidad. El otro se deriva del valor intrínseco de la narración, y es lo que se asocia con el carácter del tiempo presente. El mito refleja los sentimientos que siempre se han dado en la humanidad: el amor, el odio, la venganza, el rencor, la cobardía, la añoranza... Esta doble estructura logra

\footnotetext{
${ }^{239}$ David R. Olson y Nancy Torrance, Cultura escrita y oralidad, Barcelona, Gedisa, 1995, pp. 25-46.

${ }^{240}$ Claude Lévi-Strauss, op. cit., 1995, p. 232.
} 
actualizar acontecimientos históricos mediante la realidad sentimental. El mito, al igual que el discurso médico y religioso, tiene una doble vertiente que es a la vez histórica y ahistórica y, explica que el mito pueda pertenecer simultáneamente al dominio del habla y al de la lengua, ofreciendo al mismo tiempo, en un tercer nivel: el carácter de objeto absoluto $^{241}$.

Para que podamos entender con más claridad la doble estructura del lenguaje, es necesario el papel del personaje ${ }^{242}$. El personaje no es importante por ser descrito en un tiempo determinado ni en una clase social concreta. Lo que realmente nos interesa son las relaciones personales que se establecen a lo largo de la novela. De esta forma, el personaje es comprendido como un punto con proyecciones pasadas y futuras que se entrecruzan y se limitan con las proyecciones de otros personajes. A esto lo llamaremos entretejer relaciones humanas, y es precisamente, el elemento que nos ayudará a ahondar en los sentimientos de los personajes.

La novela del siglo XIX retoma esta argucia, y se convierte en el género de la intersubjetividad, donde las proyecciones de los personajes se ven determinadas por el ámbito político-social-económico en el que viven. A partir de ahí, las características físicas como tales carecen de importancia, a no ser que al analizarlas sean comprendidas en el ámbito simbólico de las proyecciones.

\footnotetext{
${ }^{241}$ Claude Lévi-Strauss, op. cit., 1995, p. 232-233.

${ }^{242}$ Gonzalo Navajas, op. cit., p. 88.
} 


\section{3.- Sacralización de los rasgos femeninos}

Edward Morgan Foster estudió en profundidad las diferencias entre las personas reales y los personajes en la novela ${ }^{243}$. En su detallado análisis observó que el homo fictus, como es natural, está hecho a imagen y semejanza del homo realis. Pero como también es lógico, no pueden coincidir plenamente. La teoría de Foster afirma que el hombre de ficción, como el real, generalmente nace, es susceptible de morir, requiere poca comida o sueño y se halla ocupado en entretejer relaciones humanas ${ }^{244}$. Es inevitable que exista un punto de referencia común, que no es otro que la realidad a imitar. El personaje, al igual que toda persona real, no es consciente de su naturaleza esencial en el transcurso de la historia. El individuo se constituye como tal a través de un sistema simbólico y cultural en el que participa. Esta cultura le ayudará a ver y organizar el mundo y, al mismo tiempo, le ayudará a verse y a comprenderse a sí mismo ${ }^{245}$.

Si no analizamos a la mujer bajo estos símbolos culturales, nos quedaremos confinados al terreno biológico, y la materialidad que nos ofrece este campo tan sólo nos podrá asegurar la permanencia inmutable de mujeres clavadas en una época que no sirven de modelo para la actual ${ }^{246}$. Por lo tanto, buscaremos características femeninas simbólicamente sociales.

\footnotetext{
${ }^{243}$ E. M. Foster, Aspects of the Novel, New York, Harcourt, 1955.

${ }^{244}$ E. M. Foster, Aspects of the Novel, New York, Harcourt, 1955, p. 56.

${ }^{245}$ Gonzalo Navajas, op. cit., pp. 89.

${ }^{246}$ Ernst Cassirer, An Essay on Man, Yale University Press, 1978, p. 68.
} 


\subsection{1.- La corriente francesa. La función estética del desorden}

Una característica del romanticismo literario francés es su índole intelectual, no popular. En efecto, el pueblo, no tenía queja alguna del arte neoclásico, porque no tenía acceso a él. Para el pueblo, el estallido romántico liberador fue la misma revolución, la guerra, la guillotina, la sangre. Por eso su revolución no fue cultural, sino política. Más adelante y desfasada, vino la revolución cultural. Los intelectuales se movieron en el ámbito de la contrarreforma, en donde el catolicismo se impuso desarraigando la mayoría de los mitos y ritos del paganismo precristiano. Estos se vieron reducidos a meros cuentos y juegos, al Folklore en general. En una palabra, acabaron perdiendo su fuerza de creencia $\operatorname{viva}^{247}$.

Los intelectuales se oponen a la imposición de esta lógica y se refugian en cualquier elemento caótico que rompa con las teorías autoritarias. Se orientan hacia un sentido regresivo e irracionalista. Muchos escritores se hicieron eco de las múltiples reformas que los políticos llevaron a cabo para hacer de la ciudad un lugar seguro. Este nuevo espacio se asociaba al orden y a la aplicación de unas leyes que garantizaban el bienestar social. Pero como dice Camille Paglia, la sociedad es una construcción artificial para defenderse de las fuerzas de la naturaleza ${ }^{248}$. La naturaleza es el principio

\footnotetext{
${ }^{247}$ Rafael Llopis, op. cit., 1974, pp. 52-57.

${ }^{248}$ Por supuesto, no creo necesario explicar muy detalladamente que esta relación deriva de una visión bipolar del mundo. Para Paglia, igual que para otros muchos estudiosos, el mundo aparece clasificado en términos de oposición: arriba-abajo, derecha-izquierda, blanco-negro, mujer-hombre, el día-la noche, lógica-naturaleza... Bajo estos conceptos las características femeninas regirán una parte del mundo: el lado izquierdo, la noche, la luna, la naturaleza, el caos... y las características masculinas regirán todas las contrarias: el lado derecho, el día, el sol, la lógica, la razón, el orden... Bajo estos términos de oposición, también se han asimilado de forma errónea los conceptos de maldad y de bondad. Así el hombre representará el bien y la perfección; y la mujer el mal y la imperfección. Mantengo lo de 'de forma errónea' porque no en todos las culturas se ha asimilado de igual modo el paralelo existente entre mujerhombre y mal-bien. Todo lo contrario, en algunas culturas los puntos mujer-hombre y mal-bien se comprenden como dos partes de un todo. Dos partes que al mismo tiempo que generan tensión, también generan un equilibrio necesario para que se dé la unidad.
} 
del Todo y es el telón de fondo sobre el que se basan nuestras ideas. Nuestra naturaleza es la desmesura, el desorden y el $\operatorname{caos}^{249}$. Por lo que la vida civilizada requiere un estado de ilusión permanente. Sin él la cultura revertiría en el miedo y en la desesperación. Sin ella estaríamos a merced de la barbarie y de su fuerza desmedida.

Bajo estas premisas vemos como evoluciona el nuevo concepto de monstruo. Hacia finales del siglo XVIII, lo monstruoso deja de verse como la exageración de las características físicas, y comienza a verse como la alteración de la regla. Este cambio conlleva una racionalización de las formas, es decir que se asientan las definiciones de cómo debe ser el aspecto físico y el carácter moral de las personas ${ }^{250}$. Todo lo que se salga de estos parámetros representa una sobreabundancia en lo moral, y una exuberancia física que no está contenida por la norma. Esta actitud se aprecia en el Traité de tératologie de Isidore Geoffroy Saint-Hilaire al dar la definición de monstruo:

Cualquier desviación de tipo específico, o dicho de otra manera, cualquier particularidad orgánica que presente un individuo en comparación con la gran mayoría de individuos de su especie, edad y sexo constituye lo que puede denominarse una anomalía. La palabra “monstruosidad" se ha utilizado a menudo como sinónimo de anomalía [...] al contrario otros autores sólo han incluido bajo el nombre de 'monstruosidad' las anomalías más graves y evidentes, por lo que han dado a este término un sentido más amplio ${ }^{251}$.

Por lo tanto, todo lo monstruoso está desvinculado de la norma y de lo contenido. En contraposición, lo monstruoso se alineará con la desmesura de la naturaleza y su consecuente amenaza. Como veremos a continuación el sexo o el amor desmedido

\footnotetext{
${ }^{249}$ Todo lo contrario a Rousseau, a Sade, Hobbes y Locke, que mantienen que la agresividad es natural, y que la vuelta a la naturaleza significa dar rienda suelta a la violencia y a la lascivia. En consecuencia, es la sociedad la encargada de controlar y refrenar los excesos.

${ }^{250}$ Alain Corbin, op. cit., vol. II, pp. 268-277.

${ }^{251}$ Citado en Alain Corbin, op. cit., vol. II, p. 269.
} 
también son una amenaza que se puede llegar a encarnar en el cuerpo de la mujer ${ }^{252}$. La sociedad se ve como una frágil barrera para defenderse contra la naturaleza. Pero el peligro radica en el interior del hombre pues, en realidad, las personas son animales jerarquizados. Pero ¿qué ocurre si centramos nuestra mirada en la mujer? Es entonces cuando la mujer deja de entenderse como canon de belleza clásico, rompe con su tranquilidad serena de ángel del hogar y se comprende como un espectáculo artificial. Este nos proporciona una sensación de inseguridad que nace de la desmesura y de la desproporción.

Es entonces cuando en medio de esta atmósfera de irracionalidad se comienza a trabajar con una imagen desmedida y sublime de la mujer. Se trata de imágenes heredadas de la mitología o del folklore, pero que nos hacen experimentar una inferioridad física, de terror. La sensibilidad se ve reducida porque se siente extremadamente débil ante el poder de la naturaleza, rescoldos de una cultura que todavía no ha sido olvidada. Con estos elementos culturales se construye la imagen de la fémina sublime en los cuentos de miedo. Así que la nueva protagonista romántica se convierte en una distracción caracterizada por el pavor, el terror y el dolor de lo sobrenatural ${ }^{253}$, un personaje que a través del miedo busca crear cierto placer estético. En el siglo XIX estos proliferan a velocidades de vértigo y, posteriormente, Rafael Llopis los clasificará de blancos y negros. En Francia surgieron las raíces del cuento de miedo blanco, pero también coexistió con el cuento de miedo negro ${ }^{254}$.

\footnotetext{
${ }^{252}$ Mario Praz, op. cit., pp. 207-282.

${ }^{253}$ Manuel Asensi Pérez, Historia de la literatura. Desde los inicios hasta el siglo IX, Valencia, Tirant lo Blanch, 1998, pp. 331-332.

${ }^{254}$ Rafael Llopis, op. cit., 1974, p. 57.
} 


\subsubsection{1.- Caracterización de la femme fatale}

Mario Praz hizo un exhaustivo análisis de estos detalles físicos y llegó a la conclusión de que la mayoría de ellos proliferaron durante la época del romanticismo. Para Praz estos rasgos son herencia directa de la figura del dandy. Esta figura varonil se aleja de las leyes de la urbe y, en consecuencia, practica el vicio porque se ajusta a las leyes de la naturaleza ${ }^{255}$. Este es un mundo que carece de contenido moral porque prima la satisfacción de las necesidades básicas. Para Proust, el placer y el vicio están limitados por su propia naturaleza, pues se mueven en un círculo en donde el único sentido es la destrucción y la transgresión. Pero esta figura literaria no se comprende sin su pareja, la joven infeliz y perseguida.

Los gritos de Beatriz resonaban en el palacio...

Con los ojos extraviados y el cabello destrenzándose sobre los hombros pálidos, de una blancura lilial, se retorcía a los pies del antiguo lecho salomónico. La condesa estremeciose oyendo aquel plañir que hacía miedo en el silencio de la noche y acudió presurosa.

(...) Beatriz hacía recordar aquellas blondas princesas ¡santas de trece años! que martirizaban su carne, tentada por Satán. Al entrar la condesa, se incorporó con extravío, la faz lívida, los labios trémulos, como rosas que van a deshojarse. Su cabellera magdalénica encubría la candidez de los senos.

-¡Mamá!¡Mamá, perdóname!...

Y le tendía las manos, que parecían dos blancas palomas azoradas. La condesa quiso alzarla en sus brazos:

-¡Sí, hija! ¡Sí!... ¡Acuéstate ahora, pobrecita mía!...

Beatriz retrocedió, los ojos horrorizados, fijos en el revuelto lecho:

$\overline{{ }^{255} \text { Mario Praz, op. cit., pp. 115-172. }}$ 
-¡Ahí está Satanás! ¡Ahí duerme Satanás!¡Viene todas las noches! Ahora vino y se llevó mi escapulario... Me ha mordido en el pecho. ¡Yo grité, grité!... Pero nadie me oía. Me muerde siempre en este pecho...

Y Beatriz mostrábale a su madre el seno, la blancura eucarística, donde se veía la huella negra que dejan los labios de Lucifer cuando besa ${ }^{256}$.

Este es uno de los motivos más viejos del mundo, y sirve para resaltar la idea de que la virtud es perseguida y sólo triunfará en el cielo $^{257}$. Pero en el sadismo se produce una interesante inversión de los valores. Así apreciamos que el vicio es el elemento activo y positivo, mientras que la virtud es el elemento pasivo y negativo. Esta ideología encierra una sátira contra la sociedad contemporánea que honra el vicio, el poder y la hipocresía y, sin embargo, oprime la virtud.

El caso es que Mario Praz confirma que estos elementos negativos se desplazan hacia la mujer creando así la belleza contaminada ${ }^{258}$. Bajo este prisma se daba un nuevo sentido al concepto de belleza. Para potenciar estéticamente esta idea, el romanticismo centró su atención en la sensibilidad. Ahora las descripciones de las amadas son descripciones que atienden más a los sentidos que a la inteligencia. Así que se apela a una belleza minada por la enfermedad o incluso pútrida, y se escriben versos a cadáveres donde se diserta sobre la belleza moribunda ${ }^{259}$. Se trataba de la belleza aumentada por lo horrendo de la situación; cuando más triste y más dolorosa parezca la fémina, más hermosa se la considerará. De aquí, Mario Praz destaca que el descubrimiento del horror como fuente de deleite y belleza terminó por afectar al mismo concepto de belleza, y lo

\footnotetext{
${ }^{256}$ Ramón del Valle-Inclán, La cara de Dios, Madrid, Taurus, 1972, pp. 113-114.

${ }^{257}$ Mario Praz, op. cit., pp. 174-345.

${ }^{258}$ Mario Praz, op. cit., pp. 347-516.

${ }^{259}$ Mario Praz, op. cit., pp. 96-102.
} 
horrendo ya no volvería a ser una categoría de lo bello, sino que será uno de los propios elementos de belleza. Mario Praz explica todo esto a partir del bellísimo poema que Percy Shelley compuso al cuadro Medusa de Leonardo Da Vinci ${ }^{260}$.

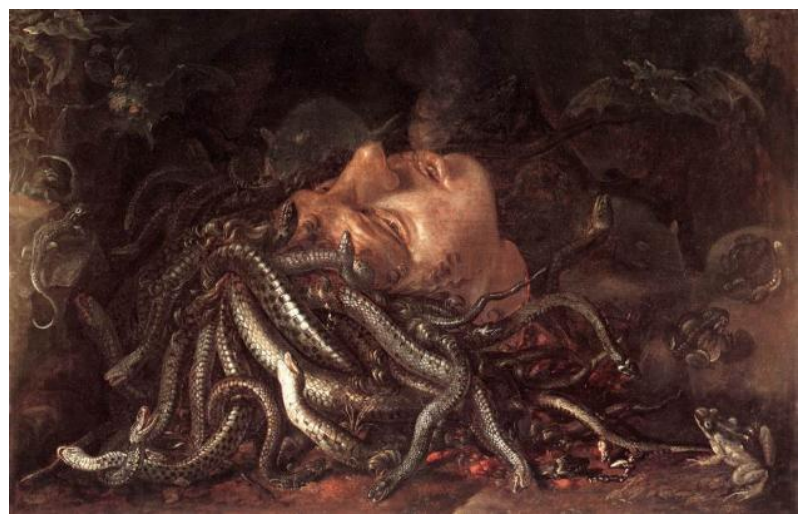

Ahí yace, observando sobre el cielo de la medianoche, tendida en una nebulosa cima del monte. Allá abajo tierras distantes vence temblorosa; su horror y su belleza son divinos. Sobre labios y párpados parece yacer cual sombra la hermosura, donde brillan exaltados y ardientes, luchando en lo hondo, los tormentos de la angustia y la muerte.

Mas es el horror, no la gracia, lo que torna en piedra el alma de quien la observa; es ahí que se graban las facciones de esa cara muerta, hasta que sus rasgos crecen plenamente y nada más puede concebir el pensamiento; lo que da a la contorsión un carácter armónico y humano es el color melodioso de la belleza lanzando a las tinieblas y la dolorosa mirada.

\footnotetext{
${ }^{260}$ Mario Praz, op. cit., pp. 65-68.
} 
De su testa salen, cual de un solo cuerpo, como hierba de una acuosa roca, pelos que son víboras, que se enroscan, fluyen, se enredan en largas marañas y tejen con infinitas volutas una radiante malla, como si se burlaran de la tortura y la muerte que llevan dentro y serraran el aire sólido con una actitud de desgreñadas fauces.

Desde una piedra vecina, un ponzoñoso lagarto espía despreocupado esos ojos de Gorgona; mientras en el aire un espectral murciélago sin rumbo, que se había alejado enloquecido de la caverna que esa luz espantosa hendía, vuelve apresurado cual polilla que se esfuerza por alcanzar una vela; el cielo de medianoche brilla con luz más pavorosa que la oscuridad de la cueva.

Es la fascinación tempestuosa del terror; en las serpientes centellea una mirada abrasadora y feroz, encendida por ser ese inextricable error, que convierte los angustiantes vapores del aire en un espejo que trastoca constante el terror y la belleza que ahí moran; un semblante de mujer, serpentinos rizos, que en la muerte contempla el firmamento desde esas rocas húmedas ${ }^{261}$.

${ }^{261}$ Percy B. Shelley, Adonis y otros poemas, Buenos Aires, Espasa-Calpe, 1954. Traducción de Miguel Ángel Montezanti. 
Esto, que en los siglos anteriores era fruto de una actitud intelectual, se convierte para los románticos en una actitud propia de la sensibilidad. Desde entonces se desarrolló un poderoso gusto por la belleza minada, por la figura de la mujer enferma o moribunda ${ }^{262}$.

Pese a las técnicas literarias utilizadas, para los escritores románticos no era ni una paradoja ni un juego, era algo que se daba en la vida cotidiana. Pues las mendigas hermosas, las ancianas seductoras, las negras fascinantes y las cortesanas humilladas eran un conjunto de temas que formaban parte de la vida real.

\subsubsection{2.- La naturaleza exótica de la femme fatale}

En el reino animal, vemos como las hembras son más feas. Ellas tienen la piel y el plumaje más gris para camuflarse mejor y proteger a las crías. Por el contrario, los machos son más hermosos y espectaculares. Tienen un mayor porte y su plumaje es más favorecedor. Todo esto es para atraer a las hembras y enfrentarse a los otros machos. Asimismo, apreciamos que todo elemento exótico recae sobre los machos con una finalidad productiva y sexual. En relación al ser humano vemos cómo el ideal exótico y erótico corren parejos. Habitualmente, el exotismo es una proyección fantástica que necesita una manifestación sexual. Pero ahora, en el siglo XIX, los deseos desenfrenados y las crueles imaginaciones asumen formas concretas ${ }^{263}$. Evidentemente, Gautier y Flaubert nos transportan a estos climas de la antigüedad bárbara y oriental, en donde la mujer se convierte en el paradigma de la crueldad. Un ideal nacido de la naturaleza y en donde confluyen exotismo y erotismo.

\footnotetext{
${ }^{262}$ Mario Praz, op. cit., pp. 96-102.

${ }^{263}$ Mario Praz, op. cit., pp. 216-217.
} 
Esto se concretizó en mitos antiguos que la contrarreforma intentó silenciar ${ }^{264}$. Exactamente, Jane Harrison los sitúa en la religión griega preolímpica, donde el nacimiento de la tragedia se debe al culto dionisíaco. Los protagonistas son siempre hombres, y en ellos recae la importancia de hacer primar el orden biológico. Pero, ahora, las mujeres son las que quiebran la acción masculina. Si nos centramos en la belleza femenina veremos cómo la fealdad ctónica se transforma. Ellas no sólo se adornan para aumentar su valor como propiedad, sino también para asegurar su atractivo. Estamos ante un desvío, pues el valor exótico-erótico ya no recaía sobre el hombre, sino sobre la mujer. El cuerpo de la mujer pasa a representar una modalidad más tenebrosa y mecánica $^{265}$. Este es el caso de Medea, Fedra, Cleopatra, Lady Macbeth... No se trata de un exotismo genérico, sino de un exotismo que nutre un clima cultural especial fruto de la nostalgia del pasado. Por ello, los mitos antiguos como la Esfinge, la Venus, el Adonis, Diana, Endimión,... acuden a ilustrarlas. En donde la mujer se perfila como mantis religiosa, una especie de lady Macbeth oriental con un canibalismo desenfrenado. Las mujeres son mucho menos morales que los hombres e introducen una crueldad pura. Ella es realmente el problema al que se le intenta dar solución. La tragedia es un juego masculino donde la identificación de la mujer con la naturaleza es universal. Así que la inhostilidad de la tragedia hacia las mujeres deriva de la inhostilidad de la naturaleza hacia los hombres ${ }^{266}$. Mitológicamente, el sexo representa el punto de contacto entre el hombre y la naturaleza. Es un punto de intersección. Un punto de equilibrio necesario, donde la moral y las buenas intenciones quedan a merced de los impulsos más

\footnotetext{
${ }^{264}$ Camille Paglia, Sexual Personae. Arte y decadencia desde Nefertiti a Emily Dickinson, Madrid, Valdemar, 2006, pp. 35-37.

${ }^{265}$ Mario Praz, op. cit., p. 221.

${ }^{266}$ Camille Paglia, op. cit., pp. 30-33.
} 
primitivos. Para que estos se despierten será necesario que la mujer rompa el equilibrio encarnando simbólicamente en la naturaleza.

Esquivar la apariencia física cuando se habla de la femme fatale no sólo es absurdo, sino que no tiene ninguna lógica. Su descripción física forma parte de su forma de ser, por ello se la llama belleza turbia, una belleza contaminada, perversa o incluso minada. Se trata de criaturas tremendamente hermosas y atractivas. Pero al mismo tiempo, encarnan todos los vicios y son capaces de destapar todas las armas de seducción con sus voluptuosidades. Añadidas a sus curvas nos encontramos con las descripciones clásicas de la cabellera, que suele ser larga, abundante y, en ocasiones, pelirroja ${ }^{267}$. En cuanto al color de la piel diremos que se pondrá el acento en la blancura. Esta característica tiene una doble simbología. Por un lado, se muestra la blancura divina que se explicaba en los textos bíblicos y, por otro lado, se recurre a la blancura de piel del discurso médico, en el cual se explicaba que aunque la piel pareciera limpia podía ocultar gérmenes. Por lo tanto también se apelaba a la belleza contaminada. Esta última, en lugar de elevar a la mujer hacia la divinidad, la arrastra hacia el inframundo. Tal podría ser el caso de la Salambó que describe Gustave Flaubert:

Tenía la cabellera cubierta de polvo de oro, rizada sobre la frente, y por detrás le caía por la espalda en largas trenzas adornadas de perlas. Las luces de los candelabros avivaban el colorete de sus mejillas, el oro de sus vestidos, la blancura de su piel; llevaba alrededor del talle, en los brazos, en las manos y en los dedos de los pies tanta abundancia de piedras preciosas que el espejo, como un sol, le devolvía sus rayos, y Salambó, de pie al lado de Tanach, se ladeaba para verla, sonreía entre aquella luz deslumbradora ${ }^{268}$.

\footnotetext{
${ }^{267}$ Erika Bornay, Las hijas de Lilith, Madrid, Cátedra, 1995, pp. 113-117.

${ }^{268}$ Gustave Flaubert, Salambó, Barcelona, Debolsillo, 2008, pp. 218-219.
} 
Los ojos suelen ser de color verde, pero en algunas ocasiones también podemos encontrar los ojos oscuros. Son mujeres paradigmáticas y de una maldad destructiva. Todas poseen el mismo tipo de belleza imperiosa, disoluta y letal ${ }^{269}$.

\subsubsection{3.- La naturaleza mística de la femme fatale}

En Francia se instala el catolicismo, y con él se desarraigan o asimilan las formas precristianas. Así que se ha experimentado una domesticación de lo numinoso, pues se ha ido atenuando a través de $\operatorname{los} \operatorname{siglos}^{270}$. Por lo que estamos ante el mito pagano desnaturalizado, domeñado y sustituido por el catolicismo. Con el paso del tiempo el mito se perdió, de forma que en Francia apenas queda algo de su energía original. Esto conlleva que no se conservara ningún mito pagano emocionalmente vivo. Sin embargo, Rafael Llopis mantiene que allí se asientan dos corrientes literarias que buscan recuperar el carácter siniestro de los mitos. Ambas se forjan sobre la idea de terror, así que diferenciamos entre la corriente de miedo negra y la corriente blanca.

La raíz blanca está representada por el propio Charles Perrault. Pero, a diferencia de Perrault, Jacques Cazotte se adentra en el terreno emocionalmente vivo y por consiguiente peligroso. En su obra principal, El diablo enamorado, Cazotte aborda el mundo del ocultismo y de la Cábala, de la magia ceremonial y de la evocación de los espíritus elementales. Antimaterialista, antirrevolucionario y bastante crédulo con sus propias ficciones, Cazotte convierte todo este material en arte. Pese a su inmadurez y a su ingenuidad, la obra de Cazotte contiene un elemento que, a falta de mitos paganos, va

\footnotetext{
${ }^{269}$ Erika Bornay, ibídem, pp. 113-117.

${ }^{270}$ Rafael Llopis, op.cit., p. 58.
} 
a constituir un tema relativamente constante en la literatura fantástica francesa: el satanismo. En donde se recupera el significado originario del término sexo.

Este en la cultura griega venía a designar a daimon, al demonio. Se trataba de una divinidad inferior de los dioses del Olimpo, que no era ni maligno ni benigno, sino que representaba las dos cosas al mismo tiempo. De forma que estamos ante un nuevo equilibrio muy fácil de romper. Este equilibrio es simbólicamente representado por elementos de la naturaleza. Normalmente, unos tienden a representar lo femenino y lo masculino. Por supuesto, con la llegada del cristianismo, el equilibrio se quiebra a favor de la pecaminosa mujer. Los cultos femeninos ponen el acento en el pecado original, y es entonces cuando se potencia la figura de la serpiente, la noche, la luna... ${ }^{271}$. Este exotismo caracterizará de tal forma la figura femenina que, por el contrario, el hombre aspirará a ser "the powerless of the furious roge of a beautiful woman". Ahora es él quien asume la actitud pasiva ante su nueva diosa, con la que el amor será martirio, placer y dolor ${ }^{272}$.

Pero el elemento satánico no se manifestará poderosamente hasta la llegada del Marqués de Sade, principal representante de la corriente negra prerromántica.

\subsection{2.- La corriente alemana y la inglesa. La función de la maldad femenina}

El romanticismo francés no contó con un arranque popular, sino todo lo contrario, fue completamente intelectual, por lo que el aspecto tenebroso fue tomado de la cultura alemana y de la inglesa. Originalmente, Rafael Llopis diferencia dos corrientes del

\footnotetext{
${ }^{271}$ Paglia, Camille, op. cit., pp. 23-79.

${ }^{272}$ Mario Praz, op. cit., p. 231.
} 
cuento de miedo: la blanca y la negra. La blanca está desarrollada fundamentalmente en Alemania y es popular, humorística, casi nunca terrorífica, sólo en ocasiones brumosa y melancólica. La negra se desarrolla fundamentalmente en Inglaterra y es macabra, de mal gusto, sensacionalista y tremebunda. En líneas generales, se puede pensar que no existían cuentos de miedo antes del Romanticismo. Sin embargo, sí podemos encontrar fragmentos aislados de verdadero relato de terror ${ }^{273}$. Aunque también es cierto que no se pueden calificar de narraciones de terror porque su finalidad no es tanto producir miedo como placer estético. Aunque en ellas el miedo desempeñe un papel, no desempeña una función puramente estética. El relato de miedo es aquel cuya finalidad es producir miedo como placer estético ${ }^{274}$. En ambas corrientes las féminas desempeñan un papel tenebroso.

La corriente francesa llegó a ser tan poderosa y alcanzó tanta influencia que me coartó mi campo de estudio. Si leemos entre líneas, podemos llegar a deducir que anteriormente esta figura ya existía. No se trata de una imagen creada por los románticos franceses, aunque sí es cierto que ellos la catapultaron. Hacia la segunda mitad del siglo XIX observamos cómo la idea de mujer asesina o devoradora de hombres ya era latente. Realmente la definición de mujer fatal aparece por primera vez en los años finiseculares, después de que la imagen ya hubiera sido creada en la esfera literaria y, después, en las artes plásticas ${ }^{275}$. En ambos mundos, en la pintura y en la escritura, encontramos rasgos muy particulares, tanto a nivel visual como psicológicos, pues vemos como irremediablemente los hombres son incapaces de resistirse a la

\footnotetext{
${ }^{273}$ Tal es el caso de Beowulf o el Kalevala, las tragedias de Sófocles, Eurípides y Esquilo, Eneas, Ulises...; viajaron por el mundo inferior La Jerusalén liberada, Os Lusiadas, La Divina Comedia, los Sueños de Quevedo...

${ }^{274}$ Rafael Llopis, op. cit., p. 25.

${ }^{275}$ Erika Bornay, op. cit., pp. 113-117.
} 
tenebrosa atracción que las jóvenes ejercen en ellos. Tal es el caso de la Gioconda de Walter Pater, de A Rebours de J.K. Huysmans, e incluso, de La cara de Dios de Ramón del Valle-Inclán.

\subsubsection{1.- La corriente inglesa y la simbología del castillo}

En su huida de todo lo nuevo, el Romanticismo corre a refugiarse en la Edad Media, época monolítica, segura y hostil a toda evolución. Como símbolo de esta época tenebrosa, penetra en la literatura uno de sus personajes más fantásticos y oscuros: el castillo.

Es curioso poder observar el aspecto ambivalente de los castillos del Romanticismo literario. Por un lado, aparece el castillo habitado y ricamente decorado. Es un espacio donde la nobleza revive sus glorias pasadas. Por otro lado, surge el castillo en ruinas, sólo habitado por el eco de una vida pretérita que ya es muerte, que, al quererla revivir, ya no es ausencia, sino presencia muerta. El castillo muerto es la contrapartida del castillo vivo. Al intentar devolver la vida al viejo castillo sólo se consigue acentuar su muerte. El recuerdo nostálgico de una época de esplendor para la nobleza sólo hace más patente su actual decrepitud y vacío.

Este tipo de novela, llamada novela negra (por lo tenebroso) o novela gótica (por la arquitectura de su escenario) muestra una especial predilección por los sitios opresivos, cerrados o decrépitos como puede ser ruinas, tumbas, cementerios... pero sobre todo el castillo en ruinas, el cual viene a recordar la caída de una época gloriosa para la aristocracia. El primer castillo que aparece en la literatura es en 1764 El castillo de 
Otranto de Horace Walpole ${ }^{276}$. Sin embargo, le siguieron otros muchos como Los castillos de Athlyn y Dunbayne, Un romance siciliano, Romance de la selva (1791), Los misterios de Udolpho (1794), El italiano o El confesionario de los penitentes negros, Gastón de Blondeville... ${ }^{277}$

\subsubsection{1.- La amada fantasma}

A lo largo del siglo XIX, podemos encontrarnos con un sinfín de cuadros que representan la preocupación de muchos maridos y madres hacia sus hijas y esposas enfermas.

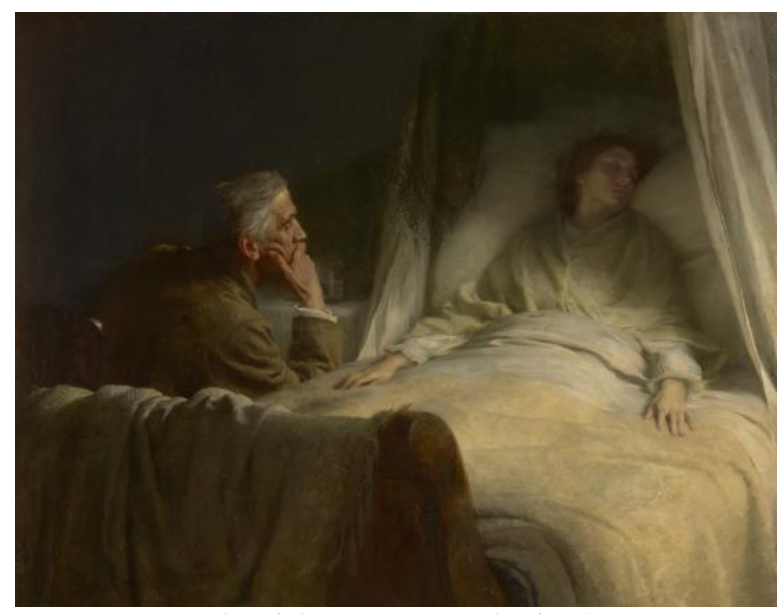

Frank Dicksee, La crisis, hacia 1891

La mentalidad de la época asociaba una salud normal con actitudes peligrosas e, incluso, masculinizantes. Los maridos victorianos consideraban a sus mujeres auténticos ángeles, pero los ángeles humanos eran débiles, desvalidos y enfermizos. Esta debilidad significaba la pureza física y mental de la mujer antes y después del matrimonio. Por lo que muchos pintores las retratan como Una sombra, Un respiro, Ansiedad, La madre

\footnotetext{
${ }^{276}$ Rafael Llopis, op.cit., pp. 31-35.

${ }^{277}$ Una de las figuras más importantes para el asentamiento del castillo fue la autora Ana Radcliffe.
} 
moribunda, In excelsis... A tal extremo llegó esta noción que a finales del siglo XIX muchas jóvenes europeas y americanas murieron $^{278}$.

Este no fue un estado imaginario soñado por los ideales de los poetas. Era una costumbre que minaba la sociedad de la época, y que Abba Goold Woolson llamó la Teoría de la clase ociosa. Para Abba estar enferma se consideraba un símbolo de clase y, por consiguiente, de delicadeza. Pero lo cierto es que a las mujeres se les pedía que fueran ángeles antes y después del matrimonio. Se les prohibía cualquier gesto que no fuera comedido o necesario; así pues comenzaron a proliferar las inválidas como profesión. Pues como Woolson manifiesta, esta figura llegó a convertirse en una verdadera imagen de culto para la clase ociosa. A medida que avanzaba el siglo XIX, se les prohibía mostrar una actitud activa. Pasa tiempos como tomar el sol, hacer ejercicio, dar paseos al aire libre e, incluso, algunos movimientos de brazos y piernas, eran considerados innecesarios ${ }^{279} \ldots$ Las niñas crecen completamente blancas y artificiales, porque el culto a la invalidez conlleva unos tintes de Virtud. Por supuesto, muchas de ellas desarrollaron enfermedades reales como la tuberculosis. Tal fue el caso de Alice James, la hermana de Henry y William James, que dependía de los cuidados continuos de enfermeras y sirvientes, pues padeció una larga agonía ${ }^{280}$. Woolson describe en su obra el trágico destino que les esperaba a las muchachas de clase media cuando encontraban marido:

\footnotetext{
${ }^{278}$ Bram Dijkstra, Ídolos de la perversidad. La imagen de la mujer en la cultura de fin de siglo, Barcelona, Debate, 1994, pp. 25-27.

${ }^{279}$ La imagen de la muchacha tísica estaba tan relacionada con la disposición piadosa que debían tener que muchas dejaron de comer para cultivar la apariencia de la virtud tuberculosa. Es muy probable que los antecedentes de la anorexia nerviosa se remonten al siglo XIX, en donde las jóvenes aprendieron una amplia variedad de formas de "suicidio lento". Para más información consultar: Abba G. Woolson, Woman in American Society, en especial el capítulo "La invalidez como profesión".

${ }^{280}$ Bram Dijkstra, op. cit., pp. 27-29.
} 
Nada más triste que comprobar el rápido desvanecimiento de las mujeres jóvenes después del matrimonio. Las amigas que amábamos en el colegio, llenas de vida y jovialidad, que parecían nacidas para una espléndida y triunfante femineidad, apenas si podemos reconocerlas cuando nos las encontramos pocos años después de su resplandeciente boda. Los numerosos deseos de salud y felicidad con los que fueron colmadas aquel día de fiesta sólo parecen haber servido al marido. En ese lapso, él se ha vuelto más guapo y robusto, pero su pobre y pequeña esposa, con las mejillas hundidas, perdido el color y gastadas las sonrisas, parece un desanimado espectro de la chica que recordábamos ${ }^{281}$.

Esta imagen de tísica sublime es aceptada socialmente y llega a convertirse en la joya resplandeciente de toda virtud social. Pero el romántico, que ama las tinieblas, tomará a esta figura como referencia para representar lo irracional del sacrificio. Este tomaba forma de mujer, pero el contenido se hallaba en las tinieblas de la tumba ${ }^{282}$. Así que la figura de la amada moribunda se convertirá en un tropo muy trabajado durante la primera mitad del siglo XIX. A partir de él se comienza a cultivar la no muerta.

Hacía tiempo que la enfermedad de lady Madeline había desconcertado a los médicos. Una constante apatía, una constante extenuación gradual de su persona y accesos frecuentes, aunque transitorios, de carácter parcialmente cataléptico, eran la insólita diagnosis. Hasta entonces ella había resistido con firmeza la opresión de su mal y se había negado a guardar cama, pero a la caída de la tarde de mi llegada a casa se rindió (como su hermano me contó esa noche con inexpresable agitación) al aplastante poder de la fuerza destructora; y supe que la rápida visión que de su persona había tenido yo sería probablemente la última, porque nunca más volvería a ver a la dama, por lo menos con vida ${ }^{283}$.

\footnotetext{
${ }^{281}$ Bram Dijkstra, op. cit., p. 30.

${ }^{282}$ Rafael Llopis, op. cit., p. 34.

${ }^{283}$ Edgar Allan Poe, "La caída de la casa Usher", en E. A. Poe, El gato negro, Madrid, Anaya, 1995, p.
} 199. 


\subsubsection{2.- El origen del fantasma}

La fuente de inspiración la encontramos en los mitos primitivos. Lévy-Brulh cuenta que la figura del fantasma fue una herencia directa de creencias primitivas ${ }^{284}$. En estas historias se enseñaba que los muertos seguían viviendo tras el fallecimiento. Por aquel entonces se creía que los espíritus eran vivos que iban poco a poco dejando de pertenecer a la comunidad. A medida que sus parientes van cicatrizando el dolor de la pérdida, las almas se van introduciendo en el más allá.

Los románticos recuperan esta imagen e indagan en los sentimientos del espíritu. Es entonces cuando los fantasmas, movidos por la añoranza, la pena y el cariño, se presentan antes sus familiares por la noche. Pero este sentimentalismo es llevado hasta el extremo. Por lo que el pobre muerto, obsesionado por querer estar con sus familiares, se convierte en un ente peligroso, que intenta atraparlos y arrastrarlos a los horrores del sepulcro.

En los mitos eslavos, el muerto -convertido en vampiro -sólo ataca a los familiares, a los que le amaron y le aman aún. Además, sólo ataca durante algún tiempo después de su muerte. Luego, al fin, el fantasma reposa en paz. La presencia de la muerte, por último, se convierte en mera ausencia.

Rafael Llopis concluye diciendo que la muerte en sí no es terrorífica. Lo terrorífico es la vida que queda en la muerte. Vida, que por cierto, está en nosotros mismos. Esta vida de la muerte no es más que nuestro sentimiento desarraigado violentamente de su objeto. Al desaparecer el objeto, el sentimiento pervive, pero sin raíces ni aplicación ya, se va

\footnotetext{
${ }^{284}$ Lucien Lévy-Brulh fue un sociólogo que dedicó parte de sus investigaciones a la observación de la posible influencia que la mentalidad de los pueblos primitivos han ejercido en las sociedades occidentales actuales. Fruto de sus esfuerzos, en 1935 publicó La mitología primitiva.
} 
retrayendo, se va pudriendo, recorre todas las fases de la putrefacción hasta quedar reducido a un esqueleto blanco e inofensivo ${ }^{285}$.

Pero, mientras tanto, el muerto conoce un nuevo tipo de vida, lívido y nocturno. Por eso, las losas de piedra de las sepulturas eran tan pesadas, porque se comprendían como un medio para impedir que el muerto escapase. Por eso se consideraba que el $k a$ o cuerpo astral moraba en la tumba o sus alrededores mientras duraba la putrefacción del cadáver. Pero esta putrefacción estaba cargada de un valor simbólico: de lo que se trataba era de la putrefacción del afecto en los vivos, de su caída como costra, de la cicatrización final.

\subsubsection{2.- La corriente blanca y el folklore alemán}

En Alemania se asienta el luteranismo. Este fue mucho menos rígido que el catolicismo, y favoreció indirectamente la presencia de las creencias precristianas. En suma, aún hoy basta rascar un poco la epidermis cultural de Alemania para que surja el paganismo nórdico. En los largos inviernos nórdicos se contaban leyendas populares que se ambientaban en un castillo del Rin o en los montes Hartz, pero también en el cementerio del pueblo o en una cripta familiar.

En ellos abundan los elfos y las hadas, los duendecillos malévolos o bondadosos, las brujas, y también los alquimistas, cabalistas, nigromantes y doctores místicos de toda especie. El romanticismo alemán es fabuloso, legendario, sombrío como una bruma del pasado, heroico como una canción de gesta o dulce como una balada antigua. Pero en él es difícil encontrar cadáveres en putrefacción, osarios y cuartos secretos, como en la novela gótica inglesa. En Alemania no hay novela negra. Lo que encontramos en

\footnotetext{
${ }^{285}$ Rafael Llopis, op. cit., pp. 32-33.
} 
Alemania son cuentos breves siempre fantásticos y, a veces, tenebrosos. Pero nunca morbosos ni macabros. Junto con estos cuentos literarios, lo terrorífico macabro sigue siendo patrimonio de la tradición oral popular y no encuentra expresión escrita en Alemania.

¿Y cómo es posible que en Alemania el romanticismo sea más popular que en otros países, y, sin embargo, no recoja lo macabro popular? Pues precisamente por eso. Los cuentos de aparecidos se cuentan en voz baja, pero nunca se escriben: ¡sería tentar al Diablo! La creencia es aún demasiado fuerte. Los muertos son mucho más peligrosos que los gnomos. Los escritores alemanes carecen del escepticismo exasperado que impulsa a los románticos de otras latitudes a tocar temas más prohibidos y atroces.

Los primeros románticos ingleses leen y se encuentran numerosas leyendas germánicas, generalmente escritas por autores anónimos. El terror literario se considera en todas partes como un fenómeno alemán. Sin embargo, en la literatura alemana apenas hay cuentos de miedo. Prácticamente ninguno después del romanticismo ${ }^{286}$. El hecho es que, cualesquiera que sean las causas de su abandono, las tenebrosas tradiciones germanas fertilizan en el romanticismo de otros países, donde se manifiestan en su aspecto más lúgubre y terrorífico. En cambio, en la propia Alemania se presentan como con timidez, revistiéndose de un aspecto feérico tradicional, fantástico, maravilloso, pero casi nunca descarnadamente terrorífico ${ }^{287}$.

\footnotetext{
${ }^{286}$ En primer lugar, se cree que uno de los factores principales es que en Alemania no se llega a superar del todo la creencia porque ésta ha ido evolucionando gradualmente y adoptando formas cada vez más racionales y populares, lo que ha impedido la aparición de un escepticismo radical, como en Francia. Ello se traduce en un excesivo respeto por lo sobrenatural, que sólo osa manifestarse en su faceta más tradicional e infantil. Por otra parte, en el ámbito filosófico, frente al empirismo inglés y al materialismo francés, Alemania se rige como campeona del idealismo, que en vez de reprimir lo sobrenatural, canaliza gran parte del anhelo de absoluto propio del romanticismo.

${ }^{287}$ Rafael Llopis, ibídem, pp. 41-45.
} 


\subsubsection{1.- Hadas, brujas y otras representaciones populares}

De las antiguas mitologías se resucita una nueva imagen de la mujer donde su fertilidad es una característica muy importante ${ }^{288}$. Antaño la mujer era relacionada con la madre tierra. Esta figura tenía una importante simbología reproductora, pero también contaba con una potente función. Esto ayudó a mantener intacto su rol de protectora y de esclava del hogar. Sin embargo, aunque su papel era recibir al cansado hombre al llegar a casa, ya no se la veía como una flor marchita y sensible. Sino que se la sentía como el cálido útero de la tierra que siempre estaba dispuesta a ayudar ${ }^{289}$. De esta forma el cuerpo erotizado de la mujer se convirtió en un símbolo vivo del espíritu de la naturaleza.

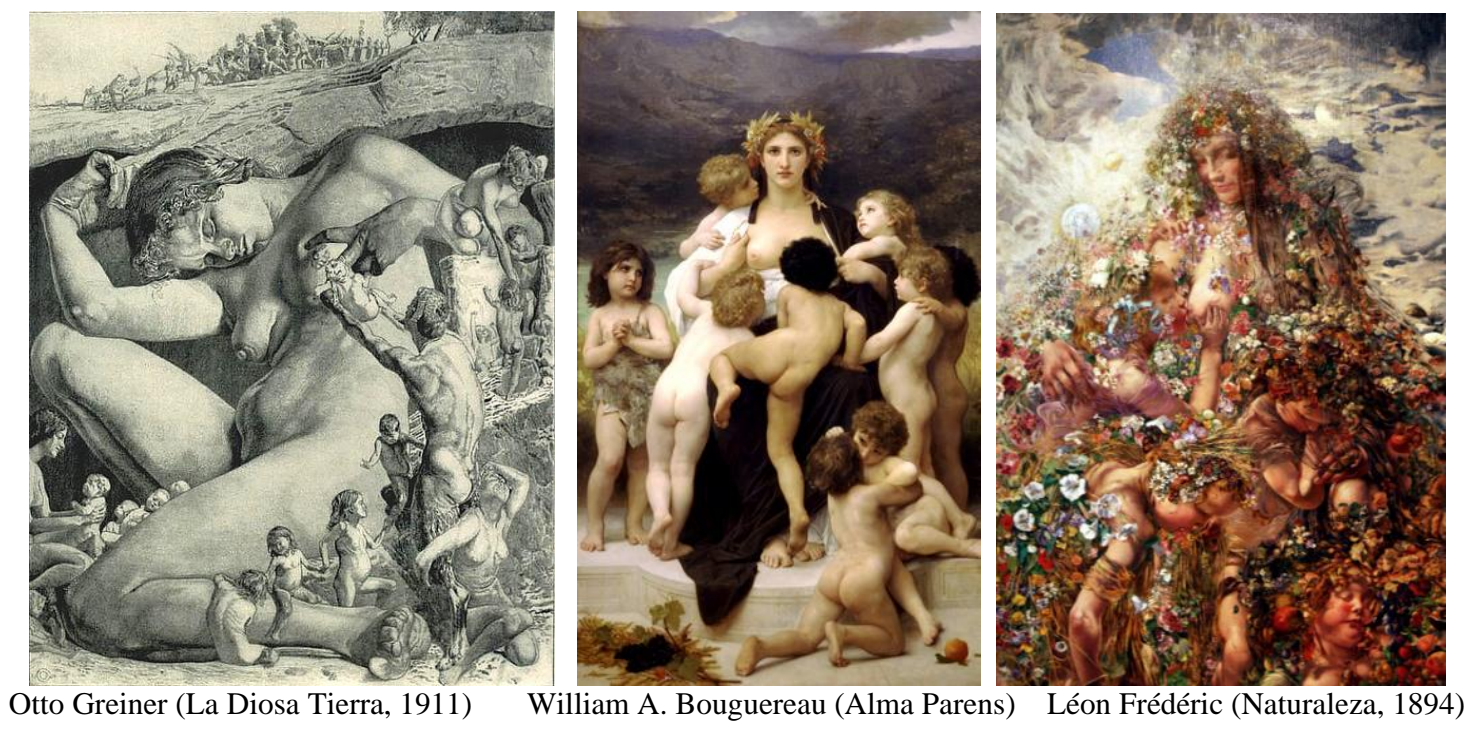

Con frecuencia, al encarnar el espíritu de la madre tierra, apareció retratada flotando en el aire. Artísticamente, se convirtió en una alternativa a la mujer inválida.

\footnotetext{
${ }^{288}$ Bram Dijkstra, op. cit., p. 84.

${ }^{289}$ Bram Dijkstra, op. cit., p. 87.
} 


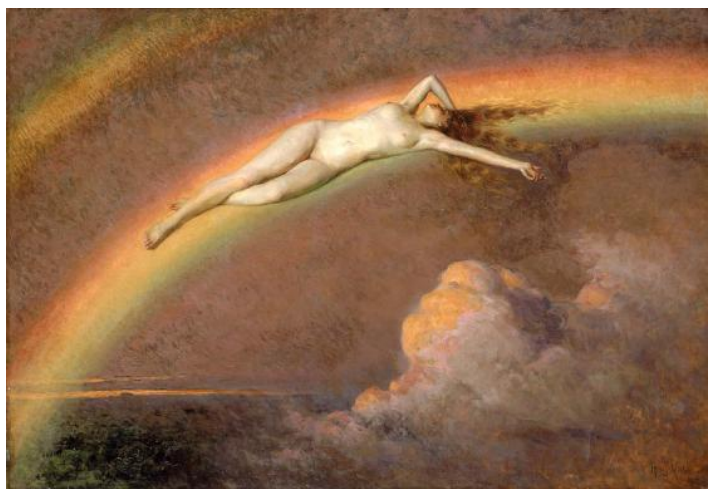

Henry Mosler (El espíritu del arco iris, 1912)

Fue así como encarnaron a las frívolas ninfas de las montañas o, simplemente, a una suave ráfaga de viento.
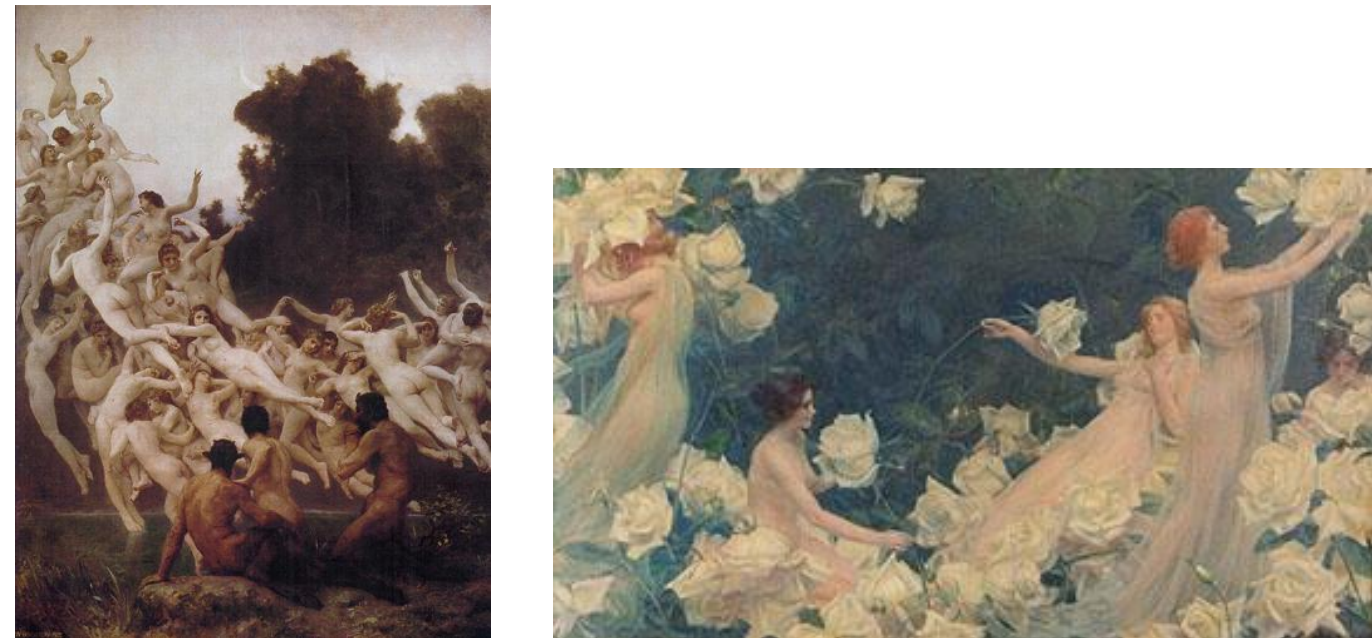

William Adolphe Bouguereau (Las Oréades, 1902)

Charles Courtney Curran (El espíritu de las rosas, 1899)

Es obvio que la mujer ingrávida tenía mucho en común con la mujer postrada. Ambas son pasivas y sensuales, pero ahora nos topamos con un nuevo tipo de sensualidad. Giovanni Segantini en su obra El castigo de la lujuria (1891) deja muy claro que ambas mujeres son sospechosas de ceder al pecado de Onán. De ahí que ambas se nieguen a ser madres. En consecuencia, las dos figuras son caracterizadas como antimaternales y autoeróticas. Por ello, las niñas y las ninfas son retratadas a horas crepusculares, 
momento que se suele asociar al desenfreno de los placeres de la carne y a la secreta lujuria ${ }^{290}$.

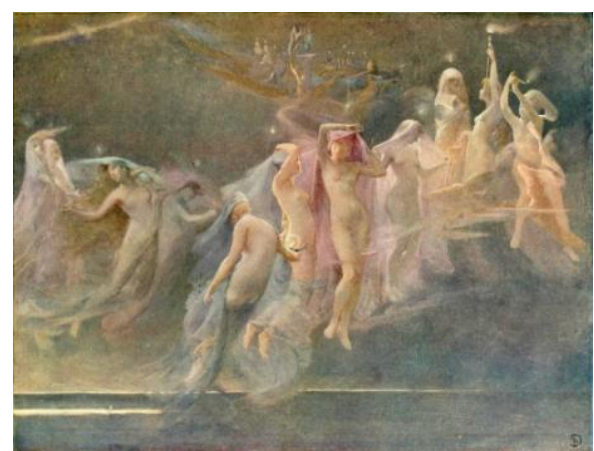

Sarah Paxton Ball Dodson (Las estrellas de la mañana, 1890)

Esta temática, que podría parecer olvidada o anclada en el siglo XIX, renace en la actualidad con fuerza en jóvenes artistas como Sparrek o Simon Birch. Sparek usa fotografías e imágenes manipuladas para crear escenas muy simbólicas. Su experiencia como bailaría profesional de ballet, le lleva a trabajar la plasticidad y la elegancia de un cuerpo femenino muy volatil ${ }^{291}$.

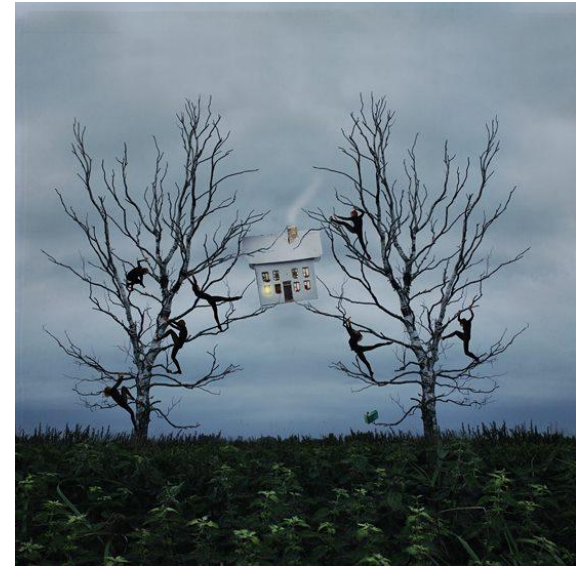

Obstacles

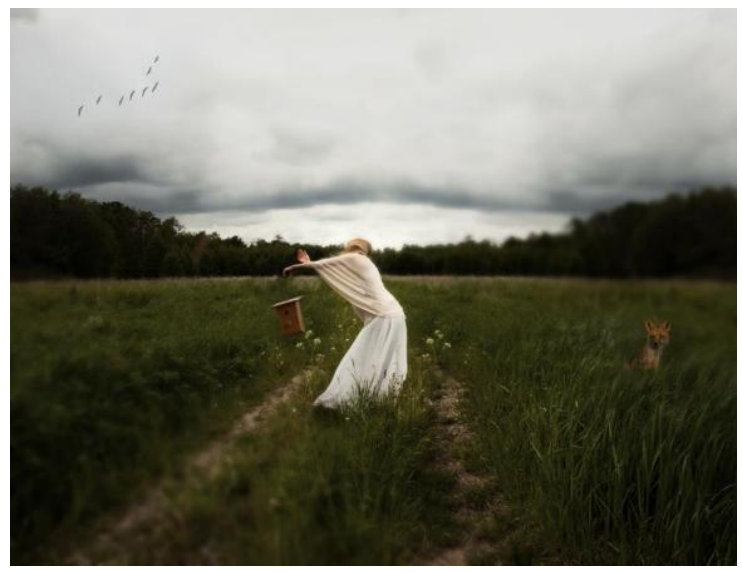

Longing Winds

\footnotetext{
${ }^{290}$ Bram Dijkstra, op. cit., pp. 90-91.

${ }^{291}$ Se pueden encontrar muchas más en: http://www.sparrek.org
} 


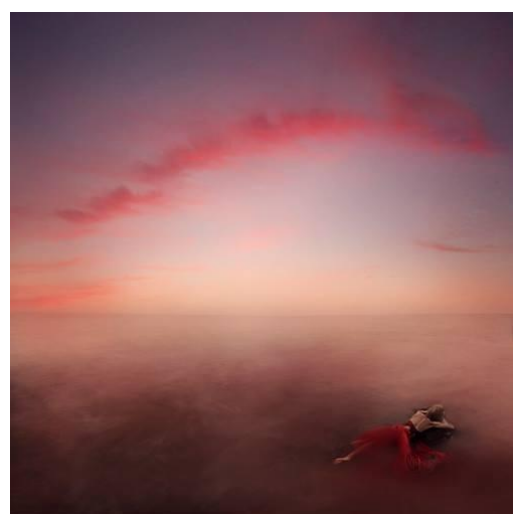

The day that sailed away

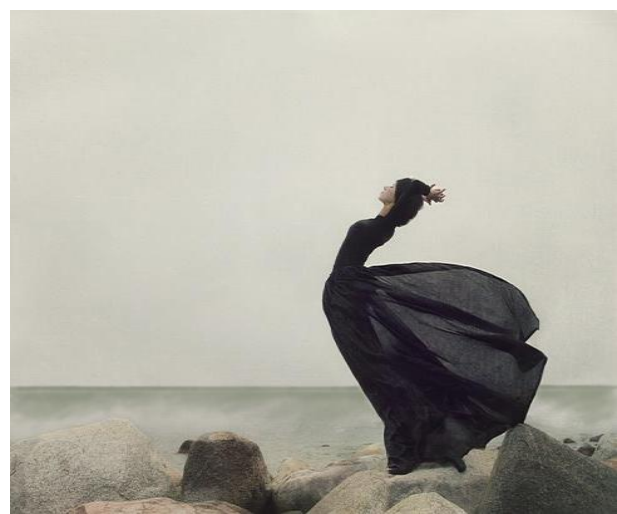

When imposible ends

Simon Birch es un artista que nació en Estados Unidos y en la actualidad vive en Hong Kong. Sus cuadros son unos preciosos óleos en donde trabaja las emociones de los cuerpos. En el caso de los cuerpos femeninos podemos observar como la tensión es palpable.
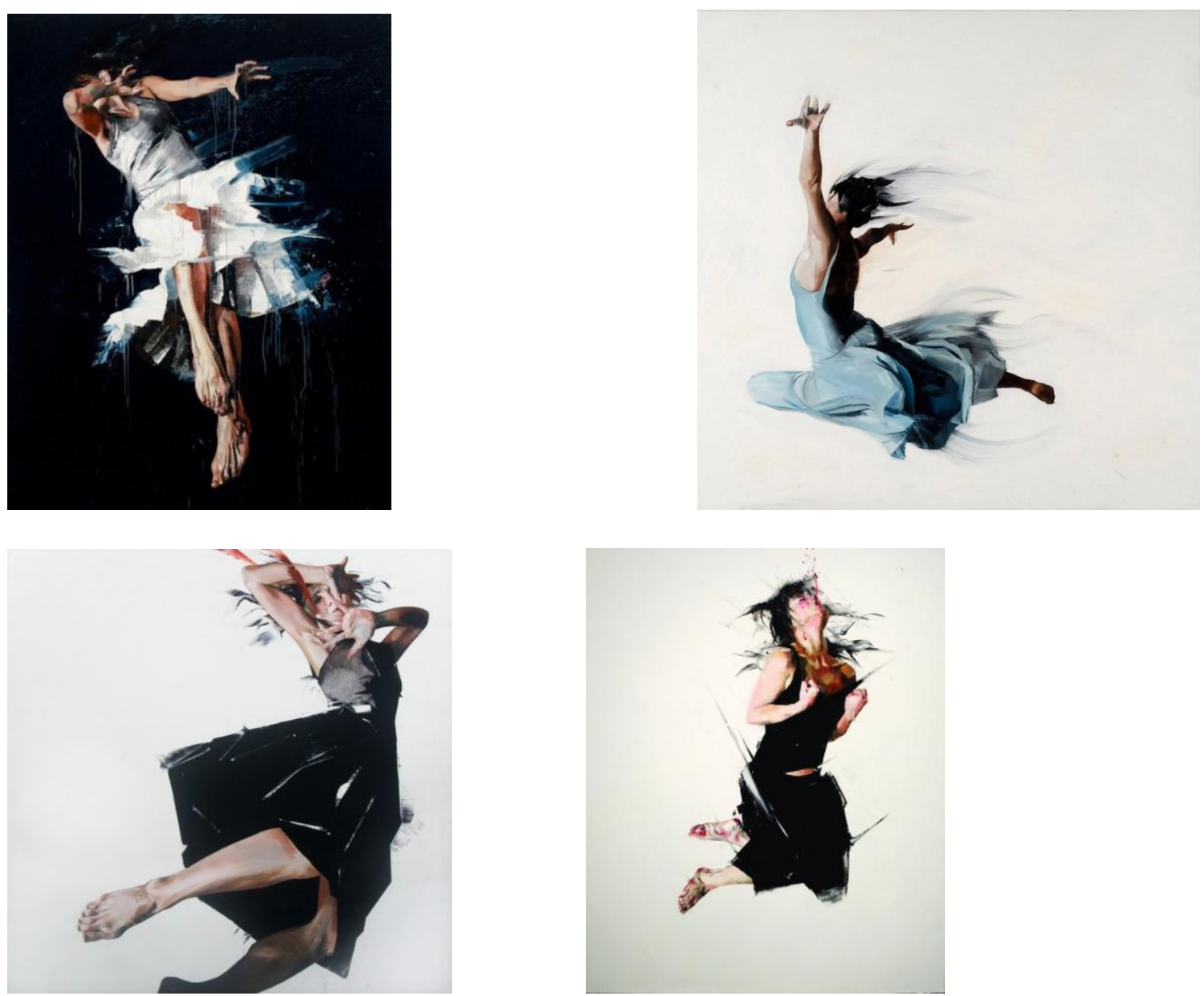


\subsubsection{2. - Los cuentos románticos}

Estas bases del cuento se asentaron en la época prerromántica de la mano de Goethe. Para él, el cuento no debía guardar relación directa con la realidad. Pero, para que la imaginación no entre en conflicto con el intelecto, el cuento debía despertar una emoción en el lector.

En 1770, con la aparición del Sturm und Drang de Klinger (1770), se forma una llamada "primera escuela romántica". A este primer movimiento pertenecieron los hermanos Schlegel, Novalis y Ludwig Tieck. Sin embargo, los cuentos de Tieck son los que encarnan el prototipo del cuento fantástico alemán. Ludwig Tieck escribe cuentos poéticos y legendarios, muy influenciados por las ideas de Goethe, Novalis y por los cuentos de hadas de Perrault y de Mme d'Aulnoy. Estos se desarrollan en un ambiente melancólico y brumoso, en donde reviven los antiguos personajes de los mitos alemanes. Los elfos y las brujas de Tieck tienen un cariz francamente siniestro y se acercan bastante al cuento terrorífico, pero conservan características de la tendencia blanca del cuento de miedo como la fantasía épica, las brumas, el humorismo melancólico... ${ }^{292}$ En ellos no hay elementos macabros.

Posteriormente, con la llamada "segunda escuela romántica", junto a Brentano, Eichendorf y Kleist surge otro gran escritor fantástico, Achim von Armin. Este autor escribía cuentos donde lo irreal pierde de nuevo la nitidez de contornos. También tenemos que destacar los cuentos de E.T.A. Hoffmann, los cuales adquieren un tono más vago y sombrío. Por último, encuadrados con Uhland, Lenau y Heine, hay que citar

\footnotetext{
${ }^{292}$ Dentro de esta época también nos encontramos con Ernesto Guillermo Teodoro Hoffmann (1776-1822) y su Fantasías al estilo Callot.
} 
a Adalberto von Chamisso y a Teodoro Storm. Todos ellos forman parte de la categoría de "los últimos románticos".

En Alemania, una vez pasada la erupción romántica, lo fantástico casi desaparece como género. La literatura alemana conserva el idealismo y la metafísica tradicionales. Pero la literatura fantástica ulterior requerirá un escepticismo, un humorismo burlón, una flexibilidad espiritual y, también, una superficialidad que no se dan en Alemania ${ }^{293}$.

\section{4.- El erotismo como problema inicial}

La dominación simbólica que sufren las mujeres radica en la adopción de una negación de la existencia pública y visible. Socialmente, la mujer casada vive por y para las personas de su hogar, nada más. Esto se traduce en el rechazo a la existencia legítima y pública. Las féminas tienen la obligación de ser completamente invisibles, incluso, la importancia de su trabajo recae en que sean invisibles. Se trata de trabajos imperceptibles porque aparentemente no tienen repercusión en los parámetros productivos. Desde el punto de vista masculino, ellas hacían algo más importante: prestar apoyo a la dura rutina masculina. Con la ayuda femenina, ellos no se preocupaban por problemas cotidianos como la comida, la limpieza de la ropa, el mantenimiento de la casa... Ellas no sólo estaban fuera del sistema de producción, sino que suponen una seguridad. Ellas son los pilares lo sostienen los varones.

Sin duda alguna la femme fatale es una figura artística que se atreve a cuestionar este orden simbólico. Ahora, la imagen femenina del siglo XIX será potencialmente visible. Se crea una imagen artística capaz de tomar conciencia de que es un ser por y para el varón. Así que los cuadros y las novelas de la época se llenan de personajes femeninos

\footnotetext{
${ }^{293}$ Rafael Llopis, op. cit., pp. 46-51.
} 
que se saben observados. Hete aquí que las categorías de percepción y de apreciación se invierten. Ellas adoptarán sobre sí mismas el punto de vista del dominador y, quitándose la capa de la moralidad, muestran sus categorías de percepción de forma directa ${ }^{294}$.

Muchos han sido los que han relacionado la reciente dominación simbólica de las féminas con la revolución sexual. Pero si seguimos ese camino corremos el riesgo de confundir sexo y erotismo. Siguiendo a G. Bataille, vemos que el sexo es una necesidad biológica que compartimos con los animales. Pero el erotismo, a diferencia del reino animal, se sustenta sobre la idea de la belleza estética. Bajo estas premisas la femme fatale se comprende como una mujer que desea ser mirada, que desea destacar y ser el punto de mira tanto para hombres como para mujeres. Su dominación radica en su potente erotismo, y en consecuencia en los signos sexuales visibles o apreciables ${ }^{295}$.

\subsection{1.- El erotismo, su experiencia interior y su comunicación}

La distancia que separa la actividad sexual de la actividad erótica es muy considerable. A medida que nos adentramos en el siglo XIX la distancia se potencia a través del tabú que crearon las autoridades médicas y religiosas. El erotismo era negado y prohibido porque no buscaba ni la reproducción ni el cuidado de los niños. Su único objetivo era la búsqueda psicológica del goce, independientemente de la actividad sexual ${ }^{296}$.

En contra de lo que se pueda pensar, el erotismo no nace por la visión de una persona poderosamente atractiva. El sentimiento erótico funciona al revés. Esta se sitúa en el

\footnotetext{
${ }^{294}$ Pierre Bourdieu, op. cit., p. 144.

${ }^{295}$ Esta idea es completamente inversa a la que defiende Pierre Bourdieu en La dominación masculina, Angrama, Barcelona, 2000, p. 144.

${ }^{296}$ Goerges Bataille, El erotismo, Barcelona, Tusquets, 1997, pp. 15-16.
} 
plano de una experiencia interior y personal. Es decir que, una persona reconoce a otra como atractiva porque responde a sus deseos interiores. El hecho de que un varón reconozca a una mujer como potencialmente erótica podría verse ligado a múltiples interpretaciones subjetivas donde entraría el gusto personal de cada uno ${ }^{297}$.

También es cierto que hablar de la experiencia personal de cada individuo nos lleva al carácter arbitrario. Sin embargo, la experiencia interior de cada sujeto responde a impresiones objetivas. Es decir, el hombre materializa su deseo interior en unos determinados elementos ornamentales y exteriores. Esta relación nunca se da de forma independiente, siempre la encontramos vinculada a tal o cual aspecto del cuerpo femenino $^{298}$. Por lo tanto, las características del cuerpo femenino ayudan a salir al hombre de su individualidad, pero al mismo tiempo están llamadas a volver al cuerpo masculino para satisfacer el deseo. Este movimiento de ida y vuelta tan característico es llamado por Bataille el movimiento erótico, y es innegablemente objetivo ${ }^{299}$.

Ahora bien, el erotismo se fundamenta en el juego que se da entre la prohibición y la transgresión. En el momento en que nos sentimos atraídos por un objeto, el deseo nos arroja fuera de nosotros y nos impulsa hacia él. Cuando la atracción física se da entre dos personas nace una comunicación (gestual, visual, con palabras...), pero habitualmente esta no se admite. La prohibición que ejerce la autoridad desempeña un papel muy importante al establecer unas normas y unos límites acerca de nuestra persona $^{300}$ : las autoridades prohíben todo tipo de erotismo para evitar que se den

\footnotetext{
${ }^{297}$ Goerges Bataille, op. cit., pp. 36-40.

${ }^{298}$ Generalmente, se trata de algún aspecto de la vestimenta femenina que está orientado a destacar una parte u otra del cuerpo femenino. Por ello, las autoridades pedían moderación en las formas de vestir.

${ }^{299}$ Goerges Bataille, op. cit., p. 36.

${ }^{300}$ Goerges Bataille, op. cit., p. 147.
} 
experiencias al margen de la actividad reproductora. Pero estas prohibiciones no hacen más que acentuar el carácter prohibido y hacerlo más apetecible si cabe. En consecuencia, la transgresión busca la forma de superar esas normas dejándonos llevar por el deseo.

\subsection{2.- La evolución de los elementos eróticos}

El concepto de belleza ha variado a lo largo de la historia, y analizarlos implicaría definir la belleza del cuerpo en términos generales. Lo que intentamos mediante esta definición es no hablar de belleza en general, sino limitarla al concepto erótico. Desde este punto de vista, la belleza será una de las características que habilite el deseo ${ }^{301}$.

Los ascetas dicen que la belleza femenina es la trampa del diablo. Sólo una mujer bella puede sacar al hombre de su cerrada individualidad y obsesionarlo con la posesión ajena. Aunque conseguir a la mujer se presentará como una tarea imposible, la propia naturaleza del deseo impulsará al varón a intentar conseguirla. Esta búsqueda le llevará hasta el extremo, lo cual conlleva que el hombre incumpla los límites marcados. En esta situación, la fémina vuelve tolerable una situación desordenada y violenta. La belleza femenina arrastra consigo la pérdida del hombre, el cual será capaz de perseguirla hasta aplacar su deseo. Este impulso se embrolla con un exceso de violencia que puede implicar la propia muerte del varón ${ }^{302}$.

\footnotetext{
${ }^{301}$ Goerges Bataille, op. cit., p. 147-148.

${ }^{302}$ Goerges Bataille, op. cit., p. 275-276.
} 


\subsubsection{1.- El cuento de miedo y la belleza de lo horrendo}

La evolución de los elementos eróticos está estrechamente relacionada con los cambios que se han dado en las prohibiciones. En la transgresión muchos textos autoritarios prohibieron las relaciones con los animales, con las prostitutas, con menores de edad, la violación... Todos estos actos eran comprendidos como crímenes que alteraban el orden de la sociedad. Las autoridades médicas y religiosas observaron que el hombre se perdía por medio del goce. Para evitarlo, trabajaron imágenes horrorosas que ejercían una amenaza directa. Estas desempeñaron la función de límite y buscaban obstaculizar la caída en el pecado ${ }^{303}$. El sentido de las prohibiciones gira alrededor de dos imágenes centrales: una de la animalidad, y la otra de la enfermedad.

Pero aún así, para Bataille se mantiene el sentido de la aberración. Dentro del campo de la belleza humana, a un hombre se le juzga bello siempre que se aleje de la animalidad, porque su aspecto animal es desagradable. Sin embargo, la cuestión es mucho más difícil cuando hablamos de las mujeres. El instinto sexual perfila la belleza de la mujer en el anuncio de sus vergüenzas. Especialmente, en sus partes pilosas o animales. Pero el deseo erótico se encuentra en la belleza que niega esa animalidad. La mujer se esfuerza por alejarse de su origen animal, y esta negación consigue precisamente todo lo contrario: exaltar las partes animales. Es aquí donde se concentra el sentido de la aberración, y la constante transgresión de las normas morales ${ }^{304}$. Porque indirectamente se resalta el instinto sexual de naturaleza caótica, desorbitada e incontrolable.

En torno al eje de la enfermedad giran imágenes horrorosas como la de la sangre o la del vómito. Estas sensaciones son diferentes según el individuo ante el que nos situemos,

\footnotetext{
${ }^{303}$ Goerges Bataille, op. cit., p. 273.

${ }^{304}$ Goerges Bataille, op. cit., pp. 146-149.
} 
pero normalmente son elementos desagradables por su relación directa la muerte. Se trata de un vértigo ante un miedo ancestral. Normalmente, la muerte se comprende como el fin, la desaparición del cuerpo. Las autoridades prohibieron en sus discursos las relaciones sexuales con las prostitutas, porque estas eran portadoras de graves enfermedades que irreparablemente podían llevar al hombre a la muerte. Pero este acto prohibitivo hizo más tentadora la figura de la prostituta, pues, es tan intenso el deseo que lo único que le preocupa es saciarlo aunque el precio sea la muerte. Ahora, la muerte adquiere un nuevo sentido. Ya no es vista como una transición, sino que está estrechamente relacionada con el placer. La muerte propia o la ajena se alcanza al llegar al estado del gozo, y es en el éxtasis cuando nos encontramos con el horror a la muerte o al contagio. No es que el horror se confunda con la atracción, pero sí es cierto que el horror refuerza la atracción $n^{305}$.

Esta característica del horror es la que conquistó el intelecto de los escritores del siglo XIX. Ninguno de ellos confundió el horror con la atracción, pero sí se hicieron eco de que el sentimiento de horror se manifestaba en el deseo pasional y, en consecuencia, reforzaba la atracción. Explicar esto supondría sumergirnos en miedos innatos de la humanidad, y que por el peso de la razón han sido olvidados. Sin embargo, hubo innumerables escritores que bucearon en los ritos precristianos y los rescataron. En ellos encontraron una manifestación directa de la belleza de lo horrendo. Tal es el caso de Kalevala, Las tragedias de Sófocles, Eurípides, los viajes por el inframundo de Eneas y Ulises, La Jerusalen Liberada, Os Lusiadas, La Divina Comedia, Los sueños de Quevedo... e incluso Beowulf en donde el protagonista se ve poderosamente atraído por un demonio femenino.

\footnotetext{
${ }^{305}$ Goerges Bataille, op. cit., p. 274.
} 
165 | La femme fatale en la publicidad del siglo XX

Muchas de estas escenas influenciaron a los románticos. Los cuales las potenciaron hasta conseguir que las narraciones de terror y el propio miedo desempeñaran una función estética $^{306}$. Es entonces cuando surge el boom de la amada muerta o la no muerta, lo que más tarde daría pie al crimen pasional.

${ }^{306}$ Rafael Llopis, op. cit., pp. 25-28. 


\title{
4.- El orden irracional del personaje erótico. La inversión de los órdenes sociales en el género de terror
}

\author{
La muerte es lo más terrible y mantener la \\ obra de muerte es lo que mayor fuerza requiere. \\ Hegel \\ Una gran figura sombría la literatura fantástica: \\ no se trata de la carne sino de la muerte \\ Louis Vax \\ ¡La amaba, y la destruí! \\ Lord Byron
}

El interés de la estética romántica por la subjetividad, y el auge de la psicología, han tenido como consecuencia una atención creciente hacia el mundo interior del personaje $^{307}$. En ese sentido, el relato se presenta como un procedimiento válido para profundizar en el conocimiento de la psique humana. En general, se trata de racionalizar los sentimientos, pasiones o deseos íntimos con el fin de conocer la auténtica personalidad del protagonista. Por supuesto, desde un punto de vista psicológico, cuando más siniestro y oscuro sea el personaje más rico será su interior ${ }^{308}$.

Todo elemento que se preste a un análisis psicológico está cargado de los tintes propios de las leyes morales. Estas se rigen sobre dos principios subjetivos, pero al mismo tiempo fundamentales: el bien y el mal. Para hacer esta realidad palpable los románticos pondrán el acento en el mal, pero en ningún momento hablaran del mal absoluto, sino que más bien hacen referencia a un mal natural, vulgar y sin artificios.

\footnotetext{
${ }^{307}$ Manuel Asensi Pérez, op. cit., p. 393.

${ }^{308}$ Manuel Asensi Pérez, op. cit., pp. 404-406.
} 
Los autores no buscarán la maldad en actos concretos, sino que ésta se perfila mediante una extraña red de elementos simbólicos. Elementos que conectan entre sí a los personajes para que el lector palpe la fatalidad. Así que la maldad y la fatalidad de los personajes derivan de su propia interacción ${ }^{309}$.

\section{1.- El erotismo terrorífico}

Al hablar del erotismo podríamos trtazar una perspectiva histórica de la belleza femenina. Esto nos permitiría hacer un análisis de los elementos que consideramos bellos. Pero este punto de vista incidiría sobre un concepto artístico de belleza que recae en las formas objetivas del aspecto exterior. Sin embargo, también es necesario abordar los aspectos seductores e intangibles de los cuerpos. Estos elementos sexuados responden a movimientos vivos que nos remueven interiormente.

Para Georges Bataille, el erotismo es un desequilibrio en el cual el ser se cuestiona a sí mismo frente al objeto erótico. Es tan fuerte la atracción que el sujeto siente por el objeto que, en cierto sentido, el ser se pierde objetivamente. Es entonces cuando el sujeto se identifica con el objeto, y este ocasiona su caída final ${ }^{310}$.

Muchos autores del siglo XIX tuvieron como fin representar al ser en lo más íntimo. Así que lo acompañaron hasta el mismo punto del desfallecimiento. El paso del estado normal al estado de deseo erótico supone en nosotros una disolución relativa del $\operatorname{ser}^{311}$.

\footnotetext{
${ }^{309}$ Umberto Eco, Historia de la fealdad, Barcelona, Lumen, 2007, pp. 278-279.

${ }^{310}$ Georges Bataille, op. cit., pp. 33-39.

${ }^{311}$ Georges Bataille, op. cit., pp. 21-22.
} 
Un estado psicológico que hipnotizó a muchos escritores, y que les llevó a profundizar en la actividad erótica y en la disolución del ser como objeto ${ }^{312}$.

\subsection{1.- La condena del erotismo}

La relación entre erotismo y moralidad encuentra su origen en las relaciones entre erotismo y las lejanas supersticiones religiosas.

La raíz morfológica de "erotismo" es "ero-". Este término servía para designar al dios primordial Eros. Para la antigua Grecia Eros fue un dios que existió desde el principio del mundo, y que se identificaba con elementos o principios naturales. Esta divinidad respondía a la atracción sexual, al amor y al sexo; por ello hoy en día lo conocemos como el dios de la fertilidad. Existen varias versiones sobre cómo fue concebido Eros. En la Teogonía de Hesíodo se dice que surge del Caos primordial junto con Gea (la tierra) y Tártaro (el inframundo). Según Aristófanes en Las Aves Eros nace de un huevo puesto por la Noche (Nix) quien lo concibe con la Oscuridad (Érebo). Pero, posteriormente, nacen varias versiones alternativas en donde se le hace hijo de Afrodita (diosa del amor) y Ares (dios de la guerra). O, incluso, Platón menciona en El Banquete que Eros fue concebido por Poros (Abundancia) y Penia (Pobreza) en la fiesta de cumpleaños de Afrodita. Todas ellas son asociaciones muy simbólicas que lo vinculan a lo tenebroso y a lo violento. Aunque, para que este personaje se merezca la etiqueta de

\footnotetext{
${ }^{312}$ En el movimiento de la disolución de los seres se compone de dos actantes. Uno es el participante masculino al cual le corresponde el papel activo. El otro actante es la parte femenina, la cual cumple con el rol pasivo. La parte pasiva es esencialmente disuelta como ser constituido. Pero para un participante masculino la disolución de la parte pasiva sólo tiene un sentido: el de preparar una fusión en la que se mezclan dos seres. Es el hombre quien disuelve al agente pasivo. La imagen de la femme fatale como objeto erótico supone la puesta en escena de una estructura inversa a la que se acaba de exponer. Así que, será ella quien disuelva al hombre como ser constituido.
} 
prohibido debemos rescatar los textos de Eratóstenes. Para él Eros era el dios que representaba el amor entre hombres, y Afrodita el amor entre hombres y mujeres.

Originalmente Eros no tuvo nada que ver con la reproducción, pero sí con la actividad sexual ligada al placer. Este concepto evolucionó, se desligó de la práctica sexual entre varones y alcanzó un significado más genérico: el placer desvinculado de su actividad reproductora. Es el placer de la belleza o el placer por el placer. Como era de esperar, esta práctica fue completamente prohibida por las autoridades médicas y religiosas ${ }^{313}$.

La esencia de toda religión es determinar los actos prohibidos y los actos culpables. Pero toda prohibición lanza un mensaje negativo que ayuda a resaltar aquello que no se debe hacer. De forma indirecta resaltan unas normas, unos límites que incitan a la transgresión. El cristianismo, al igual que otras religiones, intentó privar al mundo del erotismo, pero el resultado final es confuso. Para configurar una sociedad ordenada y jerarquizada, el cristianismo fue favorable al mundo del trabajo y resaltó de él la importancia del esfuerzo. Como contrario a este principio, encontramos la dejadez y la vagancia. Como es de esperar, estas características se dan en clases acomodadas, cuya abundancia material les permite no depender del trabajo. Pero el exceso de tiempo libre también les permite caer en hábitos nada saludables. De ahí que los médicos y la iglesia asociaran el trabajo con prácticas buenas y saludables y, en consecuencia, la ociosidad con la maldad. Pues en estos momentos vacios de preocupaciones era donde se temía que el pecado o el demonio obraran ${ }^{314}$. Pero estas reglas no hacen más que potenciar la prohibición y subrayar la idea de la transgresión.

\footnotetext{
${ }^{313}$ Guillermo Solana, Las lágrimas de Eros, Madrid, Museo Thyssen-Bornemisza, 20 oct. 2009 - 31 ene. 2010, pp. 53-54.

${ }^{314}$ Guillermo Solana, op. cit., pp. 27-30.
} 
Fruto de ello tenemos el libertinaje del siglo XVIII que vino determinado por el sentido originario de la abundancia vinculada a Eros. Originalmente, el fin fundamental del dios Eros era la actividad sexual, así que periódicamente se celebraban ritos muy específicos en su conmemoración ${ }^{315}$. Estos tomaban forma de bacanal que se entendían bajo el resplandor divino, por lo que en origen el erotismo tenía un sentido religioso ${ }^{316}$.

Pero al mismo tiempo se da algo muy importante que no se había producido antes. Estamos ante el paso del erotismo desenfrenado de los siglos XVI y XVII al erotismo consciente del siglo XVIII. Este cambio se da a través de un nuevo lenguaje literario de la voluptuosidad, un lenguaje iniciado por Sade quien describe el arrebato violento y opone estados de nervios contradictorios, ante los cuales sólo responden tónicos o calmantes $^{317}$.

\subsubsection{1.- La metamorfosis de Satanás}

A principios del siglo XIX, y como fruto de la prohibición del libertinaje, se consolida una de las figuras más impactantes del mundo de la literatura, la del dandy. Mario Praz sitúa su origen en la primera imagen hermosa que se dio de Lucifer, y esta se materializa con el cuadro de la "La caída de Lucifer" de Lorenzo Lotto.

\footnotetext{
${ }^{315}$ Las bacanales ilustradas en las monedas y en las vasijas tracias o, incluso, las bellas pinturas de la Villa de los Misterios en Pompeya, son ejemplos visuales del desenfreno que se daba durante los ritos.

${ }^{316} \mathrm{Si}$ seguimos por este camino, resulta trivial decir que "la religión prohíbe el erotismo" porque el erotismo tiene sus raíces en la religión. Pero sí es cierto que en la historia del erotismo el cristianismo presenta un claro papel de prohibición y de condena. La nueva censura que se impone sobre el erotismo le da una luz siniestra. Lo prohibido le da un sentido del que antes carecía, pues todo lo que se veta, de alguna forma incita a la transgresión. Sin esta propia acción carecería de poder maligno.

${ }^{317}$ Alain Corbin, op. cit., vol. II, pp. 60-80.
} 


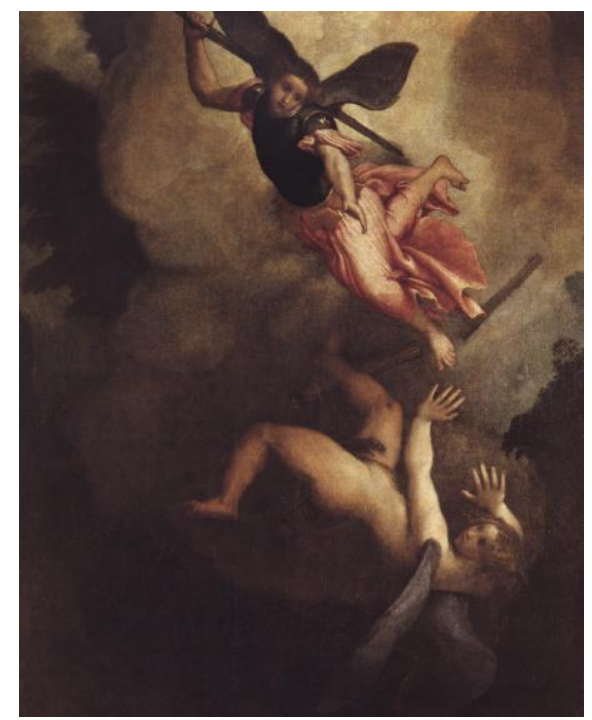

Lorenzo Lotto (La caída de Lucifer)

John Milton tuvo muy presente este importantísimo cuadro cuando escribió su primer libro Paraíso perdido en 1667. Una de las características más importantes que desarrollaba su personaje fue la belleza caída. Es decir, la poderosa atracción del pecado y, en consecuencia, la belleza y la satisfacción que reside en el mal.

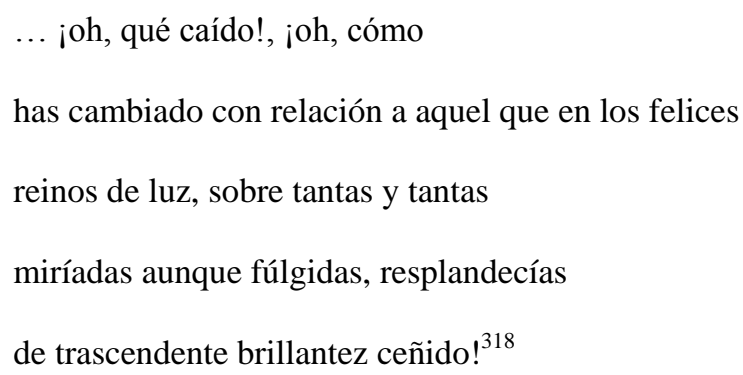

El personaje es descrito como la cara adversa de Dios, el cual se percibe como portador de malos designios, porque todo lo que hay a su alrededor está sembrado de maldición. En consecuencia, es un personaje que no sólo se destruye a sí mismo, sino también todo lo que le rodea ${ }^{319}$ :

\footnotetext{
${ }^{318}$ Mario Praz, op. cit., p. 119.

${ }^{319}$ No es casualidad que sea esta figura la que de paso a la figura del vampiro.
} 
Él sobre los demás en estatura y en porte

descollaba soberbio: todavía su Forma

no había perdido todo el nativo

centelleante fulgor, y parecía

nada menos que un Arcángel derrocado

y de gloria un oscurecido exceso:

Como cuando el nuevo Sol brilla

por el aire horizontal caliginoso

privado de rayos, o cuando lo cubre enteramente

el dorso de la Luna en oscuro eclipse:

Desastroso crepúsculo que ennegrece

la mitad de las Naciones, y alternativamente

a los grandes Monarcas en el temor suspende.

Aunque envuelto en tan oscuro velo

el Arcángel refulgía sobre todos los demás

pero su rostro lleno de surcos tenía

del rayo las profundas cicatrices:

Está la otra Cura sobre la pálida mejilla,

pero bajo miradas de coraje intrépido

y de considerado orgullo, vigila

para la venganza ${ }^{320}$.

Realmente se trata del esplendor de una belleza divina que no ha desaparecido del todo, sino que permanece ofuscada tras la melancolía y la muerte. Por supuesto, no es necesario explicar que para potenciar esta figura se retomarán características medievales tales como la belleza maldita, la energía heróica... A finales del siglo XVIII, el Satanás de John Milton transfiere su siniestra fascinación al bandido generoso y al delincuente sublime. Son innumerables los fondos pintorescos que comienzan a llenarse de rebeldes

$\overline{{ }^{320} \text { Mario Praz, op. cit, pp. 119-120. }}$ 
y de hijos de Satanás, pero el mundo literario tampoco se queda corto. Es entonces cuando, antes del Romanticismo, podemos encontrar Räuber Karl Moor de Schiller (1781), las obras de Klopstok, El monje de Mathew Gregory Lewis (1796), Bandidos de Schiller, Brave of Venice (1805), Abällino Dergrosse Bandit de Heinrich Zschokke (1794), los corsarios y los infieles de Lord Byron en El Infiel, René de Chateaubriand... Todos ellos poseen los mismos caracteres que el Satanás de Milton. Tienen una frente pálida y altiva, bajo una apariencia calmada esconden pasiones tenebrosas, pero nunca nadie podrá decir con precisión en qué consisten ${ }^{321}$.

\subsubsection{2.- La metamorfosis de Ave}

La figura del dandy no tiene sentido si no es por la aparición y el sufrimiento de la víctima. La protagonista es una joven muchacha, bella hasta el extremo, pero infeliz a causa de la persecución que sufre por parte del individuo masculino. La mayoría de los escritores ingleses no parecen darse cuenta de la naturaleza cruel y aterradora de los espectáculos donde se sitúan sus heroínas perseguidas. Estos ambientes les permiten mostrar el tema del incesto y el vicio. En el caso del incesto, vemos como llegó a ser ennoblecido por Prévost en Clevelan (1731) y por Chateaubriand en René $e^{322}$.

La idea del vicio unida a la joven perseguida aparece renovada a través de Clarisa Harlowe de Richardson. En ella Richardson se apoya en la observación de las costumbres cotidianas de la vida real de las mujeres ${ }^{323}$, y a ello le suma una pintura particular de las torturas físicas y morales que sufren diariamente las mujeres. En

\footnotetext{
${ }^{321}$ Mario Praz, op. cit., pp. 118-150.

${ }^{322}$ Mario Praz, op. cit., pp. 210-214.

${ }^{323}$ Como, por ejemplo, en Las Religieuse de Diderot que parte de un escándalo acontecido en la vida real.
} 
conjunto, la obra responde a la filosofía del Marqués de Sade, en donde se manifiesta que la virtud lleva a la miseria y a la ruina, y el vicio a la prosperidad. De ahí lo que Mario Praz denominará las máscaras o teoría de la decadencia. En ella se desarrolla la idea de que el vicio es un elemento característico del sistema natural humano. Pero aparece encubierto por las relaciones sociales que conllevan el ambiente social y las pesadas costumbres. En consecuencia, para Sade la práctica del vicio es normal, porque se ajusta a las leyes de la naturaleza. Se trata de una realidad que carece de contenido filosófico, simplemente hay placer en la destrucción y en la transgresión de la virtud. Esta inversión de valores es la base del sadismo, en donde el vicio será el elemento activo y positivo, y la virtud el elemento pasivo y negativo.

En el Romanticismo, se cree que la mejor forma de expresar literariamente las pasiones es comenzar por asentirlas. De este modo, Sade propone el vicio y el mal como verdad. En ambos casos se trata de una sátira contra la sociedad contemporánea que honra el vicio como herramienta de pode, y que se sirve de la hipocresía para oprimir a la sociedad $^{324}$. Al respecto podemos encontrar varios ejemplos, tales como Manon Lescaut de Edgar A. Poe, Confessions de Rousseau, Les Amours de Milord Edouard Bamston, el poema Der Gott y el poema Die Bajadare de Goethe, y Kabale und Liebe de Schiller. La belleza contaminada es la belleza de Medusa que tanto obsesionó a Shelley (1819) y la misma que caracterizó al personaje femenino en Melmoth, el errabundo (1820) de Charles Maturin.

Para Mario Praz el nacimiento de la belleza contaminada se dio cuando a la figura femenina se le suma el cliché del ideal byroniano. Sólo entonces, con el influjo del héroe byroniano, es cuando se da el origen de la mujer fatal. Este paso se llevó a cabo

\footnotetext{
${ }^{324}$ Mario Praz, op. cit., pp. 190-210.
} 
de la mano Walter Pater, quien leyó la historia de la femme fatale en la sonrisa de la Gioconda $^{325}$. Para Pater la belleza femenina de la dama procedía del interior, pues se mostraba vetusta como las rocas, pero era capaz de ocultar extraños pensamientos, fantásticas divagaciones y pasiones exquisitas. Su sabiduría era la misma que la de un vampiro que ha muerto varias veces y conoce los secretos de las tumbas, desciende a los mares profundos, y todavía conserva la luz crepuscular.

Es una belleza que procede del interior y se expresa sobre la carne, el depósito, célula a célula, de extraños pensamientos, de fantásticas divagaciones y de pasiones exquisitas. (...) Es más vetusta que las rocas entre las cuales se asienta; como el vampiro, murió muchas veces y aprendió los secretos de la tumba; descendió a profundos mares y de él conserva a su alrededor la luz crepuscular; traficó extraños tejidos con mercaderes de Oriente; y, como Leda, fue madre de Elena de Troya; y como Santa Ana, fue madre de María; y todo esto no ha sido para ella más que sonido de liras y de flautas, y vive solamente en la delicadeza con la que ha modelado los mudables lineamientos, y coloreado los párpados y las manos. La imaginación de una perpetua vida, que junte miles de experiencias es de antigua data; y la filosofía moderna ha concebido la idea de la humanidad como sujeta al influjo de todos los modos de pensamiento y de vida. Ciertamente, Monna Lisa podría ser considerada como la encarnación de aquella antigua fantasía y el símbolo de la idea moderna ${ }^{326}$.

\subsubsection{3.- La coronación de la maldad femenina}

El sistema legislativo de la Europa actual surge por una nueva reorganización del sistema judicial y penal. Estos cambios en los sistemas penales consisten en diferenciar entre la falta y el crimen. La falta fue entendida como una infracción contra la ley natural, la ley religiosa o la ley moral. Por el contrario, el crimen era una ruptura contra

\footnotetext{
${ }^{325}$ Mario Praz, op. cit., pp. 254-255.

${ }^{326}$ Mario Praz, op. cit., p. 255.
} 
la ley civil explícitamente establecida en el seno de una sociedad por el lado legislativo. De esta forma, vemos cómo se desligan el poder judicial y el religioso. Ahora el crimen no tendrá ninguna relación con la falta moral o religiosa ${ }^{327}$.

Desde entonces, el poder judicial estableció unas leyes útiles para la sociedad e intentó reprimir todo aquello que era nocivo para la sociedad. El crimen ya no era algo relacionado con el pecado, ahora se trata de un daño social, algo que perturba a la sociedad. Rousseau ya afirmó que el criminal era el individuo que rompía el pacto social; era la persona que osaba pervertir el pacto que se había dispuesto con el surgimiento de las sociedades disciplinarias. El crimen y la ruptura del pacto social son nociones idénticas que simbolizan un peligro. Así, la ley penal es concebida para que el individuo pague el daño que ha causado a la sociedad ${ }^{328}$.

Ahora bien, tanto la figura del dandy como la femme fatale son personajes que simbólicamente cuestionan el sistema judicial y el penal. Ambos se ven motivados por el círculo vicioso de la voluptuosidad y la lujuria. Argumentalmente, se ven atrapados en una red de causas y consecuencias de la cual instintivamente no pueden escapar. En ocasiones, estos hechos adquieren un ritmo vertiginoso que les conduce al asesinato. Sin embargo, debido a la explicación psicológica de las causas, sus atrocidades se ven justificadas como una falta moral. Por lo que se automostrará en el terreno del pecado religioso, en lugar de en el ámbito judicial-penal ${ }^{329}$.

Un dato curioso a destacar es que el criminal, enemigo interno de la sociedad, conoce perfectamente las leyes y huirá de ellas. El crimen es su obra y, como consecuencia,

\footnotetext{
${ }^{327}$ Michel Foucault, La verdad y las formas jurídicas, Barcelona, Gedisa, 1995, pp. 92-95.

${ }^{328}$ Michel Foucault, op. cit., p. 93.

${ }^{329}$ En la mayoría de los casos, sus pecados están vinculados a la sexualidad o a la sensualidad excesiva.
} 
vemos cómo el delincuente intentará ocultar todo tipo de pruebas que lo vinculen con el delito. Así pues, estamos ante una obra no reconocida. La imagen del autor se convierte en la figura del gran desconocido. Pues, a la hora de la verdad, nuestro personaje se esconde entre la sociedad encubierto por la falsa máscara de la normalidad. Pero su obra es el reflejo de su auténtica identidad monstruosa y asesina.

Por el contrario, la femme fatale no se oculta. Tras sus curvas voluptuosas se alza orgullosa de su empresa, como si ella tan sólo desempeñase su deber. Tal es el caso de Judith o de Salambó cuando liberan a su correspondiente pueblo.

Ella interpreta con insólita audacia el mito de Prometeo: la necesidad del crimen que abruma al hombre resuelto a elevarse hasta la condición titánica; y confiere no sé qué salvaje ardor patético al ímpetu repetido de la voluntad individual hacia lo universal, al afán de romper la corteza de la individualidad para sentirse única esencia del universo ${ }^{330}$.

De esta forma, son figuras destinadas a potenciar la idea del crimen como algo justificado. Pero cuando el argumento que justifica el asesinato desaparece, nace una connotación más aterradora si cabe: el placer de matar por matar. Esta nueva figura les permite indagar más profundamente en la psicología femenina, pero para hacerla más atractiva la cubren con el erotismo propio de las tierras lejanas. Es entonces cuando se dan la mano mujer-muerte-erotismo. Tal es el caso de las obras de Gautier, Flaubert o Wilde que nos transportan a las cimas de la antigüedad bárbara y oriental para dar forma concreta a los actos más crueles ${ }^{331}$.

\footnotetext{
${ }^{330}$ Mario Praz, op. cit., p. 278.

${ }^{331}$ Mario Praz, op. cit., pp. 219-225.
} 


\subsection{2.- Tipos de erotismo}

La actividad sexual reproductiva la tienen en común los animales sexuados y los hombres, pero al parecer sólo los hombres han hecho de su actividad sexual una actividad erótica, donde la diferencia que separa al erotismo de la actividad sexual simple es una búsqueda psicológica independiente del fin natural dado en la reproducción y del cuidado que dar a los hijos ${ }^{332}$.

Bataille mantiene la idea de que el erotismo se define por la independencia del goce. Sin embargo, la reproducción se considera un fin en donde entran en juego dos seres discontinuos.

Cada ser es distinto de todos los demás. Su nacimiento, su muerte y los acontecieminetos de su vida pueden tener para los demás algún interés, pero sólo él está interesado directamente en todo eso. Sólo él nace. Sólo él muere. Entre un ser y otro ser hay un abismo, hay una discontinuidad $^{333}$

La reproducción es comprendida como la constante necesidad de romper esa barrera y conseguir la perduración del ser mediante la concepción de un bebé. La idea de continuidad gobierna un sentimiento de nostalgia en el individuo que se forma mediante tres tipos de erotismo.

\subsubsection{1.- El erotismo de los cuerpos femeninos}

Recordemos que el siglo XIX es el siglo en que más desnudos artísticos encontraremos; pero, sin embargo, en la vida normal se fomenta la idea de que el cuerpo femenino debía de ir pulcramente cubierto. Tanto el discurso religioso como el médico filtran en la sociedad que el cuerpo vive en un estado continuo de comunicación. De esta forma, se

\footnotetext{
${ }^{332}$ Georges Bataille, op. cit., p. 15.

${ }^{333}$ Georges Bataille, op. cit., pp. 16-17.
} 
comprende que algo tan sencillo como los gestos puede llegar a decir mucho de la propia personalidad de una mujer, así que colectivamente se recomienda que se repliegue sobre sí misma y evite todo gesto posible ${ }^{334}$. Socialmente, vemos al cuerpo femenino como un cuerpo cerrado bajo las poderosas reglas de la mesura. Desde este punto de vista, y centrándonos en el caso de la seducción, podemos afirmar que el cuerpo femenino debe ser férreo como una roca ante los continuos ataques del filtreo masculino. Porque la mujer no puede ceder a no ser que sea con fines reproductivos. Todo lo que se salga de este esquema médico y religioso se vinculará a un sentimiento de obscenidad, ya que significa la perturbación de la individualidad de un nuevo cuerpo femenino.

Ahora bien, la femme fatale rompe directamente con este rol social porque es ella la que ve su propio cuerpo como un elemento erótico. Un objeto que no despierta los instintos sexuales del varón, sino que los refleja. Ella toma conciencia de su propio cuerpo y entra en el juego erótico. Ella tiene el poder para ofrecer su cuerpo y, por consiguiente, el poder sobre su propia disolución ${ }^{335}$. No se trata de que la mujer sea el agente activo, sino que será la forma de representar la voluptuosidad la que marca el paso de la actitud normal al deseo. Por ello el desnudo es tan importante en el siglo XIX. Ya no es el hombre quien desnuda a la mujer, sino que es la mujer la que se desnuda. La acción decisiva de quitarse la ropa es crucial en el acto erótico, porque la desnudez se opone al

\footnotetext{
${ }^{334}$ La moda femenina de llevar corsés se mantiene hasta 1810 , porque tenía la finalidad de evitar que las mujeres se movieran. De esta forma se buscaba afinar la figura femenina evitando cualquier tipo de exceso en sus movimientos.

${ }^{335}$ Georges Bataille, op. cit., pp. 20-23.
} 
estado cerrado del cuerpo que se venía imponiendo. Así es como el desnudo femenino adoptará una poderosa simbología ${ }^{336}$.

\subsubsection{2.- El erotismo de los corazones femeninos}

Georges Bataille afirma que el erotismo de los corazones es más libre que el erotismo de los cuerpos. Bajo mi punto de vista es mucho más esclavo. La figura femenina y su excesivo sentimentalismo se convierten en el blanco perfecto para el escritor del siglo XIX. La introspección de los sentimientos se convierte en una vía perfecta para indagar en la esencia de la feminidad. Es entonces cuando muchos de ellos pusieron el dedo en la afección recíproca que sentían los amantes. Como es lógico, el contexto en el que se sitúan aparece marcado por el discurso religioso. De esta forma, todo lo que rodea a la pareja fomentará la simpatía moral como pilar indiscutible de su amor, y sólo a partir de él la pasión se prodiga como la fusión de los cuerpos. Esta unión sentimental va acompañada de múltiples promesas de felicidad. Su esencia es la sustitución de la discontinuidad de cada uno de los amantes por una continuidad maravillosa en pareja.

Esto se basa en una pasión afectiva que nos repite sin cesar: si poseyeras al ser amado, tú corazón, oprimido por la soledad, formaría un solo corazón con el ser amado. Ahora bien, esta promesa es ilusoria, porque la imagen de esta fusión toma cuerpo con una intensidad loca. La unión de los dos corazones simboliza una eterna búsqueda donde triunfa el sentimiento de la inseguridad. Esto se hace sentir sobre todo en la angustia

\footnotetext{
${ }^{336}$ En las civilizaciones antiguas, el desnudo era considerado un simulacro en sí mismo. Simbólicamente equivalía al acto de dar muerte a la víctima. Por lo que en la antigüedad el acto de amor y el acto de sacrificio compartían los fundamentos del erotismo: el desnudo. El hecho de desnudar a una mujer simbolizaba que representaba el papel de víctima, y el papel masculino era el de sacrificador. Pero ahora, con la recuperación de la femme fatale los roles se invierten, y será la mujer la que sacrifique. También es cierto que esta inversión no es original del siglo XIX, pues ya en la antigüedad existían ritos en donde la mujer era quien sacrificaba al varón.
} 
femenina, que vive la continuidad con el amante como inalcanzable. Es una búsqueda impotente y temblorosa. La promesa de la felicidad tranquila encubre un largo sufrimiento. La pasión nos adentra así en el sufrimiento, pues en el fondo es la búsqueda de un imposible. Por lo que la pasión comienza introduciendo desavenencia y perturbación.

En consecuencia, la mujer afectada puede tener un sentido más violento que el deseo de los cuerpos. Porque la idea obsesiva de la felicidad lleva consigo un desorden, en donde la posesión del amante se convierte en una prioridad enfermiza. La mujer buscará ante todo poseer a su amado. Pero si no puede poseerlo, a veces piensa en matarlo. Con frecuencia preferiría matarlo a perderlo. La posesión del ser amado no significa la muerte, antes al contrario; pero la muerte se encuentra en la búsqueda de esa posesión. Lo que está en juego es esa furia ante la imposibilidad de la continuidad en el ser $\operatorname{amado}^{337}$.

En consecuencia la pasión de los corazones está condenada a la muerte, pide para sí el deseo de matar o de suicidarse.

\subsubsection{3.- El erotismo sagrado de la feminidad}

Desde el discurso religioso se nos explica que el amor de Dios es la idea más perfecta que existe del sentimiento amoroso. En esencia, Dios ama toda la naturaleza y a cada uno de sus componentes. Por lo que la continuidad de Dios se manifiesta en cada uno de los objetos que componen el mundo, incluidos los hombres. Según esta relación todo objeto divino es idéntico a lo sagrado, porque Dios se encuentra en él. Como parte de la

\footnotetext{
${ }^{337}$ Georges Bataille, op. cit., pp. 24-26.
} 
naturaleza, las personas también pueden experimentar esa relación directa con Dios. Esta se llama 'experiencia mística'.

La experiencia mística revela la ausencia de un objeto mediador. De forma que la experiencia permite a la mujer fundirse con lo divino mediante su manto sagrado. Por su parte, la experiencia mística introduce en la mujer el sentimiento de la continuidad. Lo introduce por unos medios distintos del erotismo de los cuerpos o del erotismo de los corazones. Más exactamente, la experiencia mística prescinde de los medios que no dependen de la voluntad. Se trata de la voluntad de replegarnos sobre nosotros mismos. Por lo que el erotismo sagrado, tal como se da en la experiencia mística, sólo requiere que nada desplace la continuidad del sujeto. Porque en esta individualización es donde se encuentra la relación con lo sagrado.

De esta forma vemos cómo el erotismo sagrado se abre hacia la continuidad del ser. Un ser que, aunque humano, formaría parte de la divinidad por medio de su relación con lo sagrado. Este vínculo representa la muerte de un ser discontinuo. Hay, como consecuencia de la muerte violenta de la mujer, una ruptura de la discontinuidad de su ser; lo que subsiste es la continuidad del ser en la divinidad. Esta visión de la experiencia mística nos lleva a creer que, esencialmente, lo sagrado de los sacrificios primitivos es análogo a lo divino de las religiones actuales. Asimismo, la muerte se abre camino en el erotismo sagrado. La cuestión que planteó la muerte es la aparente precipitación de la condición humana hacia la eternidad. Me parece que este pensamiento debería ser la base de la interpretación del sacrificio religioso y, en especial, el del sacrificio femenino ${ }^{338}$.

\footnotetext{
${ }^{338}$ Georges Bataille, op. cit., pp. 19-28.
} 
En el sacrificio, no solamente hay desnudamiento, sino que además se da muerte a la víctima (el objetivo del sacrificio es la destrucción del ser vivo). La víctima muere, y entonces los asistentes participan de un elemento misterioso que esa muerte les revela. Este elemento podemos llamarlo lo sagrado.

\section{2.- El cuento de miedo impulsa la maldad femenina}

El siguiente análisis está realizado a partir de estudios tan importantes como los de Mario Praz, Simone de Beauver, Isabel-Argentina Fuentes, Edward Said,... Todos aplicaron diferentes puntos de vista a los estudios femeninos, y consiguieron hacer un catálogo bastante amplio del siglo XIX. Pero cuando retomé sus estudios para aplicarlos a las figuras publicitarias del siglo $\mathrm{XX}$, me di cuenta de que me faltaban algunos elementos, algunas nociones o, incluso, simplemente matices que me impedían proyectar estas figuras hacia el futuro. Era como si la femme fatale hubiera muerto en el siglo XIX, y esto, por supuesto, era una idea completamente falsa. Así que retrocedí y reanalicé las bases que sustentaban a las figuras canónicas del siglo XIX. Este capítulo es fruto de esa revisión.

Para ello me centré en los elementos que caracterizaran la actitud femenina, pues estos son los que potencialmente marcan la evolución erótica de la figura femenina. No se trata de ver las posibles reminiscencias físicas, sino de cómo la actitud erótica de antaño es la madre de la publicidad de hoy en día.

Pero en una cabeza aislada hay más atractivo trágico...; una cabeza de mujer, estudiada tres veces, con divino y sutil cuidado; esboza muchas veces la juventud y en la vejez, siempre hermosa más allá del deseo y cruel por encima de las palabras, pálida de orgullo y cansada de obrar mal; una silenciosa ira contra Dios y los hombres arde, blanca y reprimida, en su claro 
rostro. En el dibujo que observamos lleva un arreglo de tipo oriental más que occidental, pero, de hecho, según la fantasía del artista; trenzada al modo de escamas compactas como de una crisálida de serpiente, alzada y ondulada y redondeada como la de una concha marina. Todos sus ornamentos parecen participar de la naturaleza fatal de la mujer, inexplicablemente; llevar en ellos la marca de una belleza recién salida del infierno; y todo eso no por causa de algún vulgar expediente simbólico, de algún emblema serpentino o de otro modo bestial; los brazaletes y los anillos son de una forma y de una ejecución muy inocentes; pero al tocar sus carnes se ha impregnado de un significado letal y maligno. Anchos brazaletes dividen el hermoso esplendor de sus brazos; sobre la desnudez de sus firmes y luminosos senos, justamente bajo del cuello, pasa una faja metálica. Sus ojos están llenos de orgullosa e impasible lascivia de oro y de sangre; sus cabellos, espesos y crespos, parecen prontos a separarse vibrando y a desnudarse en serpientes. Su garganta llena y fresca, redonda y dura a la vista, como su pecho y sus brazos, se muestra erecta y majestuosa, y la cabeza se posa rígida sobre ella sin reclinar o alzar el mentón; su boca es más cruel que la de un tigre, más fría que la de una serpiente, y hermosa como la de ninguna mujer ${ }^{339}$.

Se trata de observar cómo el aspecto oscuro, siniestro y pernicioso puede llegar a ser un auténtico reclamo publicitario.

\subsection{1.- Inglaterra}

A finales del siglo XVIII se comienza a palpar la necesidad de romper con géneros enclaustrados y con formas de expresión demasiado pesadas para los nuevos $\operatorname{argumentos}^{340}$. Esta búsqueda se manifestó mediante tres tipos de obras:

\footnotetext{
${ }^{339}$ Mario Praz, op. cit., pp. 250-251.

${ }^{340}$ Manuel Asensi Pérez, op. cit., p. 388.
} 
A) Obras que impulsan el sentimentalismo y el individualismo con la mentalidad propia del Antiguo Régimen, como Pamela de Samuel Richarson (1689-1761), La virtud recompensada de Clarisa Howard (1740), y Joseph Andrews (1742).

B) Obras que reaccionan contra el sentimentalismo como es el famoso caso de Sentido y Sensibilidad de Jane Austin (1755).

C) La novela gótica, también llamada, novela negra ${ }^{341}$. Esta es precisamente la que más nos interesa. Recordemos que los románticos, en su afán de recuperar una época dorada, reconstruyen el mundo literario del castillo. Pero no un castillo cualquiera; se trata de un castillo de formas sublimes como el que se representó durante el gótico. Este escenario será el lugar en donde se ubiquen la mayoría de estas novelas, por lo que recibirán el nombre de novelas góticas. Pero al mismo tiempo son espacios antiguos, pesados y con poca luz, por lo que serán ámbitos propicios para que se desenvuelvan las tinieblas de lo desconocido, de lo irracional y de la muerte ${ }^{342}$.

\subsubsection{1.- La Belle Dame Sans Merci}

En los primeros veinte años del siglo XIX se dieron importantísimos cambios internos en el mundo de las ideas y de los sentimientos. Estamos ante los años en los que despegan los estudios de la psicología y del psicoanálisis. Por lo que es destacable que

\footnotetext{
${ }^{341}$ Rafael Llopis, op. cit., p. 35.

${ }^{342}$ Fue la poesía Quejas o pensamientos nocturnos sobre la vida, la muerte y la inmortalidad de E. Young la primera en abrir las puertas al no muerto. A partir de estos versos el muerto se tramó en varias corrientes filosóficas, como el swedenborgianismo, el mesmerismo y el martinismo. Todas ellas consiguieron varios tintes psicológicos que tuvieron sus frutos en las plumas románticas de Percy, R. Blair, Gray, Maturin, Polidori, Mary Shelley...
} 
este movimiento reciba una gran influencia del orden psicológico. La lectura de tratados de psicología facilita a los escritores una serie de herramientas para analizar a los personajes. El personaje del siglo XIX ya no será caracterizado por sus actos, sino por sus pensamientos. Ahora, su forma de actuar puede parecer justificada tras una pequeña explicación de las ideas del personaje ${ }^{343}$. Ante estas premisas, la mente de los personajes se vuelve como un libro abierto para el escritor ${ }^{344}$.

Esta filosofía consiguió aunar la maldad con un sentimentalismo excesivo. Como consecuencia directa vemos cómo todo tipo de personajes marginales son alzados al nivel de héroes angustiados. Todos sus crímenes aparecen perfectamente razonables tras la explicación de su compleja psicología. Es así como el poeta consigue un análisis subjetivo de la realidad que le rodea ${ }^{345}$.

La búsqueda de estos héroes se focalizará en el pasado, de forma que se intenta representar a héroes reconocidos por todos ${ }^{346}$. Para encontrar a sus héroes y heroínas, muchos autores bucearon en el pasado de la antigua Roma, la Italia del Renacimiento, la

\footnotetext{
${ }^{343}$ Esteban Pujals, Historia de la literatura inglesa, Madrid, Gredos, 1988, p. 321.

${ }^{344}$ Pero lo que realmente se muestra como una perita en dulce es la mente de los personajes marginales, asesinos, crueles... Todo tipo de personas que se mantengan al margen de las leyes morales y religiosas será digno de ser representado. Tal es el caso de los personajes que dibuja Lord Byron en El Corsario (1814), Lara (1814), Manfred (1817), Caín (1821), Don Juan (1819-1823), Darkness (Tinieblas, 1816). Todos ellos son personajes que cumplen perfectamente con el prototipo romántico, pues llevan sobre los hombros la marca del exilio y de la soledad. Características idóneas para indagar por qué se han comportado así y por qué obraron mal en su momento. Lo cierto es que no se trata de dar una explicación racional a las consecuencias, sino más bien de una escusa para explicar los sentimientos de desolación que puede sentir una persona que en el fondo es mala.

${ }^{345}$ Esteban Pujals, op. cit., pp. 321-328.

${ }^{346}$ Existen autores, como Jane Austen, que se sienten atraídos por la cotidianidad.
} 
España medieval, la Inglaterra histórica y la Escocia feudal. Así se escribirán auténticos melodramas desencadenados por las pasiones de la novela gótica ${ }^{347}$.

La mejor de este género es The Black-Eyed Susan (1829) de I. Pocock ${ }^{348}$. Algunos de los autores de esta época rescatarán a los personajes famosos y enigmáticos para indagar en ellos. Tal fue el caso de Walter Scott, creador de la novela histórica, quien leyó la historia de la femme fatale en la Gioconda.
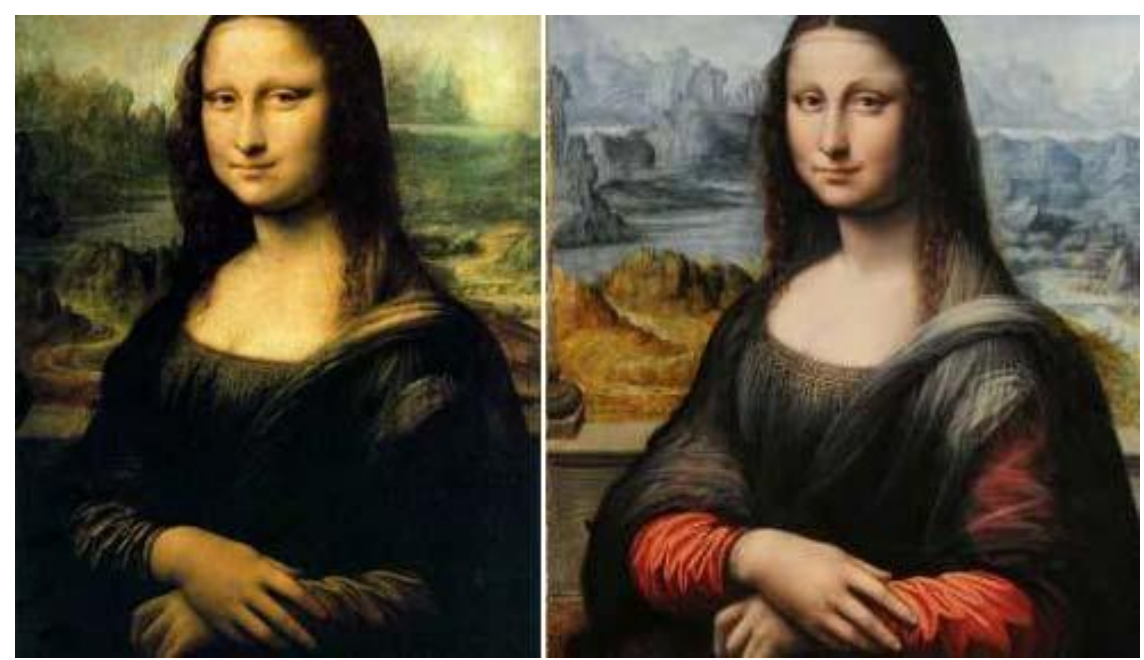

Y Shelley, quién para muchos, marcó el inicio del Romanticismo con el poema Medusa.

\footnotetext{
${ }^{347}$ Tal es el caso de Virginus (1820), William Tell (1825) y The Wife (1823) todas ellas de James Sheridan Knowles; De Montfort (1800) y Henri Quez (1836) de Joanna Baille; Bertram or the Castle of St. Aldobrand (1816), Manuel (1817) de Ch. Maturin. Incluso el drama llega a desplazarse al mar, por lo que hacia 1820 el Nautical Melodrama gozaba de gran popularidad. Muchos de ellos mostraban a héroes de clase baja, encarnados por marineros que de forma cotidiana se enfrentaban con la muerte.

${ }^{348}$ Con la llegada del Realismo y del Naturalismo el drama se sitúa también en la familia. Un gran ejemplo lo encontramos en las novelas de John Walker como The factory Lady (La joven de la fábrica, 1832), The mysterious stranger (El forastero misterioso), The wizard priest (El sacerdote brujo).
} 


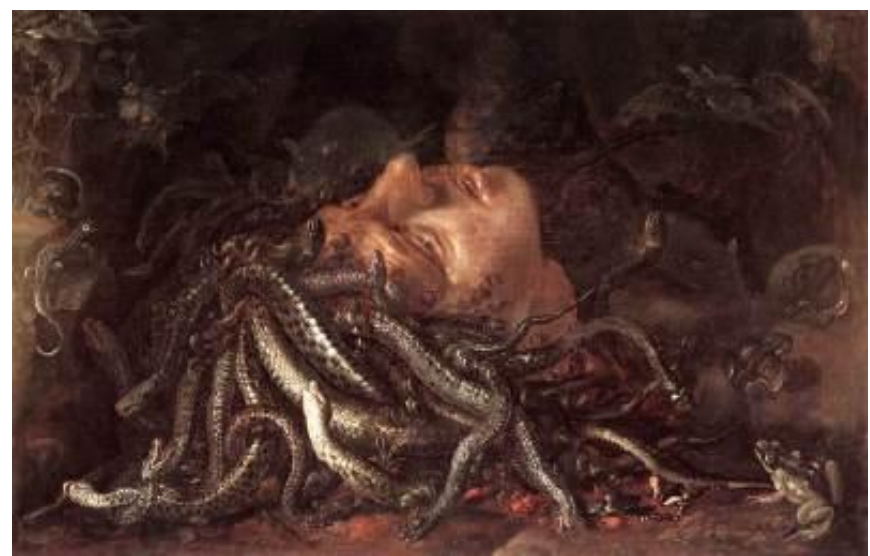

Leonardo Da Vinci (Medusa)

El estudio de épocas pasadas implicó la recuperación de textos antiguos. De ahí que muchos autores recuperen baladas folklóricas que, de alguna manera, han permanecido vivas en el trasfondo cultural de un país. Este movimiento cultural llevó a Wordsworth y a Coleridge a escribir Lyrical Ballads (1798). Sin embargo, otros poetas rescataron a personajes propios del folklore para indagar en su personalidad. Así que del mismo modo que el bandido, el corsario o el asesino se convirtieron en héroes, los personajes malvados del folklore también se ennoblecieron. Tal fue el caso de Queen Mab (1813) y de Prometheus Unbound (1820) ambas de Percy Bysshe Shelley. La Nymph of the Downward Smile (La Ninfa de la Sonrisa Caída) y de Endymion (1818) de John Keats. Este último poema abarca cuatro libros y cuatro mil versos para explicar cómo Cintia aparece en los sueños del joven rey Endimión y se enamoran. Por supuesto, el final es feliz, pero el hecho no tendría más importancia si no fuera porque, al igual que los citados, el protagonista es un espíritu femenino. Un espíritu que se le aparece en sueños al rey de los pastores del Monte Latnos. 


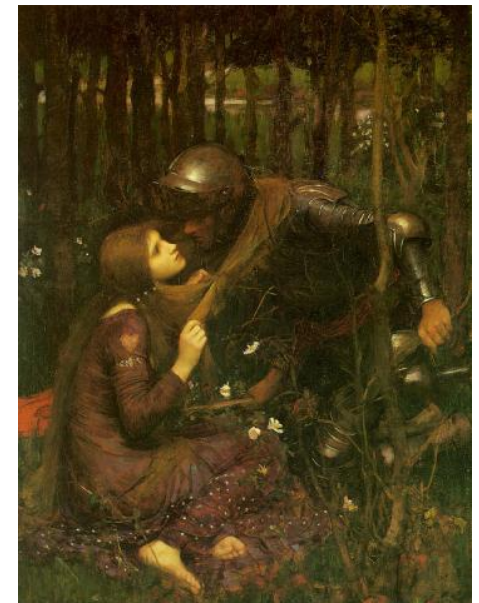

John Williams Waterhouse (1893)

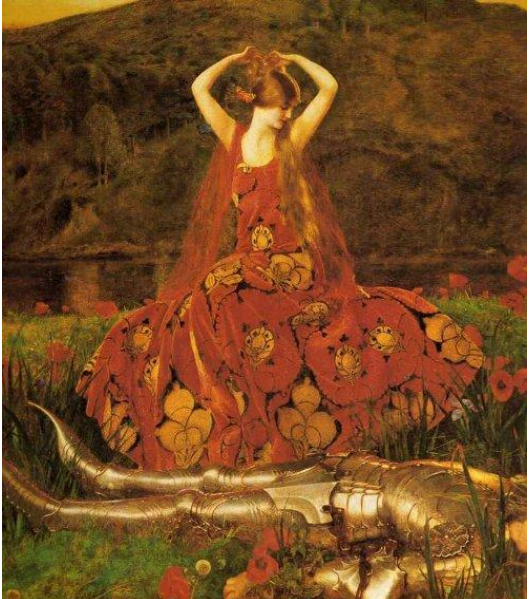

Frank Cadogan Cowper (1923)

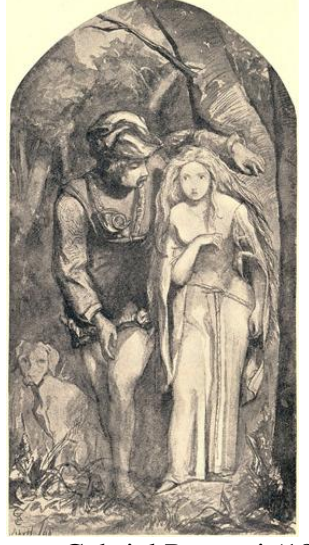

Gabriel Rossetti (1848)

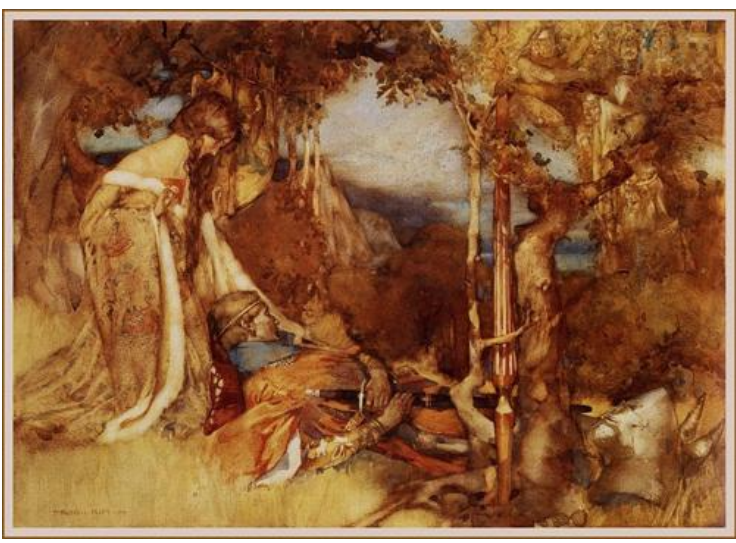

William Russell Flint (1908)

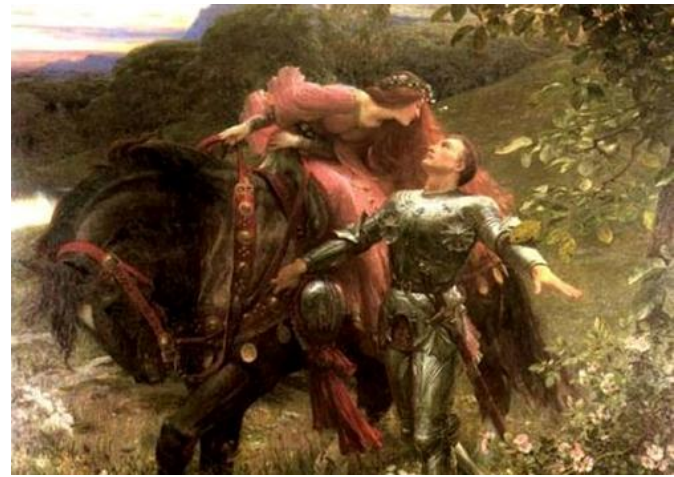

Frank Dicksee (1902)

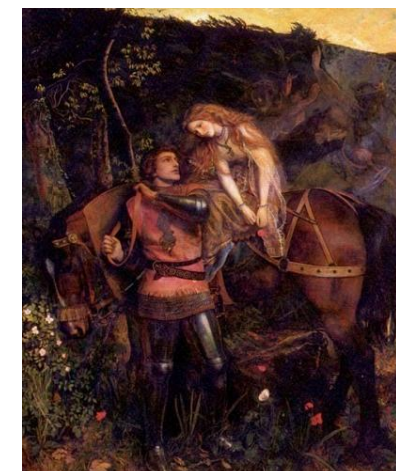

Arthur Hughes (1861-1863)

Este mismo tema es retomado otra vez bajo la pluma de John Keats al reescribir una de sus baladas más famosas: La Belle Dame Sans Merci (1820). Se trata una balada de 12 estrofas de pie quebrado que cuenta cómo un caballero aparece subyugado por la visión de una hermosísima dama en sus sueños. 
190 | La femme fatale en la publicidad del siglo XX

\section{La Belle Dame Sans Merci}

I

¿Qué os aflige, oh caballero andante,

Solitario y pálido vagabundo?

El junco está marchito en el lago,

Y no cantan los pájaros.

II

¿Qué os aflige, oh caballero andante,

Tan macilento y tan apenado?

El granero de las ardillas está lleno,

Y la cosecha ya recogida.

III

Un lirio veo en tu frente

Húmedo de angustia y de febril rocío,

$\mathrm{Y}$ en tu mejilla una rosa desmayada

También se marchita.

IV

Encontré una dama en el prado,

Muy hermosa, doncella de cuento de hadas;

Su cabello era largo, sus pies ligeros

Y sus ojos salvajes.

V

Una corona tejí para su cabeza,

Y también brazaletes, y un fragante espacio;

Me miró al tiempo que me amaba,

Y lanzó un dulce gemido. 
191 | La femme fatale en la publicidad del siglo XX

VI

La senté sobre mi corcel al paso,

Y nada más sucedió en todo el día

Pues a un lado inclinada, cantaba

Una canción encantada.

VII

Raíces me buscaba de dulce sabor,

Y miel silvestre, y rocío de maná,

Y en una extraña lengua me decía:

“¡Con el alma te amo!”

VIII

Me llevó a su gruta de duendes,

Y allí lloró y suspiró con aflicción,

Y allí con cuatro besos cerré sus ojos

Silvestres, salvajes.

IX

Y allí me arrulló hasta caer dormido,

Y allí soñé... ¡Ah, adiós, dolor!

El último sueño que jamás soñé

En a ladera de la fría colina.

X

Pálidos reyes vi, también princesas,

Pálidos guerreros, todos ellos con una palidez mortal;

Y gritaban: “ ¡La bella dama sin piedad

Os ha esclavizado!" 
XI

Vi sus hambrientos labios en la oscuridad,

Como horrorizados, muy abiertos,

Y me desperté y me hallé aquí

En la ladera de la fría colina.

XII

Y así es como aquí permanezco,

Solitario y pálido vagabundo,

aunque el junco esté marchito en el lago

y no cante ningún pájaro ${ }^{349}$.

Aquí se nos hace patente la evolución de una de las características de la amada muerta, pues se trata de un espíritu capaz de embelesar y arrastrar a la figura masculina hasta el más allá ${ }^{350}$.

\subsection{2. - Alemania}

El prerromanticismo alemán está comprendido entre 1760 y principios de 1770 , pero el movimiento no tomará nombre hasta 1770 , cuando F. Klinger estrena su obra teatral Sturn und Drang ${ }^{351}$. Es entonces cuando se inicia una época de búsqueda hacia nuevos discursos teóricos y filosóficos ${ }^{352}$. En el campo literario el discurso teórico se ve

\footnotetext{
${ }^{349}$ John Keats, Poemas escogidos, Madrid, Cátedra, 2005, pp. 153-157.

${ }^{350}$ Como ya veremos más adelante, esta es la figura que Baudelaire desarrollará en Vision of Oxford.

${ }^{351}$ Rafael Llopis, op. cit., p. 41 y 46.

${ }^{352}$ El romanticismo francés, siendo esencialmente análogo al alemán, es su opuesto en cierto sentido. En Francia hubo una contrarreforma y el catolicismo se impuso, desarraigando la mayoría de los mitos y ritos
} 
orientado a la ruptura con la tradición y a trabajar hacia la fragmentación y el idealismo de los Schlegel, Jean Paul, Novalis, Schelling, Hegel... En Alemania no hubo materialismo, porque el racionalismo se había desarrollado allí de forma idealista. Esto contribuyó a que el romanticismo alemán no fuera revolucionario, sino evolutivo. En Alemania no encontraremos relatos llenos de cadáveres morbosos y macabros. Allí se trabaja en la búsqueda de nuevos modelos literarios, y los encuentran en Kalligone de Herder. En esta obra se trata el lenguaje como experiencia del pueblo. Así la poesía se vive como la semilla de la expresión del pueblo. Esta tenía sus raíces en los sentimientos y creencias cultivadas en el folklore, por lo que se comienza a indagar en

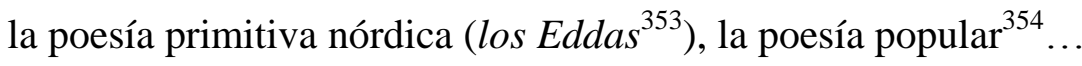

Muchos escritores siguieron las pautas de la tradición oral popular que se encuentra plagada de elfos, duendes malvados y bondadosos, hadas, brujas, alquimistas, nigromantes y cabalistas. Estos heredaron elementos propios de las canciones de gesta y de las baladas antiguas, en donde el elemento fantástico aparece como una bruma del pasado. Rafael Llopis los enmarcó como cuentos de miedo procedentes de la épica ${ }^{355}$. Sin embargo, otros resucitaron con fuerza los terribles mitos nórdicos poblados de elfos y gnomos. Estas eran historias que las familias contaban alrededor del fuego para pasar

\footnotetext{
del paganismo precristiano. Por un lado, estos se integraron en el catolicismo y, por otro, en virtud de la dinámica creencia-arte, quedaron reducidos a meros cuentos y juegos. De esta forma, el folklore se vinculaba al ámbito infantil, de la inocencia y de la fantasía. Por fuerza, el irracionalismo no tuvo cabida y se impuso la razón y la lógica de las teorías filosóficas. Lo cual dio pie a que dentro del terreno de la filosofía positivista se desarrollara la estética emocional que buscaba romper con la estética neoclásica y, trabajar hacia los sentimientos naturales.

${ }^{353}$ Con este nombre se conocen dos recopilaciones literarias islandesas medievales; juntas forman el corpus de la mitología nórdica del que bebieron los románticos.

${ }^{354}$ Manuel Asensi Pérez, op. cit., pp. 301-302.

${ }^{355}$ Rafael Llopis, op. cit., p. 44 y 140.
} 
los largos inviernos. Estos fueron Lore Lei, Erlkönig ${ }^{356}$, la Dama Blanca ${ }^{357}$ o el Perro Negro.

\subsubsection{1.- Lore Ley}

Como un signo de repulsa ante la voraz modernidad, los románticos alemanes intentarán volver constantemente a la naturaleza. Las bases del concepto naturalista de la época las encontramos en Kant, Friedrich Wilhelm Schelling y Friedrich Schleiermacher. Todos ellos influyeron de forma importante en la creación literaria, pero será Johann Gotttlieb Fichte $^{358}$ quien asiente la verdadera naturaleza animal del hombre. Tras esta influencia literaria se llega a la convicción de que la sociedad necesitaba renovarse por medio de la literatura y el arte. Este afán conlleva eliminar los límites y, para ello, se intenta fusionar todos los saberes y todos los géneros literarios.

Fruto de esta preocupación se mezclan todas las percepciones sensoriales, y nace lo que los alemanes llamarán "Universalpoesie”. Este afán de infinitud más el sentimiento de nostalgia se reflejan en un fuerte subjetivismo, una excesiva importancia concedida al sentimentalismo, en el interés por lo irracional, las fuerzas ocultas, el mundo de los

\footnotetext{
${ }^{356}$ Der Erlkönig, comúnmente conocido como el Rey de los Elfos, a quien Goethe le compuso un poema titulado Die Fischerin.

${ }^{357}$ La Dama Blanca fue una ópera de François-Adrien Boïeldieu basada en varios episodios de diferentes novelas de Walter Pater. En ella se consiguió llevar al espectáculo musical tópicos del romanticismo gótico, tales como un castillo misterioso, una heredera desaparecida, una fortuna oculta y un fantasma.

${ }^{358}$ Eliminará las fronteras entre el objeto y el sujeto al considerar al yo como fuente de toda realidad.
} 
sueños y una total liberación de la fantasía ${ }^{359}$. De esta forma se cultivan géneros nuevos que intentan poner en duda los cánones de composición ${ }^{360}$.

Fruto de esta fantasía se rescata la amenazadora figura de Lore-Ley. En un principio, el nombre de Lorelei era el nombre de un risco alemán situado en el río Rin. El risco cuenta con una altitud de 120 metros, y además tiene secciones cubiertas de piedras, salientes y aguas poco profundas combinadas con corrientes muy peligrosas. Por supuesto, este era un lugar muy difícil para navegar y fue evitado por todos los marineros. Sin embargo, ocasionalmente algún que otro barco caía presa de las fuertes corrientes y se estrellaba contra las rocas. Este sitio estaba asociado a varias leyendas populares, pero sin duda alguna una de las más famosas fue la de la ondina Lore Ley. Clemens Bretano fue el primero en recogerla en 1801 en su obra $Z u$ Bacharach am Rheine. Más tarde Heinrich Heine compuso el poema:

\author{
Busco en vano esto que siento \\ de por qué estoy tan triste y apenado; \\ una historia me ha dejado sin aliento \\ sin descanso en éxtasis he quedado. \\ Fresco está el aire y oscurece \\ calmo está el Rin en su mover; \\ la cima acantilada luz parece \\ es el último brillar del sol atardecer. \\ La más pura de las doncellas sentada \\ allá arriba lleva a maravillar. \\ Su dorado tesoro se mostraba; \\ su dorado cabello ella al peinar. \\ Con un peine de oro ella al usar \\ canta una canción ensoñadora \\ su melodía extraña al sonar \\ es intensamente abrumadora.
}

\footnotetext{
${ }^{359}$ Luis A. Costa (coord.), La literatura alemana a través de sus textos, Cátedra, Madrid, 1997, pp. 487490.

${ }^{360}$ Tal es el caso del fragmento (fragment) que derivaba de la tradición del aforismo, y el cuento popular de carácter anónimo y de tradición popular será el que dé la novela corta (novelle). Esta última es comprendida como una transformación del cuento popular.
} 
El pescador en su pequeña barca apresado es en su anhelo y suspirar. No ve las rocas no las abarca sólo allá arriba se pierde en su mirar.

Creo que el oleaje pronto arrojará a ambos, a su fin a la barca y al ser; eso es lo que esa canción logrará la Lorelei en hechizante atardecer.

\subsection{3.- El no muerto bajo las formas de la feminidad}

Durante el prerromanticismo se engendrarán los relatos de miedo que se proyectarán durante todo el siglo XIX. Las protagonistas de muchos de ellos son fantasmas femeninos de piel blanca, de gesto hierático y de frialdad extrema en el trato. Pero estos nunca se quedaron estancados, sino que poco a poco fueron evolucionando. Uno de los autores que ayudó en su evolución fue Edgar Allan Poe. El autor norteamericano consiguió aunar la tendencia inglesa y la tendencia alemana. En Poe, el terror aparece quintaesenciado, destilado y sublimado. Fue Poe ante todo un poeta que, tanto en verso como en prosa, hizo poesía del terror, acaso la más pura, la más elemental y la primera de las poesías ${ }^{361}$. De esta forma estamos ante mujeres perdidas en la encrucijada de la vida y la muerte.

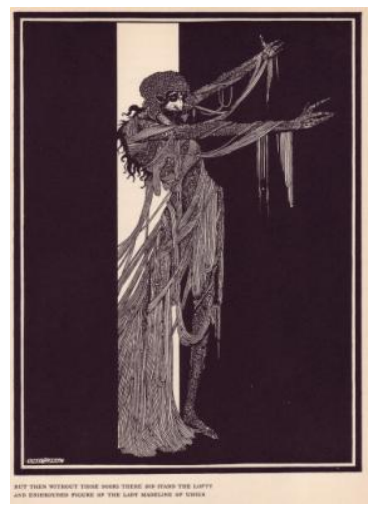

${ }^{361}$ Rafael Llopis, op. cit., p. 145. 
Era de elevada estatura, más bien delgada, y en sus últimos días incluso demacrada. En vano intentaría la descripción de su majestad, la serenidad de su porte o la incomprensible ligereza y soltura de su paso. Entraba y salía como una sombra. Nunca me daba yo cuenta cuando aparecía en mi cerrado estudio, salvo por la amada música de su dulce y profunda voz, mientras posaba su mano de mármol sobre mi hombro. Jamás mujer alguna la ha igualado en la belleza de su rostro. Era el resplandor de un sueño de opio, una etérea y animosa visión más extravagantemente divina que las fantasías que flotaban alrededor de las almas adormecidas de las hijas de Delos. Sin embargo, sus facciones no tenían esa regularidad que nos han enseñado falsamente a adorar en las obras clásicas de los paganos. "No hay belleza exquisita -dice Bacon, lord de Verulam, refiriéndose con justeza a todas las formas y genera de la hermosura sin algo de extraño en las proporciones." No obstante, aunque veía que las facciones de Ligeia no eran de una regularidad clásica, aunque percibía que su hermosura era en verdad "exquisita" y sentía que había mucho de "extraño" en ella, sin embargo he intentado en vano detectar la irregularidad y averiguar mi propia percepción de lo "extraño". Examiné el contorno de su frente alta y pálida: era impecable - ¡qué fría de veras esa palabra aplicada a una majestad tan divina! -la piel, que rivalizaba con el más puro marfil, la amplitud dominante y la serenidad, la suave prominencia de sus parietales, y luego los cabellos de negro azabache, satinados, abundantes y naturalmente rizados, que mostraban la plena fuerza del epíteto homérico “cabellera de Jacinto". (...) Para los ojos no tenemos modelos en la antigüedad remota. Quizás también ocurriera que en aquellos ojos de mi amada yacía el secreto al cual alude el lord de Verulam. Eran, he de creerlo, mucho más grandes que los ojos normales de nuestra raza. Eran aún más grandes que los ojos de gacela de la tribu del valle de Nourjahad. (...) Me poseía la pasión de descubrirlo. ¡Aquellos ojos, aquellos grandes, luminosos y divinos ojos! Para mí llegaron a serlas estrellas gemelas de Leda, y yo, para ellos, el más devoto de los astrólogos ${ }^{362}$.

Una de las figuras que hipnotizó a los románticos franceses fue la que se perfiló con el poema de Anabel Lee.

\section{ANNABEL LEE}

Sucedió hace muchos, muchos años,

\footnotetext{
${ }^{362}$ Edgar Allan Poe, El gato negro, Madrid, Anaya, 1995, pp. 174-176.
} 
en un reino junto al mar.

Allí vivía una doncella conocida

por el nombre de Annabel Lee;

y esa doncella no vivía con otro pensamiento

que el de amarme y que yo la amara.

Yo era un chiquillo y ella una chiquilla,

en aquel reino junto al mar;

pero nos amábamos con un amor que era más que amor -

mí Annabel Lee y yo -.

Con un amor que los alados serafines del cielo

envidiaban de nosotros.

Y éste fue el motivo por el que, hace mucho tiempo,

en aquel reino junto al mar,

un viento llegó desde una nube, helando

a mi hermosa Annabel Lee;

entonces vino aquel hidalgo pariente suyo

y la apartó de mi lado,

para encerrarla en un sepulcro

en aquel reino junto al mar.

Los ángeles que no eran tan felices en el cielo,

nos tenían envidia

-¡Sí!- éste fue el motivo (como toda la gente sabe,

en aquel reino junto al mar)

para que el viento viniera por la noche desde la nube,

helando y matando mi Annabel Lee.

Pero nuestro amor era mucho más fuerte que el amor 
de aquellos que eran más viejos que nosotros

-de muchos que sabían más que nosotros-

y ni siquiera los ángeles allá arriba en el cielo,

ni los demonios en las profundidades del mar,

podrán nunca separar mi alma del alma

de la hermosa Annabel Lee.

Jamás brilla la luna, sin que yo sueñe

con la hermosa Annabel Lee;

jamás salen las estrellas, sin que yo sienta los brillantes ojos

de la hermosa Annabel Lee;

y así, durante toda la noche, permanezco tendido al lado

de mi querida, mi querida, mi vida y mi novia,

allá en el sepulcro junto al mar

en su tumba junto al mar sonoro ${ }^{363}$.

E. A. Poe consiguió perfilar la figura femenina que despertaba el sentimiento de amor eterno. No se trata sólo de describir la pérdida de una mujer, sino de dibujar la pérdida de una mujer que siempre será recordada como la persona amada. Es un sentimiento de amor que vivirá siempre. Esta noción de eternidad es la que se clava en el espíritu de los románticos y se filtra en las descripciones de las féminas. Es entonces cuando se perfilan los sentimientos irracionales, pero muy poderosos como la añoranza del amor perdido. Estos en el folklore giran alrededor de la figura del no-muerto, pues son mujeres, que sabiéndose amadas, no quieren alejarse del esposo tras la muerte, por lo que muchos románticos convertirán a las féminas en fantasmas que vuelven de sus tumbas cada noche.

\footnotetext{
${ }^{363}$ Edgar Allan Poe, Poesía completa, Barcelona, Ediciones 29, 1998, pp. 75-77.
} 
Para Isabel-Argentina Fuentes la mujer soñada por el escritor, y progresivamente por el esteta de fin de siglo, responde a una construcción deliberada de la nueva metáfora. Se trata de la metáfora de la corporalidad ${ }^{364}$, en donde vemos cómo se nos describe el cuerpo de un familiar que se echa de menos, o el cuerpo de una amada al que se la ha amado hasta el exceso. En consecuencia, no caben descripciones negativas, todas serán bellas. Todas tienen una carne ideal, algo de mármol y la luz blanca de las estrellas ${ }^{365}$.

\subsection{4.- La decadencia del fantasma}

Rafael Llopis se centra en la tesis de G. M. Tracy para confirmar que la edad de oro de los cuentos de fantasmas va desde 1898 hasta $1911^{366}$, llegando a alcanzar su apogeo con "Ghost Story", iniciada por Le Fanu. Aunque el cuento tradicional de fantasmas perdura hasta nuestros días, desde el punto de vista formal la mutación del cuento representa cambios culturales, políticos y económicos producidos por algunos de los

\footnotetext{
${ }^{364}$ Isabel-Argentina Fuentes Herbón, op. cit., pp. 83-92.

${ }^{365}$ En Lo femenino y lo sagrado, de Catherine Clément y Julia Kristeva, observamos que gradualmente se tendió a la sacralización de la blancura femenina. Para ellas esto responde a una maniobra ideológica que se da dentro de una estructura jerárquica de los poderes sociales. Según estas autoras las manifestaciones de lo sagrado sólo se dan en dos formas posibles: mediante lo bendito y lo sagrado. E insisten, en que la mujer se caracteriza por sus tintes sagrados. No profundizaré en las discusiones feministas que han intentado analizar la blancura de la mujer. Pero sí señalaré que gracias a estas discusiones este tópico nunca cayó en el olvido. La excesiva blancura de la amada muerta perduró durante todo el siglo XIX, y conllevó una reinterpretación de la mitología del eterno femenino. De esta forma, a finales del siglo XIX se observa cómo la blanca belleza femenina hace alusión a dos temas. Uno sería el erotismo que despierta la necrofilia; esta debemos comprenderla como si fuera el último canto del cisne. El último canto hacia la belleza de la amada antes de despedirnos de ella. La otra temática es la perversión de la imagen de la inocencia. Este tema sería el contraste entre la idea de la pureza de la amada en vida frente a la blancura diabólica que caracteriza a la amada muerta o al fantasma.

${ }^{366}$ Pero fuera de estas fechas también tenemos que destacar a Montague James (1862-1936) con sus obras Corazones perdidos, La mediatinta, El número 13, El conde Magnus y ¡Oh, silba y acudiré!
} 
hechos de la primera guerra mundial. De hecho muy pocos escritores caminaron hacia una nueva vía y, en consecuencia, el fantasma inicia una larga decadencia ${ }^{367}$.

Pese que muchos escritores continuaron trabajando en los cuentos de fantasmas, la mutación de la historia de miedo fue el reflejo de una profunda crisis socio cultural ${ }^{368}$. El arte fue comprendido como una expresión de sensibilidad, un reflejo de la crisis del siglo XIX que creó el terreno propicio para bucear en las profundidades del alma. En este momento el muerto y la noche desaparecen o, mejor dicho, se subordinan a una nueva Gestalt $^{369}$ estructurada en torno a contenidos arquetípicos y cósmicos.

Según Jung, estas eran imágenes heredadas pasivamente como fenómenos naturales de ahora y siempre. Sin embargo, Heinrich Zimmer mantiene que el rigor de estas no recaía sobre la imagen, sino sobre la vivencia ${ }^{370}$. Esta vivencia es una imagen en potencia, por lo que tendrá hambre de forma. Así que el no muerto abrió la puerta al mundo prohibido del subterráneo e inició una infinita espeleología de lo irracional. Para Rafael Llopis el escritor que inició esta revolución en las formas del miedo fue Machen, quien descendió hasta las profundidades con Lo Tremendum. Será en esta obra en donde

${ }^{367}$ Rafael Llopis, op. cit., pp. 191-193.

${ }^{368}$ Muchos intentaron luchar por mantener viva la vía de tradicional Ghost story, tales como Violet Paget (1856-1935) con obras como El papa Jacinto, Dionea, Rávena y sus fantasmas, Oke de Okehurst, Amour dure, La virgen de los siete puñales..., o Edwuard Frederick Benson (1867-1940) con La confesión de Charles Linkworth, Al otro lado de la puerta, La cosa del vestíbulo o sus cuentos vampíricos de la Habitación de la torre y Señora Amworth. Vale la pena destacar a autores de la talla de Walter de la Mare, Cynthia Asquith, W.W. Jackobs y su Pata de mono, Oliver Oniu y La rubia insinuante, F. Marion Crawford y Pues la sangre es la vida, La litera de arriba y La calavera aulladora. También encontramos a Shane Leslie, Robert Aickmann, Christopher Wooforde, H. Russell Wakefield, A. N. L. Munby y La mano de alabastro.

${ }^{369}$ Se trata de una corriente psicológica moderna. El término Gestalt no tiene una única traducción, aunque generalmente se traduce como 'forma', también puede interpretarse como: figura, estructura,... La base de esta psicología gira alrededor de este concepto, pues se piensa que la mente, mediante diferentes leyes, configura su experiencia a partir de todas las sensaciones que percibimos gracias a los sentidos (el tacto, la vista, el olfato, el gusto y el oído).

${ }^{370}$ Para los anuncios de publicidad el rigor será la vivencia que todavía no se ha experimentado. Es lo que está por venir. 
los mitos históricos de la humanidad dejan de ser comprendidos como mitos, pero no porque tengan pretensión de verdad objetiva, sino porque sólo consiguen ser una expresión subjetiva $^{371}$.

\subsubsection{1.- La evolución de la Belle Dame Sans Merci}

La balada de "La Belle Dame Sans Merci" consiguió popularizar la figura de una joven muy peligrosa. Una de sus características es que era capaz de atrapar al amante con sus hermosísimos cabellos largos. Goethe se hace eco de los riesgos que encierra su melena, y lo demuestra en el diálogo entre Fausto y Mefistófeles. De aquí surge la idea de la melena red que propagará el cuadro inacabado de D.G. Rossetti La Belle Dame Sans Merci.

Sin embargo, La Belle Dame Sans Merci, de J.W. Waterhouse, enfatiza la doble acción de seductora-apresando. En este caso, la hechicera es una bella doncella de mirada hipnótica, que logra atraer al caballero haciendo que se arrodille ante ella. Acto simbólico en el que se comprende que el amante cae rendido y completamente vencido a sus pies. Después lo conduce a 'el fin grot' o 'gruta de los duendes'. Esta es la imagen que también utilizan Munch en sus pinturas, y Maeterlinck y Swinburne ${ }^{372}$ en sus textos $\operatorname{literarios}^{373}$.

\footnotetext{
${ }^{371}$ Rafael Llopis, op. cit., pp. 196-229.

${ }^{372}$ Swinburne, Poemas y baladas.

${ }^{373}$ Erika Bornay, op. cit., pp. 228-229.
} 


\subsubsection{2.- La persistencia de la mujer que arrastra}

El acto violento de arrastrar no queda aislado y se extiende a otros personajes. Tal es el caso del pequeño relato titulado "Visiones de Oxford". Este aparece publicado en Los paraísos artificiales de Baudelaire, y en él se resalta la figura de la Mater Tenebrarum. Es decir, Nuestra Señora de las Tinieblas, hermana menor de Nuestra Señora de los Suspiros. Se trata de un ídolo terrible que adopta una apariencia femenina, no por casualidad, pues se trata de una mujer zoomórfica. Baudelaire la llama la madona de los irregulares pasos, pues combinando los pasos lentos y rápidos se acerca a los suicidas para aconsejarles con gracia trágica. De forma que, cuando un joven decide enterrar su corazón en el tormento aparecen en escena las tres diosas de la tristeza. La más joven de ella es Nuestra Señora de las Tinieblas. La Mater Tenebrarum no obedece a ninguna inclinación perversa, sino que siguiendo los suplicios y tormentos de los hombres se presenta como 'madre refranera' o como 'madre amorosa'. Los atrae con dulces cantos y los arrastra hasta el abismo de la muerte. Todo vale cuando se trata de alumbrar a los superhombres. Un ejemplo muy claro lo encontramos en La sirena negra de Pardo Bazán $^{374}$.

\section{3.- El orientalismo como caracterización física}

El punto de partida del orientalismo es la experiencia británica y francesa en Oriente. Edward Said afirma que, el "interés de Europa hacia Oriente siempre ha sido de orden político, económico y militar. La colonización oriental despertó la necesidad de una conciencia geopolítica que se sustentaba sobre textos económicos, sociológicos e históricos. Son discursos de una distinción geográfica básica que buscan una serie

\footnotetext{
${ }^{374}$ Isabel-Argentina Fuentes Herbon, op. cit., pp. 237-239.
} 
completa de intereses. Primero constan de descripciones geográficas, descripciones sociológicas y de análisis psicológicos. Pero, no se trata de estudios culturales, sino de una incipiente necesidad de comprender. Incluso, en algunos casos, de controlar, manipular e incorporar. En consecuencia, en ellos se manifiesta un mundo diferente, alternativo y nuevo. Es un discurso, que de ningún modo se puede hacer corresponder directamente con el poder político, pero que se produce y existe en virtud de un intercambio desigual, puesto que se conforma a través de un intercambio con el poder intelectual, con el poder cultural y con el poder moral. Este intercambio desigual es lo que Edward Said llama orientalismo ${ }^{375}$.

En segundo lugar, la corriente artística se fundamenta en la exterioridad. Es decir, cuando hablamos de la India o del Egipto de Beckoford, Byron, Goethe o Víctor Hugo, no se trata de una verdad histórica, sino de sus representaciones. Estas son imágenes que toman forma a través de ritos ancestrales. Son escenas primitivas y originarias, que los escritores utilizan para dar un comienzo a la cultura foránea. Said destaca que la idea de comienzo implica necesariamente un acto de delimitación, que constaría en extraer un punto de partida dentro de una gran masa uniforme. Al fin y al cabo es la creación de un punto de partida, un comienzo.

Por lo que la idea de orientalismo que ha forjado Occidente puede llegar a sustituir al verdadero Oriente. Said añade la idea de que el orientalismo sólo tiene sentido desde el punto de mira de Occidente, no de Oriente". Este filtro cultural es el que potenciará las características eróticas de las féminas. Es el velo que nos hace falta para comprender el

\footnotetext{
${ }^{375}$ Edward Said, Orientalismo, Madrid, Libertarias, 1990, pp. 31-32.
} 
erotismo/exotismo de hoy en día. Es lo que tenemos que atravesar para poder llegar a comprender la influencia actual que recibimos de los mitos ${ }^{376}$.

\subsection{1.- La mujer-bestia}

En La bella, enigma y pesadilla. Esfinge, medusa y pantera Pilar Pedraza hace una exposición de varios monstruos femeninos. El objetivo es recopilar a todas las féminas que simbolicen la fusión entre la mujer y la bestia. Aunque son de origen griego, ninguno de ellos ha sido rescatado, porque han sobrevivido a épocas anteriores como el Renacimiento, Manierismo, Romanticismo, Modernidad... Esta mezcla tan particular estimula la inteligencia y la sensibilidad al igual que representa una promesa y un engaño ${ }^{377}$.

Para Pilar Pedraza en la figura del monstruo-hembra se unen ideas bipolares como humanidad-bestialidad, seducción-muerte, deseo-pesadilla... Muchas de ellas se concretizan en la feminidad ambigua como la esfinge griega, la sirena clásica, las Gorgonas (especialmente Medusa) y la pantera. Es la objetualización del oscuro objeto del deseo.

Si nos fijamos, la Esfinge, Medusa y las sirenas se relacionan directamente con el héroe, por lo tanto tienen una proyección histórica dada por la mitología. En este caso tenemos a Edipo, Perseo y Ulises, que son quienes vencen a las ogresas. Por supuesto, esto es un discurso constante a través de la historia, y no es otro que el triunfo del bien sobre el

\footnotetext{
${ }^{376}$ Edward Said, op. cit., pp. 41-42.

${ }^{377}$ Pilar Pedraza, La bella, enigma y pesadilla. Esfinge, medusa y pantera, Barcelona, Tusquets, 1991, pp. $11-13$
} 
mal. La mitología reviste a las féminas con características de bestia, las envilece y las convierte en híbridos monstruosos que buscan la perdición del héroe.

El presente apartado sigue la argumentación de Pilar Pedraza, pero dejaremos de lado la figura de la pantera, pues será tratada en el apartado de las mujeres animales. Por lo que en este apartado podemos distinguir entre la esfinge, Medusa, sirenas, arpías y $\operatorname{vampiros}^{378}$.

\subsubsection{1.- La Esfinge}

Cuenta la historia que la esfinge fue una ogresa que tenía aterrorizaba a la población de Tebas. Les proponía enigmas a los ciudadanos y, si no eran capaces de resolverlos, los devoraba. Esta figura fue heredada del antiguo Egipto, donde al principio fue masculina con pechos y rostro de mujer, cuerpo de león y alas de ave rapaz ${ }^{379}$. Posteriormente, y según ilustran las imágenes de las cerámicas, fue adoptada por Grecia como genio funerario o como ogresa violadora y asesina de jóvenes varones ${ }^{380}$.

Existe toda una variedad de esfinges, por lo que Pilar Pedraza hace un recorrido por la historia de la Esfinge para ir desvelándolas. Una de ellas es la de Efeso, un íncubo femenino que mata abrazando y sofocando. Etimológicamente el término esfinge significa la que aprieta, la que oprime o la que ahoga. El abrazo de la ogresa es completamente activo: en él la hembra se extiende sobre el macho, le cubre con su cuerpo y le oprime con su peso. Este monstruo es un íncubo que mata abrazando,

\footnotetext{
${ }^{378}$ Pilar Pedraza, op. cit., pp. 12-13.

${ }^{379}$ Erika Bornay, op. cit., p. 257.

${ }^{380}$ Pilar Pedraza, “Algunos aspectos de la Esfinge en la cultura moderna", separata del libro Homenaje a José Antonio Maravall, Valencia, 1986, p. 1 (175).
} 
sofocando y hasta seduciendo. El hecho de que las víctimas ofrezcan un aspecto desvalido ha hecho que Laistner y Delcourt relacionen las esfinges con las pesadillas que oprimen al durmiente y les plantean enigmas irresolubles, mientras les hacen sentir agobio e indecisión. Ambos autores las recuperan del folklore y las relacionan con las Damas del Mediodía. Estas eran espíritus femeninos que, al igual que una amante celosa y perversa, se abalanzan sobre el durmiente para hacerle preguntas ininteligibles. Al principio le acarician, pero conforme su desesperación aumenta, comienzan a golpearlo hasta matarlo ${ }^{381}$. De lo que los griegos estaban seguros es de que debían enfrentarse desnudos ante este tipo de seres: ningún tipo de arma servía.

Esta vertiente ha quedado sepultada en la memoria de Occidente y, en consecuencia, ha primado la esfinge del mito de Edipo. Finalmente, Pilar Pedraza define esta esfinge como un híbrido entre Yocasta y Astarte. Ambas forman las dos caras de una misma moneda. Yocasta representa a una mujer fértil que cumplía a la perfección los papeles de madre-esposa-abuela. Por el contrario, Astarte encarnará el lado más agresivo de la Esfinge: es una doncella cantora, estéril, destructora de jóvenes, de los cuales abusa hasta consumirlos. Hoy en día, la esfinge tebana es la única que se encuentra en la cultura occidental. Esta esfinge pertenecía a la genealogía de los dioses pre-olímpicos destinados a ser aplastados por la estirpe de $\operatorname{Cronos}^{382}$. Pero algunos vástagos de la primera bestialidad fueron reservados por la moira para pruebas iniciáticas de los héroes ${ }^{383}$.

\footnotetext{
${ }^{381}$ Pilar Pedraza, op. cit, pp. 24-52.

${ }^{382}$ Hesiodo en su Teogonia la cataloga como hija de Orto y de Quimera, nombrada por Fix como la Funesta. Apolodoro, en contrapartida, la hace hija de Tifón y de Equina, víbora monstruosa del fondo marino. Y Eurípides cree que es hija de Equidna y Gea. Pausanias la relaciona con Layo y una concubina, y Paléfato la tiene como una amazona amancebada en tiempos de Cadmo.

${ }^{383}$ Pilar Pedraza, op. cit., pp.17-115.
} 
Tras un largo periodo de latencia medieval, la esfinge resurge de la mano del Humanismo, y ocupa un lugar privilegiado en las artes figurativas del Renacimiento. Ahora aparece como representación emblemática de la Doxa. Es decir, como opinión y conocimiento, conocimiento que no proviene de la razón, sino de tradiciones, suposiciones y errores. Este doble sentido, tanto positivo como negativo, multiplica el atractivo de su belleza. En el emblema CLXXXVII de Andrea Alciato ${ }^{384}$, la esfinge aparece descrita como la tradición humanista que reza a la manera griega. Así que, para Alciato, la monstruosidad de cada ser representa un vicio diferente. Las alas del ave son la levedad del ingenio y la trivialidad o superficialidad; el rostro de doncella es la concupiscencia; el cuerpo y las patas de león son la soberbia. Por supuesto, no debemos comprenderlos a todos juntos como una suma, sino como un conjunto de tres vicios y, como producto final, tenemos la ignorancia. Para completar la imagen que se perfiló durante el Renacimiento de la Esfinge, señalaremos la obra Pierio Valeriano (1556) titulada Hieroglyphica. Nuestra protagonista está situada en los templos egipcios y advierte, a modo de jeroglífico, que los principios místicos deben de ser guardados, protegidos, inviolables por medio de enigmas, por lo que serán tratados como los $\operatorname{arcanos}^{385}$. La idea de que ocultará una gran fortuna nace en el Renacimiento, sobre todo de la mano del jesuita Athanasius Kircher y de Sâr Peladan. Así aparece en el suelo de la catedral de Siena, como guardiana de los arcanos, como emblema de la agudeza del ingenio. Así lo recoge Paulo Giovio en su libro Empresas militares y amorosas $(1561)^{386}$.

\footnotetext{
${ }^{384}$ Andrea Alciato, Emblema CLXXXVII, en Emblematum Liber, Augsburgo, 1530.

${ }^{385}$ Pilar Pedraza, op. cit., pp. 38-42.

${ }^{386}$ Pilar Pedraza, op. cit., pp. 80-85.
} 
Maria Delcourt estudia con detenimiento el caso de Edipo y la Esfinge, y observa que esta se ha mantenido viva hasta nuestros días gracias al carácter de enigma que se le ha otorgado. Edipo era cojo ${ }^{387}$. Nació con mal pie, e incluso pudo haber nacido deforme. En Las ranas de Aristófanes aparece descrito con esta deformidad, y a causa de ella sus padres lo abandonan en el monte o lo arrojan al agua. Pero el hecho de salvarse le adjudica el carisma de elegido para una gran misión. Pasó toda su infancia en Corinto, en la mansión de Pólibo. Desde pequeño tuvo grandes problemas para andar, por lo que tardó mucho en caminar erguido. Normalmente, se arrastraba. Hasta que un día Mérope se lo prohíbe, y es entonces cuando Edipo comienza a utilizar bastones con forma de esfinge en el mango. Pero hasta que llegó este momento, tuvo que soportar cuchicheos de la servidumbre sobre las condiciones misteriosas de su nacimiento y miradas de soslayo hacia sus pies.

La imagen de Edipo frente a la esfinge es muy significativa. La esfinge tebana no pregunta a sus víctimas su nombre, a ella no le interesa si son capaces de adivinar el nombre de la propia ogresa. Esto era algo propio de los monstruos y de los demonios del folklore. Lo que pregunta la esfinge es el nombre del propio Edipo. Esto representa a Edipo frente a un espejo. Edipo se mira a sí mismo y ve la mezcla de lo humano y lo animal que hay en él. Ve su marcha infantil a cuatro patas. Realmente, representa la lucha interior entre su naturaleza humana y animal. Sin embargo se trata del mismo pathos que oprime al propio monstruo. Al ocultar la angustia que le provoca su naturaleza híbrida, ella se vuelve esquizofrénica y prepotente, y proyecta sobre los tebanos su opresión. A modo de espejo plantea un enigma funesto en el que están contenidos todos los conflictos ${ }^{388}$. En consecuencia, los hombres la temen porque no

\footnotetext{
${ }^{387}$ Si nos fijamos el nombre de Edipo suena a voces como bípedo, trípode, tetrápodos...

${ }^{388}$ Pilar Pedraza, op. cit., pp. 57-73.
} 
saben distinguir entre su dignidad humana y sus inclinaciones bestiales. Son incapaces de reconocerse en el monstruo. Aquí el espejo cobra vida y agrede. Los espiritualistas finiseculares vieron en él la alegoría de la lucha entre el hombre y la naturaleza. Como dice Edourard Schuré (1841-1929) en Précurseurs et révoltés (1904) ${ }^{389}$ :

¡La palabra de tu enigma es el hombre, soy yo!

Pues todo lo que tú eres, yo lo soy ${ }^{390}$

Pues su victoria no le da ni libertad ni felicidad. Así lo destaca el poeta griego Kavafis:

La Esfinge se abalanza sobre él

con dientes y garras

$\mathrm{y}$ con todo su furor.

Edipo siente miedo

-esa presencia lo atemoriza,

ese rostro, esa pregunta

que él jamás hubiera imaginado.

Pero en tanto el monstruo

se dispone a acometer,

Edipo, rápidamente, piensa en su defensa:

Ya no siente temor. Ahora sabe que dispone

de la respuesta a esa pregunta, y vencerá.

Pero tal victoria no lo alegra.

Su melancólica mirada

no se dirige ya a la Esfinge: mira en la lejanía

la estrecha senda que conduce a Tebas

y que conducirá a Colona.

\footnotetext{
${ }^{389}$ Los griegos eran unos grandes aficionados a los oráculos délficos, los consejos pitagóricos, los enigmas y las adivinanzas.

${ }^{390}$ Pilar Pedraza, op. cit., p. 76.
} 
$\mathrm{Y}$ en su alma nacen augurios

que si una Esfinge los hubiera propuesto

hubieran vencido a Edipo.

Preguntas de imposible respuesta ${ }^{391}$.

Pero no siempre nos movemos en el ámbito del simbolismo. Personalmente me parece muy interesante la obra de Conrado Gesner, quien representa la esfinge de Edipo como un fiero mono hijo de Pelayo. Parece un intento de concentrar dos esfinges en una sola. Por un lado la de los poetas, que sería la que hemos explicado hasta ahora; y la que aparece en los estudios de zoología antiguos y modernos entre la caterva de los cinocéfalos, los sátiros y otras bestias africanas. Por la misma línea siguen Pierio Valeriano y Gerónimo de Huerta ${ }^{392}$. Johann Heinrich Füssli (1741-1825) contemporáneo de Goya, David y Blake, fue formado en teología y filología clásica. Fue uno de los pintores que más textos literarios ha ilustrado; entre ellos podemos encontrarnos con Homero, Dante, Shakespeare, Milton y las mitologías germanas. Pero lo que más nos interesa es que él también retrata a la esfinge con forma de simio terrorífico, sobre todo en Pesadilla (Nightmare). Su obra Edipo y la Esfinge trata este tema mediante la oscuridad y con la ayuda de interpretaciones contradictorias. Poco a poco la esfinge fue perdiendo su naturaleza brutal de ogresa o, al menos, se ocultaba bajo la falsa máscara intelectual de los enigmas.

\footnotetext{
${ }^{391}$ Pilar Pedraza, op. cit., p. 77.

${ }^{392}$ Pilar Pedraza, op. cit., pp. 43-44.
} 


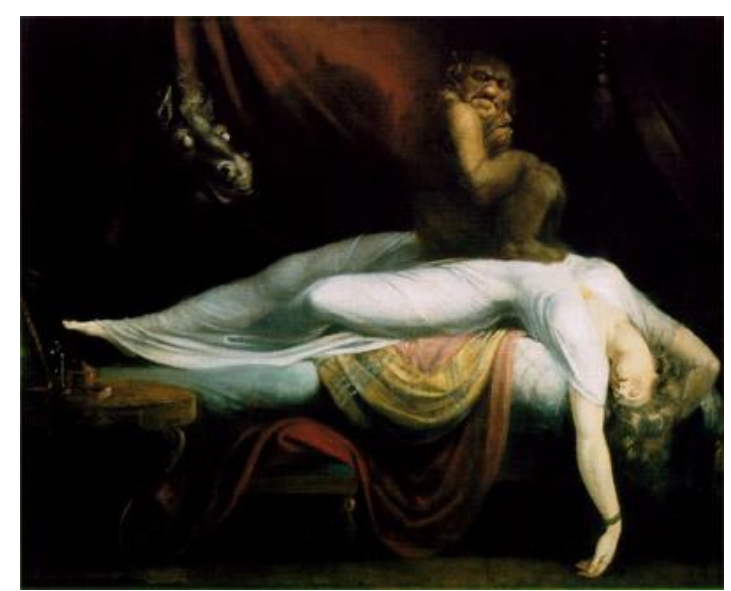

Henry Füssli (Pesadilla, 1781)

La esfinge llega a alcanzar así el máximo potencial erótico y exótico, pues armoniza el misterio que encierran los secretos jamás desvelados con la nueva estética simbolista. De forma, que los lectores se sentían fuertemente atraídos por su enigmática respuesta, por su naturaleza arcaica y por el esoterismo ${ }^{393}$. Gracias a esta ha sobrevivido hoy en día como mujer-bestia portadora de enigmas. Pero en el discurso romántico y decadentista, la esfinge se convertía en el futuro paradigma de la mujer fatal. Algunos ejemplos los encontramos en el mundo literario cuando leemos La tentación de San Antonio de Flaubert, A rebours de Huysmans, La esfinge de Wilde o los Poemas de Albert Samain $^{394}$. Pero sin lugar a dudas, el simio que mejor ha encarnado los enigmas antiguos es el que Edgar Allan Poe describió en Los Asesinatos de la calle Morgue. Para ello el autor norteamericano nos situó en los orígenes de la novela negra al presentarnos un doble asesinato enmarcado en el enigma del espacio cerrado. El relato cuenta cómo una anciana y su hija son asaltadas en su casa durante la noche. Pese a que

\footnotetext{
${ }^{393}$ Erika Bornay, op. cit., pp. 257-258.

${ }^{394}$ Aunque, sinceramente, el mundo pictórico no se queda corto, pues podemos encontrar grandes e importantísimos cuadros tales como La pregunta (1875) de D. G. Rossetti, Edipo y la Esfinge (1864) de Gustave Moreau, El beso y la Esfinge (1895) de Franz von Stuck, La Esfinge y Psique (1899) de Jan Tooropo, La Esfinge (1879) de Rops, Esfinge (1909) E. Munch, La Esfinge (1890) de Maximilián Pirner, Las esfinges (1906) de Gustave-Adolph Mossa, El ángel, De la animalidad (1889), La caricia (1896) de Fernand Khnopff. Parece que Fernand Khnopff buscó inspiración en los héroes decadentes que J. K. Huysmans retrató en Des Esseintes. Aunque también es cierto que la obra literaria se publicó más tarde, concretamente en 1894 por la revista inglesa "The Studio" con el título de El encuentro del ángel con la animalidad.
} 
la estancia estaba completamente cerrada por dentro, un asesino logra entrar, las mata y vuelve a salir sin utilizar la puerta. La estructura del relato está planteada a modo de enigma dedicado a resolver la identidad del asesino/a. Pero el misterio se ve resuelto cuando la violencia del asesinato se encarna en la agresividad animal de un gigantesco orangután que se había escapado.

La persecución duró así un buen rato. Hallábanse en las calles en completa tranquilidad, porque serían las tres de la madrugada. Al descender por un pasaje situado detrás de la rue Morgue, la atención del fugitivo fue atraída por una luz procedente de la ventana abierta de la habitación de madame l’Espanaye, en el cuarto piso de la casa. Se precipitó hacia la casa, y al ver la cadena de pararrayos, trepó ágilmente por ella, agarróse al postigo, que estaba abierto de par en par hasta la pared, y, apoyándose en ésta, se lanzó sobre la cabecera de la cama.

(...) el terrible animal había asido a madame l'Espanaye por los cabellos, que en aquel instante tenía sueltos, por estarse peinando, y movía la navaja ante su rostro, imitando los ademanes de un barbero. La hija yacía inmóvil en el suelo, desvanecida. Los gritos y esfuerzos de la anciana (durante los cuales estuvo arrancando el cabello de su cabeza) tuvieron el efecto de cambiar los probables propósitos pacíficos del orangután en pura cólera. Con un decidido movimiento de su hercúleo brazo le separó casi la cabeza del tronco. A la vista de tanta sangre su ira se convirtió en frenesí. Con los dientes apretados y despidiendo llamas por los ojos, se lanzó sobre el cuerpo de la hija y clavó sus terribles garras en su garganta, sin soltarla hasta que expiró. Sus extraviadas y feroces miradas se fijaron entonces en la cabecera del lecho, sobre la cual la cara de su amo, rígido por el horror, apenas se distinguía en la oscuridad. La furia de la bestia, que recordaba todavía el terrible látigo, convirtióse instantáneamente en miedo. Comprendiendo que lo que había hecho le hacía acreedor de un castigo, pareció deseoso de ocultar su sangrienta acción. Con la angustia de su agitación y nerviosismo, comenzó a dar saltos por la alcoba, derribando y destrozando los muebles con sus movimientos y levantando los colchones del lecho. Por fin, apoderóse del cuerpo de la joven y, a empujones, lo introdujo 
en la chimenea en la posición en que fue encontrado. Después se lanzó sobre la madre y lo precipitó de cabeza por la ventana ${ }^{395}$.

Este pasaje, junto con el cuadro de Füssli, no han pasado desapercibidos para los ilustradores modernos. Tal es el caso de Deak Ferrand, un pintor suizo que tras recibir una formación clásica trabajó como animador 3D para las películas y la publicidad de Group Image Buzz, y que hoy en día tiene su propia empresa de efectos visuales, HATCH. Pero lo que nos interesa de su obra es Minion, una imagen terrorífica con la que se logra aunar el texto de Poe y el cuadro de Füssli ${ }^{396}$.

En el campo literario debemos añadir la figura de Sâr Josephine Péladas y su obra en tres actos Edipo y la esfinge. También tenemos el Edipo de Corneille (1659), en donde se introducen los amores de Teseo y Dircea; Voltaire retoma los amores de Yocasta y Filoctetes. Martínez de la Rosa también escribe su propio Edipo en 1829, y Hugo von Hoffmannsthal en 1905. Jean Cocteau escribe la obra teatral de cuatro actos llamada $L a$ machine infernale $(1934)^{397}$. Ya entrados en el siglo XIX encontramos el tratamiento de la esfinge como si de una quimera se tratase, tal es el caso de Flaubert en El enfrentamiento entre la Esfinge y la Quimera, de Wilde, Sâr Péladas, Edouard Schuré con su El ángel y la esfinge en donde plantea el eterno enigma del cuerpo de la feminidad. Konrad ya mantiene que no se trata de matar al hombre, se trata de poseerlo para renacer. También Heinrich Heine en el prefacio A Buch der Lieder escribe un poema a la esfinge con la cual mantiene un escarceo romántico levemente

\footnotetext{
${ }^{395}$ Edgar Allan Poe, Relatos, Cátedra, Madrid, 2001, pp. 232-233.

${ }^{396}$ John Howe, Christian L. Scheurer, H. R. Giger, Swiss Design in Hollywood, Valencia, Universidad Politécnica de Valencia, 2009, pp. 33-38.

${ }^{397}$ Pilar Pedraza, op. cit, 1991, pp. 83-87.
} 
sadomasoquista del que se desprende la idea del beso de hielo y fuego de la estatua. Este fue motivo de inspiración para Bécquer, Mérimée y para las amantes lívidas de E. A. Poe. Para finalizar este apartado señalaremos la obra de Jean Baudrillard Les stratégies fatales de $1983^{398}$.

\subsubsection{2.- Medusa}

Las Gorgonas eran tres hermanas llamadas Esteno, Euríale y Medusa. En su Teogonía, Hesiodo dice que las tres ogresas son hijas de Ceto y Forcis, los cuales eran dioses marinos y primordiales; y que viven al otro lado del ilustre Océano, en un confín del mundo hacia la noche, donde viven las Hespérides de voces agudas. Esta última era la única mortal y fecunda; por ello dio a luz a dos especies diferentes de criaturas. Por un lado tenemos a los monstruos como Equidna (la Víbora); pero, por el otro, tenemos la rama de los sublimes como Pegaso o Crisaor (el de la espada de oro). En Griego Medusa significaba la soberana, la dominadora. Por supuesto, su naturaleza marina fue declinando en el mito y en la poesía a favor de una monstruosidad de carácter infernal. De ahí que Homero la sitúe en los infiernos, Virgilio en el vestíbulo de Hades, y Dante en el Infierno ${ }^{399}$.

El mito originario sólo explica la decapitación del monstruo. Así que, de alguna forma, quedaba la puerta abierta para que otros autores pudieran completar la historia. Los primeros fueron Apolodoro de Atenas ${ }^{400}$ e Higynio ${ }^{401}$, que intentaron explicar el porqué

\footnotetext{
${ }^{398}$ Otras obras importantes son La esfinge de Miguel de Unamuno (1898), La esfinge de los hielos de Jules Verne (1897), La narración de Arthur Pym de Poe (1838) y La esfinge maragata de Concha Espina (1914).

${ }^{399}$ Pilar Pedraza, op. cit., pp. 159-163.

${ }^{400}$ Apolodoro de Atenas escribió Biblioteca mitológica.
} 
de sus cabellos. Para ello, comentan que fue Medusa quien osó comparar su hermosa cabellera con la de Atenea. Obviamente, ésta castigó su soberbia tornándola una maraña de víboras ${ }^{402}$.

Pilar Pedraza destacar el aspecto de Medusa Hermética. Para comprenderlo con claridad debemos recordar las descripciones de Filostrato en Imágenes. Esta figura se extiende sobre el simbolismo alquímico, y se sitúa en el hermetismo neoplatónico. El fin es atribuir a cada Gorgona un reino, y unos poderes diferentes sobre las distintas regiones de la psique humana. Desde este punto de vista, cada una de las Gorgonas dominaba una parte del alma. Euríale dominaba el alma irracional, Esteno el alma racional y Medusa el alma sensual. Se trata de una metáfora de la concupiscencia. Pese a que en el mito se aconseja reprimir los bajos apetitos, Medusa encarna el acto de la caída. Pues a partir del camino de la perfección se rebaja al nivel de las bestias y cede a la provocación del rey de los mares ${ }^{403}$.

Ella era la figura más bella y el partido codiciado por muchos,

y en toda ella no había parte más admirable que sus cabellos;

he conocido a quien dijo haberla visto. El soberano del piélago,

cuentan, la deshonró en el templo de Minerva; la hija de Júpiter

se volvió y se cubrió el casto semblante con la égida,

y para que el hecho no quedara impune, cambió la cabellera

de la Gorgona en repugnantes, feas serpientes de agua.

\footnotetext{
${ }^{401}$ Cayo Julio Higino, autor de Fábulas (donde encontramos a Medusa) y de Astronomía poética.

${ }^{402}$ Pero Ovidio tiene otra versión en la que dice que el soberano de los mares deshonró a Medusa en el templo de Minerva. Fue entonces cuando la hija de Júpiter se cubrió el casto semblante con la égida y cambió los cabellos de Medusa.

${ }^{403}$ Pilar Pedraza, op. cit., pp. 181-186.
} 
Y aun, para aterrar y dejar paralizados a sus enemigos,

lleva delante del pecho las serpientes que ella creó ${ }^{404}$.

Desde el punto de vista expresionista, Gustav Meyrink rescata el simbolismo alquímico $^{405}$. Principalmente, observamos cómo en su obra hay dos temas de carácter meduseo: la mineralidad y el doble. Por supuesto, ambas aparecerán perfectamente entrelazadas. Pero cabe analizarlas de forma separada para comprenderlo a la perfección. En la mineralidad, observamos cómo utiliza la metáfora de la piedra preciosa "viva" desplazada hacia la mujer. Un ejemplo muy claro lo encontramos en El dominico blanco, donde se compara el recuerdo de una mujer con la piedra de Alejandría. Este resulta ser un mineral que de día es de color verde oscuro y de noche rojo ardiente. Se trata de un recuerdo que paraliza e hipnotiza. Es una mirada hacia el pasado traicionero. Bajo este punto de vista, el autor francés Blaise de Vigenère destaca que las Gorgonas simbolizan las tres caras del tiempo: presente, pasado y futuro ${ }^{406}$, en donde Medusa representa el pasado, porque el hombre corre el riesgo en cualquier época de petrificarse por su fijación obsesiva ${ }^{407}$.

La figura de Medusa adopta la misma capacidad destructora que los recuerdos obsesivos. Así que ella es capaz de convertir a los hombres en piedras, incluso después de ser

\footnotetext{
${ }^{404}$ Publio Ovidio Nasón, Obras completas, Madrid, Espasa, 2005, pp. 795-803.

${ }^{405}$ Vivió entre 1868 y 1932, y escribió El Golem en 1915, El rostro verde en 1916, El dominio blanco 1921 y El ángel de la ventana en 1927.

${ }^{406}$ Pilar Pedraza, op. cit., p. 190.

${ }^{407}$ En cuanto a los retratos renacentistas que podemos destacar de Medusa, los que más nos interesan son los de Leonardo, Caravaggio y Rubens. Al final del siglo XIX, destacaremos la figura de Lafred Kubin (1877-1959), un ilustrador y pintor cuya esencia era el relato de la descomposición y la ruina apocalíptica de un país artificial. De entre sus manos destacaremos El reino de los sueños, cuyo personaje es Claus Patera. Pero nos centraremos en analizar el alcance que tuvo su medusa expresionista. Lafred Kubin retrató a Medusa como un Demiurgo apocalíptico y, sobre esta figura debió de ejercer una fuerte influencia la Medusa como doble perverso que ya perfiló Gustav Meyrink en su ambiente expresionista.
} 
decapitada. Realmente estamos ante un tema muy recurrente en el mundo artístico, desde Caravaggio, hasta $L I$ de H. R. Giger, pasando por Rubens, E. Burne-Jones, F. Khnopff $^{408}$, Franz von Stuck ${ }^{409}$ o el Friso de Beethoven de Klimt (1902) ${ }^{410}$.

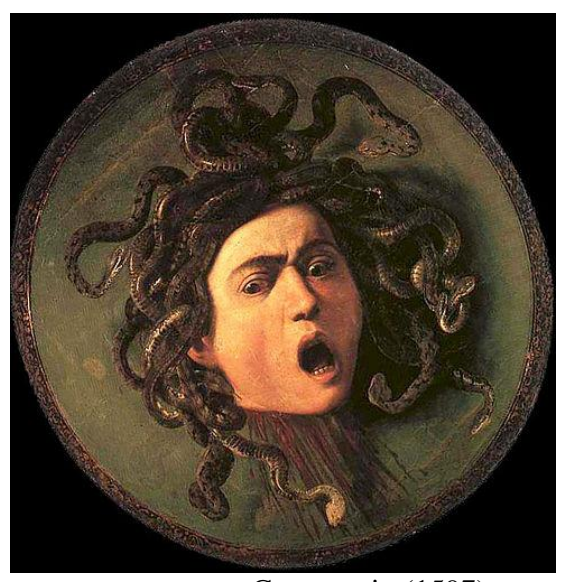

Caravaggio (1597)

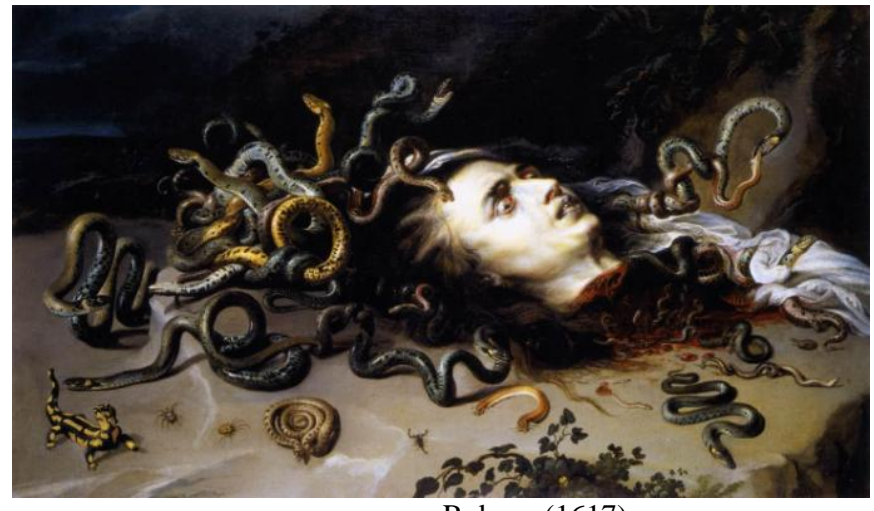

Rubens (1617)

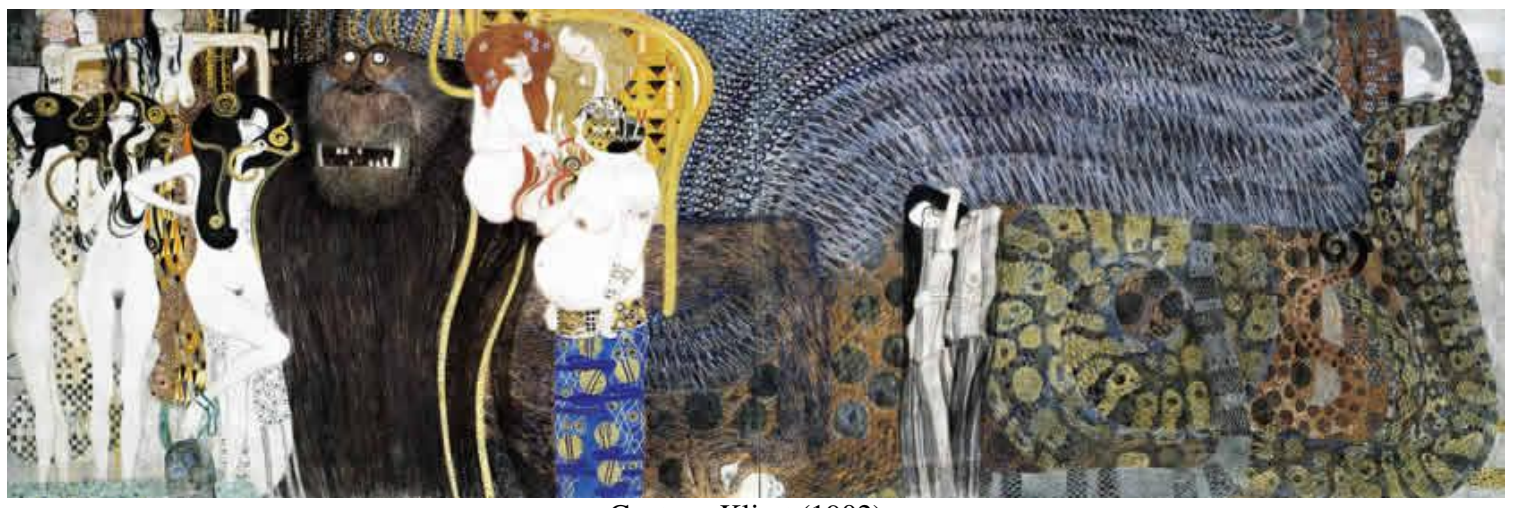

Gustave Klimt (1902)

\footnotetext{
${ }^{408}$ Dentro de los cuadros de Khnopff tenemos que destacar Isthar, Medusa dormida (1896) y La sangre de la Medusa (1895).

${ }^{409}$ Erika Bornay, op. cit., pp. 269-275.

${ }^{410}$ En sus Potencias enemigas aparecen descritos todo tipo de voluptuosidades, impudor e intemperancia, pero siempre centrados en el monstruo Tifón y en las hermanas Gorgonas.
} 


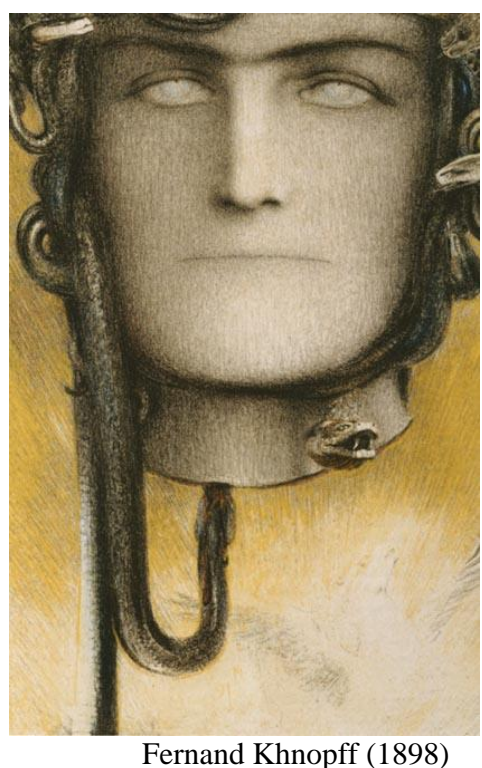

Fernand Khnopff (1898)

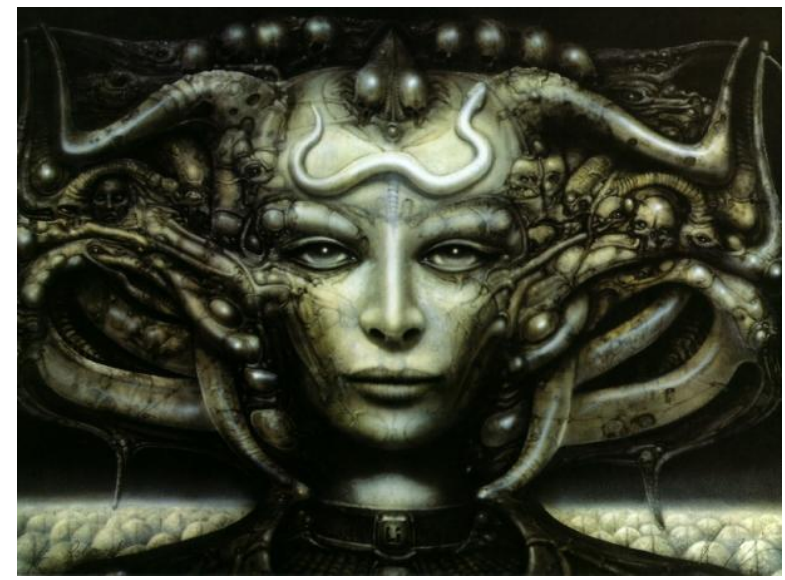

H.R. Giger (19774)

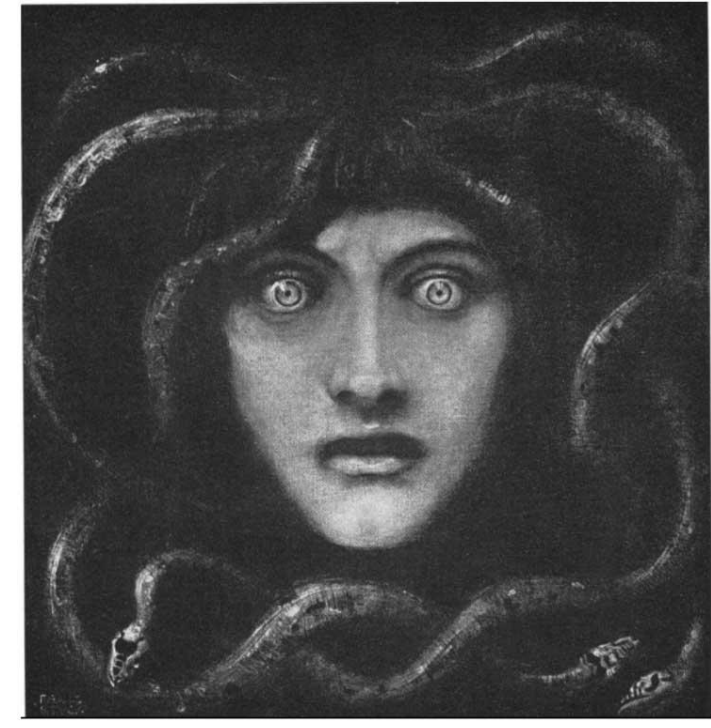

Franz von Stuck (1892)

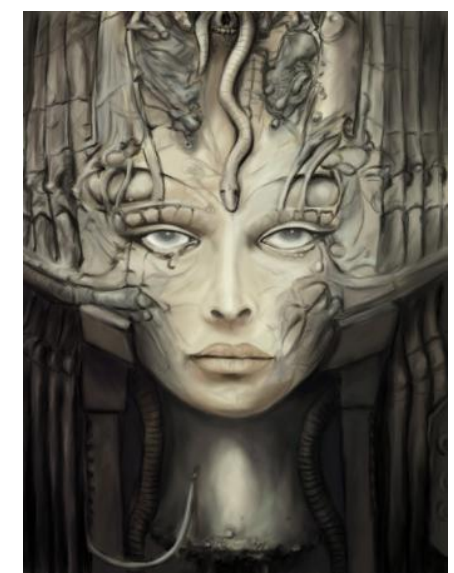

H. R. Giger (1974)

Esta función paralizadora de Medusa contiene la idea de detener la mirada del mal. Para vencer a Medusa no era necesario conocer su secreto viperino, sino saber cómo sortear su mirada, por lo que muchos griegos supersticiosos adoptaron la imagen de esta diosa para evitar las miradas negativas y los malos deseos ${ }^{411}$. Llevar medallas y adornos con la cabeza de Medusa se convirtió en una moda para evitar el mal de ojo. De esta forma, Medusa adquiría el carácter de mineralidad mediante la metáfora del talismán. De ahí la importancia misteriosa de los joyeros y alquimistas, porque sólo ellos pueden trabajar los minerales con este fin tan especial.

\footnotetext{
${ }^{411}$ Pilar Pedraza, op. cit., pp. 209-218.
} 
Por otro lado, la metáfora del doble la encontramos en El Golem y en El dominico blanco. Para poder comprender la figura del doble a la perfección debemos hacernos eco de las palabras de Pilar Pedraza. Para esta la estrecha relación que une a Atenea y a Medusa es muy importante y no debemos olvidarla. Atenea era la luz iluminadora y siempre iba acompañada de una lechuza, considerada ave lucífuga, y así la describe:

Los ojos de Atenea son glaucos, verdes o azules, como el aire o como el agua cuando el sol los atraviesa, límpidas gemas frías, diurnas, capaces de matar a la sacerdotisa que penetra en el templo inadecuadamente, de hacer temblar las rodillas de los héroes, de soportar la vista petrificante de Medusa, pero también de encender la lujuria de su hermano Hefaistos. Atenea Oxyderkes, de aguda visión; Atenea Gorgopis, la de los ojos de Gorgona ${ }^{412}$.

Tanto Medusa como Atenea son caracterizadas con la figura de la serpiente. Por un lado Medusa tiene una naturaleza viperina con la cual convierte a sus castigados en serpiente, y Atenea también cuenta con una serpiente, la de Erictonio $^{413}$. Además su justicia puede convertirse en una crueldad monstruosa, pues adquiere un cariz meduseo. De este modo Medusa puede ser la Otra, la gran doble de las culpas inconfesables ${ }^{414}$. El sistema de dobles de la novela de Meyrink funciona bajo estos dos binomios. Uno está encarnado en el binomio Medusa-protagonista principal y, en el otro, se enfrentan la novia del protagonista ante Medusa, por lo que tenemos Medusa-Virgen. La Gorgona simboliza la vida muerta, es decir la materia que pretende cubrirse con las galas de la espiritualidad. Pero en el fondo vemos el vacío del mal, la mentira y el pathos del muerto viviente.

\footnotetext{
${ }^{412}$ Pilar Pedraza, op. cit., pp. 176-178.

${ }^{413}$ Esta nació de la tierra fecunda por el semen de Hefaistos que cayó sobre el muslo de Atenea.

${ }^{414}$ Pilar Pedraza, op. cit., pp. 176-179.
} 
La medusa de Gustav Meyrink es aquella que, siendo poderosísima y casi indestructible, sólo puede ser aniquilada por sí misma. De esta forma, se trata de una medusa interior, propia de la persona. Debemos señalar que los basiliscos matan al mirar a sus víctimas, pero Medusa mata al ser mirada. Ella no hace brotar la muerte, sino que es un estupor por ella producido el que mata.

Las primeras luces de la aurora surgieron en el horizonte. Las nubes de la noche gravitaban sobre la tierra como una pesada cortina negra; manchadas de naranja y de malva, me trajeron a la memoria la cabeza de Medusa, una cabeza inmóvil, suspendida, al acecho, que parecía querer tragarse el sol. Al mismo tiempo me pareció un sudario del infierno con la imagen de Satanás $(\ldots)^{415}$.

Es un monstruo solitario que se caracteriza por su ataque automático ${ }^{416}$. El hombre, como víctima, se ve atrapado en una maraña de contradicciones y queda petrificado. Es la imagen del reverso de Narciso al borde de su espejo líquido, y Medusa simboliza su propia imagen deformada ${ }^{417}$.

\footnotetext{
${ }^{415}$ Pilar Pedraza, op. cit., pp. 214-215.

${ }^{416}$ Paul Diel relaciona a las Gorgonas con las Erinias. Estas últimas eran entidades viperinas que metaforizan los tormentos de la mala conciencia. Es decir, son los remordimientos que martirizan a los grandes culpables, el ofuscamiento paralizante. Pero hay una diferencia importante: Medusa es una Gorgona solitaria que no busca a sus víctimas, sin embargo las Erinias son diosas sociables, superyoicas, castigadoras de las faltas cometidas contra el orden establecido.
}

${ }^{417}$ Pilar Pedraza, op. cit., pp. 217-234. 


\subsubsection{3.- Sirenas}

“¿Qué cantaron las sirenas? ¿Qué nombre tomó Aquiles cuando se escondió entre mujeres? Preguntas que, aunque sorprendentes, no se encuentran libres de toda conjetura.

Thomas Browne Urnas funerarias

En Las metamorfosis de Ovidio leemos que las sirenas son hijas del dios Aquelarre. Son jóvenes y hermosas doncellas con cabeza y pecho de mujeres, pero con el resto del cuerpo de ave. Sin embargo, Pilar Pedraza resaltar que son hijas del Río Aqueloo y de Melpóneme, Terpsícore o Calíope, de quienes heredan la musicalidad. Por ello también existen dos tipos nombres de sirenas: unos son semejantes a los graznidos de las aves, estos eran Teles, Redne, o Molpe; pero existían otras con nombres preciosos y musicales como Písinoe, Agláope, Telxíope, Parténope, Leucosia, Ligia... ${ }^{418}$. Se contaba que estas tenían una voz tan hermosa que lograba embelesar a los navegantes, los cuales corrían el riesgo de estrellarse contra las rocas. Probablemente, de ahí venga la raíz semítica que define a las sirenas como mujer que lía a los hombres con mágicas melopeas $^{419}$

De sus cantos se desprenden dos cosas. Primero, que prometen una sesión de cantos épicos a quién se detengan a escucharlas y, en segundo lugar, que con sus cantos van a arrullar el descanso de quienes vienen de una campaña muy larga. Como ejemplos literarios encontramos Kafka o el poema de León Felipe:

\section{$\underline{\text { Las Sirenas }}$}

Hoy tengo el vino dulce y en la sangre

\footnotetext{
${ }^{418}$ Pilar Pedraza, op. cit., pp. 115-122.

${ }^{419}$ Erika Bornay, op. cit., p. 275.
} 
el ritmo vago y sordo de una canción lejana y luminosa.

¿Quién canta al otro lado de las nubes?

¿De dónde llega esa canción?

¿No estaban muertas las estrellas?

Después que hayamos blasfemado

con la razón enfurecida,

hay que dejar abierta la loca ventana de los sueños,

porque ocurre que hay días

en que el hombre quiere engañarse y que le engañen...

Y él mismo se embarca en la playa

y en el barco más frágil

para ir a buscar a las sirenas ${ }^{420}$.

También es importante el fragmento de la República de Platón:

... en cada uno de estos círculos había una Sirena que giraba con él, haciendo oír una sola nota de su voz siempre con el mismo tono; de suerte que de esas ocho notas diferentes resultaba un acorde perfecto. Alrededor del huso y a distancias iguales estaban sentadas en tronos las tres Parcas, hijas de la Necesidad: Láquesis, Cloto y Atropos, vestidas de blanco y ceñidas sus cabeza con cintillo. Acompañaban con su canto el de las Sirenas ${ }^{421}$.

En ambos textos podemos observar un simbolismo platónico y pitagórico con carga positiva. Se trata de un canto en donde los astros aparecen personificados. Son cantos ascensionales que arrastran a las almas al mundo superior de los planetas, por lo que es un símbolo positivo. De ahí que podamos señalar al suizo-alemán Arnold Böcklin y su cuadro Las sirenas (1873). En su pintura observamos cómo las mujeres-pájaro son

\footnotetext{
${ }^{420}$ Pilar Pedraza, op. cit., pp. 125-126.

${ }^{421}$ Pilar Pedraza, op. cit., p. 128.
} 
utilizadas con una fuerte tendencia al simbolismo, como metáforas mitológicas para expresar nociones cósmicas y filosóficas, pero sobre todo sentimientos.

Los cuadros del inglés J.W. Waterhouse son también importantes, porque también ayudan a escenificar el cambio físico.

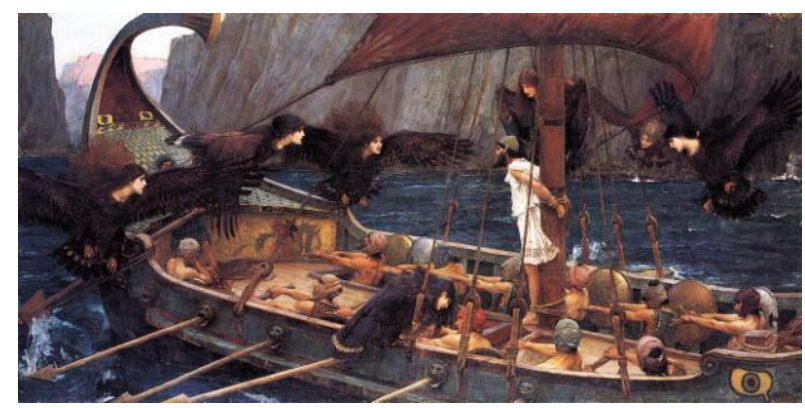

John William Waterhouse (1891)

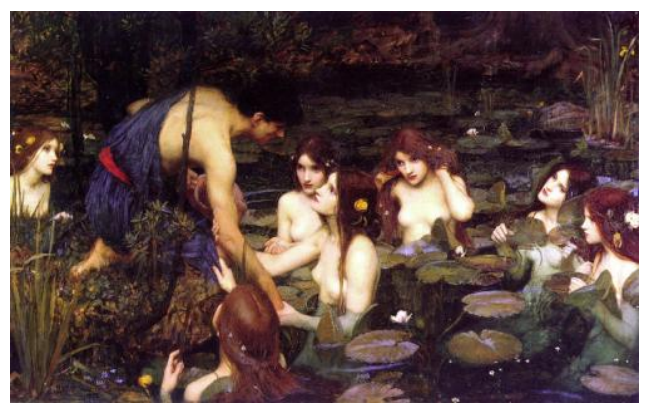

John William Waterhouse (1896)

En ambos cuadros se bebe de una larga tradición en el arte europeo, donde es muy común la asociación entre la mujer y el agua. Por lo que si nos fijamos vemos que el simbolismo ya no es ascensional, sino descensional. El mito ha dado un giro completamente siniestro, pues si en un principio las gentiles náyades tenían propiedades curativas, ahora son sesgadas a los temas de sirenas y ninfas. Este cambio responde a un arquetipo ideal de belleza, que no posee la sugerencia ni sensualidad fatídica, pero hace referencia al peligro inherente a la mujer. Desde este punto de vista, tanto las sirenaspájaro como las sirenas-pez eran consideradas seres de mal agüero. Se creía que arrebataban el alma a los vivos y se la llevaban a Perséfone, su reina ${ }^{422}$. De esta forma, los poetas, los artistas y los mitógrafos siempre las asociaron al mundo de las profundidades, ya sea con el reino de Hades o con la Reina de los Muertos, la que nunca ríe. Por contagio, sus cantos fueron funestos con acentos sepulcrales. No sé sabe qué hacen con sus víctimas, si las devoran o si les espera una muerte cruel. Sólo se dice que las víctimas, que normalmente son hombres, no vuelven a ver ni a sus esposas ni a sus

\footnotetext{
${ }^{422}$ Pilar Pedraza, op. cit., pp. 116.
} 
hijos $^{423}$. En Ulises y las Sirenas (1891) y en Hilas y Las Ninfas (1896) de John William

Waterhouse, vemos mujeres que intentan con todas sus fuerzas arrastrar al varón al fondo del agua $^{424}$.

El poeta y la sirena (1895) de Gustave Moreau y La sirena (1897) de Armand Point:

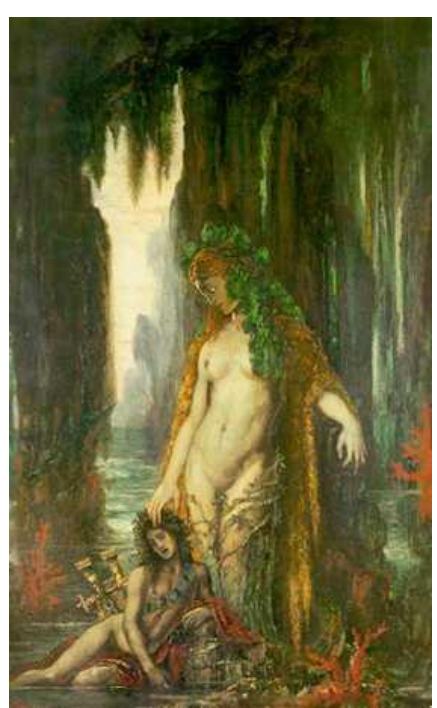

Gustave Moreau (1895)

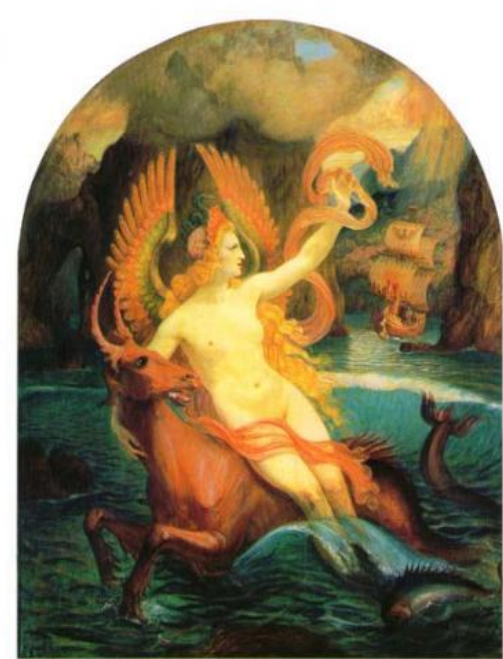

Armand Point (1897)

Si nos centramos en el mundo literario, encontraremos más casos, como es el caso de

Las canciones de Bilitis de Pierre Louys; El pescador y su alma de Oscar Wilde;

Gualba la de mil veus de Eugenio D’Ors, quien trata de mostrar a la ninfa del Gorg

\footnotetext{
${ }^{423}$ Además, también es interesante destacar In Esaiam de San Jerónimo en donde se hace una interpretación estoica del canto de las sirenas como metáfora de la atracción sexual. El hombre es un juguete en manos de la mujer. También Alciato en 1531 escribe un emblema titulado "Sirenas" que dice así: "las mujeres es cosa que acaba en negro pez, porque la libido trae consigo muchos monstruos...". Estas ideas literarias se complementan con las imágenes de Las sirenas de Gustav Klimt y EL poeta y la sirena (1983) de Gustave Moreau. Este último es un coágulo de sabias metáforas eruditas, un cliché simbolista de la Belle Dame Sans Merci y de Doxa de Max Ernst. La sirena de Moreau aparece caracterizada con plantas acuáticas de un intenso color rojo en torno a su cabeza. Asimismo, vemos cómo algunas plantas trepan por sus piernas hasta llegar a la cadera, por lo que se puede pensar que sus piernas no sean del todo humanas. Pero por si todo esto no fuera poco, esta imagen terrorífica muestra el triunfo de la materia sobre el espíritu, el canto terrestre sobre el celeste, el de la feminidad sobre la virilidad, el de la naturaleza sobre el arte... Sus obras no son meras ilustraciones de fábulas antiguas, son riquísimos productos en los que se da un diálogo constante entre culturas y una voluntad de estilo tan potente como atormentada.
}

${ }^{424}$ Erika Bornay, op. cit., pp. 276-281. 
Negre; Los Argonautas. Otro ejemplo mucho más cercano sería Doña Teodora de Álvaro Cunqueiro ${ }^{425}$. Pero no cabe ninguna duda cuando afirmamos que la sirena más famosa que ha dado el mundo de la literatura es Lore Ley. Existen varias versiones al respecto, pero una de las primeras fue la de Clemens Bretano, poeta alemán de baladas románticas. Bretano cuenta cómo la hermosa Lore Ley con la seducción de sus cantos se sitúa en el alto y peligroso estrecho pasaje del Rhin y arrastraba a los navegantes hasta que naufragaban. Más tarde, H. Heine la describe como un ser mucho más cruel en El libro de las canciones (1844), y E. von Steinle ejecuta una iconografía inspirada en la lectura de Bretano ${ }^{426}$.

También tenemos que destacar las obras Jason y los Argonautas, Odisea (XII, 39), en cuento "La ciudad de bronce" en Las mil y una noches, La sirenita de Hans Christian Andersen, Epistola ad Pisones de Horacio.

\subsubsection{4.- Las Arpías}

Las arpías reciben una descripción física muy parecida a las sirenas, pues tienen el cuerpo de ave y la cabeza de mujer. Aunque siglos más tarde Ariosto les añadirá una cola de serpiente, lo cual ayudará a diferenciarlas. Las arpías también son emisarias del Hades, habitan en los infiernos, son raptoras de almas y suelen ser representadas llevando a un hombre desnudo entre sus garras ${ }^{427}$. Al mismo tiempo, son conocidas por

\footnotetext{
${ }^{425}$ Pilar Pedraza, op. cit., p. 137.

${ }^{426}$ Erika Bornay, op. cit., pp. 224-226.

${ }^{427}$ Esto es lo que se puede observar en las tumbas y en los vasos griegos.
} 
su rapidez y avidez. La confusión entre las sirenas y las arpías es muy común, y es fácilmente visible en La arpía de Edward Munch (1900) ${ }^{428}$.

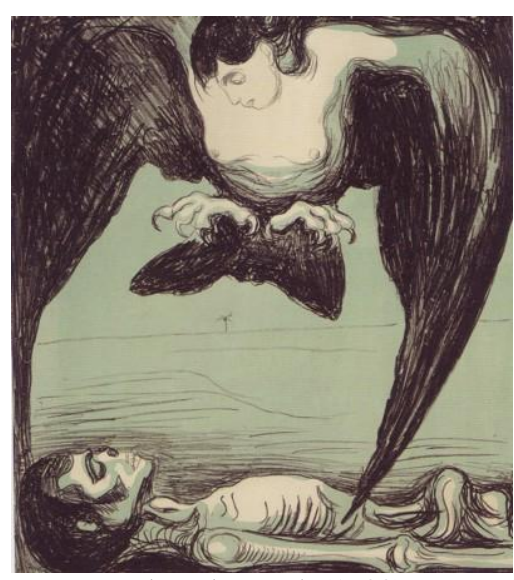

Edward Munch (1900)

Ya desde la antigüedad Dante y Virgilio las clasificaron como ogresas roba-niños, seductoras fatales, ladronas de almas, fatídicas, bellas y atroces encarnaciones de la muerte. Todas funestas para la raza humana. Incluso Hesíodo dice que conoce dos arpías llamadas “Aelo, la tempestuosa” y "Ocípeta, la del rápido vuelo ${ }^{429 "}$. Homero añade a la pequeña lista a "Poderga, la de los blancos pies", ésta fue fecundada por Céfiro y dio a luz a Janto y a Balio, ambos corceles de Aquiles ${ }^{430}$. Además, también podemos añadir a "Celeno, la sombría", la arpía que aparece en la Eneida de Virgilio. Todas ellas son descritas como aves con rostro de doncellas, con repugnantes deyecciones de sus vientres, con manos curvas, caras lívidas de carne, garras curvas, con cola de serpiente y un horrible hedor. Dante las sitúa en los Infiernos, pero originalmente fueron expulsadas por los boreádas de Tracia y por los troyanos de las Islas Estráfades. Las doncellas voladoras son emisarias del Hades, raptoras de almas

\footnotetext{
${ }^{428}$ Erika Bornay, op. cit, pp. 282-285.

${ }^{429}$ Hija de Electra y Traumante.

${ }^{430}$ Las arpías antiguas solían tener amoríos con los vientos, por lo que sus hijos solían ser caballos rapidísimos y sólo se dejaban montar por los héroes. Actualmente las arpías se caracterizan por ser completamente estériles, un ejemplo muy claro lo tenemos en El discreto, XIII de Gracián.
} 
cuya función comparten con las sirenas ${ }^{431}$. Con la llegada del Renacimiento y del Barroco se dio a la arpía el lugar de una complicada simbología emblemática. Se consiguió hacer de ellas una imagen jeroglífica de la preocupación, de la inquietud y de la obsesión devoradora, especialmente en el contexto de la avaricia. Ejemplos con estas características los encontramos en el Teatro moral de la vida humana de Otto Vaeniu y en la película de Harpya de Raoul Servais ${ }^{432}$.

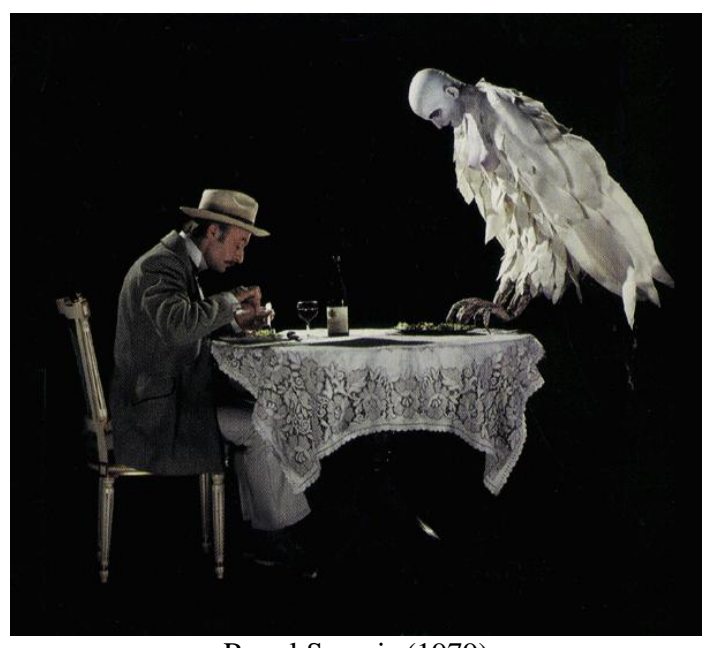

Raoul Servais (1979)

Sabemos (...) que sus lágrimas son de lejía, que vomitan ácido sulfúrico y que, cuando escupen, hacen grandes agujeros en los sueños. Es su risa sonora, hueca y poco profunda, generada en la bóveda del paladar y no en el pecho, o bien fina y como de falsete -muy peligrosa esta última, más irritante la primera-. Unas largas y pintadas de escarlata rematan sus dedos nudosos, cargados de anillos de oro verde y piedras falsas: manos que sugieren un gran manejo de recibos estampados en papel barato, rosarios de cuentas sintéticas, preservativos y cuchillos. Las Harpías sufren de pies fríos y sus narices destilan perpetuamente un moquillo delgado, semejante por su química al aceite de ricino.

\footnotetext{
${ }^{431}$ Encontramos dos ejemplos, uno en el Canto I de la Odisea, donde Odiseo hace decir a Telémaco que su padre fue arrebatado por las arpías en plena juventud. El otro ejemplo lo vemos en el Canto XX, donde Penélope ruega a los dioses que le den una muerte semejante a la de las hijas de Pandáreo, que fueron raptadas por las arpías en plena juventud.

${ }^{432}$ Pilar Pedraza, op. cit., pp. 138-156.
} 
Sabemos también el porqué de su hambre sempiterna, que hace que sus tripas rujan como cañerías: se debe al hecho de que los ácidos de sus estómagos son tan corrosivos que disuelven los alimentos apenas los engullen ${ }^{433}$.

\subsubsection{5.- Los vampiros}

Los vampiros estaban representados por murciélagos y otras alimañas nocturnas. El murciélago es un habitante de la oscuridad y de las tinieblas, por lo que está relacionado con el principio pasivo de la noche y la muerte ${ }^{434}$. Tal vez la dificultad que existe para diferenciarlas de las arpías radica en Las metamorfosis de Ovidio, pues en ella se nos explica que las estriges son hijas de las arpías. Éstas eran pajarracas ávidas de sangre humana, de cabeza grande y pico curvo. Con ojos desmesurados, saltones y llenos de horrores, garras retorcidas, con el cuerpo cubierto de plumas blancas y con rostro de mujer $^{435}$. Sus hábitos nocturnos eran por todos muy sadidos, pues los griegos y los romanos conocían a varias ogresas roba-niños. Una de ellas era Gelo: esta fue una muchacha de Lesbos que había muerto virgen y volvía por la noche para robarlos. Pero no sólo Gelo tenía predilección por las víctimas infantiles. En su mayoría las vampiresas chupaban la sangre a los niños o les arrancaban las entrañas ${ }^{436}$. Ovidio

\footnotetext{
${ }^{433}$ Pilar Pedraza, ibídem, p. 145.

${ }^{434}$ Para Albert Pénot estas son características más que suficientes para relacionar al murciélago con la mujer.

${ }^{435}$ Algunos ejemplos visuales los encontramos en los cuadros de EL vampiro de Edward Munch; La novia Corinto (1797) de Goethe; El vampiro de Philip Burne-Jones, inspirado probablemente en La muerte enamorada de T. Gautier, el cual retrata a la cortesana Clarimonde. Cuenta la historia que se convirtió en un vampiro tras morir en una orgía. Ahora desea beber la sangre del sacerdote Romualdo para conseguir con él un simulacro de vida. Por último también es importante destacar el cuento de "La muerte enamorada" en Cuentos fantásticos del siglo XIX de VV. AA.

${ }^{436}$ Todas estas imágenes son reflejo de los temores colectivos que tenía la sociedad. Todos estos aspectos se imbrican para explicar quién es esta figura con forma de mujer. En la obra Edward Munch. Symbols and images, el propio Munch acaraquién es ese 'otro' que perturba su vida privada. Pero su obra se ve fuertemente influenciada por Nietzsche y la obra de Strindberg De l'inferiorite de la femme. Al mismo
} 
cuenta el caso estremecedor del Rey Procas ${ }^{437}$, quien durante su niñez fue atacado por las estriges; pero, por suerte, lo salvaron en el último momento. También en el Satiricón de Petronio se deduce que las estriges se apoderan de los muertos ${ }^{438}$.

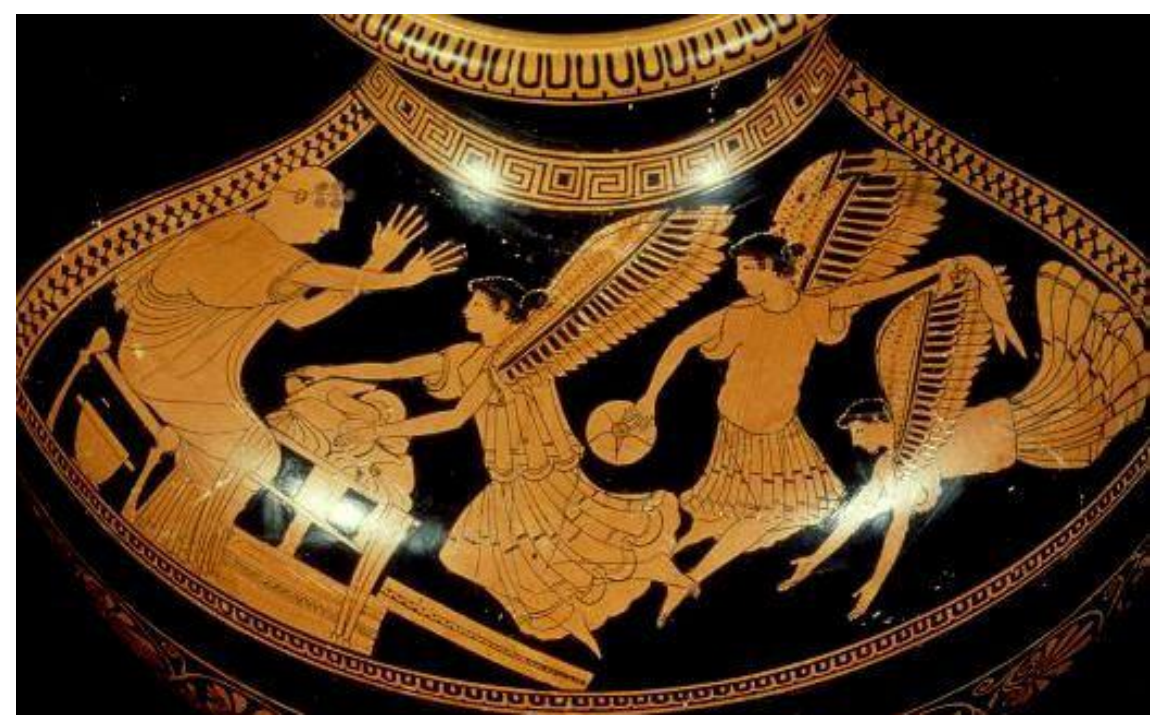

\subsubsection{1.- Lamia}

Lamia fue una muchacha de Libia a la cual Zeus amaba. Heras, la esposa de Zeus, por envidia hizo morir a todos los hijos que ella paría. Loca de dolor y sedienta de venganza se ocultó en una cueva. Poco a poco se convirtió en una ogresa que robaba y devoraba a los hijos de las mujeres más dichosas que ella. Además, padecía de insomnio y Zeus, compadeciéndose de ella, le otorgó el don de quitarse los ojos para que descansara. Lamia se convirtió en un icono de las mujeres fatales, de modo que simbólicamente llegó a representar a las meretrices que atraen a los hombres por medio de artimañas y

tiempo, también se dejó influir por la visión romántica del poeta Przybysz Zewki al cambiar el título de su cuadro Amor y dolor por el de El vampiro. Przybysz le abrió las puertas del mundo de Drácula de Bram Stoker, La Gioconda de Walter Pater, La muerte enamorada de T. Gautier...

${ }^{437}$ En Ovidio, Fastos, VI, 115 ss.

${ }^{438}$ Pilar Pedraza, op. cit., pp. 146-156. 
atacándoles con su parte serpentina ${ }^{439}$. Por lo que podemos encontrar varias imágenes que resaltan esta conexión, tales como La mujer murciélago (1890) de Penot; Hacia el abismo (1897) de Henri Martin; El gusano vencedor de Frank Kupka, quien, haciéndose eco de un tema de Poe, representa a un "gusano" como una diabólica ogresa alada con ojos sin pupilas, rodeada de símbolos de muerte y que contempla cómo la humanidad sucumbe a sus pies; Otoño (1894) de Xavier Mellery, en donde la naturaleza depredadora de la mujer se refleja en los efectos que la noche ejerce sobre la araña, la cual es capaz de devorar a su compañero.

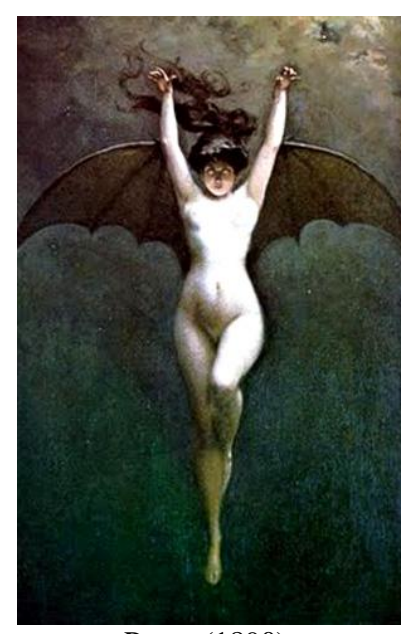

Penot (1890)

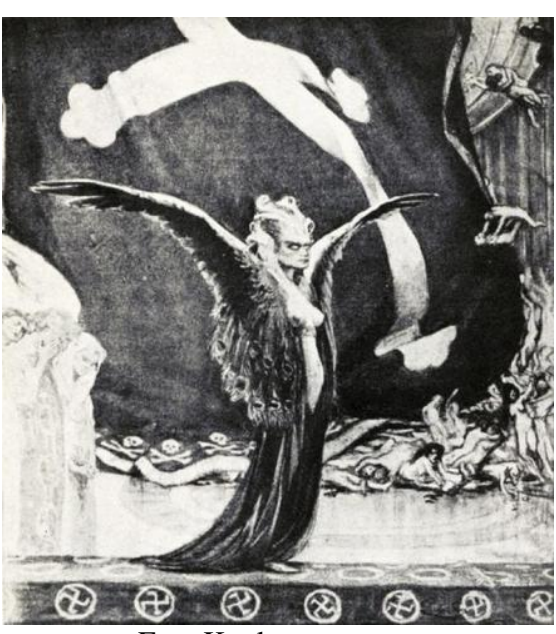

Fran Kupka

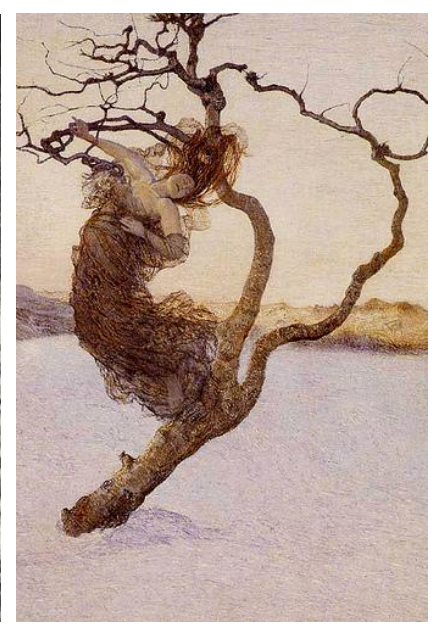

Xavier Mellery (1894)

\subsubsection{2.- Empusa}

Empusa era un espectro infernal del cortejo de Hécate, capaz de transformarse en diversos animales y en una mujer seductora de aspecto refinado. Empusa no es propia de una cultura concreta, sino que tiene equivalentes en muchas culturas, ya que se trataba de una mujer que producía pesadillas y terrores nocturnos a mujeres y niños, pero preferentemente atacaba a los jóvenes varones. Tal es el caso en Las ranas de Dionisos y Jantias, quienes se encuentran a Empusa camino a la mansión del Hades,

\footnotetext{
${ }^{439}$ Pilar Pedraza, ibídem, pp. 149-150.
} 
Vida de Apolonia de Tiana IV, 25, La novia de Corinto de Goethe; La tentación de san Antonio de Flaubert... Todas ellas son antepasadas de las vampiras modernas, las cuales viven en el ultramundo en donde mantienen sus cuerpos ficticiamente vivos gracias a la sangre que extraen del joven enamorado. Viven en una opulencia inconsciente y sufren cuando son obligadas a reconocer la miseria de su nada ${ }^{440}$.

\subsubsection{3.- Las herederas}

Estas creencias pre-cristianas fueron reprimidas por parte de las autoridades religiosas. Pese a que esta figura literaria cuenta con una historia tremendamente larga, las autoridades observaron que la tradición era especialmente intensa en Europa central. Esto ayudó a potenciar la idea de que tales creencias estaban vinculadas a pueblos bárbaros y de costumbres dudosas. Normalmente, estas prácticas se hallaban ligadas a ritos oscuros en donde la sangre simbolizaba la vida eterna. Esto supone una inversión del cristianismo, por lo que se censuró y se rebajó al nivel de cultura oral, de reflejo del folklore de un pueblo que se percibe como inculto y supersticioso.

Pero, sin duda alguna, podemos afirmar que los románticos se dieron cuenta que desde el punto de vista del folklore, el vampiro tiene una larga tradición. Así que la recuperaron y potenciaron el carácter erótico que tiene la sangre. Muchas fueron las obras que trabajaron este punto, tales como La novia de Corinto de Goethe, El manuscrito encontrado en Zaragoza de Potocki, Vampirismus de E. T. A. Hoffmann, El vampiro de Polidori, Varney el Vampiro de Thomas P. Prest, Berecine de E. A. Poe, Carmilla de Sheraidan Le Fanu...

\footnotetext{
${ }^{440}$ Pilar Pedraza, op. cit., pp. 150-156.
} 


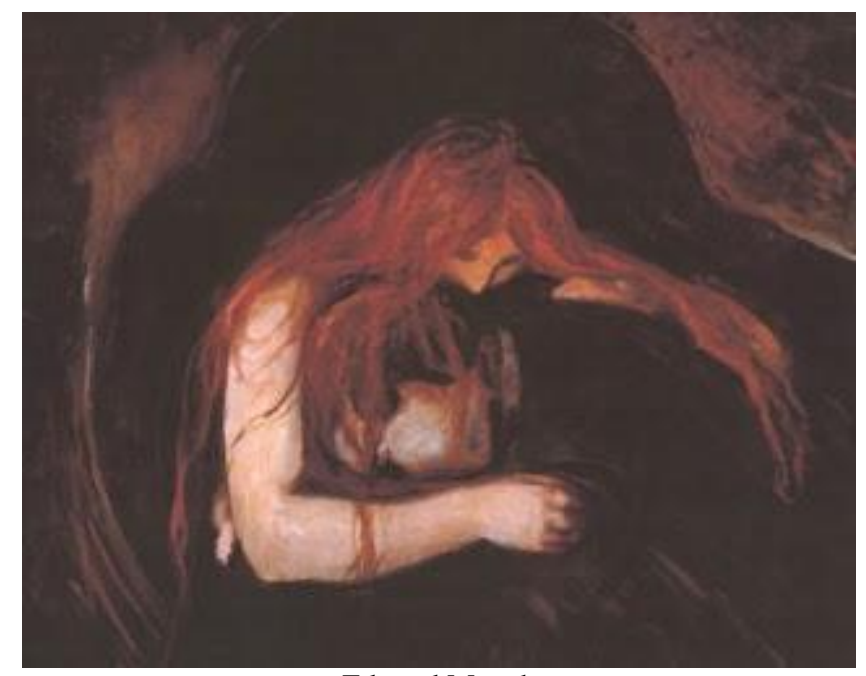

Edward Munch

\subsection{1.- La proliferación}

La figura literaria del vampiro puede rastrearse fácilmente hasta nuestros días. Existen multitud de películas, series, libros, cómics, cuyos protagonistas son vampiros. Probablemente algunos de los más conocidos son los protagonistas de la saga cinematográfica de Crepúsculo. La historia está basada en las novelas de Stephenie Meyer, quien narra una historia de amor entre vampiros adolescentes, lejos de los estereotipos comerciales. Desde un punto de vista literario, podemos afirmar que Stephenie Meyer se hace eco de las características que ennoblecieron a los bandidos románticos, por lo que la imagen asesina y depredadora del vampiro se ve alzada al nivel del héroe. Si en su origen nuestro personaje fue una figura negativa, ahora su deseo desenfrenado por la sangre lo carga de valores amenazantes, pero al mismo tiempo representa la tentación. Tal es el caso de los populares dibujos de Victoria Francés: 

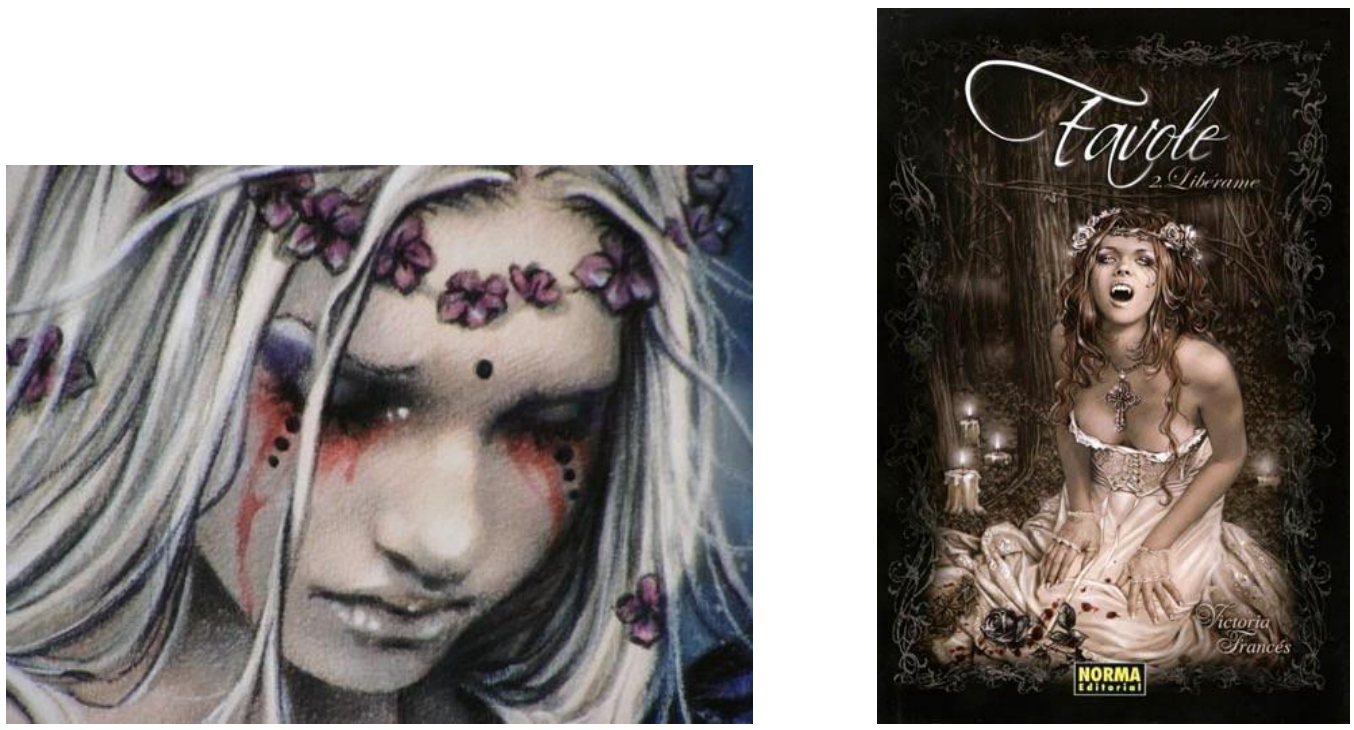

Muchos han sido los expertos que han achacado al peso de las religiones la actual difusión de los orígenes del vampirismo. Sin embargo, el daño que los románticos hicieron por medio del erotismo no es menor. Hoy en día, y a causa de una excesiva influencia del sentimentalismo romántico, la figura del vampiro se ha visto completamente desvinculada de lo que fue en origen.

\subsection{2.- La mujer monstruosa}

Pilar Pedraza habla de la figura femenina fusionada con la bestialidad para representar simbólicamente la unión entre muerte y seducción. Sin embargo, la ciencia-ficción actual recupera el discurso de científico del siglo XVIII. Hacia finales del siglo XVIII, la medicina comienza a asentar las bases de lo que hoy conocemos como la medicina alienista (psiquiatría) y la biología. En origen se estableció que la medicina alienista trataba al loco o al inválido y para estudiarlo en profundidad debía ser encerrado en un asilo con el fin de enseñarle la razón. Ahora bien, la biología debí decicarse al estudio de las formas físicas. A través de un análisis detallado, este último campo estableció unas normas fijas para definir la anatomía femenina y masculina. Todo lo que saliera de 
esos parámetros debía ser estudiado como "alteración de la norma". Esto en ocasiones podría confundirse con las anomalías. Pero, para no confundirnos Alain Corbin advierte que los inválidos deben ser encerrados en un psiquiátrico y las mosntruosidades se estudian a través de un embrión enfrascado. Así que la biología estudia tanto la norma, como las monstruosidades que se dan fuera de la norma. Esporádicamente algunos individuos nacían con una dualidad cuando por norma sólo debía haber una unidad. Este es el caso de dos cabezas, dos narices, dod bocas... Y también se podía encontrar la individualidad cuando debía haber la dualidad: dos ojos, dos orejas, dos brazos, dos piernas... $^{441}$

Esto nos lleva sin lugar a dudas al tema del vientre maldito. Pero antes de seguir esa línea, nos detendremos en el concepto de "embrión” y en el estudio que a través de él se desarrolla. Como ya hemos dicho la ciencia-ficción actual no duda en abordar este campo y plantea la pregunta de qué pasaría si no se destruyeran esos embriones. En 1995 el director Roger Donaldson lleva a la gran pantalla un guión de Dennis Feldman, este se titulo Species. Especie mortal y nos cuentaba cómo en un laboratorio algunos científicos juegan a ser Dios al cruzar el ADN humano con el de un alienígena. El resultado del experimento es una atractiva joven que en ocasiones se transforma en una montruosa criatura muy difícil de definir. El experimento parece evolucionar con normalidad, pero algo falla en los planes de los biólogos y deciden matarla con gas. La joven, desengañada por el cariño que los médicos le habían mostrado a lo largo de su infancia, se escapa del observatorio para aparearse y producir crías que destruyan a la raza humana.

\footnotetext{
${ }^{441}$ Alain Corbin, op. cit., vol. II, pp. 268-277.
} 


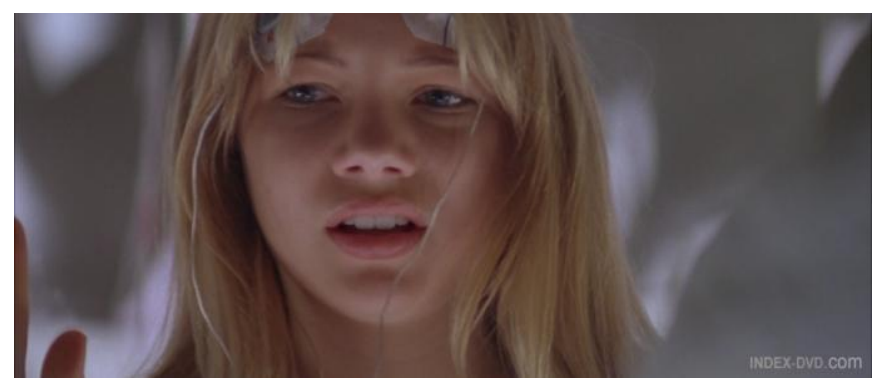

Spesies. Especie mortal (1995)

Otro caso muy similar lo encontramos en el año 2009 de la mano del director Vincenzo Natali al llevar al cine Splice. Experimento mortal. Clive y Elsa son una pareja de científicos brillantes que trabajan para un laboratorio farmacéutico. Su último experimento trata de diseñar un hibrido de varias especies de animales con el ADN humano. Ellos esperan que el embrión resultarte les ayude a revolucinar la medicina moderna, pero el resultado es una joven llamada Dren, un nuevo escalón del árbol evolutivo.
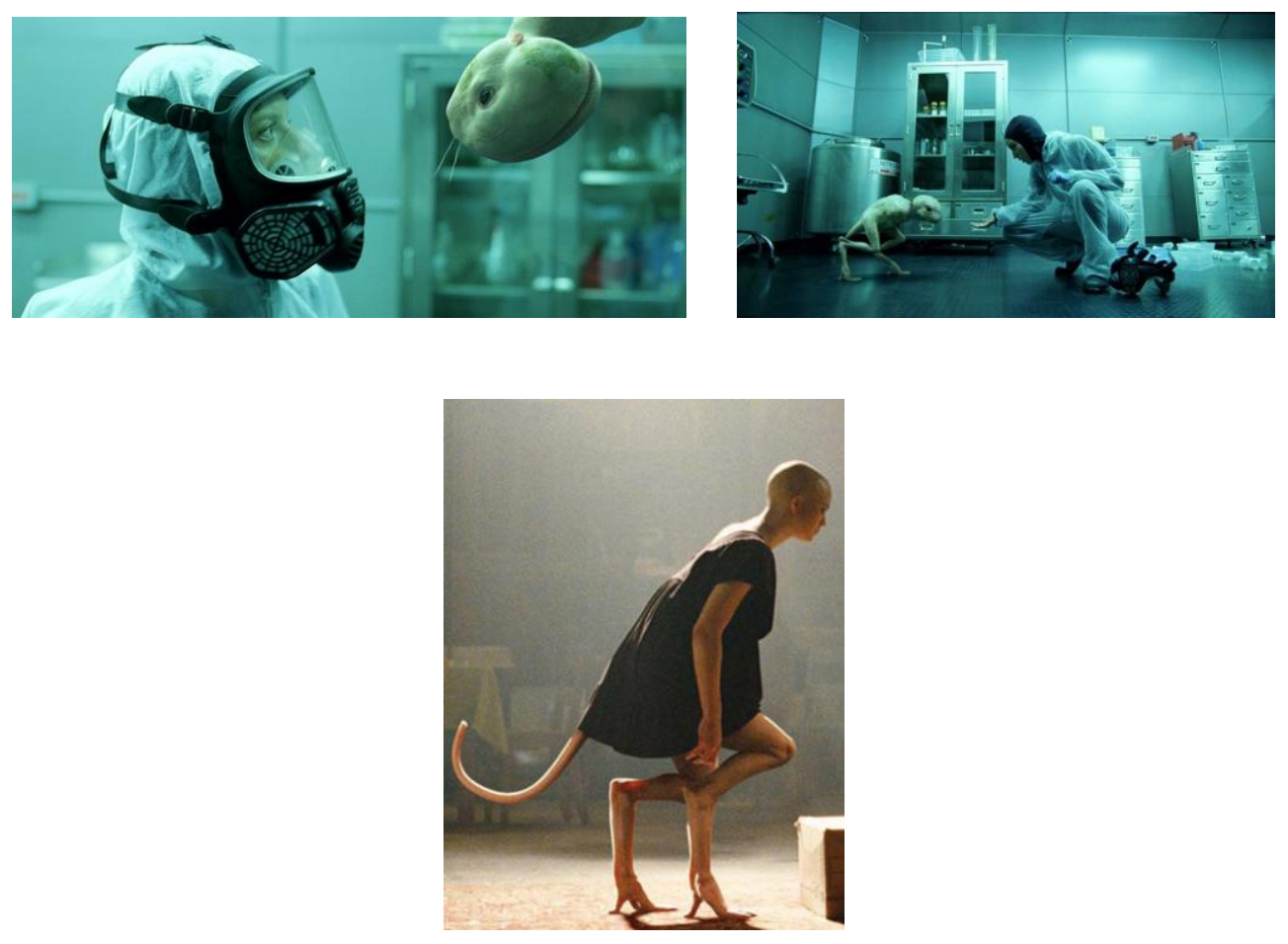

Pero la naturaleza animal de la joven no tarda en aflorar y se convierte en una pesadilla que deben eliminar. 


\subsubsection{1.- El vientre maldito}

En el siglo VIII el tema de los embriones deformados llevó a los biólogos a determinar que estos nacimientos se daban por culpa de la degeneración de la especie humana. Eran excepciones, cuerpos que se salía de la norma y que debían evitarse a toda costa. Una vez estudiado el funcionamiento biológico de estos cuerpos, los médicos investigaron el origen de las malformaciones y llegaron al vientre materno y al espacio en el que los niños habían nacido. Se trataban de barrios marginales en donde la higiene escasea y el vicio lo corrompe todo. Este tema fue recogido en $\grave{A}$ rebours de Huysmans y en Espectros de Ibsen, en ambas obras vemos cómo el vicio no sólo destruye el capital de las élites, sino que también provoca pesadillas mórbidas. Médicamente se catalogaba a estas madres como alcohólicas o tuberculosas, histéricas o degeneradas. Para evitar la regresión de la especie se fomentaron prácticas higiénicas que ayudaban a las mujeres a tener un buen concepto de su cuerpo ${ }^{442}$.

Estas mujeres rompían con la idea de sacralización del cuerpo femenino. Es decir, que no encarnaban al cuerpo dispuesto para recibir el milagro de la creación. Antes, por medio del concepto de la virginidad y de la contingencia, las jóvenes encarnaban la pureza y la divinidad. Pero, ahora el exceso y el vicio, corrompe su cuerpo arrastrándola al pecado. De ella sólo puede nacer el Mal. El discurso paternalista organizó un orden vertical, que jerárquicamente situaba el Bien arriba y el Mal bajo. De este modo la figura mujer-madre se situaba en un peldaño u otro según la pureza de su cuerpo. Por supuesto, la doncella virgen se situaba cerca de la divinidad, pero aquella que ensuciaba

\footnotetext{
${ }^{442}$ Alain Corbin, op. cit., vol. II, p. 198.
} 
su cuerpo era relacionada con la tierra y el submundo. De ahí que el vientre femenino fuera capaz de engendrar los monstruos más horribles del mundo ${ }^{443}$.

Existen muchas historias, películas y novelas que acarban el tema sin ningún pudor. Sin embargo cabe resaltar que algunas de ellas se hacen eco y muestran cómo el Satanismo hereda estas teorías. No pretendo ahondar en las raíces de esta corriente religiosa, pero si es necesario advertir que el Satanismo se comprende como la inversión del Cristianismo. Por ello era necesario buscar a una madre para el futuro mesias. Este fue el caso de la novela La semilla del diablo de Ira Levin o de La profecía de David Seltzer.

\subsection{3. - Las mujeres animales}

Las afinidades mujer-bestia son uno de los asuntos que más tinta han derramado, y desafortunadamente desembocaron en el libro La mujer delincuente: la prostituta y la mujer normal, de C. Lombroso. Pero dejando este episodio de lado, también hallamos la obra de Khnopff titulada El encuentro del ángel con la animalidad. En ella se oponen dos ideas muy curiosas. Por un lado, la obra muestra la pureza y la espiritualidad del ángel asociado al hombre y, por otro lado, asocia la bestialidad a la mujer. Como consecuencia destaca la poderosa imagen de la esfinge. Su obra no es más que una alegoría de la ecuación hombre-educación versus mujer-naturaleza ${ }^{444}$.

\footnotetext{
${ }^{443}$ Simone de Beauvoir, op. cit., pp. 125-129.

${ }^{444}$ Realmente se trata de una herencia directa de la obra de Freud El malestar de la cultura.
} 
El siglo XIX se llenó de imágenes de mujeres relacionadas con animales, por lo que era muy frecuente encontrarlas. Fueron tan abundantes que resultan muy estimulantes por su calidad simbólica, pero sobre todo debido al gran número en que se produjeron.

Todas ellas relacionaban a la mujer con la materia, la naturaleza y con la bestia. Estas metáforas se construyen sobre importantes preocupaciones filosóficas que convivieron durante todo el siglo XIX. Preocupaciones que visualmente representó perfectamente Gauguin en La pérdida de la virginidad, y que compartía con escritores contemporáneos como Mallarmé, Aurier y Mirbeau.

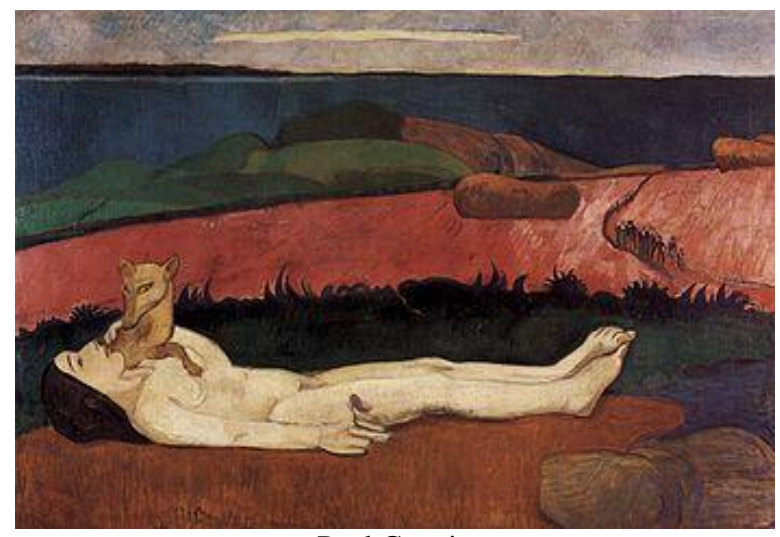

Paul Gaugin

Este tipo de relaciones era muy frecuente hallarlas en las exposiciones académicas del salón de la Société des Artistes Français. Un ejemplo muy claro lo encontramos en el año 1901 con la obra de P. Ribera Patas de terciopelo. Este texto ofrece una Pompier "Tigresa" que evoca las rancias imágenes de las primeras "Vamps" del celuloide ${ }^{445}$. Pero la figura del tigre también la encontramos en la obra El amor de Omega y el tigre

\footnotetext{
${ }^{445}$ Erika Bornay, op. cit., pp. 295-297.
} 
de Edward Munch (1908-1909), en donde el tigre, al igual que en Gauguin, simboliza la crueldad $^{446}$.

\subsubsection{1.- Serpiente}

En el texto bíblico la serpiente sirve de disfraz para el Diablo, pero esto no sólo se ve en el Génesis, sino en todo el Antiguo Testamento. El significado que con ella se extiende es el del despertar de la concupiscencia, el cual se comprende como la primera manifestación del desorden que el pecado ha introducido en el Paraíso.

La serpiente era el más astuto de todos los animales del campo que Yahvéh Dios había hecho. Y dijo a la mujer: “¿Cómo es que Dios os ha dicho: No comáis de ninguno de los árboles del jardín?”. Respondió la mujer a la serpiente: “Podemos comer del fruto de todos los árboles del jardín. Mas del fruto del árbol que está en medio del jardín, ha dicho Dios: No comáis de él, no lo toquéis, so pena de muerte". Replicó la serpiente a la mujer: "De ninguna manera moriréis. Es que Dios sabe muy bien que el día en que comiereis de él, se os abrirán los ojos y seréis como dioses, conocedores del bien y del mal". Y como viese la mujer que el árbol era bueno para comer, apetecible a la vista y excelente para lograr sabiduría, tomó de su fruto y comió, y dio también a su marido, que igualmente comió. Entonces se les abrieron a entrambos los ojos, y se dieron cuenta de que estaban desnudos; y cosiendo hojas de higuera se hicieron ceñidores $^{447}$.

La falta que comete la pareja es duramente castigada con la expulsión del Paraíso y con la consecuente pérdida de la familiaridad divina. La condena afecta a las actividades

\footnotetext{
${ }^{446}$ Otras litografías completan la serie. Los títulos son: El sueño de Alfa, Omega y el asno y Los hijos de Omega. En su totalidad cuentan la historia de Omega, una mujer que al no verse satisfecha sexualmente por Alfa, lo sustituye por un asno. De ahí que nazcan algunos personajes híbridos entre hombres y bestias, llegando a crear situaciones un tanto peculiares, en las que Omega los abandona y Alfa los mira un tanto desconcertado.

${ }^{447}$ Génesis, 3: 1-7.
} 
esenciales de los humanos, en el caso de la mujer revertirá obre su papel de esposa y de madre y, en el caso del hombre, recae sobre su función trabajadora. Pero hay que advertir que se trata de penas hereditarias, por lo que pasarán de padres a hijos durante generaciones. A partir de este momento, la mujer es asociada al pecado originario.

\footnotetext{
Dijo, pues, Yahvéh Dios a la mujer: “¿Por qué lo has hecho?” Y contestó la mujer: "La serpiente me sedujo, y comí". Entonces Yahvéh Dios dijo a la serpiente:

"Por haber hecho esto, maldita seas entre todas las bestias y entre todos los animales del campo. Sobre tu vientre caminarás, y polvo comerás todos los días de tu vida. Enemistad pondré entre ti y la mujer, y entre tu linaje y su linaje: él te pisará la cabeza mientras acechas tú su calcañar”. A la mujer le dijo: "Tantas haré tus fatigas cuantos sean tus embarazos: con trabajo parirás los hijos. Hacia tu marido irá tu apetencia, y él te dominará". Al hombre le dijo: "Por haber escuchado la voz de tu mujer y comido del árbol del que Yo te había prohibido comer, maldito sea el suelo por tu causa: con fatiga sacarás de él el alimento todos los días de tu vida. Espinas y abrojos te producirá, y comerás la hierba del campo. Con el sudor de tu rostro comerás el pan, hasta que vuelvas al suelo, pues de él fuiste tomado. Porque eres polvo y al polvo tornarás ${ }^{448}$.
}

La relación entre la mujer y la serpiente es ancestral, pues desde el principio de los tiempos a la mujer se le recuerda su participación en el pecado original. En el siglo XIX se potencia el vínculo sexual que une a ambas figuras: Lilith, Eva y sus equivalentes se sientan en lo más alto en el trono de fin de siglo. Todas ellas revelan una lasciva afinidad con el bíblico reptil, como se puede ver en el cuadro de Kenyon Cox.

\footnotetext{
${ }^{448}$ Génesis, 3: 13-19.
} 


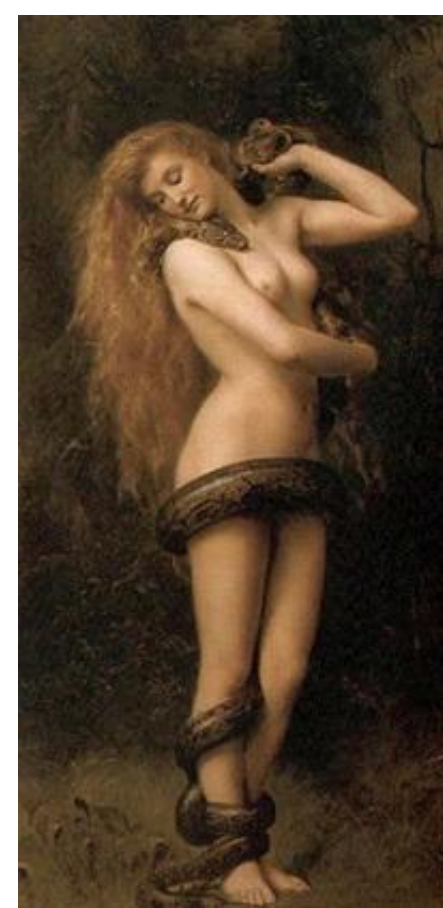

Kenyon Cox
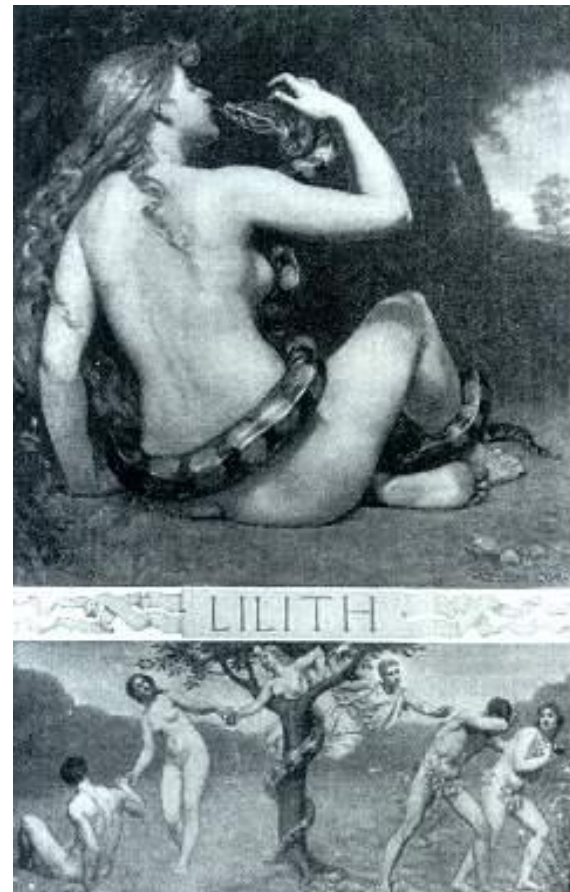

Kenyon Cox (1892)

Lilith fue el paradigma de la iconografía de la perversidad. No sólo huye de la tutela de su esposo, sino que también seduce a varios hombres e, incluso, a diablos. Su descripción la caracteriza con una larga melena, una tremenda carga erótica y una serpiente como aliada o como amante. Podría tratarse de una simbolización del maligno disfrazado o de una perfecta simbiosis con él. Sin embargo, los cuadros más destacados con respecto a este tema son los de Franz von Stuck, como La sombra, Sensualidad (1891), El pecado (1893), El vicio (1899) ... 


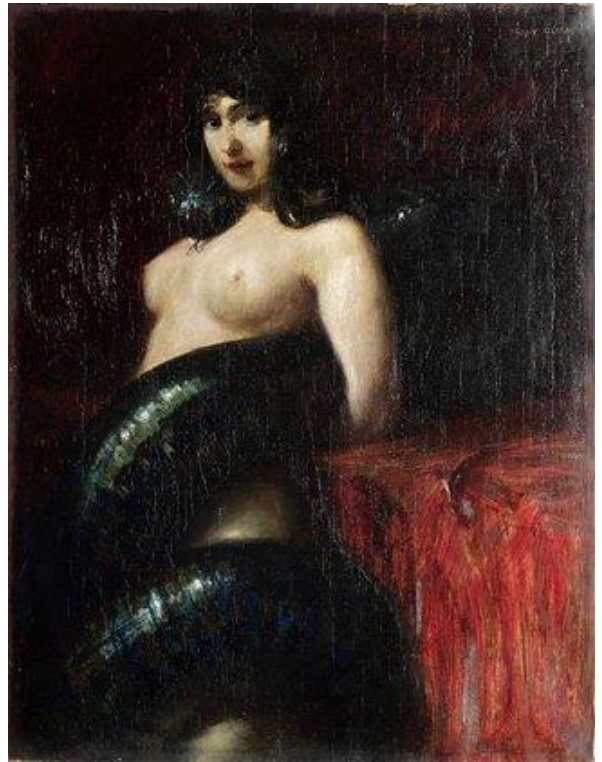

Franz von Stuck (Sensualidad)

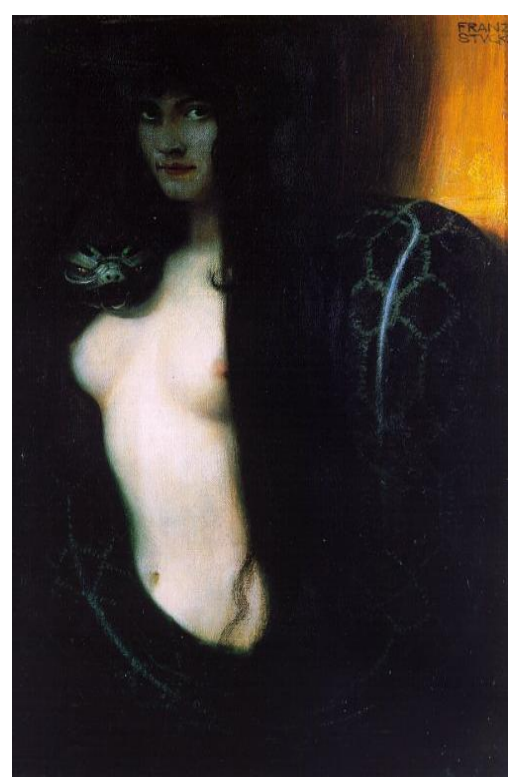

Franz von Stuck (El Pecado)

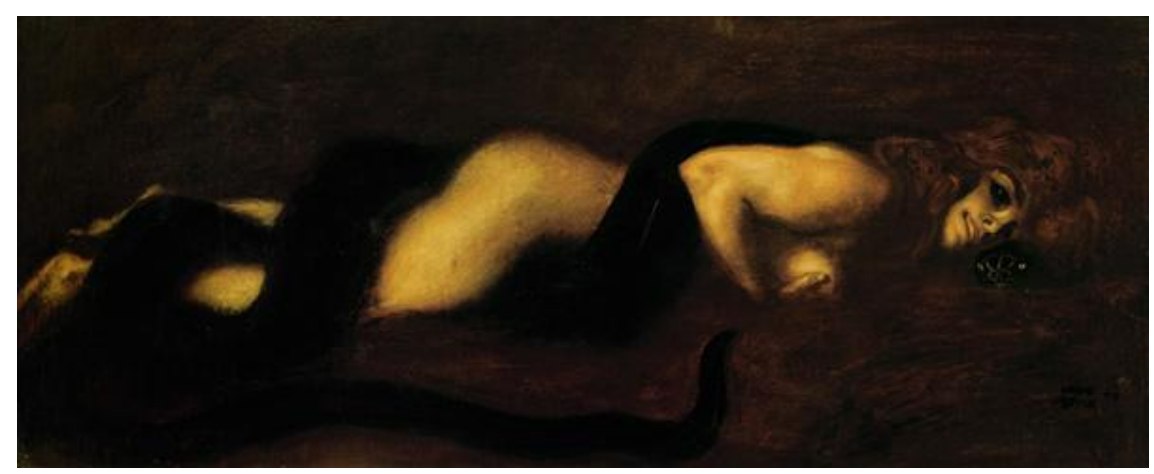

Franz von Stuck (El Vicio)

Todos ellos están basados en la idea de la caída de Adán y, por añadidura, en la significación fálica del reptil. La combinación de ambos elementos convierte a sus obras en símbolos con una gran carga sensual ${ }^{449}$. Jean Delville recoge esta carga sexual y al mismo tiempo la convierte en dominación en la obra Ídolos de la perversidad (1891). En ella se señala a una diosa caracterizada con una cabeza coronada con una serpiente. Lo mismo ocurre en El eterno ídolo (1893) de A. Rodin, en Gustav Klimt con sus

\footnotetext{
${ }^{449}$ Otros pintores que también muestran la relación mujer-serpiente han sido A. Fould, L. Corinth, L. Lévy-Dhurmer, Ch. A. Winter, C. Strahtmann, G. Moreau, F. von Lenbach, E.R. Mughes...
} 
Serpientes del agua I, Serpientes del agua II o Amigas (1904-1907), y en el poema "La serpiente que danza" de las Las flores del mal de Baudelaire ${ }^{450}$.

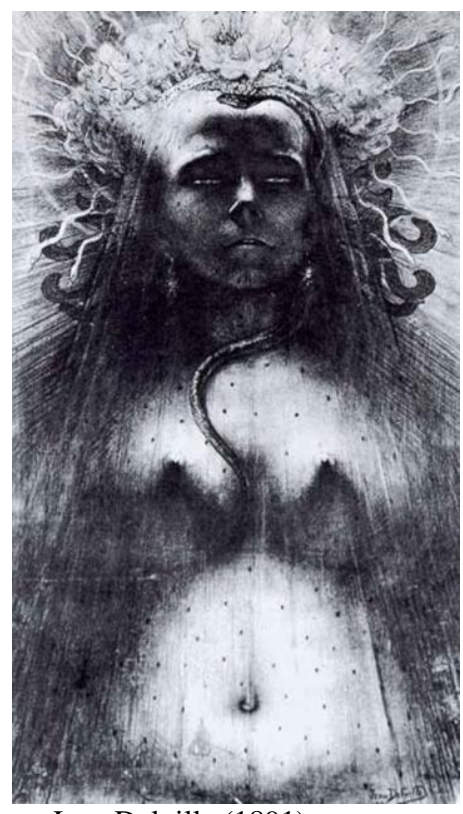

Jean Delville (1891)

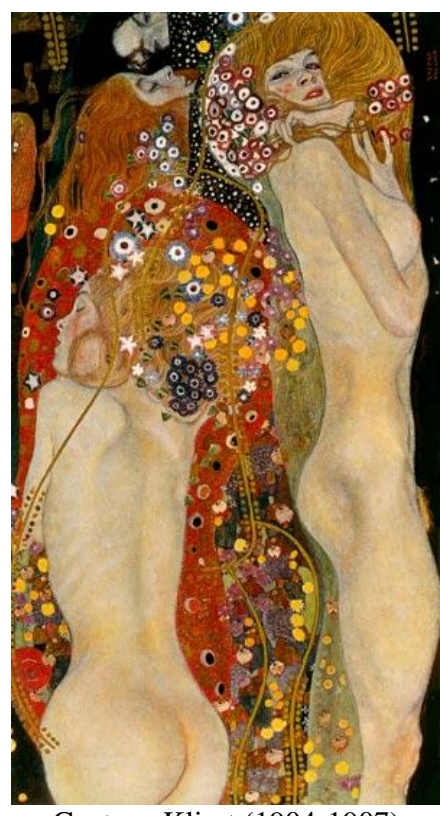

Gustave Klimt (1904-1907)

\section{$\underline{\text { La serpiente que danza }}$}

¡Cuánto gozo al mirar, dulce indolente, tu corpóreo esplendor como si fueran seda iridiscente tu piel y su fulgor.

Y sobre tu profunda cabellera de un ácido aromar -cual un mar errabundo, sin ribera, en azul ondular;

Como bajel que despertó del sueño al viento matinal, lanzo mi alma en soñador empeño hacia el piélago astral.

En tu mirada que nada revela de dulzura ni hiel, mezcla de oro y hierro se congela para el doble joyel.

Mirando la cadencia con que avanzas bella de lasitud, dijéranse las serpentinas danzas al ritmo del laúd.

\footnotetext{
${ }^{450}$ Erika Bornay, op. cit., pp. 295-306.
} 
Agobiada de un fardo de molicie tu cabeza infantil

se balancea como en la planicie una leona febril.

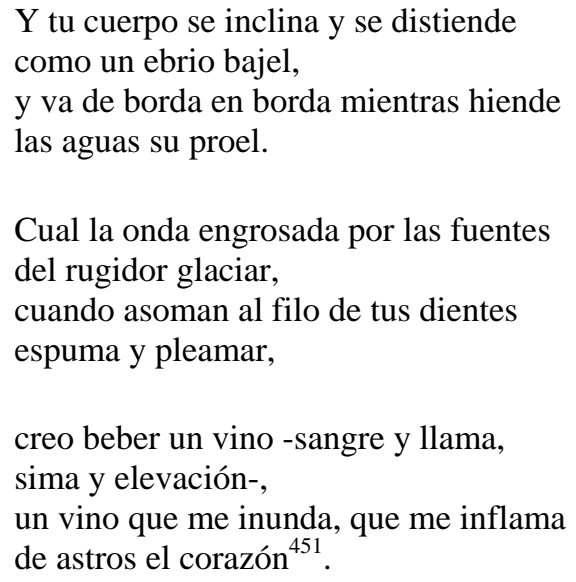

\subsubsection{1.- Salambó}

Gustave Flaubert publica en 1862 Salambó, y fue su segundo gran best seller después de Madame Bovary. Se trata de una novela violenta y con una potente carga erótica. Tras varios disgustos con el género realista, G. Flaubert decide dejarlo de lado y sumergirse en la novela histórica. La obra cuenta el fin de la primera guerra púnica, cuando un pueblo de mercenarios vuelve a Cartago tras prestarle servicios militares. Los cartagineses reciben a los soldados, les dan cobijo y comida durante una noche. Al día siguiente los expulsan sin pagarles los servicios que han prestado. Es entonces cuando el pueblo extranjero se subleva y comienza el núcleo violento de la novela. La solución la tiene una mujer: Salambó. Hija de Anibal, rey de Cártago, de la cual se enamora el jefe de los mercenarios.

Para narrar este episodio histórico Flaibert estudia durante cinco años los textos clásicos de Polibio, Plutarco y Plinio. Pero se da cuenta de que cuando intenta plasmar este

\footnotetext{
${ }^{451}$ Charles Baudelaire, Las flores del mal, Madrid, Cátedra, 1997, pp. 159-161.
} 
material sólo consigue un estilo académicamente pesado y aburrido, pues pasa mucho tiempo describiendo elementos, por ejemplo de guerra, que el lector desconoce.

He escrito unas quince páginas de Cártago, es decir, casi la mitad del primer capítulo. Me temo que sea un latazo, francamente; me parece que derivo hacia lo trágico y que escribo en un estilo académico deplorable ${ }^{452}$.

Pese que Flaubert insiste en que todos los datos que aparecen en la novela están recogidos históricamente, su amigo Sainte-Beuve mantiene que Gustave Flaubert no busca resucitar la verdad histórica y la sustituye por una visión idealizada de la realidad historica $^{453}$.

La antigüedad, por el contrario, no admite, en nuestra opinión, la novela histórica propiamente dicha, que supone una gran familiaridad y afinidad con el tema. Existe, de ella a nosotros, una solución de continuidad, un abismo. La erudición, que puede tender un puente os enfría al tiempo que nos deja helados. No es posible recomponer la civilización antigua con ese aire de facilidad y resucitarla por entero; en todo momento se nota el esfuerzo o el juego, la marquetería. La antigüedad se restituye, no se resucita. Lo que se puede hacer con ella es una especie de novela-poema, que la representa un poco idealmente, una obra más o menos dentro del género de Los mártires $(\ldots)^{454}$.

Bajo estas palabras podemos intuir la descripción de la figura femenina. Salambó, adoradora de la diosa Tanit, tenía como animal de compañía una serpiente pitón con quien se creía que mantenía un coito ritualista ${ }^{455}$.

\footnotetext{
${ }^{452}$ Carta escrita a Jules Duplan, para más información sobre las cartas consultar en: Gustave Flaubert, Salambó, Barclona, Debolsillo, 2008, p. 372.

${ }^{453}$ Gustave Flaubert, op. cit., p. 375-391.

${ }^{454}$ Carta escrita de Sainte-Beuve a Gustave Flaubert. Para más información consultar en Gustave Flaubert, Salambó, Barcelona, Debolsillo, 2008, p. 376.

${ }^{455}$ Erika Bornay, op. cit., 2010, pp. 223-224.
} 
La pesada tapicería se agitó, y por encima de la cuerda que la soportaba apareció la cabeza de la pitón. Bajó lentamente como una gota de agua que se desliza a lo largo de una pared, se arrastró entre las ropas esparcidas, y luego, con la cola pegada al suelo, se irguió cuan larga era, y sus ojos, más brillantes que carbunclos, se clavaban como dardos en Salambó.

El miedo al frío o el pudor tal vez le hicieran vacilar al principio. Pero se acordó de las órdenes de Schahabarím y se adelantó; la pitón se dobló y, poniendo sobre la nuca la mitad de su cuerpo, dejaba pender su cabeza y su cola como un collar roto, cuyos dos extremos llegaban hasta el suelo. Salambó se la enroscó en torno a su cintura, bajo sus brazos, entre sus rodillas; luego, cogiéndola por la mandíbula, aproximó su pequeña boca triangular hasta la punta de sus dientes y, entornando los ojos, se cimbreó a la luz de la luna. La blanca luz parecía envolverla en una niebla de plata; la huella de sus pasos húmedos brillaba en las losas; las estrellas palpitaban en la profundidad del agua, y la serpiente apretaba contra ella sus negros anillos atigrados de placas de oro. Salambó jadeaba bajo aquel peso excesivo, se doblaba, se sentía morir, y con la punta de la cola le golpeaba suavemente el muslo; luego, al cesar la música, la serpiente cayó al suelo ${ }^{456}$.

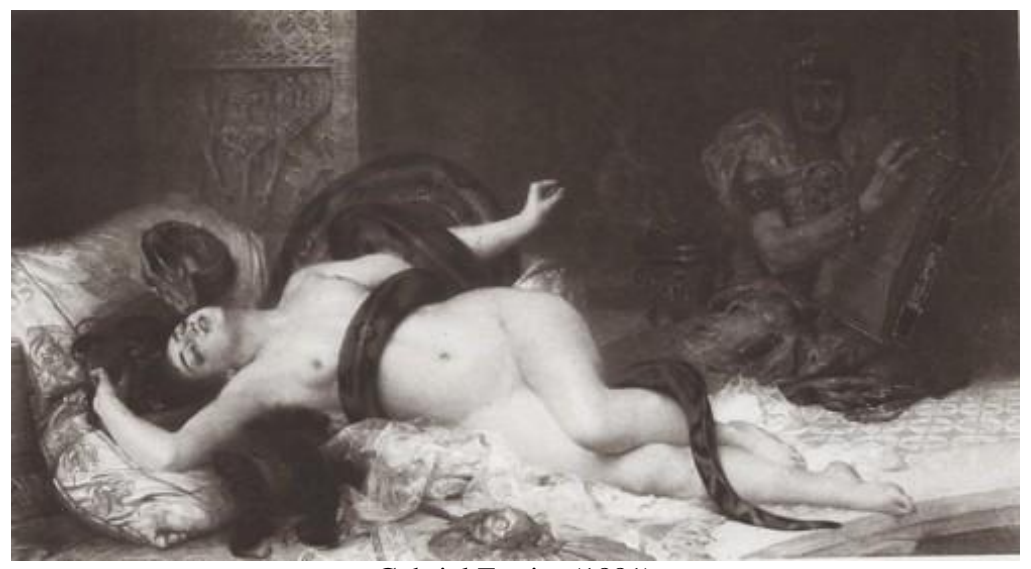

Gabriel Ferrier (1881)

Esta increíble escena representa la preparación de Salambó para seducir con éxito a Matho, el jefe de los mercenarios. Podríamos pensar que el trágico final que le aguarda a ambos está relacionado con el pecado original, pero no es así. En apariencia Matho

\footnotetext{
${ }^{456}$ Gustave Flaubert, op. cit., pp. 216-217.
} 
halla la muerte por la pasión que siente hacia la joven, y Salambó por enamorarse del ultrajador. Si profundizamos un poco más, veremos cómo la tragedia está relacionada con el ultraje del templo de la diosa Tanit, antigua diosa de la fertilidad y patrona de Cartago. Al principio de la novela, Matho osa a robar el velo protector de la diosa, iniciando así toda la sangrienta contienda. Salambó, aunque hace lo posible por recuperar el velo, la verdad es que ansia tenerlo para sí.

Salambó se levantó, como su esposo, con una copa en la mano para beber también. Pero cayó, con la cabeza hacia atrás, por encima del dosel de su trono, pálida, rígida, con los labios abiertos y sus cabellos destrenzados colgando hasta el suelo.

Así murió la hija de Amílcar por haber tocado el velo de Tanit ${ }^{457}$.

Esta imagen se contrapone a todas las que se dan en la novela, pues la joven aparecerá caracterizada con un poder y una seguridad en sí misma que muchos artistas pintaron como la altanería propia de una diosa.

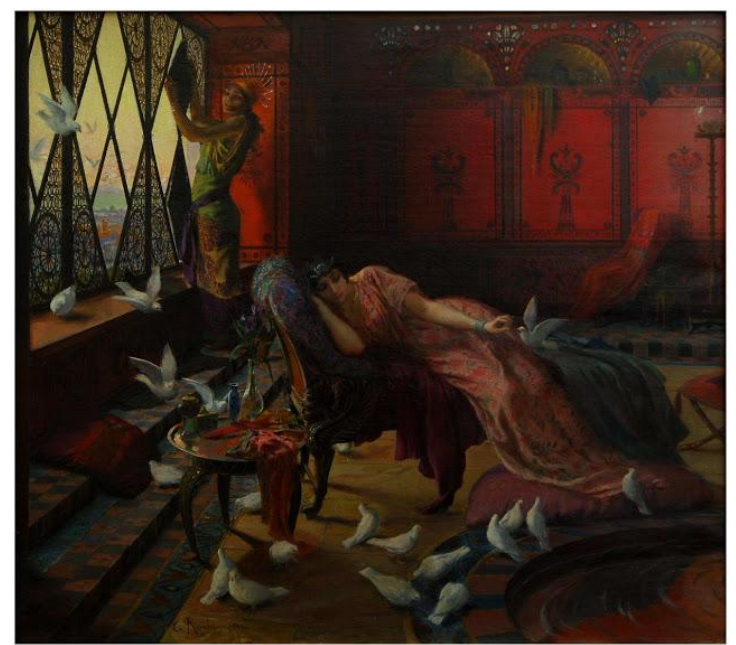

G. Antoine Rochegrosse (1896)

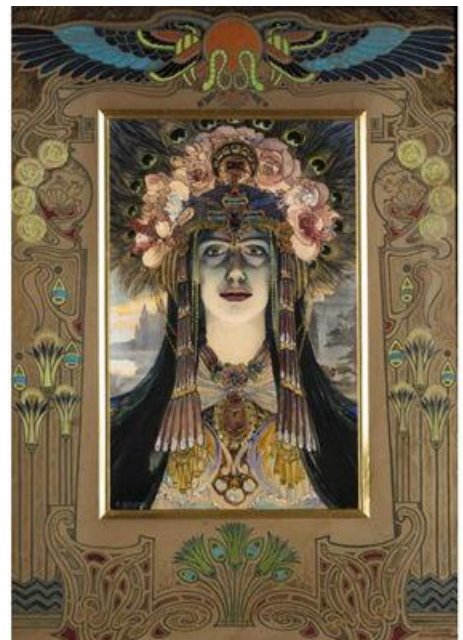

A. A. Edouard Cossard (1899)

$\overline{{ }^{457} \text { Gustave Flaubert, op. cit., p. } 359 .}$ 


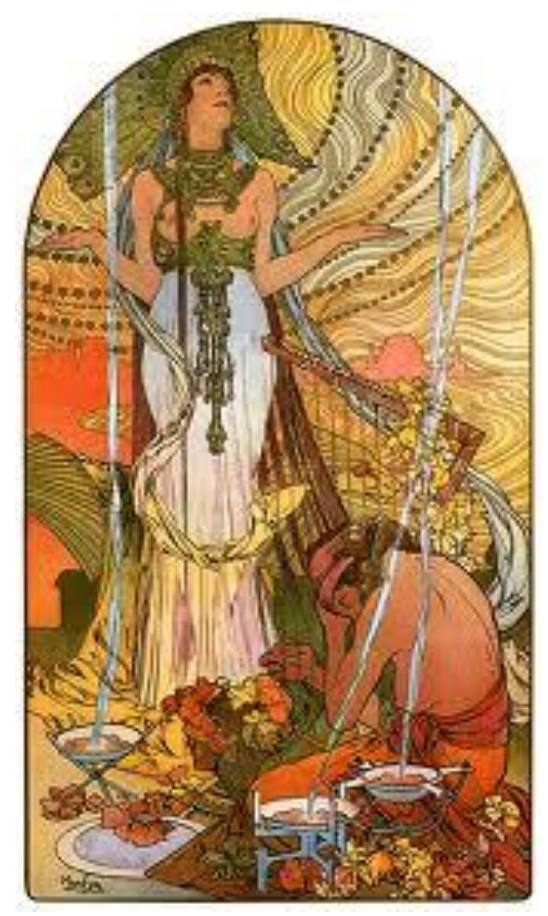

Alfons Mucha (1897)

\subsubsection{2. - La pantera}

El siguiente animal que nos ocupa es la pantera. Un animal de hermosas formas y refinadas costumbres, que ocupa un lugar privilegiado en la zoología pre-científica de los tratados antiguos. Su ubicación es dudosa y fluctuante, pero Gerónimo de Huerta menciona en la Historia natural de Plinio (1602) que ya aparece en las fuentes clásicas. Aunque hay que reconocer que ésta era descrita completamente blanca con manchas negras que semejaban ojos. En aquel entonces se desconocía la imagen de la pantera negra, por lo que la mujer felina era representada con el color blanco.

Esto nos permite comprender que, en la antigüedad, todavía no se había asociado el carácter tenebroso del color negro de la pantera con la figura femenina. Sin embargo, sí se reconoció el fascinante destello de los ojos de las panteras, y este se desplazó hacia las féminas. Pero la evolución erótica de la pantera pasa por el perfume. Por supuesto, su arma más poderosa y sutil era el perfume. Gerónimo de Huerta ya avisa que este 
animal utilizaba su olor corporal para atraer a sus presas ${ }^{458}$; de esta forma, animales como la cabra se veían seducidos por su olor corporal antes de ser devoradas por el felino. Hay que destacar que estas eran unas tácticas seductoras muy similares a las de las sirenas. Unas lo hacen mediante el oído y otras mediante el olfato. En sus correrías, la pantera utiliza una máscara interesante que es la ausencia parcial o el ocultamiento total $^{459}$. Es decir, que como todos los animales saben de su ferocidad, ella se oculta y deja que sus víctimas acudan a ella porque la huelen. Por lo que los moralistas la proponen como emblema de la hipocresía.

¿No cabe la posibilidad de que, ante la pantera y su olor, la cabra experimente un violento deseo de ser cazada (...) perseguida o busque a su asesina y se entregue a sus garras en busca de una muerte violenta, pero también infinitamente deseable? $?^{460}$

Aunque hay que advertir que será posteriormente cuando la belleza, el perfume y la exquisitez de las manchas se trenzarán con los desnudos mitológicos y con los simbolismos estéticos, dando lugar a curiosas invenciones acerca de costumbres venatorias.

Los textos clásicos de Aristóteles, Plinio, Eliano y san Isidoro ya se planteaban que las características de la pantera eran muy peculiares. En principio, le encanta el olor del alcanfor. Este era el árbol que cuidaba o vigilaba, de ahí que ella también huela bien. Al mismo tiempo, la pantera odia el olor del ajo, al igual que los vampiros y, cuando cae enferma, su buen gusto se pervierte. Se aleja del árbol y comienza a utilizar materiales viles como la sangre de cabrón y el excremento humano. La pantera es una bestia dionisiaca que acompaña a Baco, ya sea como cabalgadura o como animal de tiro de su

\footnotetext{
${ }^{458}$ Estas ideas las veremos posteriormente reflejadas en los anuncios de publicidad.

${ }^{459}$ Pilar Pedraza, op. cit., p. 243.

${ }^{460}$ Pilar Pedraza, op. cit., p. 245.
} 
carro. E incluso, en ocasiones, el mismo dios también adoptará su forma para aparecerse a los humanos con mucha docilidad, por lo que a la pantera también le gustará el vino. Un ejemplo muy claro de docilidad y elegancia lo encontramos en Heliogábalo en sus orgías de osos, de leones y panteras, y en Juan de Mandeville en su Libro de las maravillas del mundo de finales del siglo XIV. En ambos las panteras son descritas como atrevidas, feroces y alardean de fuerza. Pero, interiormente son muy apacibles, por lo que los antiguos las comparaban con las mujeres, pues ambas son muy capaces de realizar grandes hazañas sin dar puñetazos en la mesa ${ }^{461}$.

\subsubsection{1.- Cat People}

Como ejemplos visuales podemos destacar la famosa película de Cat People de 1943 de Jack Tourneur. Por supuesto, antes que esta película ya existía la variante fílmica de la bella y la bestia, como por ejemplo King-Kong. Pero la diferencia es que en este último caso el monstruo está desdoblado y proyectado hacia el exterior de ella. Por lo que, como dice Pilar Pedraza, estamos ante la institución represora de lo monstruoso.
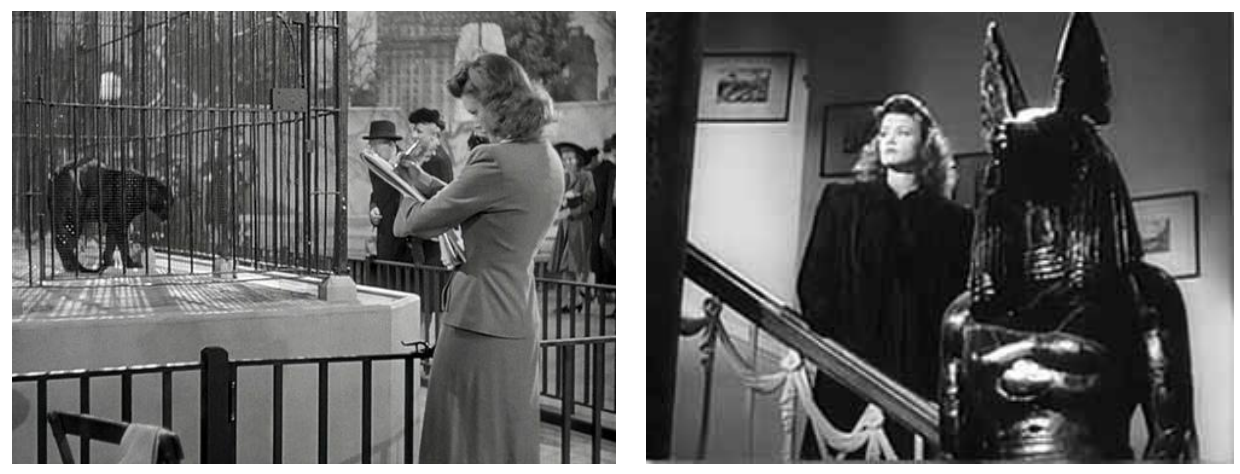

De este modo la pantera se comprende como un doble bestial, una proyección de los temores que provoca el engaño. Es un símbolo de la ferocidad de los celos femeninos,

\footnotetext{
${ }^{461}$ Pilar Pedraza, op. cit., pp. 237-251.
} 
como un espejo ante el cual cada uno ve sus propios temores y deseos. Pero estas ideas evolucionan, y se consolidan como una simbólica institución represora de lo monstruoso. Ahora se aprecia el peligro que tiene para el hombre la conquista de una virgen custodiada por su propia histeria. Esto lo vemos en el remake de Cat People (1982) de Paul Schader y en el King-Kong de Guillermin.

Realmente, Cat People se trata de una fantasmagoría donde los deseos danzan, entrelazan y dan vueltas sobre sí mismos, bajo el concepto de máscara. Irena desea ser esposa como las damas, pero al mismo tiempo no quiere renunciar a su pantera interior, por lo que se engatusa a sí misma con la falacia de la felicidad de las amantes y de las madres. Pero también se autocontempla en la jaula del parque como si se tratara de un espejo. La pantera nunca se ve en la película, sino que está omnipresente como si fuera el fantasma de la propia Irena Dubrovna. La secuencia que contribuye a que el espectador tenga esta idea de omnipresencia, y de reflejo de la joven protagonista, comienza con el plano de las huellas ensangrentadas de un felino que, poco a poco, se van transformando en unos zapatos femeninos con tacón. Después vemos cómo Irena saca un pañuelo y se limpia la cara. Por supuesto, se trata de una secuencia ambigua que se rige a partir de la asociación de ideas. Ideas que transmiten los planos de su abrigo destrozado, de unas ovejas, de ella fatigada sin que se explique por qué... A partir de aquí la imagen simbólica despega ${ }^{462}$.

\subsubsection{2.- Catwoman}

Catwoman es un personaje ficticio creado por los DC Cómics. Su primera aparición se dio en 1940 de la mano de los dibujantes Bill Finger y Bob Kane para Batman $N^{\circ} 1$. En

\footnotetext{
${ }^{462}$ Pilar Pedraza, op. cit., pp. 252-259.
} 
un principio esta mujer fue una ladrona que utilizaba el disfraz de anciana y recibía el nombre de Gata. Un nombre poderosamente simbólico que ayudaba a resaltar sus movimientos delicados y su carácter avispado. Sin embargo, con el paso de los años, el personaje fue evolucionando, y sus gestos y vestimenta cambiaron por completo.

Hoy en día, el personaje de Catwoman busca encarmar la sensualidad, la elegancia, la elasticidad, la independencia... de los gatos. Pero no alcanza la maldad o la ferocidad que puede encarnar la pantera. Por ello, el personaje, aunque originariamente fue concebido como uno de los enemigos de Batman, es uno de sus aliados.

Otro de los datos curiosos que recubre al personaje es que el nombre real de la heroína es Selene, el cual deriva de la deidad griega Selene, diosa lunar y de la noche que acabó siendo suplantada por Artemisa.

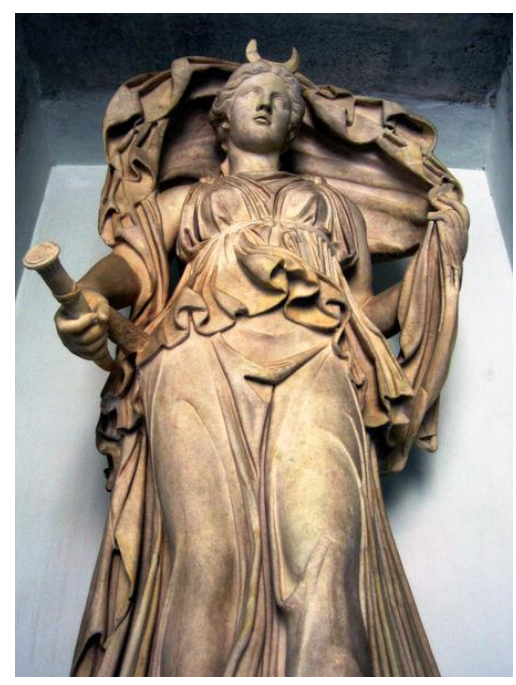

Casualidad o no, en el comic el personaje de Selene sólo adoptará la personalidad de Catwoman por la noche. Con un vestido necho como la noche y con unas orejas gatunas que son muy similares a la luna que la diosa portaba en la cabeza. 


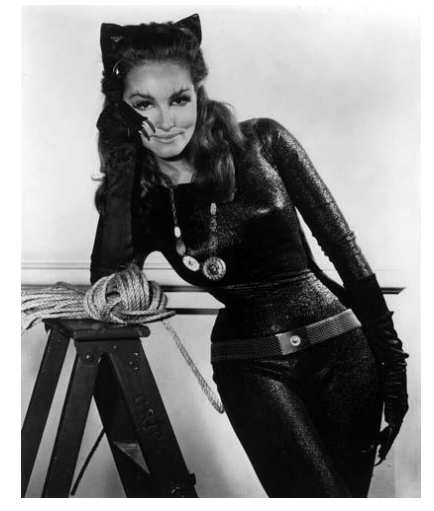

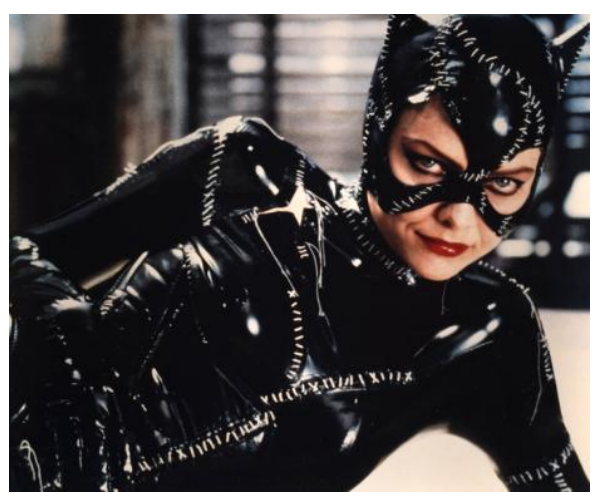

Michelle Pfeiffer

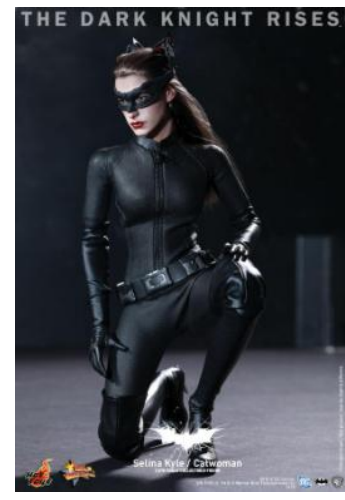

Anne Hathaway

Imagen que el cine no dudó en destacar y potenciar con la ayuda de famosas actrices y modelos. Julie Newmar, Michelle Pfeiffer, Halle Berry, Anne Hathaway...

\subsubsection{3.- Las mujeres insectos}

El insecto es uno de los animales que mejor encarna la máscara que adopta la identidad femenina a nivel social. Así lo comprendió el fotógrafo Laurent Seroussi, quien en sus fotografías logra la fusión sensual de las féminas con estos diminutos animales.
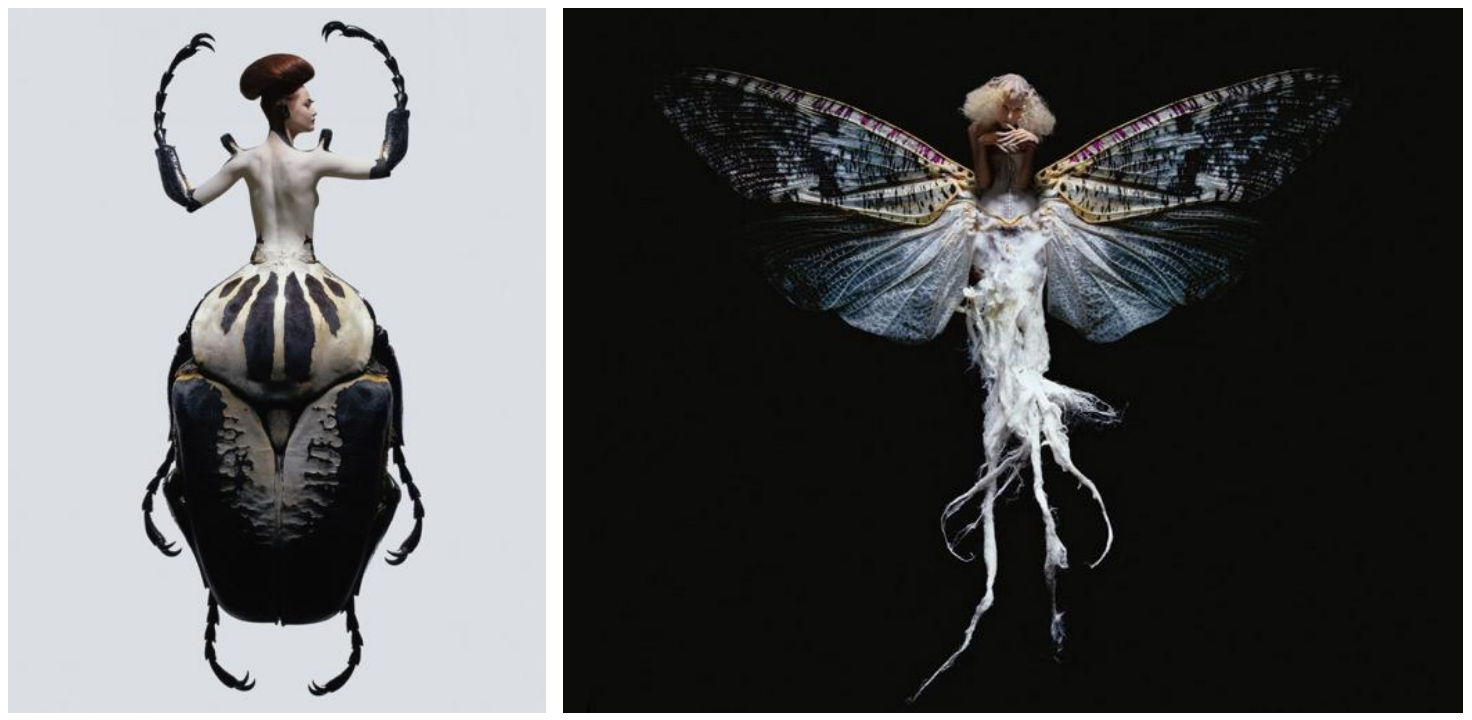

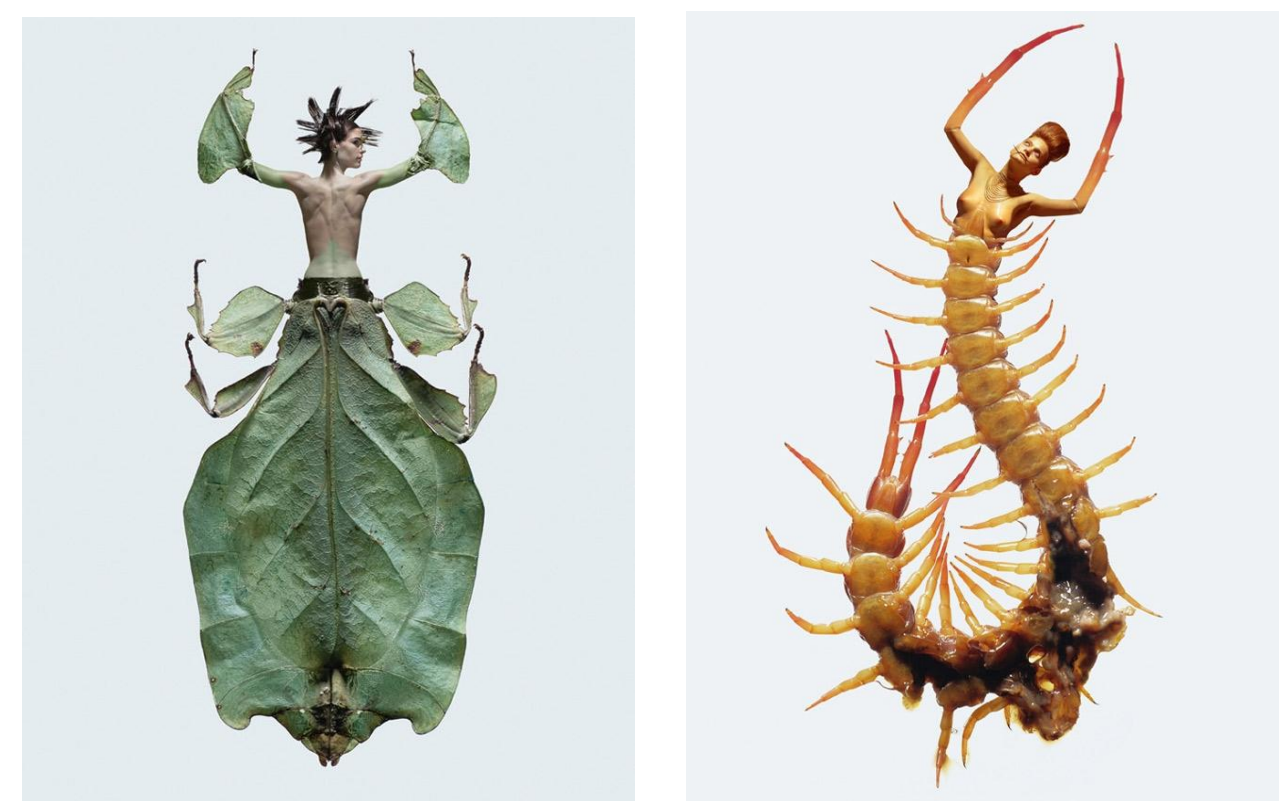

Se trata de una mujer que logra su metamorfosis por medio de la materialización de sus sueños. Ahora las niñas no sueñan con convertirse en princesas, sino en hadas bellas y terroríficas. Hadas que Guillermo del Toro no dudó en utilizar en el Laberinto del Fauno.

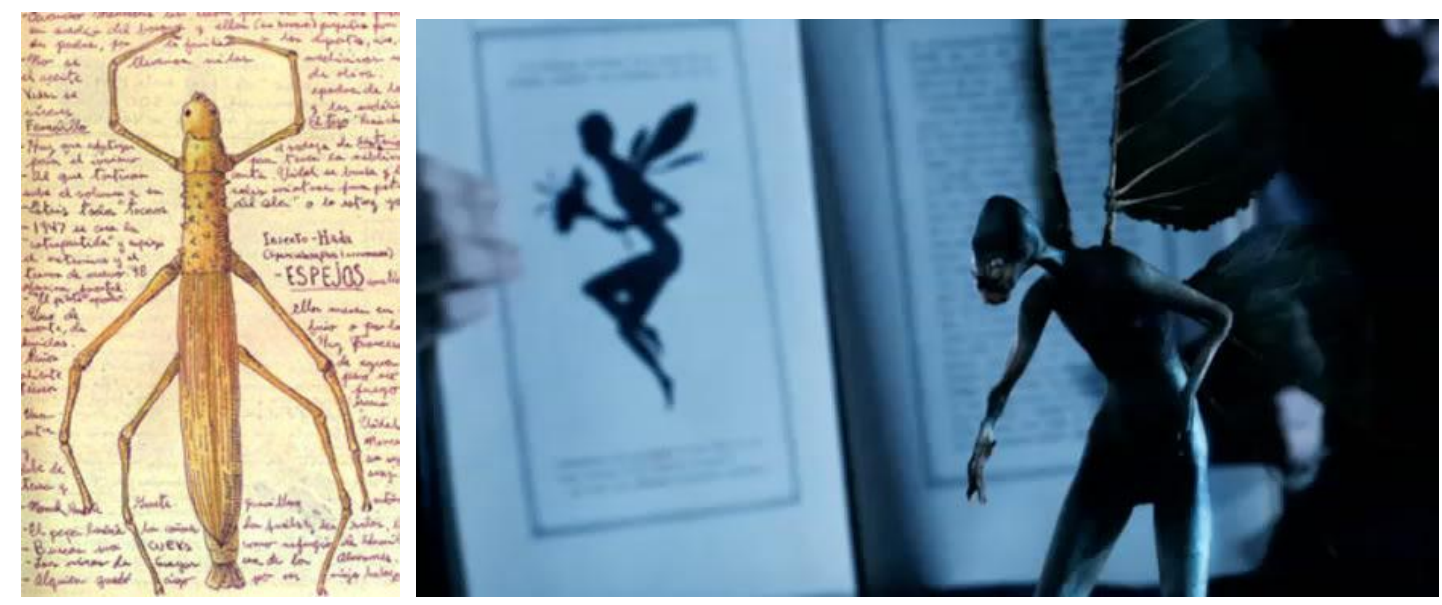

Estas son insectos que adoptarán la misma forma que las hadas de los cuentos para ayudar a la joven protagonista de la película. 


\title{
4.3.3.3.1.- La araña
}

El paso del tiempo no afecta a todos los personajes femeninos por igual. Unos parecen quedarse inmóviles y apenas evolucionan; sin embargo, otros evolucionan y alcanzan niveles que nada tienen que ver con su origen. Tal vez este fue el caso de la mujer araña. Si nos remontamos a la mitología grecolatina, nos encontramos con la figura de Aracne a quien la diosa Palas Atenea castiga por su orgullo y soberbia:

\author{
No se distinguía a Aracne ni por su patria \\ ni por su cuna, si por su arte; su padre, el colofonio Idmon, \\ tenía esponjosas lanas con un tinte foceo; \\ había muerto su madre, que también era plebeya \\ y había sido igual a su marido. Pese a ellos en las ciudades \\ lidias había conseguido con su esfuerzo un nombre famoso, aunque \\ había nacido en casa humilde y habitaba en la humilde Hipepas. \\ Para contemplar su obra extraordinaria, a menudo \\ abandonaron las ninfas los viñedos de su querido Timolo, \\ abandonaron sus queridas aguas las ninfas de Pactolo. \\ Y no sólo les gustaba contemplar los vestidos confeccionados, \\ sino también mientras se confeccionaban (tanta belleza había \\ en su arte), cuando amontonaba la lana en bruto en los primeros \\ ovillos, o cuando con los dedos moldeaba el material y \\ ablandaba los vellones, semejantes a nubes, que cubrían un largo \\ recorrido, o cuando con un toque del pulgar hacía girar al torneado \\ huso, o cuando bordaba con la aguja: sabrías que la había enseñado \\ Palas. Pero ella lo niega y ofendida por tan gran maestra \\ “¡que compita!”, dijo, “conmigo, nada rechazaré si me vence”. \\ Palas toma la figura de una anciana, añade falsas canas a sus \\ sienes y sostiene también con un báculo sus débiles miembros. \\ Entonces empezó a hablar así: "No todo lo que despreciamos
}


pertenece a la vejez: la experiencia viene con los años maduros.

No desprecies mi consejo: búscate entre los mortales

la mayor fama en el trabajo de la lana;

cede a la diosa y pide perdón, osada, por tus palabras

con voz suplicante: ella, si se lo pides, te perdonará"463.

Pese la advertencia, la joven desprecia el consejo de la anciana y persiste en destacar que su trabajo es mejor que el de la propia diosa. Es entonces cuando tiene lugar el reto que inmortalizó Velázquez. Aracne y la diosa Atenea, vestida de anciana, se baten en duelo. Cada una debe realizar un tapiz diferente y ganará el más bello de los dos.

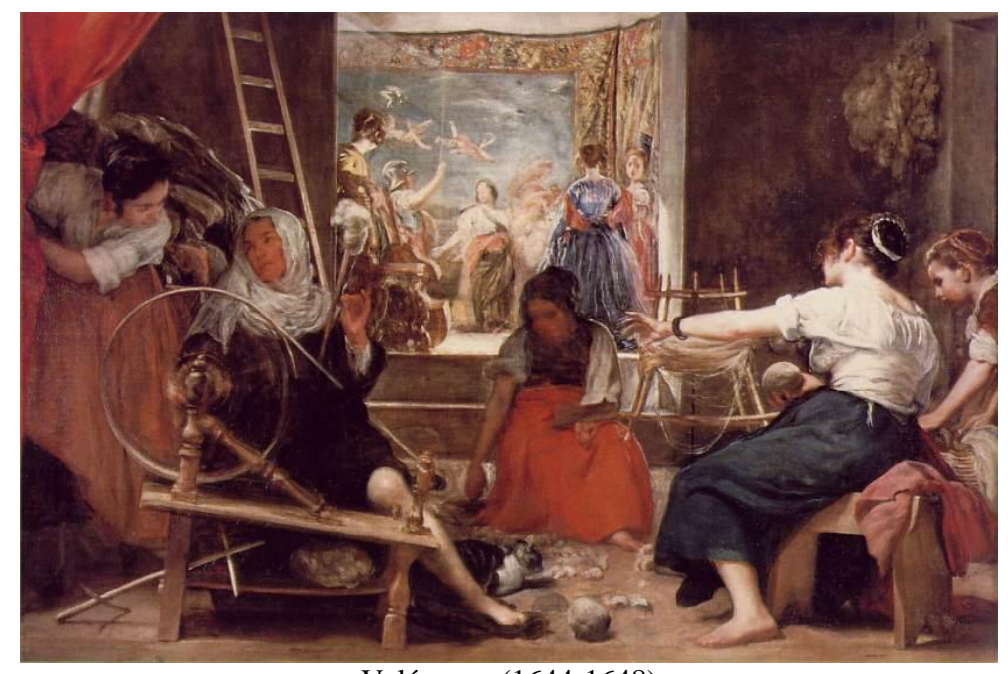

Velázquez (1644-1648)

El tapiz de Aracne resulta ser el más bello, por lo que Palas se alza furiosa y castiga la osadía de la joven:

No Palas, no la Envidia podría criticar aquella obra.

Se dolió con el éxito de la varonil doncella rubia

y rompió el lienzo bordado de crímenes celestiales;

y según tenía la lanzadera procedente del monte de Citoro,

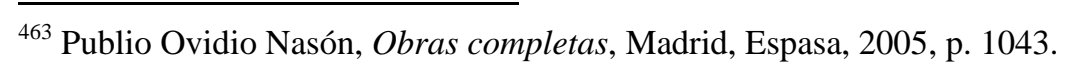


golpeó tres o cuatro veces en la frente a la Idmonia Aracne.

No lo soportó la desgraciada y se ató con valor su garganta con un lazo; mientras colgaba Palas, compadecida, la levantó

y le dijo así: "Vive pues, pero cuelga malvada,

y el mismo castigo, para que no estés segura en el futuro,

este declaro para tu familia y tus remotos descendientes"

Cuando Aracne se levanta, observa asustada que su cuerpo se ha transformado en una araña.

El vínculo entre mujer-araña ha seguido vivo hasta nuestros días; sin embargo la relación con el insecto varía según la perspectiva que se le quiera dar al personaje. La biología ayudó a enriquecer la simbología de la araña cuando dio a conocer a la nueva "viuda negra". Se trataba de un arácnido que, en ocasiones, devoraba al macho tras la cópula. De ahí su nombre de "viuda", y "negra" porque es de color negro salvo una manchas pequeñas rojas en el lomo. Los Cómics Marvel recuperaron esta figura orgullosa y le sumaron la característica de la perversión sexual y la del asesinato. Fue así como los dibujantes Stan Lee y Jack Kirby personificaron al animalillo y lo convirtieron en una de las super heroínas de moda. En Tales of Suspense se contaba que Natalia Alianova Romanov era una famosa bailarina que se casó con Alexi Shostakov, el cual ejercía de espía para el KGB. Un día a Natasha se le informa de que su marido ha muerto en una misión del gobierno, por lo que ella decide enrolarse. Desde entonces se la conoce como la "Viuda Negra". Se trata de un personaje muy popularizado a través de los cómics, videojuegos y películas. Pero se encuentra muy lejos de la fígura de la araña: lo único que comparten es el carácter altivo, frío, y el papel de viuda que

\footnotetext{
${ }^{464}$ Publio Ovidio Nasón, op. cit., p. 1049.
} 
Natasha asume. Ahora bien, si Aracne presumía de lo bien que tejía, la bailarina rusa se enorgullece del cuerpo atlético que tiene. Por lo que normalmente su aparición en escena va vinculada a alguna exhibición de volteretas imposibles y caídas paradigmáticas que la asemejan a las arañas.

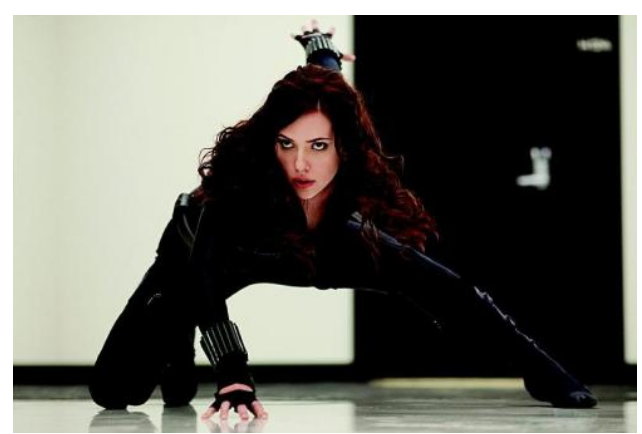

Los vengadores

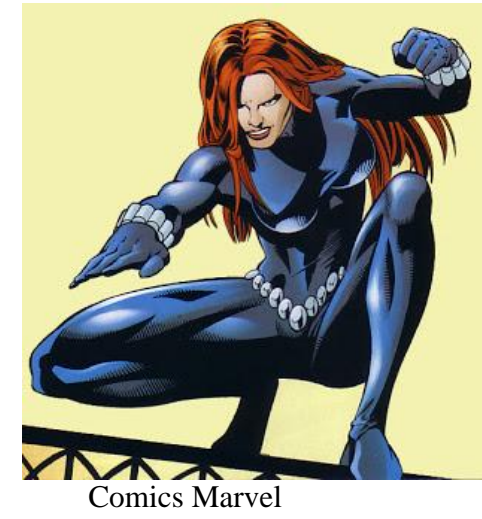

Se trata de una mujer que se aleja de la función de hilandera, pero que encarna la violencia, la fuerza y lo letal de la araña.

En 1987, el director de cine Bob Rafelson rueda la película de El caso de la viuda negra. El guión, escrito por Ronald Bass, cuenta la historia de una agente federal llamada Alex Barnes que, por casualidad, investiga las muertes de dos hombres ricos. Aparentemente, no existe ningún vínculo entre ellos, pero Alex comienza a sospechar de una joven cuyos maridos han muerto envenenados y ha mantenido relaciones con los fallecidos. De esta forma, vemos cómo el crimen pasional pasa a formar parte de la figura femenina, por lo que se potencia la relación sexo-muerte. Algo que será muy recurrente en el género policial. 


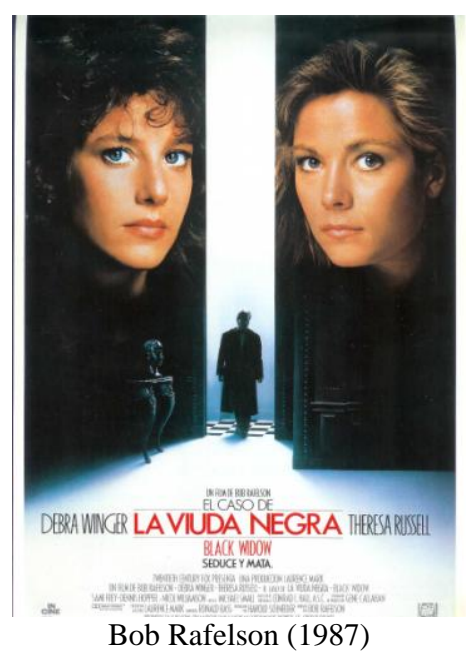

Estas visiones potencian especialmente la muerte como vínculo existente entre la mujer y la araña. Sin embargo J.R.R. Tolkien bebe directamente de las antiguas mitologías, entre ellas, la griega, la celta, las sagas nórdicas, e incluso la Biblia hebrea. Inspirándose en todo ello escribe El Silmarillion. Su primer capítulo cuenta la historia de la creación de Eä y de unos seres espirituales llamados “ainur”. Todo ellos carecían de cuerpo y de la posibilidad de crear cosas propias. Pero, por el contrario, tenían suficiente poder para corromper y destruir las obras de sus semejantes. Tolkien no cuenta exactamente el origen de la araña gigantesca, pero si afirma que uno de los ainurs, llamado Melkor, se reveló contra su creador y quiso apoderarse de Eä con la ayuda de otros espíritus. La malicia de Melkor llegó a corromper a Ungloiant, Sauron y a los balrogs. Los cuales, después de revelarse, habitaron Eä. Ungloiant habitó en un lugar escondido de Eä llamado Avathar; era un espacio olvidado, donde no entraba la luz y las sombras lo dominaban todo. Allí tomó la forma de una gigantesca araña que se alimentaba de la luz que atrapaba con las redes que tejía. Pero cuanto más devoraba más hambre tenía. El tierno animalillo vivió y creció hasta límites insospechados. Todas estas características las hereda su hija, Ella-Laraña. Es tan longeva que ningún ser viviente de la Tierra Media puede asegurar con certeza cuántos años tiene. Es un ser ancestral, de los días 
antiguos de la creación. Vive escondida en las oscuras cavernas que hay cerca de la torre Cirith Ungol.

Allí tenía su morada, desde tiempos inmemoriales, una criatura con cuerpo de araña, la misma que en los Días Antiguos habitara en el País de los Elfos, en el Oeste que está ahora está sumergido bajo el Mar, la misma que Beren combatiera en Doriath en las Montañas del Terror, y que en ese entonces, en un remoto plenilunio, había venido a Lúthien sobre la hierba verde y entre las cicutas. De qué modo había llegado hasta allí Ella-Laraña, huyendo de la ruina, no lo cuenta ninguna historia, pues son pocos los relatos de los años Oscuros que han llegado hasta nosotros ${ }^{465}$.

La aparición de Ella-Laraña se produce justo cuando los protagonistas de El señor de los Anillos se cruzan con ella. El encuentro es muy breve, pero muy significativo, pues se trata de la personificación del vacío, de la nada, de la oscuridad... de la muerte.

Entraron en la caverna. A los pocos pasos se encontraron en la tiniebla más absoluta e impenetrable. Desde que recorrieran los pasadizos sin luz de Moria, Frodo y Sam no habían visto oscuridad semejante: la de aquí les parecía, si era posible, más densa y más profunda. Allá en Moria, había ráfagas de aire, y ecos, y cierta impresión de espacio. Aquí, el aire pesaba, estancado, inmóvil, y los ruidos morían, sin ecos ni resonancias. Caminaban en un vapor negro que parecía engendrado por la oscuridad misma, y que cuando era inhalado producía una ceguera, no sólo visual sino también mental, borrando así de la memoria todo recuerdo de forma, de color y de luz. Siempre había sido de noche, siempre sería de noche, y todo era de noche $e^{466}$.

"Y mientras Frodo aún hablaba, sintió que una maldad inmensa lo envolvía, y que unos ojos de mirada mortal lo escudriñaban. A corta distancia de allí, entre ellos y la abertura donde habían trastabillado, dos ojos se iban haciendo visibles, dos grandes racimos de ojos multifacéticos: el

\footnotetext{
${ }^{465}$ J.R.R. Tolkien, El Seños de los Anillos. Las dos torres, Barcelona, Minotauro, 1966, p. 436.

${ }^{466}$ J.R.R. Tolkien, op. cit., p. 428.
} 
peligro inminente por fin desenmascarado. El resplandor del cristal de estrella se quebró y se refractó en un millar de facetas, pero detrás del centelleo un fuego pálido y mortal empezó a arder cada vez más poderoso, una llama encendida en algún pozo profundo de pensamientos malévolos. Monstruosos y abominables eran aquellos ojos, bestiales y a la vez resueltos y animados por una horrible delectación, clavados en la presa, ya acorralada. (...) Frodo miró por encima del hombro y vio con terror que los ojos venían saltando detrás de ellos. El hedor de la muerte lo envolvió como una nube ${ }^{467}$.

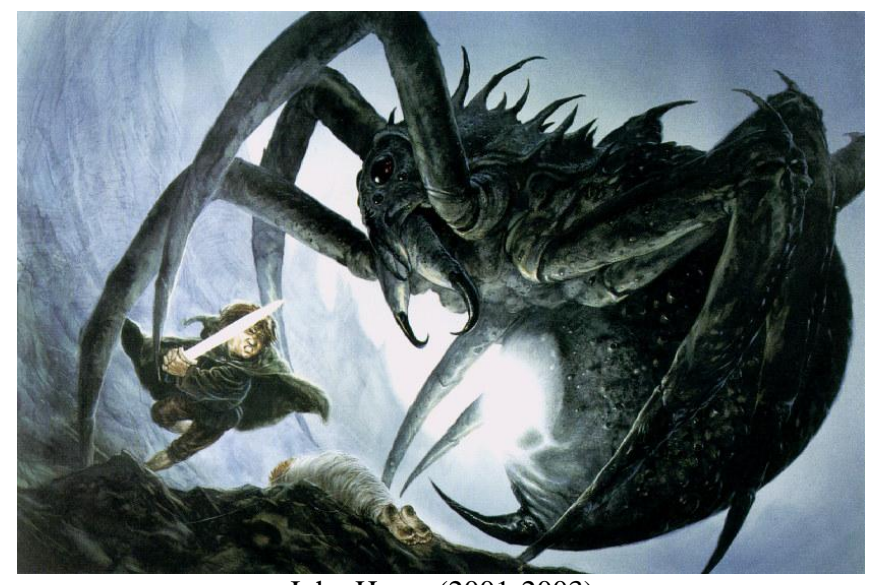

John Howe (2001-2003)

A diferencia de los otros autores, Tolkien retoma la función tejedora de la araña y la vincula con su maldad.

\section{4.- Los personajes históricos como icono de la feminidad}

La ficción del realismo tradicional, sabido es, creía a ciegas en un modus operandi basado es una reproducción mimética de cierta 'realidad' que la 'ficción' copiaba en el texto como mejor sabía, suscribiendo las leyes de la verosimilitud hasta extremos que condujeron a esa misma ficción realista a la condición de descripción autoritaria de la 'realidad' convencional, de acta notarial $(\ldots)^{468}$.

\footnotetext{
${ }^{467}$ J.R.R. Tolkien, El Seños de los Anillos. Las dos torres, Barcelona, Minotauro, 1966, p. 432-433.

${ }^{468}$ Javier Aparicio Maydeu, Lecturas de ficcón contemporáneas. De Kafka a Ishiguro, Madrid, Catedra, 2008, p. 47.
} 
Al lector sólo le quedaba observar con todo lujo de detalles los vestidos, las costumbres, las descripciones de las armas de guerra, los pensamientos íntimos, la fisionimía... Todos ellos descritos por un narrador omnisciente y autoritario que deambula por un tiempo histórico.

Durante el siglo XIX existe un creciente interes por la novela histórica. Observamos cómo varios autores se sumergen en textos históricos para tomarlos como fuente de inspiración. Sin embargo, autores como Gustave Flaubert consideran que gran parte de este material presenta importantes problemas a la hora de plasmarlo. El lector se cansa con descripciones interminables sobre objetos que nunca ha visto y nunca verá. Para Gustave Flaubert el intento de reflejar los detalles históricos sólo lleva a un estilo académico deplorable, pesado y aburrido. Para él la antigüedad no se acopla a la novela histórica porque carece de familiaridad y de afinidad con el lector. Así que no buscará resucitar la verdad histórica, sino que la sustituirá por un idealismo histórico. Bajo esta realidad idealizada se alzará su femme fatale cartagonesa: Salambô.

\subsection{1.- Mujeres seductoras y asesinas}

En el inconsciente colectivo de los humanos perduran, incomprensiblemente, algunos mitos históricos cubiertos por la oscuridad y el engaño

Juan Antonio Cebrián

Muchas de las figuras femeninas que ha dado el mundo de la historia tuvieron que vivir plenamente sumergidas en el sistema patriarcal. Todas ellas son muestra de un intento de adaptación, de lucha y de continua supervivencia. Sin embargo, una mujer que puede sobreponerse a las presiones varoniles es una mujer peligrosa, porque representa a una 
fémina que no sólo conoce las reglas sociales, sino también que también sabe cómo sortearlas.

Estas féminas fueron las que inspiraron a los autores del siglo XIX. Históricamente, fueron mujeres muy inteligentes y próximas al poder, por lo que representaron un blanco muy fácil para todos aquellos que quisieron derrocarlas. Pues la esencia sexual femenina es muy fácil de manchar y de enturbiar. Esto fue lo que ocasionó su declive histórico, pero al mismo tiempo lo que les confirios es la inmortalidad literaria.

\subsubsection{1.- Cleopatra}

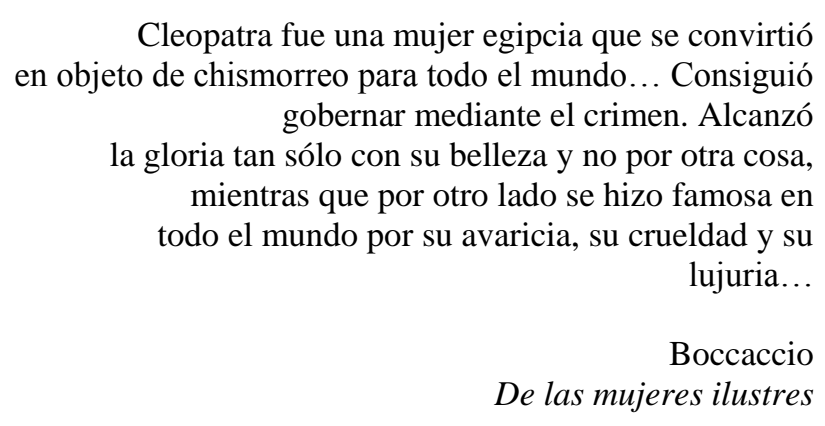

La profesora Joyce Tyldesley publicó en 2008 la biografía de Cleopatra ${ }^{469}$. En esta obra se menciona que, posiblemente, tras la muerte de Auletes, son Cleopatra y su hermano

Ptolomeo los que ascienden a la corona:

Aunque la tradición ptolemaica sugiere la posibilidad de que Cleopatra se casase con su hermano poco después de la muerte del padre de ambos, su matrimonio no consta en ninguna parte. Una inscripción realizada por Cleopatra en la barca o en el santuario de la barca del dios de la tierra, Gueb, en el templo de Coptos, muestra a la reina haciendo ofrendas a la tríada divina de Min, Isis y Horus, y la describe como "Señora de las Dos Tierras, Cleopatra Filópator,

\footnotetext{
${ }^{469}$ Profesora de Egiptología en la Universidad de Manchester y miembro del Museo de Manchester. Ha colaborado en programas de radio y televisión sobre el mundo egipcio y es autora, entre otros muchos libros, de las biografías de Ramses II el Grande y de las reinas Hatchepsut y Nefertiti, así como de Los descubridores del antiguo Egipto.
} 
Amada de Min-Ra de Coptos, Esposa de Rey, Hija de Rey”, pero no se nombra al marido-rey, por lo tanto podría ser Ptolomeo XIII o Ptolomeo $\mathrm{XIV}^{470}$.

Cleopatra asciende a la corona con dieciocho años, y aunque no se conocen los límites de edad legales para casarse, se pensaba que lo políticamente correcto era que las jóvenes tuvieran entre quince y diecinueve. Esto la dejaba en una situación muy comprometida, pues siendo reina, se le exige que pronto engendre hijos. Sin embargo, Ptolomeo contaba con apenas diez años, y era demasiado joven para consumar el matrimonio.

Además de esta situación, también hay que advertir, con cautela, que los primeros documentos de esta época manifiestan que Cleopatra gobernaba sola. Ptolomeo debía ser la parte dominante de la pareja. Pero, como era menor, gobernaba a través de un consejo regente y su figura quedó arrinconada. Sobre Cleopatra recayó todo el peso de la monarquía y se convirtió en una mujer rey, una mujer faraón.

La marginación de su hermano tuvo grandes e importantes consecuencias. Ptolomeo se encontró completamente desprotegido ante la poderosa influencia de su tutor Teodoto, del soldado Aquilas y del eunuco Potino. Se trataba de una corte de alejandrinos ambiciosos que educaron al joven príncipe con el fin de alcanzar sus propias ambiciones. Una vez cumplida la edad correspondiente para gobernar decide actuar contra su hermana, quien, a su vez, encontró apoyo en Roma ${ }^{471}$.

Históricamente, cuando hablamos del reinado de Cleopatra nos encontramos con un país al borde de la guerra civil, en el que una parte apoyó a Cleopatra y otra, muy poderosa, apoyó a su hermano. Probablemente, esto propició todo tipo de relatos y de

\footnotetext{
${ }^{470}$ Joyce Tyldesley, op. cit., p. 46.

${ }^{471}$ Joyce Tyldesley, op. cit., pp. 46- 51.
} 
chismorreos. Tal fue el caso de Plutarco, que en su obra Vidas paralelas ${ }^{472}$ caracteriza a Cleopatra como una fémina sexualmente voraz. De esta fuente, sin lugar a dudas, bebe William Shakespeare al escribir Julio Cesar (1600), Antonio y Cleopatra (1606) y Coriolano (1607). Dante también se hizo eco de la mala relación entre los hermanos y sitúa a Ptolomeo en el noveno círculo de su Infierno. Aunque, sin duda, uno de los textos más famosos fue el que escribió la pluma de Plutarco al contar cómo el mercader siciliano Apolodoro introduce a Cleopatra en el palacio del César. La escena no sería tan sorprendente a no ser porque fue introducida escondiéndola en un pequeño fardo de sábanas. Al llegar ante la presencia de Julio César, el siciliano desenrolla una exótica y anacrónica alfombra persa, y parece que seductoramente se desmaya. Tal vez fue este episodio junto con el enrevesado panorama político el que ayudó a perfilar la imagen que hoy en día hemos heredado.

\footnotetext{
Cleopatra, despojada de cualquier significado político, sería recordada como una mujer extranjera e inmoral y, casi de la noche a la mañana, se convirtió en el más aterrador de los estereotipos romanos: una mujer antinatural. La mujer que adoraba a los dioses groseros, dominaba a los hombres, se acostaba con sus hermanos y paría hijos bastardos. Una mujer cuya necedad era tal que pensaba que algún día podría gobernar Roma, y cuyas artimañas lograron engañar a un hombre decente y apartarlo de su hogar y de su casa ${ }^{473}$.
}

Obviamente no estamos ante una figura nueva. Cleopatra siempre intentó revestirse con la mezcla Eros-Tánatos. En consecuencia, la encontraremos vinculada a historias de amor, pero todas ellas trágicas. Podremos ver cómo su poderosa influencia llega incluso hasta Rusia, en donde Pusnkin escribe Noches Egipcias (1835). Cleopatra es una mujer que se deja acariciar por el rastro de la noche y, con ella buscará exaltar su feminidad.

\footnotetext{
${ }^{472}$ Esta obra de Plutarco fue traducida al francés en 1559 por Jacques Amyot y, posteriormente, al inglés en 1569 por Sir Thomas North.

${ }^{473}$ Joyce Tyldesley, op. cit., p. 223.
} 
Para ello se perfilará un cuerpo femenino bajo una línea muy delicada, estática, bella, de figura arabesca, completamente enjoyada y con un exiguo atuendo.

Tal es el caso del cuadro de Gustave Moreau llamado Cleopatra (1887) y de sus notas publicadas con el título de L'assembleur de Rêves.

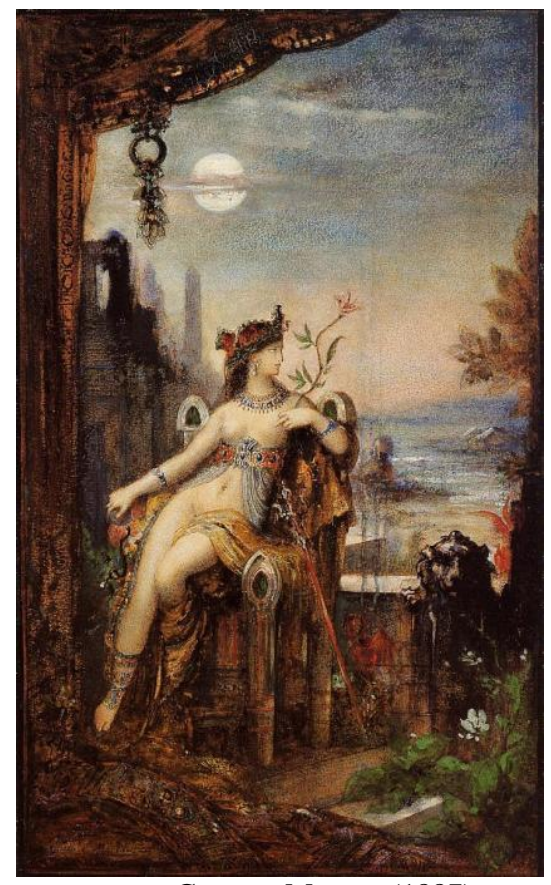

Gustave Moreau (1887)

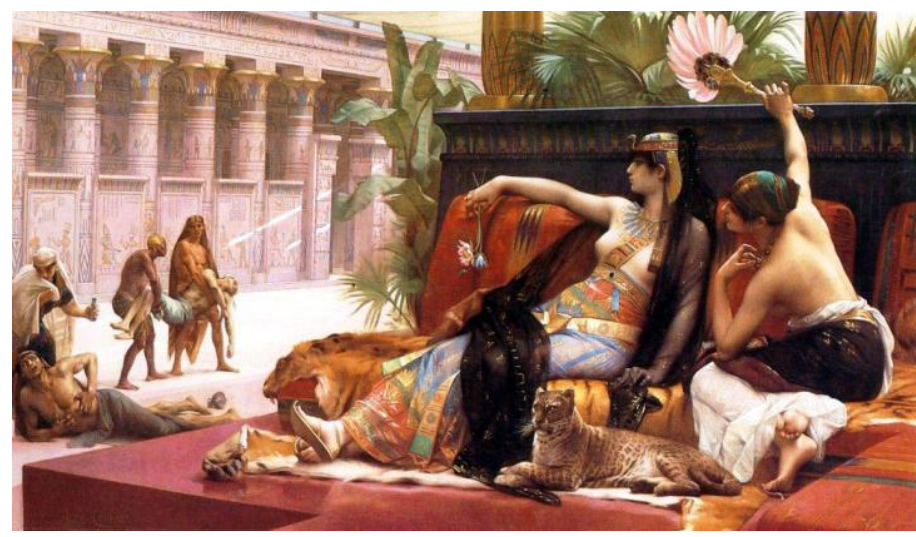

Alexandre Cabanel (1887)

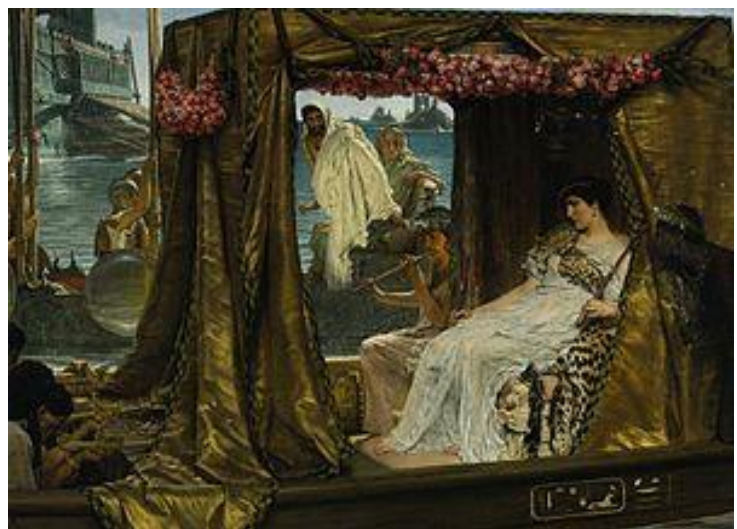

L. Alma Tadena

También, cabe destacar la importante Cleopatra que dibuja Alexandre Cabanel en

Cleopatra ensayando el veneno con sus amantes. Es un cuadro que se expone a finales de siglo en el Salón de París (1887), y en donde se puede apreciar una fuerte influencia 
de la imagen de la "doncella tigre". Este carácter también se destaca en la figura que perfila L. Alma-Tadema en Antonio y Cleopatra. La figura de Cleopatra llega a uno de sus puntos más altos cuando Ch. A. Winter dibuja Fantasía Egipcia en 1898. Ya casi finalizado el siglo, Winter estrecha más los lazos entre el Eros y el Tánatos. Para conseguirlo se ayuda de dos motivos muy importantes: la serpiente y los sapos que hay a sus pies. Con ellos logra hacer una ecuación visual muy clara: mujer-muerte. Ambos animales son elementos no sólo vinculados a la muerte, sino también al pecado de la lujuria. De forma que lo que Winter intenta es recuperar los peligros fatales que caracterizan a un tipo de mujer muy concreta ${ }^{474}$.

\subsubsection{2.- Mesalina ${ }^{475}$}

La vida de Mesalina aparece completamente ligada a la de su marido. Claudio César se vio privado de la figura paterna desde la más tierna infancia y padeció graves enfermedades en su juventud. Lo cual le supuso tener que soportar continúas vejaciones:

Su madre, Antonia, repetía con frecuencia que era un engendro que la naturaleza había dejado sin terminar, y, cuando quería tachar a alguien de estúpido, decía que era más tonto que su hijo Claudio $^{476}$.

Su abuela rara vez le hablaba y su tío abuelo Claudio menciona en sus obras:

(...) Los dos estamos, por otra parte, de acuerdo en que debemos decidir de una vez por todas qué criterio hemos de seguir respecto a él. Pues si es apto, por decirlo así, en todos los sentidos, ¿qué motivo tenemos para dudar en promocionarlo haciéndole pasar gradualmente por las

\footnotetext{
${ }^{474}$ Erika Bornay, op. cit., p. 232.

${ }^{475}$ Erika Bornay, op. cit., pp. 234-238.

${ }^{476}$ Gaivis Suetonius Tranquillus, Vidas de los doce césares, Madrid, Gredos, 1992, p. 268.
} 
mismas etapas que hemos hecho atravesar a su hermano? Y si, por el contrario, pensamos que es inferior, que tiene dañadas las facultades físicas o mentales, no hay que proporcionar a los hombres, que tienen por costumbre burlarse de estas cosas y ridiculizarlas, la ocasión de reírse no sólo de él, sino también de nosotros. Siempre estaremos, en efecto, indecisos, si deliberamos acerca de cada circunstancia concreta sin haber establecido previamente si lo juzgamos capaz de desempeñar honores o no ${ }^{477}$.

Según el texto de Suetonius se pasó toda la vida sufriendo constantes humillaciones de su propia familia, como dejarlo sin comer si llegaba un poco tarde o de tirarle huesos a la cara si se quedaba dormido en la mesa después de comer.

Sin embargo cuando llegó al poder quiso olvidar todo lo que habría sufrido hasta entonces. De este modo, proclama una amnistía total y honra con varios festejos a muchos de sus familiares. Incluso consiguió ganarse la estima y el favor de la plebe y de los soldados. Claudio llevó a cabo obras importantes y necesarias, pero...

Era cruel y sanguinario por naturaleza, como demostró en los asuntos de importancia y de menor trascendencia. Hacía aplicar inmediatamente la tortura en los interrogatorios y los castigos de los parricidas, y exigía que se hiciera ante su vista. (...) En todos los combates de gladiadores, patrocinados por él o por otra persona, mandaba degollar incluso a los que habían caído por casualidad, especialmente a los reciarios, para verles la cara mientras expiraban. Un día en que una pareja de gladiadores se dieron muerte entre sí, ordenó fabricar de inmediato con las espadas de ambos unos cuchillos pequeños para su uso personal ${ }^{478}$.

Su primera mujer fue Plaucia Urgulanila, de la cual se divorció por su conducta libidinosa y porque era sospecha de asesinato. Un poco más tarde se casó con Elia Pétina, de la que también se divorció por ofensas más leves. Valeria Mesalina fue su

\footnotetext{
${ }^{477}$ Gaivis Suetonius Tranquillus, op. cit., p. 268.

${ }^{478}$ Gaivis Suetonius Tranquillus, op. cit., pp. 294-295.
} 
tercera esposa, hija de Barbado Mesala, su primo. Con ella tuvo a su hija Octavia y a un varón, que al principio llamó Germánico y luego Británico ${ }^{479}$.

Mesalina fue tremendamente famosa por su belleza. Tuvo una importantísima influencia en las decisiones políticas de su marido, pero pasó a la historia por su feminidad desenfrenada. Pese a que fue madre, también era constantemente infiel a su esposo con miembros de la nobleza romana, soldados, actores, gladiadores,.${ }^{480}$ Pero Mesalina sobrepasó los límites cuando se casó con su amante Cayo Apio Junio Silano. Lo más curioso es que Claudio César selló este contrato matrimonial.

(...) pues se le había hecho creer que lo fingían deliberadamente para alejar y transferir a otro un peligro que le amenazaba, según hacían presagiar algunos prodigios ${ }^{481}$.

Ya fuese por el agravio de su mujer o porque ambos intentaron quitarle el imperio, Claudio despreció el amor que sentía por Mesalina. Durante algún tiempo se refugió en el campamento de los pretorianos. Se dice que una de las características que tenía el emperador era su flaca memoria. Así que no recordaba la mayoría de los edictos de muerte que promulgó o, incluso, el de su propia esposa.

Poco después de haberse sentado a la mesa tras la ejecución de mesalina, preguntó por qué no venía la emperatriz. Mandó avisar a muchas personas para que fueran al consejo o a jugar a los dados el mismo día siguiente de haberlas condenado a muerte, y, como si se retrasaran, encargaba a su mensajero que las reprendiera por dormilonas ${ }^{482}$.

\footnotetext{
${ }^{479}$ Gaivis Suetonius Tranquillus, op. cit., pp. 267-289.

${ }^{480}$ Erika Bornay, op. cit., p. 234.

${ }^{481}$ Gaivis Suetonius Tranquillus, op. cit., p. 293.

${ }^{482}$ Gaivis Suetonius Tranquillus, op. cit., pp. 297-298.
} 
Por otro lado, en los Anales de Tácito se cuenta que fue Narciso quien tomó toda la iniciativa de matar a Mesalina, el cual anunció a César su muerte durante la comida, aunque éste ni interrumpió el festín ni hizo preguntas al respecto.

A finales de siglo, en plena Decadencia, esta figura se convierte en un bombón y surgen obras como La mujer de Claudio (1873) de Alejandro Dumas hijo y Mesalina de Pietro Cossa (1875). Entre una publicación y otra nos encontramos con el fantástico cuadro de Mesalina de Gustave Moreau (1874). En esta obra la protagonista aparece completamente desnuda junto con su amante, un marinero de Triba.

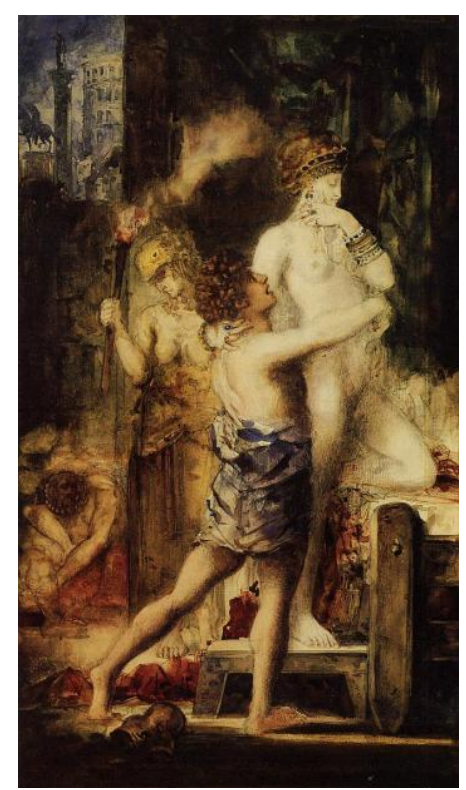

Gustave Moreau (1874)

Gustave Moreau ya comenta, en su cuaderno L'assembleur de rêves, que Mesalina está bellamente vestida sólo con sus joyas. Pera será Aubrey Beardsley quien, sin despojarle de su fatalidad, le dé un tinte del pesimismo psicológico heredado del Romanticismo. De esta forma, primero realiza un grabado en 1895 con el título de Mesalina y, dos años más tarde, aparece como ilustración con el título de Mesalina regresando a casa. 
Beardsley trata con una maestría impresionante la conjugación del blanco y del negro, pero al mismo tiempo contrasta con otra figura femenina a su lado.

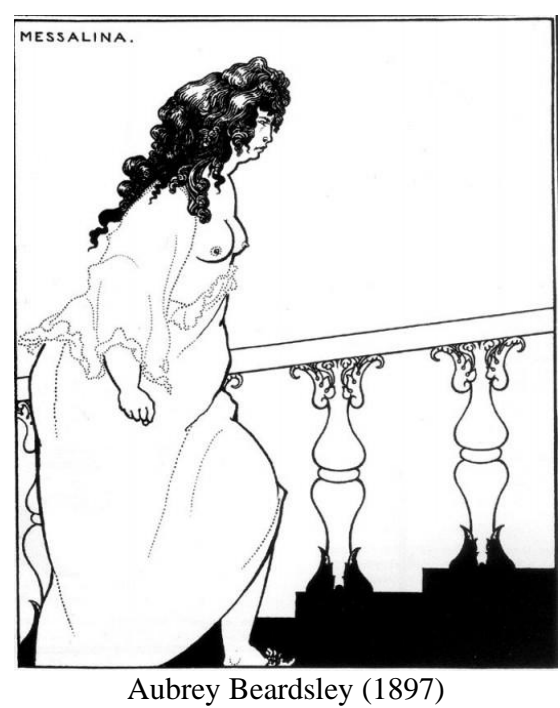

Toulouse-Lautrec tuvo la oportunidad de ver varias óperas en Burdeos. Una de ellas fue Mesalina $^{483}$. La representación tuvo un éxito tremendo, pero esta no tendría gran importancia para nosotros si Toulouse-Lautrec no hubiera estado entre los espectadores. Pues al poco tiempo, e influenciado por la ópera de Isidore de Lara, expone su obra Mesalina sentada ${ }^{484}$.

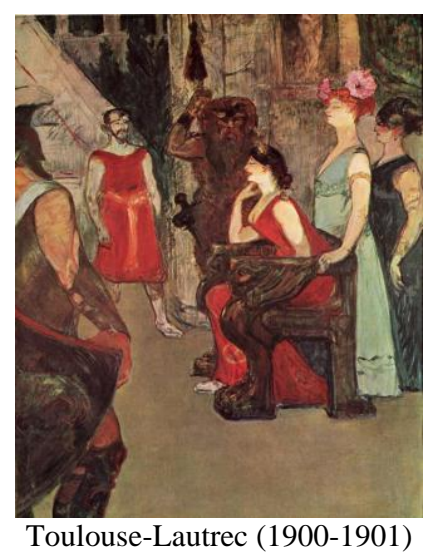

\footnotetext{
${ }^{483}$ Es una tragedia de cuatro actos compuesta por Isidore de Lara. Se estreno en la Ópera de Monte-Carlo el 21 de marzo de 1899 y fue recibida con mucho entusiasmo.

${ }^{484}$ Erika Bornay, op. cit., pp. 235-236.
} 


\subsubsection{3. - Lucrecia Borgia}

Tras la muerte del papa Inocencio VIII, el seis de agosto de 1942 se abre un cónclave para elegir al nuevo papa. Por aquel entonces la imagen que proyectaba la iglesia era débil y fragmentada a causa de las constantes luchas internas entre los barones. Uno de los bandos más importantes estaba encabezado por el cardenal Giuliano della Rovere, quien llegó a urdir diversos intereses con los partidarios del reino de Nápoles, los Sforza de Milán y sus propios amigos.

En el fondo, todo era un juego de alianzas y de intereses políticos, pero el cardenal Borja podía añadir a estos, además, la enorme cantidad de dinero y de beneficios eclesiásticos que estaba a disposición de repartir entre los otros cardenales si salía elegido papa ${ }^{485}$.

De esta forma, en la noche del diez al once el sobrino de Inocencio VIII era elegido papa por unanimidad. Rodrigo Borja, venciendo al cardenal Giuliano della Rovere, se convertía en el papa Alejandro VI.

Ya desde los primeros meses de pontificado, Alejandro VI tuvo que ocupar sus días y las noches en el juego inacabable de los equilibrios italianos, en la seguridad de sus estados y en la afirmación de la propia autoridad sobre los barones romanos ${ }^{486}$.

Además de los barones italianos, algunos de sus enemigos reconocidos serían los reyes de Nápoles, los duques de Milán, la signoria de Florencia o la república veneciana, los franceses, y el nuevo poder castellano encarnado por los Reyes Católicos. Entre unos y

\footnotetext{
485 Joan F. Mira, Los Borgia. Familia y Mito, Valencia, Bromera, 2000, p. 51.

${ }^{486}$ Joan F. Mira, op. cit., p. 54.
} 
otros urdieron diferentes planes para imponer su control y su voluntad ante el nuevo papa no italiano $^{487}$.

El casamiento de Lucrecia de Borgia con Giovanni Sforza, primo de los duques de Milán, vino a significar una alianza con los estados del norte. Este matrimonio tuvo lugar el doce de junio de 1493 en el Vaticano, y se festejó con una gran celebración, bailes y un impresionante convite. Pompa que sin duda se contrapone a la huida que protagonizó el joven marido: la mañana del Viernes Santo de 1497, Giovnni Sforza, harto de aguantar los desprecios de la familia Borgia, montó a caballo y abandonó a su esposa. Tal vez asustada por las presiones del duque de Milán y del cardenal Ascanio Sforza, Lucrecia también abandonó su casa y se refugió en el convento de clausura de San Sixto, del cual no quiso salir durante meses ${ }^{488}$. Lo cierto es que se alojó en el convento con la única protección de Pedro Calderón. Este fue un camarero del papa que gozaba de absoluta confianza para proteger a Lucrecia. Sin embargo, apareció flotando en las aguas del Tíber sin que nadie se preguntase nada sobre aquella misteriosa muerte. Al poco tiempo, Lucrecia abandonó el convento con un niño entre sus brazos. Esto contribuyó a gestar y acrecentar la leyenda negra de los Borgia. En especial sobre la figura de Lucrecia, la cual se pensaba que mantenía relaciones con su padre y con sus hermanos. No ayudaban mucho las bulas papales que el papa Alejandro VI emitió. La primera está fechada el diez de septiembre de $1501 \mathrm{y}$, en ella, se dice que el padre del bebe es el propio César Borgia, y "de mare ignota". Pero el mismo día se emite una segunda bula papal en donde se dice que el padre de la criatura es Alejandro VI ${ }^{489}$.

\footnotetext{
${ }^{487}$ Joan F. Mira, op. cit., pp. 51-58.

${ }^{488}$ Joan F. Mira, op. cit., p. 82.

489 Juan Antonio Cebrián, Los Borgia. Historia de una ambición, Madrid, Ed. Temas de Hoy, 2006, pp. 157-159.
} 
Su padre empleó mucho tiempo y esfuerzo en encontrarle un nuevo candidato. Tras mucho buscar, lo encuentra en el hermano de Sancha de Aragón, esposa de su hermano Juan. El afortunado fue Alfonso de Aragón, sobrino del rey Federico de Nápoles. El matrimonio fue muy bien recibido y significó un tiempo de felicidad para los esposos que en verdad se amaban. Sin embargo el verano de 1500 el duque de Bisceglie, es decir Alfonso de Aragón, aparece gravemente herido en las escaleras de la iglesia de san Pedro. La historia cuenta que el quince de julio de ese año regresaba a su palacio tras haber cenado en el Vaticano ${ }^{490}$, cuando fue atacado por unos mendigos. Curiosamente, al joven no le robaron nada, pero lo dejaron muy mal herido. Al poco tiempo falleció al cuidado de los médicos del Vaticano, lo cual consolidó la leyenda negra de los Borgia.

El complicado drama doméstico de los Borja empezaba a tomar proporciones absolutamente insólitas, y aún había de conocer episodios tan turbios y tan extraños que puedan dar pábulo a algunos de los capítulos más oscuros de la leyenda familiar. Los Borja del mito son también los Borja de los muertos en la familia ${ }^{491}$.

La figura de Lucrecia Borgia fue retomada por muchos escritores y pintores del siglo XIX para encarnar el arquetipo de la depravación femenina. Nació en 1480, en pleno Renacimiento, en donde el ambiente de la corrupción política es claramente palpable. Desde los dos años, fue apartada de su madre y criada a la sombra de su padre. Las obras literarias agrandaron de tal forma su figura que se la describe como una joven cándida y tremendamente hermosa. Haciéndose eco de la importancia de la descripción histórica, Huysmans la sitúa en la Italia corrompida de la época, de forma que su maldad vendría justificada por la corrupción que la rodeó desde niña. Se dice que todos sus matrimonios buscaban un interés político, marcado por las ambiciones del padre.

\footnotetext{
${ }^{490}$ Juan Antonio Cebrián, op. cit., pp. 182-185.

${ }^{491}$ Joan F. Mira, op. cit., p. 84.
} 
Por lo que corrió el rumor que la joven envenenaba a sus enemigos políticos, e incluso algunos afirmaban que Lucrecia llevaba un anillo bañado en arsénico.

Una de las obras pictóricas que mejor representa su crueldad es el cuadro Lucrecia Borgia de D. G. Rossetti, en donde la joven aparece lavándose las manos después de haberle administrado un veneno a su marido. Este cuadro recibió una gran influencia estructural de Sidonia von Bork de Sir Edward Burne-Jones. A través de sus tramas políticas, Lucrecia desarrolló todo un perfil de asesina. Esto le dio tanta fama que podríamos decir que durante todo el siglo XIX permaneció viva, y así fue como llegó hasta los oídos de Víctor Hugo, quien le escribió toda una obra.

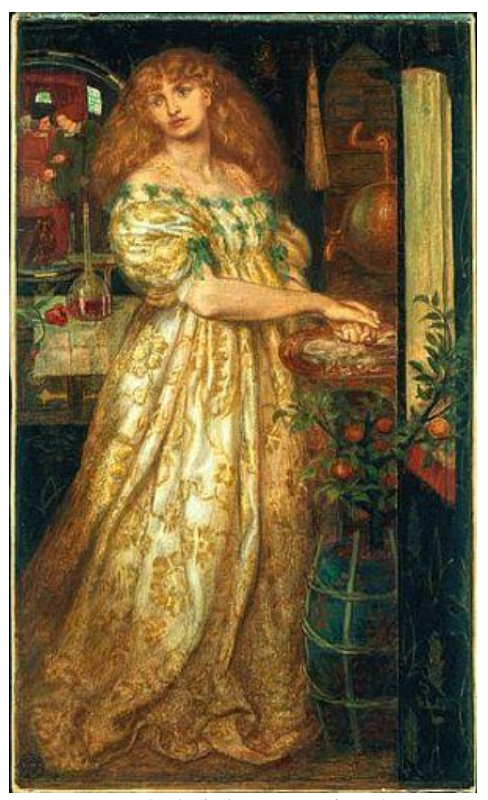

Dante Gabriel Rossetti (1861)

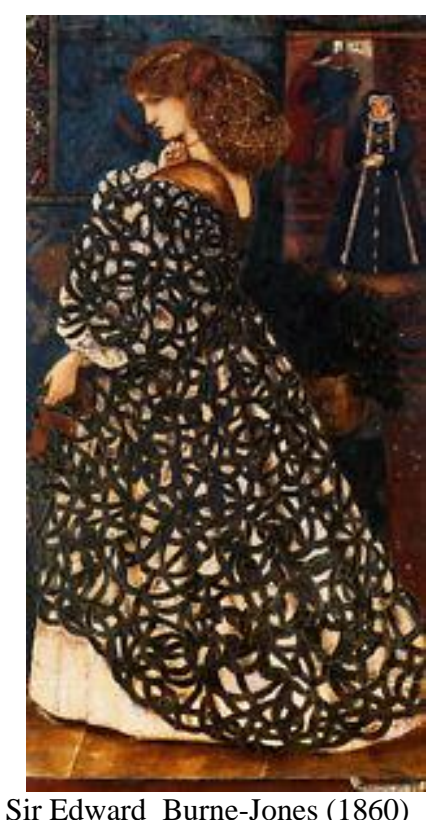

Sir Edward Burne-Jones (1860)

En 1833, Víctor Hugo publica su obra Lucrecia Borgia. El autor francés no quiso plasmar la vida de la joven sino, más bien, su mito. Con ello se perfila una tragedia que Felice Romani recoge para componer el libreto de la ópera de Dozinetti. Esta ópera fue estrenada en diciembre de 1834 en Milán bajo la producción del propio Víctor Hugo. Tuvo tanto éxito que se estrenó en varias ciudades. Sin embargo, tras el estreno en París en 1840, a Víctor Hugo se le prohibió financiar más producciones, y la obra se 
reescribió con el título de La Rinegata y los protagonistas fueron ubicados en Turquía. Por supuesto, no sólo podemos encontrar obras ficcionales alrededor de este personaje, sino también obras teóricas que dedicaron páginas a analizar la importancia de los elementos que habían llegado a caracterizar a este arquetipo ${ }^{492}$. Entre ellas encontramos las obras de Mario Praz y la de Patrick Bade ${ }^{493}$.

\subsubsection{4.- Venus}

En su origen, Venus no tenía los atributos propios de la femme fatale, pero su peculiar tratamiento a través de la historia del arte lo aproxima al mito objeto de nuestro estudio. Una de sus más tempranas manifestaciones para encarnar la fatalidad se dio en la ópera Tannhäuser de Richar Wagner ${ }^{494}$. La ópera se estrenó en Dresde en 1845 y tiene lugar en Turinga a comienzos del siglo XII. El joven trovador Tannhäuser se encuentra en el reino de Venus, llamado Venusberg. Allí, harto de amor y rodeado de ninfas, bacantes y faunos, añora el amor puro de la princesa Elisabetta, así que se propone regresar e invoca a María Salvadora para que le libere del reino. Una vez ante su amada, se organiza un certamen de canto, y pese a que participan los mejores trovadores de Alemania, la joven Elisabetta no tiene ninguna duda de que su amado saldrá vencedor. El premio para el afortunado será la propia mano de Elisabetta ${ }^{495}$.

\footnotetext{
${ }^{492}$ Erika Bornay, op. cit., p. 239.

${ }^{493}$ Patrick Blade, Femme Fatale. Images of evil and fascinating women, Nueva York, 1979, p. 13.

${ }^{494}$ Ópera en tres actos cuyo libreto y música fue compuesto por Richard Wagner. La obra es la fusión de dos leyendas alemanas: la del caballero Tannhuäser y la del concurso de canto del castillo de Wartburg. Ambas historias son contadas en el primer acto, y en el segundo acto, de forma independiente, se simboliza la lucha entre el amor divino de la Virgen María y el amor profano de la diosa Venus.

${ }^{495}$ Ricardo Mezzanotte, La ópera. Enciclopedia del Arte Lírico, Madrid, Aguilar, 1977, p. 10.
} 
Ahora bien, cuando llega el torneo, Tannhäuser no lo puede evitar y hace una alabanza al amor libre de Venus. Es entonces cuando la joven Elisabetta cae herida de amor, pues sabe que la pasión que el trovador siente por la diosa se interpondrá entre los dos y los conducirá irremediablemente a un amor trágico. Pero lo que nos interesa es que

\footnotetext{
Richard Wagner conocía muchas de estas fuentes, como por ejemplo la novela de Novalis Enrique Ofterdingen (1802), las narraciones Tannhäuser, Der Hörselberg, Der getreue Eckhart y Der Watburger Krieg de los cuentos de Jacob y Wilhelm Grimm (1816), la novela de Ludwig Tieck Der getreue Eckart un der Tannhäuser (1817), la narración de E.T.A. Hoffmann Der Kampt der Sänger (1819), la Sagenschatz des Türingerlandes (1835) de Ludwig Bechstein, y no podemos olvidar el poema irónico de Heine Der Tannhäuser $(1836 / 1837))^{, 496}$.
}

En todas ellas el amor libertino de Venus está muy presente, pues es la condena que acompañará al joven trovador hasta la muerte.

Esta ópera llegó a París en marzo de 1861, y obtuvo tanto éxito en la época que Baudelaire le escribió un ensayo apologético titulado Richard Wagner et Tannhaäuser (1863). Unos años después, A. Beardsley escribió una pequeña narración, en 1894, a la cual le adjuntó varios dibujos. Pero esta no fue la única relación entre pintura y literatura, también se dio el caso de que el cuadro de E. Burne-Jones titulado Laus Veneris fue resultado de la fuerte influencia que al pintor le habían causado los poemas de Swinburne ${ }^{497}$.

\footnotetext{
${ }^{496}$ Sigrid Neef, Ópera, Barcelona, Tandem, 2005, p. 772.

${ }^{497}$ Erika Bornay, op. cit., p. 158.
} 


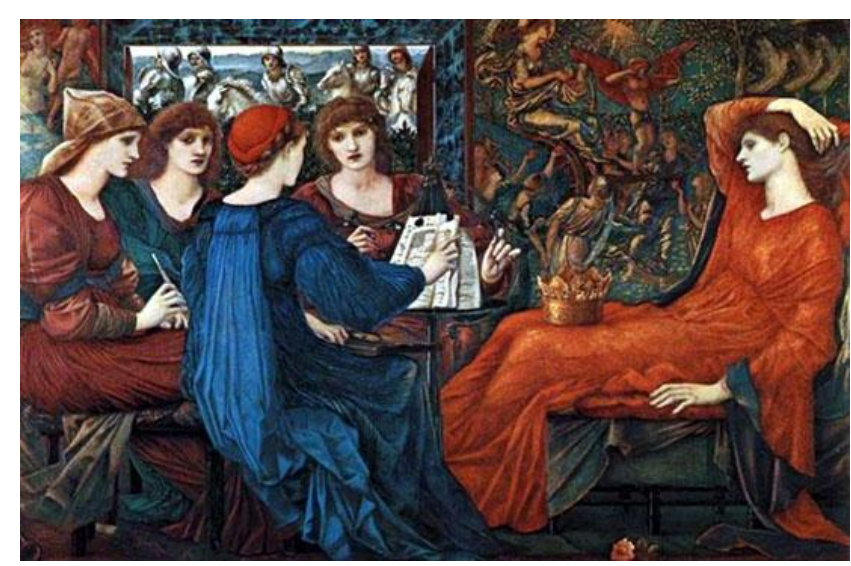

Edward Burnes-Jones (1873)

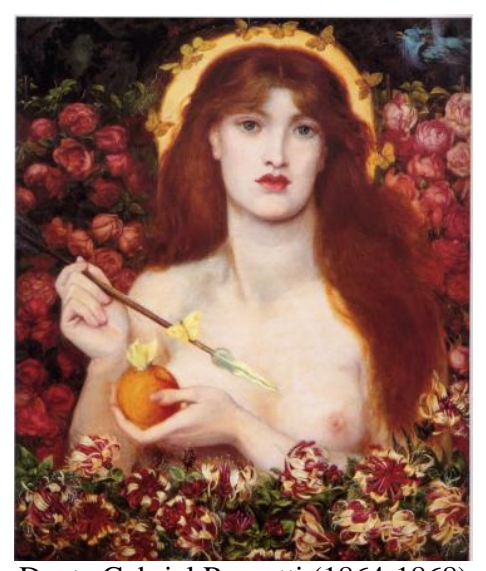

Dante Gabriel Rossetti (1864-1868)

El poeta inglés ejerció también una fuerte influencia sobre D.G. Rossetti, pues en su poesía reflejaba constantemente la mezcla de temas paganos, clásicos y cristianos, de ahí que nos haya llegado una Venus heterodoxa y algo viciada. Un ejemplo muy claro lo tenemos en Venus Verticordia (1864-1868), en donde encontramos una figura sincrética de Eva, de una Santa y, por supuesto, la misma Venus. Es una figura que responde a las convenciones victorianas del desnudo. Pero parece salir no de la espuma del mar, sino de entre las flores del paraíso. Las flores en este cuadro tienen un marcado significado erótico, ya que simbólicamente se escogen las madreselvas y las rosas. Además, la cabellera parece sacada de un poema puramente baudeleriano, en donde abunda la sensualidad femenina y la fuerza primigenia. Además, lleva la manzana. En este cuadro la fruta tiene una doble simbología: por un lado tenemos un reflejo de la cultura pagana como la de la manzana de la discordia en el juicio de Paris, y el reflejo del cristianismo cuando se evoca el fruto prohibido como reflejo de la tentación del demonio. Algo curioso es el dardo que también lleva en las manos y con el que hiere a los hombres ${ }^{498}$.

\footnotetext{
${ }^{498}$ Erika Bornay, op. cit., p. 161.
} 


\subsubsection{5.- Astarte Syriaca}

Astarte Syriaca es una figura femenina propia de la mitología asirio-babilónica, que también fue conocida como Ishtar. Tomó muchos rasgos de Afrodita, la cual en Grecia no sólo representaba el amor y el placer, sino también la crueldad de la guerra. Astarte fue la hermosa reina del mundo infernal, y se la veneraba por medio de la prostitución sagrada. El culto a esta diosa penetró en varias esferas del pueblo de Israel; incluso en El libro de los Reyes se menciona que Salomón también sucumbió a ella.

Salomón amó a muchas mujeres extranjeras, además de la hija de Faraón, moabitas, ammonitas, edomitas, sidonias, hititas, de los pueblos de los que dijo Yahvéh a los hijos de Israel: "No os uniréis a ellas y ellas no se unirán a vosotros, pues de seguro arrastrarán vuestro corazón tras sus dioses", pero Salomón se apegó a ellas por amor; tuvo setecientas mujeres con rango de princesas y trescientas concubinas. En la ancianidad de Salomón sus mujeres inclinaron su corazón tras otros dioses, y su corazón no fue por entero de Yahvéh su Dios, como el corazón de David su padre. Salomón se fue tras Astarté, diosa de los sidonios, y tras de Milkom, monstruo abominable de los ammonitas. Salomón hizo lo malo a los ojos de Yahvéh, y no siguió plenamente con Yahvéh como David su padre. Entonces edificó Salomón un altar a Kemóš, monstruo abominable de Moab, sobre el monte que está frente a Jerusalén, y a Milkom, dios de los ammonitas. Lo mismo hizo con todas sus mujeres extranjeras que quemaban incienso y sacrificaban a sus dioses ${ }^{499}$.

Posteriormente, en el siglo XVIII Sebastiano Conca escribe La idolatría de Salomón. Astarte se caracterizaba por su irritabilidad y su carácter violento, pero aún así lograba embelesar a los hombres provocando sus instintos más bestiales, y retenía a sus amantes durante una hora, tiempo más que suficiente para fulminarlos con su funesto amor. Creo que es interesante destacar dos imágenes de esta deidad.

\footnotetext{
${ }^{499}$ Salomón, El libro de los Reyes, Libro IV, 11: 1-8.
} 


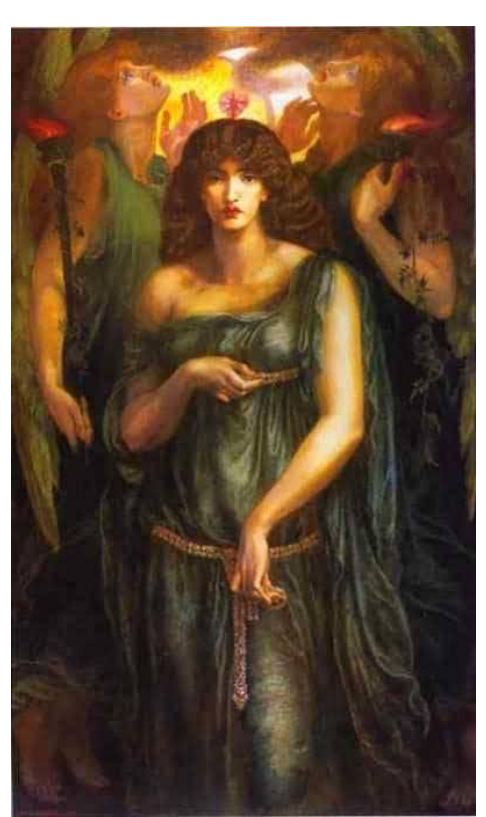

Dante Gabriel Rossetti (1877)

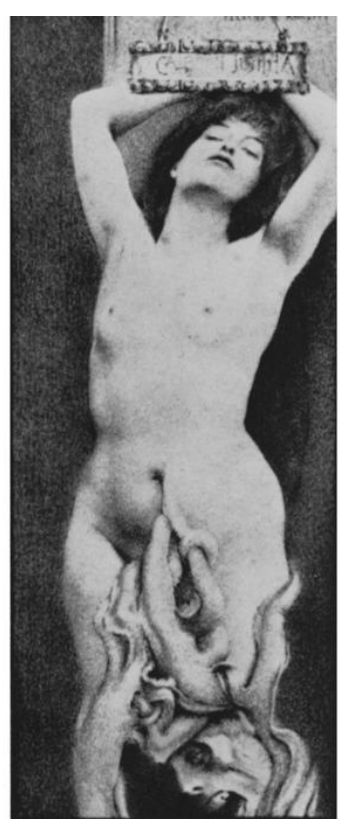

Fernand Khnopff (1888)

Una sería la Atarté Syriaca de D.G. Rossetti, (1877), la cual, situada en el submundo coloca las manos a la manera de Venus púdica. Dada la oscuridad del más allá surge la necesidad de alumbrarla con antorchas, de ahí la apertura de luz que hay en el fondo. De este modo su relación con Afrodita es evidente, pero también se hace evidente en el soneto que M. Henderson escribió para la obra de Rossetti:

Mystery lo! betwixt the Sun and Moon Asterté of

The Syrians: Venus Queen Ere Aphrodite was ${ }^{500}$.

La otra imagen de Isthar es de Fernando Khnopff y data de 1888. Se trata de una imagen terrorífica que hizo servir de portada para el libro de Isthar de Josephin Pélada $(1888)^{501}$. La imagen muestra a una mujer encadenada y con expresión de éxtasis. Es

\footnotetext{
${ }^{500}$ Erika Bornay, op. cit., p. 168. Traducción: "He aquí un misterio! Entre el Sol y la luna de Astarte/ Los sirios: Venus Afrodita era la reina de Ere".

${ }^{501}$ Escritor y ocultista francés que nació en 1858 y murió en 1918. Perteneció a la orden de la Roxe Croix y en 1888 publicó su obra más famosa, Isthar. Esta línea ocultista, que ayuda a aunar sexualidad y divinidad, es la que heredaron muchos de los autores de la ciencia ficción actual; tal es el caso de H. G. Giger.
} 
una joven aprisionada por unos tentáculos fálicos. Lo que desconcierta un poco de la imagen es que no sé sabe si los tentáculos mutilan las piernas de la joven o forman parte de ella. De todos modos, esta obra es un claro ejemplo de la imagen que mostrará la mujer en la novela de terror, pues simbólicamente representará la maldad, el pecado y la muerte como castigo ${ }^{502}$.

\subsubsection{6.- Proserpina}

Finalizaremos este apartado con Proserpina, la antigua diosa romana de los infiernos ${ }^{503}$. Cuenta la mitología que Plutón, hermano de Zeus y dios del submundo, se ve alcanzado por las flechas del caprichoso Cupido. Es entonces cuando se enamora de Proserpina, una joven mortal a la que decide secuestrar y llevársela consigo al reino del Hades.

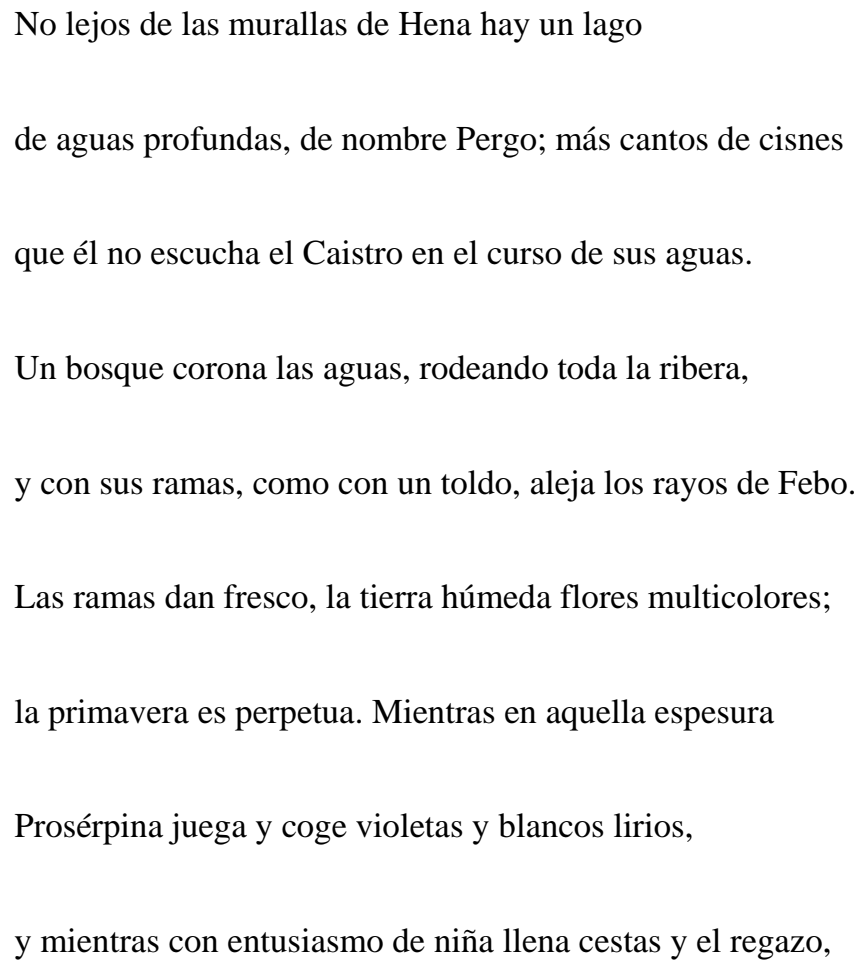

\footnotetext{
${ }^{502}$ Erika Bornay, op. cit., pp. 166-168.

${ }^{503}$ Es la equivalencia griega de Perséfone.
} 
y se esfuerza por superar en la tarea a sus amigas, verla,

amarla y raptarla Dis fue apenas un segundo; hasta tal punto

es de impaciente el amor. La diosa ${ }^{504}$, aterrada, llama

con gritos desesperados a su madre, a sus amigas, pero

más veces a su madre; se desgarró el vestido desde el cuello

y las flores recogidas se le cayeron de su túnica desceñida;

y tan grande era la inocencia de sus años infantiles que

incluso esta pérdida causó dolor a la doncella. El raptor

conduce su carro, apremia a sus caballos llamando a cada uno

por su nombre, y a lo largo de sus cuellos y crines sacude

unas riendas manchadas de negruzco orín, y atraviesa

lagos profundos y los pantanos de los Palicos, que huelen

a azufre y borbotean a través de hendiduras de la tierra,

y por donde los Baquíadas, raza originaria de Corinto, la entre dos mares,

fundaron sus murallas en medio de puertos desiguales ${ }^{505}$.

Démeter acude asustada al dios Zeus y le pide que traiga de vuelta a su hija. La desconsolada madre sabe que todos los recuerdos quedan borrados con el paso de la Laguna Estigia, y teme que, sin estar muerta, no guarde recuerdo alguno del mundo de los vivos. Zeus accede pero con la condición de que la joven no haya comido ningún fruto del mundo de las tinieblas. Pero ya es tarde. Con malas artes, Plutón seduce a

\footnotetext{
${ }^{504}$ La diosa Venus observa la escena, porque ha sido ella quien le ordena a su hijo Cupido que cargue sus flechas contra Plutón.

${ }^{505}$ Publio Ovidio Nasón, Obras completas, Madrid, Espasa, 2005, p. 1025.
} 
Proserpina y le ofrece una granada. La joven sólo come un pequeño grano de la granada. Pero esto ya es suficiente para impedir que vuelva con los vivos. Sin embargo, se le permitirá pasar una pequeña parte del año con su familia. Tal leyenda es retomada por D. G. Rossetti en Proserpina (1877).

Existe un fuerte paralelismo entre la manzana de Eva y la granada de Prosepina, pero no es tanto por el hecho de desobedecer, sino por la simbología de la seducción que conlleva el fruto en sí mismo. Ahora bien, en el cristianismo la manzana simboliza el fruto prohibido y, en consecuencia, el pecado. Pero en muchos pueblos la granada simbolizó el amor, la fertilidad y la prosperidad. En la mitología griega se cuenta que tiene esta simbología porque fue Afrodita quién la plantó por primera vez, de ahí que asuman parte de las características de su dueña. De ella se desprende que el matrimonio de Plutón y de Proserpina, aunque fuese fruto de un rapto, desemboca en una vida feliz para los conyugues ${ }^{506}$.

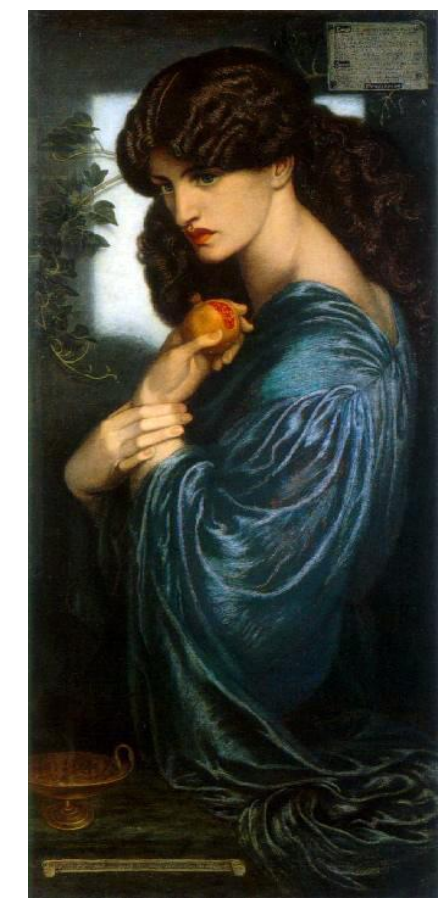

Dante Gabriel Rossetti (1877)

\footnotetext{
${ }^{506}$ Erika Bornay, op. cit., pp. 170-171.
} 


\subsection{2.- Mujeres causantes del infortunio de la humanidad}

Históricamente la imagen femenina ha simbolizado la extraña unión de dos polos completamente opuestos: Eros y Tánatos. La imagen que nos ha ocupado hasta ahora, no es más que el intento de equilibrar ambos campos, pero ha resultado prácticamente imposible, pues los artistas siempre acaban inclinándose por un argumento dramático que incita al hombre a cometer actos crueles, deshonestos y de los que probablemente se arrepienta, pues tienen consecuencias que perdurarán a lo largo de la historia.

La figura que nos ocupa a continuación es la de una mujer capaz de despertar el lado cruel del hombre. Es la mujer que no ejerce la maldad por sí misma, pero sí es capaz de hacer que otros la cometan por ella. De forma que con estas figuras se perfila una mujer malintencionada, cuyo objetivo final recae en la humanidad entera. En ellas la maldad es como un aura que influye en todos los ámbitos en donde ellas se mueven.

\subsubsection{1.- Eva}

Dijo luego Yahvéh Dios: "No es bueno que el hombre esté solo. Voy a hacerle una ayuda adecuada". Y Yahvéh Dios formó del suelo todos los animales del campo y todas las aves del cielo y los llevó ante el hombre para ver cómo los llamaba, y para que cada ser viviente tuviese el nombre que el hombre le diera. El hombre puso nombre a todos los ganados, a las aves del cielo y a todos los animales del campo, mas para el hombre no encontró una ayuda adecuada. Entonces Yahvéh Dios hizo caer un profundo sueño sobre el hombre, el cual se durmió. Y le quitó una de las costillas, rellenando el vacío con carne. De la costilla que Yahvéh Dios había tomado del hombre formó una mujer y la llevó ante el hombre. Entonces éste exclamó:

"Esta vez sí que es hueso de mis huesos

y carne de mi carne. 
Esta será llamada varona,

porque del varón ha sido tomada.”

Por eso deja el hombre a su padre y a su madre y se une a su mujer, y se hacen una sola carne.

Estaban ambos desnudos, el hombre y su mujer, pero no se avergonzaban uno del otro ${ }^{507}$.

El personaje femenino más importante en este apartado es la figura bíblica de Eva. Tal vez sea uno de los personajes más representados en el mundo artístico, pero la verdad es que pese al excesivo número de imágenes que podemos encontrar se trata de una mujer con un amplio abanico de posibilidades simbólicas. En ocasiones la encontraremos vinculada completamente a la idea bíblica del pecado, pero en otras ocasiones se realizan representaciones completamente desvinculadas de la religión.

Una imagen completamente paralela a la Biblia la encontramos en el libro Le Symbolisme en Europe (1898) y, más concretamente, en el apartado "La Renaissane Païenne", en donde León Thévenin afirma que Eva, en realidad, es un símbolo del mundo pagano, pues representa el mundo de la naturaleza y el mundo de los sentidos ${ }^{508}$. La idea de que el cuerpo femenino está ligado a la naturaleza ayuda a potenciar la visión de caos y de desorden que concluyen en la imagen cristiana del pecado. Pero no debemos fijarnos sólo en el cristianismo, ya que muchas han sido las religiones que sitúan el problema en el interior de la mujer. Es decir, que el pecado es interno, no externo. Por lo tanto muchas de las representaciones de la serpiente son entendidas

\footnotetext{
${ }^{507}$ Génesis, 2: 18-25.

${ }^{508}$ Erika Bornay, op. cit., p. 183.
} 
como una extrapolación del problema que la mujer tiene dentro ${ }^{509}$. No sería nada externo a ella.

Camille Paglia afirma que antaño la menstruación se llamaba "la maldición". Con este nombre se buscaba recordar el pecado cometido por la mujer que causó la expulsión directa del Paraíso y el castigo eterno de parir con dolor. Cada mes supone una nueva derrota de la voluntad femenina, y la sangre simboliza la mancha del pecado original. Antiguamente había un sinfín de tabús alrededor de la mujer menstruante; todavía hoy en día las judías ortodoxas se purifican de la menstruación con el mikvech, el baño ritual. Las mujeres siempre han cargado con el peso simbólico de las imperfecciones de los hombres, y todos los meses se enfrentan ante el mismo abismo del tiempo y del ser. Un abismo que se encuentra contenido en su propio cuerpo. Esta imagen del abismo la vemos completamente analizada en La Venus mecánica de Díaz-Fernández. Este se aprecia como un espacio psicológico que toma fuerza para, simbólicamente, ahogar y aplastar a las mujeres. La protagonista de La Venus mecánica lo exterioriza por primera vez al bajar a una mina:

Obdulia comenzó a sentir un estorbo en el pecho y un deseo urgente de abrir los ojos y la boca y de aspirar aire y luz. Le parecía que el universo entero la aplastaba y que pronto se encontraría rodeada de las tinieblas y el silencio eternos. Pensó que estaba enterrada viva entre aquellos hombres que se agitaban como espectros en el subsuelo de un paisaje hostil. Quiso contenerse, pero no pudo:

Quiero subir. Me hace daño esto.

Quedan otras dos capas. Cuestión de un cuarto de hora.

De ningún modo. Me asfixio aquí.

\footnotetext{
${ }^{509}$ Camille Paglia, op. cit. pp. 38-39.
} 
Cuando Obdulia se encontró arriba indemne, creyó reobrarse a sí misma. ¡Oh, que delicia! Estaba otra vez ilesa y libre, cerca de los caminos ligeros, de los vientos flexibles y de la luz radiante y total. Mientras se quitaba el "mono" de mahón y volvía a ponerse el fino abrigo gris pensó: "Yo también he bajado unos minutos al infierno, un infierno helado y negro situado, como el otro, en el centro de la tierra". ¿Qué género de culpa purgaban aquellos hombres, cuya existencia transcurría en la sepultura de la mina $?^{510}$

La mina, o el abismo interior al que la protagonista hace referencia, es un espacio que ya ha recorrido anteriormente para expiar sus culpas, sus pecados de maniquí que la llevan a abortar. Díaz-Fernández abordó con la máxima naturalidad posible el tema de las Evas Futuras. Estas no eran más que mujeres socialmente automáticas diseñadas a partir de las necesidades varoniles. Sin embargo, al igual que en todo Pigmalión resultó que tenían pensamientos, sentimientos, y que sus señores no podían hacer lo que querían con ellas.

Yo Venus mecánica, maniquí humano, transformista de hotel, tengo también mi traje favorito, mi elegancia de muchacha que sabe vestir para la calle, para el teatro y para el "te dansant". Conozco el color que arrastra a los hombres y el que impresiona a las mujeres. Finjo que voy a las carreras, que he de cenar fuera de casa o que salgo de compras por la mañana, después de las doce, bajo el arco de cristal de los barrenderos. Soy una actriz de actitudes, una pobre actriz de trapo, que no puede siquiera llevarse las manos al corazón para hacer más patético el verso que dicta el apuntador.

Odio esa asamblea de pequeñas burguesas y ese escenario que tiene un biombo y unos cofres abiertos. Pequeñas burguesas que carecen de imaginación, miden el pecado por los centímetros de tela y no conocen la gracia del escorzo ni el valor del movimiento. Cuando compran un traje, yo le lloro como una cosa mía que ha de quedarse para siempre sobre un cuerpo casto, bajo la imponente vigilancia de los padres jesuitas. Me horroriza sobremanera la vigilancia de esos vestidos que no han de sentir nunca la violencia sacudida ni la impaciente desgarradura.

\footnotetext{
${ }^{510}$ José Díaz-Fernández, La Venus mecánica, Madrid, Moreno-Avila, 1989, p. 95.
} 
Yo, Venus mecánica, maniquí humano, sé bien en qué consiste la gracia de vestirse. Tengo un alma emboscada en mi figura, un alma que late en cada uno de mis pasos, mientras cruzo lentamente el cuarto del hotel. Vosotras burguesas, no tenéis esa juventud insolente, este impudor humano, estas piernas voraces, este pecho alto y pequeño como un fruto. ¡Ah, cómo os odio, rebaño de pavas, cerditas grasientas de las provincias, buches rollizos de donde cuelga la medalla católica de la domesticidad ${ }^{511}$.

Dentro del tema de las 'Evas Futuras', Max Klinger realizó un ciclo de seis grabados con el título de Eva y el futuro (1880). En él Max nos ofrece a una mujer con una fuerza primigenia, una mujer capaz de dominar al hombre con su imperativo sexual. Sus tres primeros grabados se titulan Eva, El primer futuro y La serpiente. El primero se sitúa en el paraíso y Eva aparece pensativa, sentada junto a un estanque mientras Adán duerme al fondo de la escena. En El futuro se hace referencia a la fuerza demoníaca del apetito sexual, y este aparece simbólicamente representado por la imagen de un poderoso y vigilante tigre. En realidad se trata de una imagen que busca perfilar el deseo y la represión que sufre el mundo femenino, por lo que estamos ante una imagen fálica y patriarcal. En el grabado de La serpiente, mediante la presencia de la manzana, se hace eco del pecado bíblico, pero al mismo tiempo podemos observar cómo este no es el tema principal de la obra pictórica: realmente estamos ante el tópico de "vanitas". De este modo los grabados parecen un espacio dedicado sólo a la representación de la belleza femenina como símbolo de un poder innato. Un poder con el que puede provocar la perdición de los hombres y causar el pecado que llevará al mundo entero a la perdición ${ }^{512}$.

\footnotetext{
${ }^{511}$ José Díaz-Fernández, op. cit., pp. 78-79.

${ }^{512}$ Erika Bornay, op. cit., pp. 183-185.
} 

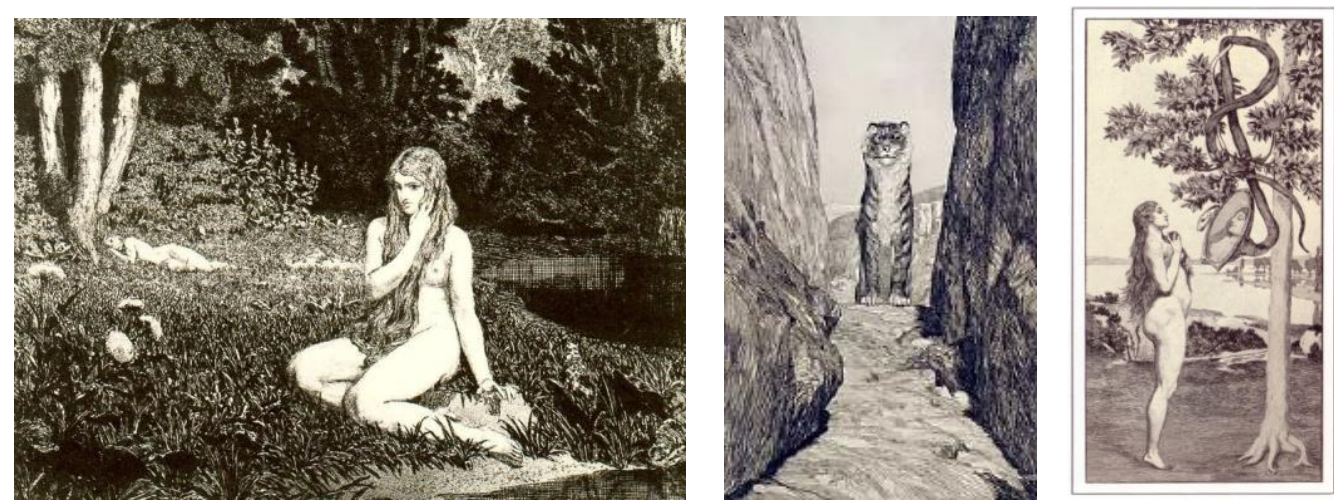

Max Klinger (Eva)

Max Kliger (El primer futuro) Max Kliger (La serpiente)

Otra imagen poderosamente erótica la encontramos en la Eva de Lucien Lévy-Dhurmer (1896). Este es un personaje al estilo de Baudelaire, donde apreciamos una imagen completamente desnuda que ayuda a hacer hincapié en la cabellera que cubre púdicamente a la mujer.

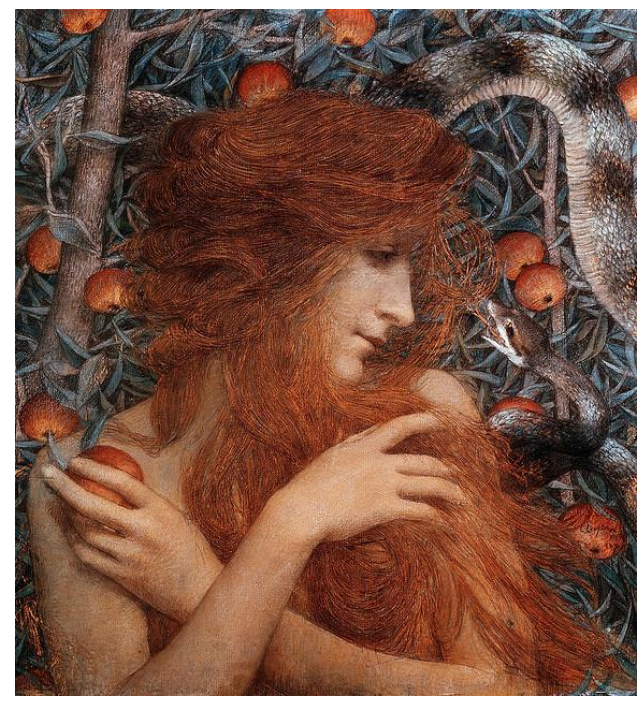

Lucien Lévy-Dhurmer (1896)

Junto a ella encontramos a un reptil, ante el cual no parece huir ni tampoco rechazarlo; todo lo contrario, Eva parece dialogar plácidamente con él. Con esta imagen se refuerza la influencia de las figuras femeninas prerrafaelistas de mirada profunda, al mismo tiempo que se evita toda alusión al texto bíblico. 
Edward Munch recurre en más de una ocasión a este tema y a la forma de presentación de la figura femenina. Un ejemplo muy claro lo encontramos en el cuadro de Adán y Eva (1908), donde el tema se aborda de una forma un tanto diferente. Si nos fijamos, la idea de la feminidad se inclina hacia una escena no erótica, pues, no existe asociación con el mal ni con el pecado ${ }^{513}$.

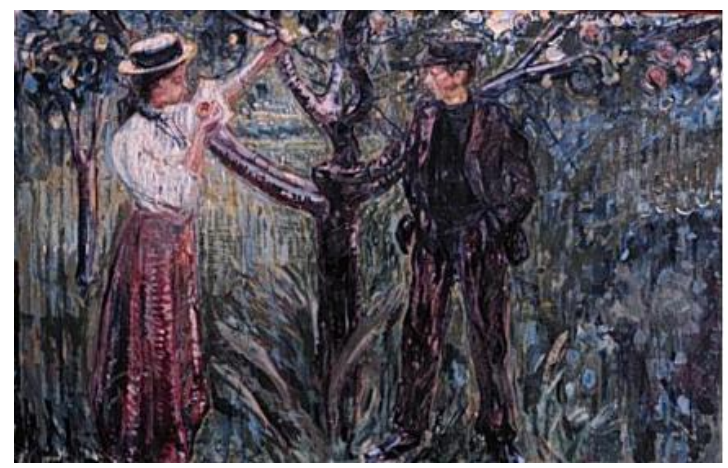

Edward Munch (1908)

\subsubsection{2.- Pandora}

En palabras de Hesíodo, en el origen del mundo la tierra producía sus frutos sin necesidad ni esfuerzo. Los alimentos existían en abundancia y la humanidad no conocía la enfermedad ni el dolor. Era un tiempo donde los hombres y los dioses mantenían una relación cordial. Se nos cuenta que se celebrara un banquete en Mecona, en cuya mesa se sentaban tanto hombres como dioses ${ }^{514}$. Probablemente, esta reunión simbolizaba el fin de la época de Cronos y daba pie a la nueva ley de Zeus. Este fue un último encuentro que ayudó a determinar cómo había de repartirse el alimento en adelante ${ }^{515}$.

Prometeo osó a tentar a Zeus, así que para el banquete preparó dos lotes con un gran buey que acaba de matar.

\footnotetext{
${ }^{513}$ Erika Bornay, op. cit., pp. 183185.

${ }^{514}$ Hesíodo, Teogonia; Trabajos de días; Escudo; Certamen, Madrid, Alianza, 2008, v. 535.

${ }^{515}$ G.S. Kirk, El mito, Barcelona, Paidos, 1970, p. 235-238.
} 
Uno contenía los mejores trozos de carne y las vísceras, pero se hallaba envuelto en la piel y el vientre del animal, mientras que el otro era un paquete muy atractivo, todo cubierto de grasa, que tanto les gustaba a los griegos, pero que en su interior sólo contenía huesos ${ }^{516}$.

Zeus eligió el segundo y, desde entonces, las ofrendas a los dioses sólo se componen de huesos. Tras este ardid de Prometeo, Zeus retiró a los hombres el fuego. Pero Prometeo lo volvió a robar, enfureciendo tanto a Zeus que acabó anunciando la llegada de un mal que alcanzaría a todos. De esta forma, y por expresa petición de Zeus, Hefesto construye con tierra a la primera mujer de la humanidad, Pandora, a la cual Atenea otorga a la belleza, Afrodita le da los encantos, Hermes pone en su corazón la maldad y la falacia, y por último Zeus le inspira la vida. Una vez creada, Pandora recibe una caja con todos los males y las miserias, y es enviada como regalo a Epimeteo, hermano de Prometeo. Ante la increíble belleza de la joven, Epimeteo olvida la promesa que le hizo a su hermano de no aceptar ningún regalo procedente de Zeus, y se casa con ella ${ }^{517}$.

Hombres y dioses la contemplan extasiados, pero se trata de una criatura un tanto paradójica, un "bello mal”, un "engaño total” (585-589): "de ella procede la perniciosa raza de las mujeres, que habitan, como una gran fuente de penas, entre los hombres, cabales compañeras no en la perniciosa pobreza, sino en la abundancia de riqueza $(591-593)^{518}$.

Finalmente, Pandora abre la caja y todos los males se extienden por el mundo, todos menos la Esperanza, que se quedó en el fondo de la caja. He aquí la verdadera objeción que pone a las mujeres la Teogonía: son zánganos, consumen la sustancia de los hombres, sin dar nada cambio. (...) Hesíodo termina diciendo que el hombre que tiene buena esposa, posee una mezcla de bien y mal.

\footnotetext{
${ }^{516}$ G.S. Kirk, op. cit., p. 236.

${ }^{517}$ Erika Bornay, op. cit., pp. 161-162.

${ }^{518}$ G.S. Kirk, op. cit., p. 238.
} 
Porque si bien es cierto que las mujeres son un lujo caro y engañoso que se impone a los esposos utilizando todos sus atractivos, también es cierto que ellas son las que cuidan a sus ancianos esposos y les dan descendencia. Por lo que conviene tenerlas cerca. (...) En resumen, (...) se trata de la invención de la mujer y de la gran maldición que supone para los hombres. Pues a partir de entonces los hombres supieron qué era el sufrimiento y el trabajo ${ }^{519}$.

E. Panofsky señala en su libro La Caja de Pandora (Madrid, 1975) que fueron los padres de la Iglesia quienes participaron en la difusión del mito con la clara intención de corroborar la doctrina del pecado original. Y al igual que Odilon Redon (1910), mantiene que existe un fuerte paralelismo que hace coincidir la figura de Eva y la de Pandora, pues ambas consiguen traer el infortunio a toda la humanidad ${ }^{520}$. Tanto Eva como Pandora no fueron temas muy recurrentes en el siglo XIX, pero sí podemos destacar cómo D. G. Rossetti pinta el cuadro Pandora (1869) con el rostro de Jane Morris $^{521}$, y le escribe un poema entre 1874 y 1878.

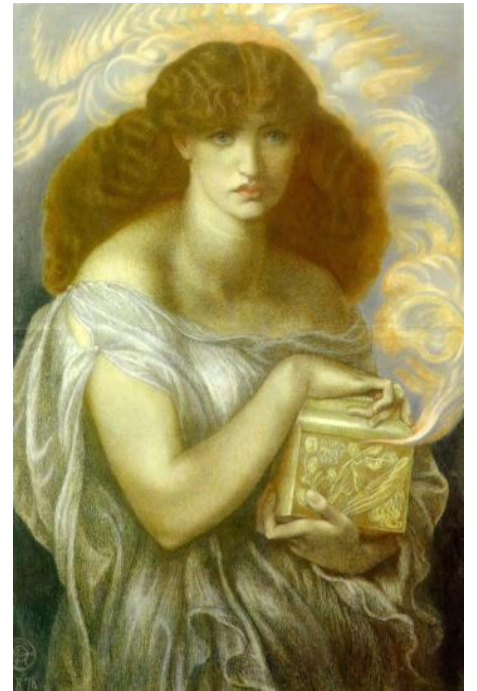

Dante Gabriel Rossetti (1869)

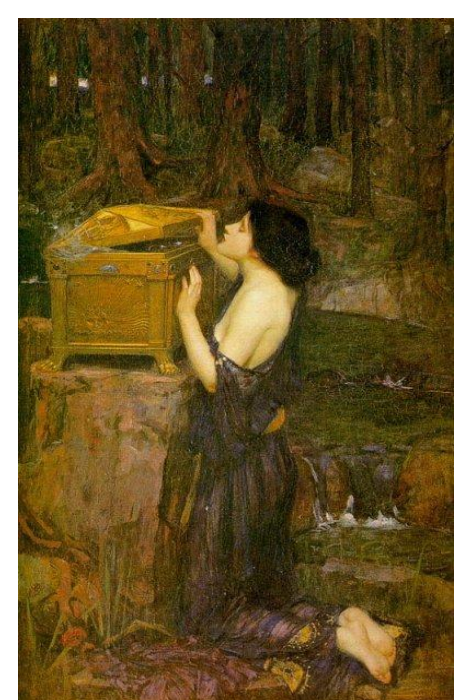

John William Waterhouse (1896)

\footnotetext{
${ }^{519}$ G.S. Kirk, op. cit., pp. 238-239.

${ }^{520}$ Erika Bornay, op. cit., pp. 161-162.

${ }^{521}$ Esposa y musa del poeta William Morris, pero también musa de D. G. Rossetti.
} 


\subsubsection{3. - Helena de Troya}

La Ilíada de Homero comienza in media res. Nos situamos en el décimo año de la guerra entre los griegos y los troyanos y, ante nosotros, se abre una escena de disputa entre Agamenón y Aquiles. Esta pequeña escena nos da a entender que el poeta no cuenta el origen de la guerra, porque todos los lectores conocen los entresijos de la historia $^{522}$.

Como es bien conocido Paris, hijo de Príamo y príncipe de Troya, rapta a Helena, esposa de Menelao. Al darse cuenta de la ausencia de su conyugue, Menelao, que es un príncipe griego, habla con su hermano Agamenón para pedirle el apoyo de las tropas griegas que él acaudilla. Al llegar los ejércitos griegos ante las murallas de Troya encuentran a las milicias troyanas esperándoles, y es entonces cuando ven cómo Paris se adelanta para desafiarlas.

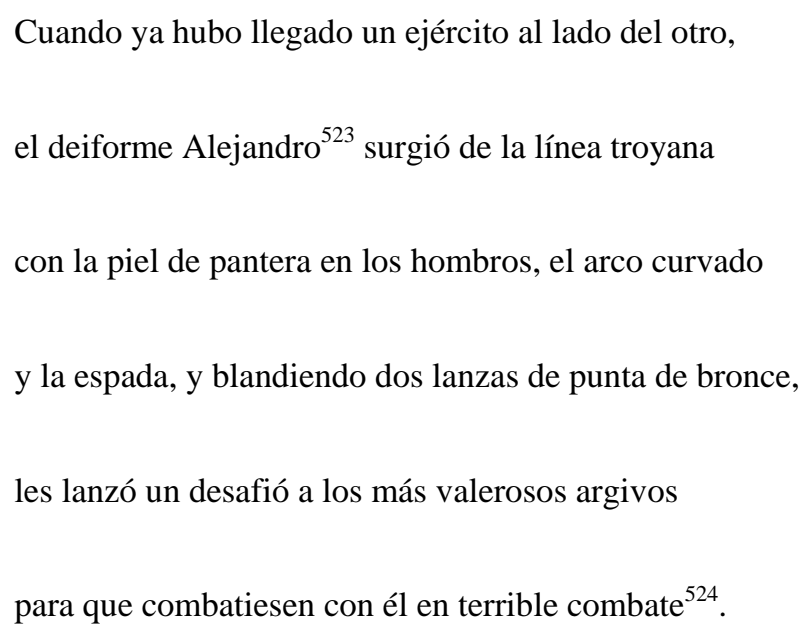

Sin embargo, al ver la furtiva mirada de Menelao, Paris da un paso atrás e intenta esconderse entre los soldados. Acto que el valiente Héctor no duda en recriminar:

\footnotetext{
${ }^{522}$ Homero, Ilíada, Barcelona, Planeta, 1980, p. XVII.

${ }^{523}$ Alejandro es otro de los nombres que toma Paris.

${ }^{524}$ Homero, op. cit., p. 52-53.
} 
¡Paris ruin! ¡El más bello galán, seductor, mujeriego!

¡Ojalá que no hubieras nacido o soltero murieses!

En verdad lo quisiera yo ahora, y a ti te valdría

más que ser la vergüenza y oprobio de todos los otros.

Los aqueos de largos cabellos se ríen de haberte

estimado un valiente campeón por tu apuesta figura

cuando no hay en tu pecho valor ni ninguna energía.

Mas si tu eres así, ¿cómo a tus compañeros reuniste

y surcaste los mares a bordo de cóncavas naves,

visitaste a extranjeros y a una mujer tan hermosa

te trajiste de tierras lejanas, esposa y cuñada

de guerreros, el mal de tu padre, tu villa y tu pueblo

irrisión para los enemigos y para ti infamia?

¿Cómo tú a Menelao, el amado por Ares, no aguardas?

¡Bien sabrías de qué varón tienes la esposa florida! ${ }^{525}$.

Esta es la primera vez que se apela a la irresponsabilidad de los amantes. Primero hacia la figura del temeroso Paris, y un poco más adelante hacia Helena. Esta última tiene lugar en las murallas de Troya, poco antes de que comience el enfrentamiento entre Menelao y Paris. Helena se encuentra tejiendo en su alcoba pero Iris, la mensajera, se aparece ante ella y la conduce a las murallas de Troya. Allí encuentra a todos los jefes troyanos hablando con el rey Príamo. Al verla le dicen al monarca:

\footnotetext{
${ }^{525}$ Homero, op. cit., pp. 53-54.
} 
- Mucho no es que troyanos y aqueos de grebas hermosas

sufran males tan grandes por una mujer como ésta

cuyo rostro es igual que el que tienen las diosas eternas.

Más, con todo, que aquí no se quede, que embarque y se vaya,

no sea plaga de todos nosotros y de nuestros hijos ${ }^{526}$.

Aunque en el poema Príamo se esfuerce por explicar que la culpa no es de Helena, sino de los dioses, la herida ya está hecha. Las palabras acusadoras, primero de Héctor y después de los jefes troyanos, sembraron la fatalidad ligada a la belleza de Helena.

Esta es la idea de destrucción y muerte a la que Helena siempre aparecerá asociada. Un ejemplo lo encontramos en una cita en el revés del lienzo Helena de Troya (1863) de D. G. Rossetti:

Helena de Troya, destructora de naves, destructora de ciudades, destructora de hombres (Esquilo en el verso 689 y siguiente de Agamenon) ${ }^{527}$.

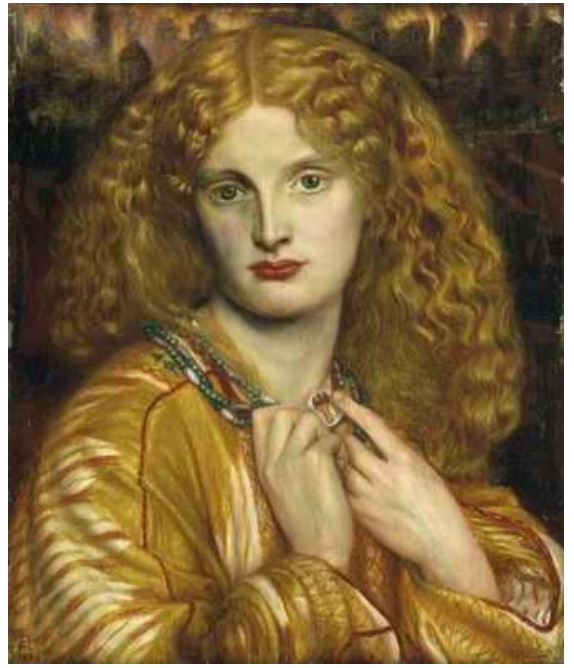

Helena de Troya (1863)

\footnotetext{
${ }^{526}$ Homero, op. cit., p. 57.

${ }^{527}$ Erika Bornay, op. cit., p. 177.
} 
Después, si centramos nuestra mirada en el rostro femenino, veremos que se trata de una faz simétrica, clásica, pero con una mirada de niña inflexible y cruel. Por supuesto, su poder reside en su belleza sensual y se manifiesta en su abundante cabellera rojiza, llena de energía. Rossetti muestra a una Helena sabedora de que ha ocasionado la guerra, y señala al espectador la antorcha dibujada en su medalla como símbolo del combate. Unos años más tarde nos encontraremos con Helena en los muros de Troya (1885) de Gustave Moreau. Se trata de una visión muy personal de la esposa del griego Menelao, pues aparece de pie, indiferente como una esfinge y vestida con una túnica de un color rojo sangriento. Es una mujer que parece impasible ante los muertos que se amontonan a sus pies ${ }^{528}$. Ary Renan, discípulo de Moreau, la define como "la más agrega encarnación del mal en la poesía de las razas arias (...)", una imagen "que avanza sobre el suelo ensangrentado" (...), "la diosa de la desgracia que sin saberlo envenena cuanto se aproxima, contempla o toca"529. Esta es la idea que G. Moreau transmite en el cuadro Helena ante la puerta Escea y que, del mismo modo, Huysmans ${ }^{530}$ lleva a la literatura al describirla:

Se alza frente a un horizonte terrible, salpicado de fósforo y rayado de sangre, ataviada con un vestido incrustado con piedras preciosas, como un relicario; (...) los grandes ojos están abiertos, fijos, con una expresión cataléptica ${ }^{531}$.

\footnotetext{
${ }^{528}$ Erika Bornay, op. cit., p. 178.

${ }^{529}$ Cabe decir que la femme fatale existe tanto en el espectador y en el analista como en el creador, lo que corrobora el gran ascendiente del mito.

${ }^{530}$ Camille Paglia, op. cit., p. 735.

${ }^{531}$ Erika Bornay, op. cit., p. 179.
} 


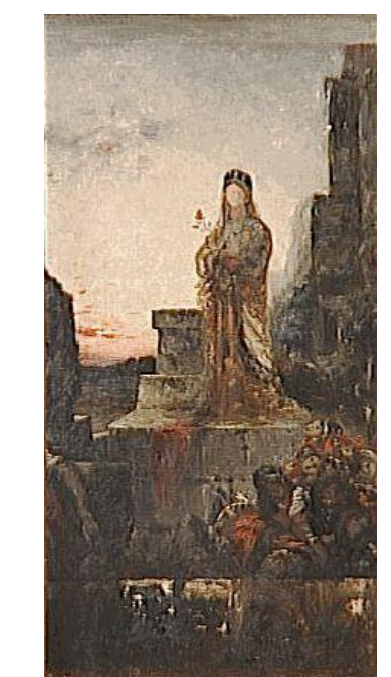

Helena en los muros de Troya (1885)

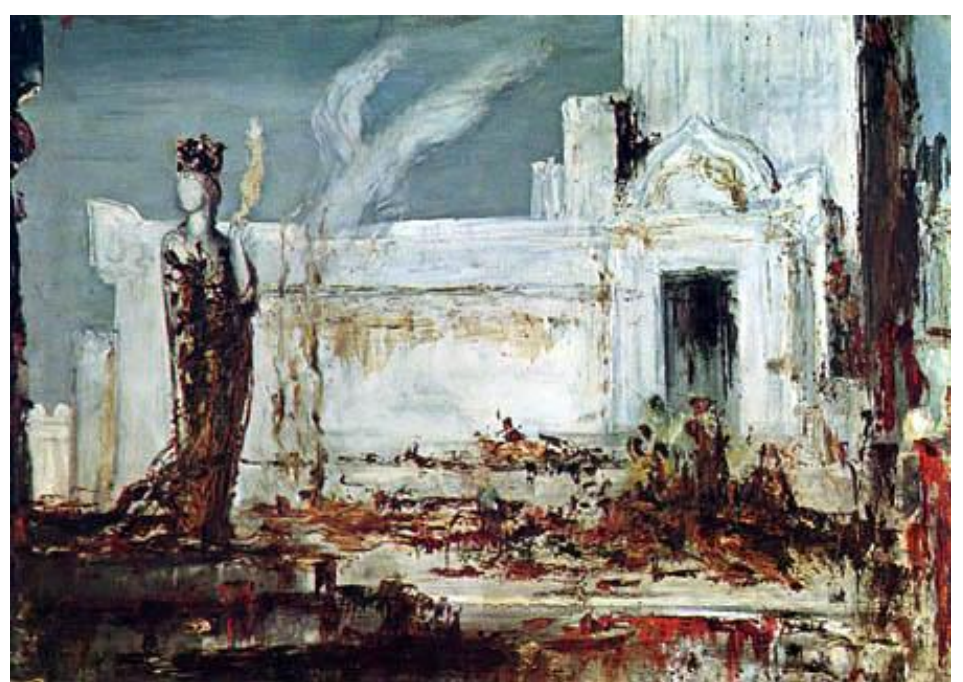

Helena ante la puerta Escea (1880)

Helena de Troya representa el amor que lleva irremediablemente al caos. Pero para Camille Paglia, la troyana sólo representa una pequeña pieza de un gran puzle que simbolizan las feminas occidentales. Paglia mantiene que el amor occidental ha sido caracterizado en el mundo artístico como un vaivén que oscila desde la atracción hasta la hostilidad. Así pues, tenemos figuras que muestran un abanico sin fin de mujeres ${ }^{532}$. Desde Safo ${ }^{533}$ hasta Helena de Troya, se busca representar la dureza de la feminidad occidental. Para ello, se señala la importancia del magnetismo erótico que las féminas emplean mediante diferentes máscaras, máscaras que buscan ocultar lo débiles que pueden llegar a ser las mujeres. Por ello la necesidad de ocultarse ante la máscara de la impasividad, de la dureza y de la frialdad. Esta es la máscara con la que Helena se cubre,

\footnotetext{
${ }^{532}$ Camille Paglia, op. cit., p. 78.

${ }^{533}$ Poetisa griega que vivió en la isla de Lesbos. Sus poemas tratan la pasión que se apodera del ser humano cuando se enamora. Para ella lo más importante eran los sentimientos que se derivan a partir de ella, como los celos, el deseo, la nostalgia, la esperanza, la desesperanza... Uno de sus poemas más famosos fue "Oda a Afrodita". Existen varias leyendas sobre su persona, pero una de ellas versa que la joven se enamoró de Faón, un joven muy bello que se había enamorado de la diosa Afrodita. Safo, al saber que nunca será correspondida se suicida. El tema fue recuperado por Ovidio quien consiguió popularizarlo en su obra Heroínas.
} 
la misma que muchas féminas han utilizado para cubrir la explotación que han sufrido $^{534}$.

\subsection{3.- Mujeres capaces de llevar a un hombre a su propia perdición}

La mayoría de estas mujeres representan el egoísmo y la avaricia en exceso. Estos son valores que ayudan a marcar la idea de la abundancia. En un principio, son sentimientos ligados al materialismo o a los bienes materiales; sin embargo, nuestras protagonistas desplazarán estos valores hacia la figura del varón. Ahora, son las mujeres las que tratan a los hombres como objetos que desean poseer y dominar. En el apartado anterior hemos visto cómo algunas mujeres son capaces de causar el infortunio a toda la humanidad; en esta ocasión nos centraremos en mujeres capaces de causar la perdición del hombre que desean poseer. Para ello, por supuesto, utilizaran todas sus armas de seducción posibles.

\subsubsection{1.- Salomé}

Es que Herodes era el que había enviado a prender a Juan y le había encadenado en la prisión por casusa de Herodías, la mujer de su hermano Filipo, con quien Herodes se había casado. Porque Juan decía a Herodes: "No te está permitido tener la mujer de tu hermano". Herodías le aborrecía y quería quitarle la vida, pero no podía, pues Herodes temía a Juan, sabiendo que era hombre justo y santo, y le protegía; y al oírle, quedaba muy perplejo, y le escuchaba con gusto.

Y llegó el día oportuno, cuando Herodes, en su cumpleaños, dio un banquete a sus magnates, a los tribunos y a los principales de Galilea. Entró la hija de la misma Herodías, danzó, y gustó mucho a Herodes y a los comensales. El rey, entonces, dijo a la muchacha: "Pídeme lo que

\footnotetext{
${ }^{534}$ Camille Paglia, op. cit., p. 383.
} 
quieras y te lo daré". Y le juró: "Te daré lo que me pidas, aunque sea la mitad de mi reino". Salió la muchacha y preguntó a su madre: “¿Qué voy a pedir?” Y ella le contestó: “La cabeza de Juan el Bautista". Entrando al punto apresuradamente adonde estaba el rey, le pidió: "Quiero que ahora mismo me des, en una bandeja, la cabeza de Juan el Bautista". El rey se llenó de tristeza, pero no quiso desairarla a causa del juramento y de los comensales. Y al instante mandó el rey a uno de su guardia con orden de traerle la cabeza de Juan. Se fue y le decapitó en la prisión y trajo su cabeza en una bandeja, y se la dio a la muchacha, y la muchacha se la dio a su madre ${ }^{535}$.

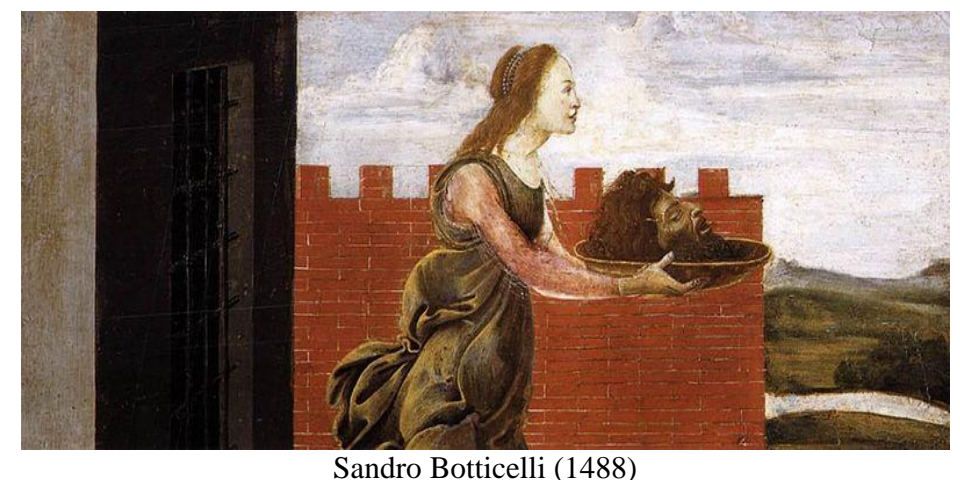

En el texto bíblico la diferencia entre Salomé y su madre, Herodías, es muy clara y no da lugar a confusión. Sin embargo, a lo largo de la historia el carácter sanguinario de la madre se desplaza hacia la joven. Esta alteración dio paso a diferentes tipos de representaciones, en donde los artistas plasmaron a Salomé como el sumun de las perversidades $^{536}$. Bajo este punto de vista podemos destacar los cuadros de Giotto, Lippi, Van Der Weyden, Cranach, Alonso Berruguete, Caravaggio, Reni, Rubens...

\footnotetext{
${ }^{535}$ Evangelio de Marcos, 6: 17-29.

${ }^{536}$ Erika Bornay, op. cit., pp. 188-189.
} 


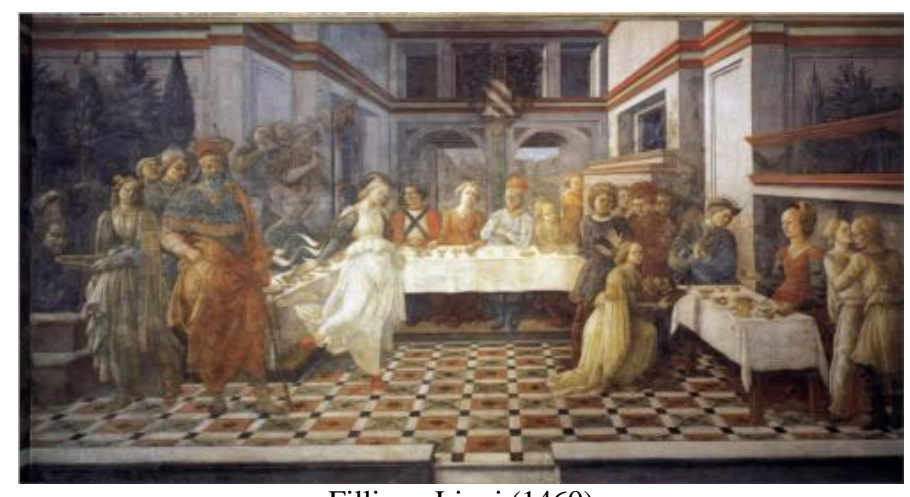

Fillippo Lippi (1460)

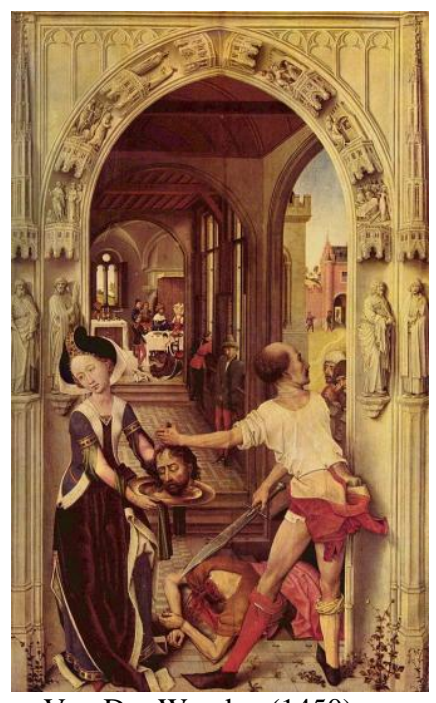

Van Der Weyden (1450)

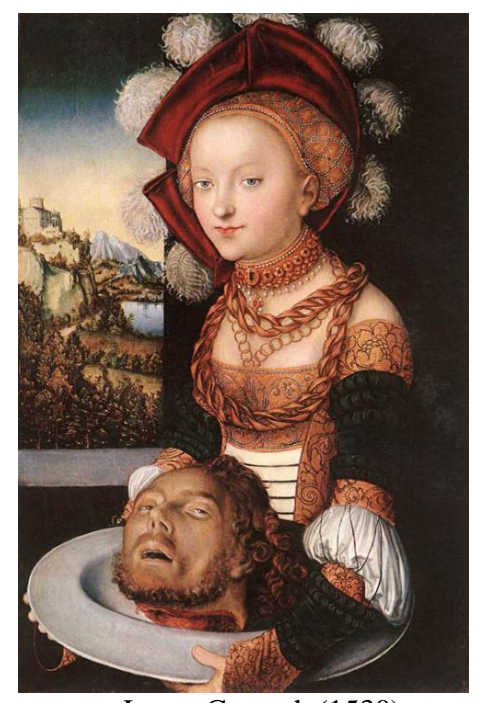

Lucas Cranach (1530)

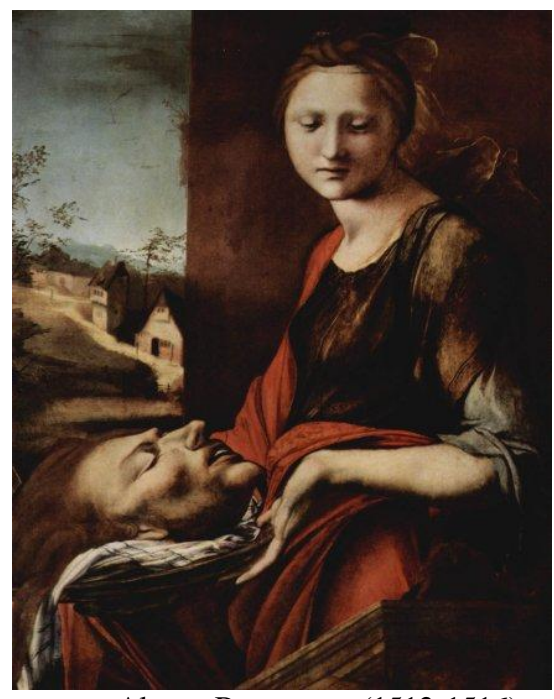

Alonso Berruguete (1512-1516)

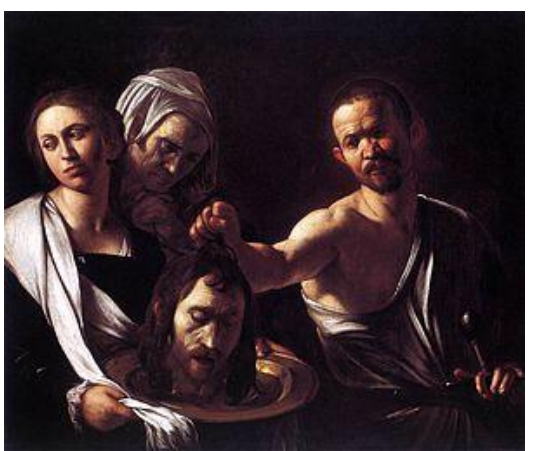

Caravaggio (1610)

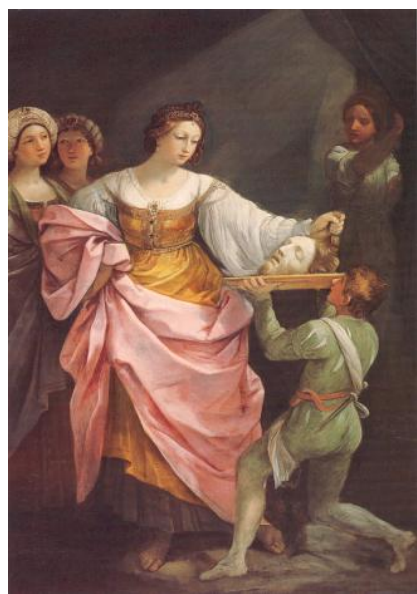

Guido Reni (1639-1642)

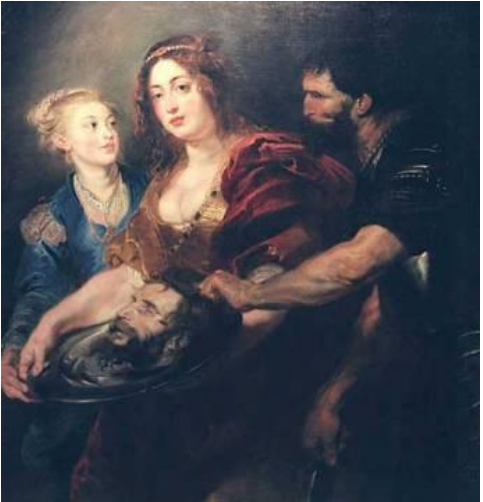

Peter Paul Rubens

En el campo literario, los nombres de Herodías y de Salomé aparecen fusionados.

Algunos escritores llegan a confundirlas y, en consecuencia, llaman Herodías a Salomé. 
Fuese como fuera, H. Heine dice que Herodías moría de amor por el Bautista y, por ello, llevaba su cabeza a todos $\operatorname{lados}^{537}$. Otra sobresaliente versión que podemos destacar sobre el personaje es la de Flaubert en Herodías. El autor francés se atreve a realizar una personal interpretación de ella: al principio presenta a una niña obediente a los deseos maternos, una inocente princesa oriental en un exótico espacio arquitectónico con azulejos arabescos y con una divinidad hindú al fondo del altar. Pero, pronto se metamorfosea en una mujer sensual al interpretar una danza casi orgiástica que despierta los más ardientes deseos de sus espectadores.

Sus pies pasaban uno delante del otro, al ritmo de la flauta y de un par de crótalos. Sus brazos arqueados llamaban a alguien que siempre huía. Le perseguía más ligera que una mariposa. Como una Psiquis curiosa, como un alma vagabunda, pareciendo dispuesta a echarse a volar. Los fúnebres sones de las gringas reemplazaron los crótalos. El abatimiento había sucedido a la esperanza. Sus actitudes expresaban suspiros, y toda su persona tal languidez que ya no se sabía si lloraba a un dios o se moría en su caricia. (...) Luego fueron los transportes del amor que quiere ser saciado. Bailó como las sacerdotisas de la india, como las nubias de las cataratas, como las bacantes de Lidia. Se volvía a todos los lados como una flor agitada por la tempestad. Los brillantes de sus orejas saltaban y la tela que le colgaba por la espalda refulgía en tornasoles. De sus brazos, de sus pies y de sus vestidos brotaban invisibles chispas que inflamaban a los hombres. Cantó un arpa. La multitud la acogió con aclamaciones. Sin doblar las rodillas, separando las piernas, se arqueó tanto que la barbilla le rozó el suelo. Y los nómadas acostumbrados a la abstinencia, los soldados de Roma expertos en libertinaje, los avaros publicanos, los viejos sacerdotes agriados por las disputas, todos, dilatando las aletas de la nariz, palpitaban de deseo ${ }^{538}$.

\footnotetext{
${ }^{537}$ Para más información consultar la obra de Heinrich Heine titulada Atta Troll.

${ }^{538}$ Erika Bornay, op. cit., pp. 190-192.
} 
Realmente, este fragmento es el complemento literario de las obras de Gustave Moreau. Justo un año antes de la aparición del texto de Flaubert, se hace público el cuadro Salomé danzante (1874-1876).

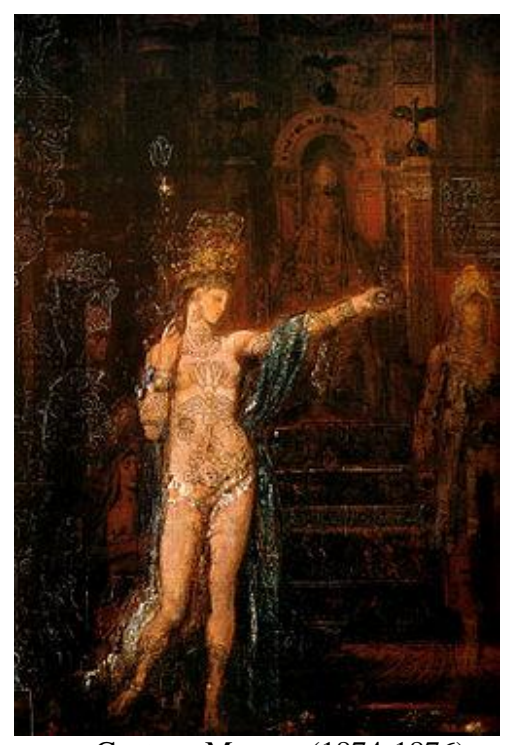

Gustave Moreau (1874-1876)

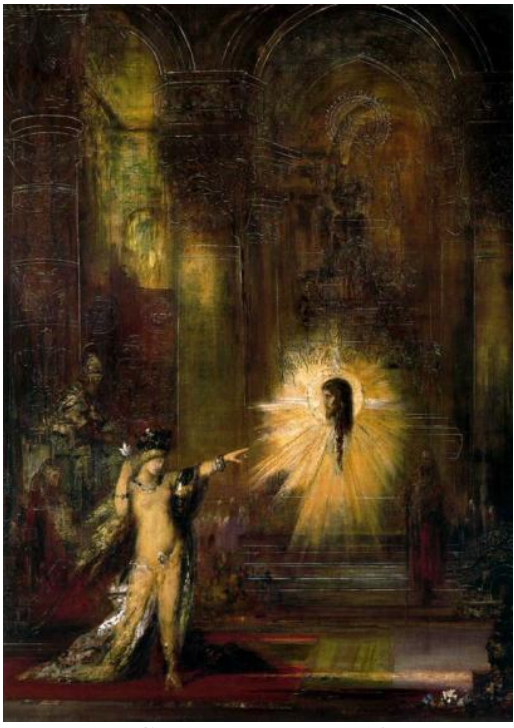

Gustave Moreau (1876)

Para poder diseñar el cuadro, Moreau investigó primero sobre la belleza satánica en los mitos primitivos, lo cual le llevó a convertir a este personaje en el punto central de su obra. Para ello, la hace pasar por diferentes países (Egipto, India, el París del siglo XIX...), épocas, estilos... etc. Estudió tratados arqueológicos y la función simbólica que ejercían las joyas y, sobre todo, ciertas piedras preciosas. Fruto de ese exhaustivo estudio es la túnica que cubre a Salomé y que simula un cuerpo tatuado. Al parecer Moreau intentó reflejar la moda adoptada por muchas prostitutas, e incluso por mujeres orientales $^{539}$. También se puede destacar el cuadro La aparición. Se trata de una famosa variante de este tema, en donde Salomé señala con espanto la cabeza de Juan el Bautista que, aureulada y sanguinolenta, se alza sobre las baldosas y la mira fijamente. Gustave Moreau condenó a todos aquellos que subordinaban sus ideales a la sexualidad, incluido

\footnotetext{
${ }^{539}$ Esta imagen simbólica es la que les sirvió a A. Corbin y de M. Callu para establecer la hipótesis de que la Salomé de Moreau podía estar representado a una prostituta mística.
} 
Salomé. Así pues, acaba otorgando a la figura bíblica un sentido moral que tradicionalmente se daba desde el Medievo.

En este sentido cabe destacar El clímax o El beso. Estas son dos ilustraciones que Aubrey Beardsley (1894) hizo especialmente como ilustración para la obra de Salomé de Oscar Wilde (1894).

(Un brazo negro, gigantesco, el brazo del VERDUGO, asoma por la cisterna, sosteniendo en una bandeja de plata la cabeza de JOKANAAN. Salomé se la arrebata; HERODES se tapa la cara con el manto. Los NAZARENOS caen de hinojos y rezan.)

SALOMÉ.- ¡Ah! ¡No querías dejarme que besara tu boca, Jokanaan!¡Bueno; ahora te la besaré! La mordisquearé con mis dientes cual si fuese un fruto maduro. Sí, ahora te besaré en la boca, Jokanaan. Ya te lo dije. ¿No te lo había dicho? ¡Sí, te lo había dicho! ¡Ah!¡Ah! Ahora te besaré en la boca... Pero, ¿por qué no me miras, Jokanaan? Tus ojos, antes tan fieros, tan llenos de arrogancia y desdén, tienes ahora cerrados. ¿Por qué los tienes cerrados? ¡Pero abre los ojos, levanta los párpados, Jokanaan! ¿Por qué no me miras? ¿Te infundo acaso miedo, Jokanaan, para que no quieras mirarme? Tampoco dice nada tu lengua, Jokanaan, esa víbora roja que escupía sobre mí su veneno. ¿Es raro, verdad? ¿Cómo será posible que esa víbora roja no se mueva ya? Tú proferías insultos contra mí, contra Salomé, la hija de Herodías, princesa de Judea. Muy bien. Pero aún estoy viva, al paso que tú estás muerto y tu cabeza, tu cabeza me pertenece. Puedo hacer de ella lo que quiera. Puedo arrojársela a los perros y a los pájaros del aire. Lo que dejen los perros, los pájaros del aire lo apurarán... ¡Ah! ¡Ah! Jokanaan, Jokanaan, tú fuiste el único hombre que amé; los demás me inspiran asco. En ti cifré mi ideal de belleza. Eras hermoso; tu cuerpo era una columna de marfil sobre basamentos de plata. Era un jardín lleno de palomas y florecido de azucenas de plata. Nada en el mundo era tan blanco como tu cuerpo. Nada en el mundo era tan negro como tus guedejas. En el mundo entero no había nada tan rojo como tu boca. Tu voz era como un incensario que difundía aromáticos sahumerios, y cuando te miraba, percibía yo una secreta música... (...) Te pusiste en los ojos la venda del que quiere ver a Dios. ¡Bueno! Pues ya has visto a tu Dios, Jokanaan; pero a mí, a mí nunca me viste. ¡Si me hubieras visto, me habrías amado! Yo siento sed de tu hermosura. Tengo hambre 
de tu cuerpo. Ni vino ni manzanas pueden apaciguar mi apetito... ¿Qué he de hacer ahora Jokanaan? Princesa, me desdeñaste; desfloraste mi alma virgen y en las venas de mi cuerpo casto infiltraste el fuego de la lascivia. ¡Ah! ¿Por qué no me miraste? ¡Si me hubieses mirado, me habrías amado! Harto lo sé, me habrías amado. Y el misterio del amor es más grande que el misterio de la muerte ${ }^{540} \ldots$

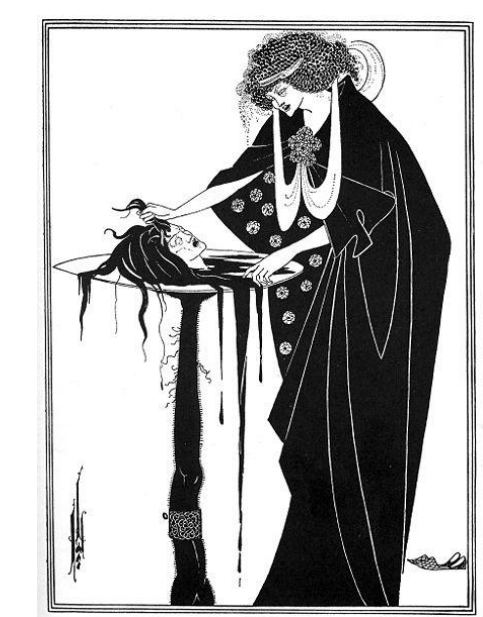

Aubrey Beardsley (El momento supremo)

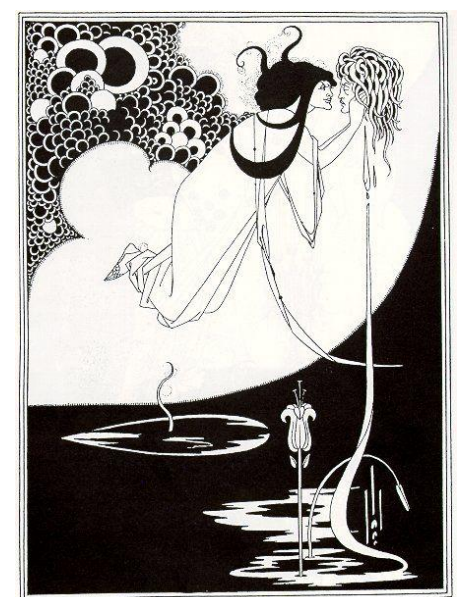

Aubrey Beardsley (El beso o el climax)

Es una pintura completamente opuesta a los excesos ornamentales de G. Moreau y consta de una línea más estilizada y arabesca. Es un grabado en blanco y negro que enfatiza la obra con fina y sutil ironía. Pero Salome sigue representándose como una mujer sádica. En esta obra vemos cómo Jokanaan se esfuerza por mantener los ojos firmemente cerrados, mientras Salomé levanta la cabeza de Juan el Bautista alumbrada por la luz de la luna. Pero no deja de llamar la atención la forma de cruz que se perfila mediante la larga gota de sangre que se desprende de la cabeza de El Bautista y de la túnica de Salomé. En cambio, en El momento supremo de Aubrey Beardsley, Salomé no es caracterizado como el objeto pasivo de la lujuria ni tampoco es un instrumento de venganza de su madre. En esta obra la joven se ve caracterizada como un agente activo de destrucción, una criatura agresiva y peligrosa a quien Jokanaan grita: “El mal entró

\footnotetext{
${ }^{540}$ Oscar Wilde, Salomé, Madrid, Biblioteca Nueva, 2000, pp. 59-60.
} 
en el mundo por la mujer. No me toquéis...". Ella, casi sin inmutarse, levanta unos mechones de la frente que se confunden con la sangre. Estamos ante un cuadro que se aproxima más a la sensibilidad artística del art nouveau que al simbolismo, porque, debido al uso de las tintas planas, se obtienen unas líneas altamente decorativas. Lo que se busca es alejarse de la seriedad y trascendencia que caracteriza al simbolismo. La seducción por esta Salome de fin de siglo llega hasta el límite de la necrofilia, tanto en la literatura, poesía, música, teatro como desde luego en la pintura. Otros pintores que también retratan a Salomé son Puvis de Chavannes, Henry Lévy, O. Redon, M. Klinger, G.A. Mossa, R. Holst... Pero, sin duda, los artistas que alcanzan el culmen de la necrofilia son Émile Fabry con su Salomé de 1892, la cual parece que arañe la cabeza del santo, y Lovis Corinth con su Salomé de 1900 que, muy enojada, le abre los ojos a Juan el Bautista para asegurarse de que está muerto ${ }^{541}$.

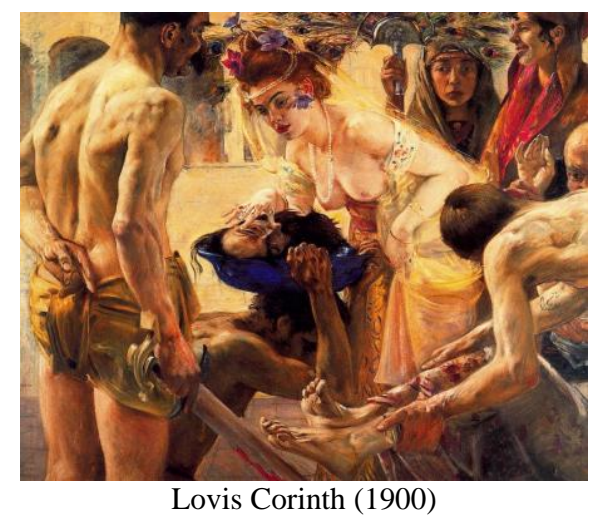

Otros pintores que inciden en la perversidad y en la necrofilia de la hija de Herodías son Lucien Lévy-Dhurmer, quién pintó su Salomé el mismo año en que se estrenó la obra teatral Salomé de Oscar Wilde en L'Oeuvre de París, en 1896. En este cuadro, Salomé abraza la cabeza de Juan Bautista mientras besa sus labios apasionadamente. La composición revela una fuerte influencia prerrafaelista, especialmente de Burne-Jones.

\footnotetext{
${ }^{541}$ Erika Bornay, op. cit., pp. 192-200.
} 
El pintor parece que se inspiró en la terrible narración que ofrece el poeta Jules Laforgue en Moralidades legendarias ${ }^{542}$.

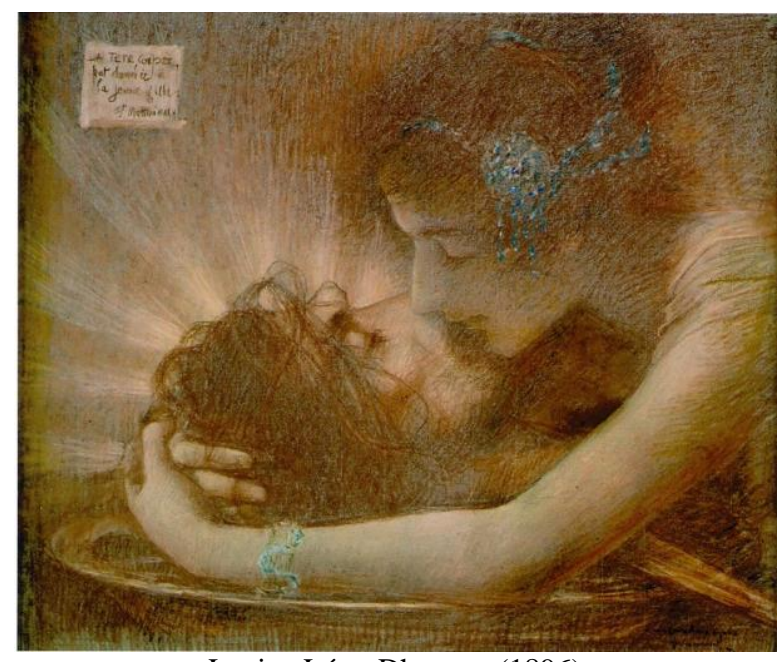

Lucien Lévy-Dhurmer (1896)

Georges Privat Livemont se atrevió a pintar a Salome en 1900-1910 completamente desnuda y tendida sensualmente sobre la piel de un oso. Aquí, la joven se muestra al espectador con su blanco cuerpo cubierto de joyas. Sin embargo, Fran von Bayros ofrece una imagen de Salomé completamente en deuda con Beardsley. Hablamos del cuadro Salomé con la cabeza de San Juan, en donde la joven ofrece sus pechos a la boca entreabierta del mártir. Por supuesto, también nos encontramos con la hipnotizante, ondulante y erótica imagen de Franz von Stuck en Salome de $1906^{543}$.

\footnotetext{
${ }^{542}$ Jules Laforgue fue considerado un poeta raro en su época. Trató temas propios del romanticismo, tales como la muerte y el decaimiento, pero los compuso mediante un impresionante uso del simbolismo irónico. También encabezó el uso del verso libre junto a Rimbaud, pero lo que hemos resaltado aquí no es precisamente un poemario, sino los cuentos en prosa que Laforgue publica con el título Moralidades legendarias en 1887.

${ }^{543}$ Erika Bornay, op. cit., pp. 200-201.
} 


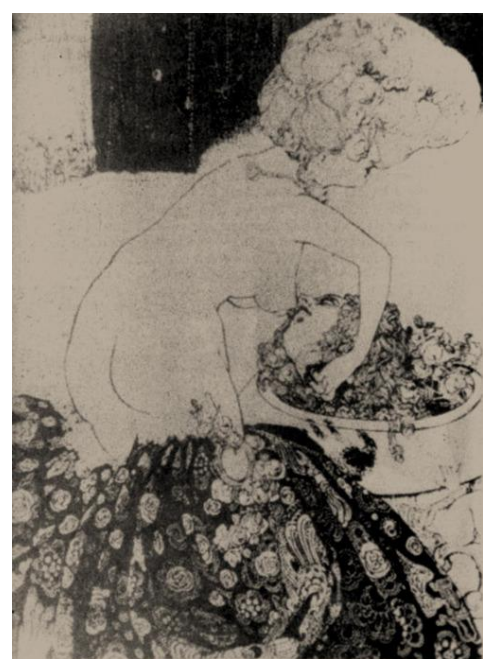

Franz von Bayros

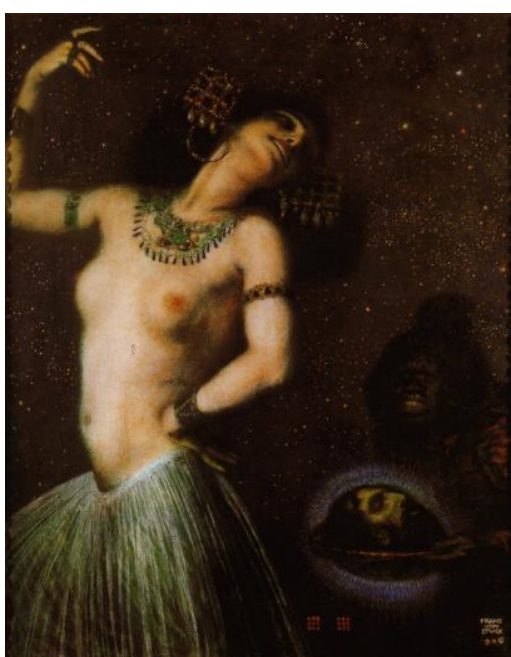

Franz von Stuck (1906)

Unos años antes, en 1901, nos encontramos con un cartel muy curioso hecho especialmente para un cabaret alemán. Este no podía ser otro que Los once verdugos de T.T. Heine. Es una imagen que cae en lo kitsch, pero provoca jocosas ironías y sarcasmos, pues, parece tratarse de una parodia humorística de la femme fatale: al mostrarla arrogante y cruel, no sólo se atreve a pedir la cabeza de Juan el Bautista, sino que pide un total de once cabezas, llegando a representar de forma divertida a los once demonios de la bandeja de plata. La sátira y la parodia que hacen de la femme fatale los prerrafaelistas aparecen muy temprano en Inglaterra, concretamente en la revista Punch. Además, cabe destacar cómo W. Hamilton recoge en su obra The Aesthetic Movement in England poemas humorísticos de principios de los años '80. No quisiera terminar este apartado sin nombrar la Salomé de Edward Munch (1903) cuya cabellera semeja una red y la de Beltrán Massés ${ }^{544}$.

\footnotetext{
${ }^{544}$ Erika Bornay, op. cit., pp. 202-203.
} 


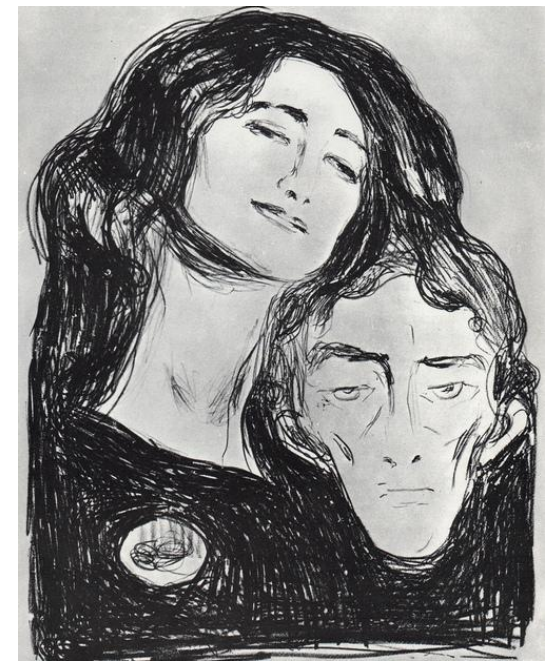

Edward Munch (1903)

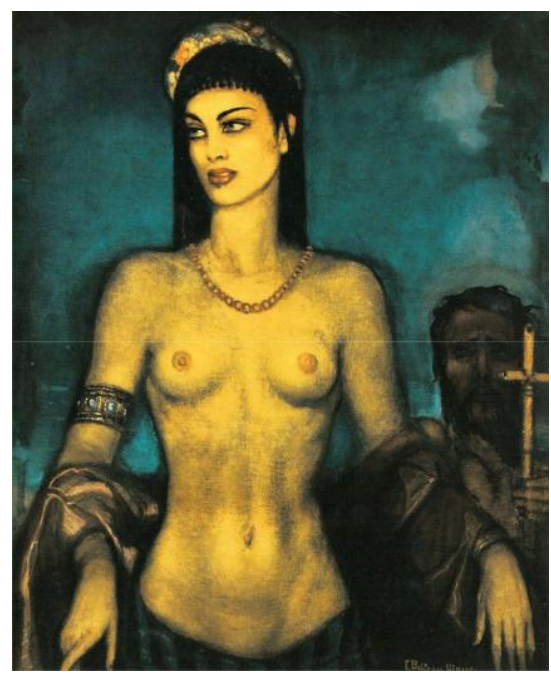

Federico Beltrán Massés (1932)

\subsubsection{2. - Judith}

Cuenta la Biblia que Judith era una joven viuda de gran templanza, de bellas facciones y de educación propia de su alto nivel social:

Judith llevaba ya tres años y cuatro meses viuda, viviendo en su casa. Se había hecho construir un aposento sobre el terrado de la casa, se había ceñido de saco y se vestía con vestidos de viuda; ayunaba durante toda su viudez, a excepción de los sábados y la vigilia de los sábados, los novilunios y sus vigilias, las solemnidades y los días de regocijo de la casa de Israel. Era muy bella y muy bien parecida. Su marido Manasés le había dejado oro y plata, siervos y siervas, ganados y campos, quedando ella como dueña, y no había nadie que pudiera decir de ella una palabra maliciosa, porque tenía un gran temor de Dios ${ }^{545}$.

El problema se desencadena cuando las tropas de Holofernes asedian Betulia. Es entonces cuando el pueblo de Israel comienza a pasar hambre. Judith, tras escuchar las amargas palabras de los moradores de Betulia, decide hablar con Jabrís y Jarmís, los ancianos de la ciudad, con quien comenta el problema. Después de algunas divagaciones Judith les responde:

\footnotetext{
545 Judith, 8; 4:8.
} 
Respondió Judith: "Escuchadme. Voy a hacer algo cuyo recuerdo se prolongará entre los hijos de nuestra raza de generación en generación. Estad esta noche a la puerta de la ciudad. Ya saldré con mi sierva y antes del plazo que os habéis fijado para entregar la ciudad a nuestros enemigos, visitará el Señor a Israel por mi mano. No intentéis averiguar lo que quiero hacer, pues, no lo diré hasta haberlo cumplido". Ozías y los jefes le dijeron: "Vete en paz y que el Señor dios te preceda para tomar venganza de nuestros enemigos”. Y dejando el aposento, regresaron a sus puestos ${ }^{546}$.

No se trata de un tema muy novedoso, pues ya fue muy tratado durante el Quatrocento y a nivel pictórico ${ }^{547}$. Pero algunos de estos cuadros fueron tratados con un sadismo visual evidente. Un ejemplo lo encontramos en Judith y Holofermes (1620-1630) de Artemisa Gentileschi, cuyo rostro aparece un increíble sentimiento de odio.
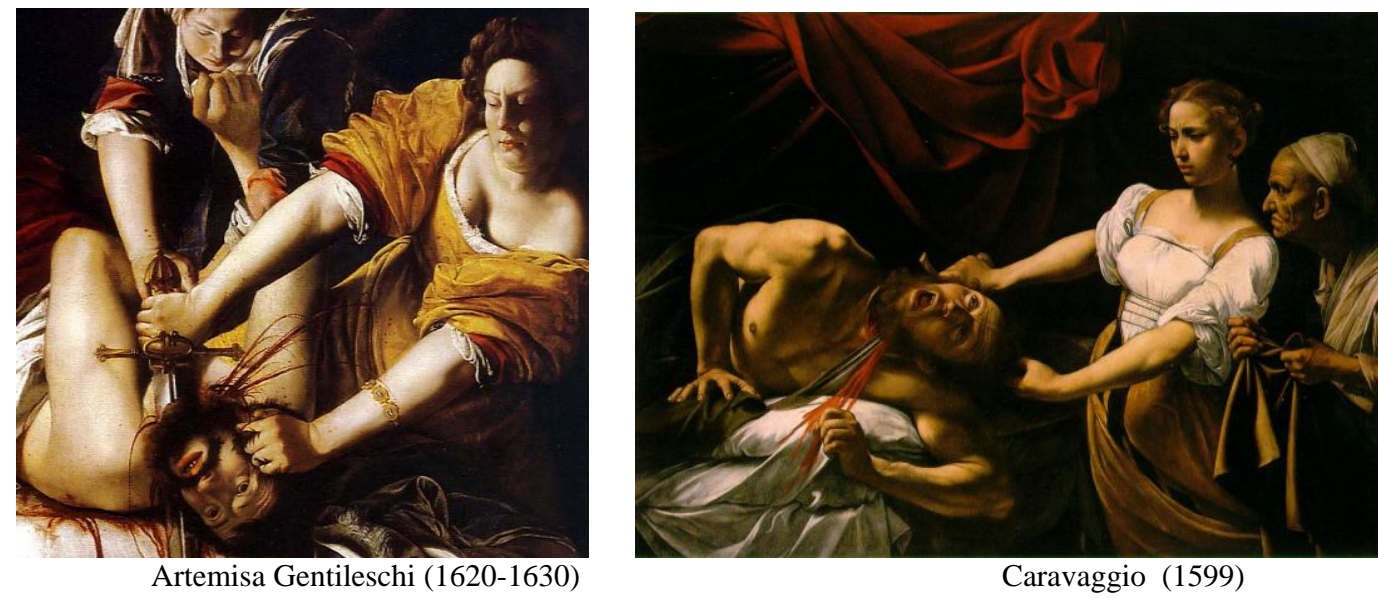

Caravaggio (1599)

Sus imposibles facciones contrastan con la versión de la heroína que pone en peligro su vida para salvar a su pueblo según la tradición. Una vez ya entrados en el siglo XVIII nos encontramos con la Judith moderna (1797-1798) de Francisco de Goya. Esta imagen, recogida en la serie de Caprichos, resulta impresionante, pues el espectador es capaz de observar cómo la venganza de Judith no va dirigida a un solo hombre sino a

\footnotetext{
${ }^{546}$ Judith, 8; 32:36.

${ }^{547}$ Fue llevado a la práctica pictórica por muchas figuras importantes, tales como Van Meckenem, Cranach, Mantegna, Botticelli, Caravaggio, Veronés, Tintoretto,...
} 
muchos. Realmente, se trata de una imagen en la que Judith se aleja de la visión tradicional. Pero, al mismo tiempo, se muestra como un antecedente directo del cuadro Judith de Lucas Cranach del siglo XVI, en donde Judith se metamorfosea en mujer fatal, y aparece como una ejecutora en la que el placer de la decapitación (entendida como la castración) supera al propio acto ${ }^{548}$.

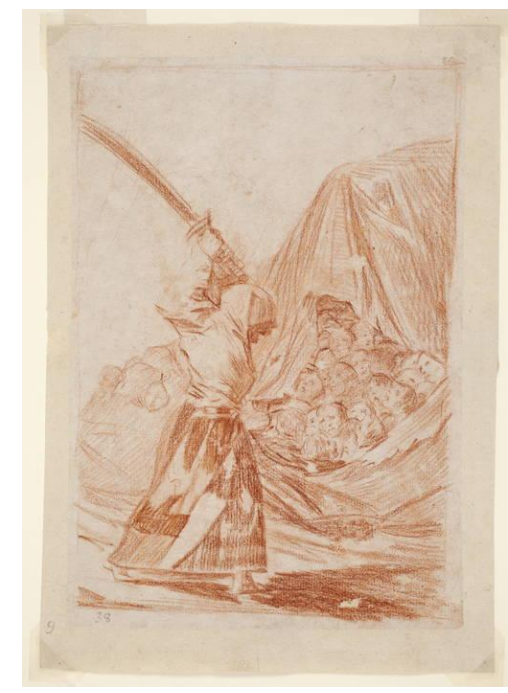

Francisco de Goya (1797-1978)

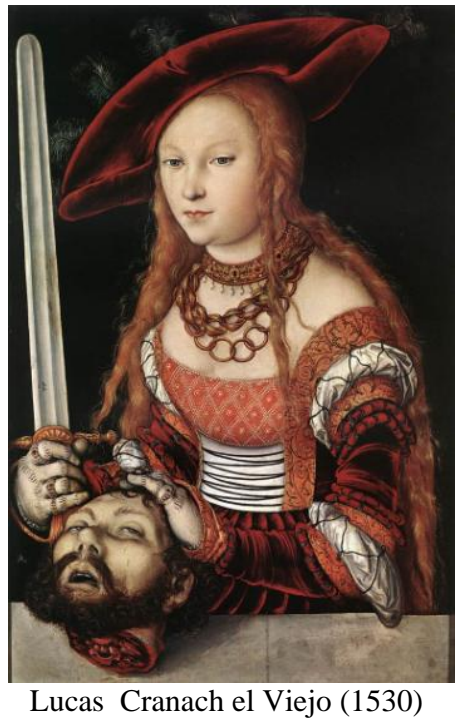

Sin embargo las obras más famosas de fin de siglo son las que representan Gustav Klint y Franz von Stuck. En el primer caso, tanto la Judith de 1901 como la de 1909 son un emblema de sensualidad, de placer, dolor y muerte. El cuadro de 1901 nos ofrece una Judith con un peinado a la moda, pero al mismo tiempo juega con una expresión impúdica de éxtasis sexual, con ojos entornados y la boca entreabierta. Gustave Klimt resalta el aspecto ficticio del decorado mediante un grafismo plano y, lo contrasta con el modelado del cuerpo. A través de esta técnica su personaje se alza victorioso y seductor.

\footnotetext{
${ }^{548}$ Erika Bornay, op. cit., pp. 203-204.
} 


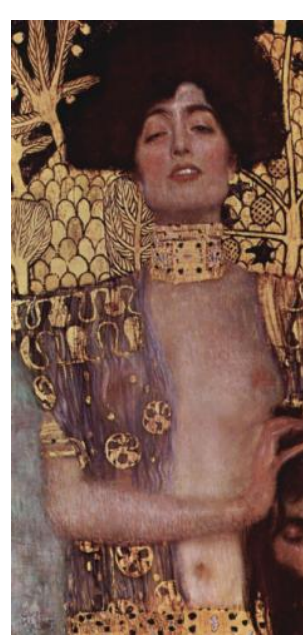

Gustav Klimt (1901)

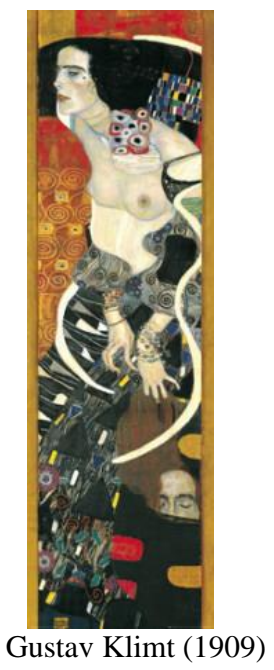

En cambio en el cuadro de 1909, Judith se alza con una verticalidad opresiva, pues se levanta decrépita y con manos afiladas como garras enjoyadas que sujetan la cabeza de Holofermes. Al mismo tiempo, el arabesco de sus ropajes deja al descubierto su pecho y la imagen que desprende de mujer devoradora y vampírica. Pero esta imagen sanguinolenta ya la encontrábamos en 1893 de la mano de Franz von Stuck cuando utiliza a su Judith como un ejemplo voraz de femme fatale. Es un personaje que refleja el vínculo entre mujer-pecado como tentación sexual. De esta forma, Judith completamente desnuda muestra su cuerpo estilizado, y aguarda el momento oportuno para dejar caer la espada sobre el general asirio que duerme en la cama muy confiado ${ }^{549}$.

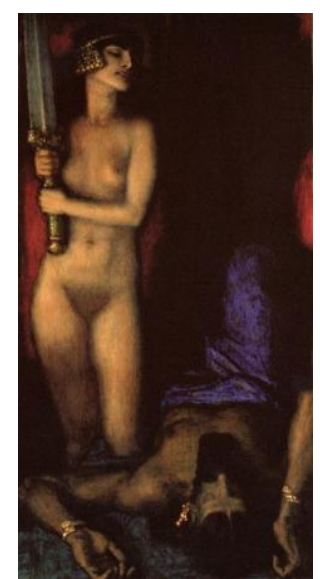

Franz von Stuck (1894)

\footnotetext{
${ }^{549}$ Erika Bornay, op. cit., pp. 210-216.
} 
En el mundo literario encontramos los poemas de T. Gautier (1843), y el poema "Une Martyre" en el poemario Las flores del mal de Baudelaire:

\section{Una mártir}

En medio de jarrones, de bordadas estofas y de muebles voluptuosos, de mármoles de cuadros, de perfumados trajes que caen en pliegue suntuoso,

en una tibia cámara, donde el aire malsano es como el de un invernadero, donde ramos murientes en cristalinos féretros exhalan su último suspiro,

sin cabeza un cadáver derrama, como un río sobre la almohada ya sin red, roja y viva una sangre que la tela se bebe con la avidez de una pradera.

Cual las visiones pálidas que hace nacer la sombra y que los ojos nos apresan, la cabeza, al montón de su pelo sombrío $\mathrm{y}$ a sus preciadas joyas junta,

cual ranúnculo, encima de la mesa de noche reposa; y ya sin pensamientos, una mirada vaga, blanca como el crepúsculo lanza sus ojos sin pupilas.

Sin escrúpulo el tronco desnudo sobre el lecho extiende en completo el abandono la belleza fatal y el esplendor secreto que le dio la naturaleza;

en la pierna, una media rosa y bordada de oro, como un recuerdo le ha quedado; la liga, como un ojo secreto que llamea, lanza mirada diamantina.

El singular aspecto de esta gran soledad y de un retrato grande y lánguido, que igual que su actitud a los ojos provoca, revela un amor tenebroso,

una culpa dicha y festejos extraños llenos de besos infernales, que gozaba el enjambre de los ángeles malos que nadaban en las cortinas;

y sin embargo en vista de la fina elegancia del hombro de roto contorno, el elegante talle, la picuda cadera como un irritado reptil, 
¡ella es aún muy joven! -Sus sentidos que muerde el Hastío y su alma crispada ¿se habrían entreabierto a la jauría loca de ansias errantes y perdidas?

¿El hombre vengativo que, viva, no pudiste saciar, ni con todo tu amor, colmó sobre tu carne complaciente e inerte la inmensidad de su deseo?

¡Di, cadáver impuro! Y por tus trenzas rígidas un febril brazo levantándote, dime, horrenda cabeza, ¿sobre tus dientes fríos dejó los supremos adioses?

- Lejos del mundo impuro, de la chusma burlona, de los curiosos magistrados, duerme en paz, duerme en paz, oh tú, criatura extraña, en tu sepulcro misterioso;

tu esposo corre el mundo, y la forma inmortal vela a su lado cuando él duerme; igual que tú sin duda él ha de serte fiel y constante hasta que se muera ${ }^{550}$.

También podemos señalar el poemario de Villier de L'Isle-Adam. Sin embargo, creo importante destacar Arii Matamoé (1892) de Paul Gauguin y La ejecución (1843) de T. T. Heine, que narra cómo un hombre es conducido hacia una fortaleza donde tendrá lugar su ejecución. Su desesperación y su impotencia radican en que el guía que le conduce hacia su destino es una mujer con una enorme espada de la que no puede escapar $^{551}$.

\subsubsection{3.- Dalila}

Dalila es un icono de la feminidad que representa la hipocresía y la traición. Por supuesto, este tema tampoco es novedoso, ya que su primera aparición se da en el Libro de los Jueces. En él no se nos da casi información acerca de la joven, pero sí se

\footnotetext{
${ }^{550}$ Charles Baudelaire, Las flores del mal, Madrid, Cátedra, pp. 427-431.

${ }^{551}$ Erika Bornay, op. cit., p. 217.
} 
desprende la idea de que Dalila no amaba a Sansón y de que sólo se acerca a él por interés.

Después de esto, se enamoró de una mujer de la vaguada de Soreq, que se llamaba Dalila ${ }^{552}$. Los tiranos de los filisteos subieron donde ella y le dijeron: "Sonsácale y entérate de dónde le viene esa fuerza tan enorme, y cómo podríamos dominarle para amarrarle y tenerle sujeto. Nosotros te daremos cada uno mil siclos de plata ${ }^{553}$.

Tras aceptar, Dalila se acerca a Sansón y, con palabras amables, intenta sonsacarle cuál es la procedencia de su extraordinaria fuerza.

Dalila dijo a Sansón: “Anda, dime, ¿de dónde te viene esa fuerza tan grande y con qué habría que atarte para tenerte sujeto?" Sansón le respondió: "Si me amarran con siete cuerdas de arco todavía frescas, sin dejarlas secar, me debilitaría y sería como un hombre cualquiera ${ }^{554}$.

Otras dos veces se repite esta misma escena, y Sansón miente en todas ellas. Los filisteos lo tienen preso pero no saben cómo matarlo sin correr peligro. Así que necesitan la ayuda de Dalila, pero Sansón desconfía de las intenciones de la joven. Dalila no se rinde e insiste, sabe que algún día Sansón abrirá su corazón.

Dalila le dijo: “¿Cómo puedes decir: ‘Te amo’, si tu corazón no está conmigo? Tres veces te has reído ya de mí y no me has dicho en qué consiste esa fuerza tan grande”. Como todos los días le asediaba con sus palabras y le importunaba, aburrido de la vida, le abrió todo su corazón y le dijo: "La navaja no ha pasado jamás por mi cabeza, porque soy nariz de Dios desde el vientre de mi madre. Si me rasuran, mi fuerza se retiraría de mí, me debilitaría y sería como un hombre cualquiera”. Dalila comprendió entonces que le había hablado con el corazón, mandó llamar a los tiranos de los filisteos y les dijo: "Venid esta vez, pues me ha abierto todo su corazón". Y los tiranos de los filisteos vinieron donde ella con el dinero en la mano. Ella hizo

\footnotetext{
${ }^{552}$ En la Biblia se explica que el nombre quizá sea un apodo que significa "la que señala".

${ }^{553}$ El Libro de los Jueces, 16: 4-5.

${ }^{554}$ El Libro de los Jueces, 16: 6-7.
} 
dormir a Sansón sobre sus rodillas y llamó a un hombre que le cortó las siete trenzas de su cabeza. Entonces comenzó a debilitarse, y se retiró de él su vigor. Ella gritó: "Sansón, los filisteos contra ti". Él se despertó de su sueño y se dijo: "Saldré como las otras veces y me desembarazaré". No sabía que Yáhveh se había apartado de ée ${ }^{555}$. Los filisteos le echaron mano, le sacaron los ojos, y le bajaron a Gaza. Allí le ataron con una doble cadena de bronce y tuvo que dar vueltas a la muela en la cárcel ${ }^{556}$.

Esta historia de traición que se desarrolla entre Sansón y Dalila interesó muchísimo a Moreau, quién realizó varias versiones al respecto.

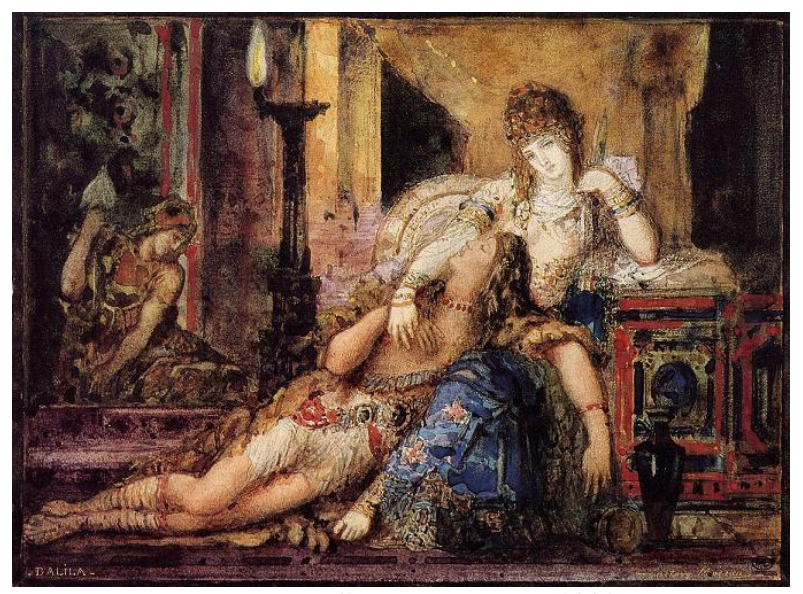

Gustave Moreau (1882)

Podemos ver cómo en ambas aparece una Dalila satisfecha, orgullosa de tener al poderoso Sansón en sus regazos. Andrea Mantegna (1495) dio un paso más allá y, en su obra Sansón y Dalila, logra caracterizarla bajo una expresión beatífica e incluso tierna. Sin embargo, la inscripción que podemos leer en el árbol nos hace creer que la inocencia aparente de la joven es sólo una máscara bajo la que se oculta su maldad ${ }^{557}$ :

\section{Foemina diabolo tribus assibus est mala peior}

(Una mujer mala es tres veces peor que el Diablo)

\footnotetext{
${ }^{555}$ En la Biblia se explica que con este acto de cortarse el pelo se viola el voto de nazireato.

${ }^{556}$ El Libro de los Jueces, 16: 13-21.

${ }^{557}$ Erika Bornay, op. cit., pp. 219-220.
} 


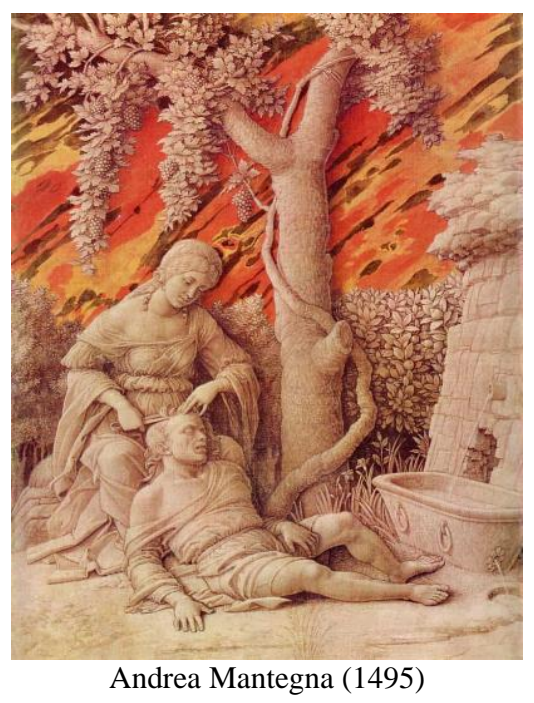

Más tarde encontraremos el Sansón y Dalila de S. Sólomon, alumno de Alexandre Cabanel. En la imagen observamos cómo los filisteos aguardan atentos a que Dalila corte las melenas al fuerte israelita. Ella, como prototipo de belleza filistea, muestra excitada el cabello cortado. Ante tal movimiento, los filisteos se echan encima de Sansón para sacarle los ojos. Más adelante, en 1901, nos encontramos con Sansón y Dalila de Max Liebermann. En este último vemos el dominio del sexo débil sobre el fuerte, pues la mujer, tras vencer al hombre poderoso, se alza triunfante con su poder sexual y con su astucia. Sólo el acto triunfante y orgulloso de Dalila levantando el mechón la identifica con el fragmento bíblico, ya que el espacio está desprovisto de decorado. Para ello se recorre a una escena intemporal ante la cual cualquiera puede sentirse idetificado ${ }^{558}$.

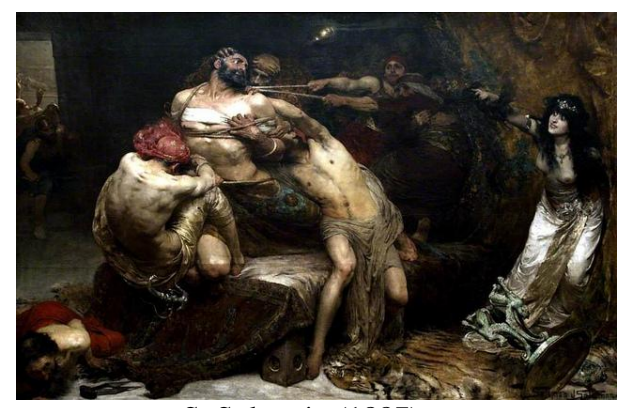

S. Solomón (1887)

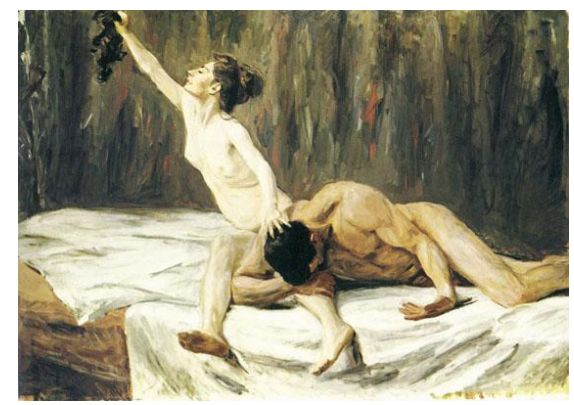

Max Liebermann (1901)

\footnotetext{
${ }^{558}$ Erika Bornay, op. cit., p. 220.
} 


\subsubsection{4.- Medea}

La última de las mujeres que nos ocupa en este apartado es Medea. En la mitología griega Medea era hija del rey Eetes y de la ninfa Idía. La joven vivía con su familia en Colquida y era sacerdotisa de Hécate. Un día reciben la visita de Jasón que solicitaba el vellocino de oro. Eurípides cuenta en su obra Medea cómo la joven, traicionando a su pueblo, ayuda al apuesto Jasón a apropiarse de él.

Medea se enamora del joven extranjero, y es plenamente consciente de que su pueblo la rechazará por haberlo traicionado, así que renuncia a su familia y se marcha con él. El problema llega cuando Jasón se enamora de Glauce, hija del rey Creonte y se compromete con ella ${ }^{559}$.

Nodriza: La desdichada Medea, en cambio, ultrajada grita: ¡Juramentos! Y reclama la máxima garantía que se vio entrechocar la mano diestra, y pone por testigo a los dioses del pago que en correspondencia recibe de Jasón. Yace ella sin probar bocado, abandonando su cuerpo a los dolores, consumiéndose en lágrimas todo el tiempo, desde que se ha sabido injuriada por su esposo; ni alza su mirada ni aparta de la tierra su rostro. Y como roca o marina ola oye las advertencias que le hacen sus amigos.

Excepto cuando, a veces, vuelve su blanquísimo cuello y llora consigo misma a su padre querido, su tierra, su casa, a los que traicionó para venirse con un hombre que ahora a ella ha ultrajado. ¡Ahora conoce la desdichada, bajo el peso de la desgracia, qué vale el no estar privado de la tierra de la patria! Odia a sus hijos, y no disfruta al verlos. Yo temo que ella vaya a tramar algo raro, [pues su alma es violenta, y no soportará ser maltratada. Bien conozco yo a ésta, y tengo el temor de que se vaya a clavar un afilado puñal en su hígado entrando en silencio en la casa, donde está extendido su lecho; o incluso que mate al rey y a su esposa y se

${ }^{559}$ Erika Bornay, op. cit., p.166. 
atraiga luego alguna desgracia mayor $]^{560}$. ¡Ella es tremenda! Desde luego que quien con ella se enemista no se llevará la palma de la victoria ${ }^{561}$.

Efectivamente, Medea, que ejerce la brujería, logra matar a Glauce por medio de un veneno.

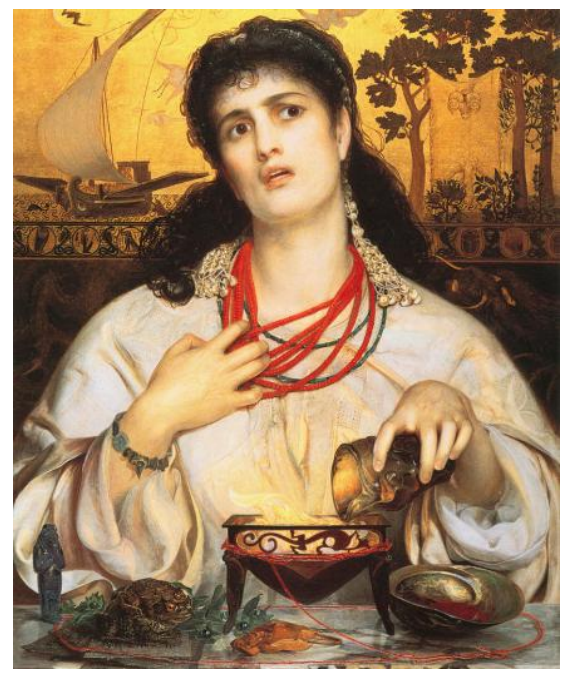

Federich Sandys (1868)

Una vez muerta Glauce, Medea cree que Jasón volverá a sus brazos. Sin embargo, llega a sus oídos que los reyes toman represalias contra ella, la acusan de brujería y la destierran. Es entonces cuando la joven se siente completamente abandonada, pues Jasón ni trata de defenderla ni tampoco quiere irse con ella.

Jasón: No es ahora cuando por primera vez he visto, sino muchas veces antes, cuán irremediable mal resulta una cólera rigurosa.

Pues tú podías habitar esta tierra y esta casa, de haber sobrellevado dócilmente las decisiones de los soberanos, mas a causa de tus locas palabras vas a ser expulsada del país. A mí nada me importa.

\footnotetext{
${ }^{560}$ Los corchetes se encuentran en la versión que recoge Alianza y, a pie de página, se explica que se utilizan para señalar que son sospechosos de inautenticidad.

${ }^{561}$ Eurípides, Alcestis, Medea, Hipólito, Madrid, Alianza, 1990, pp. 114-115.
} 
No ceses nunca de decir que Jasón es el más ruin de los hombres. Pero por lo que has dicho contra los soberanos considera que es todo ganancia el haber sido castigada con el detierro ${ }^{562}$.

Es aquí donde comienza la obra de Eurípides y la ópera que Pasolini compuso. En ambas se nos cuenta el drama que vive Medea al sentirse no sólo abandonada, sino utilizada por Jasón para conseguir el vellocino de oro. Pero la gota que colma el vaso de la paciencia de Medea es cuando Jasón la aparta de sus hijos mientras el coro la tacha de bruja. Él, que tanto apreciaba sus artes de las cuales se sirvió para salir triunfante con el vellocino, ahora la margina y la desprecia. Medea decide vengarse del hombre que tanto la ha amado, así que le quita a Jasón aquello que más quiere, sus hijos. Medea, totalmente angustiada, los degüella ${ }^{563}$.

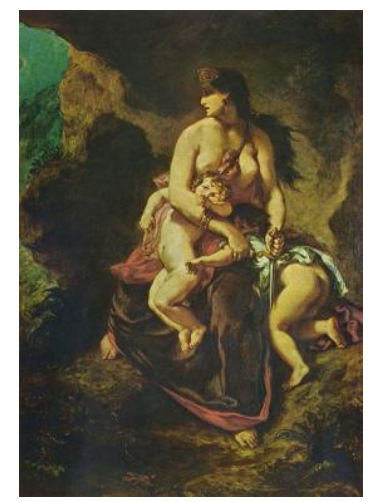

Eugène Delacroix (1862)

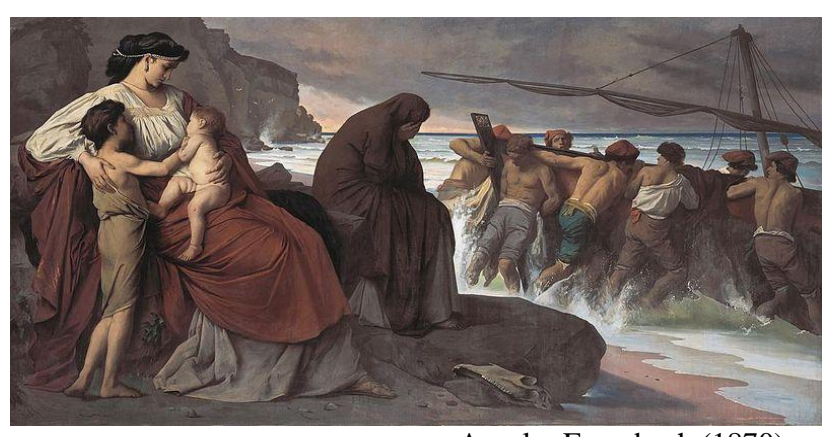

Anselm Feuerbach (1870)

Medea: Amigas, la acción está decidida: cuanto antes voy a matar a mis hijos, y me marcharé de esta tierra. No quiero, por actuar con indolencia, entregar mis hijos a otra mano más hostil para que los mate. Es totalmente necesario que mueran, y ya que así lo es, les daré muerte yo misma que les di la vida.

Mas, vamos, ármate de valor, corazón. ¿Por qué nos demoramos en realizar estos terribles, aunque necesarios, males? ¡Ea, oh desdichada mano mía, empuña la espada, empúñala, encamínate hacia la frontera en que empieza una vida de dolores!

\footnotetext{
${ }^{562}$ Eurípides, Alcestis, Medea, Hipólito, Madrid, Alianza, 1990, p. 130.

${ }^{563}$ Erika Bornay, op. cit., p. 166.
} 
¡Y no te ablandes, ni recuerdes que son tus hijos, que son lo que tú más quieres, que los trajiste al mundo! ¡Sino que olvídate en este corto día de que son hijos tuyos, y luego... llora! ¡Pues aunque los mates, sin embargo los quieres desde que nacieron! ¡Infeliz mujer soy yo! ${ }^{564}$

\section{5.- La mujer imaginada por la burguesía}

Simone de Beauvoir manifiesta en la primera parte de El segundo sexo que la femme fatale ataca el principio de transcendencia que caracteriza la feminidad, porque ella es considerada un falso infinito, por lo que se descubre como finitud, mediocridad y mentira $^{565}$. Pero Concepción Arenal dice que con estas palabras sólo se justifica al hombre, y a su intento de aplicar la ley animal del más fuerte ${ }^{566}$.

Si este mundo, actualmente regido por la cultura paternalista, sufriera un revés y se viera vinculado a la cosmología de la mujer, se caracterizaría por presentar un desequilibrio sexual ${ }^{567}$. Las mujeres han sido siempre caracterizadas por la mirada de los hombres y, en consecuencia, vienen determinadas por la definición masculina. Según la definición de los hombres, el componente fundamental de los personajes femeninos es la imagen, sobre la que se define la belleza o el atractivo físico. Esta imagen le otorga la identidad como ser social. Esto se ve en "Las mujeres y las academias" en las Obras completas de Juan Valera. Si el ser masculino es definido como un sujeto principal, el ser femenino es definido como un objeto, el Otro. El estado

\footnotetext{
${ }^{564}$ Eurípides, Alcestis, Medea, Hipólito, Madrid, Alianza, 1990, p. 162.

${ }^{565}$ Simone de Beauvoir, op. cit., pp. 47-361.

${ }^{566}$ Concepción Arenal, "Estado actual de la mujer en España", en La emancipación de la mujer en España, Madrid, Júcar, 1974, pp. 39-40.

${ }^{567}$ John H. Sinnigen, Sexo y política: lecturas galdosianas, Madrid, Ediciones de la Torres, 1996, pp. 86-
} 87. 
de la mujer es inmanente, su única función es dar hijos y alimentarlos. No tienen ninguna función creadora, pero si nutritiva ${ }^{568}$.

\subsection{1.- La loca o la histérica}

La figura de la esposa y de la madre se perfila como un ángel de trazo académico y de humilde mirada baja. De ahí el tabú social creado alrededor de las fantasías sexuales de las odaliscas, que completamente desnudas y de forma serpentina amenazan el proyecto ideal del hombre. Existen personajes que viven en secreto una doble cara que limita con las esferas de lo público y las esferas de lo privado. Esta doble función aparece arbitrada por lo socialmente tolerado en una mujer, y se destaca con el ámbito público durante el día, y el ámbito de lo privado durante la noche. Existe una fuerte mutación en el personaje, pues durante el día la mujer refleja una santidad extrema y se muestra como el perfecto ángel del hogar. Sin embargo, por la noche se convierte en una bestia lujuriosa.

En la Inglaterra victoriana se articulan las primeras voces que denuncian la farsa colectiva de la doble moral sexual. Así lo recoge la obra crítica de K. Millet titulada Política sexual. Un ejemplo muy claro lo encontramos en Villette de Ch. Brontë y en "Santa", narración recogida en El pecado de Antonio de Hoyos y Vicent. En este movimiento se trata de ilustrar y denunciar la esquizofrenia sexual de la sociedad decimonónica, donde los valores dominantes apenas consiguen ocultar la hipocresía de la duplicidad estética y ética. En este ámbito la mujer se convierte en un símbolo sexual de carnes poderosas y sin conexiones neuronales.

\footnotetext{
${ }^{568}$ Isabel-Argentina Fuentes Herbón, op. cit., pp. 456-465.
} 
Estos relatos literarios finiseculares femeninos son significativamente numerosos y representan un estudio de la esquizofrenia femenina. De forma que la fatalidad se cierne sobre el personaje masculino en forma de alucinada locura femenina. La complicada experiencia vital del personaje femenino ayuda a plasmar trágicamente la individualidad masculina. El hombre nunca se sentirá abocado hacia la alteridad secreta de la feminidad, y la mujer desde el cinismo y desde la hipocresía le negará este privilegio. La mujer saldrá siempre a escena con una máscara permanente, la máscara de los códigos sociales, y esto acentuará en el personaje un carácter exótico y fataloide ${ }^{569}$.

\subsubsection{1.- Madame D’Opporidol}

En la obra El pecado y la noche de A. de Hoyos y Vicent encontramos un cuento titulado "Madame D'Opporidol”, en donde la protagonista se inventa a sí misma y trata de orquestar un "Mise en scène". Mediante sus gestos, los detalles de su indumentaria, sus palabras y hasta sus recuerdos más íntimos, se convierte en una deudora de los tópicos manidos de la estética exótica finisecular. Así es como se describe como una duquesa gris y aburrida que se metamorfosea en una auténtica vampiresa oriental. Dice llamarse Schezerada y descender de la aristocracia otomana, pero los sucesos que cuenta el narrador traban de forma muy complicada elementos reales y elementos ficcionales, elementos de oriente y de occidente... Todos ellos connotan la historia de una mujer que desea la Quimera hasta el desvarío. Se trata de una mujer atormentada por unos horizontes completamente dominados por el uso social; de este modo prefiere habitar en su propio mundo, dado que es más gratificante que el que le rodeaba.

\footnotetext{
${ }^{569}$ Isabel-Argentina Fuentes Herbón, op. cit., pp. 140-148.
} 
De este mismo modelo derivan las figuras de la princesa y de la burguesa. La figura de la princesa casada se caracteriza por una infinita tristeza propia de las mujeres turcas contemporáneas. Eran mujeres cultivadas en la soledad del hogar debido a la creación de los harenes. Existir por y para el capricho de su marido las rebajaba al concepto de objeto, y sufrían al verse tratadas como odaliscas o bestezuelas de placer. En cuanto a las burguesas se casaban por medio de matrimonios arreglados; la novia desempeña el papel de un objeto, sin voluntad ni discernimiento. El marido sólo la comprende en cuanto a su belleza se refiere. Sin embargo, aunque la condenen al papel de odalisca, ella, en la mayoría, de los casos, es culta, erudita, vibrante y moderna ${ }^{570}$.

\subsubsection{2.- María de las Angustias}

María de las Angustias es el personaje central de La casa de Bernarda Alba de Federíco García Lorca. La historia nos dice que es la esposa de Arturo Jonás; fue hija de un psiquiatra y, en consecuencia, criada en un manicomio. Tanto Emilio Carrere ${ }^{571}$ como Antonio de Hoyos y Vicent ${ }^{572}$ recogen la historia de María de las Angustias. Ambos la catalogan como una mujer muy lúcida, pero con importantes desarreglos psiquiátricos de origen sexual. Del mismo modo que León Roch y Pepe Rey ${ }^{573}$, Arturo Jonás encomienda a su mujer la maravillosa misión de ser el ángel del hogar:

\footnotetext{
${ }^{570}$ Isabel-Argentina Fuentes Herbón, op. cit., pp. 149-154.

${ }^{571}$ Emilio Carrere, "La voz del enigma" en Del amor, del dolor y del misterio, en Obras Completas.

${ }^{572}$ A. de Hoyos y Vicent, "El caso clínico" en La novela corta, no X, Año I, Madrid (29 de enero de 1916) p. 13 .

573 Benito Pérez Galdós inventa estos personajes. León Roch para la novela La familia de León Roch, y Pepe Rey para la novela Doña Perfecta.
} 
-¿Tú? ... ¡La misión más bella, más grande, más santa, una misión de caridad, de ternura, de amor! Es grande, enorme, la obligación que nos imponemos; pesado de llevar el fardo, pero nuestro cariño nos sostendrá, y tal vez llegue un día en que, como tu padre, podamos decir al comparecer ante Dios: Señor, he cumplido con mi deber ${ }^{574}$.

Pero María de las Angustias tiene la imagen femenina condicionada por la figura prerrafaelista de la objetualización y de la frialdad femenina. Se trata del reflejo de la feminidad psicológica que a modo de laberinto intenta escapar de la agonía del tedio. Este aburrimiento representa el estancamiento de la persona y se refleja como un retroceso evolutivo de la propia persona. Sin embargo, María de las Angustias logra despertar su animalidad y hace triunfar a la bestia. Pero, como consecuencia debe morir y, por supuesto, morirá matando ${ }^{575}$.

\subsection{2.- La muñeca o la autómata}

El prototipo de la femme fatale finisecular procede del Naturalismo y se define por atacar la esencia de la condición masculina en su totalidad. Philippe-Auguste Villiers de L'Isle-Adam en sus cuentos, Cuentos crueles (1883) y en La Eva futura (1886), narra cómo un hombre se resiste a renunciar a su ideal de perfección femenina y a considerar, por tanto, a la mujer de carne y hueso como la única compañera que puede encontrar de por vida. De esta forma, vemos cómo el hombre finisecular actúa como un Pigmalión,

\footnotetext{
${ }^{574}$ Isabel-Argentina Fuentes Herbón, op. cit., p. 241.

${ }^{575}$ Isabel-Argentina Fuentes Herbón, op. cit., pp. 240-245.
} 
que eternamente insatisfecho necesita construir una imagen femenina a medida de sus ensoñaciones: buscan la mujer perfecta ${ }^{576}$.

Siguiendo la misma temática, en donde la figura femenina es creada por el hombre enamorado, nos encontramos con la figura de la muñeca o de la autómata. La autómata reaparece con frecuencia en la literatura romántica de temática fantástica. El precedente más claro de todos es El hombre de arena (1817) de E.T.A. Hoffmann. Luego le siguieron obras tan importantes como Cuentos fantásticos del XIX de Ítalo Calvino, quien insistió en los mismos motivos y en la relación directa con un subjetivismo filosófico de base ${ }^{577}$.

En el ámbito del modernismo español nos encontramos con la autora Pilar Pedraza y sus Máquinas de amar. Secretos del cuerpo artificial (1998), en donde expone una serie de criaturas inventadas por la cultura occidental. En él encontramos figuras de cera, estatuillas de fina porcelana, muñecas, autómatas, muñecas hinchables... que representan una caricatura de la mujer real y la imagen ideal de la feminidad. Para Pilar Pedraza todas ellas no son más que una fantasía erótica masculina. A la misma conclusión llega Ángel Sala en "La máquina, eterno femenino" allá y pone el acento en la dicotomía mujer-mal. A nivel cinematográfico vemos Metrópolis (1926) y Blade Runner (1982), obras en donde la figura femenina forma parte de la esencia de lo repulsivo frente a un mundo fundamentalmente patriarcal y masculino, en donde el creador sigue respondiendo a modelos culturales machistas.

\footnotetext{
${ }^{576}$ En estos cuentos la protagonista será Andreida Hadaly, quien sucumbe a la ley inexorable de la fatalidad de su destino. Ella será la personificación metafórica de dos mundos en decadencia cuyos últimos destellos se van apagando.

${ }^{577}$ Isabel-Argentina Fuentes Herbón, op. cit., pp. 435-455.

578 Ángel Sala, “La máquina, eterno femenino”, en VV.AA., Nosferatu. Revista de cine, n²3, Donostia enero de 1997.
} 
Pero, como ya dice Lily Litvak en el Erotismo fin de siglo (1979), el jardín modernista finisecular no es un espacio abierto ni natural, sino todo lo contrario, es un espacio

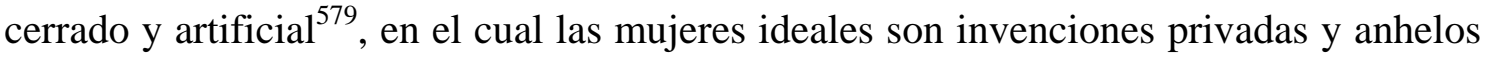
íntimos de refugio y de evasión tan frecuente como los paraísos. ${ }^{580}$

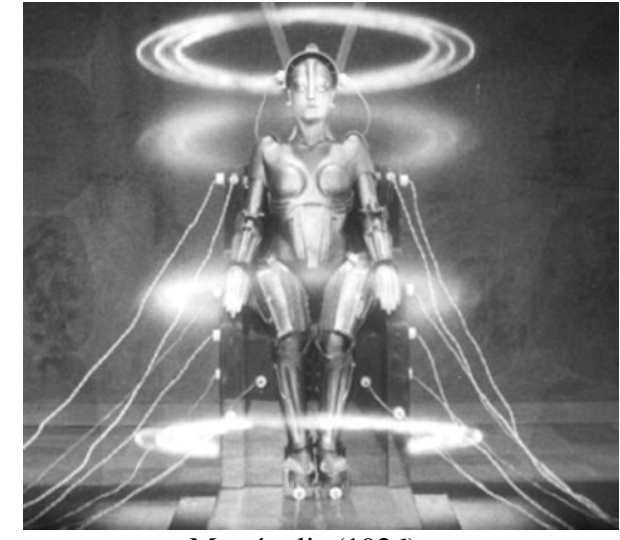

Metrópolis (1926)

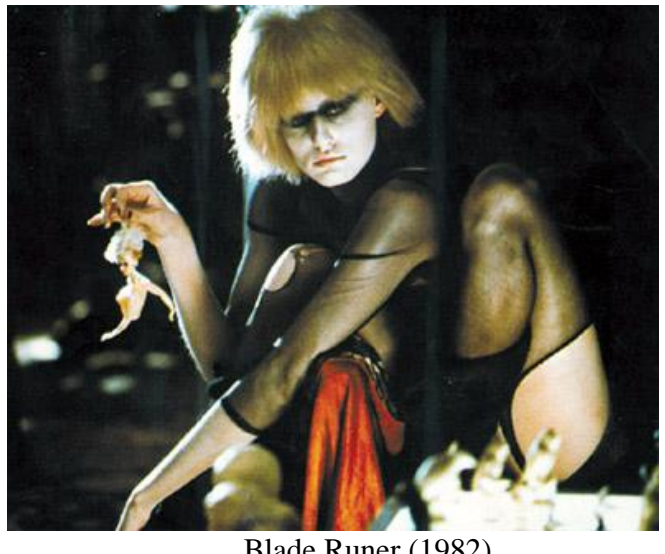

Blade Runer (1982)

\subsubsection{1.- La muñeca diabólica}

La muñeca, creada por manos masculinas, representaría la fantasía varonil de la mujer perfecta. Isabel-Argentina Fuentes describe esto como $\mathrm{M}=\mathrm{m}^{2}$, lo cual debe leerse: la Mujer es mona y manejable. En resumen, la bella autómata es la bella estúpida. Se trata de una belleza señorial que procede de los cánones de la justicia sociopoética que representa la dialéctica de dominio-sumisión. Una mujer silenciada que habla mediante las palabras que le enseña su marido y señor. De esta forma el matrimonio se convierte en una jaula de oro en la que la mujer prisionera aprende a hablar y a pensar siguiendo los patrones de su esposo. Es decir, aprende a pensar bien y a hablar bien. Tal es el caso de Olimpia en El hombre de arena de E.T.A. Hoffmann. Esta joven, aunque es

\footnotetext{
${ }^{579}$ Idea que se ve en R. Valle-Inclán, "Sonata de otoño", en Sonatas. Memorias del Marqués de Bradomin, ed. cit., p. 55.

${ }^{580}$ Isabel-Argentina Fuentes Herbón, op. cit., pp. 102-105.
} 
completamente adorada por Pacorrito Migajas, se siente presa de un canon de belleza que responde a las expectativas políticosociales impuestas por los hombres.

Estas mismas argumentaciones se siguen manifestando hoy, pero en lugar de poner el foco de atención en los cánones sociales vividos como jaulas, se da importancia a la naturalidad con que se aceptan esos cánones impuestos, y cuando las féminas quieren revelarse les es completamente imposible. De forma que algunos personajes resaltan cómo la mujer ejerce un doble papel: el de prisionera y el de su propia carcelera. El hombre se presenta como un Pigmalión potencialmente tolerado, pero cuando ellas se dan cuenta de que son prisioneras, les resulta completamente imposible escapar. Tal es el caso de Alma de Rodrigo Blaas, un cortometraje que cuenta la sorprendente historia de una niña que es encerrada en el interior del cuerpo de una muñeca o, también, la historia de La novia de Chucky. Esta es la cuarta de cinco películas dedicadas al muñeco Chucky, pero en la que nos ocupa se cuenta cómo siguiendo los consejos del novio, la joven acaba prisionera en el interior del cuerpo de una muñeca ${ }^{581}$.
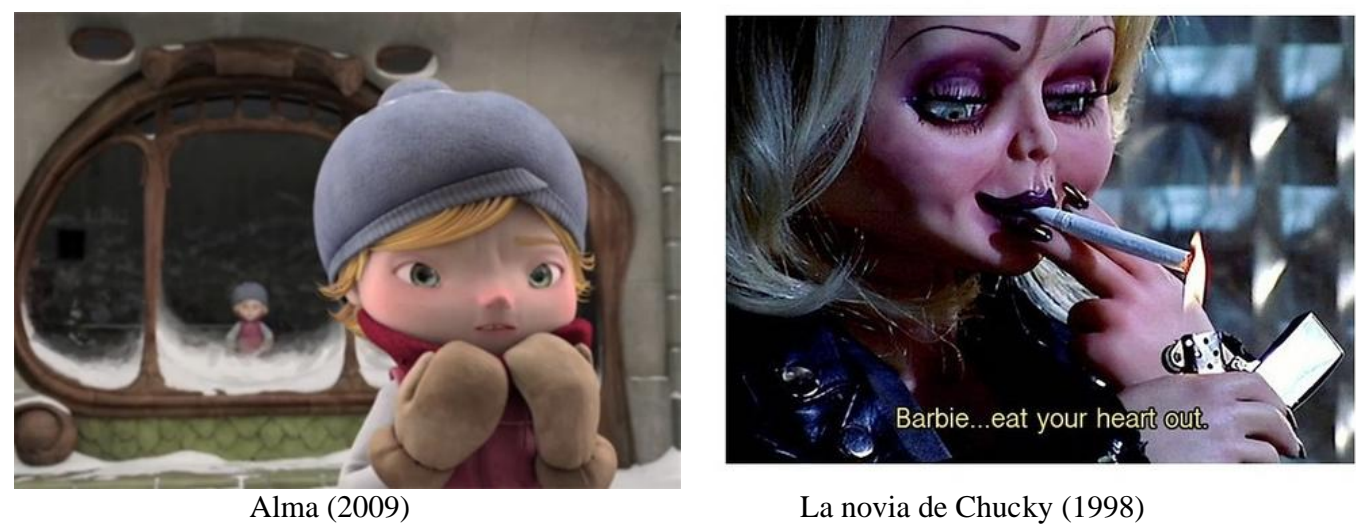

La novia de Chucky (1998)

\footnotetext{
${ }^{581}$ Isabel-Argentina Fuentes Herbón, op.cit., p. 397-434.
} 


\subsection{3.- La materialidad femenina}

La paz del matrimonio burgués se sostiene gracias al oro o a la apariencia del oro. Encontrar el origen de esta idea sería meramente imposible, pero podemos remontarnos hasta el Ars Amatoria de Ovidio ${ }^{582}$, en especial cuando se dice "Aurea sunt vere nunc saecula: plurimus venit honos, auro conciliatur amor" ${ }^{, 583}$. Este no es un ejemplo aislado, pues existen estudios acerca del binomio mujer-dinero entre los que podemos destacar a Edmundo González-Blanco y la tesis de Carmen Servén Diez.

En el caso de González-Blanco vemos como recurre a los versos de Ovidio para explicar el esplendoroso pasado de Pompeya y en especial el de Mesalina. En cambio en la tesis de Carmen Servén ${ }^{584}$ se muestra que la presencia del dinero responde a una sensibilidad social dominante en la época, pues todos los autores criticaban la actitud reverencial que la sociedad adopta frente a la riqueza. Por lo que, en la literatura, aparece la sociedad ligada a tres temas recurrentes: el matrimonio ventajoso, el adulterio y la prostitución. Todo ello motivado por la necesidad económica reinante.

Simone de Beauvoir también aborda el tema y propone una explicación del adulterio femenino: lo plantea como una silenciosa venganza por estar desposeída de capital propio. Pero el mismo concepto de venganza lleva aparejado la maldad intrínseca de la mujer. Así se muestra en la constante lucha de Valenzuela, el personaje femenino de $L a$ voluntad de vivir de Blasco Ibáñez. J. Casal Duero y J. F. Montesinos también señalan a los personajes de Galdós como reflejo de una dimensión social de la que forman parte.

\footnotetext{
${ }^{582}$ Es un poema didáctico que transmite una serie de consejos sobre las relaciones amorosas.

583 Traducido viene a decir: “Con el oro se obtiene honores, con oro se consigue amor”.

${ }^{584}$ Carmen Servén Diéz, La relación entre el amor y el dinero en la novelística de la restauración (Valera, Pereda, Pérez Galdós, “Clarín”, Pardo Bazán, palacios Valdés).
} 
Son mujeres, que preocupadas por las grandezas del reluciente metal, faltan a todos sus deberes de madre y de esposa ${ }^{585}$.

Pero debemos advertir que la mujer mala no es lo mismo que la mujer fatal. El concepto básico de maldad durante las corrientes realistas no responde a un fundamento metafísico, sino que viene determinado por la nefasta influencia del medio socioeconómico. Las mujeres entran en la dinámica socioeconómica del sistema que se ha reestructurado tras la revolución burguesa, y esto conlleva un verdadero equilibrio de clases, en donde veremos a infinidad de personajes que intentan ascender en la "feria de las vanidades".

Muchos autores encuentran su inspiración en ámbitos sociales muy pobres, y centran su atención, por ejemplo, en el ramo textil, concretamente en las modistillas de aspecto desmejorado. De ahí el personaje de Carmela en La Tribuna (1883), en "Del amor, del dolor y del misterio" y en el "Elogio de las niñas cursis" de Emilio Carrere, o en "La educación de las jóvenes" publicado en la revista Fainé. E incluso, Concepción Arenal, en la obra La emancipación de la mujer en España, incluye un artículo titulado "Estado actual de la mujer en España" (1895) en donde explica que al entrar en el sistema, las mujeres deben asumir una posición dentro de la cadena de explotación laboral. Desde esta perspectiva, la mujer es mala en la medida en que transgrede las reglas sociales del juego. Porque si traspasa los límites, se atreve a cuestionar la jerarquía de poderes y de la propiedad. La idea de maldad le viene definida, por la doble moral de una burguesía machista, que utiliza los términos de pecado y honra para excluirla de la buena sociedad. Por lo que el término maldad no es una categoría unívoca, pero sí es un concepto móvil y cambiante que los hombres utilizan a su capricho. Para ellos, la maldad femenina

\footnotetext{
${ }^{585}$ Ambos estudiaron en profundidad la vida y obra de Galdós. Casal Duero escribió Vida y obra de Galdós y, J. F. Montesinos, escribió Galdós.
} 
obedece a motivaciones externas que tienen su origen en el hecho social. El peligro que puede representar un ángel del hogar es que quiera exhibirse con alas doradas como los iconos bizantinos. Una mujer adecuadamente vestida y enjoyada puede representar el bienestar social de un matrimonio adinerado y moderado. Pero una mujer pomposamente vestida no sólo supone una exageración de las formas, sino también un peligro para la economía del macho sustentador. Como consecuencia, la mujer hunde los principios del orden burgués minando su principal base económica y la mascarada de la decadencia como virtud pública neobarroca. El sexo mercenario se compra con oro.

Sin embargo, la maldad de la femme fatale finisecular no obedece a motivaciones externas, es perversa y goza de la perversión. Por supuesto, esta pasa de la pura espiritualidad a la pura sensualidad. Y, con el cambio, se siente orgullosa de su maldad interiorizada. Es mala porque es mala, no porque la hagan mala las agresiones del medio social. Vampiriza todo: el dinero, el poder, la salud, la inteligencia... y en ello reside su atractivo, en ser mala. Su atractivo perverso va más allá del bien y del mal. Se reviste de una extraña crueldad diabólica que es, a la vez, tentadora y bella. Sus excesos de crueldad, su naturaleza sanguinaria la convierten en una ramera ávida de gastarlo todo en lujo. Fue comprendida como la 'gran amadora' o 'la gran criminal' porque se divierte haciendo sufrir a los hombres. A esta idea Concepción Arenal le suma el concepto de enemigo. Uno de los mayores enemigos de las mujeres no son los hombres, es el tedio. Esto se convierte en un tópico finisecular 'taedium vitae', en donde se relaciona tedio-maldad, y este es el motivo literario de Las flores del mal, La niña Chole, Mesalina, La princesa Vanda Orloff, Las insaciables de Nieves Sigüenza, La voluntad 
de vivir, "La noche de Walpurgis" en El pecado y la noche de Hoyos y Vicent, en donde todas matan por aburrimiento ${ }^{586}$.

\subsubsection{1.- Rosalía, la de Bringas}

Décadas antes de que el personaje literario de la femme fatale adquiriera toda su dimensión simbólica como metáfora de la decadencia del ángel del hogar, el ángel femenino se presentaba como una figura moderna. Un ángel sin alas que había ocupado de forma similar un espacio simbólico en el imaginario colectivo. Era una mujer divina que tiene que aprender a revolotear a la luz de la inteligencia masculina. Pero llega un momento en que necesita huir del tradicionalismo decimonónico, y es así como se convierte en la ideal compañera del rico burgués. Se continúa confinando a la mujer en el ámbito de la domesticidad y de la familia, pero se observa cómo la conversión del ángel del hogar en bestia corre a cargo del marido. De esta forma el ángel del hogar comienza a verse como una figura fácilmente corrompible. Tal es el caso de Rosalía Pipaón de la Barca, quien sangra a su marido donde más le duele, el bolsillo. Bram Dijkstra, en Ídolos de la perversidad ${ }^{587}$, señala que la figura de la vampiresa establece una relación muy estrecha entre la sangre, el oro y el semen ${ }^{588}$.

Este personaje simboliza dos cosas, por un lado la infecunda sed de la mujer-niña y, por otro, el ansia estéril que siente la prostituta por el dinero. El binomio lujuria-dinero se suma a la cualidad vampírica en el retrato moral. Pero, además, es una mujer que vive en un contexto en donde priman los privilegios económicos derivados de la pujante

\footnotetext{
${ }^{586}$ Isabel-Argentina Fuentes Herbón, op. cit., pp. 435-455.

${ }^{587}$ Bram Dijkstra, op. cit., pp. 333-400.

${ }^{588}$ Isabel-Argentina Fuentes Herbón, op. cit., pp. 397-399.
} 
sociedad industrial, momento en el que el patrón Oro rige los destinos humanos y modela la escala de valores. Pero como hay clases y clases, algunas se ven obligadas a prostituirse $^{589}$. Como diría Blasco Ibáñez en los Enemigos de las mujeres, "Para el amor se necesita dinero". Para el autor valenciano las mujeres de la época no muestran otra preocupación que el dinero. Por ello, algunos personajes representan a "los enemigos de la mujer" en Villa-Sirena ${ }^{590}$. Son personajes que tienen por mente a un híbrido monstruoso, debatiéndose contantemente entre la ética del vampiro y la del cinismo ${ }^{591}$.

Existen muchos personajes en la época que representan esta perversión del ángel del hogar. Entre ellos podemos destacar a Eufrasia en Los episodios nacionales de Galdós, las protagonistas de "La princesa y el granuja" o "Théros"; pero nosotros nos detendremos en el personaje de Rosalía en Rosalía, la de Bringas de Galdós. Ella es el perfecto ejemplo del ángel condenado, pues desde el principio aparece caracterizado como un ángel imparable en su caída en las arenas movedizas del capitalismo. Pasa por el engaño, el robo, el adulterio y la prostitución ${ }^{592}$. Rosalía se ve como una nueva Eva, seductora de adanes burgueses y seducida a su vez por los lujos de la industria textil.

\footnotetext{
${ }^{589}$ Emilia Pardo Bazán, "Como en las cavernas”, artículo de serie La Vida Contemporánea, publicado en La Ilustración Artística, n 1029, 16 de septiembre de 1901.

${ }^{590}$ Isabel-Argentina Fuentes Herbón, op. cit., pp. 400-402.

${ }^{591}$ Para saber si esto es reflejo de la realidad de la época, las feministas Woolson y Clafin, manifiestan que es necesario demostrar el consumo rampante de las mujeres de la década de 1870. No parece razonable dudar de que se hubieran convertido en auténticas máquinas de despilfarrar, pues es fácilmente visible que llegaron a transformar la moda del siglo XIX en su propia jaula dorada. De esta forma la vida femenina alcanzó el mero triunfo decorativo, en donde los hombres se dedicaban a hacer de ellas educados ornamentos de la sociedad de consumo. Por lo que, alrededor de 1900, la idea materialista de la mujer pasaba por la figura del vampiro, la cual se vinculaba a todo lo negativo: el dinero, el sexo y la posesión.

${ }^{592}$ Muy lejos de Rosalía queda la lascivia de Mesalina (de E. González-Blanco), la conciencia de la niña Chole (de R. Valle-Inclán) atormentada por el pecado, el atractivo de la brutalidad de Filomena Roldán (de A. de Hoyos y Vinent en La caja de Pandora). Todas ellas, muy al contrario de Rosalía, no necesitan justificar la búsqueda del placer prohibido.
} 
E. Zola abarca la misma problemática en su obra El paraíso de las damas (1883). De hecho esta novela dio nombre a un gran almacén de la época, pero al mismo tiempo mostró un nuevo concepto de venta que revolucionó el mercado. Resultó todo un éxito incipiente en técnicas decimonónicas de marketing comercial y causó una gran convulsión social. Llegó a cautivar a todas aquellas que entraban en el gran almacén o que buscaban productos apenas deseados porque ni siquiera los habían imaginado. Esta nueva imagen moderna de la mujer juega a hacer añicos el tradicional rol social de los poderes femeninos ${ }^{593}$.

También en los Episodios nacionales de Galdós los personajes de Eufrasia Carrasco, Quijada de Terry y Teresa Villaescusa son caracterizados por encontrarse anclados en un tiempo inmemorial que se rige sólo por las apariencias. Pero, del mismo modo que sus compañeras francesas, comparten una extraña mezcla de mala vida e importante sofisticación. Una combinación que las sitúa a la altura de los papeles estelares de los ídolos de la perversidad como Céfora, Rafaela, Valeria, Eloisa... En el caso de Eufrasia Carrasco, observamos una clara referencia al lujo y a la ostentación que bordea la elegancia sublime. Muy al contrario de la cursilería ridícula de la de Bríngas, Eufrasia está marcada por la norma pública de la decencia y por la vigilancia, más o menos, estricta de Lea y de doña Leandra. Así pues, se acaban resaltando los mecanismos de control ideológicos de un grupo social dominante. Dentro de la sociedad de la época, el matrimonio era comprendido como santo y seña de la condición pública de la decencia. Este concepto es completamente incompatible con la mitología de la femme fatale. Así Eufrasia es descrita como la cara inversa de la santidad, y su propia familia la catalogará como pecadora, demente, desdichada, y se la prefieren muerta antes que deshonrada ${ }^{594}$.

\footnotetext{
${ }^{593}$ Isabel-Argentina Fuentes Herbón, op. cit., pp. 403-414.

${ }^{594}$ Isabel-Argentina Fuentes Herbón, op. cit., pp. 418-420.
} 
Para ellos, Eufrasia, no sólo se pierde como persona, sino que también gana el calificativo de ídolo exótico pagano:

$$
\text { (...) se ha ido a los infiernos cubierta de diamantes, esmeraldas y topacios }{ }^{595}
$$

Su belleza se había convertido en la clave de un éxito social que la había llevado a los altares del amor como imagen de culto.

\section{6.- El cuerpo femenino como simulacro de enfermedad}

La imagen de la femme fatale se complica cuando a las características sociales de un arquetipo se le suma el imaginario colectivo de finales del siglo XIX. Este se puede retomar de la infinidad de carteles propagandísticos de Ramón de las Casas y de la campaña que se hizo contra el contagio de la sífilis. Esta enfermedad favoreció la libre asociación de la epidemia con la belleza maldita que caracterizaba a las enfermas ${ }^{596}$. En fin, se trataba de una imagen completamente alegórica que popularizó la unión de la idea femenina de Eva con la imagen diabólica de la serpiente. Por supuesto, algunos autores concretaron estas ideas en la figura de la prostituta. Tal es el caso de Juan Ramón Jiménez ${ }^{597}$, Baudelaire ${ }^{598}$, Félix Sardá y $\operatorname{Salvan}^{599} \ldots$

A partir de los años sesenta del siglo XIX se fue extendiendo la prostitución por toda Europa. Esto facilitó que la figura fuese representada sin velos y con mucha más crudeza. Una vez llegado 1870, la literatura naturalista y después las artes plásticas la

\footnotetext{
${ }^{595}$ Isabel-Argentina Fuentes Herbón, op. cit., 2010, p. 422.

${ }^{596}$ Isabel-Argentina Fuentes Herbón, op. cit., p. 97-102.

597 Juan Ramón Jiménez, “Las amantes del miserable” en Vida Nueva, 1899.

${ }^{598}$ Baudelaire, "L'avertisseur" en Las flores del mal.

${ }^{599}$ Félix Sardá y Salvan, El liberalismo es pecado, 1887.
} 
tomaron como un referente importante cuyos antecedentes literarios fueron Mary Howitt, W. Scott, Dickens, Zola, Goncourt, Huysmans, Guy de Maupassant... y como antecedentes pictóricos tenemos los murales de Pompeya, Carpaccio, Hans Baldung Grien, Jan Steen, William Hogarth, Fuseli, Goya, la Hallada (1845) de D.G. Rossetti, el Despertar de la conciencia de H. Hunt ${ }^{600} \ldots$

\subsection{1.- La cortesana}

Alain Corbin hace un análisis completo de la prostitución y se detiene en los pintores más representativos del tema. En un principio nos encontramos con las imágenes de Constantin Guys ${ }^{601}$. Muy amigo de Baudelaire, fue caracterizado como pintor de la vida, por lo que fue ideal para que el propio Baudelaire hiciera una apología de las obras de Guys ${ }^{602}$. A la manera de un cronista, pintó las imágenes de diferentes tipos de escenarios finiseculares como bailes, cafés, casas de citas, soldados, dandies, chicas, carruajes y caballos... para dejar constancia de la prostitución parisina.

La ejecución de estos monotipos surge con el auge de la novela que trata los temas de la prostitución. Tal es el caso de Marthe, histoire d'une fille de Huysmans, La fille Elise de E. Goncourt, La maison Tellier de Guy de Maupassant, Nana de Zola, Mines des courtisanes de Lucian... La iconografía erótica de este período está basada en el mundo

\footnotetext{
${ }^{600}$ Erika Bornay, op. cit., p. 240.

${ }^{601}$ Alain Corbin, Les filles de noche. Misère sexuelle et prostitution aux 19e. et 20e. siècles, París, Ed. Aubier Montaigne, 1978.

${ }^{602}$ Baudelaire, Obras completas, Paris, Gallimard, Biblioteca de la Pléida, 1961, p. 1152.
} 
promiscuo de las maisons closes de Edgar Degas, a través del cual podemos resaltar el cuadro de El cumpleaños de la patrona $(1879)^{603}$.

Otro de los grandes pintores de este tema fue Toulouse-Lautrec, quién también creyó que los prostíbulos eran lugares de inspiración ${ }^{604}$. Toulouse pasó tiempo encerrado en algunas maisons closes como la de Rue D’Amboise y la de Rue Des Moulins. En la primera se inscribió como si fuera un hotel y escribía cartas a las mujeres que no sabían escribir; así lo recoge J. Bouret en Toulouse-Lautrec. Sin embargo, el de la Rue Des Moulins era un establecimiento de lujo, completamente amueblado y decorado con todos los estilos posibles. Desde el gótico hasta el rimbombante estilo de Luis XVI, pasando por el chino y el persa. Allí se instaló en 1894, y fue allí donde recibió a sus amigos, como en el caso de Durand-Ruel, quien organizaba sus exposiciones. En 1896 se hicieron públicas alrededor de 50 escenas bajo el título "Elles". Por supuesto esta no fue la primera, pues ya antes, en 1894, se hace una exposición en el Salón de la Rue des Moulins $^{605}$. En ésta se buscó poner el énfasis bastante marcado en la sensualidad, pero al mismo tiempo, todas las imágenes reflejaban una atmósfera social bastante espesa ${ }^{606}$.

\footnotetext{
${ }^{603}$ Edgar Degas realizó alrededor de un centenar de obras alrededor de este tema. Al morir, la familia quiso destruirlos porque los consideraba pornográficos. Pero la intervención de Ambrosio Vollard evitó que se destruyeran todos; sólo consiguió salvar unos pocos.

${ }^{604}$ Como antepasados podemos encontrar a Carpacio y a Vermeer, pero también señalar a Rops, Guys, Degas y a Van Gogh como contemporáneos de Toulouse. Probablemente también se inspiró en los grabados de Ukiyo-e, especialmente en Utamaro.

${ }^{605}$ Erika Bornay, op. cit., pp. 240-252.

${ }^{606}$ Un ejemplo lo encontramos en el que anuncia la novela Reine de Joice (1892) del polaco Víctor Joze. Esta imagen recibió una fuerte influencia de las estampas japonesas, en donde la situación de las figuras adquiere una composición significativamente importante, en donde predominan los colores planos, se hace énfasis en el gesto y la silueta recibe un detrimento del detalle.
} 


\subsubsection{1.- Olimpia}

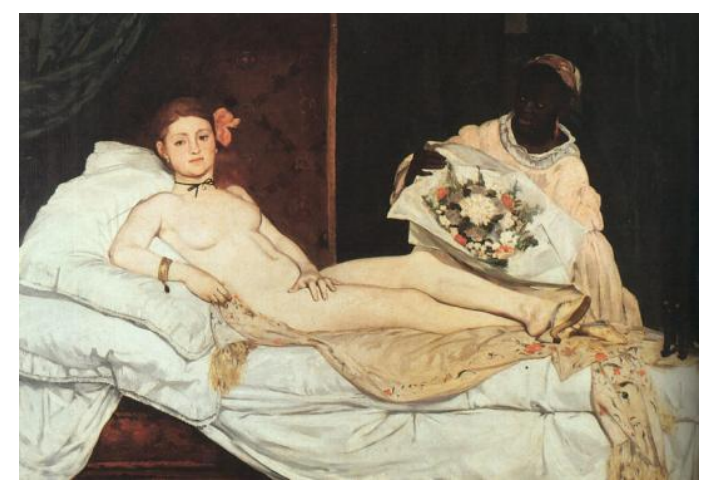

Edouard Manet (1863)

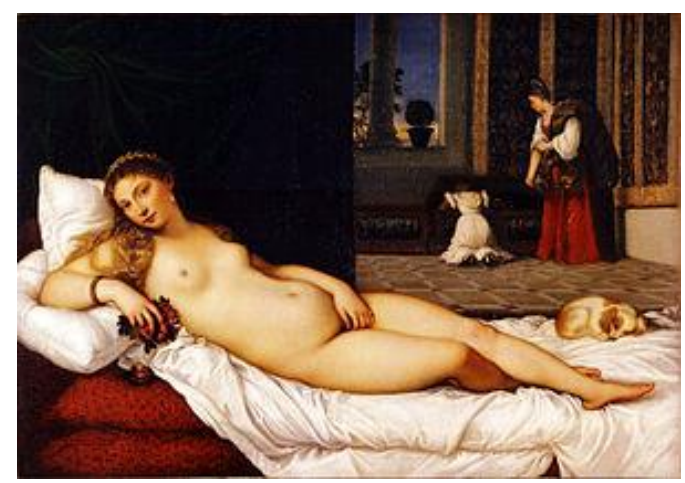

Tiziano (1538)

En 1863 se presentó por primera vez el cuadro Olympia de Edouard Manet. Fue una obra que recibió una marcada influencia de la tradicional Venus de Urbino de Tiziano, pero que al mismo tiempo ocasionó un tremendo escándalo. Este cuadro irritó mucho al salón porque se trataba de una mujer que transgredía el orden social establecido. La mujer concupiscente, que conduce al buen burgués a los placeres prohibidos fuera del lecho matrimonial, y que se atreve a despreciar el ramo de un admirador. Se trata de una obra que va más allá de la belleza superficial; no sólo se trata de representar el amorpasión, sino que se atreve a retratar el amor venal después del amor-pasión.

En cuanto a los aspectos formales de la obra, podemos destacar que existen en ella duros contrastes de color, así como la ausencia de matices volumétricos. Pero también es cierto que apreciamos una fuerte influencia literaria. Por un lado, porque era gran amigo de Baudelaire, y se conoce la fascinación que ambos sentían por el mundo de la prostitución. Al mismo tiempo, observamos que tanto el maquillaje alegórico como el maquillaje mitológico hacen alusión a una imagen visual de la novela de Emilie Zola ${ }^{607}$.

\footnotetext{
${ }^{607}$ Erika Bornay, op. cit., pp. 242-243.
} 


\subsubsection{2.- Nana}

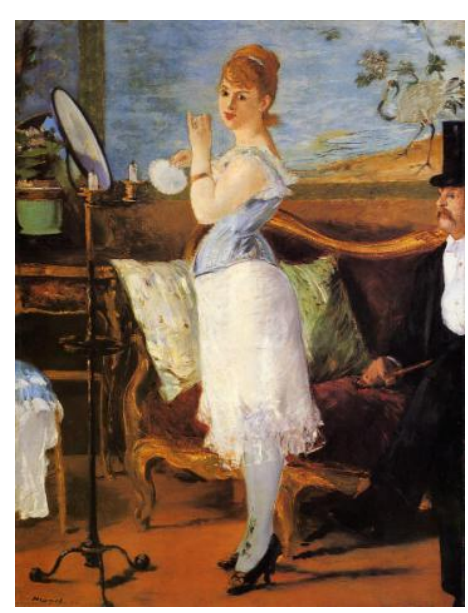

Edouard Manet (1877)

Después de Olympia, en 1877 Edouard Manet también se atreve con la figura de $N_{a n a}{ }^{608}$. Este personaje fue creado por E. Zola y publicado en 1880. Nana no es como la mujer fatal de Baudelaire, Nana es una "cocotte" en ropa interior de atrayentes redondeces. Es la mujer capaz de detener el aire con su lápiz de labios o con su borla de polvos. Se atreve a mirar despóticamente al espectador sin titubear.

... (Nana) era confusamente el diablo, con sus risas, con su pecho y su grupa hinchados de $\operatorname{vicios}^{609}$.

Es posible que esta Nana influenciara La toilette de Rops (1878-1880). Pero la Nana de Manet es fatal por lo que simboliza, no por lo que aparenta. Su rostro es fresco y cuenta con una sonrosada ingenuidad, pero simboliza el mundo de las licencias carnales. El mundo del mal escondido bajo la máscara de la inocencia.

J. Richardson observa que dentro de la prostitución existe una acentuada jerarquía ${ }^{610}$. Nana es una cortesana, la cual pertenece a la categoría de "el poder de ser representada".

\footnotetext{
${ }^{608}$ F. Cachin y H. Huysmans realizaron diferentes estudios sobre la relación que mantuvo el pintor Manet con el escritor Baudelaire. F. Cachin escribió Manet y Huysmans El Artista.

${ }^{609}$ Erika Bornay, op. cit., p. 244.
} 
Es la meretriz "ideal", la que se relaciona con el poder y con el dinero, porque a su lado tenía a un burgués que la mantenía y le daba todos los caprichos. A diferencia de Olympia, muchos críticos vieron en Nana la Petite Faubourienne o el abyecto objeto de la concupiscencia proletaria. Realmente, ambos cuadros de Manet fueron un anticipo de todas las categorías de cortesanas que vinieron después: courtisane, cocotte, joueuse, lionne, empoisonneuse, amazone, fille de marbre, horizontale, mangeuse d'hommes... petite faubourienne ${ }^{611}$.

\subsection{2.- La mujer venal}

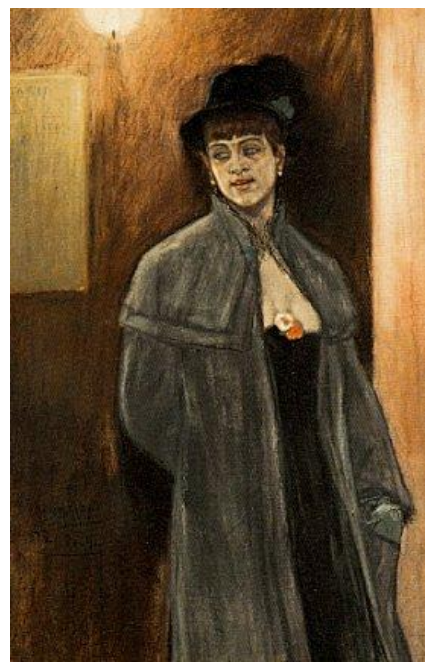

Félicien Rops (1882)

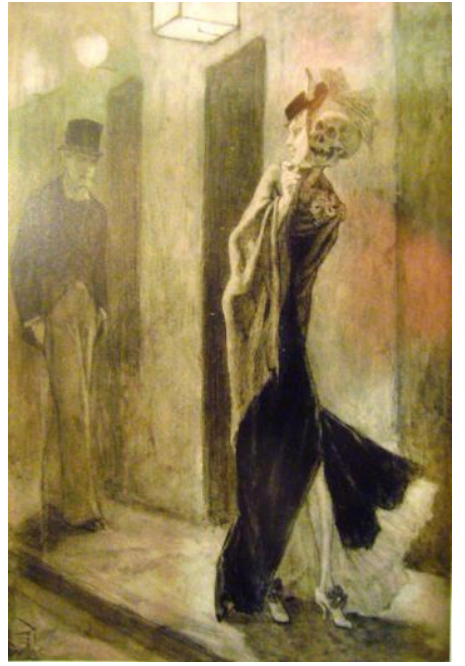

Félicien Rops

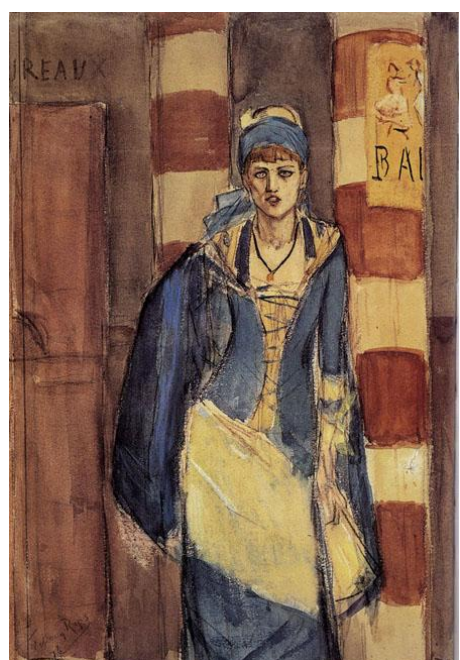

Félicien Rops (1876)

Resultan muy interesantes las imágenes de Félicien Rops, pues desde un punto de vista artístico refleja la marginalidad y recrea el submundo venéreo. Es un mundo lleno de máscaras e hipocresías, en donde se discriminaba la figura de la cortesana y se admitía a la ramera callejera. En su obra El Rydeack de 1865, Félicien Rops refleja un mísero barrio de Amberes cerca del puerto. En él vemos a una joven en el dintel de una puerta

\footnotetext{
${ }^{610}$ J. Richardson, Les courtisanes. La demi-monde au XIX e siècle, París, 1968.

${ }^{611}$ Erika Bornay, op. cit., pp. 243-245.
} 
en donde se puede leer "Meubelen-kamers" (habitación por noche). La joven, con una insignificante sonrisa, enseña el tobillo a un cliente. Su cuadro Mors Syphilitica muestra a una siniestra meretriz callejera con una guadaña y con un cuerpo completamente cadavérico. Por supuesto, la imagen refleja la educación propia de la época, en donde la idea de mujer podía estar asociada de forma muy peligrosa al vicio, a la enfermedad y a la muerte. En 1882 finaliza el cuadro Indigencia; en él vemos a una demacrada ramera en la esquina de una calle. La joven tiene los ojos y las cejas groseramente maquillados, y espera pacientemente la llegada de un algún transeúnte. También es importante señalar la Bebedora de absenta de 1876, cuadro que tuvo tal éxito que Huysmans la

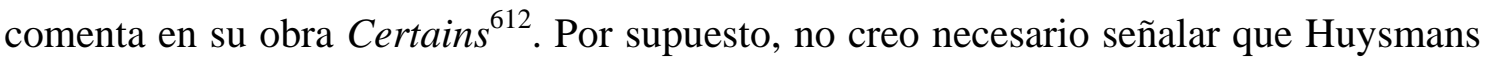
no fue el único escritor que se sintió fascinado por el tema de las prostitutas callejeras, sino que también encontramos a Baudelaire, Verlaine y Félicien Rops entre sus seguidores. Después, hallamos otras dos obras tituladas La canción del querubín (18781880) y El cuarto vaso de coñac (1880) en donde las prostitutas aparecen con sus clientes. Pero no contento todavía con esta caracterización del ambiente del burdel, también retrata El consejo de revisión (1878-1880), en donde se muestra la inspección de la patrona acompañada de un "pension-naire" a la aspirante a "fille soumise".

Todas estas imágenes tratan de encarnar el peligro social y moral que representa la mujer de la calle. El peligro se concibe como un abismo en el que el hombre sucumbe al acceder a los placeres femeninos. La prostituta callejera es la mujer venal que se sitúa fuera de la ley divina, la cual ordena no caer en los peligros de la carne. También es cierto que La educación sentimental de Aubrey Beardsley de 1984 nos ayuda a centrarnos en la idea de que en Inglaterra, debido a la religión protestante, nunca se dio un clima favorable para tratar el tema de la prostitución sin maquillaje ni de manera

\footnotetext{
${ }^{612}$ Huysmans, Certains, París, Librairie Plon, 1908, p. 95.
} 
sincera. En El callejón de Munch observamos, a pesar de los distintos lenguajes pictóricos, que todas estas obras buscan representar un fragmento real de la vida social de la mujer de la época. Pues se la tacha irónicamente de 'fatal', pero se la trata como a una mercancía usada por la misma sociedad que la discrimina y explota ${ }^{613}$.

\subsubsection{1.- La maldad de la prostituta}

Normalmente, solemos analizar a los personajes bajo sus elementos estéticos, pero ahora intentaremos abarcarlos desde la perspectiva funcional. Cuando un sujeto busca su propia identidad se establece un paradigma de oposiciones bastante interesante. En un principio, el personaje novelesco se autoconcibe como un yo interiorizado con una conducta, un dogma y una moralidad perfectamente detallada. Ante este punto aparece el otro exterior y contrapuesto ${ }^{614}$. Este es el esquema que toda prostituta dibuja sobre el resto de personajes. Ella es "la otra", la que complementa la moralidad masculina. Así que la mujer venal aparece descrita, o vivida, como una escisión del varón protagonista. Es decir, es algo o alguien que se experimenta como extraño y que irrumpe y limita la libertad del yo masculino. De esta forma, la extraña aniquiladora se comprende como una expresión de la maldad porque acortará la libertad, o las posibilidades de realización, del protagonista. La otra, entendida como un obstáculo, se presenta al personaje principal como reflejo del mal. El personaje masculino ve que todo lo que la rodea son males sociales que le impiden desarrollarse como persona: penalidades económicas, limitaciones de la clase social a la que pertenece, imposibilidad de mejorar en su trabajo... Desde este punto de vista, y bajo la vivencia personal del protagonista, el bien

\footnotetext{
${ }^{613}$ Erika Bornay, op. cit., pp. 240-256.

${ }^{614}$ Víctor Bravo, Los poderes de la ficción, Venezuela, Monte de Ávila Latinoamérica, 1987, p. 63.
} 
se esconde en su interior varonil, en su identidad innata. Su pureza y su inocencia permanecerán pulcras si no se dejan contaminar por las prostitutas ${ }^{615}$.

Ahora bien, llegados a este punto debemos de diferenciar entre la oposición $\mathrm{bien} / \mathrm{mal}$ para el personaje y la oposición bien/mal para el lector. Bataille conocía esta diferencia y se permitió la licencia de acentuar la función de la maldad en las novelas. Tal es el caso cuando un personaje limitado desde un punto de vista social, económico e intelectual, sólo tiene dos opciones: o someterse al sistema impuesto u oponerse a él. El sometimiento significaría vivir preso de las normas que impone la sociedad, pero oponerse supondría romper las normas. Esta ruptura es una forma de vivir buscando la libertad. En el primer capítulo intenté perfilar de alguna forma las normas que tanto el discurso médico y religioso intentaban imponer a la sociedad como las reglas morales. Toda ruptura con estos discursos supondría una manifestación del mal, y esto, concluirá Bataille, no es otra cosa que la expresión de la libertad del individuo. Por lo que desde el punto de vista del lector el mal, en la literatura, es una forma de libertad.

Por supuesto, una de las formas de oponerse a estos discursos canónicos es quebrar las prohibiciones que se establecieron sobre el cuerpo. El cuerpo femenino es el cuerpo que más se ha visto sometido por las leyes y las normas. Estamos ante un cuerpo que ha sido silenciado desde la Edad Media. Su textura, su peso, sus formas... han sido completamente ocultadas, y se le impuso la alegoría de la virtud. La pérdida de la inocencia y de la pulcritud encierra una moraleja que convierte al cuerpo en un recinto propicio para albergar el bien ${ }^{616}$.

\footnotetext{
${ }^{615}$ Víctor Bravo, ibídem, p. 64.

${ }^{616}$ Mario Praz, op. cit., pp. 96-102.
} 
Ahora bien, también es cierto que todo discurso normativo nace por unas causas y con unas finalidades muy concretas. Las leyes no se crean porque sí y las autoridades raramente se pronuncian si no detectan un problema. Todo texto legislativo se fundamenta en una necesidad social. Es necesario leer algunas de las obras y artículos de Mary Nash para darse cuenta de la realidad en la que vivían las mujeres de la clase social media-baja. Existía una realidad femenina, una tragedia que iba mucho más allá de la problemática feminista y que sólo se atrevieron abordar los escritores y pintores del romanticismo. Se trata de un drama que se encierra tras las figuras de las bellas mendigas, de las ancianas seductoras, de las negras fascinantes y de las cortesanas humilladas $^{617}$. Como ya hemos dicho antes, estas figuras no sólo son utilizadas por su riqueza estética, sino también porque responden a una cruel realidad. Reflejan el drama de las niñas explotadas sexualmente desde los cinco años por sus padres ${ }^{618}$; el drama de las mujeres que veían cómo sus maridos morían por accidentes laborales o por el alcoholismo dejándoles al cargo de una considerable prole; la necesidad de ejercer la prostitución para mantener a los miembros de una casa; las violaciones en grupo de jóvenes de clase media-alta que se aprovechaban de las obreras que volvían solas a casa; la imposibilidad de trabajar porque legalmente la mujer no recibía la formación necesaria para manipular una máquina de coser... Tales desgracias eran realidades que los escritores como Ibsen retrataron.

De esta forma, toda representación de la maldad femenina no es otra cosa que atreverse a cuestionar, desde un punto de vista artístico, los discursos socialmente canónicos y poner el acento en una realidad social que existía. Pues la mujer no se rebela ante el

\footnotetext{
${ }^{617}$ Mary Nash, Mujeres en el mundo. Historia, retos y movimientos, Madrid, Alianza, 2005.

${ }^{618}$ Según Mary Nash las niñas podían ejercer legalmente la prostitución a partir de los 12 años. Esta ley surge porque la prostitución infantil era una realidad palpable en la época.
} 
hombre: la mujer sólo intenta sobrevivir. Pero esta supervivencia se muestra invirtiendo el discurso canónico, tanto el religioso como el científico. Así pues, la maldad femenina se expresará mediante el lenguaje del cuerpo, en las formas de la alteridad.

\section{7.- La era del Individualismo}

La exploración del mal durante el romanticismo aparece como una de las obsesiones del arte occidental. El mal se comprende como un elemento externo al hombre e innato en la naturaleza. Pero cuando llega, lo invade todo, lo corrompe y lo destruye inevitablemente. El mal es una gran presencia perturbadora que aparece personificada en la figura del Demonio y que se opone a la figura de Dios. De esta forma tenemos los dos clásicos puntos opuestos del Bien y el Mal. Esta expresión maniqueista del universo viene resguardada por el discurso religioso. En la Biblia se narra cómo Dios, movido por la bondad y el amor, creó al hombre y después a su compañera. Se trata de un Dios que mira por la unidad y el equilibrio. Un Dios trabajador que fue interrumpido por el despotismo de Lucifer, el ángel portador de la luz que se reveló contra Él. A partir de este momento ambos forman dos puntos completamente opuestos. Si Dios es la Unidad, el Amor, el Perdón, la Conciliación y la Justicia; Lucifer será el Individualismo, el Rencor, la Envidia, la Desconfianza, la Venganza y la Injusticia.

Desde tiempos inmemoriales, las fronteras entre el Bien y el Mal son muy claras e infranqueables. El hombre que está hecho a imagen y semejanza de Dios no puede ser malo por naturaleza, pero su corazón es débil y puede dejarse tentar. El creyente debe de ser fuerte en su fe para no verse amenazado. A partir de aquí, el discurso religioso no comprende ni asimilará la maldad del ser humano per natura, pero si asumirá la figura del Diablo como una dialéctica necesaria entre ambos terrenos. De esta forma, el Diablo 
representará la tentación del pecado, una jugosa instigación que facilita el paso del Bien al Mal. Así pues, la religión está pensada para ser vivida en comunidad, en grupo. Porque la tentación se produce en la soledad ${ }^{619}$.

\subsection{1.- Normas estéticas ante las que el mal responde}

Según René Wellek, en el siglo XIX europeo podemos diferenciar dos clases de $\operatorname{rasgos}^{620}$. Por un lado tenemos los rasgos dependientes del proceso revolucionario de la época y, por otro lado, los independientes. A nosotros nos interesan precisamente los que dependen de la Revolución. Estos se caracterizan por el afán de libertad y suponen una rebeldía contra todo tipo de límite: límites del género literario, de la unidad, de la norma, de las reglas de la poética clásica... De ahí la afición por los temas de desarraigo, de marginalidad y del vivir fuera de la ley, tales como el pirata, el corsario, el bandolero, el ángel caído o rebelde, el mendigo... y en el caso de las féminas encontramos a prostitutas, brujas, mendigas, mujeres insatisfechas...

Todos estos personajes ofrecen una libertad. No se trata de la libertad del genio, sino de la libertad como principio de toda obra de arte. La libertad se impone como un principio sin normas regularizadoras. Así que la literatura se llenará de personajes que, mediante su cuerpo, representen la ruptura con el orden social. En consecuencia, no sólo tenemos a personajes marginales, sino también a personajes orgullosos de situarse

\footnotetext{
${ }^{619}$ Víctor Bravo, op. cit., pp. 84-90.

${ }^{620}$ René Wellek, Conceptos de crítica literaria, Venezuela, Ediciones de la Biblioteca Universidad Central de Venezuela, 1968.
} 
conscientemente fuera de la sociedad. $\mathrm{Y}$ es entonces cuando el ser humano, ya sea hombre o mujer, puede optar por dos vías posibles: el satanismo o el titanismo ${ }^{621}$.

\subsubsection{1.- El satanismo}

Algo que viene dado de la mano del discurso religioso es el demonismo o satanismo. Este efecto retórico nunca fue creado por ningún artista, sino que siempre residió en el seno religioso. Definiremos el demonismo como el desplazamiento del mal hacia el sujeto, estando anteriormente personificado en la figura del Diablo. Por lo tanto, el eje central del demonismo es la maldad (originalmente demoníaca) y todas sus diferentes representaciones (en la humanidad). En el cristianismo católico este desplazamiento se da en el momento en que Eva acepta la manzana de la Serpiente para dársela primero a Adán. Por lo tanto, el desplazamiento de la maldad del Diablo no se orienta hacia el hombre, sino hacia la mujer: será la mujer la que originalmente encarne la maldad del Diablo.

Esta figura debe entenderse en el plano que fue creada: en el de la religión. Y como tal, se postula en dos terrenos: en el divino y en el humano. En cuanto a la divinidad, debemos advertir que el Diablo, Demonio, Satán o Lucifer, es comprendido como antiguo ayudante de la Divinidad, era el Ángel Portador de la Luz que fue castigado por su soberbia y despotismo. Es el ángel que pretendió ser como Dios, y que, expulsado del Reino de los Cielos, calcula su cruel venganza por medio de la destrucción de la obra divina.

\footnotetext{
${ }^{621}$ Víctor Bravo, op. cit., pp. 63-97.
} 
Según el dogma, el Diablo siempre será el otro, el enemigo, el hereje. En cambio, en el terreno humano, el diablo será analizado bíblicamente como el calumniador, el tentador... el que pretende destruir a la humanidad para vengarse del castigo divino.

De esta forma, la humanidad se muestra fácilmente corruptible ante los planes de venganza de Lucifer. Muchas novelas románticas encierran una constante lucha entre el bien y el mal, en donde la humanidad queda en medio y a merced de ser utilizada como instrumento de cada uno de los lados. Los personajes son marionetas atadas a un destino que no han elegido, pero al que se ven sometidos y limitados. Sólo les quedan dos posibilidades: asimilar la desgracia que les ha tocado vivir o revelarse mediante el discurso de la maldad ${ }^{622}$.

\subsubsection{1.- Elementos que lo caracterizan}

Satanás, el ángel portador de la luz, de la claridad y del entendimiento, ha sido desterrado a las tinieblas. Desde el principio del siglo XIX, ya con los románticos, podemos apreciar que tanto personajes como autores asumen el destierro como algo innato. Novalis mantuvo que la relación entre el hombre y mundo es conflictiva. Lo cual no sólo se vio como un sentimiento, sino también como una función retórica.

Los autores decimonónicos se sienten incomprendidos, y basarán su arte en hacer distantes los objetos. Su retórica fomenta la lejanía entre el yo y el mundo que le rodea. De ahí que el héroe romántico se caracterice por la ausencia de patria. Schiller hablará de los románticos como de personas desterradas que languidecen por una patria que no tienen, de ahí el culto a las ruinas y a la noche. Este culto se expresa mediante dos vías:

\footnotetext{
${ }^{622}$ Víctor Bravo, op. cit., pp. 77-85.
} 
el desquite de la naturaleza frente a la civilización, y la patria perdida como lugar de ensueños. Esto deriva en un excesivo sentimentalismo caracterizado por la melancolía entre el yo y la realidad, y la nostalgia de estar en todas partes y en ninguna. En todo momento la realidad aparecerá deformada por el sentimentalismo extremo. La nostalgia de un tiempo pasado, mejor y familiar lo invade todo. Se trata de un intento frustrado de recuperar el pasado, para responder al deseo de encontrar una estabilidad temporal en una sociedad en continuo cambio.

Se alude a un hombre que en su ansiedad quebranta los límites y le pide cuentas a Dios; el hombre se vuelve hacia Dios de forma arrogante: se auto concibe como un dios caído, deshorientado por la oscuridad que le rodea y que no puede comprender.

\subsubsection{2.- El pacto}

Existe toda una serie de historias del Demonio que corren a cargo de la teología, y de las cuales, la historia del arte se ha hecho eco. Pero en el campo ficcional tres son las novelas góticas que marcan un antes y un después en la posibilidad estética del Diablo. Estas son El castillo de Otranto (1764) de Horace Walpole, El monje (1794) de Mathew G. Lewis, y Melmoth, el errabundo (1820) de Charles Maturin.

En la novela de Walpole, vemos cómo el castillo de Manfred está habitado por duendes y fantasmas. Pero su presencia no es casual; por supuesto, tales apariciones sobrenaturales tienen la finalidad de castigar un delito.

En la novela de Mathew G. Lewis, la figura del Diablo se ve cristalizada en la “tentación", y comienza a dar pie a una de las desviaciones fundamentales en la literatura posterior: el pacto. El monje Ambrosio, que bordea los lindes de la santidad, 
se ve tentado por la figura de Matilde ${ }^{623}$. Tras sucumbir al cuerpo femenino, Ambrosio realiza un pacto con el Diablo que lo llevará al asesinato y a la voluptuosidad de la casta Antonia. El texto de Lewis, que se adelantará al Fausto de Goethe, plantea no sólo la corrupción de la santidad, sino la innovadora fórmula del pacto que conlleva la perdición definitiva del pecador y del pactario.

La novela de Charles Maturin plantea dialécticamente la presencia del Mal contra el Bien. Pero rompe con la estrategia maniqueista que se venía dando, y ahora nada es lo que parece. En su novela, se atreve a cuestionar lo buenas que eran algunas instituciones reconocidas en la época. Plantea que algunas de ellas, como la Santa Inquisición, ocultan obras malvadas bajo las reglas de la moralidad y del bienestar social. Por lo que, vemos como el Bien, en ocasiones se pueden tornar en Mal y viceversa. De ahí que la aparición del diablo, o de alguien con poderes diabólicos, pueda llegar a verse como salvación en lugar de verse como tentación.

Por supuesto, la novela de Maturin llega hasta el último extremo al plantear el Bien y el Mal en términos tan complejos. Este testigo lo recoge Balzac y lo desplaza hacia la exploración natural del deseo. El modelo del pacto supuso la posibilidad de cumplir los deseos. Pero condenó su esencia: la posibilidad de satisfacer el deseo sólo acontece a través de su imposibilidad. Balzac observa cómo la realización de los deseos de los personajes lleva al cansancio y a la saciedad de todo. Tal es el caso de La piel de zapa (1831) de Honoré de Balzac, El retrato de Dorian Grey (1891) de Oscar Wilde y "La pata de mono" (1902) de W. W. Jacobs ${ }^{624}$. Por lo que uno de los elementos que

\footnotetext{
${ }^{623}$ Es interesante resaltar que Matilde representa el Diablo. Pero ninguna de las obras que he estudiado, ni la de Erika Bornay o la de Isabel-Argentina Fuentes o la de Praz, estudian a la mujer-Diablo. No existe en una clasificación para esta figura.

${ }^{624}$ Víctor Bravo, op. cit., pp. 77-80.
} 
constituyen el demonismo fue el pacto, y este supuso la indagación estética del Mal que hoy día todavía se sigue elaborando ${ }^{625}$.

\subsubsection{3.- El pacto femenino. Las brujas}

La relación ancestral que ha unido a la mujer con el demonio se ha explicado desde distintos y muy variados discursos: desde el discurso bíblico hasta el drama cósmico la mujer se ha visto como la heredera directa del Demonio ${ }^{626}$. Así se explica que la naturaleza femenina sea sinuosa, como una maraña de ramas retorcidas que trepan y se arrastran; son tentáculos de fétida vida orgánica que Wordsworth nos enseñó a considerar hermosos. Incluso los científicos de la época romántica hablaban del cerebro reptil que tenía la especie humana. Este era la parte más antigua de nuestro sistema nervioso superior, un asesino superviviente de la era $\operatorname{arcaica}^{627}$.

Pero al margen de esta idea un tanto rocambolesca, vemos como en Francia y en Inglaterra entre muchos escritores y artistas decadentistas se puso de moda el tema de las ciencias ocultas y la magia negra. En cuanto a la vida personal fueron numerosísimos, pero aquellos que lo reflejaron en sus obras fueron algunos menos, como Eliphas Lévy, Huysmans y su Là-Bas, Oscar Wilde y El retrato de Dorian Gray... Pero el pintor por excelencia de este asunto fue Félicien Rops, quien en su

${ }^{625}$ Este movimiento cultural se sigue trabajando en el campo cinematográfico. En donde festivales internacionales, como el de Sitges, han establecido la sección de "Satanismo".

${ }^{626}$ Erika Bornay, op. cit., pp. 183-188.

${ }^{627}$ Camille Paglia cree que la mujer premestruante oye señales de ese cerebro reptil. Tal vez este le incite a la irritación o a la rabia y ponga de manifiesto la perversidad latente del hombre, por lo que se desatan las fuerzas del infierno de la naturaleza ctónica dormida en lo más profundo de la mujer. La lucha de toda mujer premestruante por dominarse pone de manifiesto el enfrentamiento de los cultos celestes y de la tierra. La identificación de la mujer con la naturaleza es correcta; por lo que la mujer embarazada es demoníacamente perfecta. Cuando se da el paso hacía lo ilícito, se produce un violento movimiento hacia la desolación exterior, y el modelo básico es la expulsión de Adán y Eva del Paraiso. 
cuadro Los diablos fríos (1860) representa una figura femenina de opulentas carnes, de ojos cerrados y de breve sonrisa ${ }^{628}$, abrazada por un oscuro y alado Lucifer ${ }^{629}$.

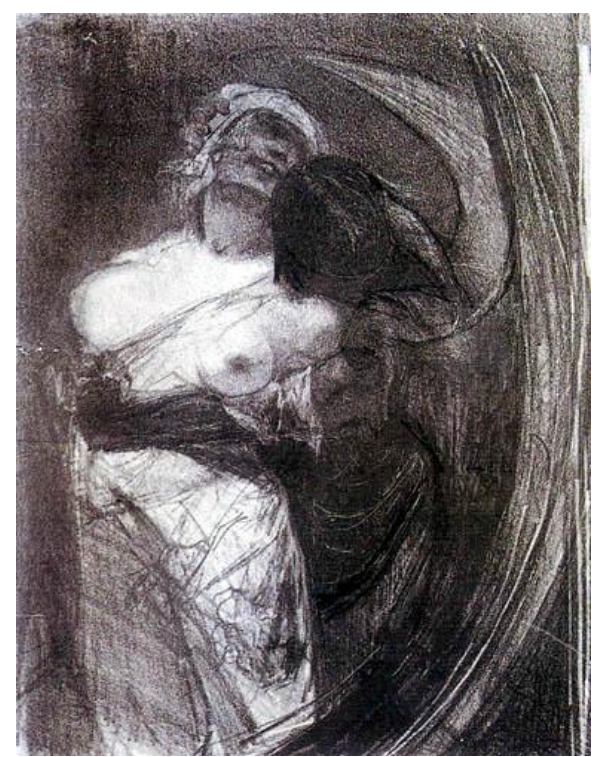

Félicien Rops (1860)

Para muchos de ellos se trataba de la imagen simbólica de la naturaleza femenina. Una imagen que toma forma de serpiente a partir del pasaje del Génesis. Pero la serpiente no podemos entenderla como tal, sino como un elemento simbólico ${ }^{630}$. Se trata de la naturaleza ctónica y del auténtico enemigo de Dios.

${ }^{628}$ Erika Bornay, op. cit., p. 341.

${ }^{629}$ Tras este mismo cuadro se anuncian las series de Las satánicas (1882), Las diabólicas (1879) y Naturalia (1883). También es cierto que las obras de Rops no pueden ser explicadas desde la transposición del satanismo baudeleriano, sino que la respuesta se encuentra desde los términos plásticos del convencido análisis de la época de Huysmans en Certains. En El diablo mostrando la mujer al pueblo, Otto Greiner mantiene que la relación entre la mujer y el diablo se establece como cómplices y amigos, pues ella sonríe orgullosa de su relación con Lucifer. Seguidor de Max Klinger y de su obra Encadenada (1884), Otto Greiner muestra una escena que recuerda a un aquelarre, donde vemos exactamente a una prostituta tendida sobre el cuerpo de un diablo que la mantiene firmemente sujeta mientras la muestra ante un coro de hombres de frac y con sombrero de copa. Se trata de la misma hipocresía moral que también había mostrado Edward Munch en El callejón. Es la representación de la humillación femenina como mercancía. Del mismo modo tenemos los óleos de Gauguin titulados Cuentos bárbaros; si nos fijamos concretamente en Muchacha con demonio (1895-1903) observaremos a una joven nativa acompañada por un ser extrañamente zoomórfico.

${ }^{630}$ Erika Bornay, op. cit., pp. 183-188. 
La serpiente era el más astuto de todos los animales del campo que Yahvéh Dios había hecho. Y dijo a la mujer: “¿Cómo es que Dios os ha dicho: No comáis de ninguno de los árboles del jardín? Respondió la mujer a la serpiente: "Podemos comer del fruto de los árboles del jardín. Mas del fruto del árbol que está en medio del jardín, ha dicho Dios: No comáis de él, ni lo toquéis, so pena de muerte". Replicó la serpiente a la mujer: "De ninguna manera moriréis. Es que Dios sabe muy bien que el día que comiereis de él, se os abrirán los ojos y seréis como dioses, conocedores del bien y del mal". Y como viese la mujer que el árbol era bueno para comer, apetecible a la vista y excelente para lograr sabiduría, tomó de su fruto y comió, y dio también a su marido, que igualmente comió ${ }^{631}$.

El pacto es algo propio de la naturaleza, y en esta siempre prima el instinto sobre el intelecto. El Diablo quiere engañar al hombre, pero para conseguirlo con éxito necesita utilizar a la mujer. Conque al pacto originario debemos añadir la tentación que Eva ejerce sobre Adán, y es cuando la transgresión femenina adquiere carácteres cercanos al sacrilegio y el deseo se torna pasión y perversión. Esto se ve en el cuento "La dicha en el crimen" de Las diabólicas, en donde el doctor Torty establece una triple relación: mujer-bestia-diablo ${ }^{632}$.

Popularmente se conoce que las brujas rechazaban el cristianismo por lo que, mediante el pacto con el Diablo, eran rebautizadas. Esta ceremonia consolidaba la relación de la mujer con el Mal y, a través de él, la bruja adquiría el poder de para desarrollar maleficios y el don de la clarividencia. El estereotipo popular de las brujas se afianzó durante las persecuciones que sufrieron a lo largo de la Edad Media. Entre otras cosas se pensaba que el Diablo dejaba una marca en la piel de las jóvenes tras realizar el pacto. Estas y otras muchas ideas, como el conocimiento de las plantas, sirvieron de guía a muchos tribunales.

\footnotetext{
${ }^{631}$ Génesis, 3; $1: 6$.

${ }^{632}$ Erika Bornay, op. cit., p. 343.
} 


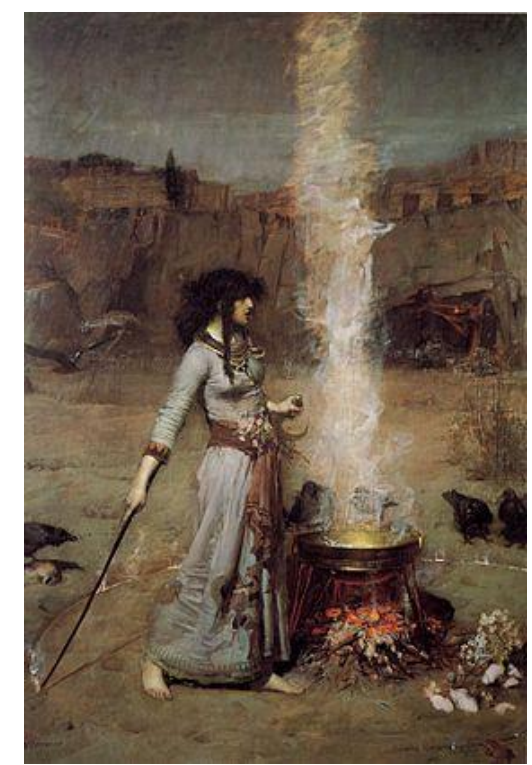

El círculo mágico (John William Waterhouse)

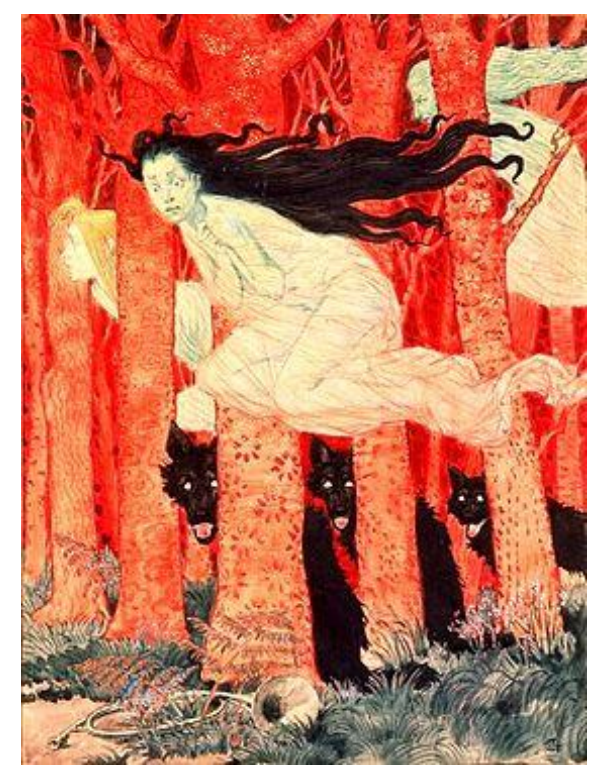

Trois femmes et trois loups (Eugène Grasset)

Si la serpiente simbolizaba el pacto entre la mujer y el Diablo, también existían otros muchos animales que representaban sus poderes mágicos. Tales eran el gato negro, el cuervo, el sapo, la araña, la rata o la liebre. Las superticiones populares no sólo cuentan que las brujas vivían rodeadas de estos animalillos, sino que también podían transformarse en ellos para realizar fechorías.

El estereotipo de la anciana que vive en lamontaña aislada de toda la humanidad se fomentó durante toda la Edad Media.

Son mujercillas de baja condición, que malviven en los valles alimentándose de castañas y de hierbas. Si no toman un poco de leche, no sobrevivirían. Por eso son malicentas, deformes, de color terroso, con los ojos salidos, y de su mirada se deduce que poseen un temperamento melancólico y bilioso. Son taciturnas, distraídas y se distinguen poco de los poseídos por el demonio. Hablan con tal determinación que, si solo se atiende a sus palabras, podríamos creer que son ciertas las cosas que cuentan con esa convicción, cosas que nunca han sucedido ni nunca sucederán ${ }^{633}$.

\footnotetext{
${ }^{633}$ Gerolamo Cardano, Sobre la variedad de las cosas, citado en Umberto Eco, Historia de la fealdad, Barcelona, Lumen, 2007, p. 208.
} 
Y se han conservado hasta la actualidad.

Por la noche yacía despierto, y a la luz de la luna que penetraba en la habitación contemplaba aquellos forúnculos y aquellos bultos que en mi imaginación infantil se convertían en los bocios y en las verrugas de una terrible bruja jorobada con una espantosa enfermedad de la piel, un espíritu condenado por sus pecados contra los hombres, que debía estar atrapado, atormentado en el yeso desconchado de una vieja pared de la periferia. A veces, la bruja abandonaba el muro y penetraba en mis pesadillas (tenía muchas pesadillas cuando era niño), y entonces, cuando me despertaba aterrorizado, la veía sonreir malignamente en una esquina de la habitación, con la cabeza envuelta en las tinieblas y los ojos resplandecientes en aquella horrible piel manchada, mientras el hedor de su aliento infectaba el aire; entonces me esentaba en la cama, gritando, y la bruja no regresaba a su pared hasta que acudía mi madre y encedía la luz, pero yo tenía que dejar encendida la lamparilla el resto de la noche ${ }^{634}$.

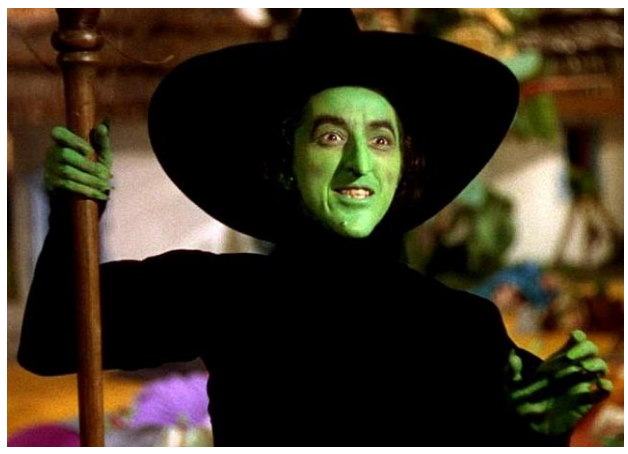

El Mago de Oz (1939)

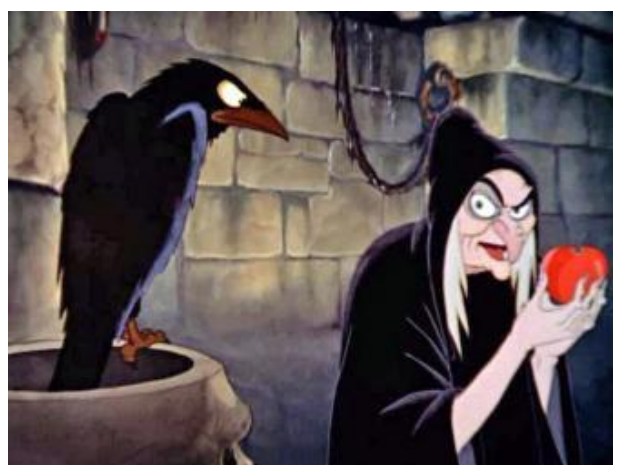

Blancanieves (1937)

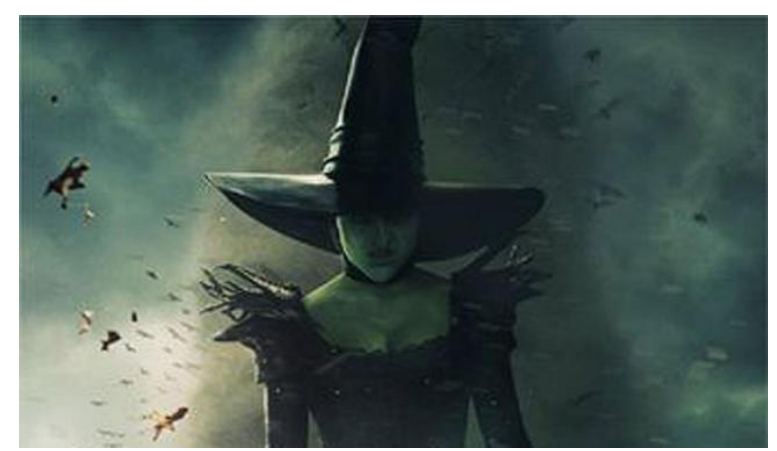

Oz, un mundo de fantasía (2013)

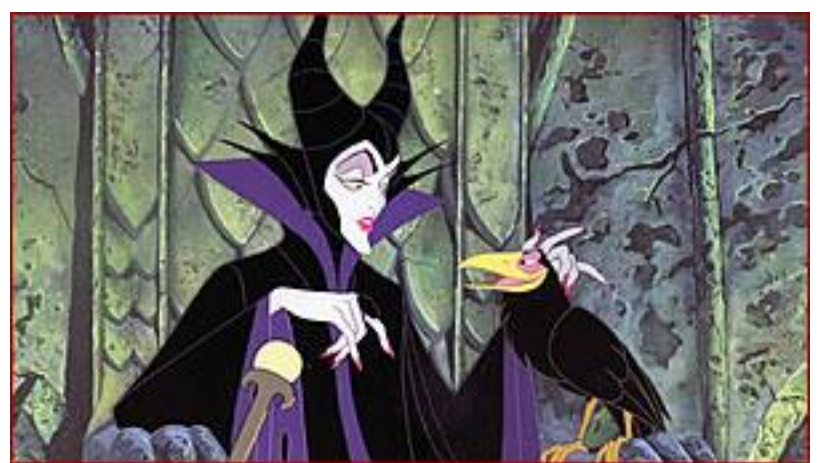

La bella durmiente (1959)

${ }^{634}$ Patrick McGrath, Spider, citado en Umberto Eco, Historia de la fealdad, Barcelona, Lumen, 2007, p. 214. 


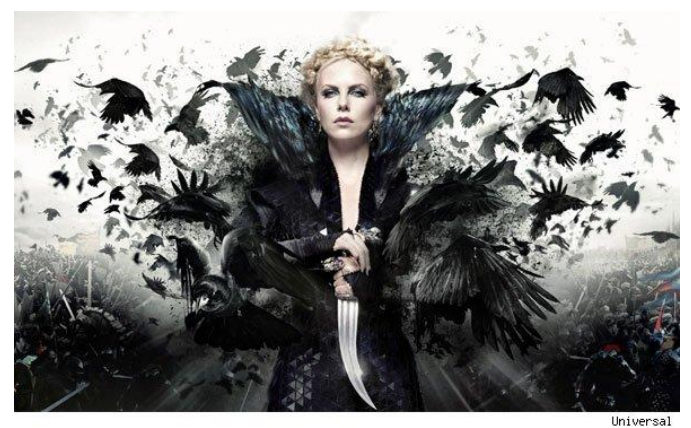

Blancanieves (2012)

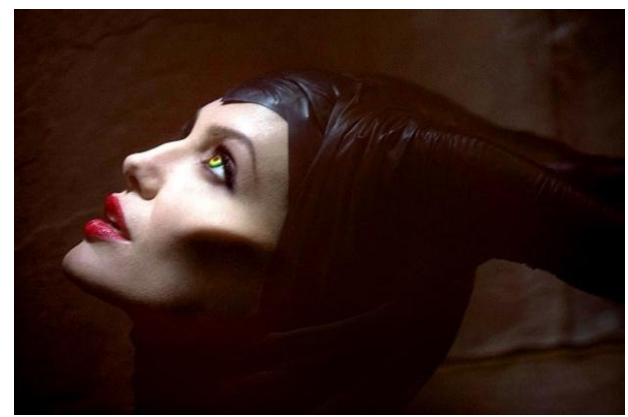

La Bella Durmiente

\subsection{1.- Circe}

En su regreso a Ítaca, Ulises hace escala en la isla Eea, pero antes de desembarcar envía a sus compañeros para que inspeccionen el terreno. El regreso de los marineros se hace eterno, así que Ulises decide ir a la isla. Es entonces cuando encuentra a sus hombres convertidos en cerdos, leones o perros, según su carácter. Circe, dueña y señora de Eea, logra seducir al héroe homérico y lo retiene en la isla durante un año. Muchos artistas de fin de siglo vieron en esta maga un claro ejemplo de los peligros del sexo femenino. Ya Arthur Hacker en su obra nos muestra a una Circe (1893) voluptuosa que se adorna los cabellos con las rosas que aparecen esparcidas a su alrededor, mientras mira impasible como los compañeros de Ulises se van transformando en cerdos de forma progresiva. Al respecto, el crítico de arte M. H. Spielmann ${ }^{635}$ escribe un artículo en donde establece un paralelismo claro entre la depravación sexual del tema y la sociedad contemporánea, incluyendo el eterno femenino como causa de la ruina de los hombres.

\footnotetext{
${ }^{635}$ M.H. Spielmann, “Circe”, Londres, Royal Academy Pictures, 1893.
} 


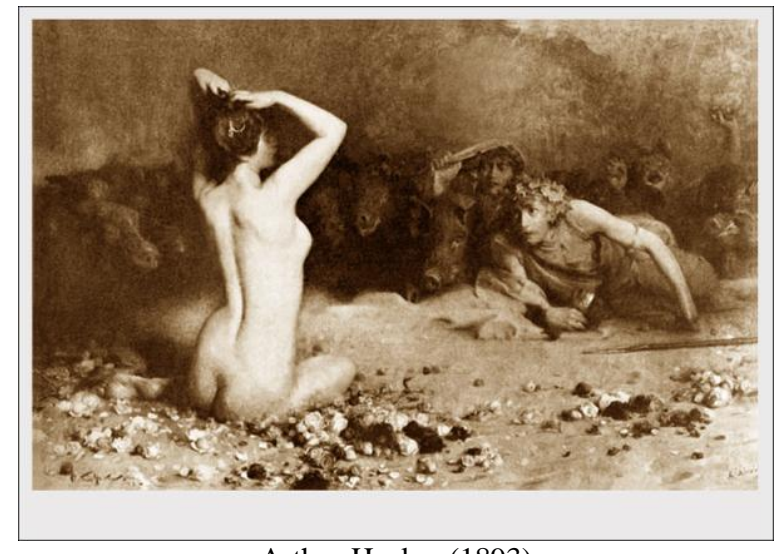

Arthur Hacker (1893)

De la misma idea beben obras como la de Lévy-Dhurmer. En su Circe (1897) se aprecian unos ojos y una sonrisa muy similares a la Gioconda; con copa de champagne en mano muestra su nombre grabado en el collar. Sin embargo, John William Waterhouse en su obra Circe envenenando el mar (1892) muestra a la maga echando una pócima en el agua para hechizar a su rival, la mujer de Glauco, a quien transformará en un monstruo marino para aplastarlo.

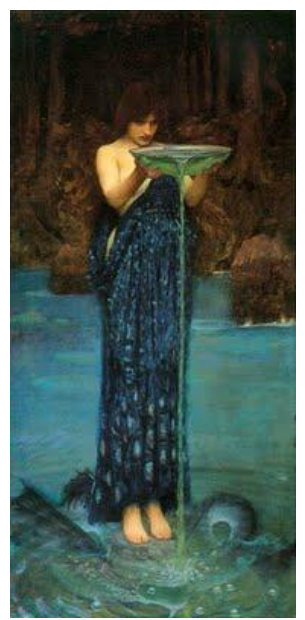

John William Waterhouse (1892) 
Félicien Rops da un paso más y presenta su Pornócrates (1878) en el "Cercle des XX" en Bruselas (1886). Para sus contemporáneos denotó "el vicio" a través de sus escasos $\operatorname{vestidos}^{636}$.

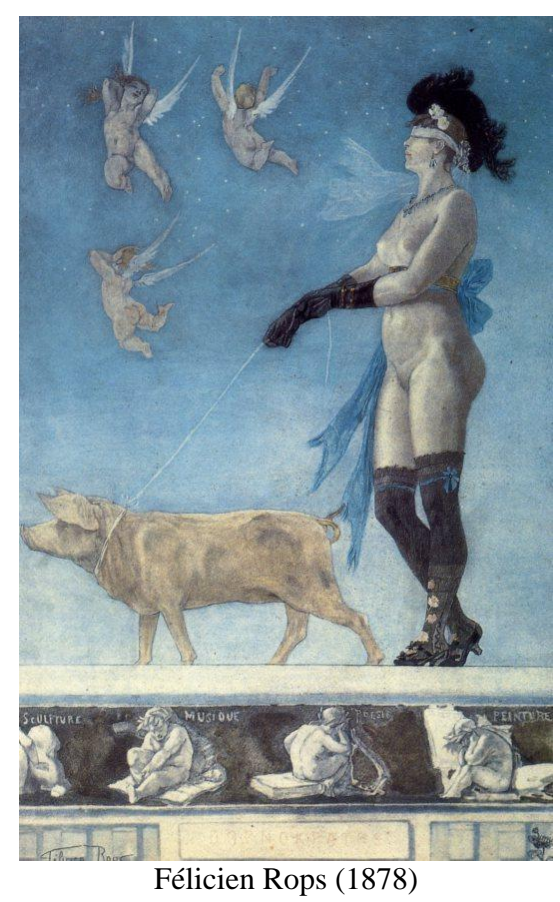

\subsection{2.- Sidonia von Bork}

Este apartado recibe el mismo título que la novela terrorífica que Wilhem Meinhold publicó en 1847. Fue traducida al inglés durante el romanticismo y cuenta la historia de Sidonia, una joven bellísima de una familia noble de Pomerania. Era una bruja que destruía a todos los que interferían en sus planes. Con la ayuda de sus hechizos provocó la muerte y la esterilidad de varios duques de Pomerania. Finalmente, fue capturada y condenada a la hoguera a la edad de ochenta años. Esta novela encantó a Rossetti, a

\footnotetext{
${ }^{636}$ Erika Bornay, op. cit., pp. 171-174.
} 
Swinburne, a su círculo y a E. Burne-Jones, quien más tarde dibujaría a Sidonia von Bork (1860) maquinando un perverso plan ${ }^{637}$.

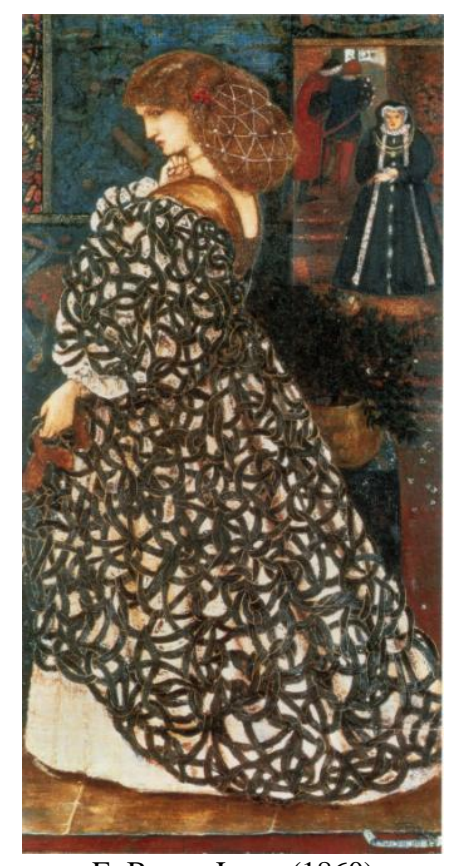

E. Burne-Jones (1860)

\subsection{3.- La Condesa Sangrienta}

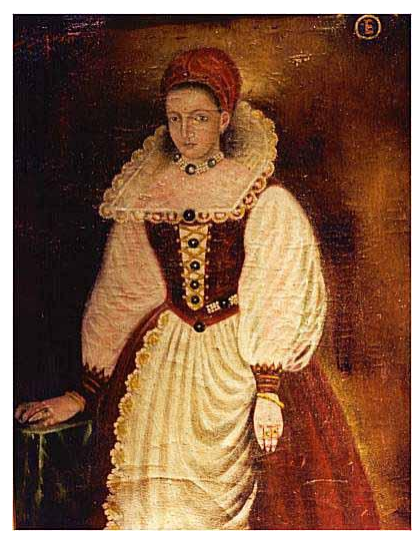

Este es uno de esos personajes en donde la historia y la leyenda se entremezclan de tal forma que los límites son un poco complicados de discernir. Para comenzar diremos que su nombre completó fue Erzsébet Báthory de Ecsed; nació en 1560 en Transilvania, y creció en el seno de una de las familias más importantes de Hungría, por lo que recibió ${ }^{637}$ Erika Bornay, ibídem, pp. 226-228. 
una educación muy buena y muy elevada para la época. Con apenas quince años se casa con su primo Ferenc Nadasdy. Cinco años después del matrimonio la joven se queda embarazada y tiene a su primera hija, Anna. Le seguirán dos más, Orsolya y Katalin. Hasta que finalmente llega el varón llamado Pablo. Pero el marido de Elizabet muere en una batalla y ella queda al cargo de todas las tierras y criados, lo que la convierte en una mujer completamente vulnerable para la época. Pero su situación todavía se hizo más delicada el día en que su primo, Gabor I Báthory, es nombrado rey de Transilvania. La cuestión es que ella ayudaba económicamente a su familia, incluido a su primo. Al ser nombrado rey, ella traicionaba al rey Matías II de Hungría. Lo cual, y siendo viuda, la colocaba en una posición todavía más difícil y la hunde en una atmósfera de peligrosas tramas políticas.

A partir de este momento la historia y la leyenda se mezclan. Por aquel entonces empiezan a correr rumores muy extraños. Se dice que comenzaron a desaparecer las jóvenes doncellas vírgenes de los pueblos de alrededor. Estos rumores fueron creciendo hasta el punto de ir acompañados de acusaciones de brujería hacia Báthory. Se decía que, por miedo a envejecer, Elizabet mandaba secuestrar y matar a jóvenes vírgenes para beber o bañarse en su sangre.

Mary Nash analiza esta idea en su obra... Existía un rumor popular que contaba las propiedades curativas de los cuerpos de las doncellas vírgenes. Los orígenes de las creencias populares son muy remotos, pero todas ellas certificaban que los cuerpos puros de las niñas tenían propiedades mágicas. Se creía que abusar de una niña podía curar muchas enfermedades veneras, o que beber la sangre de una virgen proporcionaba longevidad. De ahí que durante el siglo XIX la pornografía infantil y el tráfico de menores aumentaran en niveles alarmantes. 
La condesa Báthory diseñó una serie de artilugios muy macabros para torturar y matar a las jóvenes con el único objetivo de sacarles el máximo de sangre posible. Finalmente, la condesa mató a un número tan grande de vírgenes que no pudo ocultar por más tiempo sus atrocidades. Así que, siendo descubierta, se la acusó de brujería y se la condenó a morir emparedada.

\subsubsection{2.- El titanismo}

Si el satanismo se caracteriza por el pacto, el titanismo es la imagen del rebelde que rompe con el mundo y se enfrenta a él. Lucha con grandeza y esfuerzo deseando alzarse como un hombre nuevo y puro, adánico, no contaminado por nadie. Se trata de alguien que no se arrepiente, que se mantiene rebelde hasta el fin de sus días. No aspira a sustituir a Dios, porque, realmente, sus aspiraciones tienen su justificación en la tierra. Se releva ante el misterio cotidiano; este desafío procede de la duda y de la exigencia de libertad $^{638}$.

Estamos ante un personaje cuyo único anhelo es descifrar la realidad del mundo que le rodea. Para ello aceptará la muerte desde una perspectiva muy diferente a la de la idea de transito. No se trata de la visión cristiana del viaje al más allá, sino que se concibe la muerte como fin. El individuo aceptará la muerte sin arrepentirse de sus pecados, como el Fausto de Goethe. La muerte puede comprenderse como un castigo para el hombre o para la mujer que se ha atrevido a descubrir los misterios del mundo. Pero el despótico protagonista no lo verá así, pues se trata de una muerte aceptada. Para demostrarlo será capaz de fundirse en un abrazo final de amor y muerte. De ahí que uno de los tópicos más característicos del Romanticismo sea el desposorio con la muerte. De este derivan

\footnotetext{
${ }^{638}$ Mario Praz, op. cit., pp. 115-118.
} 
otras ideas como la del lecho-tumba, la del mundo al revés o la alteración de los sentidos que propicia la visión de la propia muerte ${ }^{639}$.

\subsubsection{1.- Carmen}

Prosper Mérimée publica en 1845 su novela Carmen y esta influyó tanto en Georges Bizet que en 1875 estrena su ópera Carmen. En España también ha sido llevaba a la gran pantalla de la mano de Carlos Saura y de Vicente Aranda (2003).

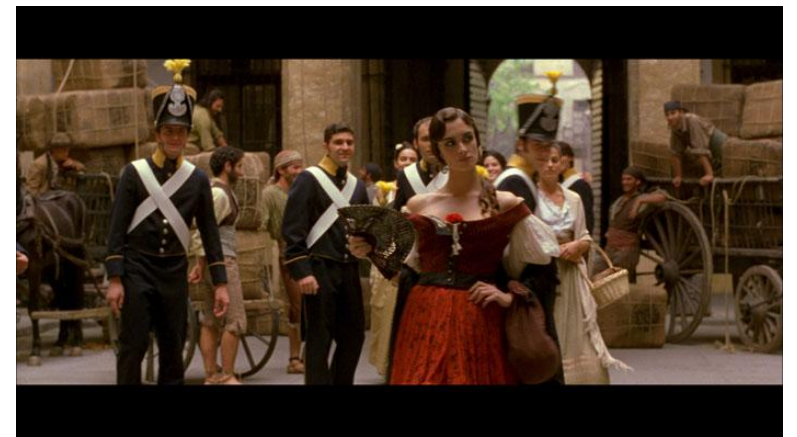

Carmen (Vicente Aranda)

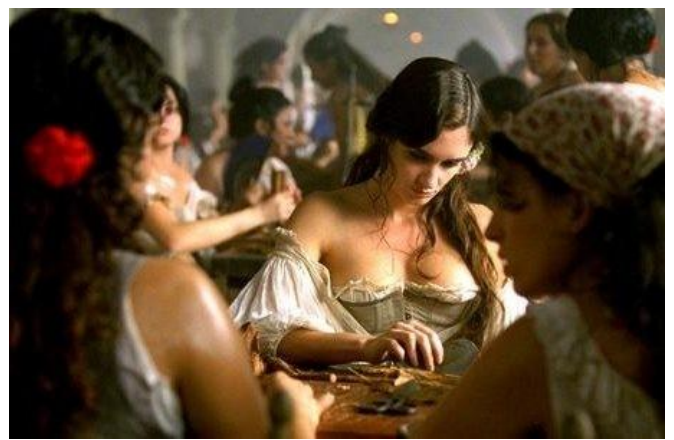

Carmen (Vicente Aranda)

Todas ellas se ambientan en Sevilla para contar la historia de Carmen, un hermosímima gitana con un temperamento muy fiero que embruja al cabo Don José y lo lleva por el camino de la desventura. La joven no sólo es tratada como la fémina que arrastra al cabo a la deshonra, sino también como la encarnación del mismo diablo. En la película de Vicente Aranda, no sólo se menciona en el largometraje, sino te también se percibe visualmente desde la introducción:

\footnotetext{
${ }^{639}$ Víctor Bravo, op. cit., 1987, pp. 83-86.
} 


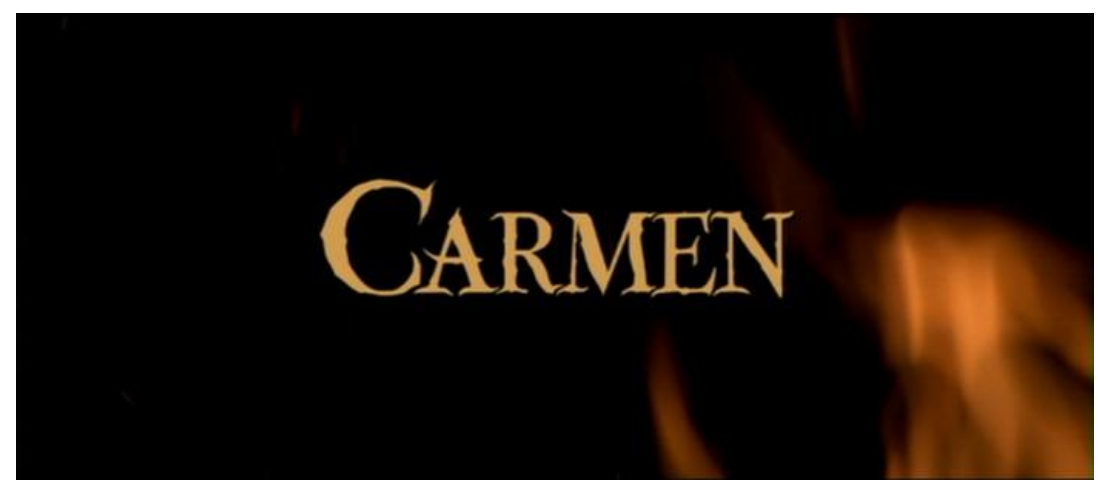

Carmen (Vicente Aranda)

Carmen encarna todas las pasiones y vive al máximo sin temer las consecuencias. Este argumento es precisamente el responsable de la estructura narrativa de la historia, pues comienza contando el origen de la pasión que surge entre Don José y Carmen; un amor tortuoso y prácticamente imposible que lleva al joven muchacho a la desesperación. Esto se aprecia muy bien con el fragmento de La Habanera que inicia la ópera de Bizet, en él ya se plantea que Carmen cuando ama es como un pájaro caprichoso que nadie puede enjaular. Don José se enamora de ella y sueña con establecerse como una pareja normal. Pero la trama se complica y observa que Carmen es una joven imposile de controlar ni de atar. Loco de ira y harto de la libertad amorosa de la que goza Carmen, Don José la mata. Mediante este argumento vemos como desde el principio la joven gitana asienta las bases de su propia personalidad, las cuales le llevan irremediablemente a la muerte.

\section{8.- El aprendizaje de la femme fatale}

Fijémonos en las obras donde las protagonistas son niñas o jovencitas adolescentes. Por supuesto, no es necesario hacer hincapié en que detrás de ellas se esconde el tema de la pornografía infantil, cuestión que destapó el periodista W. T. Stead en 1885. Por ley una niña llegaba a la pubertad a los doce años; sin embargo era muy fácil encontrarlas en los 
burdeles antes de esa edad. Así lo recogen R. Pearsall en "The Stead Case", A. Corbin en Les filles de noce misère sexuelle et prostitution (19e siècle) y $\mathrm{R}$. Pearsall en The worm in the bud. The world of Victorian Sexuality. Además, hay que añadir la creencia popular de que las enfermedades venéreas que se habían extendido se curaban desflorando o violando a una virgen. Dicho dogma hacía pensar que llevar el mal a la inocente podía curar, por lo que dicha leyenda fue asumida por muchos prostíbulos y favoreció la explotación de menores. Bruselas fue considerada el centro de la prostitución infantil, allí había cientos de jóvenes de todas partes de Europa que habían sido raptadas, engañadas y vendidas. No es extraño que la Palm Mall Gazette imprimiera a modo de panfleto "The Maiden Tribute of Modern Babylon", aludiendo a la figura del Minotauro y a su cuota de vírgenes sacrificadas ${ }^{640}$.

Paralelamente, en el siglo XIX, en el mundo literario aparece el culto a la virgen púber. Es decir, a la inocencia y a la pureza de la infancia; pero también se sospecha contaminada por la misma morbosa e inmadura fijación erótica. Así se demuestra en William Wordsworth en Atisbos de inmortalidad por los recuerdos de la niñez, la contraposición de las obras de William Blake de Canciones de inocencia y Canciones de experiencia, y las imágenes de una infancia fantástica de Coleridge y C. M. Bowra en La imaginación romántica.

En Francia, Mario Praz hace notar cómo Chateaubriand confiesa haberse sentido atraído por las andrajosas adolescentes venecianas. Especialmente, por una niña descalza vestida únicamente con un harapo. Ya en los prerrománticos surge una fuerte admiración y culto por la etapa virginal de la infancia, pues es la época más pura del ser

\footnotetext{
${ }^{640}$ Erika Bornay, op. cit., 2010, pp. 142-143.
} 
humano. Así vemos la obra de Dante Vita Nuova, donde la protagonista es la jovencísima Beatriz.

Algunos románticos tardíos, algunos prerrafaelistas, decadentistas y estetas, utilizaron la figura de la niña-virgen para oponerse al modelo agresivo del mundo industrial. Se trata de una figura menos obscena que la de la mujer madura. No tiene curvas ni vello púbico, y resulta ser una figura más tranquilizadora y menos exigente, por lo que la niña-virgen sería una de las figuras tópicas del fin de $\operatorname{siglo}^{641}$.

\subsection{1.- Las niñas}

En la segunda mitad del siglo XIX la idea de pureza cambia. La imagen de niña pura y linda se llena de inconfesables titubeos, culpas e hipocresías. Son el reflejo de la aceptación de la doble moral que la sociedad les había impuesto. Un ejemplo lo encontramos con Edgar Allan Poe, quien se casa su prima Virginia de apenas catorce años de edad. Otro es el extraño caso de John Ruskin, quien escribe sobre Rose la Touche en Lilies. En este último vemos cómo se mezcla la idea del sexo con el anhelo de pureza y se canaliza en el culto a una niña en la que ya se presentía el cambio a mujer.

John Ruskin idealizó totalmente a Rose, la identificó con santa Úrsula, y pensando en ella escribió Lilies, obra de mucho éxito en su tiempo. Seguramente en Rose intentó hallar el paraíso perdido, la identidad primigenia impoluta del mundo de la inocencia, aquella que celebró Blake en sus Canciones. Pero en él, como en otros de sus contemporáneos, sexo y anhelo de pureza -que muchos ya no creían poder hallar en la mujer moderna- se mezclaban, de forma no exenta de morbosidad, en un culto a la niña que ya presentía a la mujer

${ }^{641}$ Erika Bornay, op. cit., pp. 143-146. 
(morbosidad tal vez estimulada por el conocimiento de su presencia en los prostíbulos y, como consecuencia, de su posibilidad de actuar también como un ser adulto) ${ }^{642}$.

Estas figuras jóvenes significaban el poder abandonarse a las fantasías del “amor sin miedo", pues lo hacían como si fuera un juego y con inocencia asombrosa. Este era el caso de las fotografías del reverendo Charles Dodgson, también conocido como Lewis Carrol que fotografiaba a niñas disfrazadas, pero que las rechazaba cuando entraban en la pubertad.
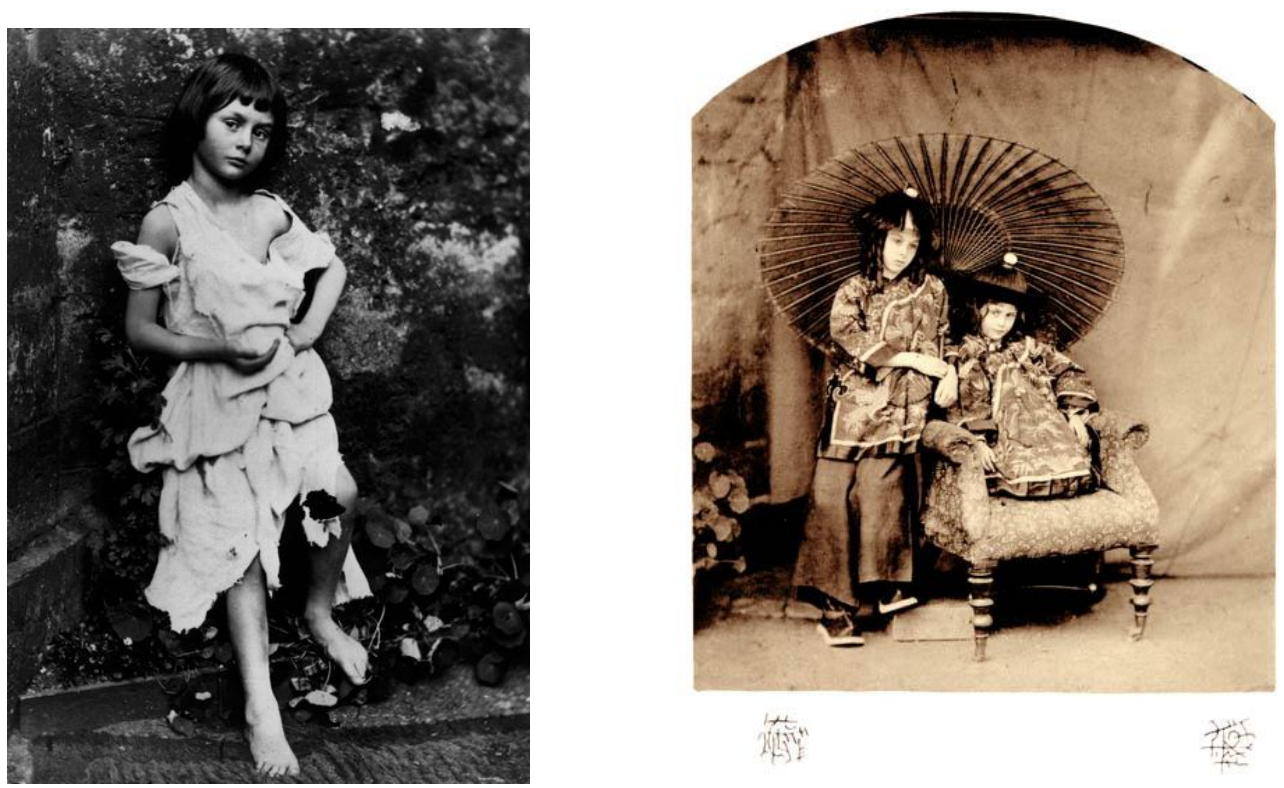

También, en este aspecto son destacables las figuras de Gautier y de los hermanos Goncourt $^{643}$.

En el articulo "Des Enfants", escrito por Paul Adam y publicado en 1895 por la revista La Revue Blanche, se advierte cómo algunas niñas reflejan conductas y características eróticas propias de la femme fatale. Pero, al mismo tiempo, son un arma de doble filo para el escritor, pues reflejan la hipocresía de la época, la presión sexual que sufrían las

\footnotetext{
${ }^{642}$ Erika Bornay, op. cit., pp. 146-147.

${ }^{643}$ Erika Bornay, ibídem, p. 147.
} 
menores, el comercio, el miedo latente a la nueva mujer moderna y las enfermedades que afectaban a la virilidad de los estetas y de los decadentes. Al mismo tiempo se mostraban como un punto fronterizo donde se diluyen la inocencia y el erotismo perverso. Así se ve en el cuadro de E. Munch La pubertad (1894), Bañista veneciana de Paul Peel (1912), Niña ante el espejo de Daynes-Grassot (1912), Biancabella y Samaritana, su hermana serpiente de Edward Robert Hughes (1894), Salomé triunfante de Edouard Toudouze (1886), los dibujos de ninfas de Coleman entre 1840 y 1870 y su Religious Traet Society inglesa, las sensuous fancies. Este último fue uno de los primeros libros moralizantes para niños, pues se comienza a temer que la inocente niñavirgen se acabe convirtiendo en la ambigua nymphet, y evolucione a la moderna Lolita. Es decir, a una aprendiz de mujer fatal ${ }^{644}$.

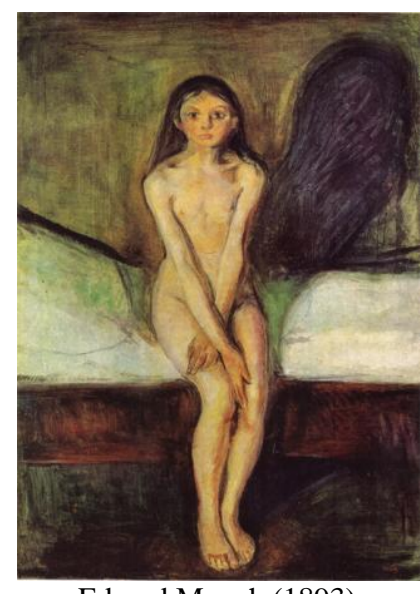

Eduard Munch (1893)

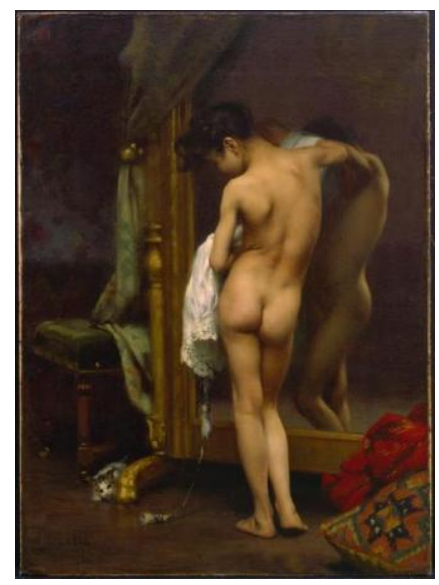

Paul Peel (1912)

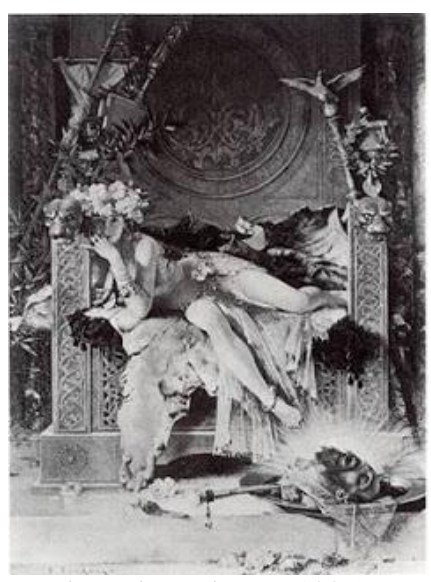

Edouard Toudouze (1886)

Uno de los casos más modernos es la novela Lolita de Vladimir Nabokov y que años más tarde Stanley Kubrick llevaría a la gran pantalla.

\footnotetext{
${ }^{644}$ Erika Bornay, op. cit., pp. 151-156.
} 


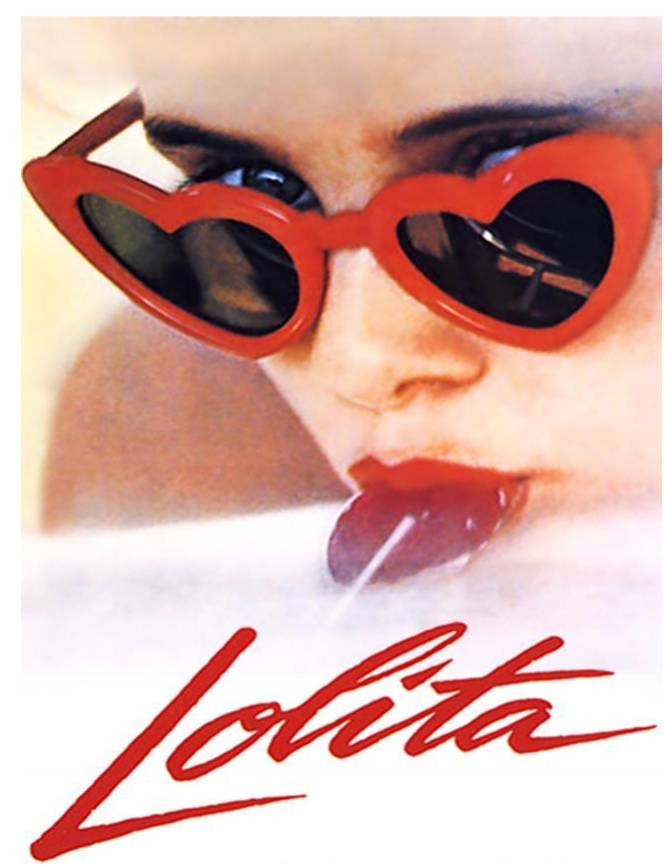

Stanley Kubrick (1962)

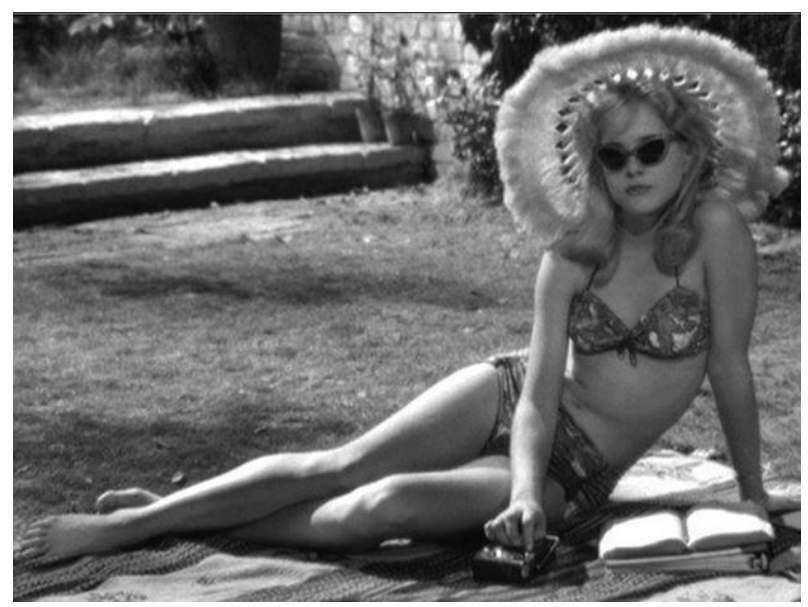

Stanley Kubrick (1962)

Recientemente, en 1997 se hizo un remake con Adrian Lyne como director. Todas ellas cuentan cómo Humbert Humbert, un profesor de literatura se traslada a un pequeño pueblo llamado Ramsdale. Allí conoce a Charlotte Haze, madre de una hermosa joven de 14 años llamada Dolores y a la que todos cariñosamente llaman Lolita. La joven encarna la belleza de la inocencia, la pureza sin corromper, el lugar prohibido por las leyes morales. Aunque es él quién se siente atraído por ella poruqe le recuerda a un antiguo amor de la infancia, será ella quién lo seduzca obligándole a cruzar el umbral de lo prohibido. 


\title{
5.- La imagen femenina en las marcas publicitarias
}

\author{
Dime y olvidaré. \\ Muéstrame y recordaré. \\ Déjame participar y entenderé. \\ Confucio
}

Para muchos, el comercio y la publicidad han ido de la mano desde los orígenes del hombre. Son como hermanos gemelos que nunca se han separado. Desde un punto de vista muy general, algunos consideran que las primeras manifestaciones de la publicidad se dieron en épocas muy remotas. Probablemente, deberíamos remontarnos al momento en que los bienes adquiridos de la naturaleza tomaron el carácter de mercancía. A partir de ahí, se inicia el trueque, el intercambio de materiales y, muy probablemente, las primeras explicaciones sobre cómo utilizar aquellos primitivos productos para sacarles el máximo beneficio posible.

Nos estamos remontando a una época en la que la definición de publicidad era muy rudimentaria. Tanto, que se veía reducida a un yo-comprador y a tú-vendedor. Por aquel entonces, había un emisor que de forma muy directa generaba un mensaje con la única determinación de informar sobre los beneficios de un producto. Obviamente, existía también el culpable de que se crease cierto mensaje: el objeto. Este último solía estar adornado por un conjunto de ideas, todas ellas codificadas por normas, signos y símbolos que eran conocidos tanto por el emisor como por el receptor. Por último, nos encontramos con el receptor; aunque nos dirijamos en singular hacia él, debemos de saber que bien puede ser una persona o un grupo de personas. 
Por supuesto, la publicidad evolucionó. Pero siempre fue entendida como una comunicación personal, en la que, a modo de conversación, los agentes interactuaban con diferentes visiones de un mismo objeto. Todo esto se vio roto con la llegada de la producción masiva. Ya en la época preindustrial se comenzó a sentir la ajetreada y alocada comunicación de masa. El pedido personalizado, el encargo de un objeto especial, la confianza con el tendero o la persona que vociferaba la llegada de los mercados ambulantes fueron sustituidos por panfletos, carteles publicitarios $\mathrm{y}$ producciones en cadena ${ }^{645}$.

\section{1.- El objeto publicitario como objeto público}

En este apartado abordaremos la incipiente llegada de la época preindustrial. Si antaño el producto se adquiría previo encargo, ahora el exceso de producción y la creciente capacidad económica de la clase media exigen cambios importantes en la venta y en la publicidad $^{646}$. Primero, se le dio una funcionalidad muy determinada y concreta mediante la publicidad informativa: si no se usa como se dice en el anuncio puede que el cliente no saque el máximo rendimiento del producto ${ }^{647}$. Pero, después, dado el aumento considerable de la competencia, la publicidad buscará persuadir, es decir, convencer al cliente. Para ello, hará falta motivar al público, por lo que se induce a la clientela a adquirir ese producto. Este, y no otro, satisfará sus necesidades ${ }^{648}$.

\footnotetext{
${ }^{645}$ Emilio Feliu García, Los lenguajes de la publicidad, Alicante, Universidad de Alicante, 1984, pp. 1617.

${ }^{646}$ Emilio Feliu García, op. cit., p. 35.

${ }^{647}$ Mario García Uceda, Las claves de la publicidad, Madrid, Escuela Superior de Ingeniería Comercial y Marketing (ESIC), 1995, vol. 1, pp. 23-25.

${ }^{648}$ Progresivamente, al producto se le aporta una serie de características que, además de hacerlo indispensable, también le darán una personalidad propia.
} 


\subsection{1.- El cambio de sociedad}

En la sociedad precapitalista del siglo XVIII, el artesano fabrica una mercancía en función de un pedido. De forma que entre el artesano y el cliente hay una estrecha relación. Una relación creada a partir de la necesidad y fomentada por los años de confianza entre el artesano y su clientela. En consecuencia, proponer a un comerciante que se anunciase podía ser ofensivo, dado que la relación se basaba en la confianza y en la profesionalidad.

Pero rápidamente desaparece el predominio artesanal de la producción en beneficio de la fabricación en masa. A esto hay que sumarle el hecho de que la burguesía colma el vacío que socialmente había dejado la aristocracia. Este desplazamiento se debe al derrumbamiento definitivo de la estratificación social y de los privilegios de los que la aristocracia había gozado durante el Antiguo Régimen. Los burgueses serán quienes hereden su capacidad de consumo, la actitud esteticista ante los objetos y una clasificación de los mismos como signo de status y de emulación ${ }^{649}$.

Con esta nueva clase social al frente del poder económico, el objeto se convierte en un paradigma de la evolución social. Pues el objeto es una concreción material de los anhelos, las angustias y las contradicciones de los burgueses. Podemos decir que el desarrollo económico de la sociedad moderna conlleva el objetualismo obsesivo. Comprar no sólo es una acción de auto afirmación que certifica y edulcora la alienación

\footnotetext{
${ }^{649}$ Emilio Feliu García, op. cit., p. 36.
} 
productiva, sino que también da coherencia a las premisas del funcionamiento del sistema económico que prolonga las necesidades más allá de las inmediatas ${ }^{650}$.

\subsection{2.- El objeto publicitario pierde su funcionalidad original}

La publicidad se ha ido haciendo cada vez más persuasiva. Ya no se trata de dar a conocer un objeto, sino que se busca hacer una cosa más popular, por lo que D. Cardona y R. F. Berasarte consideran que la publicidad es un sistema sociotécnico que intenta influir sobre el comportamiento humano. La cuestión es que el capitalismo moderno invierte las líneas clásicas. Ahora ya no se produce lo necesario, porque el sujeto consumidor ya no es quien se acerca a la tienda para hacer un pedido. Actualmente, el cliente no ejerce ningún tipo de poder sobre el sistema económico, sino que es el propio consumo en masa el que condiciona la producción. Se produce de forma ilimitada, y esto va enlazado con uno de los grandes problemas: el temor de que no se llegue a vender tal cantidad de productos ${ }^{651}$. Ante la necesidad de dar salida a todos los productos, se crean aceleradores artificiales de ventas. Entre estos destaca la publicidad. De ahí que ésta pierda su carácter informativo para acelerar y estimular la venta del producto.

Los objetos, al estar ligados a una gran rapidez de consumo, pierden parte de su identidad. Ya no están ligados ni a una función ni a una necesidad determinada. La publicidad de un anuncio va mucho más allá de la necesidad inmediata del propio objeto. Es algo que a priori NO se necesita. Pero el anuncio logra darle una actitud fetichista y, por lo tanto, la necesidad urgente de tener este objeto. A lo que debemos sumar que las

\footnotetext{
${ }^{650}$ Gloria Moure, Tapies. Objetos del tiempo, Barcelona, Ed. Polígrafa S.A., 1994, p. 106.

${ }^{651}$ Mario García Uceda, op. cit., pp. 29-31.
} 
vidas de los clientes están dominadas por el sinsentido, la ansiedad, el caos, la sordidez y, sobre todo, las prisas propias de una ciudad moderna ${ }^{652}$.

\subsection{3.- La nueva publicidad}

A media que se van perfeccionando las técnicas de ilustración gana espacio la imagen y se reduce la extensión escrita. Ya entonces comenzaba a considerarse excesiva pero, aún así, la letra seguía gozando de mucha importancia. A principios del siglo XIX, el ginebrino Rodolphe Topffer creó la historieta, una serie de dibujos autógrafos con algunas líneas de texto ${ }^{653}$.

La aparición de los primeros carteles se da en el siglo XIII, pero la invención de la imprenta aportará cambios fundamentales. Al principio, el cartel fue un medio al servicio de la propaganda política, pero con la ayuda de la imprenta se pudo desarrollar carteles comerciales más grandes y con mayor número de tiradas, folletos informativos y catálogos. Hasta entonces, el cartel estaba al servicio de los poderos políticos y religiosos, por lo que muy pocos tenían intención comercial, pues casi todos anunciaban ventas de bulas y de indulgencias. El primer cartel comercial data de 1477 de William Caxton. A partir de 1772 su uso dejó de monopolizarse y pasó a ser una actividad legalmente privada y reconocida ${ }^{654}$.

Uno de los elementos que más influyó en el desarrollo del cartel fue el mamarracho. Este se trataba de un cartel muy rudimentario cuyas imágenes eran grandes manchones pintados a mano. A estos se le sumaban algunos textos alusivos, y se utilizaba para

\footnotetext{
${ }^{652}$ Emilio Feliu García, op. cit., pp. 66-71.

${ }^{653}$ Emilio Feliu García, op. cit., p. 49.

${ }^{654}$ Emilio Feliu García, op. cit., p. 29.
} 
anunciar el estreno de una obra teatral. Como era de esperar, al principio se colgaron en la puerta de los teatros, pero posteriormente se imprimen y se fijan en las calles. De esta forma, el mamarracho empieza a conquistar el espacio público, y fue don Cosme de Oviedo el que se dio cuenta de la importancia de este sistema. De alguna manera era mucho más rentable que los anuncios publicados en prensa y, además, estaba al alcance de todo tipo de público, no sólo de aquellos que compraban los diarios.

Este sistema publicitario influyó sobremanera en la aparición del cartelismo. No era nada nuevo que la imagen del cartel adquiriera más importancia que la letra, tampoco fue relevante que el objeto anunciado estimulara la acción económica ni la compra objetual concreta. Pero lo que sí fue una completa novedad es que se hiciera para ser pegado en un muro frecuentado por un público heterogéneo y anónimo. Podemos mencionar que la explosión se da a partir de 1830, pero no podemos asegurar quién fue el padre de la criatura. La paternidad del cartel litográfico ha sido disputada por ingleses y franceses a la par. Por un lado tenemos a los pintores bohemios de Paris que fueron los primeros en ofrecer sus obras a los comerciantes para que les aplicaran un fin propagandístico. Por otro lado, en Inglaterra nos encontramos con Th. J. Barrat, dueño de la compañía de jabones Pears, que fue el primero en comprar obras de arte y utilizarlas como reclamo publicitario. Una de sus primeras obras adquiridas fue Cuadro de burbujas de Sir John E. Millais ${ }^{655}$.

\footnotetext{
${ }^{655}$ Emilio Feliu García, ibídem, pp. 50-51.
} 


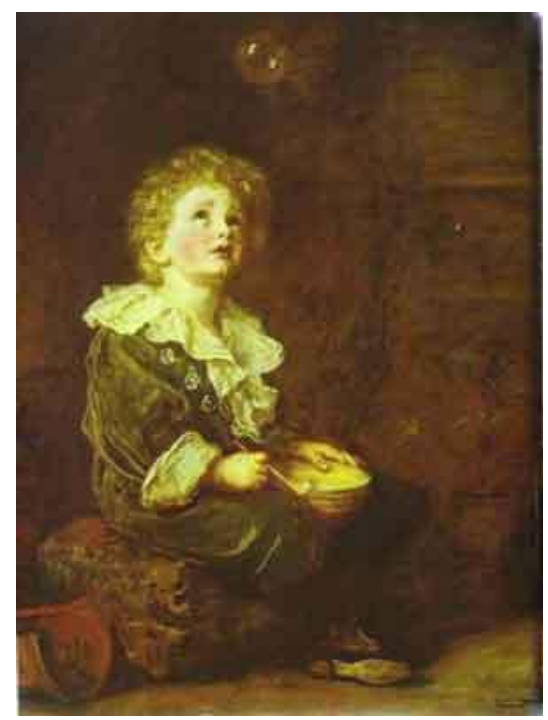

Sir John E. Millais (1886)

De todas formas muchos creen que esto es una degradación del arte, pero también es cierto que este tipo de trabajo ayuda a evolucionar rápidamente las técnicas artísticas. Entre los pintores que utilizaron este medio podemos citar a Cheret, E. Grasset, H. de Toulouse-Lautrec... En España, el cartel litográfico con fines comerciales comienza en 1870. Una de las figuras más importantes fue el dibujante Francisco Ortego Vereda con el cartel Chocolate Matías López.

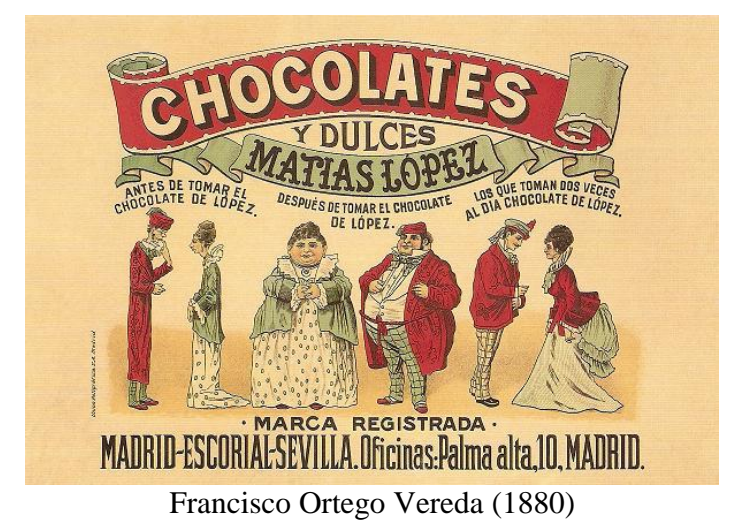

Sin duda uno de los acontecimientos más relevantes fue el primer concurso de carteles que Vicente Bosch convocó para anunciar su empresa Anís del Mono. El primero en 
ganar fue Ramón Casas. También es destacable el cartel de Pablo Picasso para la misma $\operatorname{casa}^{656}$.

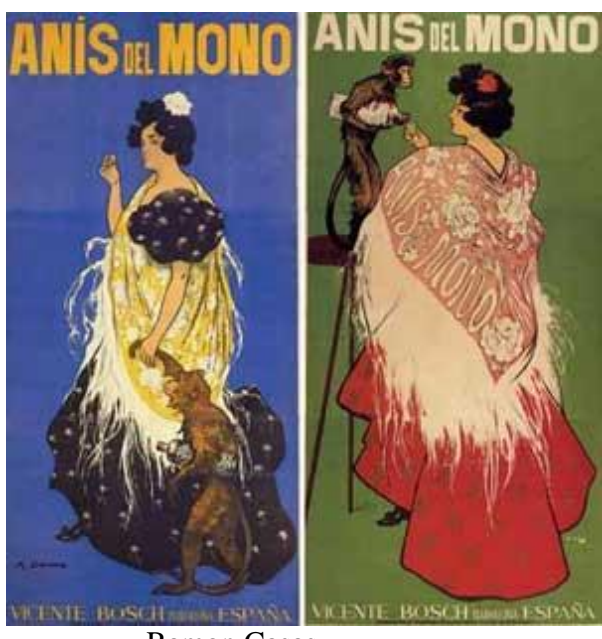

Ramon Casas

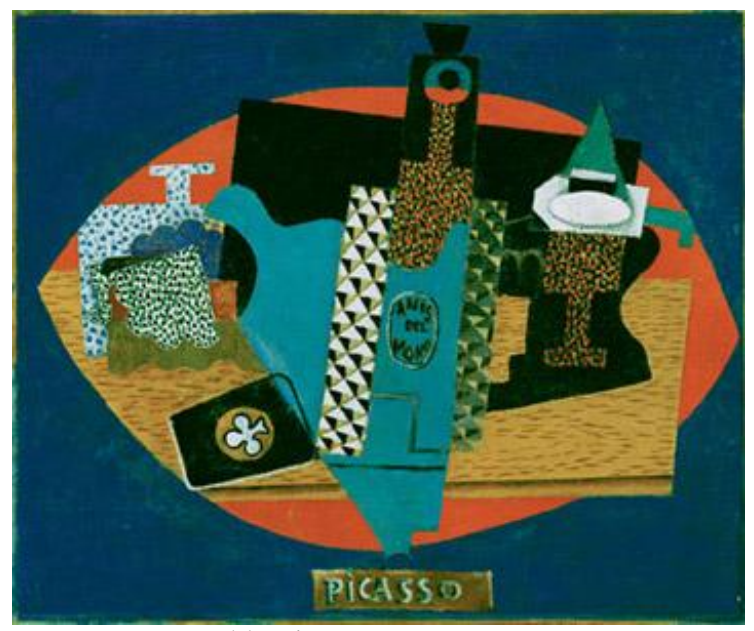

Pablo Picasso

Tras estas obras de arte existe una teoría filosófica. Los nuevos cambios económicos que se daban en la sociedad obligan al artista a replantearse los objetos. Los objetos en sí no tienen sentido alguno, estos sólo se llenan de significado cuando las personas los utilizan. Por lo que la relación persona-objeto se carga de simbología, pero esta se interpretará según la función que la persona haga del objeto. Por supuesto, esta dependencia ofrece múltiples lecturas de un mismo objeto. En el campo artístico, esto significa que todo se convierte en un configurador de la realidad, porque el creador plástico puede transformar o expandir las funciones del objeto. Así que el campo publicitario le ofrece la posibilidad de manipular elementos reales, alterar el espacio y el tiempo, transformar los materiales para darles forma, disponer las cosas de un modo determinado, presentarlas en lugares específicos ${ }^{657} \ldots$

\footnotetext{
${ }^{656}$ Emilio Feliu García, op. cit., pp. 51-53.

${ }^{657}$ Gloria Moure, op. cit., p. 95.
} 


\section{2.- El objeto publicitario como signo de status social}

Emilio Feliu García recoge en Los lenguajes de la publicidad un ejemplo un tanto sui generis acerca de la publicidad. Con él nos intenta explicar que la publicidad no nació en ningún momento determinado, sino que ésta fue utilizada desde que la tierra fue habitada. Quizá desde el momento en que Eva ofreció la manzana prohibida a Adán, pues sabiendo que era un alimento completamente prohibido, primero le cautivó, avivó su interés, hizo nacer el deseo y conquistó su voluntad. Por supuesto, en este caso no podemos contar con el material de la compra, pero este puede ser sustituido por el hecho revelador de extender la mano, aceptar y morder.

Probablemente, lo que realmente se pretende resaltar con esta escena es que los primeros pasos de la publicidad se dieron mediante la transmisión oral. Sin lugar a dudas, ésta se institucionalizaría desde muy pronto, y fue el medio básico de comunicación comercial durante mucho tiempo ${ }^{658}$.

\subsection{1.- La Antigüedad Clásica. Las señas como objetos publicitarios}

En las civilizaciones antiguas existen muy pocas pruebas acerca de la publicidad oral. Pero gracias a los restos arqueológicos de Grecia y de Roma, se han hallado datos al respecto. En ambas ciudades encontramos dos tipos diferentes de publicidad. Una de ellas es la podríamos llamar publicidad oral, y la otra es la publicidad silenciosa. Los dos son casos muy interesantes, pues de una forma u otra han influido en la idea visual de la actualidad publicitaria ${ }^{659}$.

\footnotetext{
${ }^{658}$ Emilio Feliu García, op. cit., pp. 16-17.

${ }^{659}$ Emilio Feliu García, op. cit., pp. 17-18.
} 


\subsubsection{1.- Grecia}

En el plano de la publicidad oral, es destacable la figura del heraldo. Este era un funcionario público encargado de dar a conocer las órdenes directas del poder real. Era un intermediario entre la autoridad y el pueblo, una especie de pregonero que gritaba a las puertas de las tiendas que surgieron alrededor del ágora.

Desde el plano de la publicidad silenciosa, cabe destacar en primer lugar los axones y kyrbos. Estos eran paralelepípedos de madera pintada de blanco en donde se inscribían comunicados de carácter oficial. Y en segundo lugar, también es necesario destacar la enseña. Este último era un procedimiento muy antiguo con múltiples transformaciones que ha logrado mantenerse en la actualidad. Eran símbolos gremiales esculpidos sobre madera, elementos que se solían localizar en el marco de la puerta de un comercio para que todas las personas pudieran saber qué actividad se realizaba allí. Si el viandante veía la imagen de una cabra en el soportal de alguna puerta era que allí se vendía leche, la mula indicaba que estábamos ante hornos para cocer pan, el falo ante un lupanar, la piña ante una taberna... Todos estos elementos tienen tantos matices religiosos como mitológicos. Pero también es cierto que es muy difícil darle la categoría de instrumento publicitario, porque se trataba de una información muy rudimentaria ${ }^{660}$.

\footnotetext{
${ }^{660}$ Emilio Feliu García, op. cit., pp. 19-20.
} 


\subsubsection{2.- Roma}

En Roma, y como heredero directo del heraldo griego, nos encontramos el praeco. Este era una persona que recorría las calles con el objetivo de atraer a la muchedumbre hacia las mercancías dispuestas a la venta. Por supuesto, no todas las personas podían dedicarse a la publicidad oral. Para realizar este tipo de trabajos, las funciones del candidato debían ir más alá del voceo, debía contar con una buena voz y con buena elocuencia, y estar dispuesto a trabajar tanto para el estado como para los particulares.

En cuanto a la publicidad silenciosa, debemos de destacar que era más abundante en Roma que en Grecia. Aquí nos encontramos en primer lugar con el alba, un espacio dedicado preferentemente a ofrecer mercancías y anunciar espectáculos. En segundo lugar nos encontramos con el libellum, que era un papiro escrito con grandes caracteres y adosado a la pared. Será el precursor del cartel y cuenta con ejemplos muy variados, anunciando diferentes actividades: venta de bienes de los proscritos, sentencias, espectáculos... Este también dará pie a la aparición del libellus que eran las mismas copias del libellum, pero de tamaño más pequeño, y vendidas por la calle ${ }^{661}$. Algunos de estos textos iban acompañados de imágenes secuenciadas.

En Roma, las enseñas griegas tomarán el nombre de emblemas. Sánchez Guzmán en 1976 menciona que hay tres modos de representación fundamentales. Primero tendríamos la representación simbólica del producto, en donde se suele utilizar la mitología como significante. Tal es el caso de la cabra para la lechería, el artesano serrando para la carpintería, el ánfora para la venta de aceites o la corona de hierbas para la taberna (como representación de Baco). Pero este medio de localizar algunos comercios también derivó hacia la localización de domicilios privados. Tal fue el caso

\footnotetext{
${ }^{661}$ Algunos autores también destacan la importancia de los pasquines y de los graffittis.
} 
del peral de la casa de Marcial, de la cabeza de buey en la casa de Augusto o la granada de la casa de Domiciano. Algo muy curioso ocurrió en el siglo I con la producción de la cerámica sigillata, pues algunos de los curanderos romanos emplearon sellos para marcar sus vasijas. Normalmente, sobre él se imprimía un pequeño mensaje que hacía referencia al bálsamo o al ungüento ${ }^{662}$.

Tras la caída del imperio romano el comercio se debilita y las transacciones se hacen muy escasas. En el siglo IX los mercados locales proliferan en toda Europa. En ellos, y bajo la protección de la iglesia o del señor feudal, se reunían los vendedores ambulantes y los campesinos de la comarca. Por lo que vemos cómo, pese a la decaída de las actividades comerciales, se mantuvo la actividad de vocear ${ }^{663}$.

\subsection{2.- La Edad Media. La evolución de las señas}

La Edad Media aporta importantísimas innovaciones en la publicidad silenciosa. En un principio podemos señalar que la ciudad es un espacio físicamente propicio para que la publicidad se propague. Como es bien sabido, en el siglo XI los gremios aparecían agrupados por calles. De esta forma, podíamos encontrar calles que recibían el nombre de los oficios: calle de las cestas, calle de la sangre, calle de los hornos... Por lo que las señas, que tanto proliferan en la antigua Roma, se acaban desarrollando en la vía urbana: ahora se colocaban en los extremos de las calles para señalizar la ubicación de los gremios. A partir del siglo XIII, el crecimiento y la extensión de las ciudades suprimen

\footnotetext{
${ }^{662}$ Muchos han visto en este pequeño invento el responsable de los nombres de las primeras marcas.

${ }^{663}$ Emilio Feliu García, ibídem, pp. 20-27.
} 
la concentración gremial por calles. Las tiendas se sitúan en diferentes partes de la ciudad sin ningún tipo de orden.

En consecuencia, la enseña medieval sufre un pequeño cambio: dejó de señalar un lugar concreto en donde se realizaba el producto, y pasó a identificarse con el mismo producto. Así que los comerciantes solicitaban sus propias señas por encargo y las colocaban en el marco de la puerta del comercio o en la propia fachada. Eran pequeñas obras de arte, en donde el artesano dejaba volar la imaginación para que consiguiera seducir al viandante con diferentes artificios de presentación. De esta forma, se utilizaba cualquier motivo pictórico con total libertad, ya fueran santos, animales, plantas, utensilios, objetos domésticos... sólo se buscaba que tuviera algún tipo de relación análoga o simbólica con el producto, con el comercio o con el comerciante ${ }^{664}$. Lo curioso es que con la llegada de la exportación de mercancías la venta desbordó el marco urbano y la enseña, a modo de sello, también se utilizó en sacos, fardos, toneles... Ésta será la imagen que ayude a crear la idea de marca ${ }^{665}$.

\subsection{3.- La popularización de las señas}

Las señas logran abrirse camino en el mundo mercantil. De forma que, se convierten en una especie de sello que vincula el producto con una calidad y una fama, ambas reconocidas en el mundo de las exportaciones e importaciones. Además cabe destacar que dentro de cada gremio podíamos encontrar diferentes señas, y cada una de ellas tenía la intención de vincular el nombre de un fabricante o familia al de un producto

\footnotetext{
${ }^{664}$ Posteriormente, en los siglos XIV y XV, estas se realizaban sobre placas de madera o de metal.

${ }^{665}$ Emilio Feliu García, op. cit., pp. 27-28.
} 
específico, por lo que la intención originaria de la seña fue marcar una distinción y una exclusividad: mantener esa imagen es sinónimo de calidad y de estilo.

Debemos recordar que la producción de los antiguos artesanos se hacía por medio de un encargo previo. Sin embargo, en la época preindustrial esto cambió considerablemente. Se produjo un movimiento de aceleración y de producción en cadena que llegó a suplantar a muchos gremios. La antigua elaboración cuidadosa y exclusiva se veía reemplazada por enormes máquinas que repetían una y otra vez los mismos patrones. Muchos gremios desaparecieron durante el siglo XVIII; sin embargo, otros muchos consiguieron establecerse, e incluso crecer.

Para lograr mantenerse, muchos de los artesanos que no fabricaban a nivel industrial lograron vender la idea de que su producción era mucho menor en número, pero que, a diferencia de las grandes producciones masivas, ellos ofrecían exclusividad, elegancia personificación y calidad, algo que las grandes fábricas no podían proporcionar. Para lograr posicionar esta idea, no bastaba con abrirse una tienda en el centro de una ciudad, sino que también era importante tener clientes exclusivos.

Mientras gremios como el de los sombreros caían, el gremio de los joyeros, o el de las modistillas, conocieron una creciente pujanza, pues muchas de sus producciones estaban vinculadas a pedidos hechos por personalidades importantes: realeza, nobleza, aristocracia, burguesía... Personas de determinadas clases sociales, que deseaban ostentar y lucir su posición social mediante elementos ornamentales. De esta forma, se hacen infinitud de encargos, por ejemplo a joyeros. Estos diseñaban joyas o vestidos que representaran lo mejor posible la personalidad del cliente que se lo había pedido. Estamos hablando de un arte puramente artesanal, que necesita un tiempo cuidadoso de 
elaboración y que es muy caro. Muchos de ellos lograron relacionarse con una seña o con un apellido.

Sin embargo, con el paso del tiempo, la llamada "clase media" haría acto de presencia en el mundo del consumo, así que muchas de estas elaboraciones tuvieron que abrirse al gran público: lograron vincularse a la producción masiva mediante la venta de productos más económicos. Sin embargo, nunca dejaron de recibir encargos exclusivos para clientes muy determinados ${ }^{666}$.

\section{3.- La felicidad como único objetivo humano}

La cultura preindustrial se opone a la cultura tradicional y humanista. Ya entonces la cultura comienza a formarse a partir de un mosaico de elementos dispersos que no constan de ningún tipo de organización jerárquica. Esta es el reflejo del pensamiento humano, y este no se constituye de forma ordenada, sino que en realidad es un conjunto de conocimientos que las personas recibimos de forma desordenada y aleatoria ${ }^{667}$.

El continuo bombardeo de información que las personas reciben en su día a día hace que los antiguos valores fundamentales (como la patria, Dios, el ser, la familia...) se sustituyan por una serie de valores aislados y aislantes. Para entender este caos es necesario diferenciar entre la información semántica (es decir, la lógica, la estructurada y traducible) y la información estética (que es la referente a la esfera personal e íntima). Así que, en ocasiones, la persuasión recae sobre la información estética. Pero para que

\footnotetext{
${ }^{666}$ Emilio Feliu García, op. cit., pp. 30-32.

${ }^{667}$ Existen diferentes medios de educación: unos serían los medios sistemáticos, que son los diferentes tipos de enseñanza, y otros serían los medios asistemáticos, en donde los medios de comunicación desempeñan un papel fundamental.
} 
esta sea apreciada en su totalidad por el público será necesario recurrir a la repetición y al uso de arquetipos.

Ambos elementos ayudaran a comprender un mensaje que se distribuye en un corto espacio de tiempo. Pero también es cierto que se requiere un conocimiento previo de la figura y cierta frecuencia de aparición. De estos arquetipos se desprende el tema que podría destacarse como la felicidad. Esta se sostiene sobre las condiciones de la existencia social, y se crean nuevos hábitos de comportamiento. Es decir, que si el público ve un anuncio en donde sus actores son felices, tendrá más en cuenta ese objeto que otros en donde los actores muestren otras actitudes.

Con ello la industria cultural se basa en la "síntesis de la proyección e identificación" del público. El objetivo es que el actor se convierta en un icono a seguir, pues se espera que el público diana tome como referencia al héroe y lo llegue a popularizar mediante sus relaciones con los demás individuos ${ }^{668}$.

Los temas de la cultura de masas aparecen vinculados a un proceso de mitificación y de creación de nuevos mitos. Su éxito se debe a la satisfacción inmediata del sujeto consumidor. El gran mito de nuestra sociedad es la Felicidad, que asociada a otros valores dan pie a las siguientes estructuras:

Amor-juventud-belleza

Seguridad-salud-bienestar

Posesión.

En torno a ellos aparecen otros valores formando una constelación, pero estos dos serían los centrales. Estos caracterizan a los héroes de la nueva mitología que, por supuesto,

${ }^{668}$ Emilio Feliu Garcia, op. cit., pp. 88-122. 
vienen encarnados por las estrellas de cine, los ases deportivos ${ }^{669} \ldots$ Los dioses modernos provocan una superposición entre lo real y lo imaginario. Son, al mismo tiempo, ideales inimitables y modelos de imitación. Son sobrehumanos en el papel que representan, pero al mismo tiempo son humanos en su vida real. Esta doble función facilita la mitificación ${ }^{670}$.

Con la llegada de la industrialización, todo esto se potencia y se consigue transformar “el mobiliario del hombre de la calle". La cultura mosaico nace en las primeras décadas del siglo XX al derivar de los medios de comunicación. Atrás queda la función informativa y moderada. Hoy en día, una característica del mensaje publicitario es la agresiva repetición. La repetición ejerce un tipo de presión con sus mensajes que consigue el almacenamiento aleatorio y caótico en la mente del público. Por ello, muchos de los anuncios de los años 60 y 70 tenían un ritmo muy marcado y bastante repetitivo $^{671}$

Esto no implica la pérdida del carácter informativo, pero sí que pertenece al dominio de la información aberrante. Aunque se muestre completamente diferente a la original, y desorientada, es información al fin y al cabo. Desde la teoría de la información los mensajes reales sobrepasan el mensaje semántico, y a este se sobreponen un mensaje estético. Los productos que nos proponemos analizar son meramente estéticos, por lo que se mueven dentro de la estructura amor-juventud-belleza. Son objetos puramente estéticos y superficiales, por lo que el lenguaje publicitario girará en torno a este sentido.

\footnotetext{
${ }^{669}$ Para Henry Raymond estos son los nuevos dioses del Olimpo.

${ }^{670}$ Véase los anuncios de ADIDAS.

${ }^{671}$ Emilio Feliu Garcia, op. cit., pp. 89-90.
} 


\title{
5.3.1.- El amor, prisión femenina
}

El primer tema centrado o ligado a la felicidad es el Amor. En torno a ese mundo mítico y a sus héroes aparecen una serie de modelos, ya sean hombres o mujeres.

\begin{abstract}
Jamás creación poética logró transformar de manera tan profunda la sensibilidad, (...) como la invención occidental del amor. Desde el siglo XII, el amor nunca ha dejado de ser celebrado, cantando e idealizado, ha inflamado el deseo y los corazones, ha remodelado las maneras de ser y de obrar de hombres y de mujeres, alimentando sus más locos sueños ${ }^{672}$.
\end{abstract}

Por supuesto, la cultura amorosa ha sufrido desplazamientos, pues se caracteriza por rupturas de lenguaje y diferentes prácticas que han venido determinadas por diferentes modas a lo largo de la historia. Pero, aún así, “el invento occidental del amor" ha legado un ideal imperecedero que se ha acoplado a los ideales propios de cada época. Este ideal consiste en amar y ser amado.

En la sociedad real, la educación sentimental de las mujeres debe girar en torno a los hombres. Gustarles, serles de utilidad, propiciar que las amen y honren, educarlos cuando son jóvenes, cuidarlos de mayores, aconsejarles, consolarlos, hacer que la vida les resulte agradable y grata, tales son los deberes de las mujeres en todos los tiempos. Como es obvio esto responde a una división sexual de los roles afectivos que tiene su esencia en la representación de la Feminidad. Esta consiste en existir para el otro y dedicar su vida a la felicidad del hombre.

La misma palabra "amor" significa dos cosas diferentes para el hombre y para la mujer. La mujer vive el amor como una renuncia, una entrega total en cuerpo y en alma a favor

\footnotetext{
${ }^{672}$ Gilles Lipovetsky, La tercera mujer. Permanencia y revolución de lo femenino, Barcelona, Anagrama, 1999, p. 15.
} 
del varón. Pero, para el hombre, el amor significa la posesión de la mujer: tomarla, enriquecerse y acrecentar su potencial de vida ${ }^{673}$.

La vocación femenina es la total dependencia hacia el amado, pues las mujeres sienten que a través de ellas el amor es exaltado ${ }^{674}$. Por supuesto, esto no podía dejarse de lado en la cultura de masas, y es así como el siglo XX también exalta la dependencia femenina. Se trata de un pack inseparable, en donde primero vemos cómo el amor forma parte de la identidad femenina. Tal es el caso de algunas actrices como Marlène Dietrich al decir "sólo conozco el amor y nada más", o Edith Piaf cuando afirma "haría cualquier cosa si me lo pidieras". En segundo lugar, los sueños femeninos como el reflejo de una necesidad de evasión en lo imaginario; y en tercer lugar tenemos el ideal moderno de la felicidad individual y la legítima progresión del matrimonio por amor ${ }^{675}$.

\subsection{2.- Concepción moderna de la belleza femenina}

La belleza femenina no tiene el mismo valor para el hombre que para la mujer. La mujer asume su propia figura bajo las reglas de la percepción, y sabe que una mujer bella puede ejercer una poderosa atracción sobre el varón. Ella se sabe observada, por lo que hará lo posible para alterar la imagen que proyecta y mostrar a los demás lo que desean ver. La necesidad de intentar alterar su propia imagen se debe a que, históricamente, la

\footnotetext{
${ }^{673}$ Como dice Nietzsche en El Gay Saber: "La mujer se da, el hombre se aumenta con ella". Del mismo modo Julie de Lespinasse escribía: "Sólo sé amar", y Germaine de Staël afirmaba que "las mujeres sólo existen por el amor, la historia de su vida empieza con el amor".

${ }^{674}$ Sólo de esta forma se entiende cómo en el siglo XVIII, Mlle de Lespinasse, Mme de La Popelinière y la princesa de Condé resaltan su total dependencia e idolatran al ser amado. Más tarde, en el siglo XIX, Juliette Drouet y Balzac mencionarán que "la vida de las mujeres es el amor".

${ }^{675}$ Gilles Lipovetsky, op. cit., pp. 16-20.
} 
idea de la belleza femenina se establece en torno a una oposición muy clara: el concepto tradicional de belleza y el concepto moderno de belleza.

Hasta que llegó el siglo XVII dominó el concepto de belleza tradicional. Este ya se venía manifestando desde épocas inmemoriables en las zonas campesinas, en donde existía una tremenda ausencia del culto al bello sexo. Por doquier dominaba la tendencia a menospreciar los atributos femeninos. Así se propagaron dichos populares como: $L a$ hermosa rosa se convierte en tapaculo (en la Provenza-Languedoc), Bello y bueno nunca van juntos (Aube); La muchacha hermosa es la mitad de altanera que el diablo (Alta Bretaña)... Lipovetsky manifiesta que esto era una especie de regla general para proteger lo mejor posible la virtud de las mujeres que vivían en una casa. De forma que si se decía que las hijas propias no eran muy agraciadas, era para alejar a posibles burladores o violadores.

Lipovetsky documenta que la tradición judeo-cristiana hereda la tradición clásica de la belleza. En lo que se refiere a los elementos descriptivos, estamos completamente de acuerdo. Pero hay que advertir que con el paso del tiempo la tradición judeo-cristiana ha ido enriqueciendo el concepto de belleza femenina. E incluso le añadió tintes eróticos. Por ejemplo, originariamente, en el Génesis no se narra la belleza de Eva ni se menciona que ella engañe a Adán mediante su belleza. Aunque sí es cierto que a lo largo de la historia existen diferentes versiones que matizan los encantos físicos de Eva.

La falta cometida por Eva se convirtió en el pecado originario, el primero de la humanidad que heredarían todas las féminas a lo largo de su existencia, por lo que, desde el principio, mujer-cuerpo-pecado aparecen completamente vinculados. 
A la mujer le dijo: "Tantas haré tus fatigas cuantos sean tus embarazos: con trabajo parirás los hijos. Hacia tu marido irá tu apetencia, y él te dominará ${ }^{676}$.

A partir de entonces, la utilización de la hermosura corre pareja a la corrosión, la celada, el embuste y la añagaza. Tal fue el caso de Sara, Salomé y Judith. Es por ello que los campesinos lanzan despiadadas invectivas sobre el cebo que suponen las mujeres. No es muy conveniente que una mujer sepa que es guapa. Sólo la Virgen María, a partir del siglo XII, se establece como icono femenino. Por supuesto, su característica principal fue la belleza física, pero sobre todo la belleza interior. La Virgen es hermosa porque es un reflejo de sus virtudes morales. Ambas características irán juntas, porque hasta entonces la hermosura carece de rango autónomo, y forma una unidad con el bien. De esta forma, la perfección física excluye la fealdad del alma y la fealdad exterior, pues esta última se manifiesta como un vicio interior.

Ahora bien, para que hiciese su aparición el sexo bello fue preciso que surgieran las diferentes condiciones sociales que rodean a las clases ricas y las clases pobres. La nueva condición femenina exenta del trabajo aparece vinculada a la feminidad y a los cuidados de belleza. A partir de las largas horas de tiempo libre, las mujeres de clase superior se dedican a cuidar su aspecto, a maquillarse, a engalanarse y a agradar a su marido. Ya en la antigua Roma y Grecia se registró el uso de afeites. Sería un poco excesivo mencionar que esto significó el principio del sexo bello; pero sí es cierto que se asocia con el deseo de embellecerse. Por lo que se comienza a comprender que la

\footnotetext{
${ }^{676}$ Génesis, 3: 16.
} 
mujer hermosa es una mujer ociosa, así que desde el principio la belleza fue incompatible con el trabajo femenino ${ }^{677}$.

La belleza femenina entra en una nueva fase con el desarrollo del estado y de las clases sociales. Esto se aprecia con claridad en la época clásica, cuando los antiguos poetas griegos rindieron culto en sus poemas a las diosas del Panteón. Los versos decían al mismo tiempo lo sublimes y lo temibles que podían llegar a ser. Un poco más tarde en el poemario de Píndaro y Alcmán, y en el de Safo, se escribieron poemas líricos a mujeres reales en donde los elogios ya no eran impersonales, sino que estaban dedicados a mujeres de carne y hueso. Fue así como a través de ellos la belleza femenina se impuso como fuente de inspiración en el mundo literario, dando un giro de tuerca a la tradición popular ${ }^{678}$.

\subsubsection{1.- El culto a la belleza femenina}

La idolatría del sexo bello es una invención del Renacimiento ${ }^{679}$. Hasta entonces la mujer bella era comprendida como un arma del diablo ${ }^{680}$, pues se creía que su belleza iba unida a la malignidad. Pero, con el Renacimiento europeo, el segundo sexo se convirtió en el sexo bello, y encarna la obra divina que es capaz de elevarse al rango de ángel. Como consecuencia, se crea un poderoso signo ascensional que por

\footnotetext{
${ }^{677}$ Esta idea es muy importante para la caracterización de las prostitutas menores de edad en el ámbito del proletariado, pues conforme van pasando los años, irán marchitándose y perdiendo la belleza de la inocencia primera.

${ }^{678}$ Gilles Lipovetsky, op. cit., pp. 93-112.

${ }^{679}$ Gilles Lipovetsky, op. cit., p. 105.

${ }^{680}$ Discurso religioso heredado de la literatura latina.
} 
contraposición se sitúa frente a la fealdad del Infierno y en oposición directa con el Diablo $^{681}$.

Una bella mujer es el objeto más hermoso que sea dado ver, y la belleza, el mayor don que Dios haya concedido jamás a la criatura humana ${ }^{682}$.

\subsubsection{1.- AVE. El Ángel del Hogar}

En el Renacimiento triunfa el equilibrio de las formas y, en consecuencia, la imagen femenina es el perfecto equilibrio de la belleza humana. La mujer no se embellece con maquillaje sino con la virtud ${ }^{683}$. Estos problemas también los retoma el discurso cristiano, pues rechaza el uso del maquillaje vinculándolo a la prostitución, y por el contrario resalta los valores morales. Para ellos la belleza nace en el interior y su propia pureza hace que se irradie hacia fuera y que ennoblezca a la mujer. La característica principale de este arquetipo es el equilibrio perfecto entre el interior y el exterior. Por ello, la mujer perfecta encarnará sietes virtudes que se reflejarán en su blanca y pura piel, en las mejillas levemente sonrojadas por la inocencia, y en los cabellos que dorará el sol. Todo ello ayudará a configurar al ángel del hogar. Este se convertirá en el pilar indiscutible de la familia. Sin ella, no sólo es imposible formar una familia, sino que tampoco se conseguirá que la familia sea feliz. Pues la mujer cristiana encarna la perfección y, en consecuencia, el equilibrio familiar. La pureza que la caracteriza, la bondad, la amabilidad y el cariño son comprendidas como funciones internas que se ven

\footnotetext{
${ }^{681}$ Umberto Eco, op. cit., 2007, pp. 159-177.

${ }^{682}$ Gilles Lipovetsky, ibídem, p. 105.

${ }^{683}$ P. Ovidio Nasón, Amores, El arte de amar, Sobre la cosmética del rostro femenino, Remedios contra el amor, Madrid, Gredos, 1989.
} 
reflejadas en su funcionalidad externa, así que todas sus características internas se reflejaran en sus funciones sociales, matrimoniales y matriarcales.

Llegados a este punto, observamos que ya no hablamos de una persona de carne y hueso, ya no hablamos de una mujer real, sino que lo que estamos haciendo es perfilar el ideal quimérico de una figura femenina que nunca existirá. Una sombra del arte supremo que responde a un experimentalismo estético donde naturalismo y artificio se confunden hasta tal punto que ya no se sabe dónde empieza uno y dónde termina el otro. Se desarrolla un programa ideológico basado en la objetualización de la mujer, que trata de dar unos parámetros adecuados para la búsqueda de la esposa correcta ${ }^{684}$.

\subsubsection{3.- Los elementos físicos de la belleza}

Hasta ahora hemos intentado esclarecer cómo a través del discurso tradicional se ha llegado a crear las bases para asentar las características que debían definir a la esposa correcta. Los poetas de los Siglos de Oro ayudaron a potenciar un ideal femenino prácticamente inalcanzable. Pero que, al mismo tiempo, servía de modelo para buscar la perfección femenina. De forma que se convierte en una figura adorada por los varones y un ejemplo para las jóvenes casaderas ${ }^{685}$.

En los poemas vemos cómo se trabajan los elementos físicos de las féminas. El origen de este intenso trabajo lo encontramos en los poetas clásicos, los cuales desplazaron las características propias de la belleza divina hacia las figuras mortales. Así pues, se consigue humanizar el ideal de perfección y hacerlo un poco más accesible, por lo que

\footnotetext{
${ }^{684}$ Umberto Eco, op. cit., 2007, p. 159-177.

${ }^{685}$ Enrique Salgado, Erotismo y sociedad de consumo, Valencia, Ediciones 29, 1971, pp. 67-77.
} 
los poetas reconstruyen la estética platónica a través de los cinco sentidos. Asimismo se le da un sentido de carnalidad y de realidad ${ }^{686}$. A continuación se analizará la estética de la belleza en los Siglos de Oro a través de los sentidos. Dejaremos de lado el sentido del gusto, pues sólo tiene importancia para algunos pervertidos, por lo que no se analizará aquí. Pero también cabe mencionar que ninguno de ellos es esencial ni imprescindible. Todos son complementarios y todos se necesitan para configurar la idea de erotismo ${ }^{687}$.

- El olfato: es muy conocida la influencia de la sensibilidad olfativa tanto en la atracción como en la repulsión sexual. No entraremos en detalles, pero si mencionaremos que nuestro ángel del hogar se caracteriza por un dulce "olor a santidad”. Tal fue el caso del olor que surgía de la tumba de Santa Clara; de Inés de Sorel, la favorita de Carlos VII quien olía a violetas; y de Diana de Poitiers, quien gozó de poder absoluto en la corte de Enrique II y a quien se le construyó el castillo de Anet, porque olía ámbar.

- El oído: ciertos sonidos también son estímulos sexuales a distancia, tales como la voz, el grito, los suspiros, el canto, la risa, la música... Todos contribuyen al descubrimiento del Otro femenino. La voz de la amada que invade al enamorado y lo colma de compañía está llena de palabras celestiales y música angelical.

- El tacto ${ }^{688}:$ la filosofía del erotismo táctil demuestra que la procedencia del placer se relaciona con la temperatura de las regiones del cuerpo. De ahí la repugnancia del contacto de los viejos, los cadáveres y de las manos con

\footnotetext{
${ }^{686}$ Esta técnica es la que los artistas del siglo XIX retomaran. En el siguiente capítulo veremos cómo se desarrolla a lo largo de todo el siglo XIX, aunque será en el Decadentismo cuando alcance su mayor auge.

${ }^{687}$ Enrique Salgado, op. cit., pp. 79-94.

${ }^{688}$ El sentido del tacto casi nunca funciona por sí solo. Normalmente, va acompañado de movimientos corporales que tienen su propio aspecto fenoménico. Por ello el corsé se mantiene hasta 1810, para limitar lo máximo posible los movimientos.
} 
sabañones. Por el contrario, la amada tiene la piel suave y cálida. Por ejemplo, cuando la gente creía que el demonio intervenía en la vida de las personas, mantenían que la cópula con él era como un coito infernal y desagradable, porque su miembro viril era frío.

- La vista: la visión es un tacto a distancia. Es un sentido predominantemente amoroso, porque el ojo es el principal órgano receptor del binomio bellezaerotismo. Ya Guillermo de Lorris desarrolla la tesis de que la belleza es indispensable para el amor:

El dios Amor había elegido muy bien; iba con una preciadísima dama que se llama Beldad; poseía muchísimas cualidades; resplandecía como la luna, en presencia de la cual las otras estrellas parecían minúsculas; su carnación era suave como el rocío; era sencilla como una esposa y cándida como un lirio; su semblante era blanco y delicado; su cuerpo grácil y airoso. No llevaba pintura ni afeites porque no necesitaba usar de artificios; los cabellos luengos y rubios le llegaban hasta los pies; la nariz, los ojos y la boca eran perfectos. Siento en mi corazón una inmensa dulzura, ¡Dios me asista! Cuando rememoro toda la belleza de su persona, que no había en el mundo de tal encanto. Era, en fin, jovencísima, rubio atrayente, amable, cordial, elegante, mórbida, ligera, gentil y armoniosa ${ }^{689}$.

La vista nos permite captar los movimientos (que deben ser comedidos, mesurados, discretos, femeninos, elegantes...) y el color, y ambos son factores que actúan sobre el instinto sexual. Por supuesto, el color sexualmente más excitante es el rojo. Las mujeres lo utilizan para reforzar el tono natural de su boca o de sus mejillas. Pelligrini llama la atención sobre la seducción que ejercen las personas sofocadas por un esfuerzo. Pero los colores pastel también seducen. Estos son el azul, el rosa, el blanco... los cuales también se llamaban

\footnotetext{
${ }^{689}$ Enrique Salgado, op. cit., p. 91.
} 
los colores castos. Unas veces exaltan ternura y amor, y otras veces, evocan sexo. De hecho, Ulises quedó fascinado ante los blancos abrazos de Nausica.

En resumidas cuentas, la seducción de la belleza se debe a la percepción del conjunto. La idea del cuerpo se capta y se integra dentro de la forma, del color y del movimiento. Todo ello, junto con el tono de los ojos y de la piel, logra alinear la forma del talle, las piernas y la serenidad. El objeto erótico penetra en los hombres y les seduce a través de los sentidos. Por supuesto este fenómeno se produce dentro de la biología, y las ficciones poéticas se han encargado de potenciarlo a lo largo de toda su historia ${ }^{690}$.

\subsection{3.- La juventud}

A finales del siglo XVII en las principales capitales europeas aparecieron ensayos informativos en publicaciones periódicas. Se trataban de anuncios periodísticos que heredaban la publicidad vociferante, pero ahora la transmitían por escrito. Esta información regularmente publicada fue transcendental para la historia de la publicidad. Se trató de un espacio pensado para dar información acerca de determinados comercios. Los periódicos que abrieron estos apartados fueron: La Gazeta de Madrid (1661) redactada por Francisco Fabro Bremunda; La Gazeta de Lisboa (1641); Gante (1666); Oxford Gazette (1665)... El hecho de que algunos periódicos tuvieran numerosas tiradas impulsó a sus editores a buscar el apoyo financiero que les proporcionaban los $\operatorname{anuncios}^{691}$.

\footnotetext{
${ }^{690}$ Enrique Salgado, op. cit., pp. 104-108.

${ }^{691}$ Emilio Feliu García, op. cit., pp. 31-32.
} 
Los anuncios del siglo XVII van cambiando y perfeccionándose. Ya no se trataba de una comunicación personal como se daba en la publicidad oral. Ahora estamos ante el origen de lo que será la comunicación de masas, y se comienza a trabajar el mensaje sin posibilidad de interacción. Esto equivale a un mensaje de una sola dirección cuyo destino final es un grupo heterogéneo y anónimo. Se abandona la relación personal, y mediante instrumentos técnicos de la imagen se consigue estabilizar la publicidad informativa. Los objetivos finales de este mensaje publicitario serán múltiples ${ }^{692}$.

- Informar de las ventajas de un producto

- Valorarlo como superior a los productos que ya existían en el mercado

- Asegurarse que los clientes saben hacer un buen uso de él

- Conseguir la venta

Como era de esperar muchos de estos espacios estaban dedicados a productos de limpieza. Ya fuesen productos de cuidado personal o del cuidado de la casa, se trataba textos que explicaban cómo utilizar un producto para conseguir el máximo rendimiento de este y el máximo bienestar, en la casa y con el propio cuerpo.

Un cuerpo y un hogar limpio eran el reflejo de una buena salud ${ }^{693}$. Este fue el discurso reinante en el ámbito médico durante la época preindustrial. Pues una de las preocupaciones fue que las enfermedades que se daban en los barrios obreros se expandieran por el resto de la ciudad. Los médicos comenzaron a alzar alarmas porque el nivel de mortalidad y de enfermedades graves era muy elevado en estos barrios ${ }^{694}$. Por lo que se comenzó a canalizar el agua y a hacer uso de la propaganda informativa acerca de los productos de limpieza.

\footnotetext{
${ }^{692}$ Mario García Uceda, op. cit., pp. 30-31.

${ }^{693}$ Alain Corbin, op. cit., vol. II, pp. 281-284.

${ }^{694}$ Alain Corbin, op. cit., vol. II, pp. 53-54.
} 
Un cuerpo limpio se convirtió en sinónimo de un cuerpo sano. Es decir, que carecía de enfermedades y que podía tener una vida más larga. En consecuencia, una persona podía sentirse durante más tiempo joven. Y el periodo de juventud se convirtió en sinónimo de saludable ${ }^{695}$.

${ }^{695}$ Alain Corbin, op. cit., vol. II, p. 290. 


\section{6.- El destino de la seducción femenina}

Ya Ovidio en El arte de $\operatorname{amar}^{696}$ mantiene que el orden de la seducción se ha construido en función de un sistema permanente de oposición entre hombres y mujeres. Por un lado, al hombre es a quien le corresponde dar el primer paso y escoger las palabras adecuadas. De este modo, a la mujer le corresponde el papel de la espera y acogerse a las súplicas amorosas de forma comedida. La mujer no puede declarar su deseo, sino que debe ser la presa. Tiene que ser difícilmente accesible, para multiplicar los obstáculos y no acceder con facilidad a los ruegos masculinos. Pero realmente estamos ante una falsa espera, porque la seducción femenina no se basa en las palabras, sino en su cuerpo, tanto en el aspecto como en las estrategias de valoración estética. Todas ellas son armas de seducción que se basan en la motivación masculina ${ }^{697}$.

\section{1.- EI boom de la belleza}

La visión moderna de la belleza se caracteriza por dos rasgos. Primero se desvanece el modelo de belleza de la época clásica y se cambia por una nueva concepción moderna, en donde la hermosura es una característica propiamente física con valor autónomo y desligado del valor moral. Desde este momento no se relaciona con nada, sólo consigo misma. La belleza es una cualidad pura que sólo posee un valor estético y sexual. En segundo lugar, la belleza, como cualidad física, está dotada de escaso valor, sobre todo en el matrimonio. En este ámbito no se tiene en cuenta, pues lo que verdaderamente

\footnotetext{
${ }^{696}$ P. Ovidio Nasón, Amores, El arte de amar, Sobre la cosmética del rostro femenino, Remedios contra el amor, Madrid, Gredos, 1989, pp. 349-387.

${ }^{697}$ Gilles Lipovetsky, op. cit., pp. 45-46.
} 
prima en el matrimonio es la riqueza, el rango social de la familia y la posición social de la mujer ${ }^{698}$.

- Olvida usted el compromiso contraído anteriormente por el capitán Osborne -observó Dobbin con expresión seria.

- ¿Qué compromiso? ¿Qué diablos sugiere usted? ¿No me hará suponer...? -dijo mister Osborne, exteriorizando su cólera y su sopresa al empezar a ver claro el asunto -. ¿No me hará suponer que mi hijo es tan necio como para seguir pretendiendo a la hija de ese estafador insolvente? ¿No habrá usted venido a darme a entender que desea casarse con ella? ¡Casarse con ésa! ¡Valiente necio! ¡Mi hijo y heredero casarse con una mendiga del arroyo! ¡Maldición! Si hace eso, que se compre una escoba y se ponga a barrer las calles. Recuerdo que siempre iba tras él con sus embelecos y arrumacos, y no dudo de que lo hacía instigada por el ladrón de su padre".

- $\quad$ Mister Sedley era su amigo, señor -le interrumpió Dobbin, casi satisfecho de poder enfadarse -. En otros tiempos no lo trataba usted de estafador y granuja. Además, fue usted quien concertó ese matrimonio. George no puede jugar a cara o cruz con... ${ }^{699}$.

Pero las mujeres se siguen cuidando para agradar, así que tradicionalmente las mujeres transmitieron sus consejos de forma oral entre amigas o de madres a hijas. Por lo que, cuando se publicaron posteriormente, se hizo con el nombre de "secretos", ya que se proponían recetas de perfumes y afeites para elaborar en casa. Esta cultura se creía basada en la confidencialidad y en la magia. Pronto la artesanía cede el paso a la industrialización y los productos cosméticos también sufren un cambio muy importante: se hacen accesible a todo tipo de cliente. En la era de las masas, el culto del sexo bello adquiere una dimensión social inédita. Su uso se democratiza, pues las imágenes y las prácticas, los consejos y los cánones de belleza se difunden por medio de revistas y

\footnotetext{
${ }^{698}$ Gilles Lipovetsky, op. cit., pp. 45-60.

${ }^{699}$ William M. Thackeray, La feria de las vanidades, Barcelona, Debolsillo, 2011, p. 323.
} 
otros medios. De esta forma la idea de belleza femenina se desprende de los lazos de la muerte y del vicio.

Por aquel entonces comenzó la industrialización y el mercantilismo de la belleza, lo cual concluyó con la carrera elitista y abrió un momento democrático importante. La conjunción de las nuevas carreras que se abrieron a la belleza, la inflación de los cuidados estéticos del rostro y del cuerpo, dieron pie al nuevo momento histórico de la belleza femenina ${ }^{700}$.

\subsection{1.- La fiebre de la belleza y el mercado del cuerpo}

Si los consejos de transmisión oral constituían una cultura femenina confidencial y mágica, vemos como esta fue destruida por la proliferación de la prensa femenina. Los trucos cuchicheados fueron publicados como "epígrafes de belleza, higiene, salud", publirreportajes, despliegue de nombres de marca, comunicación de masas directa... Este mundo machacón ha educado a la mujer para una visión consumidora de la belleza. Cada vez más mujeres redactan obras destinadas a enseñar a otras mujeres cómo perfeccionar su aspecto. Las prácticas de embellecimiento dejan de ser privilegio de una élite, y se puede hablar de una democratización de la belleza porque se difunden los consejos de belleza.

El consumo cosmético aumenta de manera moderada hasta la Gran Guerra y se acelera en los años veinte y treinta. El lápiz de labios goza de inmenso éxito a partir de 1918; los aceites solares y el esmalte de uñas hacen furor en los años treinta. Sin embargo, el auge absoluto que registra el consumo en masa de productos cosméticos data de la segunda mitad de siglo. En Francia, la facturación de la industria de los perfumes y los productos de belleza se multiplicó por 2,5 entre 1958 y 1968; de 1973 a 1993 pasa de 3,5 a 28,7 millones. Durante este tiempo, el

\footnotetext{
${ }^{700}$ Gilles Lipovetsky, op. cit., pp. 119-120.
} 
consumo por habitante progresa de 106 a 840 francos. (...) Los productos de belleza se han convertido en artículos de consumo corriente, un "lujo" al alcance de todos ${ }^{701}$.

Durante siglos los cosméticos fueron privativos de cierta élite social, pero una vez llegado el siglo XX su configuración aristocrática queda desfasada.

\subsection{2.- El activismo estético y la prensa femenina}

La democratización del sexo bello coincide con la producción y el consumo de masa de los productos de belleza, pero también va acompañada de un sistema de comunicación y una promoción de las normas estéticas, cuya piedra angular la constituye la prensa femenina $^{702}$.

La prensa femenina y la cultura moderna de la belleza aumentan su popularidad una vez entrado el siglo XX. Sobre todo en la época de entre guerras ${ }^{703}$, período en el cual la prensa femenina aumenta su popularidad y los títulos se multiplican. Así aparece Le jardín des modes en 1918 o Modes et Travaux en 1919. El auge de la industria cosmética entraña la creación de nuevas revistas que exaltan la juventud, la felicidad y los cuidados de la belleza. Por ejemplo, la tirada inicial de Marie-Claire es de 800.000 ejemplares, y a las puertas de la segunda guerra mundial supera el millón. Las portadas lucen el primer plano de una joven sonriente, bella y maquillada; por supuesto, no es otra cosa que la invocación suprema de la belleza. Acaba de nacer la "Vogue del pobre". También nace la ambición de democratizar las herramientas de la seducción difundiendo una filosofía optimista y consumidora de la belleza. Los editores publican

\footnotetext{
${ }^{701}$ Gilles Lipovetsky, op. cit., p. 121.

${ }^{702}$ Gilles Lipovetsky, op. cit., pp. 120-143.

${ }^{703}$ Mario García Uceda, op. cit, Vol. 1, p. 63.
} 
publirreportajes, consejos prácticos, encartes publicitarios... para incitar al embellecimiento de la mujer.

No cuidarse supone una falta porque la mujer, por naturaleza, está hecha para agradar y fascinar ${ }^{704}$. Así que cuidarse es un intento por corregir los defectos físicos que la naturaleza ha dado a las mujeres. Siguiendo los pasos de Arthur Lefebvre, Lipovetsky diferencia dos tipos de belleza. Una sería la relacionada con las cualidades inherentes al nacimiento de la persona, o en este caso de la mujer. Y la segunda es la belleza condicionada por la conquista individual. Lo propio es la negativa a conformarse con las cualidades recibidas de la naturaleza. Por ello Zsa Zsa Gabor decía "No hay mujeres feas, tan sólo mujeres perezosas". De esta forma se potenciaba el uso del maquillaje, el ejercicio y diferentes artificios de la elegancia que de alguna forma ayudaban a ocultar la fealdad. Así que no podía existir ningún tipo de excusa para ser fea. Todas las mujeres pueden conseguir dar una imagen de sí seductora ${ }^{705}$.

Durante mucho tiempo los cuidados físicos estuvieron dominados por la obsesión del rostro, por una lógica decorativa que se concretaba en el maquillaje, en diferentes artificios de la moda y en los peinados. Ya lo decía Baudelaire en el Elogio del maquillaje:

La mujer está en todo su derecho, e incluso cumple con una especie de deber al aplicarse en parecer mágica y sobrenatural ${ }^{706}$.

Y Blanche de Gévy menciona en Leçons de coquetterie et d’hygiène pratique que:

\footnotetext{
${ }^{704}$ La belleza supone una ventaja considerable para gozar de la felicidad, status y de la fortuna.

${ }^{705}$ Gilles Lipovetsky, op. cit., pp. 145-151.

${ }^{706}$ Gilles Lipovetsky, op. cit., p. 149.
} 
Una mujer que no se cuida en absoluto no merece vivir en contacto con el mundo (...) Está permitido ser bonita, pero está prohibido ser rematadamente fea ${ }^{707}$.

En revistas como Marie-Claire, Elle y Marie-France se dedica un lugar destacado a los epígrafes de "Moda y Belleza", pero todos ellos van seguidos de importantes anuncios de productos de belleza. Normalmente, la publicidad ocupaba una considerable quinta parte de las páginas. En 1929 Ladies Home Journal dedica el 44\% de sus páginas a la publicidad. Más adelante, en los años 60 Vogue, Elle y el Jardin des Modes lo aumentan entre el $50 \%$ y el $70 \%$. Esta lógica sigue vigente en la publicidad actualidad, y se observa poderosamente en Francia, pues más de la mitad del equilibrio financiero de las revistas descansa en la publicidad. El primer puesto de los anuncios lo ocupan los productos de tocador, moda y belleza con el fin de estimular una gestión consumidora de la belleza.

Los medios de comunicación no son los indicadores del movimiento hacia la independencia de la vestimenta, pero lo acompañan al conferirle legitimidad social, estilizarlo y armonizarlo con las exigencias femeninas de seducción.

\section{2.- La condición poética del objeto publicitario}

Aprovechándose de que vivimos en una sociedad superficial, la nueva publicidad ha perdido su carácter informativo, y se sustenta sobre la conexión sin sentido de elementos aparentemente aleatorios. Ahora, el objeto anunciado también ha perdido su carácter funcional y se convierte en un objeto decorativo o fetiche. Desde la sociedad de consumo, el modo de entender el mundo pasa por su relación con los objetos.

\footnotetext{
${ }^{707}$ Gilles Lipovetsky, op. cit., p. 149.
} 
Esto ofrece grandes posibilidades al campo artístico. Pues todos los elementos que rodean al artista pueden dejar de tener una función y convertirse en un objeto configurador de la realidad. Por ejemplo, un enganche para el pelo no es igual para la obrera que se pasa horas en la fábrica haciéndolos que para la joven despreocupada que los utiliza. Tampoco será igual una mesa para un obrero que para un burgués que intenta venderlas al por mayor o para el noble que la compra. Cada uno de ellos ofrece una experiencia muy diferente a los otros. Son experiencias de vida. Los mismos elementos pueden ser representados de formas muy diferentes según la clase social en la que nos situemos.

A la hora de comprender un cartel publicitario, los artistas pueden elegir los objetos, manipularlos, alterarlos, pueden transformar los materiales que los constituyen para darles una nueva forma, disponerlos de un determinado modo, presentarlos en un lugar específico... Esto da múltiples lecturas de una misma realidad en la que el creador plástico puede transformarla o extenderla mediante elaboración de otros objetos o relacionándolos con otros mundos también constituidos por objetos. De este modo, para analizar la era de la nueva publicidad que pretendemos abordar diferenciaremos dos áreas: el lenguaje y el objeto ${ }^{708}$.

\subsection{1.- El lenguaje publicitario}

En el siglo XX el lenguaje publicitario pierde su función informativa, es decir que se recorta su papel en el anuncio y se potencia la imagen. El artista plástico comprende el producto como centro esencial de su obra y, a partir de él, clasifica sus diferentes características y lo manipula. El color, la materia, la consistencia del objeto, el

\footnotetext{
${ }^{708}$ Gloria Moure, op. cit., pp. 95-97.
} 
lenguaje... son elementos que se pueden alterar. Pero, el lenguaje también sufre un proceso de objetualización; de esta forma, se potencian los instrumentos de configuración en estado bruto ${ }^{709}$. El lenguaje es utilizado como herramienta funcional en donde el poeta concentra su actividad creativa en la estructura lingüística. Con el nuevo siglo el lenguaje pierde su función comunicativa; ahora el que vende no se dirige al cliente para informarle. El lenguaje publicitario de la nueva era recupera la función persuasiva de la antigüedad clásica, por lo que la retórica adquiere un papel tremendamente importante.

El lenguaje persuasivo de la publicidad puede intervenir en el público de diferentes formas $^{710}$ :

- Persuasión racional, dentro de la cual diferenciamos:

- La persuasión racional deductiva es la que va de lo general a lo concreto.

“Qué prefiere, tender o estar tendida?” (Miele)

"Puente aéreo, llegar y volar" (Iberia)

"La potencia sin control no sirve de nada" (Pirelli)

- La persuasión racional inductiva forma parte de la existencia concreta de un cliente y se deriva de ella a una generalización.

“Obsesión” (Golf GTI)

"Bacardi con todo" (Ron Bacardi)

\footnotetext{
${ }^{709}$ Gloria Moure, op. cit. pp. 99-100.

${ }^{710}$ Mario García Uceda, op. cit., pp. 19-40.
} 
"Levi's 508. Libertad de movimiento"

- Persuasión racional retórica, esta sólo busca transmitir contenidos ya sabidos. Se trata de una publicidad de lenguaje figurado, no literal. En donde la base la encontramos en las figuras retóricas de carácter literario y visuales publicitarias.

“Su silencio dará que hablar” Laguna Diesel. (Renault)

"Para la gente que le gusta la gente" (Renault Escape)

"El blanco del sabor" (Low Silk Cut)

- La persuasión racional analógica se desarrolla a través de la similitud con productos de calidad y de eficacia similar, de forma que mediante la mención de una marca determinada o el nombre de un fabricante se hace la publicidad de un nuevo producto. Esto es muy utilizado por las grandes marcas, sobre todo cuando quieren lanzar nuevos productos dentro de una misma línea.

"de Ford"

"Equipamiento de Serie" (Golf Cabrio)

- Una de las más conocidas es la persuasión emotiva, que se basa en la conducta emocional del individuo. Se trata de dotar al producto de significaciones y de valores positivos, subjetivos y, por supuesto, afines a su público. Todos estos elementos ayudan a configurar la imagen del producto, en donde el campo emocional es el mejor abono para la comunicación publicitaria. Este es el tipo de persuasión que utilizarán los anuncios de los productos de consumo visible, tales 
como la moda, los perfumes, los coches... Pero hoy en día también es muy utilizado para la venta de productos intangibles como seguros, loterías, ONCE...

"Giorgio Armani Parfums"

"Ahora Tú" (Nissan)

"No, tú tienes la última palabra" (Campaña contra la droga)

"Campañas de la ONCE"

"Audi"

- Persuasión publicitaria es la que actúa sobre el inconsciente y da lugar a la publicidad subliminal. Se basa en el uso de estímulos tanto visuales como auditivos.

"Ahora es tu mejor momento" Ballantine's (las formas sexuales que aparecen entre los hielos)

“¿Qué diría tu mamá si te viera con Eristoff?” (Vodka Eristoff) (La silueta que se forma en la zona abotonada de los vaqueros)

"Verás que cambio" (Vodka Smirnoff) (Las formas de falo que configuran la nariz y frente de las esculturas).

La nueva publicidad de masas tiene dos caracteres muy importantes. Primero el carácter social, en donde vemos cómo influyen actividades como la educativa, la divulgativa, la propaganda $^{711}$, la informativa... todo ello relacionado con una forma de vida concreta. Y en segundo lugar, nos encontramos con el carácter comercial, cuyo propósito es

\footnotetext{
${ }^{711}$ El concepto actual de propaganda derivó de la propaganda política que buscaba influir en las actividades y opiniones de las personas.
} 
producir una reacción en la persona, sobre todo en el campo del comprador y del usuario. Este tipo de publicidad adoptará diferentes modos ${ }^{712}$ de comunicación externa según la empresa que desee emitirlo.

\subsection{2.- El objeto publicitario}

Cuando hablamos de objeto publicitario, debemos de distinguir dos tipos de productos, uno sería el intangible y el otro el tangible. El objeto intangible es el producto que conocemos como servicios, tal es el caso de los seguros, bancos, agencias de viajes, abogados... En cambio, el objeto tangible es físico, palpable y más o menos duradero. Por ejemplo una televisión, ropa, bebidas, alimentos, juguetes, ordenadores... Para nuestro estudio sería muy interesante abarcar los diferentes tipos de mujeres que se han dado en estos anuncios. Pero nuestro campo está orientado hacia los productos de consumo con un fuerte carácter ostentoso, así que nos concentraremos en los productos tangibles. Dentro de este campo de consumo, la publicidad puede ser dividida en varios tipos según el tipo de producto $^{713}$ :

- Los productos funcionales ${ }^{714}$ : son aquellos de los que el consumidor tiene un conocimiento completo antes de comprarlo. Normalmente, para comprarlo se invierte poco tiempo porque son productos de primera necesidad. Pero para conseguir que un cliente se incline por un producto u otro que ofrecen la misma función y un precio similar, las marcas potenciaron la idea de la fidelidad. Aquí

\footnotetext{
${ }^{712}$ Publicidad, promoción de ventas, fuerza de ventas, merchandising, relaciones públicas, publicity...

${ }^{713}$ Mario García Uceda, op. cit., pp. 41-44.

${ }^{714}$ Las marcas fueron las primeras en utilizar este tipo de publicidad.
} 
tenemos productos básicos como la crema de dientes, detergentes, artículos de perfumería, de limpieza...

- Los productos de impulso: son productos de bajo coste y de uso frecuente que el cliente compra sin casi pensar. Tal es el caso de revistas, dulces...

- Los productos de alto precio: normalmente el consumidor necesita un tiempo para informarse de las características, valorar, comprar, decidir sobre la marca... El gran impedimento que representan estos objetos es el precio. Por lo que el publicista se esfuerza por comunicar lo más claro posible los beneficios del producto.

- Los productos de consumo visible: son productos que se consumen para enseñarlos porque son símbolo de status, prestigio, identificación de grupos y aceptación por parte de los otros. Por supuesto, la marca del objeto es lo primordial; esta es el halo de "imagen".

- Los productos de especialidad: son aquellos en los que por sus características, por su marca u otros elementos, el consumidor está dispuesto a invertir tiempo, esfuerzo y dinero. Pero también es cierto que necesitan una práctica especializada como la fotografía, el deporte, la caza, los coches... las marcas hacen referencia a su prestigio y a su exclusividad.

- Y por último, nos encontramos con los productos no buscados, que serían aquellos que nos encontramos por casualidad.

Cuando el creador plástico, o el poeta plástico, trabaja el anuncio publicitario, tiene en cuenta ciertas cualidades del objeto como las formas, las texturas, los colores, las imágenes... e incluye el uso funcional de los objetos, el contenido cultural que cada uno 
de ellos encierra y el contenido histórico. Todo esto forma parte de la naturaleza del objeto, a lo que se le suma el concepto de artificio. Como resultado tenemos la idea de imitación que tiene el artista, en donde la realidad natural permanece oculta tras el artificio. Esta realidad objetual y mixta sólo es posible conceptuarla desde el lenguaje. Al configurar libremente la materia y las formas, el creador plástico hace saltar las asignaciones de significado convencionales habitualmente ligadas a la funcionalidad utilitaria de las cosas, dejando aflorar un sinfín de connotaciones simbólicas, aunque los objetos mantendrán siempre su potencia simbólica múltiple, llegando a generar incontables metáforas o trastocando las conocidas ${ }^{715}$.

Los lenguajes publicitarios se conforman mentalmente desde su origen más primigenio, y tienen que ver con nuestro contacto con la materia y los objetos. Tanto el lenguaje como el objeto no establecen una relación directa con la realidad; en consecuencia, se crean metáforas que son autorreferentes ${ }^{716}$. El poeta plástico como creador auténtico se ve abocado a construir, no a redundar en las estilizaciones ornamentales. El poeta construirá su particular gramática y transformará de algún modo las “maneras" del discurso. En el fondo la publicidad es un proceso de comunicación de carácter impersonal y controlado, que a través de medios masivos, pretende dar a conocer un producto, servicio, idea o institución, con objeto de informar y/o influir en su compra o aceptación" $" 717$.

\footnotetext{
${ }^{715}$ Gloria Moure, op. cit., pp. 97-104.

${ }^{716}$ Pierre Martineau, La motivación en la publicidad. Una guía para la estrategia publicitaria, Barcelona, Francisco Cánovas (Editor), 1964, pp. 245-246.

${ }^{717}$ Mario García Uceda, op. cit., pp. 23.
} 


\subsection{3.- La condición poética de la publicidad}

Debemos saber que los objetivos publicitarios pueden ser a corto plazo o a largo plazo. Los objetivos a corto plazo se desarrollan cuando el anunciante espera vender los productos de forma inmediata. Los objetivos a largo plazo funcionan un poco diferentemente: estos se consiguen porque la publicidad busca inspirar una fidelidad permanente en la marca. Se abstiene de trivializaciones y de declaraciones sin importancia, y busca por encima de todo, construir un símbolo poderoso. Para ello elabora una personalidad muy firme y segura que la ayuda a situarse por encima de los productos sin personalidad. No se distingue ni por la calidad, ni por el precio, ni por el envase. La diferencia de estos productos viene dada, en la mayoría de los casos, por una etiqueta psicológica, que en resumidas cuentas es la imagen del producto $^{718}$.

Pero, el factor crítico radica en saber en qué medida una marca se arraiga en el ánimo del comprador. Es decir, cómo un objeto se muestra especialmente deseable. A ello contribuye la imagen del producto, que se construye por medio del conjunto total de las actitudes: el halo de significaciones psicológicas, las asociaciones de sentimientos, los mensajes estéticos indelebles, a los que también hay que sumarles las simples cualidades materiales. De esta forma, una marca o una empresa logra despertar asociaciones análogas a la personalidad humana del futuro cliente. En el fondo, cualquier acto de conducta humana es una forma de autoexpresión, de representación del yo interior.

Curiosamente, el individuo vive en un mundo lleno de símbolos, por lo que su estándar de vida se muestra como un conjunto de símbolos que considera necesarios. Cuando el

\footnotetext{
718 Se cree que la atmósfera de significaciones afectivas y representaciones subjetivas es la que proporciona los elementos más poderosos del símbolo, porque todos ellos se comunican por debajo del nivel consciente. De ahí que los elementos no racionales sean la causa del atractivo logrado.
} 
cliente vaya de compras, seleccionará un producto u otro según la personalidad que desee mostrar. Así que el acto de comprar simboliza la adhesión a la personalidad propia de la marca y al estilo de vida que esta desee potenciar. Para concluir, diremos que la imagen o la personalidad de un producto ayudarán a seleccionar la clase de clientela que atraerá, porque la personalidad es una conducta ${ }^{719}$.

\section{3.- Las diferentes funciones del objeto publicitario}

La función informativa cargó al objeto de una personalidad que se alzaba sobre los cimientos de la eficacia y de la confianza. Pero con la producción masiva y un mercado fuertemente competitivo, los objetos se ven ligados a una gran rapidez de consumo que, en ocasiones, no responde ni a la eficacia ni a la confianza. Muchas veces no están ligados a una función ni a una necesidad definida por parte del sujeto. Así que para conseguir que el objeto parezca apetecible se lo reviste de condiciones que rebasan la propia realidad del sujeto. Para ello la publicidad realiza una tarea muy concreta: mitifica los objetos. La función informativa que tenía a priori cede ante la función ideológica y la función social. Ambas trabajan de forma conjunta para conseguir la mitificación del objeto $^{720}$.

\subsection{1.- Función ideológica}

La publicidad también realiza una función ideológica, pues defiende una ética en la que la felicidad de cada cual aparece definida por el consumo y por la adquisición de las

\footnotetext{
${ }^{719}$ Pierre Martineau, op. cit., pp. 245-260.

${ }^{720}$ Emilio Feliu Garcia, op. cit., pp. 70-71.
} 
materias anunciadas. Así mismo, contribuye a la creación de la estructura ideológica de las sociedades avanzadas. De alguna forma, en la sociedad civil la posición social de cada individuo viene determinada por la posesión de determinados bienes. Su mayor o menor prestigio vendrá condicionado por el nivel que haya alcanzado en su escala profesional, social o incluso política. Esta es la sociedad que la publicidad nos mete por los ojos y por los oídos. Para conseguir sus fines con éxito utiliza técnicas muy avanzadas de persuasión descubiertas por la psicología.

Gillo Dorfles pone en relación la publicidad y el diseño industrial. Tras esta combinación, hoy día se ha llegado a la conclusión de que se debe aceptar que la publicidad influye sobre la estructura mental del individuo, sobre su comportamiento y sobre sus mecanismos tanto perceptivos como representativos. Esta incidencia llega hasta el dominio mismo de las artes. La publicidad introduce sus reglas incluso dentro de los mecanismos de construcción poética y narrativa. En ocasiones, este alcanza un nivel de influencia tan alto en la sociedad, que muchos escritores se han hecho eco y lo han criticado en sus novelas ${ }^{721}$. Un ejemplo muy claro lo encontramos en las descripciones de los personajes de American Psycho. Estas son exactamente iguales que las de un catálogo de moda.

Paso junto a ellos, que están en la barra tomando un chapán, y me dirijo hacia un chico extremadamente bien vestido con aspecto de mexicano que está sentado en un sofá. Lleva una chaqueta cruzada de lana y unos pantalones a juego de Mario Valentino, una camiseta de algodón de Agnes B. y unos zapatos sin cordones (no lleva calcetines) de Susan Bennis Warren Edwards, y está con una musculosa chica eurobasura bastante guapa -rubia oscuro, grandes tetas, piel bronceada, sin maquillar, fuma Merit Ultra Lights - que lleva un vestido de algodón

\footnotetext{
${ }^{721}$ Emilio Feliu Garcia, op. cit., pp. 70-71.
} 
con un dibujo de cebra de Patrick Kell y unos zapatos de tacón alto de seda con diamantes de imitación $^{722}$.

\subsection{2.- Función social}

La publicidad, al mismo tiempo que estimula el consumo también, asume una función social. La función social gira en torno al producto con el fin de añadirle connotaciones y elementos de significación que contribuyan a hacerlo deseable y necesario. Estos valores añadidos actúan como catalizadores del mensaje, y son los que empujan al individuo a la compra compulsiva. Son valores que conforman un universo elemental, conservador y evasivo:

La publicidad estimula a que "el hombre-consumidor" se considere como un ser que debe gozar, como una empresa de goce y satisfacción”, instaurando la 'fun morality', o el imperativo de divertirse, de proporcionarse placer, de explotar todas las posibilidades de gozar. Por tanto, el mensaje publicitario no se agota en su finalidad primera, sino que se manifiesta igualmente como medio de transmisión de un sistema de valores, de una cultura, estereotipados $^{723}$.

Vemos que el lenguaje publicitario no se limita a conseguir la compra, sino que impulsa unos valores sociales "buenos" en los objetos. Por lo que el cliente se siente atraído ante tales necesidades y expectativas. Lo que hace una empresa es crear valores socialmente aprobados por todo el mundo. Tal es el caso de Danone, que propaga la buena alimentación como fuente de salud. Por otro lado, leche Pascual se preocupa por los huesos de toda la familia y las compañías telefónicas buscan mejorar la comunicación

\footnotetext{
${ }^{722}$ Bret Easton Ellis, American Psycho, Barcelona, Ediciones B, 2000, p. 119.

${ }^{723}$ Emilio Feliu Garcia, op. cit., p. 90.
} 
con la familia. Los valores añadidos al producto están en función del consumidor, que es lo que dentro del mundo publicitario se conoce como la "población diana"724.

Esto nos ayuda a diferenciar entre consumidor del mensaje y usuario del producto, pues ambos roles no recaen sobre el mismo sujeto. Por ejemplo, se puede dar el caso de que la figura del comprador sea el cabeza de familia, pero la compra se hace pensando en los usuarios, es decir en los hijos.

Bajo esta relación las motivaciones racionales de compra que impulsan al cliente han sido sustituidas por las funciones emocionales, por lo que la economía se basa paulatinamente en la adquisición de roles por impregnación. Serán los diferentes comportamientos sociales los que marquen diferentes campañas publicitarias. Nos podemos encontrar con las campañas de introducción al consumo, que son aquellas que centran el interés en la presentación del producto, en la demostración y en la argumentación. Por otro lado tenemos las campañas de mantenimiento, en donde la presentación del producto deja paso a determinados personajes arquetipos y, en ocasiones, los ambientes identifican al producto con cierto tipo de vida y con valores sociales concretos ${ }^{725}$.

En ocasiones, las motivaciones racionales y emocionales van juntas y en otras ocasiones se sustituyen unas a otras. Dentro de las motivaciones racionales más frecuentes que impulsan a las compras encontramos:

1. Salud, protección

2. Novedad, avance

\footnotetext{
${ }^{724}$ Emilio Feliu Garcia, op. cit., pp. 92-94.

${ }^{725}$ Emilio Feliu Garcia, op. cit., p. 95.
} 
3. Asistencia técnica, características comerciales y distribución

4. Utilidad, practicidad

5. Economía

6. Variedad, adaptabilidad

7. Comodidad, bienestar

8. Seguridad, fiabilidad

9. Características técnicas específicas

Y las argumentaciones racionales más utilizadas en algunos mercados son las siguientes:

1. Alimentación: 1, 2, 4, 5 .

2. Bebidas: 8,9 .

3. Electrodomésticos: 2, 3, 9.

4. Limpieza: 2, 4, 5 .

5. Perfumería: $1,7$.

6. Automóvil: 2, 3, 4, 5, 6, 7, 8, 9 .

Los motivos emocionales los podemos dividir en tres grandes grupos:

A) Motivos sexuales:

1. Dominancia viril

2. Sex-appeal (atractivo)

3. Narcisismo 
417 | La femme fatale en la publicidad del siglo XX

4. Proximidad o contrato erótico/ sexual

B) Motivos individuales:

5. Placer sensorial (olor, gusto, tacto)

6. Optimismo

7. Salud, naturaleza

8. Seguridad

9. Evasión, liberación

10. Gratificación, suerte

C) Motivos sociales:

11. Valoración de la fama o imaginación pública

12. Status, clase, lujo

13. Éxito

14. Distinción, elegancia

15. Imitación del líder, fidelidad al prototipo

16. Relación social

17. Juventud, modernismo

18. Culto a la ideología o las costumbres

19. Familiar, maternal, simpatía a los niños 
Su distribución con los campos de mercado es ${ }^{726}$ :

1. Alimentos: 2, 5, 7, 11, 12, 13, 16, 18, 19.

2. Bebidas: 1, 2, 4, 5, 6, 7, 9, 10, 12, 13, 16, 17, 18, 19.

3. Electrodomésticos: 6, 11, 12, 16, 17, 19.

4. Limpieza: 7, 9, 15, 17, 19.

5. Perfumería: 1, 2, 3, 4, 7, 10, 12, 13, 14, 15, 17, 18, 19.

6. Automóvil: 2, 8, 12, 13, 14, 17.

Desde luego, los sectores más apoyados son la bebida y la perfumería. Estos son los que coinciden con hacer un mayor uso de los motivos sexuales.

\section{4.- Los poderes mediáticos de la seducción}

Durante mucho tiempo los cuidados físicos estuvieron dominados por la obsesión del rostro. En la actualidad las prácticas de belleza buscan cómo conservar el cuerpo joven y esbelto. No se trata de la sofisticación del aspecto físico, pero sí de rejuvenecer, tonificar y reafirmar la piel. Las técnicas de camuflaje con el maquillaje pasan a ser técnicas de prevención y de mantenimiento ${ }^{727}$. A partir de los años sesenta, la prensa femenina se esfuerza por convertir la elegancia en algo más accesible, más desenvuelto y más práctico. Se ensalzan los valores de la fantasía, de la libertad y de la actividad, por lo que se intenta dar la imagen de que la belleza es libre, y este precisamente es el

\footnotetext{
${ }^{726}$ Emilio Feliu Garcia, op. cit., pp. 95-96.

${ }^{727}$ Gilles Lipovetsky, op cit., pp. 121-125.
} 
título de la Vogue de 1968 en USA. Ahora la nueva mujer viste tal y como le gusta, o como le apetece ${ }^{728}$.

A lo largo del siglo XX la publicidad, el cine y las fotografías de moda, han difundido los modelos superlativos de la feminidad, por lo que, consiguen sacarlos del mundo demiúrgico e invaden la vida cotidiana por medio de las revistas femeninas. A partir de aquí se inicia un nuevo ciclo sobre el fondo de profesionalización del ideal estético. La publicidad con modelos y estrellas de cine refleja un ideal de belleza mediante el uso de productos de cosmética. Ahora el maquillaje deja de ser un producto de consumo, y desplaza su ideal de perfección al rostro del famoso: son las actrices y las modelos la que se convierten en productos para las masas.

\subsection{1.- La cultura demiúrgica}

A partir de los años 70 la nueva cultura juvenil difunde los modelos estéticos adolescentes. Los ídolos de aspecto juvenil, delgados y desenvueltos, hacen furor, pero también se convierten en el prototipo de los cambios de las nuevas actividades sociales: el ir a la playa; el desnudamiento del cuerpo por medio de shorts, bikinis, top-less...; el auge de los nuevos poderes; las transformaciones de la moda de los años 20 y luego en los 60 en los vestidos, pantalones, faldas cortas, prendas ceñidas... que contribuyen a valorar un cuerpo flexible, juvenil y delgado.

El sistema contemporáneo de belleza no prolonga la lógica primitiva, pero sí amplía la lógica moderna del consumo para permanecer joven y esbelto. Se impone como la

\footnotetext{
${ }^{728}$ Gilles Lipovetsky, op. cit., pp. 153-154.
} 
nueva base de la lógica estética ${ }^{729}$ que ayuda a descalificar el sedentarismo femenino y a desterrar los odiados michelines. La gimnasia se ve como una dinámica saludable que ayuda a mantener el cuerpo sano y joven. Los mecanismos de esta nueva disciplina anulan la conciencia y la voluntad para favorecer una obediencia ciega al ejercicio automático. El cuerpo del siglo XX es una máquina que debe permanecer siempre en funcionamiento $^{730}$.

\subsubsection{1.- Los arquetipos}

La publicidad busca llegar al máximo número de lectores ${ }^{731}$. Para conseguir su objetivo, buceará en el imaginario colectivo. Desde este punto de vista, no se pueden separar la conciencia del imaginante y las imágenes concretas. Esto nos conduciría a una clasificación estructural de los diferentes contenidos posibles de lo imaginario.

En el presente estudio nos negamos a ver en la imagen ficcional de la como el vulgar signo de una realidad psicológica o de la realidad intrínseca de la conciencia. Esta afirmación nos impulsa a preguntarnos cuál es el origen del semantismo en general, lo cual implica pasar de la morfología clasificadora de las estructuras de lo imaginario a una fisiología de la función de la imaginación. Lo que se busca es demostrar que existe una realidad idéntica y universal del imaginario.

Los mitos podrían ayudarnos a darle forma a la imagen que estamos buscando. No se trata de estudiar las reflexiones mutuas del trayecto antropológico, sino que debemos

\footnotetext{
${ }^{729}$ Se puede apreciar el contagio que sufre el discurso publicitario por parte del discurso médico, en que se manifiesta que la buena salud de la población pasa por la injerencia de una correcta alimentación.

${ }^{730}$ Gilles Lipovetsky, op. cit., pp. 127-129.

${ }^{731}$ A estos también se les llamará "compradores en potencia".
} 
preguntarnos sobre el condicionamiento que pueden provocar ciertos mitos e imágenes ya elaborados y utilizados como vehículos por el consenso social e histórico. Pero tampoco podemos tomar los mitos tal y como los hemos heredado de la antigüedad, pues se distribuyen en tres grandes esquemas que han evolucionado y se han desligado del concepto originario ${ }^{732}$.

Aunque para la mayoría de los clientes es inapreciable la tripartición y los regímenes a los que se someten ${ }^{733}$, es fácilmente palpable que en ellos se desarrollan estructuras míticas y estructuras sintéticas de lo imaginario. A través de ellas se revela que la relación de símbolos y el agrupamiento de isótopos que los relacionan aparecen como reveladores de estructuras: con estos vínculos se establecerá la "semántica de las imágenes", una estructura propia y cerrada que, como dicen Alain y Bachelard, sólo remite a sí misma ${ }^{734}$.

\subsubsection{1.- Función pedagógica}

Toda sociedad tiene una serie de ideologías. La ideología mayoritaria de una civilización no sólo domina, sino que también ejerce un tipo de presión fáctica sobre las ideologías menores o minoritarias. Este tipo de presión recibe varios nombres; unos lo llaman "presión pedagógica" y Jung prefiere nombrarlo "pedagogía". La interpretación

\footnotetext{
${ }^{732}$ En el primer grupo vemos los esquemas diaréticos y verticales que están simbolizados por los arquetipos del cetro y de la espada; son los isótopos de cortejo simbólico. En el segundo grupo nos encontramos con los esquemas del descenso y la interiorización que están simbolizadas por los arquetipos de la copa y sus componentes simbólicos. En el último y tercer grupo tenemos los esquemas rítmicos con matices cíclicos y progresistas. Estos últimos aparecen representados por la rueda denaria o duodenaria, el vasto lleno de brotes o el árbol.

${ }^{733} \mathrm{El}$ régimen diurno es el de la antítesis, y el régimen nocturno es el de los eufemismos.

${ }^{734}$ Gilbert Durand, Las estructuras antropológicas del imaginario, Madrid, Fondo de Cultura Económico, 2005, pp. 385-396.
} 
general que se da a este tipo de educación es negativa, porque se trata de una pedagogía mayoritaria que se impone sin dar la menor oportunidad a las corrientes minoritarias. Esta enseñanza crea nuevas formas, nuevos mitos y nuevas imágenes para reprimir las aspiraciones fantásticas ajenas a su régimen o enseñanza ${ }^{735}$.

Pero si queremos juzgar las presiones pedagógicas debemos adoptar un punto de vista estructural y sociológico. Así que dejaremos de lado el esquema mitológico que se ha dado a lo largo de la historia, pues la historia no es otra cosa que la vasta "realización simbólica" de las aspiraciones arquetípicas frustradas: por ello encontraremos sistemáticamente la figura de María canonizada y la figura de Eva como marginada.

En conclusión, la historia no explica el contenido mental arquetípico porque la historia es el dominio de lo imaginario. En cada fase histórica está presente una doble y antagónica motivación. Por un lado, tenemos la pedagogía de la imitación y, por otro, las fantasías adversas debidas a la represión ${ }^{736}$. Por así decirlo, es la "tensión" sociológica creciente la que especificará el simbolismo del arquetipo y el esquema universal en la expresión social. En la universalidad de los arquetipos y en sus símbolos más generalizados encontramos de nuevo el trayecto antropológico ${ }^{737}$.

Las proyecciones imaginarias y míticas se tomarán poco a poco como imitaciones activas, que van más allá de los modos de vida. En ellas vemos cómo se codifican conceptos socializados y solidificados en sistemas pedagógicos que, a su vez, frustran los otros regímenes de aspiración arquetípica. En cualquier época se imponen dos

\footnotetext{
${ }^{735}$ En un principio son imágenes terroríficas con un fin pedagógico.

${ }^{736}$ Por lo que la pedagogía no sigue un sentido histórico determinado, simplemente es imposible de prever. Si realmente hubiera una pedagogía social de los arquetipos, esta aparecería ipso facto como secundaria.

${ }^{737}$ Gilbert Durand, op. cit., pp. 391-395.
} 
mecanismos antagónicos de motivación. El primer mecanismo es opresivo en sentido sociológico, pues contamina todos los sectores de la actividad mental bajo el discurso de belleza y salud. Lo que se consigue es sobredeterminar al máximo las imágenes femeninas. El segundo mecanismo bosqueja una rebelión y una oposición dialéctica que suscita símbolos antagónicos ${ }^{738}$.

\subsubsection{2.- Función semántica}

Retomemos la tesis de La función de la imaginación de Lacroze: en ella se admite la universalidad de las imágenes (publicitarias) y la función que ellas ejercen. Pero, ¿cómo diseñar arquetipos universalizados? Este punto de vista denuncia el defecto de la tesis sartreana, la cual mantiene que sólo se generaliza lo singular.

Debemos saber que generalizar lo singular significa popularizar lo propio, lo interno y lo reprimido. Sí, es cierto, lo reprimido tiene la necesidad de ser simbolizado para poder ser exteriorizado; pero no es cierto que sólo lo reprimido sea simbolizado, por lo que sería bastante ridículo mostrar la femme fatale como un simple signo de la represión cultural $^{739}$.

El símbolo tiene una naturaleza semántica, por lo que una imagen simbólica es semántica. Esto quiere decir que deberíamos centrarnos en el significado de sus elementos, y en la evolución o en los cambios que se dan a través del tiempo, dado que la función de cada uno de estos elementos es completamente inseparable de su mensaje

\footnotetext{
${ }^{738}$ Resulta más o menos fácil mostrar que toda "era" arquetípica de la historia es frecuentada a la vez por todos los regímenes de la imagen, y cómo todo el clasicismo está cargado de todo el romanticismo imaginable, y recíprocamente.

${ }^{739}$ Aunque sí es cierto que la represión social ejerce un papel importante en la historia de la mujer, el objetivo de este trabajo no es explicar el origen de la femme fatale en el discurso paternalista.
} 
final. En consecuencia, veremos que el carácter semántico del símbolo femenino es creador, porque la función imaginativa siempre desborda el mecanismo de la represión ${ }^{740}$.

\subsection{2.- El espacio del arquetipo}

Gilbert Durand mantiene que la imaginación humana esta modelada por el desarrollo de la visión, luego por la audición, y finalmente, por el lenguaje. Todos ellos son medios de captación y asimilación de "la distancia". En esta reducción eufémica del distanciamiento están contenidas las cualidades del espacio.

Dentro de la definición del espacio podemos diferenciar dos tipos, el espacio algebraico de la física y el espacio psicológico. Este último es el que nos interesa. Es el que Kant nombra como elemento a priori formal de la experiencia: no es funcionalmente físico ni objetivo, sino el símbolo operativo del distanciamiento. El espacio psicológico es el espacio iconográfico puro al que ninguna deformación física o temporal alcanza, donde los objetos se desplazan libremente sin padecer la apremiante perspectiva.

El espacio imaginario que caracteriza a toda obra de arte se ve poderosamente influenciado por el espacio psicológico, por lo que cuenta con un carácter mucho más cualitativo. Es decir, que abandona el dominio de la indiferente localización e integra a los objetivos de la imagen en la pertenencia. Este espacio tiene una función simbólica en donde los elementos que conforman la imagen pertenecen a una representación especialmente concreta. El espacio psicológico es un espacio iconográfico puro, al que ninguna deformación física ni temporal alcanza. Es un espacio interiorizado, propio de

\footnotetext{
${ }^{740}$ Gilbert Durand, op. cit., pp. 399-401.
} 
una experiencia personal. Cada artista plástico será libre de articularlos como él quiera: bajo la estructura de la imitación canónica, o bajo la estructura revolucionaria y marginal. La razón final del espacio imaginativo es el eufemismo. Ahora queda analizar las categorías funcionales de estos eufemismos ${ }^{741}$.

\subsubsection{1.- El arquetipo frustrado}

Una de las influencias más importantes para los publicistas fueron los propios cuerpos trabajados en el mundo literario. Los escritores del siglo XIX elaboraron la idea del cuerpo bajo la propia experiencia vivida. Una experiencia que no es sólo visual, sino también que se puede oír (la dulzura de la voz), oler (perfumes), tocar (el tacto y la consistencia) y gustar (el sabor de la piel). El concepto real del cuerpo se percibe por todos los sentidos. Esta nueva percepción del cuerpo abre todo un abanico de posibilidades mediante diferentes arquetipos que se esfuerzan por sugerir una experiencia lo más completa posible de la carne ${ }^{742}$.

\subsubsection{2.- La carne del arquetipo frustrado}

Desde la época clásica hasta el Renacimiento, los desnudos implicaban un estudio previo de la anatomía humana. Esto conlleva el estudio de la armonía de las partes y el reflejo de las fuerzas armonizantes de la naturaleza. Pero con la llegada del siglo XIX, el cuerpo femenino se alinea con su carnalidad para mostrar su auténtica naturaleza. Por

\footnotetext{
${ }^{741}$ Gilbert Durand, op. cit., pp. 413-420.

${ }^{742}$ Enrique Salgado, op. cit., pp. 67-94.
} 
ello los elementos que caracterizan al cuerpo sólo pueden ser descritos a través de los sentidos, pues es mediante los sentimos como captamos el mundo ${ }^{743}$.

- El olfato: existen estrechas relaciones entre el olfato y la sexualidad, pues los olores genitales de la hembra se hacen más penetrantes en época de celo para atraer al macho. Aunque en los humanos el olfato está un poco atrofiado, desempeña funciones complementarias en la líbido. Por eso el uso de perfumes en los humanos representa un vestigio animal harto olvidado. Da la casualidad de que los siglos XIX y XX fueron la época en que el desarrolló la industria de la perfumería, la cual representa los antecedentes del atractivo erótico. No es por azar que los olores más famosos los se describieran en las novelas de Zola, y en los llamados poetas de los olores: Flaubert, D’Annuzio, Huysmann y Baudelaire.

Tal vez por eso Napoleón era incapaz de soportar de cerca a una mujer perfumada. En el terreno patológico el olor de la sangre, la orina, el sudor o los excrementos excitan a algunos individuos. De Blasi investiga cómo el olor varia de unas personas a otras, por ello afirma que el olor es diferente en las mujeres según si son rubias, morenas o pelirrojas. El olor del cabello, sobre todo el de la nuca, ejerce una fascinación especial. Por el contrario, la axila y la boca son inhibitorios, porque su mal olor responde a una salud defectuosa, a los gases pútridos del estómago, a las caries, al mal aliento...

- El oído: la voz, a veces, adquiere un atractivo erótico mayor. Hay voces masculinas profundas, cálidas y pastosas que poseen una muy acusada seducción. Lo mismo le ocurre al hombre cuando hace una llamada erótica, pues algunas veces se hacen con el fin de escuchar una voz femenina particularmente sexy.

\footnotetext{
${ }^{743}$ Enrique Salgado, op. cit., pp. 67-94.
} 
Por ello en el Talmud se prohíbe a los hombres escuchar el canto de las mujeres, porque es sexualmente excitante.

- El tacto: las impresiones del contacto tienen una gran resonancia afectiva y dan lugar a vivencias difíciles de objetivar: cosquillas, picazón, caricias... La fisiología del erotismo táctil demuestra que la procedencia del placer se relaciona con la temperatura de las regiones del cuerpo. De ahí la repugnancia al contacto de los viejos, los cadáveres o de las manos con sabañones. Un ejemplo muy claro lo encontramos en Madame Bovary, cuando al doctor Carlos Bovary se le hace odiosa su mujer porque sus pies están fríos en el lecho. Por el contrario, algunas personas seducen cuando están poseídas por accesos febriles. Tal es el caso de los tuberculosos con elevada temperatura en su cutis, con los labios irritados o calientes.

Otra cosa aparte es el "fetichismo del frío", que no es sino la búsqueda del frío o de bajas temperaturas. Pero esto es comprendido como una anomalía sexual. Se dan muy pocos casos en que la excitación sexual se produce por el contacto de manos frías, pues normalmente esto suele resultar indiferente. Esto es una conducta que sólo toma importancia con la necrofilia. Rousseau, en su novela Nueva Eloisa, describe un beso, y por supuesto se trata de una descripción que rebasa lo erótico.

\subsection{2.- El desnudo, el vestido y el movimiento}

Un desnudo bello es el reflejo de una cultura que alaba el cuerpo bien formado y en perfecto equilibrio. Pero el efecto erotizante del desnudo depende del grado de este. Pellegrini lo clasifica según lo que se entienda por desnudez: 
- Estar desnudo

- Desnudismo o práctica de vivir colectivamente sin ropa

- Desnudar o el hecho de quitar los vestidos

- La desnudez se puede dividir en total o parcial, esta última vinculada a ornamentos como velos, collares, piedras preciosas...

Al mismo tiempo la excitación debida a la contemplación del desnudo presenta algunas variedades como:

- La autoerótica, derivado del narcisismo

- La pluralista, que sería la que se da en las orgías

- La fortuita, como la que vive Susana observada por los viejos

- La homosexual

- La heterosexual

Magnus Hirschfeld diferencia entre coherencias y adherencias. Las coherencias son los adornos que forman un todo con la mujer como los vestidos o los peinados. Entre otras cosas, se ha discutido muchas veces si los vestidos tuvieron o no un carácter protector contra el medio ambiente. Este es un debate en el que no entraremos. Pero lo que sí interesa al presente estudio es el carácter ornamental que las vestimentas tienen para aumentar los encantos personales ${ }^{744}$, y así conseguir establecer diferencias visuales entre los hombres o las mujeres. Por lo que tiende a recurrir a breves tretas como aberturas por arriba, por debajo, laterales en las piernas, transparencias... Se buscará

\footnotetext{
${ }^{744}$ Así lo anuncia Baudelaire en La Femme.
} 
poner de relieve las curvas femeninas mediante vestidos ceñidos; o evocando la imagen del tacto mediante diferentes tipos de telas como el terciopelo, pieles, plumas o el movimiento fru-fru de la seda. Además, se adornaran determinadas partes del cuerpo, como el pecho.

Las adherencias son los elementos que se sobreponen a ellas temporalmente, como los anillos, pendientes, moscas... Curiosamente las moscas eran lunares postizos que tenían el objetivo de poner el acento en la blanca piel. Según el lugar del cuerpo en donde se colocasen recibían un nombre u otro. Por ejemplo, los lunares que se ponían en el pecho se llamaban invitatum, y los que se ponían entre los pechos se llamaban révelevses. También en la rodilla se pintaban con forma de corazón, de flor, de campana, incluso algunos llevaban un brillante en el centro. Todos estos elementos son suficientes para señalar el fin que persiguen, pues todos ellos están destinados a resaltar u atraer la mirada hacia él.

Según Pellegrini, tienen particularmente valor los guantes, medias, cinturones, ligas, sostenes... Estos elementos del vestuario representan la máxima fascinación, no por lo que cubren sino porque hacen más evidente la desnudez que hay encima de ellos. El acto de ponérselos revela la acción erotizadora táctil, pues se intuye la caricia, el movimiento lento y ajeno. Pero el acto de quitárselo también tiene significado. Tal es el caso de Rita Hayworth, pues con sólo el leve desnudo de su brazo simboliza la desnudez total del cuerpo.

Del mismo modo que el maquillaje, la moda o la vestimenta es un estímulo cromático de alto carácter sexual que potencia los movimientos femeninos, aunque estos sean moderados. Pero el maquillaje también es un medio erógeno conocido desde muy antiguo. Se aplicaba principalmente en las uñas de los pies y de las manos, en los 
párpados, en las mejillas, en los labios... e incluso el bronceado se comprendía como un maquillaje que cubría todo el cuerpo. Una característica importante de estas adherencias es el uso del color. Este tiene un carácter fundamental en el erotismo. Bien uniforme y bien combinado debe atraer la atención de quién mira, pero siempre de forma discreta. La armonización del tono de la piel con el tono de los cabellos parte de organizar los contrastes oportunos.

Por otro lado, también es importante resaltar el papel de los movimientos en el carácter erótico que tiene el cuerpo. Normalmente, los movimientos sexys requieren de la colaboración de otro. Se suelen disimular con pretextos para que parezcan inocentes, pero su carácter erotizante persiste. Como el guiño de un ojo, señas con la cabeza, diferentes actitudes de los labios, levantarse la falda para después dejarla caer, apretarse las palmas de la mano sacando pecho, reírse sacando pecho con oscilaciones rápidas, sacudirse el cabello hacia atrás para dejar ver el cuello...

Los movimientos que recuerdan actitudes copulares, destacando una proyección rítmica, se dan con mayor asiduidad en los bailes, en donde la sugerencia erótica que produce la contemplación de la danza la relaciona con los movimientos pélvicos de tipo copular. Esto a lo largo de la historia ha suscitado toda una serie de juicios. Por ello, Platón afirmaba que sólo las personas sin crédito amaban la danza; Demóstenes acusa a Filipo de Macedonia de bailar en público; Horacio decía que las danzas son una de tantas infamias de Roma; Ovidio consideraba las salas de baile como lugares de naufragio del pudor; Cicerón mantenía que el que baila está loco o ebrio, de hecho un caballero llamado Laberio fue expulsado de la Orden Ecuestre por bailar en un teatro a instancias de Julio Cesar... Entre los paganos había severísimas leyes contra el baile ${ }^{745}$.

\footnotetext{
${ }^{745}$ Enrique Salgado, op. cit., pp. 109-118.
} 


\section{5.- El eclipse de la mujer fatal}

El siglo XX marca un profundo cambio en la figura de la mujer. La figura femenina se liberará de los lazos tradicionales, poco a poco se despojará del peligro y del vicio, y su belleza se verá como una cualidad positiva. Esta metamorfosis se ve ilustrada por estrellas de cine y modelos.

Los productos de las revisas y de los médios de comunicación van dirigidos especialmente a un público femenino. Son ellas, y no los hombres, el público más atento a las figuras de seducción emblemática. Los publicicistas lo saben, así que las modelos y las actrices son un espectáculo destinado a llamar la atención de las mujeres. Los productos de maquilalje, perfumería y moda aparecen sobre arquetipos muy concretos. Todos ellos intentaran adoptar todos los tipos posibles de elegancia, por lo que tendrán un aire distante, una mirada fría, una actitud inexpresiva, inaccesible ${ }^{746} \ldots$

\subsection{1.- La femme noir}

En un principio, la secularización de la cultura no logró superar el imaginario tradicional de la seducción femenina confundida con los maleficios de Eva. Las representaciones cinematográficas de la mujer se daban en torno a oposiciones de estereotipos clásicos: la pureza/la lujuria, el ángel/el demonio, la belleza virginal/la belleza destructora, las Venus castas de Cabanel o de Bouguereau/ las Evas venenosas de Stuck o de Félicien Rops. La belleza fatal de los años 40 y 50 se exhibe como una seducción superficial, como el narcisismo frívolo y como el porte de la soberbia

\footnotetext{
${ }^{746}$ Gilles Lipovetsky, op. cit., pp. 157-165.
} 
insensible. Pero bajo esa delgada capa, todas ellas esconden en su interior a la Bestia monstruosa, indiferente, irresponsable, insensible, que se emponzoña cuando se acerca a contemplar la Salomé de Gustave Moreau.

En el cine lo que se compra y se vende es la imagen de belleza, no el cuerpo de la mujer. De ahí la emergencia de un nuevo poder de la belleza femenina. En los primeros años del cine la sensualidad se había encarnado en el estereotipo de vampiresa, como fue el caso de Theda Bara, Pola Negri y Marlène Dietrich. Todas ellas fueron diosas populares de ojos insondables, cargados de rímel, atuendos sofisticados y largas boquillas. Eran heroínas que evocan la feminidad inaccesible y destructora, pues representaban una estética dramatizada. Pero poco a poco se fue perdiendo la lascivia de la vampiresa y el satanismo de Eros.

En la gran pantalla, la figura de la vampiresa da lugar a estrellas más humanas y menos accesibles. Su tumultuosa vida amorosa responde a la búsqueda auténtica de la pasión. Esto les llevará a vivir diferentes realidades, lo cual las convertirá en portadoras de la etiqueta de la inmoralidad ${ }^{747}$.

\subsection{2.- El nuevo sex-appeal}

A partir de los años $40 \mathrm{y}$ de los 50 las figuras femeninas se independizaron del referente secular de la belleza demoníaca. En el cine y la pintura ya no ofrecen imágenes de la belleza infernal. Son mujeres sin sombra y sin prejuicios. Féminas que han perdido el carácter capital de la bipolaridad. De esta forma, Lipovetsky afirma que a partir del segundo tercio del siglo XX triunfa la era de la posmujer fatal.

\footnotetext{
${ }^{747}$ Gilles Lipovetsky, op. cit., pp. 159-166.
} 
El cine fue el que marcó el cambio, pues en él aparece la nueva figura good-bad girl.

Esta era una mujer con aspecto de vampiresa, pero de tierno corazón. Seductora pero no perversa, con el estilo glamour de Rita Hayworth o Lauren Bacall.

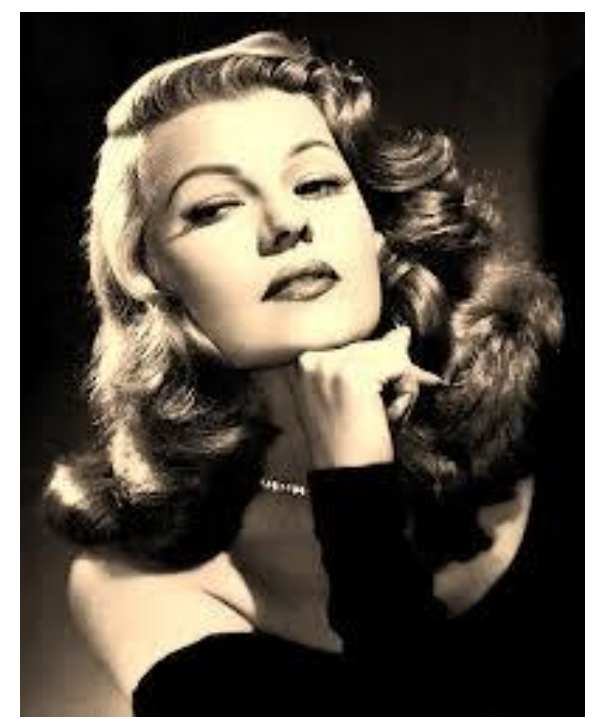

Rita Hayworth

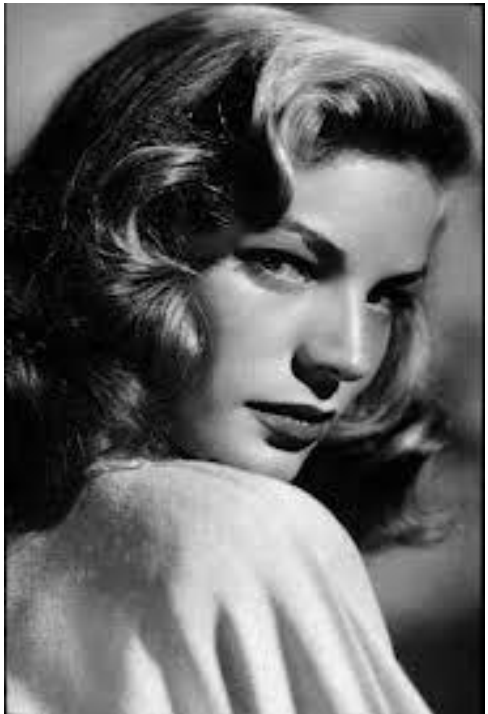

Lauren Bacall

Su belleza incendiaria responde a su dimensión satánica de antaño como devoradoras de hombres. Sin embargo, encarnan la transición hacía una nueva apariencia erótica (sexappeal) con la generosidad de sentimientos (alma pura) ${ }^{748}$.

\subsubsection{1.- Las Pin-up}

Lo que mejor ilustra el fin del imaginario de la belleza maldita es la estética sexy creada por los dibujantes y fotógrafos de los años 40 y 50. A través de sus fotografías se impone un nuevo estilo de belleza. Estas serán las Pin-up, mujeres jóvenes de piernas finas, silueta estilizada, flexible, aspecto ingenuo y provocativo, pecho voluminoso, nalgas redondas, postura incitadora y mirada hípererotizada. Todas estas imágenes

\footnotetext{
${ }^{748}$ Gilles Lipovetsky, op. cit., pp. 157-160.
} 
invaden poco a poco los soportes más divertidos: calendarios, carteles publicitarios y tarjetas postales $^{749}$. Es la era de la Pin-up.

Son destacabes las Pin-up de Varga:
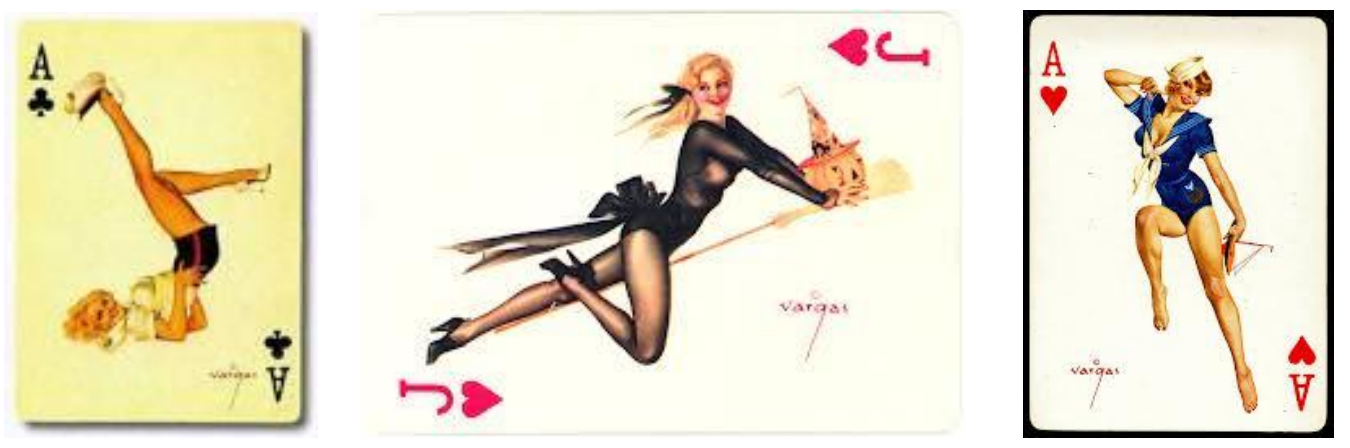

Las de George Petty:
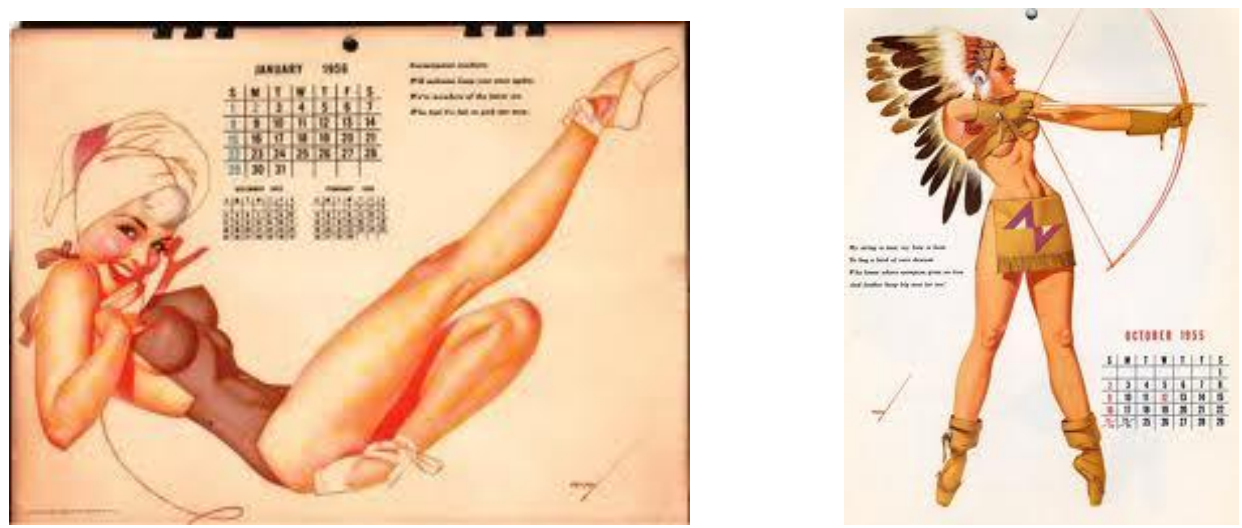

Las de Peter Driben:
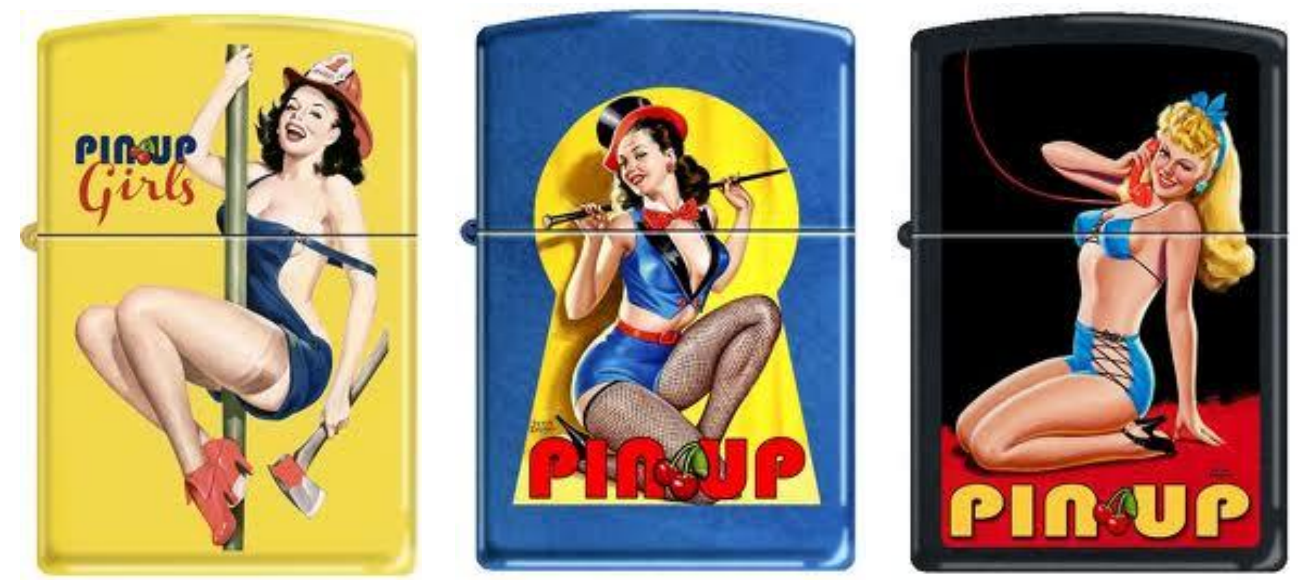

$\overline{{ }^{749} \text { Gilles Lipovetsky, ibídem, p. } 160 .}$ 
Son incitadoras, pero no perversas. Las dibujadas por Gil Elvgren y las fotografiadas por Bunny Yeager no responden ni al modelo de virgen ni al de la puta diabólica. Se ofrecen como baby-dolls. Encantadas, desvergonzadamente simpáticas, y sin más consecuencias que las destinadas a los amoríos y a las pasiones devastadoras. Con anterioridad a la "revolución sexual" de los años 60 y 70 expresaron el advenimiento de un eros femenino desprovisto de todo misterio ${ }^{750}$.

\subsubsection{2.- Las Venus de los vaqueros}

Estéticamente, se abre paso una síntesis entre sensualidad e inocencia, sex-appeal y vulnerabilidad, encanto y ternura, erotismo y jovialidad. Hollywood tomó esta imagen y creó el más resplandeciente arquetipo de la posmujer fatal. Comienza la época de la Venus de los tejanos. Más pop que románticas, más dinámicas que enigmáticas y más lúdicas que tenebrosas. En lo sucesivo la seducción femenina estará ligada al culto moderno del ritmo, al impacto de la juventud y del "furor de vivir". La oposición entre belleza etérea y belleza malsana se deja de lado para resaltar la belleza sexy. También el cine ayuda a la consagración de las pin-up con estrellas tan explosivas como Betty Grable, Marilyn Monroe, Jayne Mansfield, Anita Ekberg, Sofía Loren o Brigitte Bardot.

Todas ellas ayudaron a proyectar la nueva feminidad de encantos agresivos, erotismo desinhibido, natural, juvenil, con vestidos escotados, faldas y suéteres ceñidos, escenas de striptease, de baño, de bailes tórridos... De forma, que no quedó ni huella de la

\footnotetext{
${ }^{750} \mathrm{Al}$ igualar la idea de arte a la de belleza, y la de la belleza a la ornamentación, se crean imágenes superfluas de mujeres que evitan la confrontación directa con la realidad y establecen una superposición fetichista ante una vida dominada por el sinsentido, el caos y la sordidez. Esta estrategia de simulacro afecto a todas las áreas de expresión artística. Es conocida por el término "Kitsch" (baratija recompuesta) y se trata de una aproximación al objeto típico de la cultura de masas. En el caso de estas féminas, vemos como la belleza y las formas femeninas son exageradas hasta rayar la vulgaridad. Son imágenes que sustituyen el criterio por el gusto.
} 
maldad femenina inicial. Mediante una estética desdramatizada, las nuevas Venus cinematográficas se alzaron al nivel del mito. Tal fue el caso de Marilyn Monroe.

Tal vez en un plano menor que las Pin-up, pero las Venus de los tejanos también representaban a la mujer como objeto sexual. La hermosura femenina ya no señala hacia el abismo. Ahora es signo de una promesa de felicidad. Una feminidad que evoca más el reposo del guerrero que una identidad femenina autónoma. El fin del arquetipo de la belleza demoniaca expresa el avance de una cultura que potencia las curvas femeninas $^{751}$.

\subsection{3.- La materialidad de las modelos}

En un principio las modelos se vieron ligadas a la alta costura. Durante casi un siglo, que abarcaría desde la segunda mitad del siglo XIX hasta la primera mitad del siglo XX, esta profesión se vio desvalorizada. Pero tras la segunda guerra todo cambió y se convirtieron en un modelo de vida para las jóvenes. La pin-up, y posteriormente las Venus de los vaqueros, fueron una pura vitrina de modas, imposible de contraer el menor signo de depravación y de destrucción. Sólo encarnaban la superficialidad de la moda. Nada más. Pero eran féminas que encarnaban el incipiente desarrollo económico del país. Representaban la felicidad de la tranquilidad económica. Eran chicas que potenciaban el gasto en productos de belleza.

El éxito de las top-models actuales es el reflejo de la importancia que la sociedad le ha dado al aspecto físico. La eterna juventud y la radiante belleza física se convirtieron en el reflejo de la salud mental y física. Se trataba de una belleza sana y muy diferente a la

\footnotetext{
${ }^{751}$ Gilles Lipovetsky, op. cit., pp. 160-162.
} 
belleza fatal, que se caracterizaba como enigmática y sinónima de abismo y del caos de Eros. Las nuevas féminas de la segunda mitad del siglo XX se caracterizan por su belleza eufórica al ofrecer un espíritu de programa y de performatividad estética. La desaparición de imágenes maléficas se acompaña de la proliferación de modelos que invitan a mejorar las cualidades estéticas ${ }^{752}$.

${ }^{752}$ Gilles Lipovetsky, op. cit., p. 166. 


\section{7.- Los estereotipos en las marcas de lujo}

En un mundo marcado por la competencia directa de la calidad de los productos y de los precios bajos, observamos cómo las marcas de lujo mantienen intactos sus números de sus ventas. Esto se consigue porque, pese a sus precios altos, las marcas de lujo conservan intangibles sus valores y, mediante estos, consiguen ir más allá de los costes de producción y de distribución. En el capítulo anterior hemos mencionado que los valores que cada marca decidía representar eran abstractos. Pero, sinceramente, no son tan abstractos. Alfonso Méndiz y Carmen Cristófol realizaron un estudio estadístico al respecto y observaron que estos valores no son imposibles de mensurar y que, además, existen diversos sistemas y monitores capaces de aislar las variables.

La imagen de la marca no se encuentra tanto en el producto como en las mentes de los compradores. Se trata de un proceso psicológico, por lo que para conocer los valores de una marca es preciso acudir a los receptores de todas y de cada una de las comunicaciones que la marca realiza con el público que le interesa ${ }^{753}$. La principal fuente de información de las consumidoras de marcas de lujo son las revistas femeninas. En este proceso de comunicación, intervienen los mejores fotógrafos y las mejores modelos. Se realiza una cuidada selección de ropa y complementos, y también se realizan las mejores herramientas de estilismo fotográfico para crear deliberadamente una imagen lo más original y lo más impactante posible. Porque el último objetivo es detener durante unos segundos la atención del público-objetivo. Para llegar al cliente de

\footnotetext{
${ }^{753}$ Alfonso Méndiz Noguero, Carmen Cristófol Rodríguez, Falsedad y comunicación. Publicidad engañosa, información falsa, imagen manipulada, Valencia, Debates, 2007, pp. 45-64.
} 
una forma eficaz y rápida, se crean imágenes capaces de transmitir valores, con ello se busca obtener algo más que el propio impacto visual en el cliente.

Es innegable que la función principal de la publicidad es la venta, pero para ello se manejan determinados estereotipos comúnmente aceptados. Modelos iconográficos que muestran cómo debe ser una mujer o un hombre para triunfar social y afectivamente. Estos estereotipos femeninos resaltan valores que no recogen el concepto de mujer en su acepción más completa y frecuente. Todos buscan atraer rasgos de transgresión (Códysée), éxito (Magnun, Chanel), triunfo afectivo, triunfo profesional, placer (Opium, Quizá, quizá, quizá), el riesgo, o la libertad (A mi aire, La vida es bella). Todo esto conlleva dejar de lado la amistad, el esfuerzo y la familia. Particularmente es la moda el producto de consumo que más se identifica con el propio consumidor. El vestir y los complementos forman parte de la propia identidad de las personas.

\section{1.- Libro de códigos del análisis del contenido}

Intentar presentar un análisis de los personajes que aparecen en la publicidad gráfica, implica conocer los estereotipos utilizados por las marcas de lujo. Probablemente, estas marcas, mediante la publicidad, buscan reforzar determinados estereotipos de mujer que existen en la sociedad. Pero para comprobarlo debemos ${ }^{754}$ :

- Analizar el contenido de las publicaciones gráficas. Sobre todo los anuncios que se dan en las revistas femeninas.

- Observar si la adquisición de una determinada marca implica estar vinculada a una determinada marca social porque enlaza con un toque de distinción.

\footnotetext{
${ }^{754}$ Alfonso Méndiz Noguero, Carmen Cristófol Rodríguez, op. cit., p. 49.
} 
Para ello es necesario señalar todos los datos posibles que se desprenden de los personajes femeninos que nos disponemos a analizar. Aunque, al mismo tiempo, estos personajes femeninos tienen elementos comunes con los personajes femeninos que dio el mundo literario del siglo $\mathrm{XIX}^{755}$ :

- El sexo del personaje (femenino)

- El carácter famoso del personaje

- Determinadas características del personaje

- Etnia

- Edad

- $\quad$ Menor de edad

- Clase social

- Color del pelo

- Complexión

- Atlético

- Que parte del cuerpo aparece

- Actitud seductora / galante

- Es seducido

- Domina el espacio

- Con actitud narcisista

${ }_{755}$ Alfonso Méndiz Noguero, Carmen Cristófol Rodríguez, op. cit., pp. 51-52. 
- Rostro y cuerpo perfecto

- Sólo rostro

- Rostro sin muestras de cansancio

- Cuerpos desnudos

- Cuerpo como mero valor estético

- Relaciona el aspecto bello del personaje con el consumo del producto

- Acostado /actitud pasiva

- Desempeña alguna tarea con sus hijos

- Toma la iniciativa

- Actitud pasiva

- Encaja en el marco del anuncio

- Realiza actividades de ocio

Además, todos estos elementos también se deben entrelazar con las variables relacionadas con los propios rasgos de los estereotipos. Alfonso Méndiz y Carmen Cristófol estudiaron la apariencia estética de los personajes a partir de su aspecto externo y de los textos en los que aparecen. Y observaron que los personajes venían determinados por $^{756}$ :

- Agresividad

- Seducción

\footnotetext{
${ }^{756}$ Alfonso Méndiz Noguero, Carmen Cristófol Rodríguez, op. cit., p. 52.
} 
442 | La femme fatale en la publicidad del siglo XX

- Alegría

- Libertad

- Esfuerzo personal

- Amistad

- Familia

- Maternidad

- Fidelidad

- Modernidad

- Gozo (disfrute espiritual por la contemplación de la belleza)

- Placer (disfrute físico y sensitivo)

- Atracción sexual

- Languidez

- Debilidad

- Sometimiento

- Triunfo

- Éxito profesional

- Éxito afectivo

- Conquista

- Competitividad 
- Transgresión

- Riesgo

- Violencia

- Tristeza

- Fracaso

- Atención al hogar

- Comodidad

Todas estas variables se combinarán con los aspectos contextuales que hacen referencia al entorno, al paisaje y al decorado ${ }^{757}$.

- Contexto en donde se desarrolla

- Se transmite lujo

- Momento del día

- La imagen deliberadamente desenfocada

- Ángulo de la foto

- Se posiciona la marca como símbolo de status social

- En el contexto se relaciona la felicidad con la belleza externa del personaje

Todos estos datos fueron introducidos en el SPAD, Programa Estadístico de Análisis Multivariantes. Realmente, se trata de una herramienta destinada al análisis exploratorio

\footnotetext{
${ }^{757}$ Alfonso Méndiz Noguero, Carmen Cristófol Rodríguez, op. cit., p. 53.
} 
de datos multidimensionales. Este programa está orientado al análisis estadístico descriptivo de grandes tablas de datos obtenidos a partir de encuestas ${ }^{758}$.

Se basa en las técnicas factoriales que tienen como fundamento el álgebra lineal, descomponiendo en una matriz de datos sus valores propios. La idea subyacente de esta metodología es que se puede calcular las distancias entre las líneas y columnas de una tabla rectangular utilizando distintos tipos de medidas (correlaciones, coeficientes de contingencia, etc.). Además, desarrolla técnicas de clasificación de los elementos de la tabla (filas o columnas) a partir de los vectores propios, obteniendo caracterizaciones estadísticas automáticas de las distintas clases.

Por supuesto, todos estos datos recogidos previamente responden a unas necesidades técnicas que implican la utilización de este programa. Primero, necesitaremos introducir una serie de parámetros:

- Primero, tenemos la llamada hoja de variables. Estas son seleccionadas en función del análisis que nos dispongamos a realizar limitado por fechas.

- Segundo, mediante la hoja de individuos seleccionamos los individuos que nos interesan en función de los objetivos que nos interesan.

- En tercer lugar, nos encontramos con la hoja de ponderación. En un principio para nuestro estudio sólo nos interesan los clientes que consumen habitualmente marcas de lujo. Pero si quisiéramos dar más importancia a determinados individuos, deberíamos evaluarlos mediante una variable de ponderación. Como ya hemos dicho, para nosotros todos los individuos son iguales. Así que utilizaremos una ponderación uniforme.

\footnotetext{
${ }^{758}$ Alfonso Méndiz Noguero, Carmen Cristófol Rodríguez, op. cit., p. 57.
} 
Todos estos elementos se han analizado y se han ponderado con la finalidad de dar un poco de luz a nuestra hipótesis. Pues la publicidad analizada corresponde a marcas de alto standing que no han visto disminuido su número de ventas. Si nuestro estudio respondiera a una necesidad sociológica o antropológica, analizaríamos la relación existente entre el producto y los diferentes tipos de clientes. Pero nosotros, como filólogos, nos limitaremos a estudiar el mensaje producido por las marcas. Este pondrá su foco de atención en el contenido de las publicaciones gráficas, en especial en la creación de los estereotipos como portadores del producto publicitario y representantes de una determinada clase social. Así que el objeto publicitario pasará a ser un símbolo de distinción.

\section{2.- Análisis de la publicidad}

Una vez analizadas las variables, Alfonso Méndiz y Carmen Cristófol basan su estudio en la publicidad dedicada por y para mujeres. A partir de ella, la obra Falsedad y comunicación. Publicidad engañosa, información falsa, imagen manipulada establece diferentes estereotipos femeninos que se pueden encontrar en el mundo audiovisual. La presente tesis no comparte del todo su clasificación, pero se ha considerado un punto de partida esencial. Así pues, a continuación mostraremos los estereotipos que plantearon Alfonso Méndiz y Carmen Cristófol ${ }^{759}$.

\footnotetext{
${ }^{759}$ Alfonso Méndiz Noguero, Carmen Cristófol Rodríguez, op. cit., pp. 45-64.
} 


\subsection{1.- La mujer transgresora}

Este personaje aparece en un $33,34 \%$ de la publicidad. Es una mujer que bajo su perfil reúne valores predominantes como ${ }^{760}$ :

- El triunfo

- La conquista

- La libertad

- El gozo

- La autocontemplación

- La atracción sexual

Este personaje femenino se valora por su cuerpo atlético y atractivo. Sin embargo, su físico sólo tiene un mero valor estético, pues refleja la relación entre la belleza y la felicidad que el personaje experimenta como algo esencial. A la imagen no le queda más remedio que autodefinirse como hedonista y transgresora. Estamos ante una mujer que muestra sin pudor alguno la ausencia de su carácter maternal, y que blande orgullosa la bandera de la agresividad y de la ruptura. Es una mujer víctima de su belleza. Su cuerpo le induce a comportarse según instintos caprichosos.

\subsection{2.- La mujer frágil-sometida}

Este grupo aparece representado en el estudio estadístico por un leve 8,33\%. Su apariencia física parece caracterizada por ${ }^{761}$ :

\footnotetext{
${ }^{760}$ Alfonso Méndiz Noguero, Carmen Cristófol Rodríguez, op. cit., p. 58.

${ }^{761}$ Alfonso Méndiz Noguero, Carmen Cristófol Rodríguez, op. cit., p. 59.
} 
- La tristeza

- La debilidad

- La pasividad

- $\quad$ La languidez

- También vemos la relación directa entre la belleza y el producto anunciado

- Extremadamente delgada

Son mujeres que encarnan la fragilidad, la delicadeza y la pasividad. Debido a la flaqueza de fuerzas normalmente aparecen recostadas o tumbadas. Todas ellas tienden a reforzar el estereotipo de la mujer dependiente.

\subsection{3.- La mujer tradicional}

Este grupo aparece representado por un bajo $8,02 \%$ y se identifica con los valores de la familia. Así que podemos encontrar con facilidad en la misma imagen representados a menores de edad y a las madres que suelen protegerlos. Los valores que desprenden suelen $\operatorname{ser}^{762}$ :

- El amor

- Actividades de ocio

- Sin apenas actitud de seducción

- Ni atracción sexual

- Ni autocontemplación

${ }_{762}$ Alfonso Méndiz Noguero, Carmen Cristófol Rodríguez, op. cit., pp. 60-61. 
- Pero si hay una gran dosis de amistad

Es importante la presencia del realismo en los decorados y la total ausencia del lujo. La mujer refleja en este estereotipo relaciones vitales similares a las reales. Son imágenes que prestan atención a la vida cotidiana y a la familiar. Sin centrarse en el éxito ni en la autocontemplación, las protagonistas se preocupan por los pequeños detalles del día a día: compra, limpeza de la ropa, hacer la comida...

\subsection{4.- La mujer aspiracional}

Representan un total del $7,10 \%$ del total de los personajes femeninos analizados. Sus valores principales suelen ser:

- La ausencia de la alegría

- Sin autocontemplación

- Sin seducción

- De clase social alta

Son personajes difíciles de definir, porque carecen de rasgos propios que permitan definirlos como unidad. Pero si podemos advertir que todos ellos mantienen un estilo de vida con altos ingresos y con ciertos hábitos de ocio adquiridos de forma natural ${ }^{763}$.

\subsection{5.- La mujer integrada}

Representan un $43,21 \%$ del total. Son féminas que suelen carecer de valores rotundos para definir al estereotipo, porque la consumidora no necesita que le repitan los valores. Por regla general, son productos que se venden por su necesidad de consumo, de forma

\footnotetext{
${ }^{763}$ Alfonso Méndiz Noguero, Carmen Cristófol Rodríguez, op. cit., p. 61.
} 
que la figura femenina aparece completamente integrada en la imagen y no le quita protagonismo al producto anunciante. Así que ella llega a formar parte del grupo decorativo o del espacio. Estas son mujeres que ${ }^{764}$ :

- Carece del valor de la conquista

- Su cuerpo no es un mero valor estético

- No tienen casi valor de triunfo

- Sin casi valor de transgresión

- Pero pueden aparecer el placer, la seducción y el amor.

\section{3.- Análisis detallado de la mujer transgresora}

A continuación nos proponemos a hacer un análisis detallado de este grupo tal y como viene representado en las imágenes fotográficas de periódicos y revistas femeninas. Como ya hemos señalado al principio de nuestro estudio, la figura de la mujer ayuda a potenciar la metáfora de la máscara. Pero principalmente es la publicidad la que le da un carácter más popular al uso de esta retórica. De esta forma, estamos ante una figura femenina que se convierte en una pantomima publicitaria.

Estamos ante anuncios de productos de consumo dedicados al consumo de un público femenino. Pero, también debemos señalar que nunca existiría tal producción sin una demanda previa por parte de las consumidoras. Consecuentemente, la producción surge de una necesidad previamente conocida. Ahora bien, para conseguir una venta más o menos rápida de los productos, los anuncios responden con un amplio abanico de estereotipos para llegar al máximo número de mujeres posible. En segundo lugar,

\footnotetext{
${ }^{764}$ Alfonso Méndiz Noguero, Carmen Cristófol Rodríguez, op. cit., p. 62.
} 
tenemos que advertir que el uso de la feminidad como propaganda viene determinado por el soporte del anuncio. Es decir, los arquetipos funcionan como catalizadores, y la oscilación de un sexo tentador viene determinada por las características enmarcadas en un espacio y un tiempo dedicado a la publicidad.

De este modo, estamos ante diferentes figuras femeninas que funcionan como un sujeto de la Tentación o de la facultad de atraer al cliente, ya sea femenino o masculino, pero sobre todo femenino. Asimismo, la figura femenina se promueve como un enigma y se le atribuye un vasto margen de autonomía ${ }^{765}$.

\section{4.- La caída de la Eva Industrial}

El concepto de Tentación viene estrechamente vinculado al pasaje del Génesis. Desde el principio de la humanidad, Eva representará simbólicamente la cumbre de dos vertientes éticas: la inocencia paradisíaca y el pecado inevitable. Eva, desde su más pura inocencia, se ve instigada por la Serpiente para que ofrezca la manzana a Adán. Este, fascinado por la Eva prevaricante y precavida, acepta y muerde la manzana. Mientras, la Serpiente observa complacida el desarrollo de la acción, como preludio de la Caída. La lectura metafórica de la parábola invita a aprender del ejemplo y a no cometer el pecado original: "Tú que contemplas la escena, resiste la Tentación del Demonio en lugar de sucumbir como están a punto de hacerlo estos dos malvados”.

Pero el slogan publicitario invierte el mensaje e invita a cometer el pecado. El mecanismo es muy parecido: Eva, después de ceder ante la Tentación, coge la manzana producto y la ofrece al espectador. El cliente abandona su pasividad y, en última instancia, adquiere el papel de Adán, quien acaba mordiendo el producto que le ofrece la nueva Eva industrial. La Serpiente, en calidad de testigo y prevaricador, asiste

\footnotetext{
${ }^{765}$ Giancarlo Marmoni, Iconografía femenina y publicidad, Barcelona, Gustavo Gil, 1977.
} 
satisfecha al inminente consumo. En esta ambientación, el razonamiento pedagógico que se daba en el Génesis se ve completamente alterado: “Tú, que contemplas el anuncio, cede a la Tentación de la adquisición en lugar de ofrecer resistencia como hacen tantos malvados". Además, otra de las diferencias es que la Caída comercial no supone la expulsión del Paraíso, sino el antagónico ingreso en el Edén de la Felicidad que la propia marca promete a los compradores por medio de la Serpiente publicitaria ${ }^{766}$. En todo ellos, observamos cómo la imagen de la mujer tiene una funcionalidad determinada: la sujeción de los artículos. De este modo la usuaria está vinculada directamente al producto y no al contrario. En un principio, en las producciones de artes gráficas de finales del siglo XIX, la figura humana se veía como un sujeto plásticamente activo, acoplado a una forma, a una materia y a la función de venta o marco publicitario. Pero ahora, la modelo viva se convierte en un objeto inerte de la situación mercantil ${ }^{767}$. En consecuencia, observamos cómo el cuerpo femenino ha pasado de ser una figura extraña a ser un elemento que se encuentra completamente limitado al objeto. Se trata de un cuerpo fosilizado, un cuerpo que ha perdido toda su identidad a favor del objeto. Un cuerpo completamente desnaturalizado y artificial.

En la Biblia no se menciona cuáles son las artes que Eva utiliza para engañar a Adán, pero no cabe duda de que debiera decirle o prometerle algo tremendamente poderoso. Algo que hizo que Adán ansiara tener la Manzana. Eva fue la primera prevadicadora, fue la primera en engañar y adornar la apetitosa fruta como si del mismo Poder Divino se tratase. Eva fue la primea vendedora y Adán el primer comprador, pero la manzanaproducto fue la que adquirió toda la poderosa simbología de la atracción del pecado. Este discurso no sólo convierte al producto en algo fascinante para el cliente, sino que

\footnotetext{
${ }^{766}$ Giancarlo Marmoni, op. cit., p. 11.

${ }^{767}$ Giancarlo Marmoni, op. cit., p. 15.
} 
también caracteriza indiscutiblemente a la vendedora. Pues ella es la que lo ofrece, y como cualquier vendedora, es la persona encargada de informar acerca del producto. Esto la convierte en una usuaria experta del producto. Es decir usuaria del productopecado.

\section{5.- Clasificación femenina en la esfera publicitaria}

Antes de analizar la figura femenina, señalaremos que su iconografía y su literatura publicitaria están relacionadas con los impulsos fetichistas que la usuaria experimenta. Toda compra surge por unos motivos elementales: gustar al compañero para el cual la fémina se disfraza. Partiendo de este punto, los publicistas revisten el producto de simbolizaciones y de simulacros muy concretos. El objetivo es muy sencillo, conseguir que el objeto por sí mismo salga de su aislamiento, y que no sólo consiga llamar la atención de la futura compradora, sino también que despierte en ella la sensación del fetiche.

La incitación al fetichismo comercial no se da tanto por la calidad o la naturaleza del producto, sino más bien por la imagen que los publicistas logran dar del objeto. Los cultiparlistas basan el potencial fetichista en la ilusión de la retórica: elementos que distraen, alusiones, antífrasis, eufemismos y otros elementos que contaminan la esencia del producto. Pero la retórica es la que juega con la capacidad de extrañamiento del cliente en una atmósfera completamente ficcional, porque está dirigida a la connotación hipnotizante que el objeto publicitario ejerce sobre la cliente. En ocasiones, la relación entre el sujeto y el objeto se da como un vínculo muy fuerte que nace de repente. Casi inmediato y exclusivo ${ }^{768}$.

\footnotetext{
${ }^{768}$ Giancarlo Marmoni, op. cit., pp. 75-85.
} 


\subsection{1.- La figura erótica de la feminidad}

La meta máxima de las retóricas publicitarias está dirigida a la clientela femenina, ya que intentan alejar de ellas el fantasma terrorífico de la desnudez. Para ello, muestran el cuerpo desvestido o medio desvestido como reflejo directo de la naturaleza y no como el reflejo del episodio del Paraíso Perdido. Hacen que el cuerpo femenino potencialmente sensual se eleve como paradigma de la cotidianidad y sirva de ejemplo de la belleza radiante. Así, por medio de uso del sistema erótico, podemos encontrar un sinfín de anuncios tranquilizadores que intentan superar el tabú impuesto por el desnudo. Es entonces cuando, a causa del pudor, la desnudez se aborda por medio de la metáfora de figuras zoomórficas o botánicas, ya sean caracolas, conchas, rosas, tulipanes o crisantemos. Todas ellas son metáforas cuyo sentido analítico reside en el desnudo que hasta ahora se había censurado. Para soñar con la desnudez apacible y tranquilizadora de las modelos, la publicidad aconseja el uso de productos milagrosos. Estos no son otros que cremas adelgazantes, curas dietéticas... que nos ayudarán a manternos esbeltas y bellas ${ }^{769}$.

Ocurre que llega un momento en que el desnudo ya no es una pesadilla, sino todo lo contrario, pues se vive con plena felicidad. Pero tenemos que advertir que dentro del espacio publicitario el cuerpo femenino se comprende como soporte, como portador. De ahí que surgiera el término maniquí para las modelos de principios del siglo XX. Partiendo de esta premisa, toda prenda y accesorio que lleve la modelo está pensado para ser lucido. Los productos son exhibidos dentro de un marco exótico, que no es otro que el cuerpo femenino. También es cierto que la iconografía publicitaria hace hincapié en la promoción de un artículo mediante la sacralización. Los objetos son sacros porque simbólicamete los publicistas confieren los productos atributos divinos. Por lo que el

\footnotetext{
${ }^{769}$ Giancarlo Marmoni, op. cit., pp. 45-46.
} 
objeto aparece personificado, vivificado. Tiene el carácter de ídolo, porque se comprende como el resto que una deidad ha dejado olvidado en algún rincón. Un objeto poderoso que ha llegado a las manos del cliente; y la publicidad se encarga de explicar cuáles son sus propiedades mágicas ${ }^{770}$.

Estas prendas mágicas ayudan a ocultar parcialmente la desnudez del cuerpo. Como consecuencia, se potencia la imagen erótica, pues estos objetos ayudan a insinuar pero no a mostrar directamente. Esto se vincula al desnudo radiante. El cuerpo es bello porque se muestra de forma natural, y algunos anuncios lo potenciarán mediante las paradojas de la idea de la desnudez. Tal es el caso del slogan del perfume Ecusson que versa "El único perfume que os viste por dentro", o las fajas elásticas Lycra al decir "Es como si no llevaras nada...".

\subsubsection{1.- Las bellas salvajes}

Aprovechando que ya hemos presentado la idea del cuerpo desnudo, y el cuerpo erótico, como algo natural, mencionaremos la innumerable cantidad de soportes femeninos que, mostrándose como vírgenes de gran pudor cristiano, pueblan las costas del paraíso. La fotografía publicitaria retrata exóticas islas de mares cálidos en donde deambulan muchachas salvajes bellamente maquilladas, y ensartadas en indumentarias de fibra industrial. Como es de esperar, las modelos manifiestan sorpresa ante los ojos de los misioneros que las miran con desaprobación. Estas criaturas se mueven por el mundo, pero desconocen el sentido del pudor impuesto por la lógica del pecado. Además, ellas refuerzan su ingenuidad acentuando las poses hieráticas o excesivas de exultación. Al principio, para mostrar la esbelta figura de la joven se utilizó mucho la fotografía a

\footnotetext{
${ }^{770}$ Giancarlo Marmoni, op. cit., pp. 81-82.
} 
contraluz, por lo que se aprecia que querían mostrar el desnudo sin llegar a irritar el pudor del cliente. Un ejemplo muy claro lo encontramos en las protagonistas de los spots de Bruno Aveillan. El director caracteriza a todas sus protagonistas a modo de las ninfas; estas son féminas de una tremenda espiritualidad. Es como si la naturaleza tomara forma en ellas.
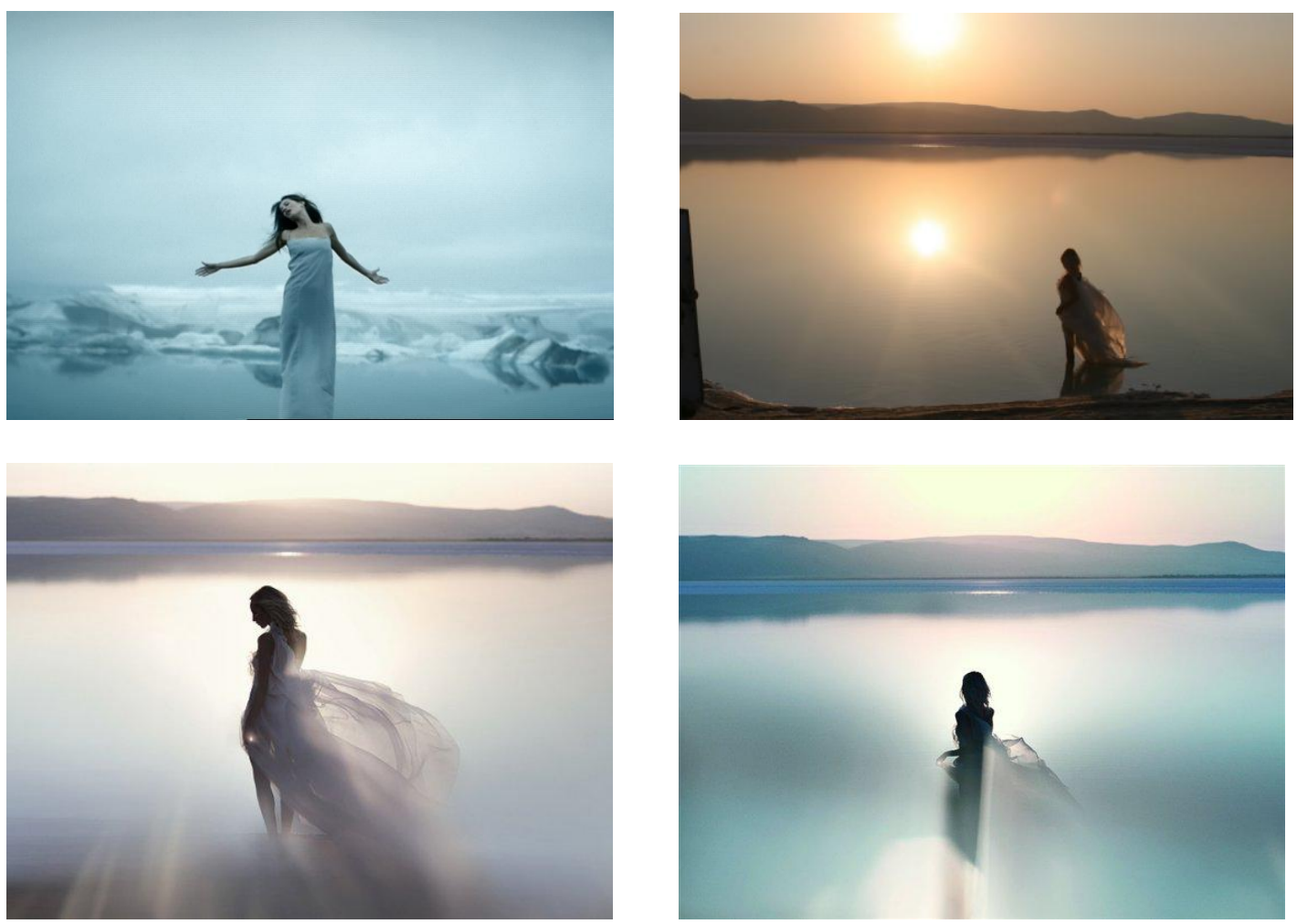

Un caso que muestra la misma conexión con la naturaleza, pero representa a la protagonista un poco más recatada, es el de la acriz Uma Thurman. El anuncio, que protagoniza para el perfume Miracle de Lancôme, muestra a una joven que asiste asombrada a un precioso amanecer. 


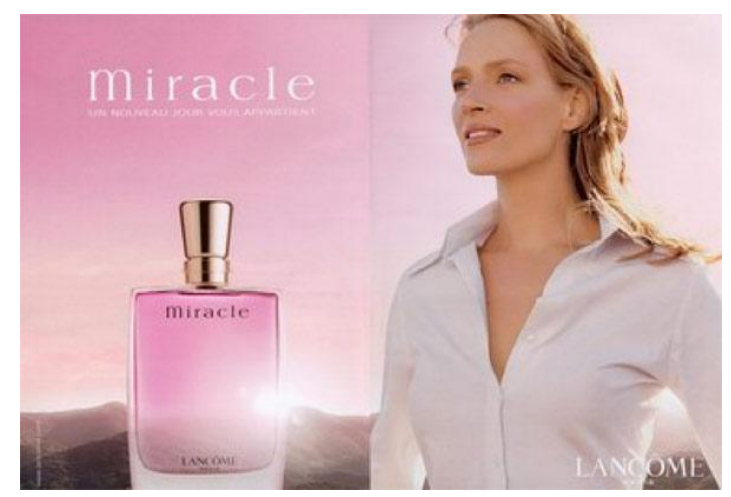

No obstante, la protagonsita del anuncio del perfume Acqua de Gioia de Georgio Armania parece recuperar la figura de la ninfa. Así que veremos a una joven en un auténtico paraíso disfrutando de la lluvia.

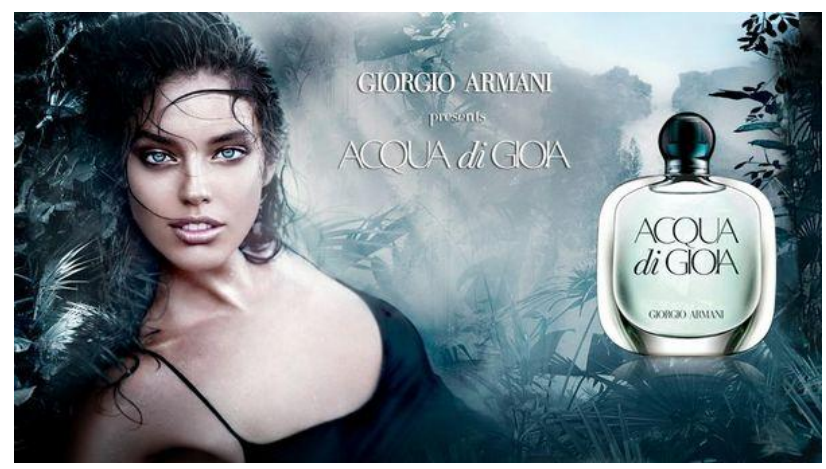

Sin embargo, gracias al consumo de cosméticos, de cremas para la piel o productos anticelulíticos, se potenciarán los desnudos parciales. Pero estas imágenes no sólo se dan en las costas paradisíacas. Las selvas y los desiertos también se llenan de bellas beduinas que a lomos de su camello cabalgan libres. Esta naturaleza tremendamente hostil y dura se convierte en el artificio orientalista en donde se ambienta el anuncio. 


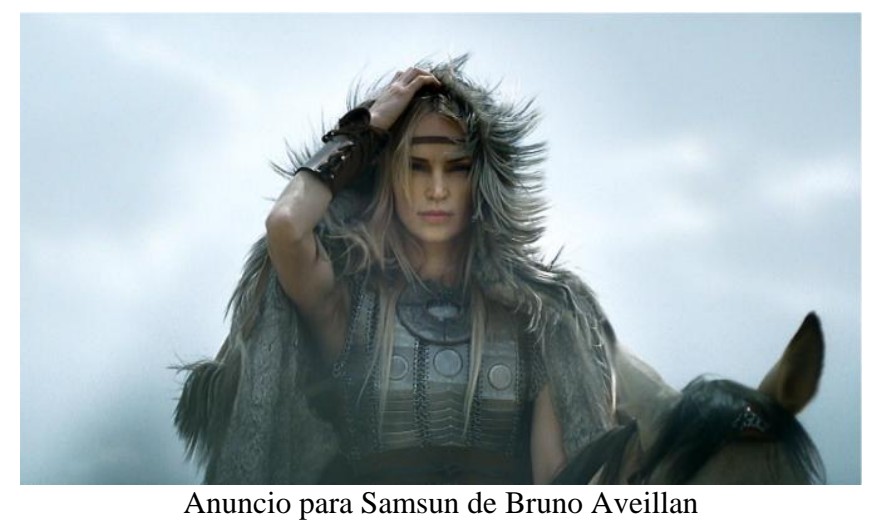

Algunas modelos se trasladan al desierto del Sahara y muestran en su rostro el poderoso uso de los cosméticos que las asemeja a las Esfinges. Tal es el caso de las retóricas utilizadas por Revlon, que usa signos propios del misterio arábigo como velos, palmeras, quincallería esclavista... ${ }^{771}$

\subsubsection{2.- La desnudez cubierta de joyas}

La relación artística entre el cuerpo desnudo y las joyas es indiscutible. Antaño existía toda una corriente literaria en donde se apreciaba a la mujer como parte de la divinidad. Las jóvenes alcanzaban su máximo nivel de glorificación al convertirse en madres. El amor incondicional de las mujeres toma forma mediante el embarazo. Es entonces cuando una mujer cumple el ideal divino de hija-esposa-madre, y tiene lugar el milagro. La mujer, mediante el perdón y el amor que encarna, está llamada a formar parte de la divinidad; por ello, a través de su cuerpo el milagro toma forma. Sin embargo, las jóvenes novicias que optan por formar parte de una orden religiosa también están llamadas a formar parte de la divinidad, pues su cuerpo permanecerá puro y limpio de pecado. Es importante señalar en este punto el término reliquias, pues, la santidad que

\footnotetext{
${ }^{771}$ Giancarlo Marmoni, op. cit., p. 51.
} 
rodea a nuestras protagonistas es popularizada por los objetos que les pertenecieron, y sobre todo, que tocaron su piel. Este es un proceso de sacralización ${ }^{772}$.

Este proceso es heredado del siglo XIX, en el cual apreciamos cómo las alhajas que tocan la piel femenina adquieren características divinas. Esto no sólo lo toma la publicidad actual, sino que también lo invierte. Ahora es el objeto el que tiene las características divinas y la mujer la que ansia tocar las joyas. Ésta ha sido la línea llevada por la campaña publicitaria del perfume de J'Adore. En un principio, la modelo Carmen Kass apareció caracterizada como una sacerdotisa sentada en un trono antes de bañarse en una piscina llena de oro líquido. La imagen final del cartel publicitario representa a la joven con cara de satisfacción sumergida en el oro, mientras el anuncio versa J'Adore. La feminidad absoluta.

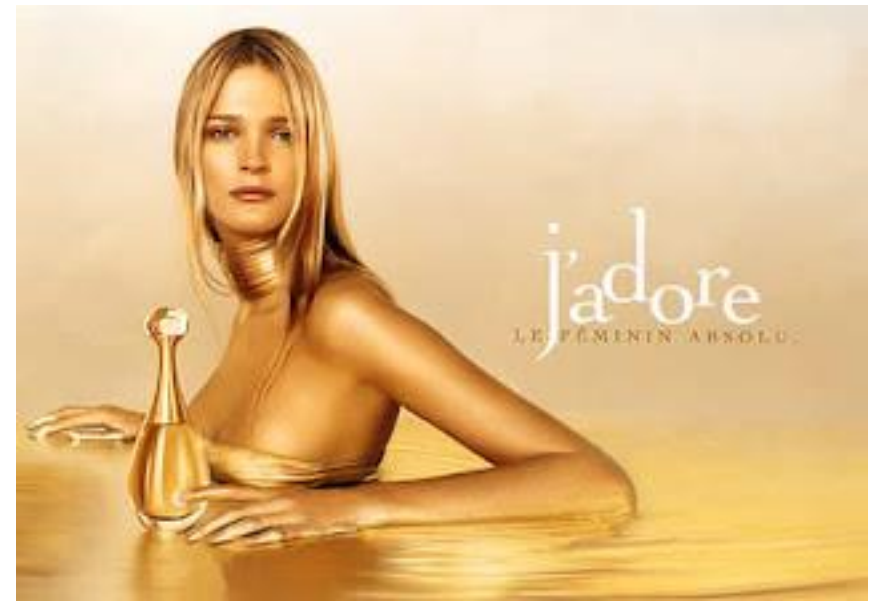

La imagen ha evolucionado hasta hoy en día, con importantes cambios en la estética. En un principio, el cuerpo vestido de Carmen Kass de dorado fue sustituido por el cuerpo desnudo de Charlize Theron, y el oro de la bañera fue remplazado por el mar de sábanas doradas. Con este nuevo anuncio se mostraba de forma directa el contacto de la piel desnuda con el color oro.

\footnotetext{
${ }^{772}$ Giancarlo Marmoni, op. cit., p. 82.
} 


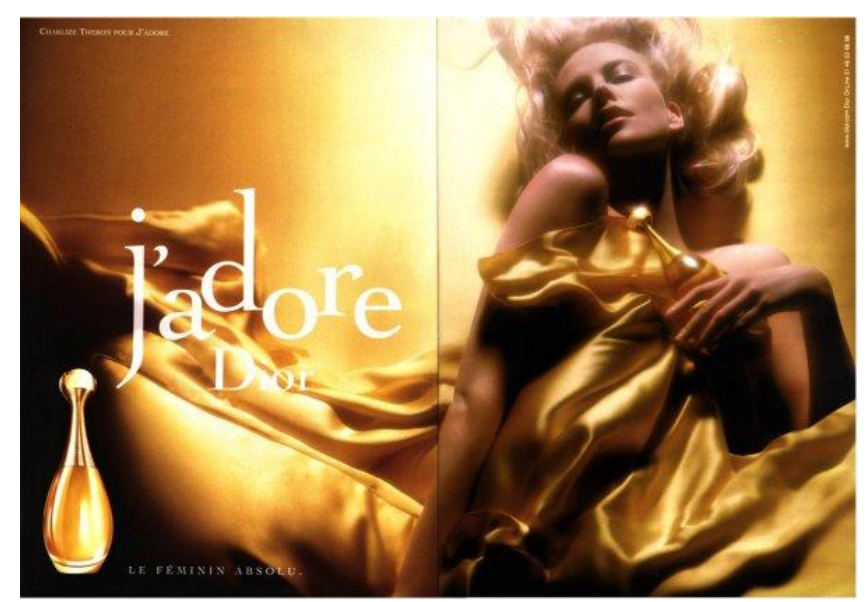

Hasta ahora, los anuncios de J’Adore sólo buscaban representar la unión piel-oro, pero, posteriormente, vemos cómo existe el interes por mostrar visualmente el ansia de la actriz por adquirir el J'Adore. Con la ayuda de los avances tecnológicos los anuncios podrán mostrar el momento exacto en que las actrices, al tocar los perfumes, forman parte de la divinidad. Esta sacralización se materializa mediante un filtro dorado que se aplica a la piel femenina de la actriz.
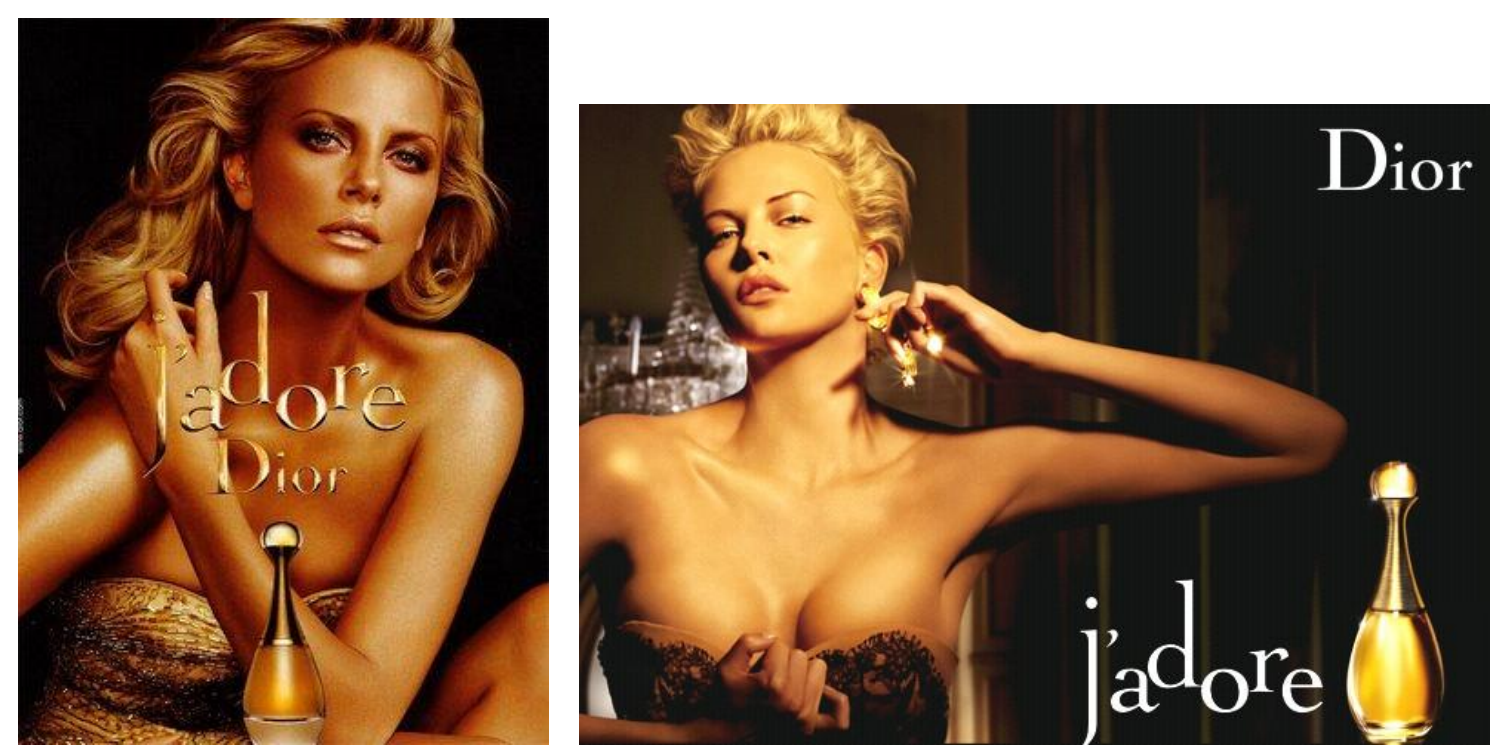

En ambas campañas publicitarias, la modelo aparece levemente dorada y contrasta con las tonalidades oscuras del fondo. Sin embargo en la última campaña de Dior, el proceso de sacralización no sólo afecta a la modelo, sino también a todo el entorno en el que ella se mueve. Este es el caso del anuncio de 2013, el cual nos cuenta cómo la modelo llega tarde a un desfile de Dior. Aparece corriendo y atraviesa la sala de los 
espejos, en donde todo el público espera impaciente. Hasta este momento, todos los colores aparecen perfectamente diferenciados y naturalizados. Sin embargo, cuando ella llega al basckstage y se pone el vestido diseñado para la ocasión, vemos cómo se apagan las luces, se encienden las luces de los candelabros y Charlize Theron aparece desfilando bajo una aureola especialmente dorada. Pero esta aureola no sólo la cubre a ella, sino que también alumbra la sala.

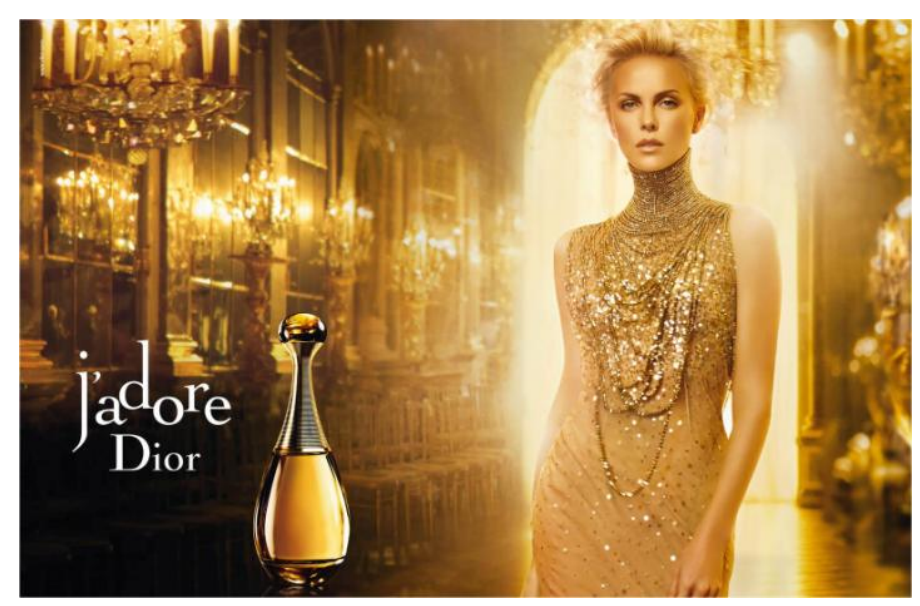

Paco Rabanne va un poco más allá y logra encarnar a la mujer oro en la campaña publicitaria del perfume One million. Aquí vemos cómo la mujer cambia su físico carnal por el de oro por medio de la voluntad masculina. Pues él con un solo chasquito de sus dedos consigue ir desvisténdola y, finalmente, convertirla en oro.

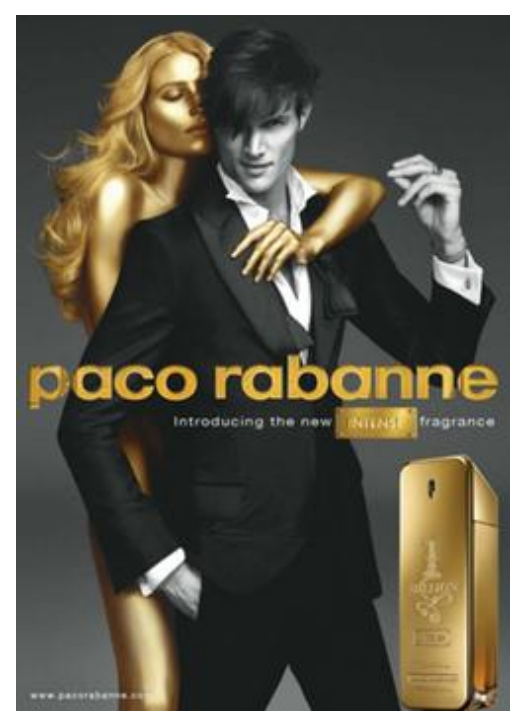


En ocasiones, vemos brazos femeninos llenos de brazaletes con formas de dragón, de serpiente, de pantera... y todo ello policromado con increíbles colores que una buena fotografía sabe plasmar perfectamente. Las portadoras suelen aparecen en pose pasiva, sentadas o echadas en un diván, mientras lucen orgullosas sus joyas. Un ejemplo muy claro lo encontraremos en todos los anuncios de joyas de Bulgary. Pero, además de la simbología que se desprende de las joyas, también debemos de observar, como ya hemos mencionado antes, el velo enigmático de la ocultación. Pues veremos cómo la modelo posa de forma sinuosa, pero también en una actitud en la que se medio esconde para dejarnos ver lo que ella quiere que veamos. Uno de estos ejemplos lo encontramos en los ojos de la modelo de Chanel, pues la joven aparece escondida tras una máscara enjoyada que curiosamente nos recuerda a la mirada de las jóvenes musulmanas.

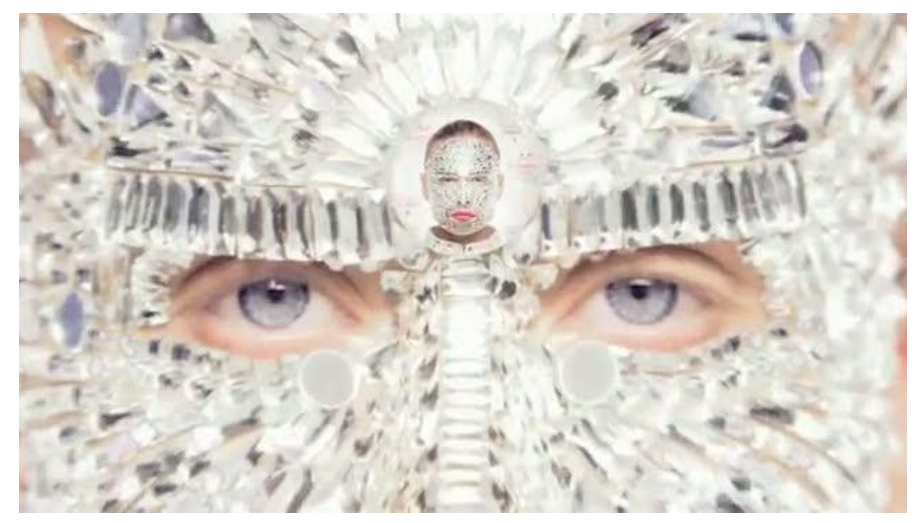

La publicidad inspirada en lo moruno es ilimitada. Pero, curiosamente, muchas de estas muchachas decoradas con joyas y diademas ostentosas se recuperan para la fetichización de productos destinados al cuidado de la piel. Así que, inspirándose en las pinturas vistosas del decadentismo, resucitan los productos auxiliares de tipo oriental, los adornos arabescos, las gemas berberiscas con alto poder ornamental, el baño íntimo y ostentoso... Este último aparece muchas representado cuando las modelos se meten en una bañera egipcia mientras portan en la cabeza una diadema de perlas y piedras preciosas, como es el caso de Loewe para su perfume Quizá, quizá, quizá. 


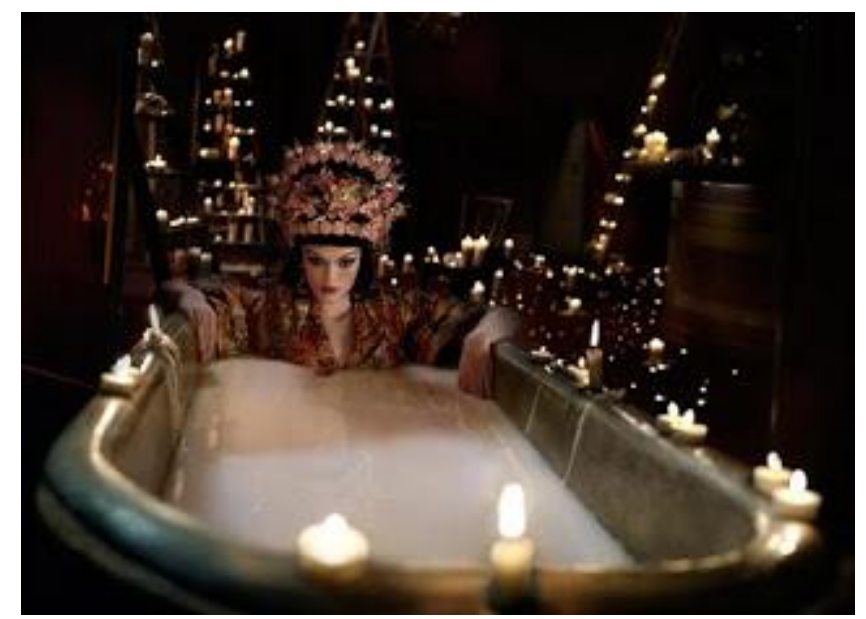

Otro caso es la concubina o sultana musulmana de la Crème Absolue de Lâncome que lleva en el antebrazo un brazalete Gilbert Albert diseñado para la casa Omega; otro, la bailarina de la crema Alva Petrova en bolero y redecilla de perlas ideada por Marc Traymor.

Uno de los campos publicitarios que más ha bebido de esta influencia es el de los persumes. A tal nivel de sacralización llegó, que Marlyrin afirmó que ella sólo dormía con un par de gotas de Chanel $N^{\circ} 5$, pues esto ya la vestía bastante.

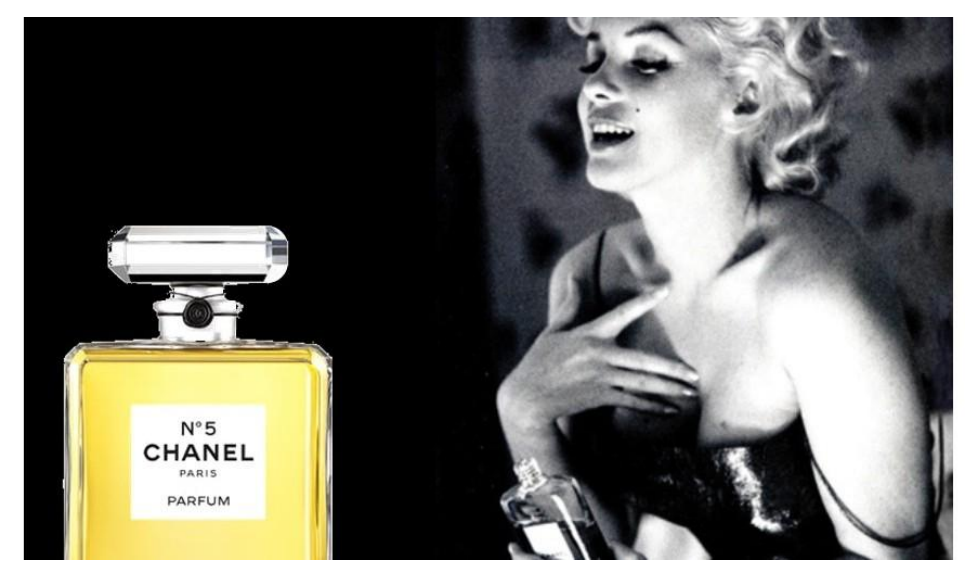

Sin embargo, la publicidad de Yves Saint Laurent llevaría esta idea hasta el extremo al representar a una modelo que, completamente desnuda, parece alcanzar el éxtasis al ponerse apenas unas gotas del perfume Opium. La imagen es poderosamente simbólica, no sólo por la posición de la joven, sino también por el fetichismo que despiertan sus 
zapatos de tacón y la tela de terciopelo sobre la que está tumbada. Esta última porque visualmente emula la caricia.

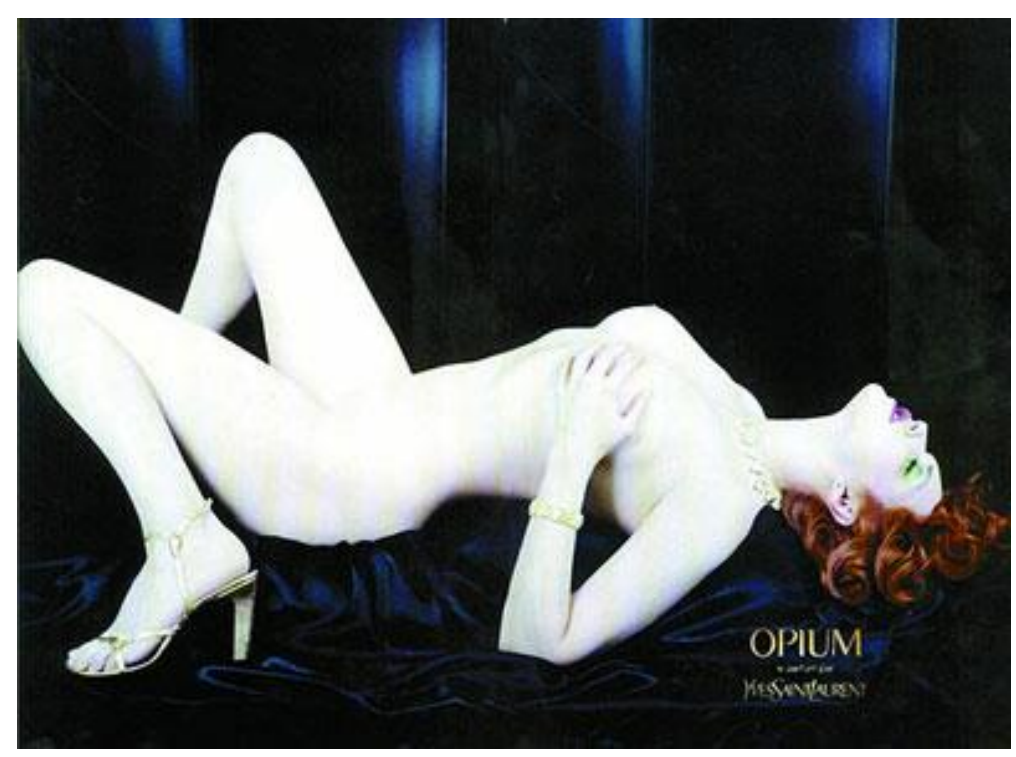

\subsubsection{3.- El reflejo del desnudo}

En el mundo publicitario es frecuente usar la imagen reflejada con el fin de despertar el fetichismo hacia el objeto que se anuncia. Pero para ello es necesario que advirtamos que el espejo realiza una función muy importante. Como reflectante que es, el espejo mostrará a la usuaria sus deseos más primitivos y originarios, por lo que intentará despertar en ella una actitud infantil, la misma que todos los niños tienen cuando quieren un objeto y lo piden con insistencia a sus padres. Este reflejo infantil tiene la función de formar al auténtico YO, al mismo tiempo que revela la identidad del Narciso-Niño. Con el reflejo se juega a mostrar nuestros anhelos más secretos. Un ejemplo lo encontramos en el anuncio del perfume Baiser Volé de Cartier, en donde una pareja de enamorados aparece bailando un vals sobre un suelo de espejos. 

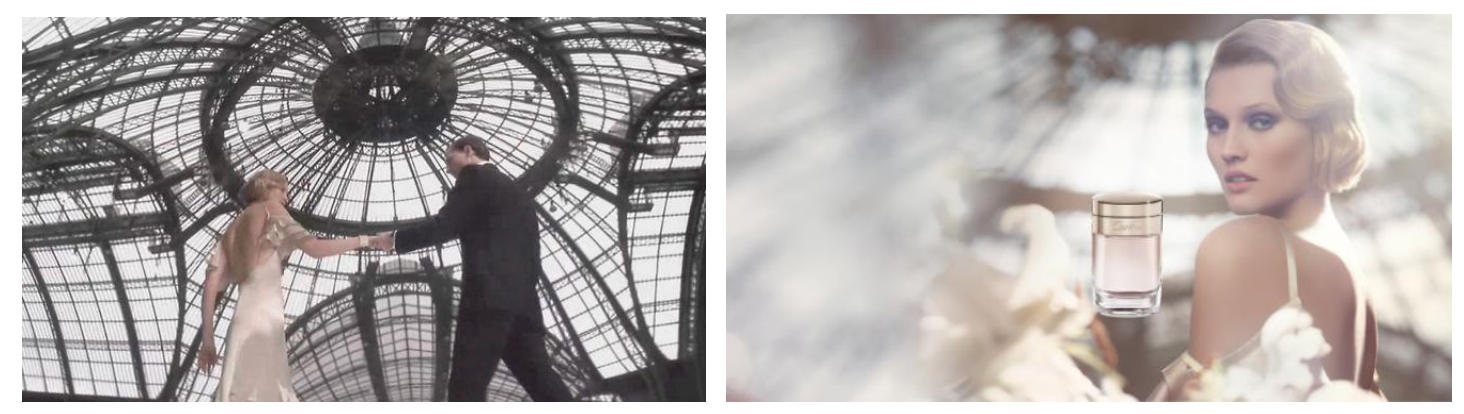

Este tipo de publicidad tiende a la formación de un Yo mercantil específico, y por lo tanto, con una identidad que se ha constituido en la autosatisfacción estética. Para ello, veremos cómo este proceso se da mediante una fase perfectamente estructurada. En primera instancia, la actitud narcisista de la modelo pasa de la singularidad existencial a la forma plural de la imagen. Como resultado vemos que el cuerpo se desplaza desde lo informal e individual hasta un concepto totalitario de sus formas. El segundo paso que se da en la actitud narcisista se transfiere otra vez de lo plural a lo material individual. Pero este concepto material se alimenta de un determinado producto mercantil.

Marmoni cataloga este episodio mítico dentro en un esquema de regresión infantil, en donde el cliente contempla su propio cuerpo como soporte de mercancías. En resumidas cuentas se trata de la hipnótica revelación de las cualidades de un artículo. Así que, mediante la duplicidad del objeto y de la modelo, el anuncio logra crear un rítmo visual que pone especial atención en las cualidades del producto. Tal es el caso de la campaña que Loewe ha llevado a cabo mediante Penelope Cruz y su hermana Mónica Cruz. Las actrices son tan parecidas, que situándolas una frente a la otra simulan el reflejo falso una de la otra. Sin embargo, el bolso es exactamente el mismo: 


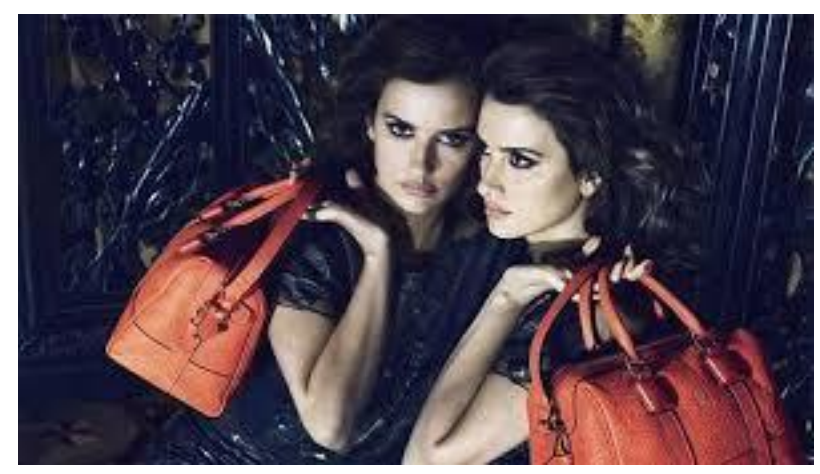

Esta técnica también es empleada por Versace para uno de sus perfumes femeninos. La pequeña diferencia es que aquí encontramos a más de un doble.

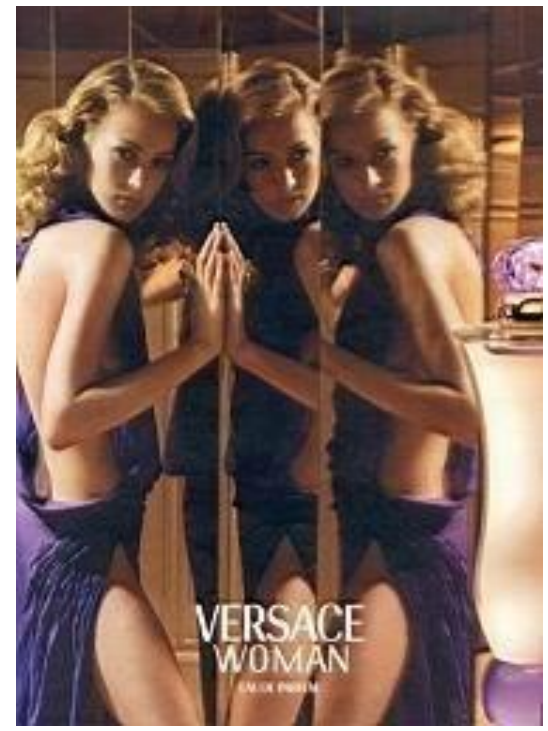

Hoy en día este tipo de función ya no se da tanto en la publicidad sino más bien en los escaparates. Aunque también es cierto que los soportes audiovisuales actuales vienen a contradecir el efecto revelador que el espejo asume a mediados del siglo. Ahora, en lugar de mostrar la identidad del Yo totalizador, recurren a pequeños detalles anatómicos. En consecuencia, este soporte específico se ve enmarcado en un contexto individual y orgánico como los ojos, mechones de pelo, orejas, pies, torsos o nalgas, soportes macroscópicos de rímel, champús, pendientes, zapatos, sostenes,... Sucede que el cliente no queda hipnotizado con la idea de un Yo adulto, que sí se daba con la imagen totalizadora que revelaba el espejo. Este nuevo reflejo parcial hace que la importancia de la imagen se centre en un detalle específico. El espejo funciona como 
catalizador, para invitar al ojo de la cliente a una mirada inconsciente. Ésta ejercerá de guía y mostrará públicamente la importancia del objeto que se desea vender. Lo que se consigue es que, de forma incoherente, la cliente desee obtener ese objeto. Este fenómeno es clasificable en la causística del fetichismo por el cual se entiende la alienación obsesiva a un solo producto ${ }^{773}$.

\subsection{2.- Las féminas y los animales}

Como ya hemos dicho, la figura femenina adquiere el valor de soporte en la esfera publicitaria, por lo que toda indumentaria que no se ajuste a los valores tradicionales será un símbolo para expresar una identidad un tanto transgresora ${ }^{774}$.

\subsubsection{1.- El visón}

El hecho de aparecer cubierta con algún tipo de piel de animal la envuelve en una metáfora que la transforma casi inmediatamente. Súbitamente, la mujer aparece como portadora de un visón, de un animal que logra caracterizarla con la turbia mirada de una madre despiadada.

El uso de la piel confiere autoridad a la mujer-soporte, pero el poder surge soberanamente gracias a la mímica de la portadora. Estos son gestos que proponen la imposición total de sus órdenes, y, por si estos no fueran suficientes, se suelen utilizar signos alusivos a su poder y a su astucia. Como es de esperar, se trata de gestos completamente gratuitos, gestos que no son motivados por ningún tipo de argumento concreto, pero que sí dan información acerca de la actitud de la modelo. De este modo

\footnotetext{
${ }^{773}$ Giancarlo Marmoni, op. cit., pp. 86-89.

${ }^{774}$ Giancarlo Marmoni, op. cit., pp. 22-25.
} 
la portadora asume el papel retórico y ficcional que la publicidad le quiere dar. En este caso, la portadora del visón se llena de la misma autoridad que la Osa Polar. Imagen ya representada antaño por la Venus envuelta en sus pieles.

Lo más curioso es que el valor semántico se desplaza hacia la piel de visón. Del mismo modo que la manzana-producto, la piel de visón promete a su futuro portador (o cliente) la misma emancipación que la Osa Polar. En tal desplazamiento es fundamental la retórica publicitaria que se desprende del personaje, pues a través de ella se observa la ostentación de poder. Esta autoridad desmedida será la que impulse al cliente a adquirir el producto $^{775}$.

\subsubsection{2.- La caza mayor}

La modelo siempre busca estimular en el Otro masculino/femenino el impulso agresivo: en este caso le ayudará a que se manifieste como un cazador, por lo que el desnudo se integrará en un contexto fálico efectivo y totalizante. La modelo realiza aquí un salto abusivo en la metamorfosis viril para discutir de manera paradójica la supremacía del compañero, y rechaza con una ceremonia hipócrita el propio sexo. Para conseguir la valoración del mismo ostentará una turbulencia felina. La idea es que el soporte femenino, llevando la piel de un leopardo, de tigre o similares, busque atribuir facultades eficientes al desnudo deficiente. Pero debido al creciente interes por los derechos de los animales, muchos anuncios muestran a los animales vivos y en completa libertad. La relación animal-joven hace que la fiera atribuya características de ferocidad a la muchacha. Esto es lo que ocurre en el anuncio de los relojes Breil, en donde la protagonista personaliza la agresividad de la pantera cuando el novio le quita su Breil. Ella enfadada sale de casa y se dirige a la sauna en la que él se encuentra.

\footnotetext{
${ }^{775}$ Giancarlo Marmoni, ibídem, p. 25.
} 
Simbólicamente, al principio del anuncio ella aparece caracterizada como una pantera que se pasea por la ciudad asustando a todo el mundo.
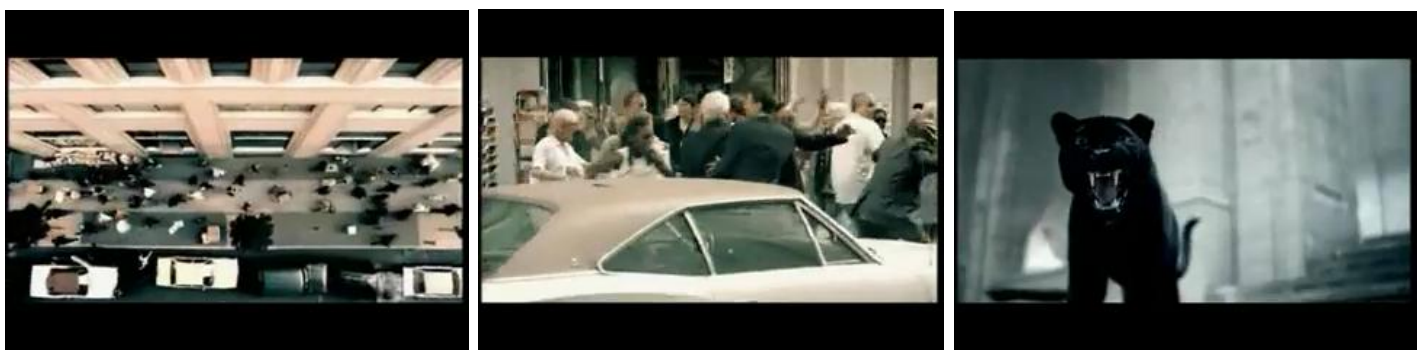

La transformación de la modelo se da cuando aparece ante el novio y se vuelve a poner su Breil.
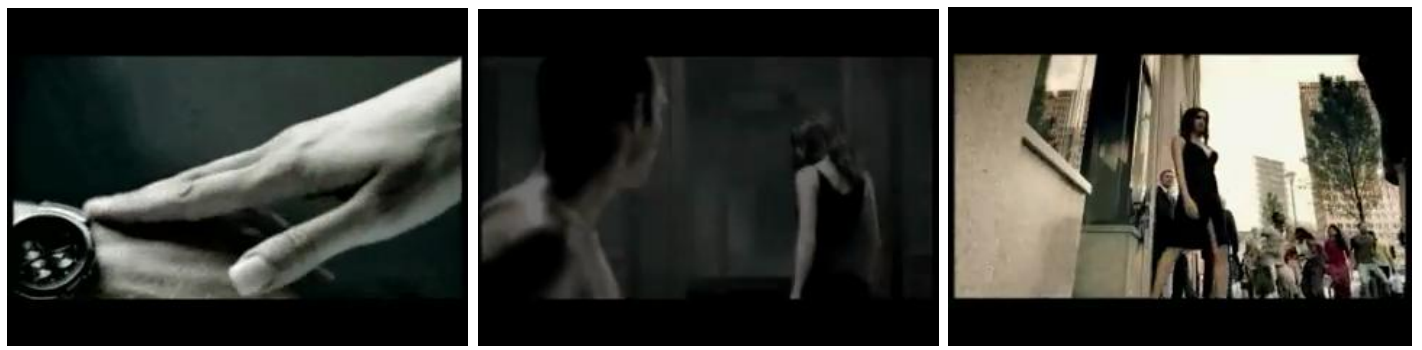

Sin embargo, para personalizar el perfume Mon Jasmin Noir, Bulgary no utiliza la figura del león como signo de ferocidad. Todo lo contrario, este desempeña la misma función visual que una tela de terciopelo: este simula la caricia y la suavidad.
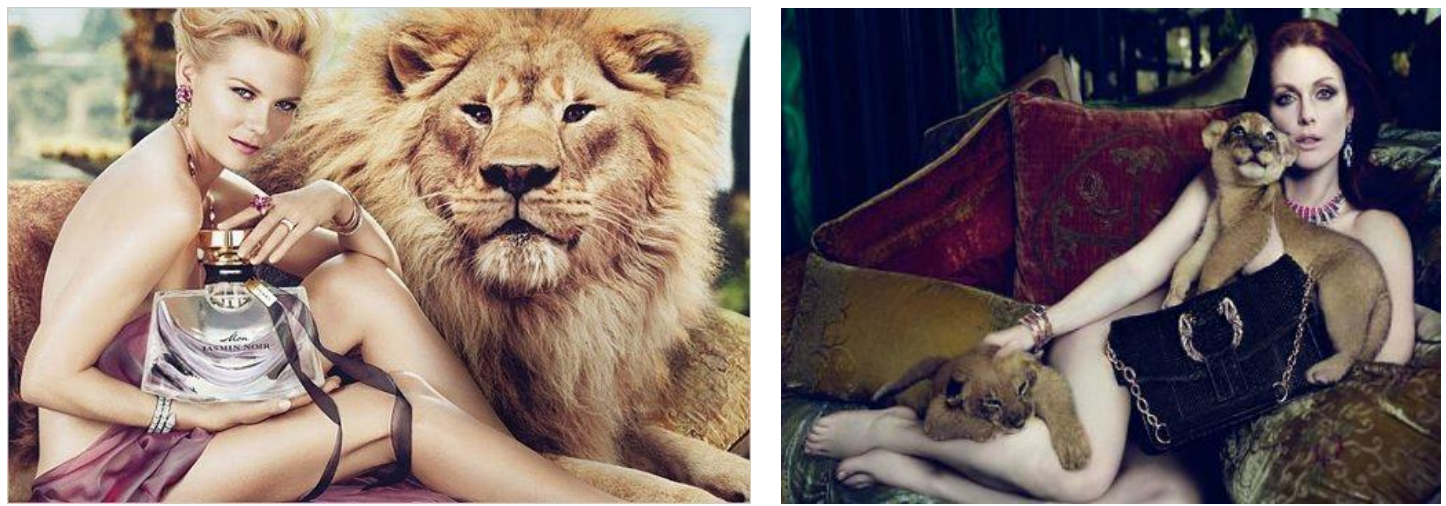


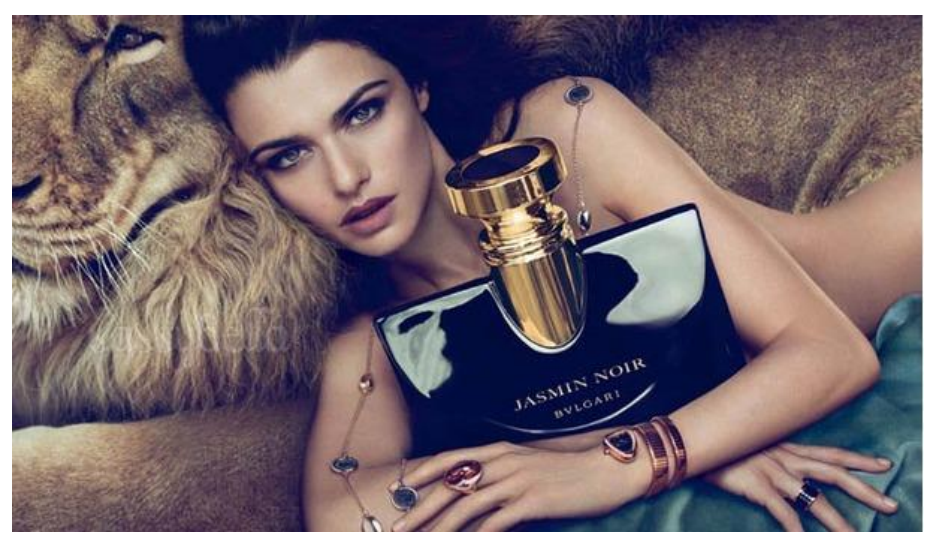

La fiera representa la pura protesta ante el cazador. El leopardo y otros animales materializan el animus femenino mediante un perfume, un suéter, un reloj... Estos animales se ofrecen como tótem de una feminidad instituida en un clan. El animal que llega a ser representado como un emblema es la pantera de Cartier.
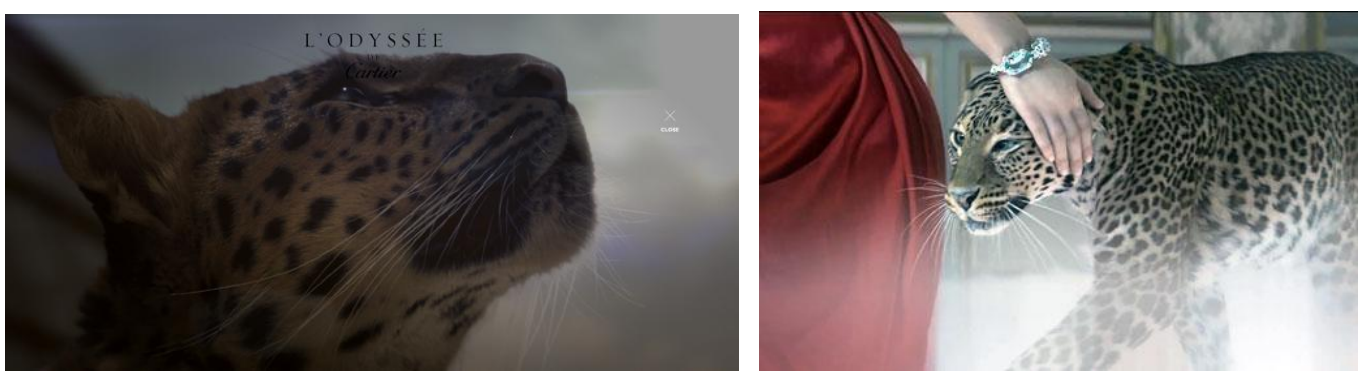

Muchos son los elementos ornamentales que caracterizan las joyas de Cartier. Sin embargo podríamos decir que, junto el elefante y el dragón, la pantera es uno de sus elementos fetiches más elegantes.
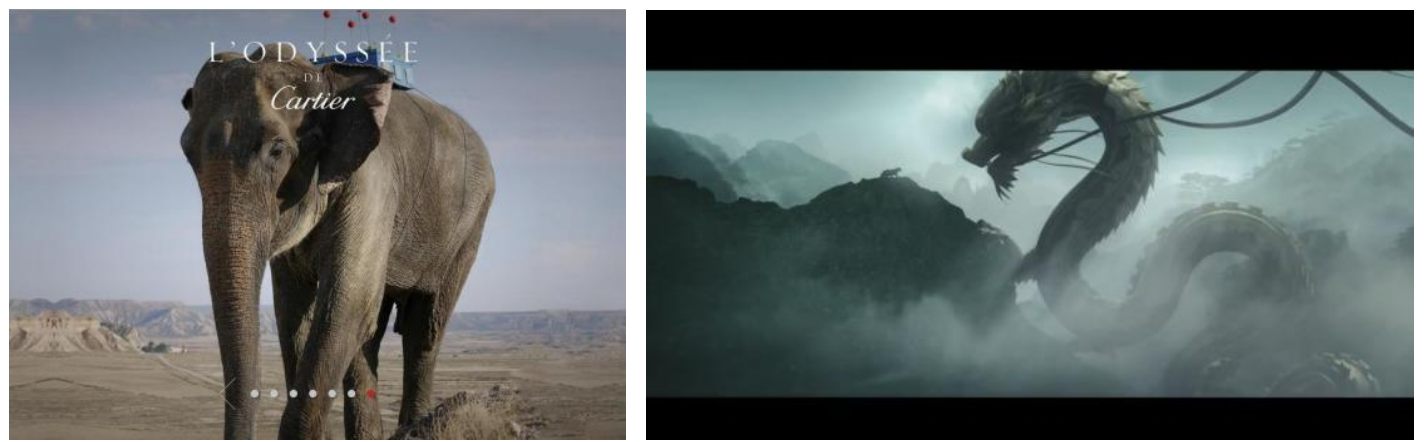
Estos elementos reflejan un consumo industrial con un determinado valor y un hermetismo muy sectario. Normalmente, su uso viene determinado por simpatía y por el reflejo transgresivo por parte del Otro ${ }^{776}$.

\subsubsection{3.- Los peces}

En ocasiones los anuncios de bañadores suscitan la aparición de peces. Estos animalillos en el ámbito publicitario se asocian como signos específicos de la playa, por lo que es bastante esperable que los bañadores y otros productos típicos del verano utilicen estas figuras. Tal fue el caso de los bañadores Goldfish-Basemonden, que utilizaron esta imagen para difundir el eslogan "Be my love-be my Gold-Fish" ("Sé mi amor-sé mi Gold-Fish"). Se trata de una frase meramente vulgar emitida por una portadora sentada sobre un pez mastodóntico ${ }^{777}$.

\subsubsection{4.- Las mariposas}

La imagen de las flores en el campo simboliza la imposibilidad de escapar. Fue entonces cuando, en medio de esta imagen estática, apareció la mariposa. Este pequeño animalillo va posándose en las flores para comer, pero casi sin darse cuenta las fecunda. Por esa imagen, las mariposas simbolizan el vehículo ambulante del polvo seminal, fuente del que fluye toda vida, luego todos los productos relacionados con las mariposas serán imantadores de la fecundidad. Tal es el caso de los pintalabios, que por un lado representan la imagen de la mariposa con las alas extendidas y, por otro lado, el

\footnotetext{
${ }^{776}$ Giancarlo Marmoni, op. cit., pp. 68-70.

${ }^{777}$ Giancarlo Marmoni, op. cit., p. 64.
} 
significado de los labios como seno receptivo. Así pues, son capaces de atraer todo tipo de mariposas oníricas. Un ejemplo muy claro lo encontramos en la barra de labios rojo Chanel que se perfila en contraste con un cielo completamente azul o con el azul de la piscina. Pero si nos fijamos en la imagen se trata de un color que también potencia el rojo que inmortalizo la imagen de Lolita.

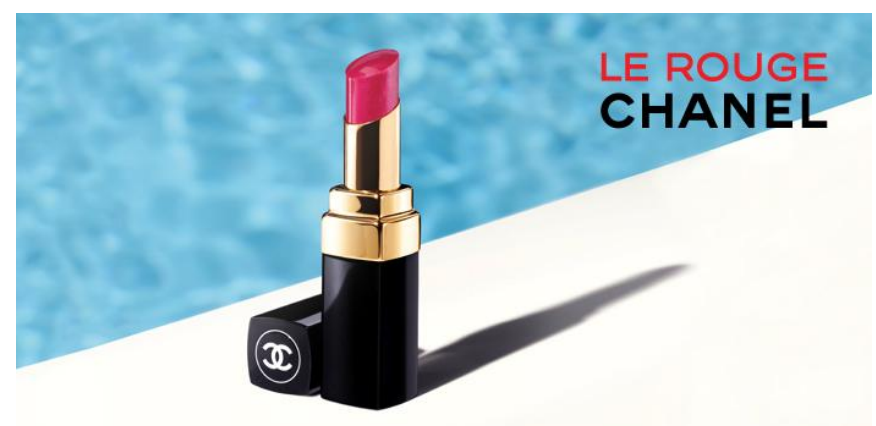

Otro caso es el pintalabios de Lip Dew Helena Rubinstein, el cual alude al rocío como precipitación atmosférica que tiene lugar durante las noches provocado por la irradiación del calor acumulado en la tierra. Al mismo tiempo y de forma metafórica, los labios lo reciben a modo de objeto pasivo pero dispuesto. Esta característica de los labios-mariposa se ve desplazada hacia la figura de la modelo. Esta es la idea que retoma Kenzo para hacer la publicidad de uno de sus perfumes. Como podemos ver a continuación el cabello de la soporte es sustituido por mariposas. Así que, los labios como elementos inmediatos de la fecundidad trasladan su característica hacia la totalidad de la imagen femenina ${ }^{778}$.

\footnotetext{
${ }^{778}$ Giancarlo Marmoni, ibídem, p. 64.
} 


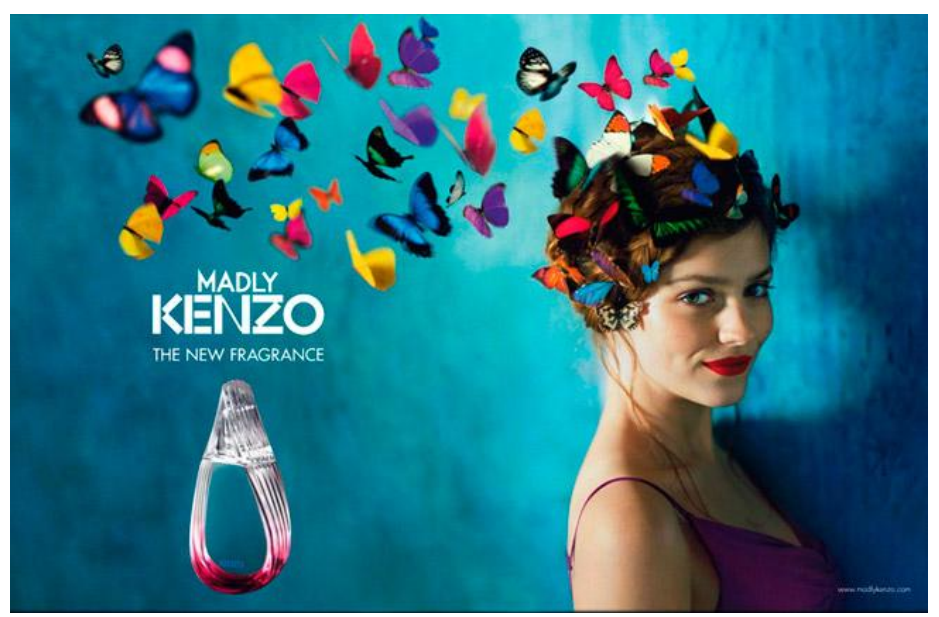

\subsection{3.- La mujer sádica}

Las prácticas sádicas, perseguidas duramente por el ámbito legislativo, se han visto rechazadas en la publicidad. Así lo atestiguan los pocos ejemplos que han quedado a modo de patologías o de residuos parasitarios en el sistema publicitario. Giancarlo Marmoni mantiene que estos persisten en contextos humorísticos o melodramáticos. Pero en un plano u otro el uso de la retórica funciona como un símbolo de coacción que contrasta con la liberación que ofrece el uso del propio producto. También es cierto que la retórica puede ejercer como un signo de función fetichista adquirida por el producto que se anuncia.

Las prácticas del repertorio sádico clásico se han visto un tanto censuradas en el mundo publicitario. Así que, como mucho, podremos encontrar escenas de flagelación y señales de fuego directamente en la piel como soporte. Debido a la censura moral hay todo un alfabeto dedicado a simular expresiones figurativas que consistan en el empleo de instrumentos propios del arsenal pecador, tales como cadenas, cuerdas, cajas, tenazas... o de imágenes y episodios que representan acciones abusivas. Por supuesto, en este tipo de escenas es fundamental la mímica de las actrices para simular el ultraje, la tribulación y el miedo. Estos elementos perfilan el álgebra sádica que no sólo se adueña del ámbito publicitario, sino que también brutaliza el soporte, es decir a la modelo. Esto 
es sólo una ambientación que emerge del caudal psíquico de las técnicas, y que, por azar, emerge entre el público de forma subliminal. Magistral fue el anuncio que Chanel realizó para el veinticinco aniversario del perfume $N^{o}$ 5. En él se contaba cómo Coco Chanel contrataba los servicios de un extraño hombre, quien siguiendo el mismo patrón que el asesino de la novela El perfume, secuestraba y mataba a las mujeres más guapas del lugar. El objeto, al igual que en la novela, era extraer las grasas de las muchachas para conseguir el mejor perfume del mundo ${ }^{779}$.
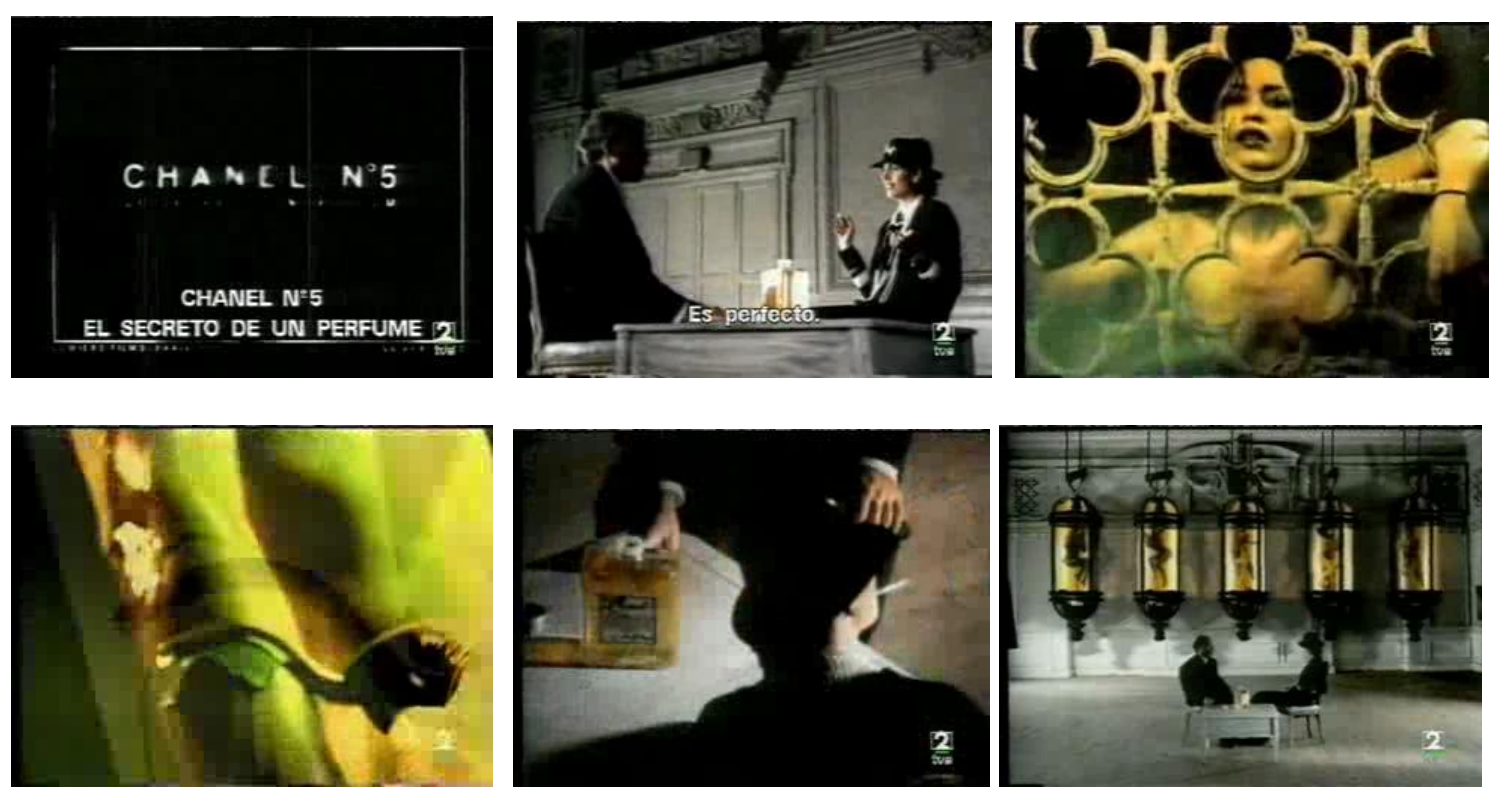

\subsubsection{1.- Las castradoras o asesinas}

Podemos señalar que la imagen de la mujer castradora reaparece intacta en la publicidad actual, aunque es completamente irreal por el exceso de dramatismo. Son hermosas jóvenes y asesinas, pero potencialmente deformadas por el optimismo mercantil. Normalmente, suelen aparecer caracterizadas con alguna especie de arma como sables o

\footnotetext{
${ }^{779}$ Giancarlo Marmoni, op. cit., pp. 16-21.
} 
cuchillos. Un icono indiscutible es la Mademoisell, que resultó ser imagen iconográfica para el whisky Usher, modelo para Green Strip y esgrimista para combiné Charmor.

Tras todos estos personajes publicitarios planea la sombra de Dalila o Judith, pues son estampas materializadas con armas punzantes. Las mujeres aparecen completamente enmarcadas en su entorno, pero con la ayuda del arma provocan una imagen desafiante, refuerzan la búsqueda de la motivación y el deleite publicitario de la misma.

Otro ejemplo lo ofrece la firma Helenka y sus bañadores Nelbarden, que bajo el lema “Capturar el sol", presentan mujeres como portadoras de sables y de colbacks en la playa. El champú Breck muestra a una mujer con el cuchillo entre los dientes. El agua de colonia Tear y su loción para después del afeitado proponen a la pareja de Sansón y Dalila para ilustrar al usuario de una barbería y a su peluquera.

Otro de los ejemplos más crudos lo hizo el fotógrafo Nick Nigth para la campaña de publicidad del perfume de Lady Gaga llamado Fame. Se trata de una serie de imágenes caóticas e inconexas que evocan el sadismo.
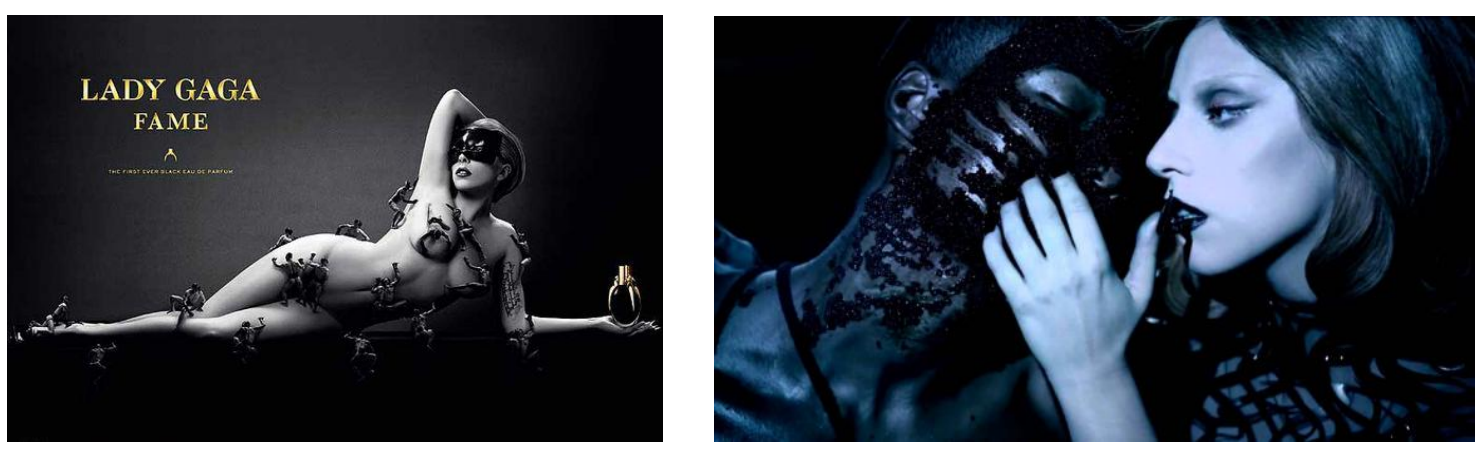

Si el totemismo nació alrededor de la prohibición de las prácticas incestuosas, el tándem publicitario se revela ante él, pues acaba mostrándose como una incitación a la 
profanación del tabú. De modo que la modelo-bestia se revela como símbolo de la madre-castradora. Es decir, una mujer que es capaz de incitar el deseo para acabar provocando la tragedia. En contraste, tenemos la tragedia del incesto y el peligro de castración $^{780}$.

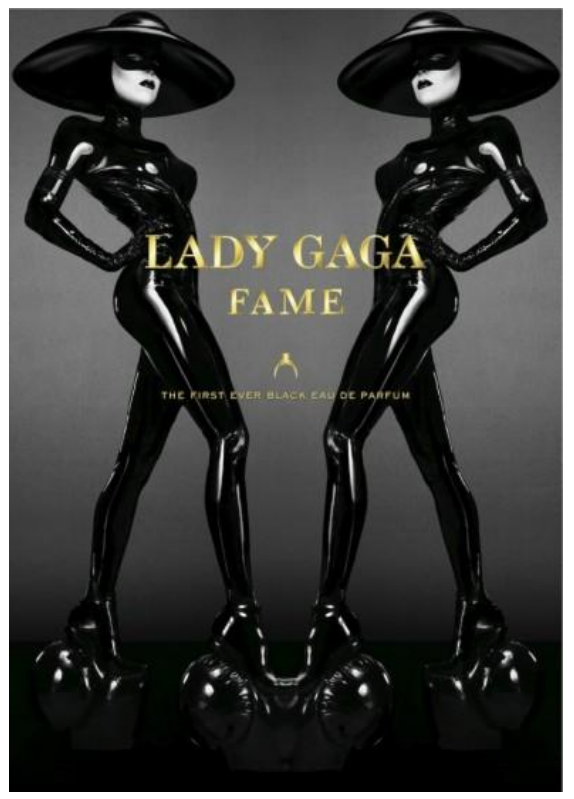

\subsection{4.- La sirena}

Marmoni mantiene que tal vez el uso del pasaje de Susana y los viejos sea excesivo para explicar algunas escenas publicitarias. Pero lo que sí es indiscutible es que la mirada impúdica de los ancianos se conserva en los anuncios en los que la usuaria no se da cuenta de que está siendo observada. En estos planos, los ojos de los espías quedarían fuera del campo visual de la joven que consume ostentosamente sales de baño, jabones, albornoces, toallas, bañadores... Productos que debido a su uso permiten soportar la mirada sin que está sea abusiva, de forma que el desnudo femenino nunca será total, sino parcial.

\footnotetext{
${ }^{780}$ Giancarlo Marmoni, op. cit., p. 36.
} 
Al no mostrar todo su cuerpo, la bañista no se siente objetivo inerme de miradas lascivas, sino todo lo contrario, aparece satisfecha por el ultraje. Este punto de vista tergiversa completamente el sentido de la leyenda. Se trata de una Susana impura, porque la estimula la corrupción de su propia inocencia. El sentido de la pureza que encierra el propio desnudo deja de ser reflejo saludable de su juventud, y se le da una vuelta de tuerca por parte de los publicistas. Ahora, el desnudo responde al exhibicionismo y no a la castidad, por lo que los objetos que cubran su cuerpo adquieren el carácter de panoplia. Es decir, que se convierten en una armadura completa $^{781}$.

\subsubsection{1.- Los espíritus acuáticos}

Todos los desnudos acuáticos que propone el mundo publicitario aparecen construidos bajo dos metas. La primera es el uso del medio como vía para la metamorfosis de la mujer. Por si solo el océano aporta un significado simbólico de transformación sexual. El mar hace referencia a una sexualidad primigenia e indiferenciada, la misma que llevó a los anfibios a la evolución bisexual. En segundo lugar, el agua favorece el estímulo de la adhesión al producto. Este aportará un sentido de libertad por el cual la cliente se siente atraída.

De los desnudos acuáticos se desprende el paradigma de la mujer primitiva orinolágnica. En las ediciones contemporáneas se manifiesta como la Venus Anadiomene surgiendo del mar con orgullosa ostentación. Se introduce, por tanto, en la noción de vacuum.

\footnotetext{
${ }^{781}$ Giancarlo Marmoni, op. cit., p. 26-27.
} 
Muchas fueron las Venus que surgieron desnudas para lucir productos como los de Dorothy Gray, cuyo eslogan decía: "El secreto del mar"782.

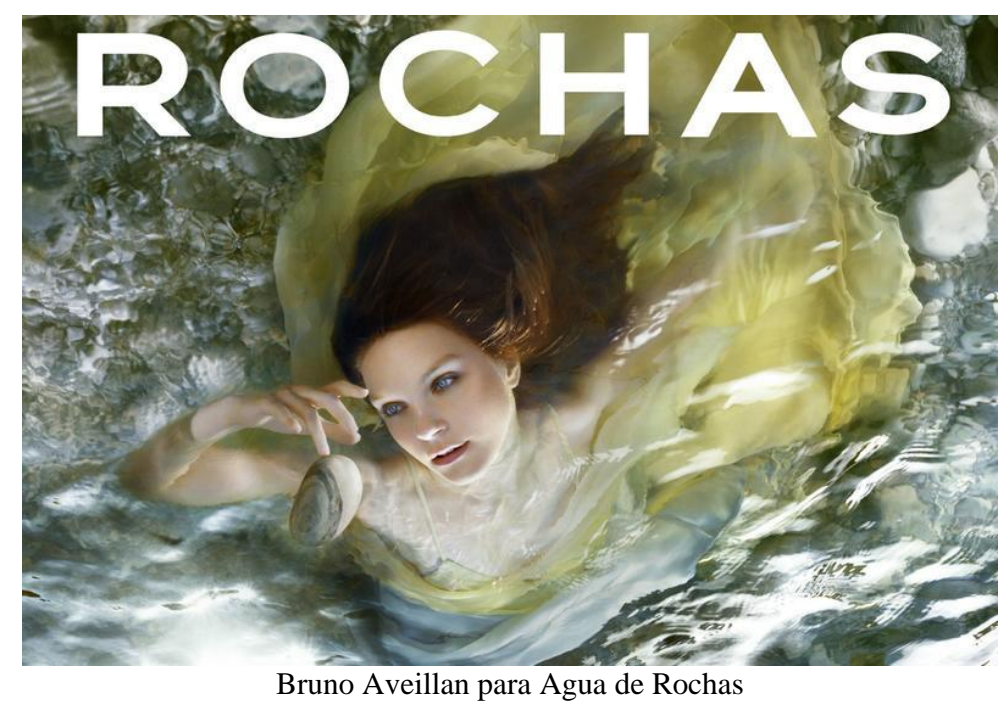

La innumerable canidad de ondinas y de ninfas marinas que están inmersas en este cuadro reflejan elegancia, perfilando así su doble atractivo, tanto para la clientela como para la ostentación.

También es destacable la ondina que surge en el anuncio de Catier titulado Painted Love by Air. Se trata de un corto patrocinado por Cartier donde un pintor aparece al terminar un retrato. El pintor sale del estudio y da una vuelta por los alrededores, pero no consigue olvidarse de la joven que acaba de pintar. Cree verla en todos lados, hasta que al final de la noche vuelve al apartamento y se queda dormido al lado del cuadro. Es entonces cuando la ondina surge del cuadro como si saliera de un mar profundo. Mira durante unos segundos al artista y se lo lleva consigo al interior del cuadro.

\footnotetext{
${ }^{782}$ Giancarlo Marmoni, op. cit., pp. 52-53.
} 

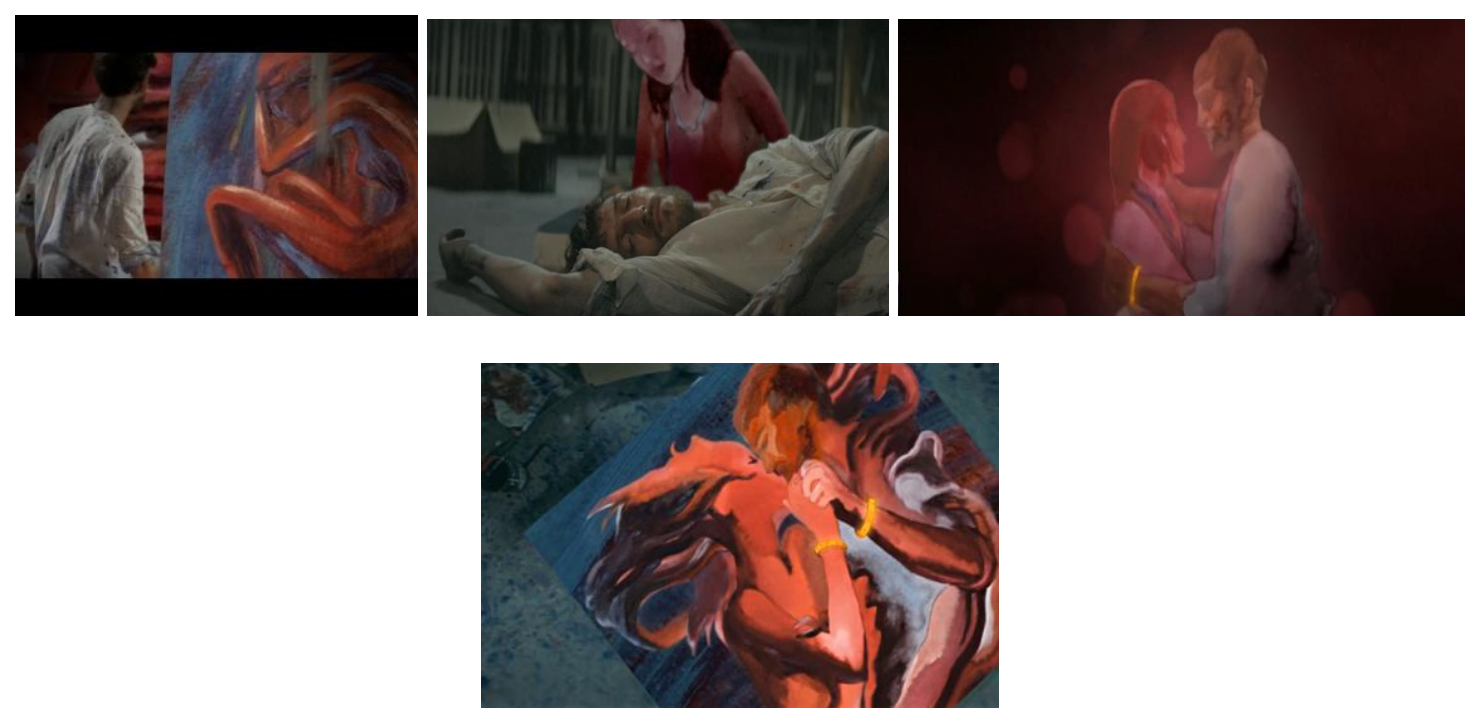

\subsection{5.- El orientalismo burgués}

En el mundo publicitario actual también hay lugar para un amplio repertorio histórico burgués. Los publicistas resucitan a modernas emperatrices, desenfadadas princesas y muchachas de las altas clases sociales para protagonizar los nuevos spots. La publicidad las rescata para recomponer las piezas de un rompecabezas iconográfico y literario. Pero este, como es de esperar, está incompleto; sólo puede ser resuelto por el carácter emotivo que aporta el espectador. Estas burguesas contemporáneas no se convierten en estereotipos exóticos como las sanguijuelas aniquiladoras de antaño, sino que más bien lo que consiguen es convertirse en fetiches desvalorizados, pues, aportan elementos descontextualizados o levemente humorísticos. Tal fue la campaña que llevaron a cabo los helados Magnum, en donde la actriz era tratada como una princesa al comer uno de los helados de la marca. Al llegar al metro, hace tanto calor que la joven compra un helado: con sólo quitarle el envoltorio, aparece todo un séquito que le abre un camino hasta su asiento en el metro. 

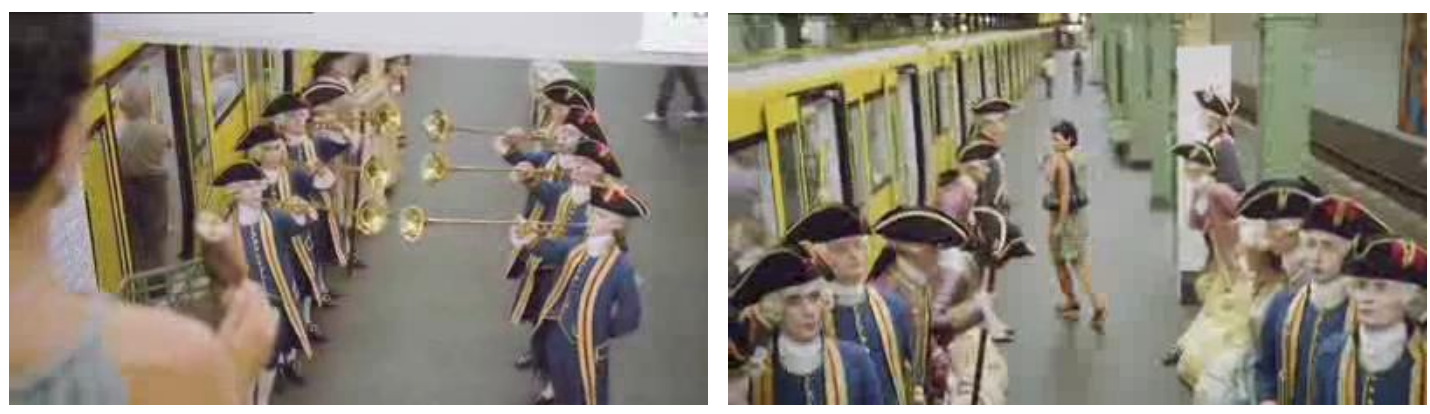

Vemos cómo del romanticismo se pasa a la comicidad, porque vuelve a entrar en funcionamiento la representación de las modelos mediante protocolos retóricos o comportamientos muy nerviosos. Tal modo de actuar crea un ambiente agitado donde convergen los modos de actuación y los objetos anunciados. De esta forma, se proponen artificiosas metamorfosis y mimetismos exagerados del consumo. La joven será acompañada durante toda su jornada laboral hasta que, al llegar a casa, se da cuenta que todo el reino está bajo de su balcón para saludarla.
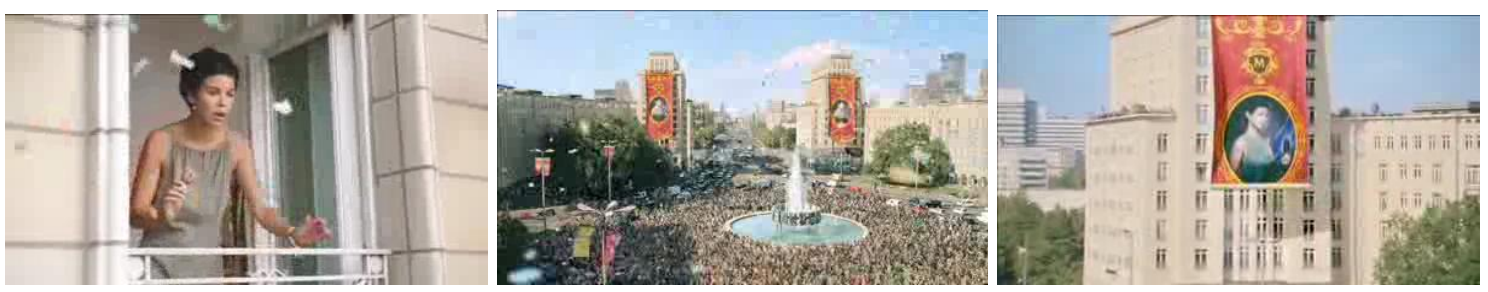

Por supuesto, este anuncio dispone de elementos cómicos, pero no todos los comerciales los tienen. Por ejemplo, los anuncios de Carolina Herrera muestran a una una alta sociedad que hace del tedio un arte. Así que podremos encontrar a jóvenes tumbadas y relajadas, al mismo tiempo que posan para una forografía equilibrada. 

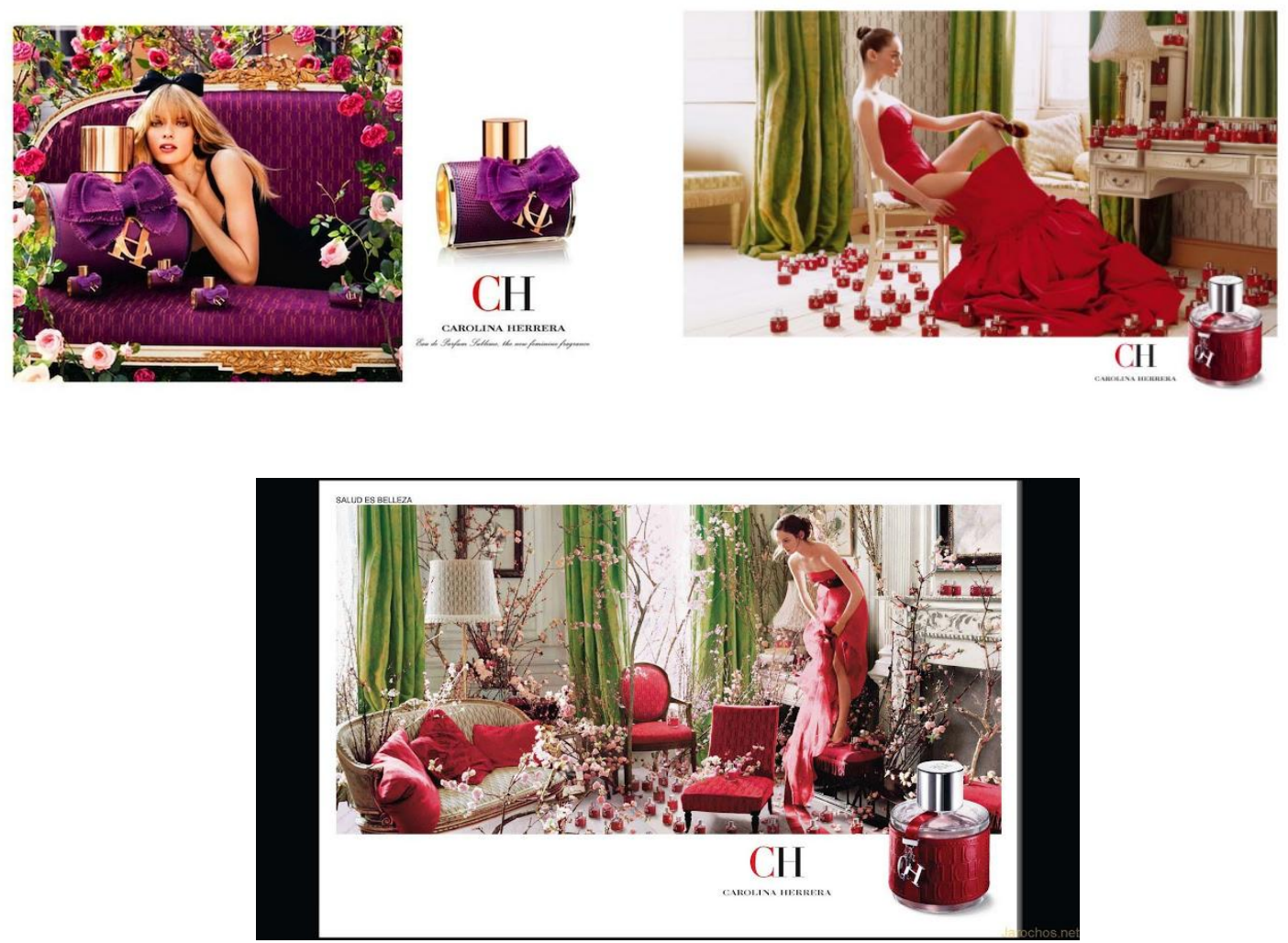

La misma idea la toma Loewe para su línea de perfumes más juvenil: A mi aire.

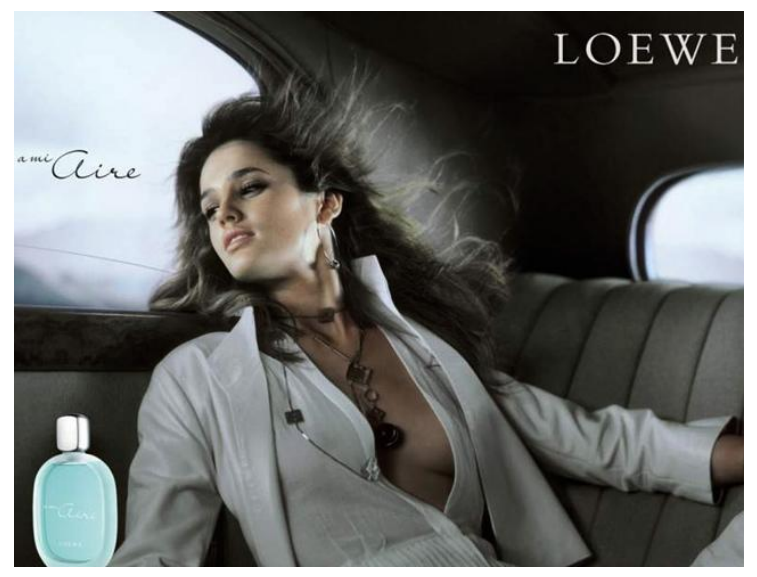

Jean Paul Gautier y Chanel muestran a mujeres un poco más maduras, también adineradas, pero cada una de ellas vive el tedio de una forma muy dierente. Por ejemplo, las féminas de Jean Paul Gautier pasan el tiempo muerto acicalándose o seduciendo al amante, y la protagonista del anuncio de Chanel viaja ${ }^{783}$.

${ }^{783}$ Giancarlo Marmoni, op. cit., pp. 40-43. 

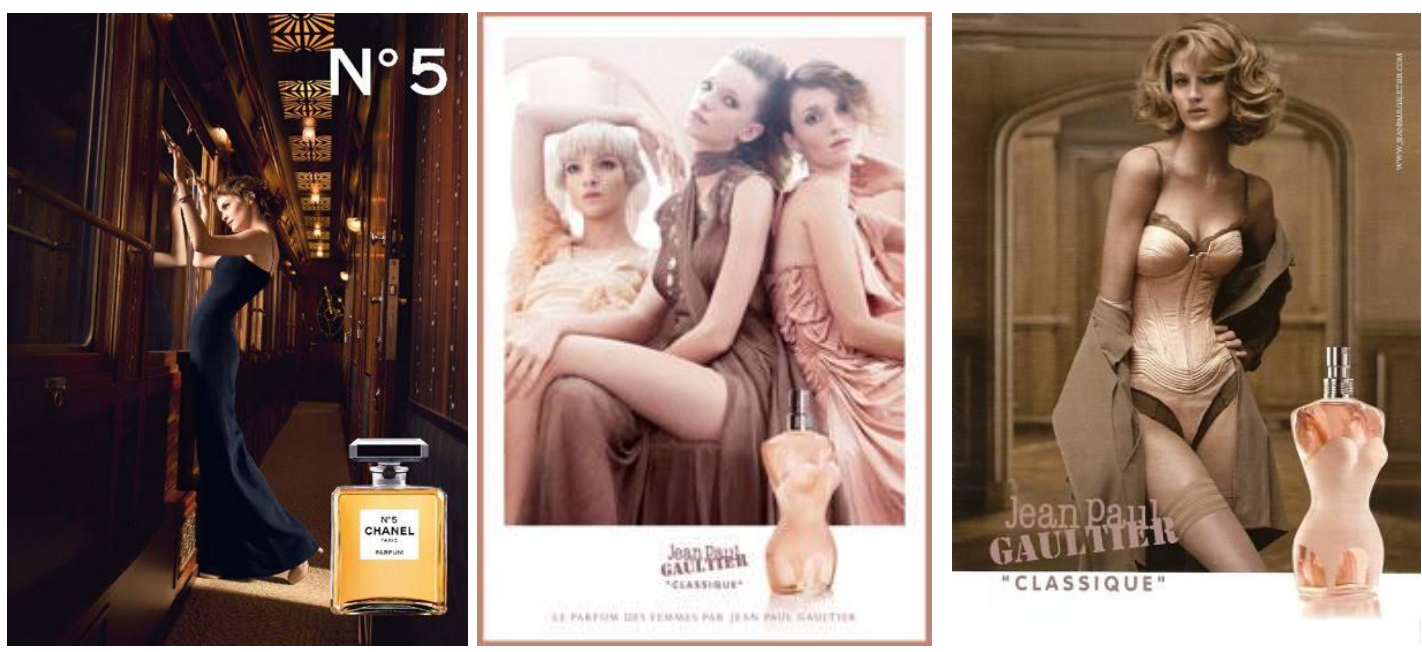

\subsubsection{1.- La Lolita publicitaria}

Muchas han sido las campañas publicitarias que han utilizado la figura moderna de Lolita para llegar a un público joven. En estas ocasiones el público diana es mucho más joven de lo normal. Ahora no se trata de vender un producto a jóvenes experimentadas o mujeres maduras, se busca un cliente en potencia: joven y que comienza a introducirse en el mundo de las compras. Por ello muchas de las protagonistas de las campañas publicitarias son o emulan ser jóvenes inocentes que juegan con su incipiente sensualidad.

Los publicistas no quieren conseguir una compra impulsiva, sino que buscan crear una clientela fija y fiel, aunque muy joven. Así que muchos de los arquetipos femenninos que muestran en sus camapañas publicitarias tienen características que muchas jóvenes clientas desean tener. Tal fue la sensualidad desenfadada que la actriz Natalie POrtman encarnó para el perfume Cherie de Dior. 


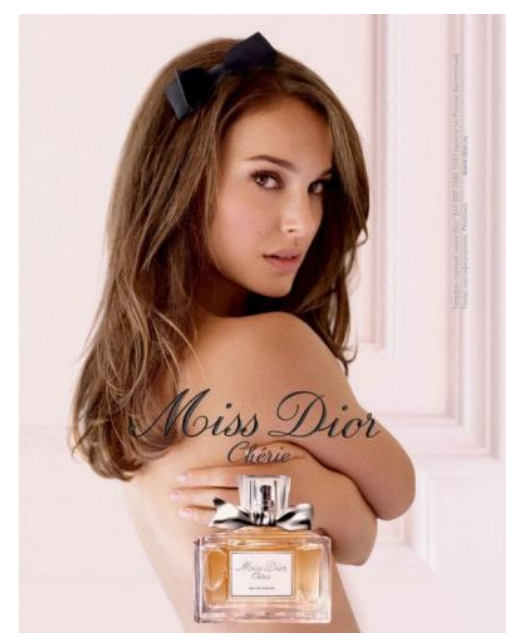

Pero sin duda, la campaña más explotada por el mundo del perfume ha sido la que protagonizó la bailaría Estella Warren para el emblemático perfume Chanel $N^{o} 5$.
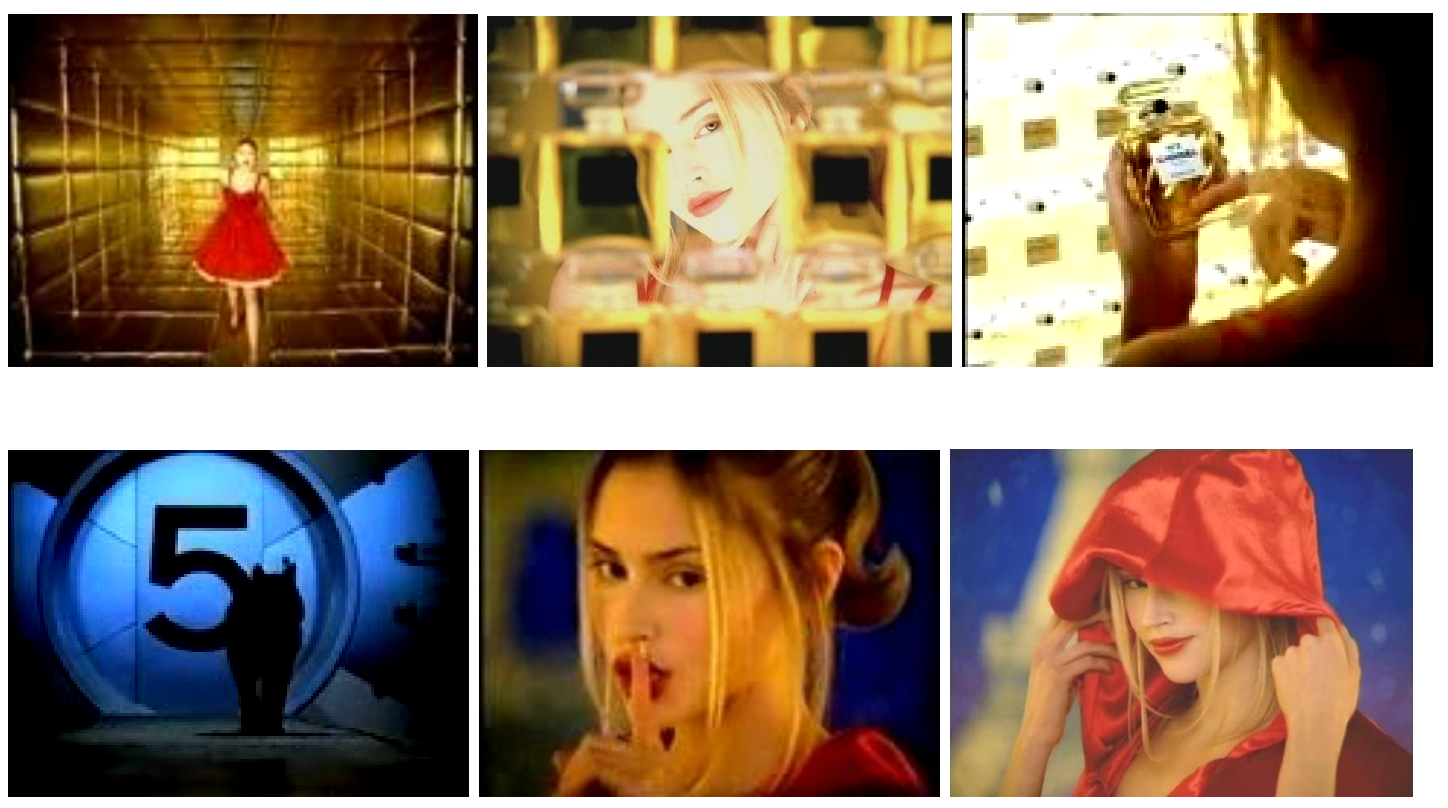

En donde una joven caracterizada como Caperizita atraviesa un gigantesco pasillo dorado hasta llegar a una sala llena de frascos de Chanel $N^{\circ} 5$. Se pone unas gitas del perfume y, cuando se dispone a salir, ve que la sigue un lobo. Pero la muchacha en lugar de asustarse, se gira hacia el lobo, lo hace callar y sale de la casa, dejando al animal aullando en soledad. 


\subsection{6.- Los sueños del cliente}

Como hemos intentado mostrar, la comunicación publicitaria se advierte como un diálogo en la que la marca muestra un estereotipo femenino, una imagen completamente canonizada ante la cual a la cliente sólo le queda soñar. En apariencia, las modelos apuntan a vértices de autonomía, agresividad, audacia y dignidad, en situaciones completamente irrealistas, como las dadas en selvas, en desiertos, en cumbres montañosas... Realmente, lo que hacen es denotar los propulsores latentes del miedo, la sujeción, la pasividad, el sentido del ridículo... que toda cliente siente. De esta forma, las modelos se convierten en el blanco de los sueños de muchas mujeres. En consecuencia, el cuerpo femenino como representación pública o publicitaria se transforma en un "estereotipo de insurrección”. Pues, levantándose desde el miedo y el ridículo de la desnudez pública, las modelos lucen orgullosas los objetos (como fajas o bragas) ajenas al sistema de pudor, y experimentando con una intervención desmitificadora.

Afirmándose desnudas se alzan un sinfín de mujeres Tarzan, Ariel, Carmen, Circe o amazonas. Pero estos arquetipos no dejan de ser disfraces hiperbólicos de un asunto de revanchard y, con él, de la suficiencia precastratoria. En realidad, estas matadoras o indígenas rousseanianas se ofrecen como una imagen un tanto violenta, incluso para el propio cliente femenino. Por lo que, para hacerlas más apetecibles, estas imágenes fueron enmarcadas, en un principio, en la esfera de los sueños. Así encontraremos una serie de anuncios que conjuran sueños terroríficos de la desnudez. Tal es el caso de la publicidad de Maidenformbra, cuyo eslogan versa "I dreamed I was..." (he soñado que era...). Por lo que la modelo se convierte en blanco de los sueños de la cliente, se transforma poco a poco en un estereotipo de insurrección femenina. Así que no se trata de una imagen que se impone de forma violenta al espectador, sino que se da de forma 
progresiva, progresión que la cliente puede experimentar a medida que vaya consumiendo el objeto. De forma que la cliente irá adoptando la misma forma de muchacha que la modelo ha experimentado previamente ${ }^{784}$.

\subsubsection{1.- Los sueños aeronáuticos}

El empleo iconográfico del cuerpo femenino en levitación ayuda a mostrar que la mercancía puede producir los mismos efectos que el sueño aeronáutico. Estamos ante la visión idealista de una mujer que, mediante gestos y movimientos lentos, muestra ser libre en un espacio amplio o imposible.
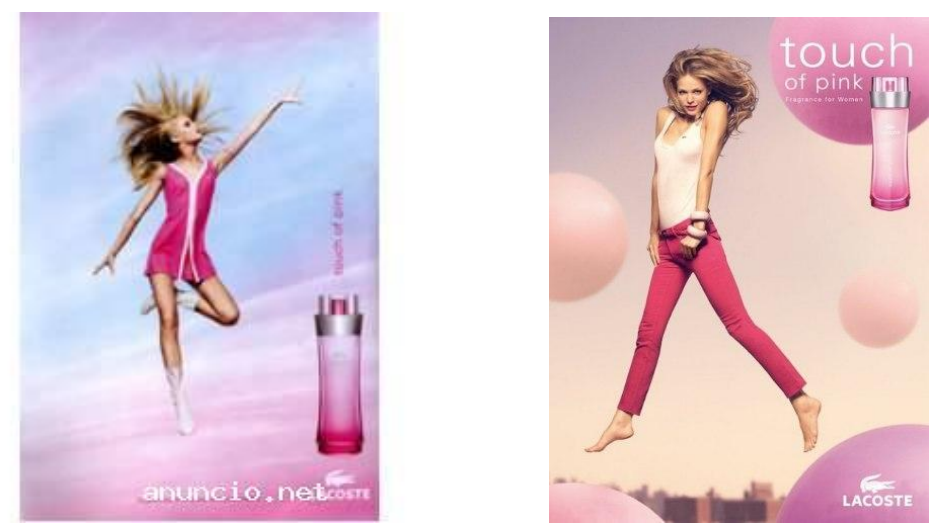

Esta experiencia aviadora implica una sensación de agilidad ante un reciente poder adquirido. No es otra cosa que el vuelo de la cliente hacia la satisfacción de su deseo de libertad ostensible, un puente onírico publicitario hacia la realización del descontento personal por medio de la satisfacción del producto, como es el caso de los siguientes modelos:

\footnotetext{
${ }^{784}$ Giancarlo Marmoni, op. cit., pp. 56-58.
} 


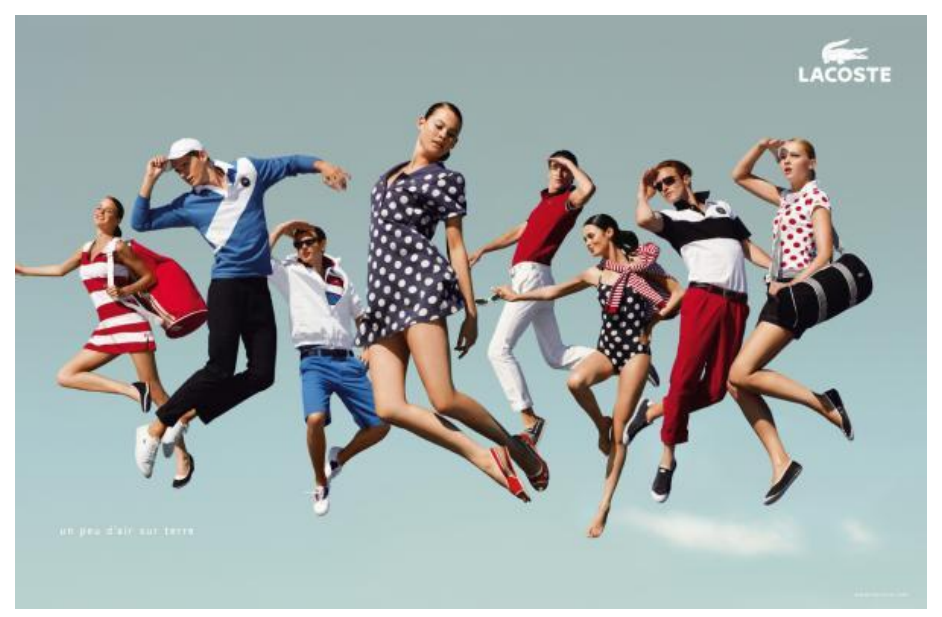

Pero, antes que a las modelos de Lacoste, pudimos encontrar a la española Ines Sastre andando sobre el agua para encontrarse con su amado ${ }^{785}$.
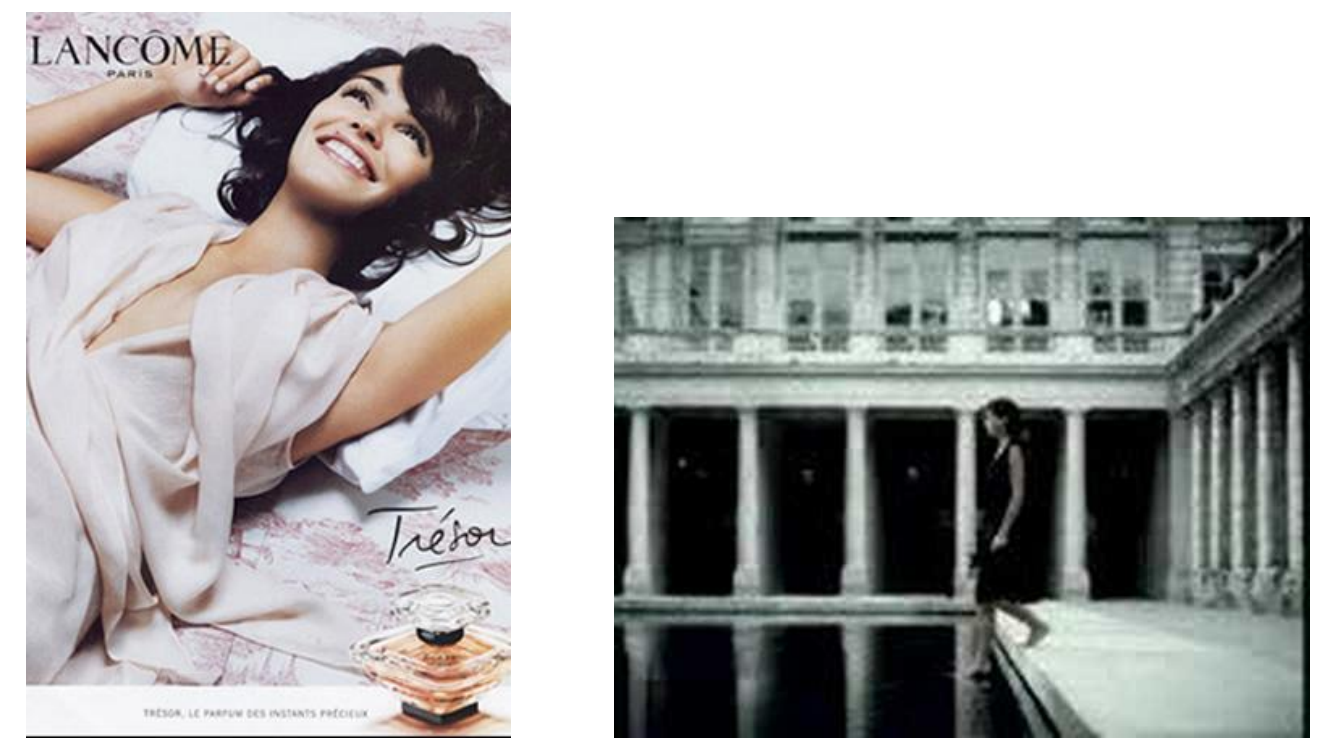

\subsubsection{2.- La fase diabólica del onirismo ${ }^{786}$}

En esta metamorfosis onírica, que se da en el mundo de los sueños, también deambula una fase diabólica. Normalmente, la relación entre la modelo y el objeto que ostenta suele ser esquiva. En primera instancia, se aprecia el uso y la adquisición del producto.

\footnotetext{
${ }^{785}$ Giancarlo Marmoni, ibídem, p. 58.

${ }^{786}$ Giancarlo Marmoni, op. cit., pp. 59-61.
} 
Pero en segundo lugar se introducen unos elementos en su contenido de criptograma que nos impiden comprender si es la usuaria quien transforma en significante erótico a la mercancía, o si es la mercancía la que transforma en mímica sexual el gesto o la pose de la usuaria. En el momento en que convergen adquisición y consumo, el objeto mercantil y la modelo aparecen contaminados por las reminiscencias soñadoras, por lo que el evento mercantil se formula como síntesis y sortilegio.

Marmoni cataloga dentro de los sueños aeronáuticos a las modelos que desempeñan el papel de astronautas, brujas, bailarinas liberadas, modelos en columpios... Aquí tenemos el caso de la bruja de Dior:

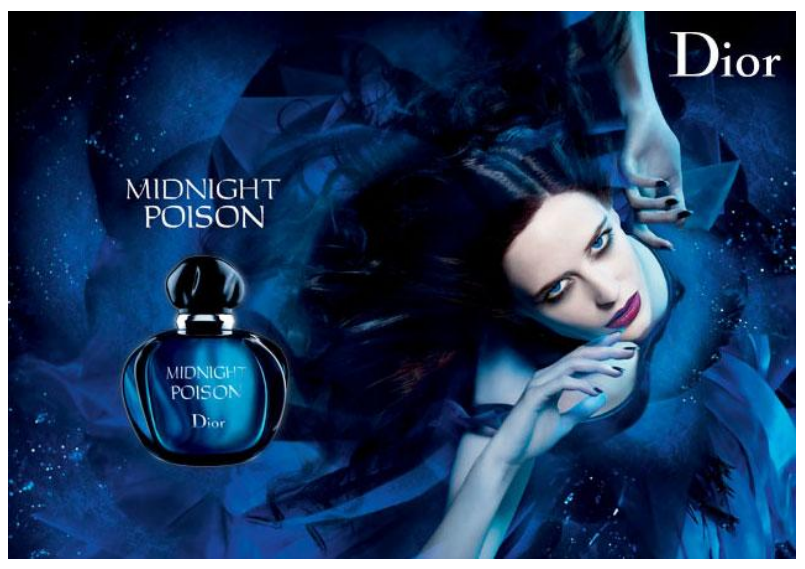

Esta sorprendente levitación también aparece representada en los anuncios de Loewe para la el perfume Aire, en donde la bailarina Carmen Corella parece encarnar al propio viento. En la siguiente campaña publicitaria, la protagonista es sustituida y su característica se desplaza hacia la botella del perfume, el cual se desvanece con una leve brisa de viento. 

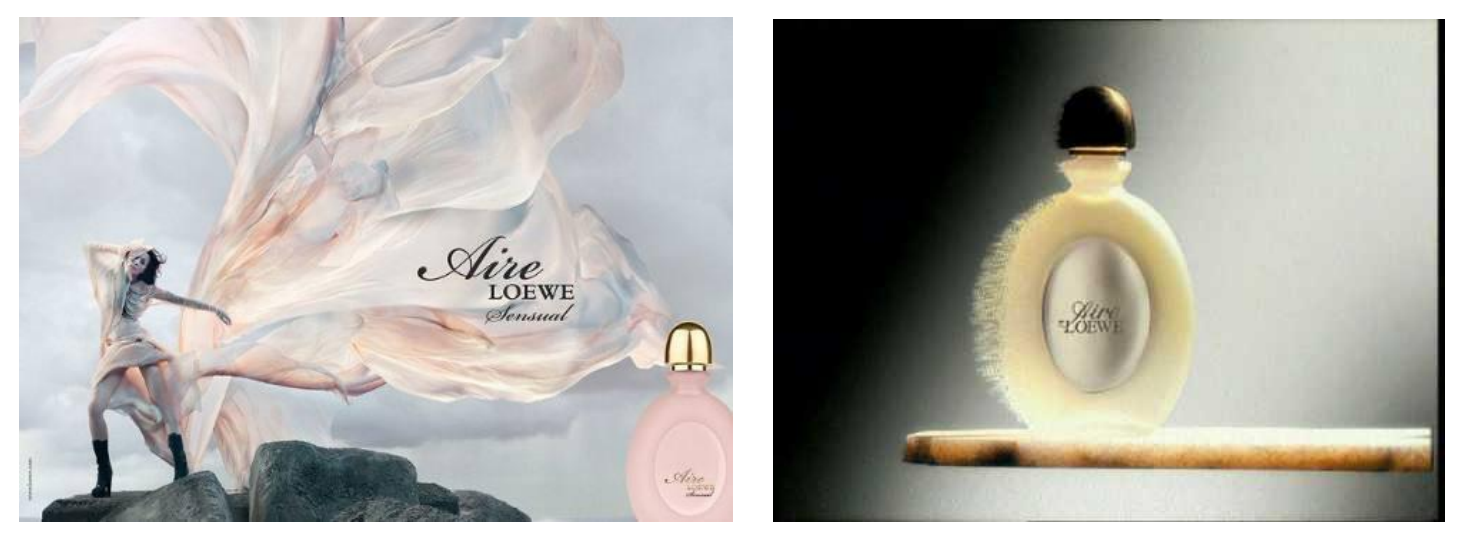

También tenemos el caso del nuncio de Chanel No5 After-Bath Oil Spray, en donde una modelo se tiende para inundar su cuello con esta loción, pero su mano se contrae sobre el atomizador mientras, su rostro asume una expresión de súcubo en éxtasis. Otra alarga el vaso lleno de hielo para que se lo llenen de Cinzano-Eisberg, y el cuello de la botella se convierte en simulacro del abuso viril ${ }^{787}$.

\footnotetext{
${ }^{787}$ Giancarlo Marmoni, op. cit., pp. 59-61.
} 


\section{8.- Conclusión}

\section{1.- Identidad colectiva}

Las imágenes que se han presentado responden a los contenidos del imaginario colectivo. Gilbert Durand destaca que el imaginario colectivo se constituye a través de tres grandes grupos:

$1^{\circ}$ ) Los esquemas diaréticos y verticales. Estos serían los signos masculinos y, normalmente, están simbolizados por los arquetipos del cetro y de la espada.

$2^{\circ}$ ) Los esquemas del descenso y de la interiorización suelen ser femeninos. Estos aparecen simbolizados por medio de los arquetipos de la copa y de todos sus componentes simbólicos.

$\left.3^{\circ}\right)$ Los esquemas rítmicos aparecen simbolizados por medio de los matices cíclicos y progresistas. Las imágenes más representadas son la rueda denaria o duodenaria, un llano con brotes y el árbol.

Mitológicamente, esta tripartición se agrupa en dos regímenes: el diurno y el nocturno $^{788}$. Estos esquemas recogen ciertas imágenes arquetípicas que ya existían en los mitos antiguos. Sin embargo, Mario Praz pone en duda que estos orígenes sea necesario tenerlos en cuenta para explicar la figura de la femme fatale. Efectivamente, dentro de este fenómeno vemos cómo se destacan historias, leyendas, héroes, arquetipos, imágenes, formas... como un mero signo de una realidad psicológica y de una realidad

\footnotetext{
${ }^{788}$ Gilbert Durand, op. cit., pp. 385-405.
} 
externa a la conciencia. Pero la historia no explica el contenido mental de todos estos arquetipos.

La mujer fatal moderna no representa un esquema evolucionista de la mitología, pero sí la utiliza como vehículo de consenso social. Jung piensa que la tipicidad sociohistórica sustituye a la atipicidad psicológica, y dicta la superioridad de tal o cual imagen. Para ello resalta el papel de la presión histórica. Por ello, el presente estudio necesitó abordar el sistema patriarcal en el primer capítulo, pues la educación varonil impulsó ciertas ideologías sobre la civilización femenina en determinado momento histórico. Gilbert Durand llamó a esto pedagogía, pero no cabe duda de que esta presión pedagógica es comprendida como negativa. De forma que podríamos hablar de arquetipos mitológicos dignos de imitación, y de arquetipos terroríficos.

Ambas imágenes responden a una función educativa que desde la antigüedad ha ido evolucionando de la mano del discurso religioso y médico. Estos discursos dieron lugar a la corriente humanista, en que se pretende igualar cultura y civilización. Realmente, se trata de una corriente elitista, en la que muy pocos individuos logran alcanzar el grado de cultura, pues, ésta es la distancia que separa a unas personas de otras según el grado de saber acumulado. Para ser sinceros, la relación entre cultura y sociedad nunca ha sido lineal, porque a causa de la utilización de términos como condición de la clase social, condición de género, la condición ética, la condición de nación... se consigue perfilar una horrible estratificación, donde las culturas aparecen clasificadas de mejor a peor. Esto permite que algunas se alcen ganadoras, poderosas y elitistas sobre el resto ${ }^{789}$. Como consecuencia, la cultura feminista siempre aparecerá subordinada ante la

\footnotetext{
${ }^{789}$ Isabel de la Cruz, op. cit., p. 24.
} 
poderosa cultura masculina. A partir de estas premisas, Leach define así el concepto de cultura $^{790}$ :

El término cultura tal como yo lo utilizo, no es esa categoría que todo lo abarca... Para mí los conceptos de sociedad y cultura son absolutamente distintos. Si se acepta la sociedad como un agregado de las relaciones sociales, entonces la cultura es el contenido de dichas relaciones. El término sociedad hace hincapié en el factor humano, en el agregado de individuos y las relaciones entre ellos. El término cultura hace hincapié en el componente de los recursos acumulados, materiales así como inmateriales que las propias personas heredan, utilizan, transforman, aumentan y transmiten ${ }^{791}$.

Muchas son las ideas que subyacen en esta definición. Pero, al ir de la mano cultura y sociedad, advertimos que el sistema paternalista no sólo lo heredamos, sino que también lo utilizamos, aumentamos y transmitimos.

Para separar sociedad y cultura, Marvin Harris destaca dos procesos. Uno lo llamaremos etnocentrismo, que es la tendencia a ver el propio sistema cultural como el mejor, y a juzgar el comportamiento y las creencias de los demás mediante los patrones de la propia cultura. Bajo estos ideales, las personas comprenden su cultura como algo particular y específico. Se trata de una visión idealizada que no dudan en heredar y transmitir. Esto es lo que le ocurre al sistema patriarcal que desde hace siglos venimos heredando. Este último, al igual que todas las culturas, tiene distintos dispositivos culturales para satisfacer las necesidades de subsistencia, de reproducción, de organizar el intercambio de bienes y de organizar la vida en común, la vida en grupos domésticos, aspectos creativos, aspectos morales, aspectos estéticos e intelectuales ${ }^{792}$. Todos estos

\footnotetext{
${ }^{790}$ Sir Edmund Ronald Leach (1910-1989) dirigió sus investigaciones especialmente hacia la antropología política, los ritos, los mitos y el estructuralismo.

${ }^{791}$ Citado por Isabel de la Cruz, ibídem, p. 24.

${ }^{792}$ Marvin Harris, Introducción a la Antropología General, Madrid, Alianza, 1991, pp. 145-153.
} 
matices están presentes en todas las culturas y son un patrón universal que permite la comparación ${ }^{793}$.

Al otro proceso cultural lo llamaremos enculturación. Este parte de la idea de que la cultura consigue modificar el entorno en que se nace. Los matices que hemos señalado se filtran en la sociedad como un canon, pero no son esenciales, ni fijos ni inmutables ${ }^{794}$. Están sujetos a cambios y a continuas reestructuraciones, porque la cultura es algo vivo y está en permanente movimiento. En consecuencia, la enculturación explica la reproducción de la cultura entre generaciones, porque generalmente la cultura entre padres e hijos es similar, pero no idéntica. Este sería el ámbito en donde operan los anuncios publicitarios, en los que se manifiesta cómo las pautas no siempre se repiten con exactitud: algunas desaparecen y se crean otras nuevas. La enculturación trata de explicarnos la continuidad, pero no los cambios culturales. Ahora bien, podemos ver cómo muchas clases sociales pobres se alojan, viven, trabajan y constituyen familias con las pautas culturales de sus padres. Cuando se habla de esto, no se quiere decir que se sitúen en un proceso de enculturación, sino que, realmente, sufren los mismos condicionamientos político-económicos.

Llegados a este punto, vemos cómo los dos procesos culturales remarcan que toda estructura social cuenta con el principio de interacción. Por su parte, el etnocentrismo ayudaría a visualizar los tipos de relaciones que existen entre diferentes clases sociales. En cambio, la enculturación ayuda a comprender la reciprocidad entre las generaciones. Este principio interactivo marca a los agentes. Pues, ya sean masculinos o femeninos, tienen muy presente que en sus propios cuerpos se escriben los correspondientes

\footnotetext{
${ }^{793}$ Isabel de la Cruz, op. cit., pp. 28-29.

${ }^{794}$ Marvin Harris, op. cit., pp. 154-156.
} 
esquemas de apreciación y de percepción. Claramente, son esquemas basados en nociones biológicas contrapuestas: pequeño/grande, alto/bajo, gordo/delgado... Estos esquemas corporales son aprehendidos a través de la convivencia en los correspondientes espacios sociales y, a través de este aprendizaje, los agentes se relacionan de una forma o de otra. Estas actitudes o modos de comportamiento ayudarán a jerarquizar a los agentes dominadores frente a los dominados ${ }^{795}$.

Desde la antropología se intenta desvincular el concepto de poder de un posible carácter específico. Siguiendo los pasos de la antropología, el presente estudio no le da una identidad concreta al opresor. Dentro de este campo, es importante señalar el poder que se ejerce con la mirada simbólica, cuya eficacia depende de la posición relativa del que percibe y del que es percibido ${ }^{796}$. Por lo tanto, la dominación masculina se da cuando la mirada coloca a la figura femenina en un estado permanente de inseguridad corporal, de dependencia simbólica. Esto es el principio de disposiciones como el de llamar la atención y de gustar ${ }^{797}$. Se espera de las mujeres que sean femeninas. Es decir, que sonrían, que sean simpáticas, atentas, sumisas, discretas, contenidas... en una palabra: difuminadas. Es decir, que ellas sólo existen cuando son el centro de las miradas. Así que se encuentran sometidas ante la necesidad de ser miradas. Pero esta mirada no es una mirada neutra, sino que es una mirada exigente.

Coexisten otros procesos de transformación cultural:

A) La aculturación es cuando los grupos minoritarios adoptan progresivamente valores y patrones de comportamiento de la cultura dominante.

\footnotetext{
${ }^{795}$ Isabel de la Cruz, op. cit., pp. 28-29.

${ }^{796}$ Pierre Bourdieu, op. cit., pp. 11-15.

${ }^{797} \mathrm{M}^{\mathrm{a}}$ Carmen África Vidal Claramonte, op. cit., pp. 83-131.
} 
B) La asimilación es cuando el grupo subordinado llega a hacerse indistinguible entre el grupo dominante.

Ambos procesos no hacen más que resaltar la capacidad de cambio que caracteriza a la cultura femenina. Con ello no se intenta definir el sistema paternalista que caracteriza a nuestra sociedad, pero sí se ha intentado apuntar que la interrelación entre hombre y mujer pasa por principios de percepción y, por lo tanto, de representación ${ }^{798}$. Llegados a este punto se observan dos mecanismos antagónicos que motivan la representación:

A) La presión pedagógica con un sentido pura y llanamente sociológico. Mediante imágenes de moda se contaminan todos los sectores de la actividad mental y se condiciona la idea del bien y del mal. Para ello se construyen arquetipos que encarnan el bien y a los que hemos de seguir.

B) Por el contrario, se esbozan imágenes de rebelión y de oposición que sugieren símbolos antagónicos propios de la imaginación humana.

Andrés Piqueras mantiene que la formación de la identidad de la persona depende del modo de relación interpersonal en que está inmersa, y de sus valores sociales ${ }^{799}$. Para entender esto es necesario que nos movamos no en términos de clase social, sino con el grupo de personas con el que normalmente se relaciona la persona de forma cotidiana. Esta elección de amigos o de compañeros da lugar al término similitud o empatía en la conformación de la propia identidad ${ }^{800}$. Pero, por oposición, también se desprende el concepto de diferencia, pues, realmente son los rasgos distintivos los que ayudan a

\footnotetext{
${ }^{798} \mathrm{M}^{\mathrm{a}}$ Carmen África Vidal Claramonte, op. cit., pp. 43-79.

${ }^{799}$ Andrés Piqueras, "La identidad" (en) Isabel de la Cruz (Coord.), Introducción a la antropología para la intervención social, Valencia, Tirant lo Blanch, 2002, pp. 37-83.

${ }^{800}$ Andrés Piqueras, op. cit., p. 39.
} 
marcar los límites del grupo social al que se pertenece ${ }^{801}$. Los marcadores son elementos perceptibles para los sujetos, pues estos están fuertemente relacionados con las entidades que prevalecen a lo largo del tiempo, como la lengua, el vestir, los hábitos, la religión... Estos dispositivos mantenedores de la cohesión materializan la identidad colectiva. Concilian relaciones de diferentes tipos entre los componentes del grupo y, logran una cierta auto presentación coherente frente al mundo exterior ${ }^{802}$.

\section{2.- Máscara engañosa}

Durante tod el siglo XVIII el tema de la sexualidad fue tremendamente importante en el ámbito médico y religioso. Ambos comprendieron el lecho conyugal como el lugar en donde coinciden la salvación de las almas y una procreación responsable. Partiendo de estas premisas, se desarrollaron toda una serie de prohibiciones, consejos y recomendaciones alrededor de las relaciones sexuales dentro y fuera del matrimonio. Todos ellos podían encontrarse en los Libros de secretos, Recetas o Literatura médica popular. La mayoría de estos textos describían la sexualidad como un proyecto divino para la preservación y multiplicación de la especie ${ }^{803}$.

Los médicos, el clero, los magistrados, las parroquias y los municipios ponen entredicho el control del individuo sobre su propio cuerpo. Así que desde principios del siglo XV hasta mediados del siglo XVII se esfuerzaron por hacer compantible el cuerpo y su sexualidad con el orden social, el respeto por la religión y el crecimiento demográfico. De forma que lograron cubrir al cuerpo de costumbre y de legislación. Pero, al mismo tiempo, ayudan a marcar el cuerpo como el espacio en donde pueden realizarse actos

\footnotetext{
${ }^{801}$ Andrés Piqueras, op. cit. p. 42.

${ }^{802}$ Isabel de la Cruz, op. cit., pp. 37-46.

${ }^{803}$ Alain Corbin, Historia del cuerpo, Madrid, Taurus, 2005, vol. I, pp. 182-187.
} 
sexuales transgresores o prácticas sexuales alternativas. Estas actividades señalaban al cuerpo como el lugar privilegiado para los crímenes contra la religión, la moral y la sociedad. A finales del siglo XVIII la sociedad burguesa, dotada de un fuerte sentido del pudor, relegó el cuerpo y su sexualidad a la periferia de lo decoroso. Se creó infinitud de prejuicios alrededor del cuerpo y de la sexualidad perniciosa. La frontera entre el sexo lícito y el ilícito se hacía cada vez más clara; y no se tardó en señalar a los barrios periféricos como foco de infección y de propagación de valores contra la moralidad cristiana. Las mujeres de cierto nivel social buscaban a toda costa diferenciarse de las “otras mujeres”. Su honra era intachable y su honestidad no se ponía en duda ${ }^{804}$.

La virginidad se convirtió en una virtud que exaltaba el autodominio. Tanto el discurso médico como el religioso resaltaban la importancia del control y de la procreción responsable. Las autoridades resaltaban el importante papel que ejercía la virginidad de una mujer, porque una futura esposa virgen representaba la perfecta abstinencia de toda acción voluntaria. Esto suponía una práctica sexual saludable dentro del futuro matrimonio, en donde el control de las pulsiones y de los impulsos masculinos era moderado por la esposa responsable ${ }^{805}$.

Este tipo de discurso ayudó a estratificar un orden social muy estricto, en donde los juicios morales cobraban una importancia tremenda. Para conseguir que el comportameinto de una mujer fuese prácticamente intachable se publicaron manuales de retórica, consejos corporales dedicados a la actio, libros de urbanidad, artes de conversación, artes del silencio... Todos ellos respondían a estudios relacionados con la fisionomía. Esta ciencia, que hoy en día se encuentra prácticamente degradada, surgió

\footnotetext{
${ }^{804}$ Alain Corbin, Historia del cuerpo, Madrid, Taurus, 2005, vol. I, pp. 167-170.

${ }^{805}$ Alain Corbin, Historia del cuerpo, Madrid, Taurus, 2005, vol. II, pp. 66-146.
} 
en el siglo XVI y alcanzó su máximo explendor en el XVIII. Fue considerada una rama de la antropología que se dedicaba a descifrar los lenguajes del cuerpo. Tuvo su origen en los antiguos tratados de adivinación mesopotánicos, en los tratados sobre la fisiognomía de la antigüedad grecolatina, en la tradición de la Edad Media occidental y árabe. Poco a poco se sistematizó y diferenció entre el ombre interior y el exterior, lo profundo y la superficie, lo escondido y lo mostrado, lo invisible y lo visible, lo latente y lo lmostrado ${ }^{806}$. Con ello deducimos que la fisiognomía estuvo estrechamente relacionada con la historia de la transformación de los lazos sociales. Casualidad o no, el espectacular desarrollo de la fisiognomía fue contemporáneo al desarrollo de la urbanidad. La fisiognomía era una ciencia que analizaba la mirada ajena sobre el propio cuerpo. De forma que con esta disciplina las jóvenes se acercaban a las normas sociales del buen comportamiento y descubrían la proporción del ideal de belleza. Aprendían a manejar y cosntruir la mirada ajena. Cureau descubre que tras los atractivos femeninos y de su gracia encantadora se enconden infinitud de vicios y de prejuicios. A estos los tratará de máscara engañosa, porque lo que realmente hacen es encubrir los secretos móviles de las féminas ${ }^{807}$.

Para practicar la urbanidad, hay que tener el don de la obervación. Hay que conocer a los hombres y descubrir sus móviles ${ }^{808}$.

Estamos ante mujeres de determinada clase social que saben vestir de forma adecada, que saben hacer los mínimos gestos posibles y que saben hablar de forma correcta.

\footnotetext{
${ }^{806}$ Con ello Cureau estableció una guía de conducta para la vida civil titulada L'Art de connaître les hommes.

${ }^{807}$ Alain Corbin, Historia del cuerpo, Madrid, Taurus, 2005, vol. I, pp. 293-296.

${ }^{808}$ Alain Corbin, op. cit., vol. I, p. 295.
} 


\section{3.- La comercialización de la femme fatale}

El desarrollo económico de la sociedad moderna provoca el derrumbamiento de la aristocracia y de los privilegios del Antiguo Régimen. Este vacío social lo cubre la recién ascendida burguesía y el objetualismo obsesivo. Esta nueva clase social hereda la capacidad de consumo que tenía la aristocracia, por lo que la adquisición de un producto se convierte en un acto de autoafirmación. El objeto se convirtió en un paradigma de la evolución social burguesa; es decir, cuando más se tiene más se ostenta. Sedas, plumas, pieles, joyas... todos los objetos innecesarios son comprendidos como la concreción material de los deseos y aspiraciones personales. Ante los objetos se adopta una actitud esteticista que ayuda a emular un nuevo status que antes no tenían. Pero, al mismo tiempo, esta actitud también es imitada por muchas jóvenes casaderas que pretenden ascender socialmente. Durante todo el siglo XIX se fomentó la idea de una vida dominada por el sentimiento fetichista. La adquisición de los objetos llegaba a despertar un sinsentido, un caos y una ansiedad, que en ocasiones minaba económicamente muchos matrimonios ${ }^{809}$.

Con la llegada del siglo XX el predominio artesanal de la producción desapareción a beneficio de la fabricación en masa. El modo de entender la nueva relación con los objetos es el resultado de la discontinuidad cognitiva del siglo XIX. Cadena en la que la figura femenina se reviste de oro y de apariencia ostentadora. Una mujer bien vestida es señal de que pertenece a la buena sociedad ${ }^{810}$.

El campo artístico observa con atención como la nueva sociedad es capaz de utilizar todo tipo de objeto para alterar sus orígenes sociales. Por lo que acaba observando que

\footnotetext{
${ }^{809}$ Goria Moure, op. cit., pp. 95-126.

${ }^{810}$ De ahí que en el siglo XX-XXI surja con fuerza la figura de la choni.
} 
cualquier objeto puede ser configurador de la realidad. Es decir, que la realidad se puede manipular, alterar y manejar. El artista puede elegir los materiales, transformarlos para darles la forma que le interese y disponerlos de un modo determinado modo. Esta idea da pie a múltiples lecturas de una misma realidad en la que el creador puede transformarla y extenderla.

El presente estudio ha intentado mostrar cómo algunos artistas publicitarios alteran la realidad mediante la creación de nuevos objetos, pero lo más curioso es que los relacionan con esquemas artísticos propios del siglo XIX en donde la propia figura femenina era caracterizada como un objeto. Todos los elementos que conforman las campañas publicitarias que hemos analizadose perciben como objetos formales y, por lo tanto, son liberados de sus funciones utilitarias. El artista concreta su actividad en alterar los objetos y estructurarlos de nuevo para romper con su función. Esto da lugar a una estructura articulada a través de signos. Esta articulación responde a la lógica objetiva e intelegibilidad, pero también al libre albedrío de su construcción. Así que la obra no establece una relación directa con la realidad, esto significa que la obra es autoreferente. Esto puede denotar una falta de centralidad, en el sentido de que con los mismos objetos pueden realizarse tantas obras de arte como objetos materiales esta contenga.

La cuestión es que la figura femenina en la publicidad también es utilizada como un objeto. Por lo tanto no hace referencia a ninguna realidad social externa, sino que remite sobre si misma. No responden ante un discurso paternalista ni feminista, aunque si es cierto que se conforma a partir de ellos. Son mujeres de una naturaleza desmedida pero que no pueden ser confundidas con aquellas que encarnan una anomalía moral. Las protagonistas de los anuncios pueden reprentar la sensualidad en exceso, pero no el sexo; 
el gozo, pero no el vicio; la libertad, pero no el libertinaje... Mediante diferentes objetos visuales se busca que las protagonistas encarnen las pasiones secretas de su público diana. Anhelos, ilusiones y esperanzas que un público superficial no muestra. De forma que se abre camino hacia lo profundo, lo interior, lo invisible, lo latente que el público esconde. Esto conlleva un descubrimiento de belleza proporcionada que fomenta las normas corporales y rechaza las deformaciones y los excesos morales. Muestra de ellos es que los anuncios más polémicos como pueden ser los relacionados con las mujeres sádicas, se han realizado mediante campañas muy limitadas.

\section{4.- La serpiente}

En su libro Los dioses en el exilio (1853), Heinrich Heine sostuvo que, tras el triunfo del cristianismo, los antiguos dioses destronados huyeron y se ocultaron, adoptando una nueva identidad y un nuevo empleo, a menudo convertidos en demonios. Esta brillante imagen de Heine iluminaría a ciertos críticos e historiadores -desde Walter Pater a Aby Warburg -que estudiaron la resurrección de los dioses paganos en el Renacimiento. Pero el Renacimiento no es el único periodo en que los dioses retornan, ni los dioses antiguos los únicos protagonistas de un retorno; también los mitos bíblicos han muerto varias veces y han regresado de la muerte como revenants. La historia del arte no es otra cosa que ese renovado exilio de sucesivos panteones, que se transforman sucesivamente en mitología, en figuras alegóricas, en tipos iconográficos y finalmente iconos populares ${ }^{811}$.

A finales del siglo XIX, los simbolistas sintieron la necesidad de revisar el nexo entre el erotismo y el mal. Esto les llevó al concepto de Caída de Adán y de Eva. Este es un arquetipo visual tan antiguo como el mismo cristianismo ha sido representado desde la antigua Roma hasta la obra de Giuseppe Cades a finales del siglo XVIII. Así que, a finales del siglo XIX, la imagen del pecado ha sido representada de tantas formas que

\footnotetext{
${ }^{811}$ Guillermo Solana, Las lágrimas de Eros, Madrid, Museo Thyssen-Bornemisza, 20 oct. 2009 - 31 ene.
} 2010, p. 17. 
ahora los artistas buscan innovar sobre el tema a través de la revisión. Tal fue el caso de Franz von Stuck:

Aunque el relieve de Adán y Eva de Franz von Stuck se atiende todavía oficialmente al esquema simétrico, el papel reservado a la serpiente carece de precedentes. Su asimilación a la mujer no es metafórica, por semejanza (como sucedía en las viejas serpientes de rostro femenino), sino metonímia, por contigüidad. Eva blande la serpiente como un arma contra Adán. Más aún: el reptil emerge, como un miembro viril postizo. En la época del Simbolismo, la serpiente no representa ya sólo a Satanás y el concepto teológico del mal; encarna sobre todo el poder del falo ${ }^{812}$.

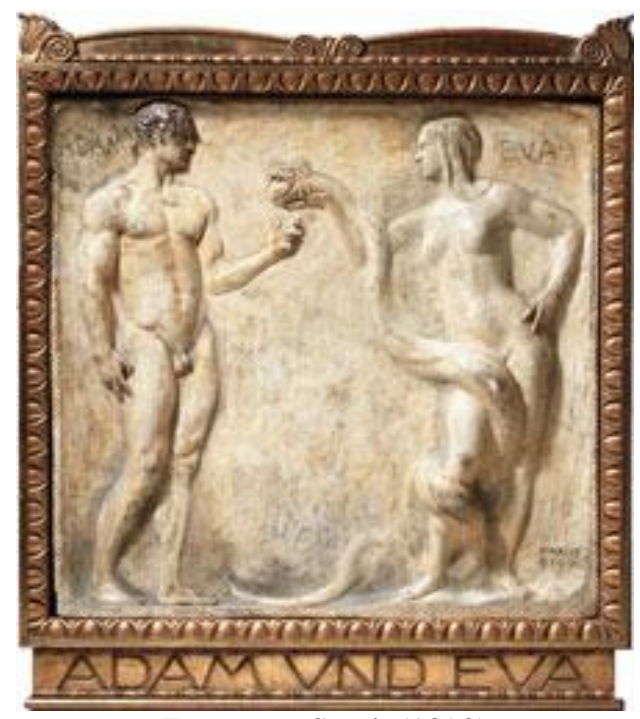

Franz von Stuck (1892)

Suck pudo conocer la obra de John Collier, y aunque ésta no representa a Eva sino a Lilith, le pudo servir para representar a la mujer arquetípica de El pecado. En este cuadro, la mujer ya no ofrece el fruto prohibido, pues lo prohibido es su propio cuerpo desnudo.

\footnotetext{
${ }^{812}$ Guillermo Solana, op. cit., p. 27.
} 


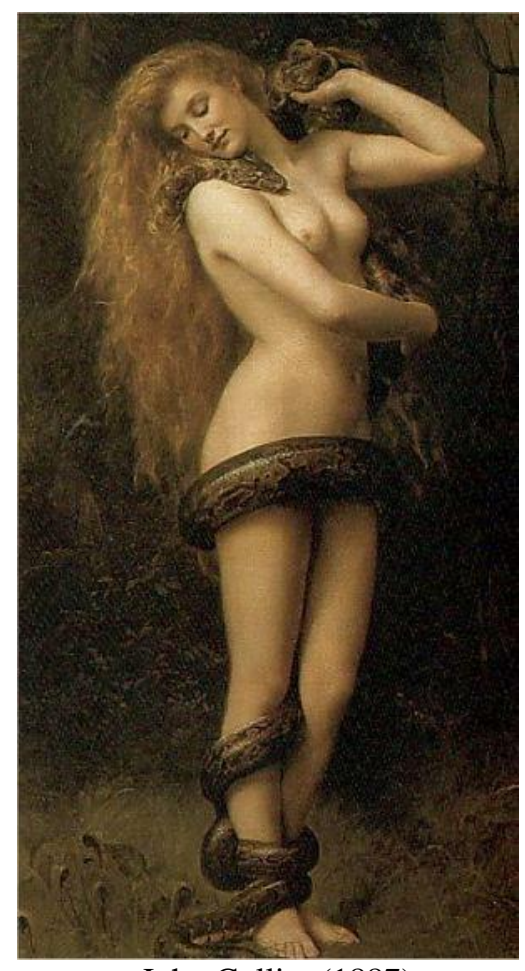

John Collier (1887)

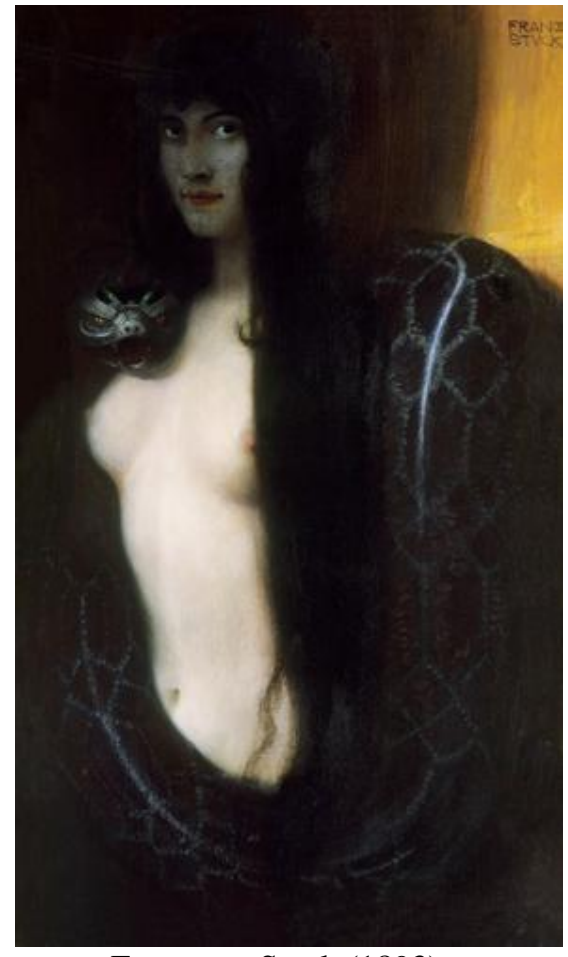

Franz von Stuck (1893)

Son destacables también las variantes que Franz von Stuck realize sobre El pecado y El vicio:

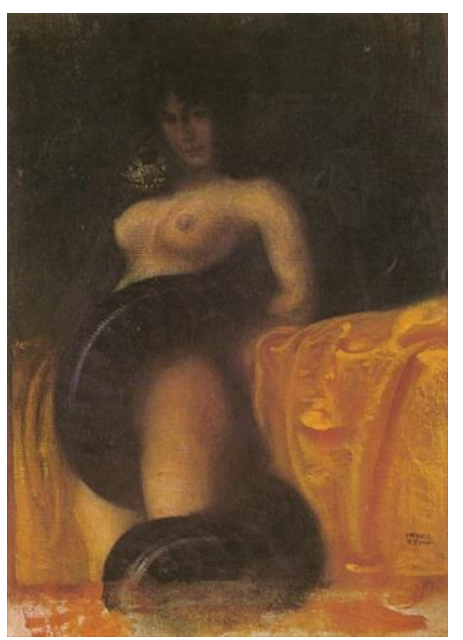

Franz von Stuck

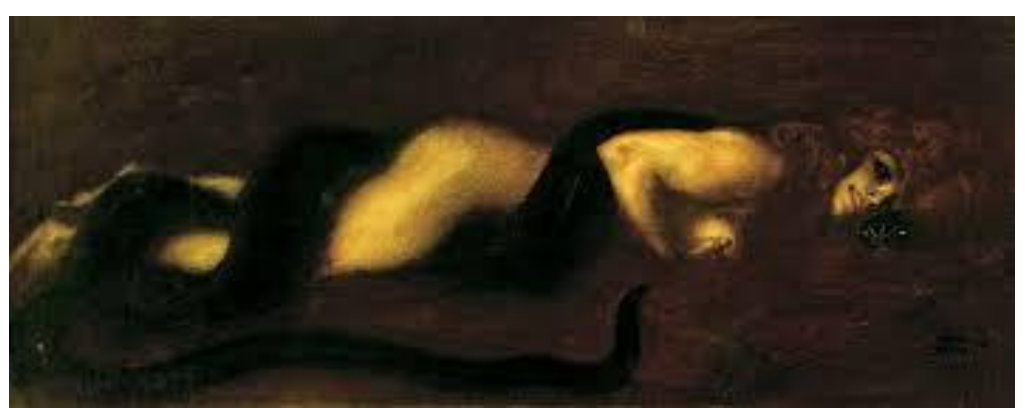

Franz von Stuck (1899) 
La imagen de Stuck posee un poder arquetípico acreditado por los innumerables ecos en la fotografía erótica ${ }^{813}$. Como tenemos las fotografías de Nastassja Kinski del fotogrfo Richard Avedon y la de Rachel Weisz del fotógrafo James White:

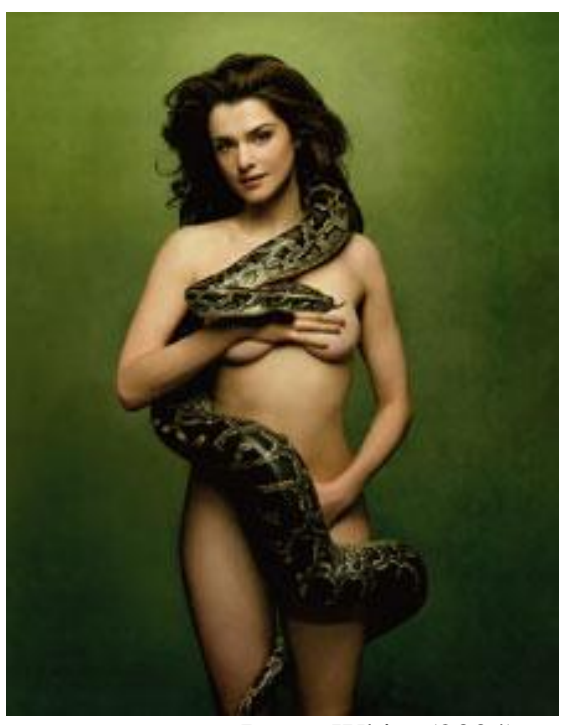

James White (2004)

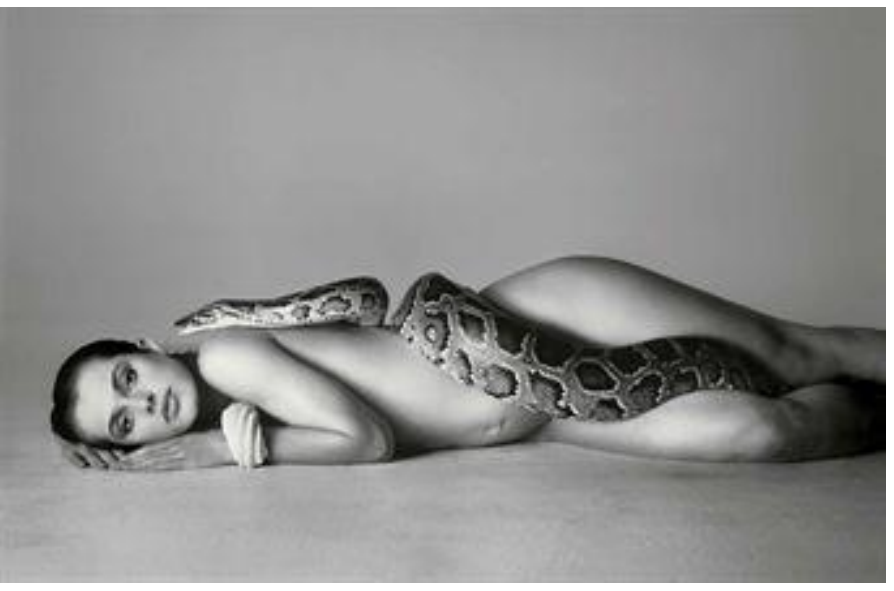

Richard Avedon (1981)

Arquetipo que las campañas publicitarias no dudan en rescatar para dirigirse a un amplio público. El objetivo es aplicar indirectamente este modelo a representaciones colectivas, porque encarna las formas conscientes y específicas de la sensualidad. La mujer ya no respresenta el pecado, sino la sensualidad.

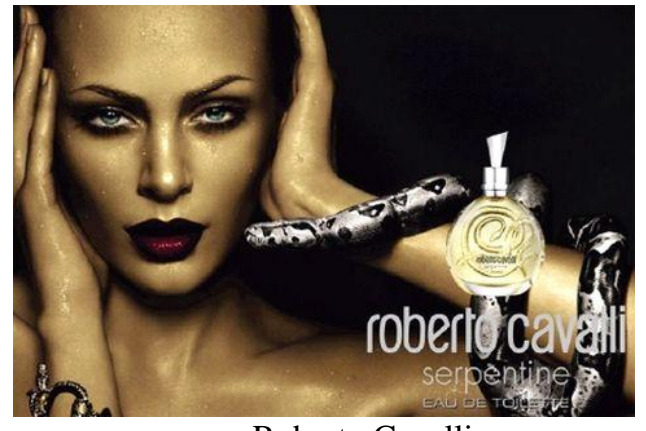

Roberto Cavalli

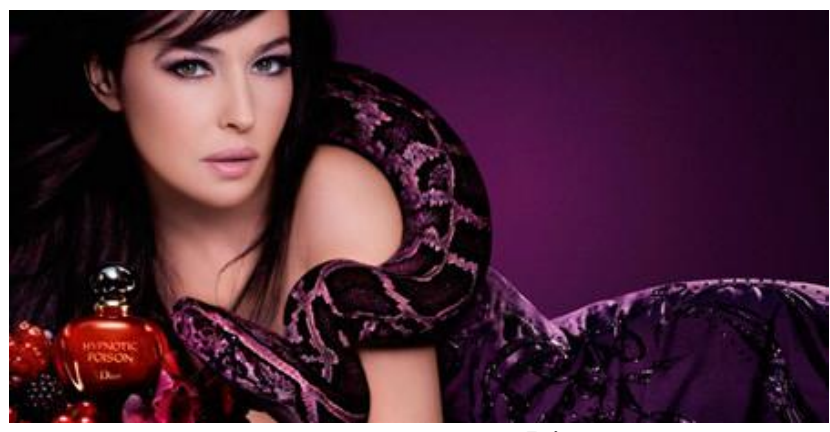

Dior

\footnotetext{
${ }^{813}$ Guillermo Solana, op. cit., p. 29.
} 


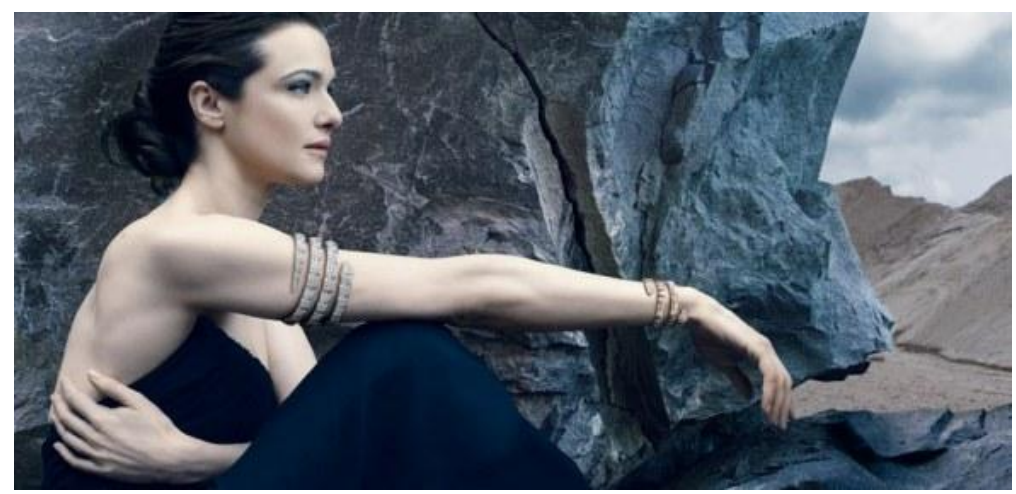

Bvlgary

Son imágenes que buscan encarnar la independencia de la sensualidad y, en consecuencia, la libertad de setirse atractiva. No para el marido o la pareja, sino para si misma. De esta forma, las campañas publicitarias dan forma a unas heroínas que todo público desea imitar porque encarnan la felicidad a través de la independencia de su sensualidad. 


\section{Bibliografía}

Amelang, James S., Nash, Mary, Historia y género. Las mujeres en la Europa Moderna y Contemporánea, Valencia, Ed. Alfons el Magnánim. Institució Valenciana d’Estudis i Investigació, 1990.

Aparicio Maydeu, Javier, Lecturas de ficcón contemporáneas. De Kafka a Ishiguro, Madrid, Catedra, 2008.

Arenal, Concepción, La emancipación de la mujer en España, Madrid, Júcar, 1974.

Ariès, Philippe; Duby, Georges, Historia de la vida privada, Madrid, Taurus, 1991.

Asensi Pérez, Manuel, Historia de la literatura. Desde los inicios hasta el siglo XIX, Valencia, Tirant lo Blanch, 1998.

Averbach, Erich, Mímesis. La representación de la realidad en la literatura occidental, México, Fondo de Cultura Económica, 1950.

Bataille, Georges, El erotismo, Barcelona, Tusquets, 2007.

Baudrillard, Jean, La transparencia del mal; ensayo sobre los fenómenos externos, Barcelona, Anagrama, 1991.

Beauvoir, Simone de, El segundo sexo, Madrid, Cátedra, 2008.

Bornay, Erika, Las hijas de Lilith, Madrid, Cátedra, 1995.

Boserup, Esther, La mujer y el desarrollo económico, Madrid, Minerva, 1993.

Bourdieu, Pierre, La dominación masculina, Barcelona, Anagrama, 2007.

Bravo, Víctor, Los poderes de la ficción, Venezuela, Monte de Ávila, 1987.

Burke, Peter, La cultura popular en la Europa moderna, Madrid, Alianza, 1991.

Burke, Peter, El Renacimiento, Barcelona, Crítica, 1993.

Butler, Judith, Cuerpos que importan. Sobre los límites materiales y discursos del “sexo”, Buenos Aires, Paidós, 2002.

Cereceda, Miguel, El origen de la mujer sujeto, Madrid, Tecnos, 1996.

Clément, Catherine; Kristeva, Juli, Lo femenino y lo sagrado, Madrid, Cátedra, 2000.

Corbin, Alain, Historia del cuerpo, Madrid, Taurus, 2005, vol. I y II.

Costa, Luis A. (coord.), La literatura alemana a través de sus textos, Madrid, Cátedra, 1997. 
Cruz, Isabel de la, Introducción a la antropología para la intervención social, Valencia, Tirant lo Blanch, 2002.

Deluze, Gilles, Lógica del sentido, Barcelona, Paidós, 2005.

Dijkstra, Bram, Ídolos de la perversidad. La imagen de la mujer en la cultura de fin de siglo, Barcelona, Debate, 1994.

Duby, Georges; Perrot, Michelle, Historia de las mujeres en Occidente, Madrid, Taurus, T. 5, 1993.

Durand, Gilbert, Las estructuras antropológicas del imaginario, Madrid, Fondo de Cultura Económico, 2005.

Eco, Umberto, La estrategia de la ilusión, Barcelona, Lumen, 1986.

Eco, Umberto, Historia de la fealdad, Barcelona, Lumen, 2007.

Feliu García, Emilio, Los lenguajes de la publicidad, Alicante, Universidad de Alicante, 1984.

Foucault, Michel, La verdad y las formas jurídicas, Barcelona, Gedisa, 1995.

Fuentes Herbón, Isabel-Argentina, Del naturalismo al decadentismo, pasando por la mujer fatal. Imagen femenina y literatura española en los inicios de la modernidad, Valencia, Universidad de Valencia, 2001.

García Uceda, Mario, Las claves de la publicidad, Madrid, Escuela Superior de Ingeniería Comercial y Marketing (ESIC), Vol. 1, 1995.

Gascón Vera, Elena, Un mito: la mujer como sujeto/objeto literario, Madrid, Ed. Pliegos, 1992.

Grosz, George, Arte y sociedad, Buenos Aires, Calderón, 1990.

Harris, Marvin, Introducción a la Antropología General, Madrid, Alianza, 1991.

Kirk, G.S., El mito, Barcelona, Paidos, 1970.

Laqueur, Thomas, La construcción del sexo. Cuerpo y género desde los griegos hasta Freud, Madrid, Cátedra, 1994.

Leach, Edmund Ronald, Replanteamiento de la Antropología, Barcelona, Seix Barral, 1972.

Lévi-Strauss, Claude, Las estructuras elementales del parentesco, Barcelona, Paidós, 1991.

Lévi-Strauss, Claude, Antropología estructural, Barcelona, Paidós, 1995. 
Lipovetsky, Gilles, La tercera mujer. Permanencia y revolución de lo femenino, Barcelona, Anagrama, 1999.

Llopis, Rafael, Esbozo de una Historia Natural de los Cuentos de Miedo, Madrid, Júcar, 1974.

Lorite Mena, José, El orden femenino. Origen de un simulacro cultural, Barcelona, Anthropos, 1987.

Lozano Domingo, Irene, Lenguaje femenino, lenguaje masculino. ¿Condiciona nuestro sexo la forma de hablar?, Madrid, Minerva, 1995.

Marmoni, Giancarlo, Iconografía femenina y publicidad, Barcelona, Gustavo Gil, 1977.

Martineau, Pierre, La motivación en la publicidad. Una guía para la estrategia publicitaria, Barcelona, Francisco Canovas (Editor), 1964.

Mayoral, Jose Antonio, Figuras Retóricas. Teóricas de la literatura y Literatura Comparada, Madrid, Síntesis, 1994.

McDowell, Linda, Género, identidad y lugar. Un estudio de las geografías feministas, Madrid, Cátedra, Universidad de Valencia Instituto de la Mujer, 2000.

Méndiz Noguero, Alfonso; Carmen Cristófol Rodríguez, Falsedad y comunicación. Publicidad engañosa, información falsa, imagen manipulada, Valencia, Debates, 2007.

Morant, Isabel, Historia de las mujeres del siglo XIX a los umbrales del XX, Madrid, Cátedra, 2006, vol. III.

Nash, Mary, Marre, Diana, Multiculturalismo y género. Un estudio interdisciplinar, Barcelona, Bellaterra, 2001.

Nash, Mary, Tavera, Susana, Experiencias desiguales. Conflictos sociales y respuestas colectivas (siglo XIX), Madrid, Sintesis, 1994.

Nash, Mary, Mujeres en el mundo. Historia, retos y movimientos, Madrid, Alianza, 2000 .

Navajas, Gonzalo, Mímesis y Cultura en la ficción. Teoría de la novela, London, Tamesis Books Limited, 1985.

Olson, David R., y Torrance, Nancy, Cultura escrita y oralidad, Barcelona, Gedisa, 1995.

Orozco, Emilio, Introducción al Barroco, Granada, Universidad de Granada, 1988.

Ovidio Nasón, P., Amores, El arte de amar, Sobre la cosmética del rostro femenino, Remedios contra el amor, Madrid, Gredos, 1989. 
Paglia, Camille, Sexual Personae. Arte y decadencia desde Nefertiti a Emily Dickinson, Madrid, Valdemar, 2006.

Pardo Bazán, Emilia, La cuestión palpitante, Barcelona, Anthropos, 1989.

Pedraza, Pilar, La bella, enigma y pesadilla. Esfinge, medusa, pantera... Barcelona, Tusquets, 1991.

Praz, Mario, La carne, la muerte y el diablo en la literatura romántica, Caracas, Monte Ávila, 1969.

Pujals, Esteban, Historia de la literatura inglesa, Madrid, Gredos, 1988.

Rama, Ángel, Ciudad letrada, Montevideo, Arca, 1998.

Revel, Jean-François, El conocimiento inútil, Madrid, Espasa-Calpe. Ministerio de Educación y Ciencia, 1993.

Rojas, Enrique, El hombre light: una vida sin valores, Madrid, Temas de Hoy, 1998.

Said, Edward, Orientalismo, Madrid, Libertarias, 1990.

Salgado, Enrique, Erotismo y sociedad de consumo, Valencia, Ediciones 29, 1971.

Sinnigen, John H., Sexo y política: lecturas galdosianas, Madrid, Ediciones de la Torres, 1996.

Tyldesley, Joyce, Cleopatra. La última reina de Egipto, Barcelona, Ariel, 2008.

Vidal Claramonte, $\mathrm{M}^{\mathrm{a}}$ Carmen África, La magia de lo efímero: representaciones de la mujer en el arte y literaturas actuales, Castellón de la Plana Universidad Jaume I, 2003.

Villiers de L’Isle-Adam, Ph. A., La Eva Futura, Madrid, Valdemar, 1988.

Wellek, René, Conceptos de la crítica literaria, Venezuela, Ediciones de la Biblioteca Universidad Central de Venezuela, 1968.

Zarone, Giuseppe, Metafísica de la ciudad: encanto utópico y desencanto metropolitano, Valencia, Pre-textos, 1993.

\section{Guiones:}

American Psycho, Dir. Mary Harron, Universal Studios, 2000, cine.

El laberinto del Fauno, Dir. Guillermo del Toro,Warner Sogefilm, 2006, cine. 
Catálogos de arte:

Arenas, Carlos; Plasencia, Carlos, H.R. GIGER. Escultura, gràfica i disseny, Valencia, Universidad Politécnica de Valencia, 2007.

Arenas, Carlos, John Howe, Christian L. Scheurer, H.R. Giger, Swiss Design in Hollywood, Valencia, Universidad Politécnica de Valencia, 2009.

Herranz, Yoland, Pese al paso del tiempo, Salamanca, Ediciones Universidad, 2007.

Moure, Gloria, Tapies. Objetos del tiempo, Barcelona, Ed. Polígrafa S.A., 1994.

Panera Cuevas, Javier, Mascarada, Castilla y León, Explorafoto, 2006.

Solana, Guillermo, Lágrimas de Eros, Madrid, Museo Thyssen-Bornemisza, 20 oct. 2009 - 31 ene. 2010.

Solana, Guillermo, El arte de Cartier, Madrid, Museo Thyssen-Bornemisza, 24 oct. 2012 - 17 febrero 2013.

Woolton, Carol, Drawing Jewels for Fashion, Philippa Hurd, Munich·London·New York, 2011. 